


\section{Pelos Caminhos de Militão}

Roger Hama Sassaki

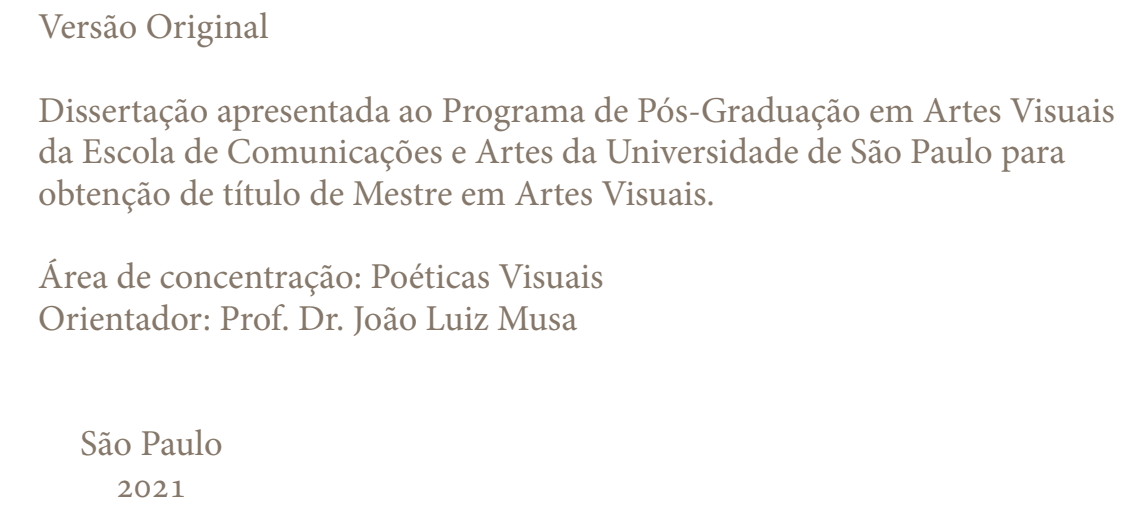


2014

2015 Venda do Estúdio

2016 Q Lápis da Naturez Em Campo com a Placa Úmida

2019 Negativos Feitos por Militão O Laboratório Móvel As Cores e o Estúdio

2020 ais da Minha Casa de Vidro Giphantie

Consideraçôes Finais

Impressão em Albúmen

O Processo do Colódio Úmido OProcesso

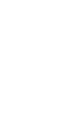
rering 


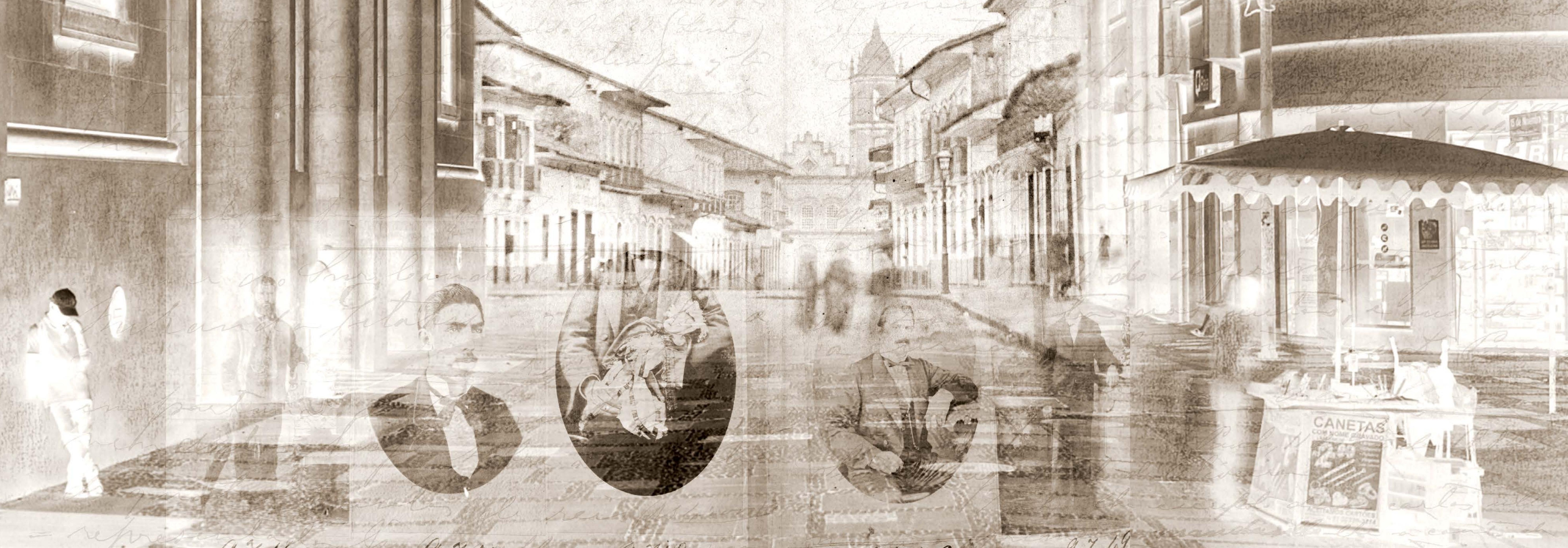




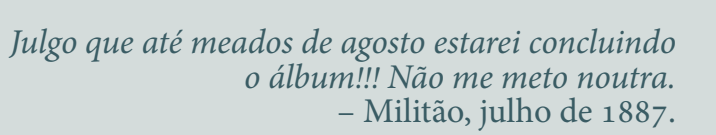

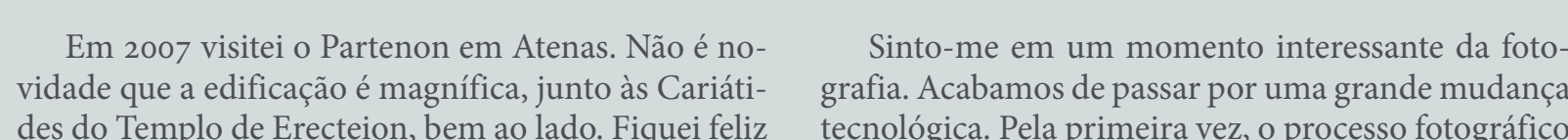

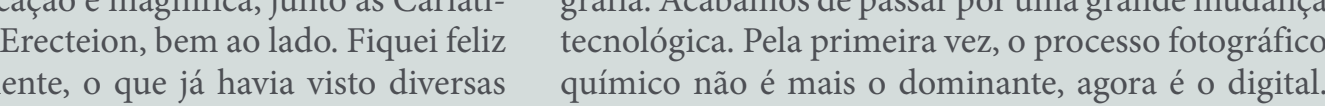
as minhas. Confesso que, por esse lado, não foi sur- e também da cópia, agora é só medida por um sen-
preendente - as edificaçóes se parecem com as fotos, sor, transcrita de forma amórfica, nummeros. Para en-

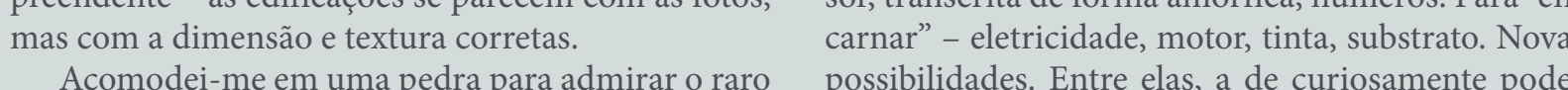

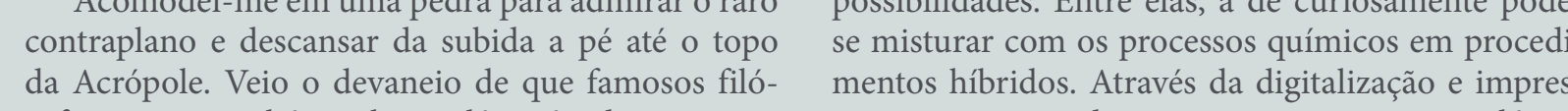
$\begin{array}{ll}\text { sofos gregos também subiram lá a pé e devem ter se } & \text { são, a imagem pode transitar entre o meio analogico } \\ \text { cansado um pouco; e quem sabe, sentado na mesma } & \text { e digital indefinidamente, podendo comecar ou ter- }\end{array}$ pedra. Conectados entáo por um suposto cansaço e minar em qualquer um deles. A A fotografaia digita Partenon, pensando no meu caminho até lá, na dis- ao mesmo tempo em que permite que a geraçáo atual

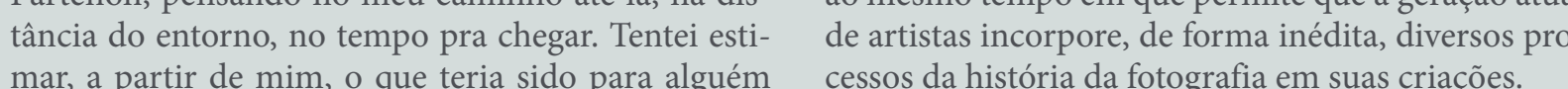

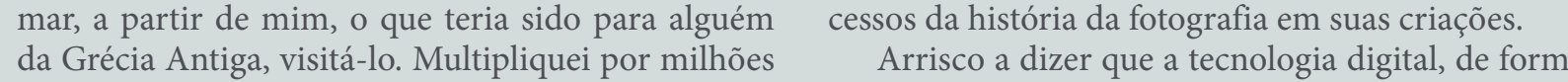
meu pequeno cansaco e pretensiosamente imaginei mais ampla, pode eventualmente abrir aos indivi-

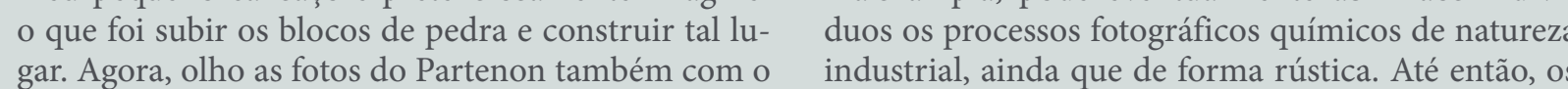
meu corpo.
Por falar em fotografias, creio que muitos hoje em $\begin{aligned} & \text { processos antigos que conseguimos fazer "em casa } \\ & \text { são os que surgiram num contexto pre-industrial, ou }\end{aligned}$ $\begin{array}{ll}\text { dia jaja ao menos empunharam uma câmerae fizeram } & \text { seja, foram desenvolvidos para serem executados con } \\ \text { uma foto. Os mais empolgados, como eu, mergut- } & \text { as mâos e não com máquinas. O processo da place }\end{array}$

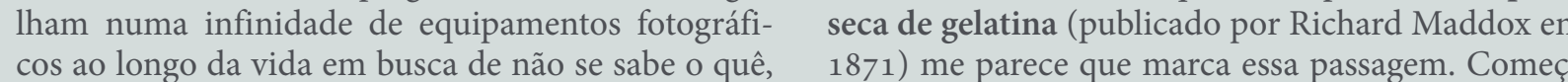
talvez uma afinidade. Substituímos nossas câmeras nos maravilhamos com as novas possibilidades. Afviamo-nos dos incômodos da antiga câmera e ace-
tamos os novos incômodos de sua substituta. De ve veem quando, bate uma saudaded de nano se se sabe
da velha camera. Da nova, asesulta outra coisa. corte (CNC) etc., para construir ou incorporar partes
mecanicicas e faer pequenos maquinários caseiros e,
por exemplo, produzuir rústicas placas de autochro-

A tecnologia digital também abriu uma via de
divulgação e troca de informaçoes sobre o fazer dos procedimentos antigos. Permitius o acesso a inímeras
publicacoeses técnicas do século 19 digitalizadas, a reproduçêes de imagens antigas de acervo e de criaçês
atuais, a grupos de discussáo de alcance mundial dedicados a vários processoso, ao registro visual de pro-
cedimentos ea muitos videos online de pessoas se

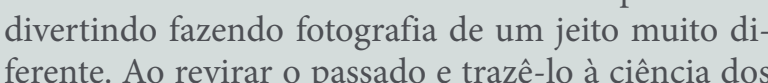
artistas de hoje, a imagem digital deixou claro uma

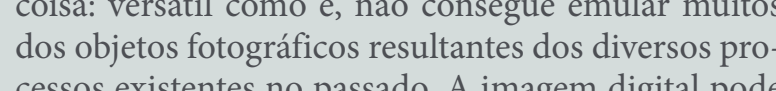
cessos existentes no passado. A imagem digital po
encarnar em diversos corpos, mas não em todos encarnar em diversos corpos, mas nào em todos.
Quando me bateu a saudaded en náo se sebe o da minha velha câmera analógica, comecei a inter
calar as longas horas ao computador e impressorar improvisado (sempre são), que se tornaram cada
vez mais longas. Livre da obrigaçâo de produção comercial, incumbeñcia àc de experimentaçóes. Quis ir além da história recente coso filmes industriais analogicos, que ainda percebo
mais perto dele au dige deul. Quis começar do início, $\mathrm{O}$ Com a ajuda dos meios digitais, consegui informaçoes para a minha viagem autodicatata ao passado
para meados de 1841 1. Um método prático de fotogra-
fia havia sido anunciada dois anos antes pelo francês Louis Jacques Mandé Daguerree nons anos seguintes
o ingles William Henry Fox Talbot anunciou tam-

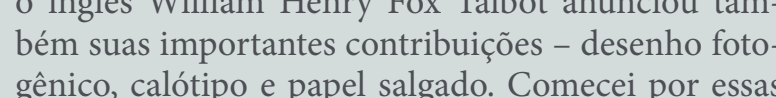

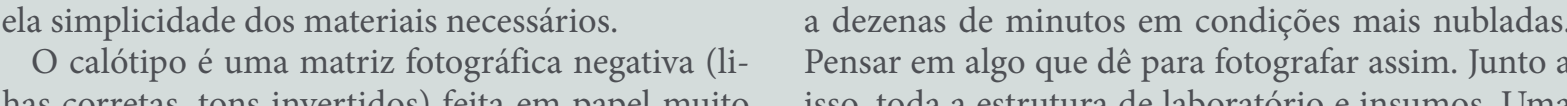

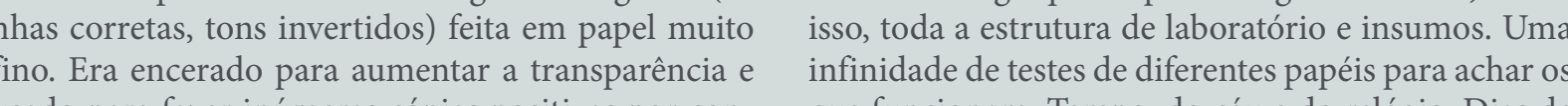
usado para fazer inumeras cópias positivas por con- que funcionam. Tempo, do céu e do relogio. Dias de
tato em papel salgado. Ambos os processos se ba- preparacáa para o dia das fotos, dias de pós produseiam em papel sensibilizado diretamente em suas çáo das fotos feitas. Dias de espera para as melhores
fibras com sais de prata. A difernnça basicá é que o
condiçoes. Dia ensolarado: fotografe; dia nublado:

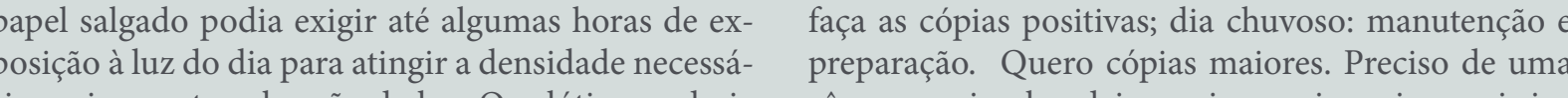
$\begin{array}{ll}\text { a, unicamente pela acão da luz. Ocalótipo poderia } & \text { câmera maior, bandejas maiores, pia maior, mais in- } \\ \text { aceber uma exposicáo muito mais breve de luz, e } & \text { sumos, mais dinheiro, mais tempo. Este e outros pro }\end{array}$

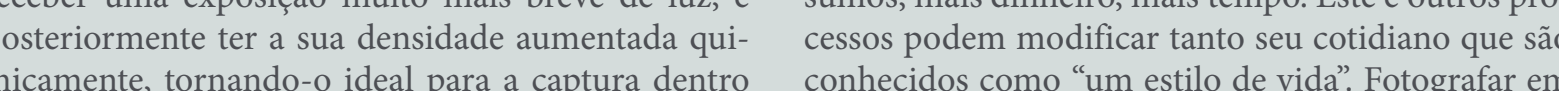

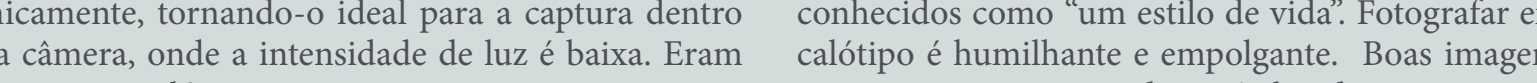

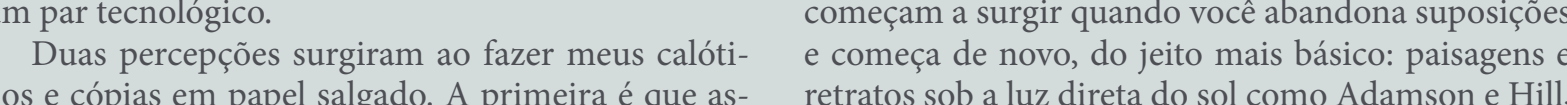

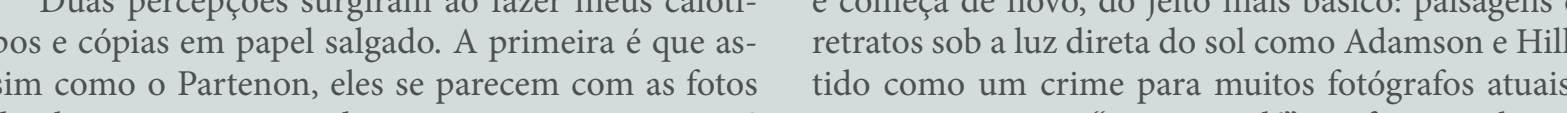

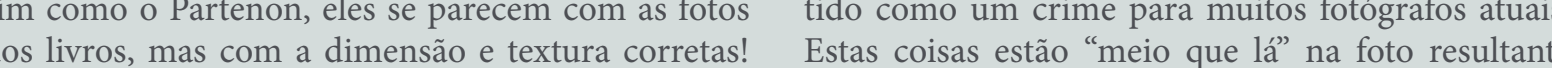

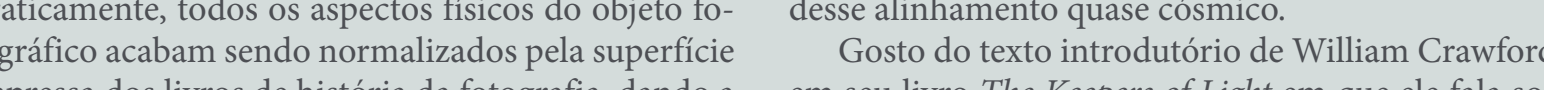

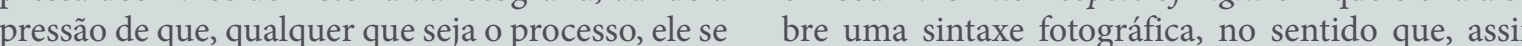

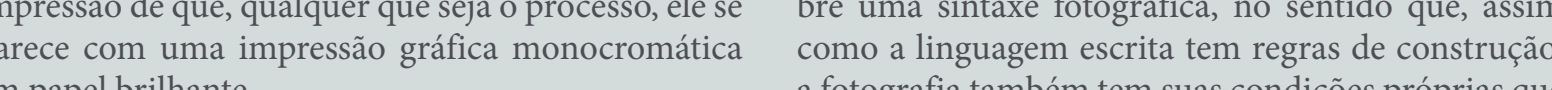
$\begin{array}{lll}\text { A segunda percepcão é de que o objeto fotográ- a fotografia também tem suas condiçōes próprias que } & \text { acabam por interferir no modo em que as imagen }\end{array}$ co traz nele muitas das condiçoes envolvidas em são concebidas. No caso da fotografiá, não são regras

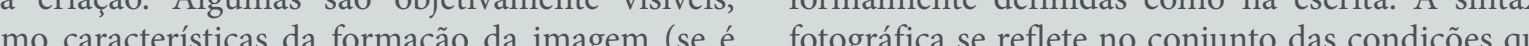

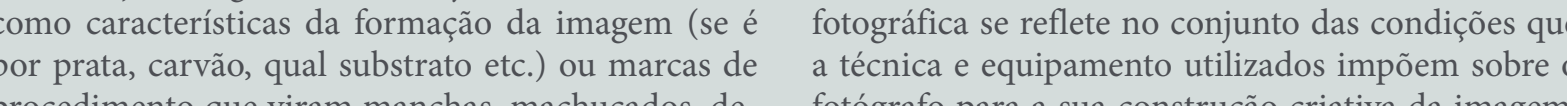

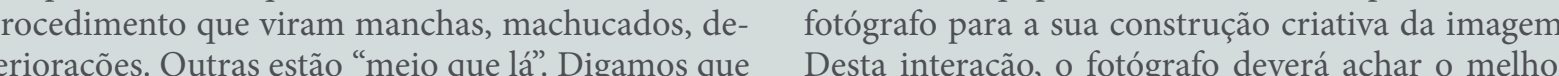
a fora é impossivel eu olhar um calótipo, antigo ou jeito de se expressar. Por consequência, um melhor focente, sem me lembrar do que passei para fazer os entendimento da técnica utilizada é também um me meus. Oequipamento grande e pesado, tripé, baixis-
sima sensibilidade à luz basicentendimento do processo criativo do fotógrafar

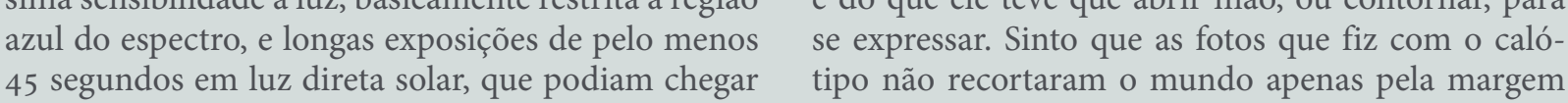




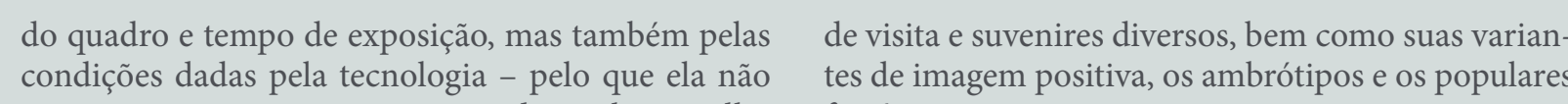

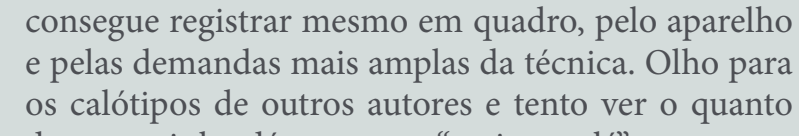

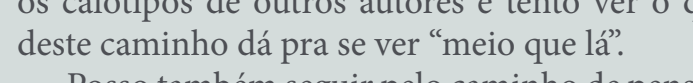

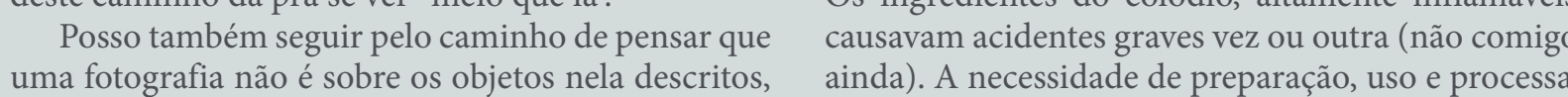

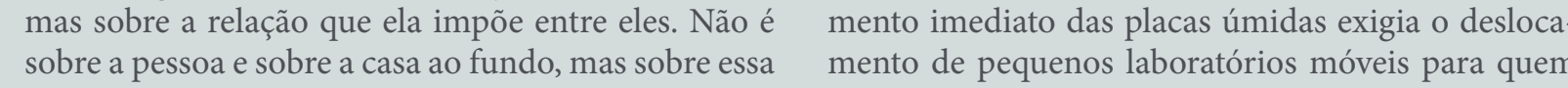

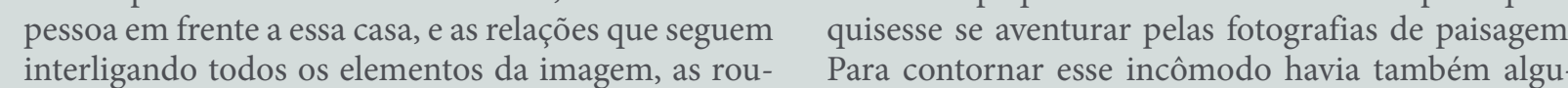

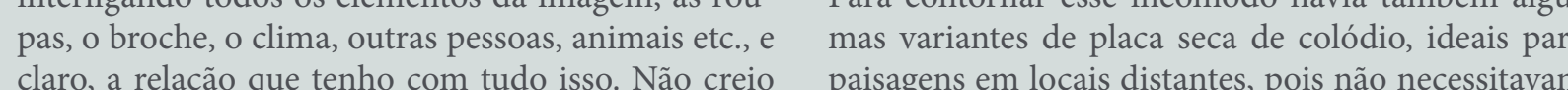

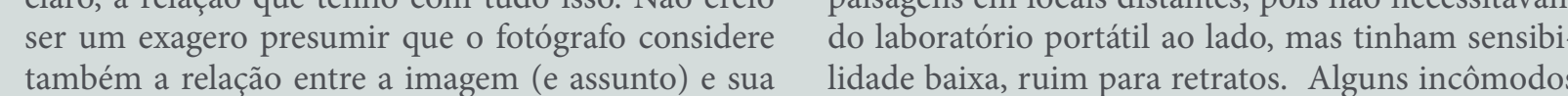

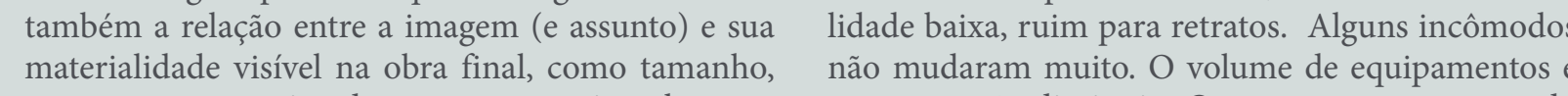

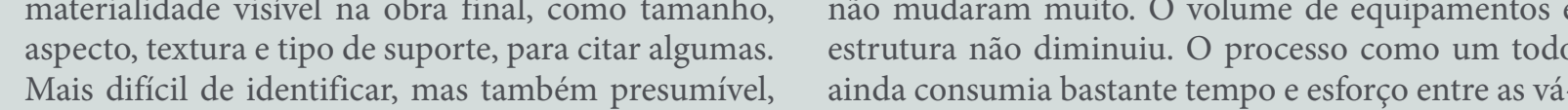

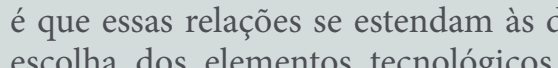

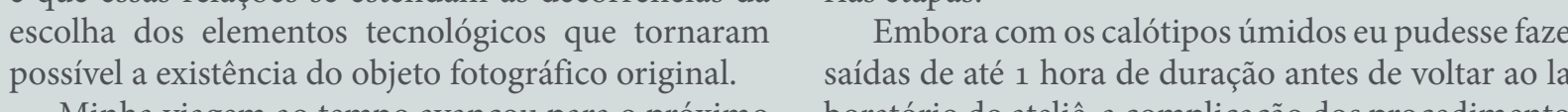

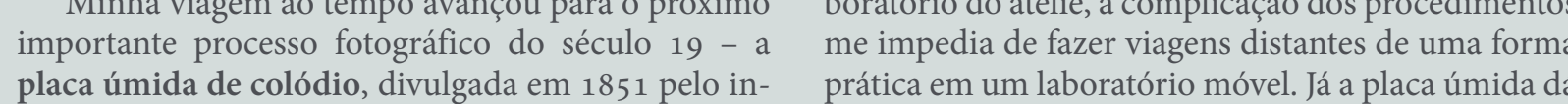

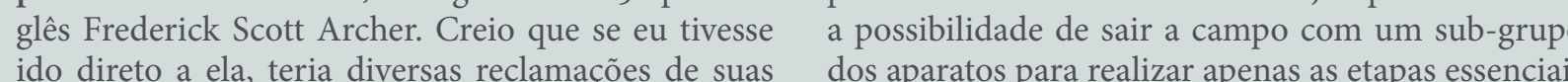

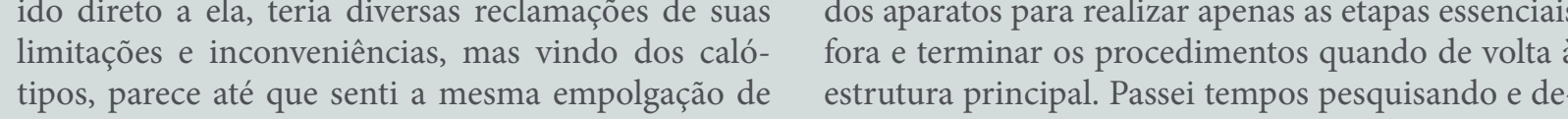

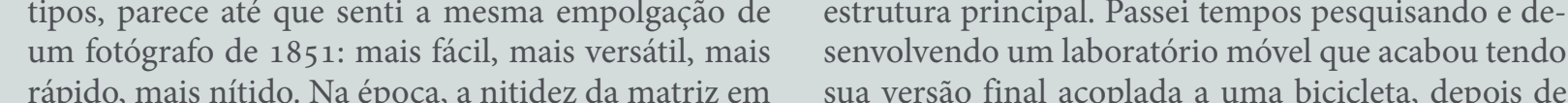

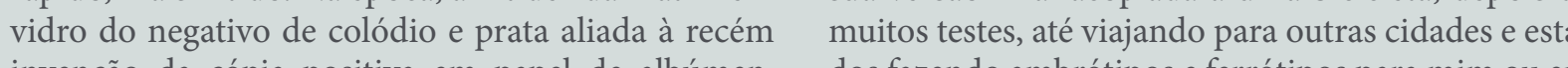
tambemm mais nitida que o papel salgatado, possibilien

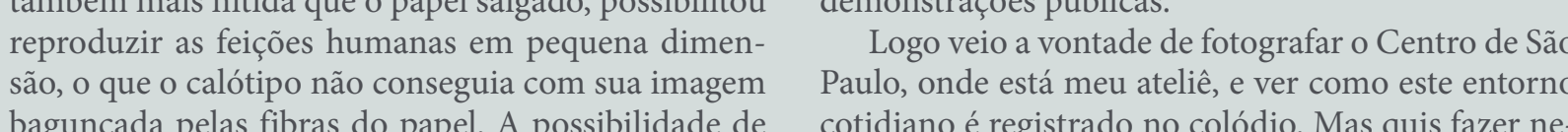

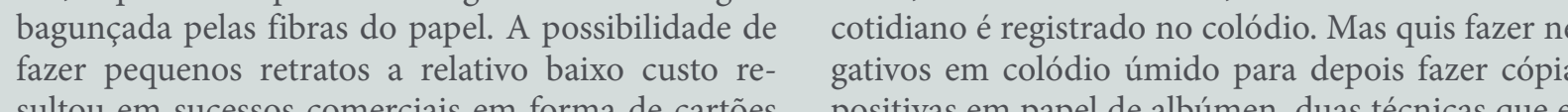

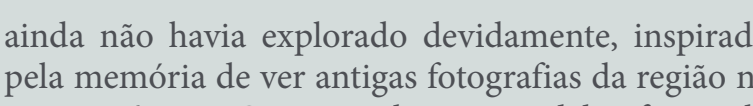

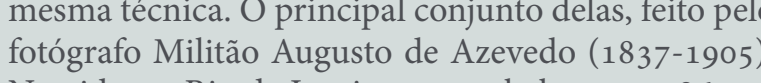

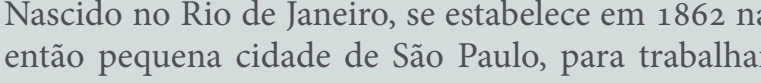

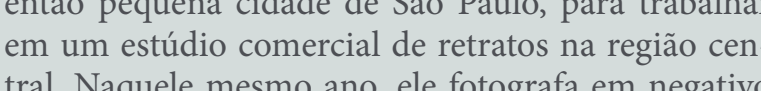

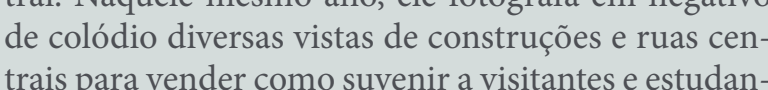
tes de passagem. Essas imagens foram 25 anos depois

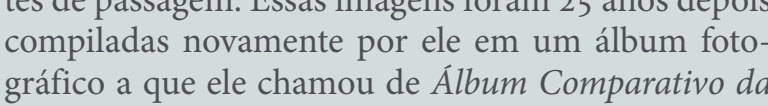

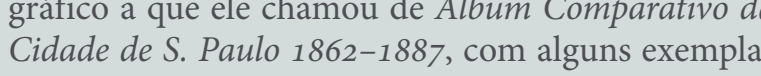
rese existentes ate hoje. Como sugere o titulo, ele jun
tou às imagens de 1862 uman nova serrie de imagens feitas por ele em 1887 , muitas delas com o ponto de

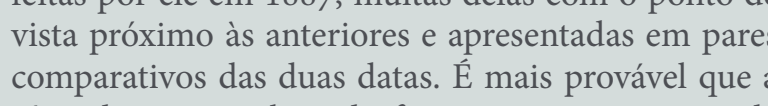
placa seca de gelatina

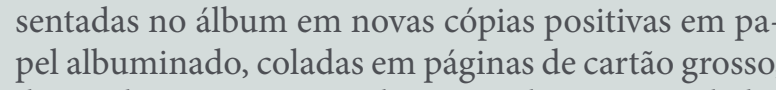
decoradas com una vinheta simples e intercaladas

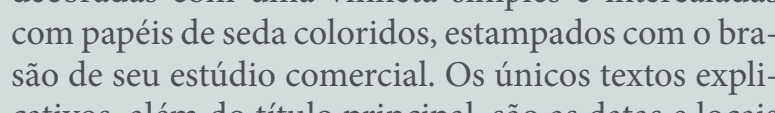
saio de seu estudidio comercial. Os unicos textos expli
cativos, alem do tituluo principal, saia as datas elocais de cada imagen

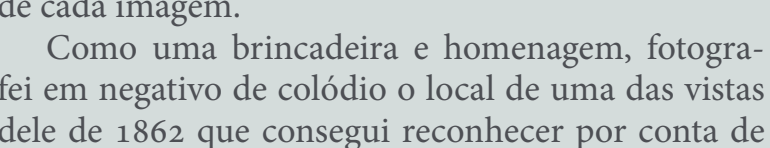
uma inica construçä remanescente e e tracado da
rua. Tentei posicionar minha camera onde achei que

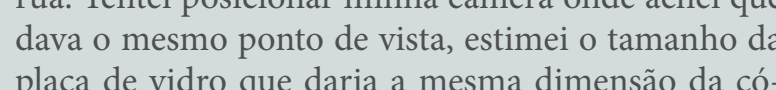

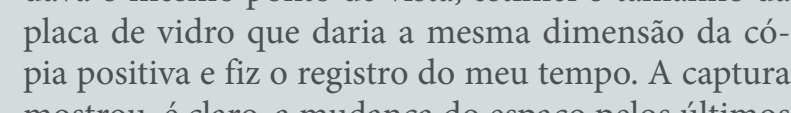

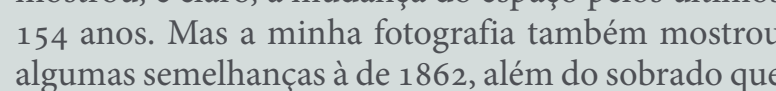

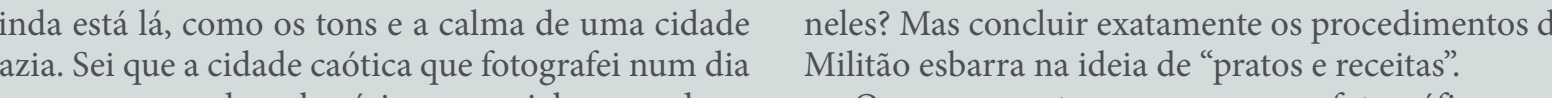

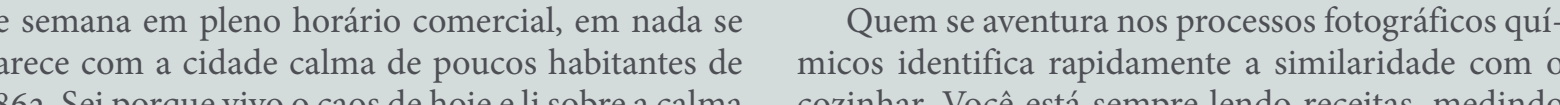

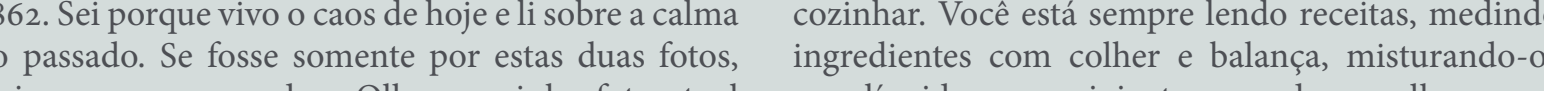

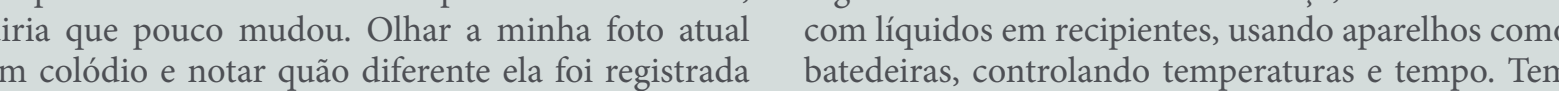

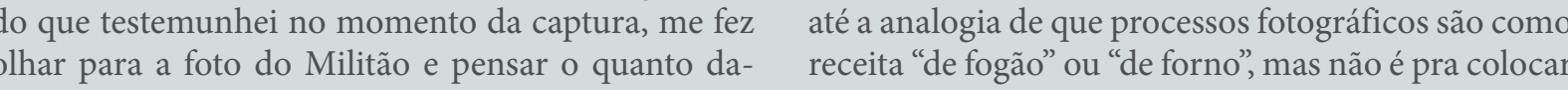

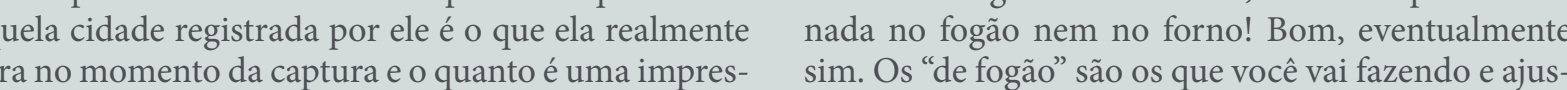

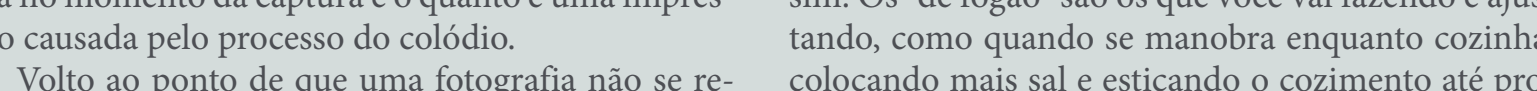

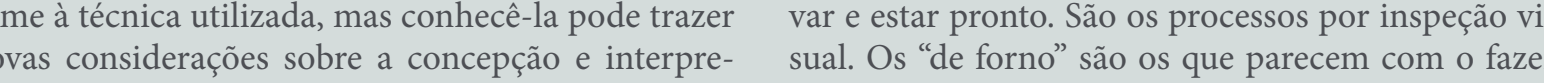

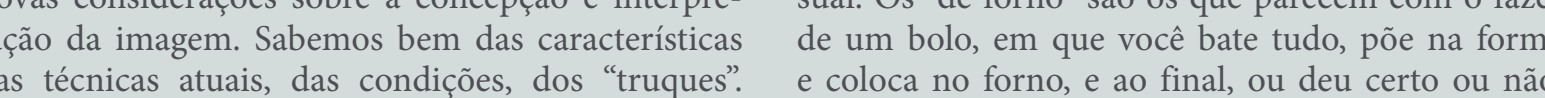

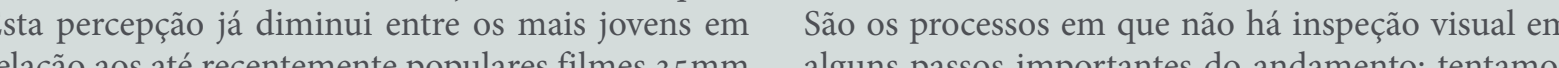

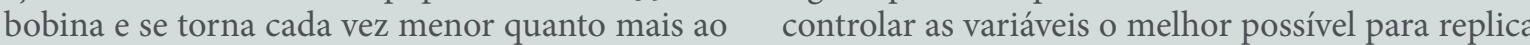
(a)

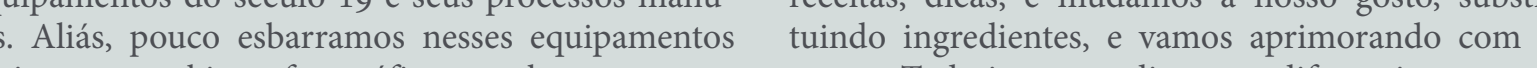
a

Assim como meu devaneio sentado na pedra na

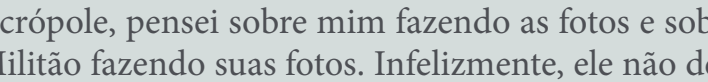

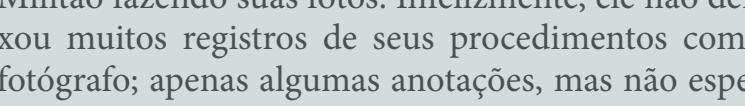

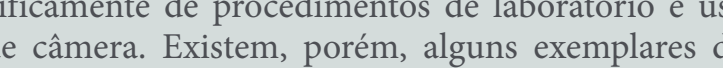

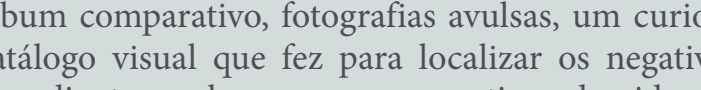

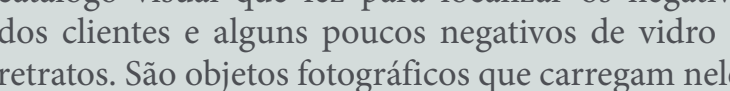

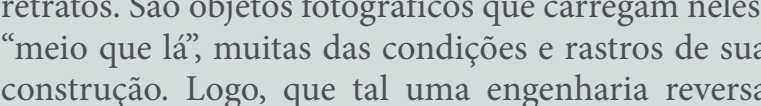

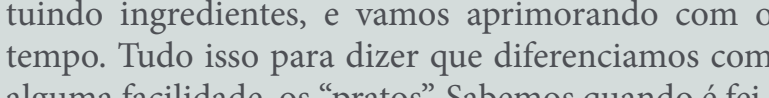

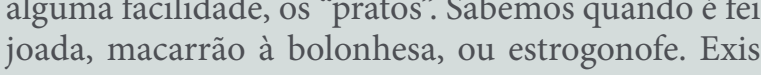

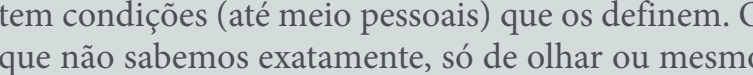

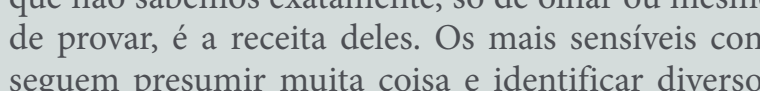

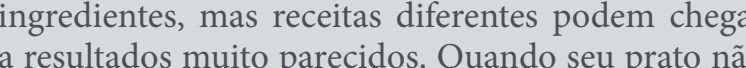
fict tá bom guanto o de outra pessoa, logo se pense

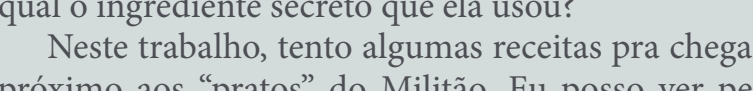

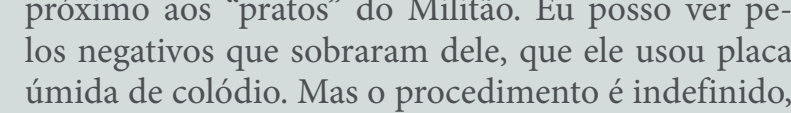




$$
=-1
$$




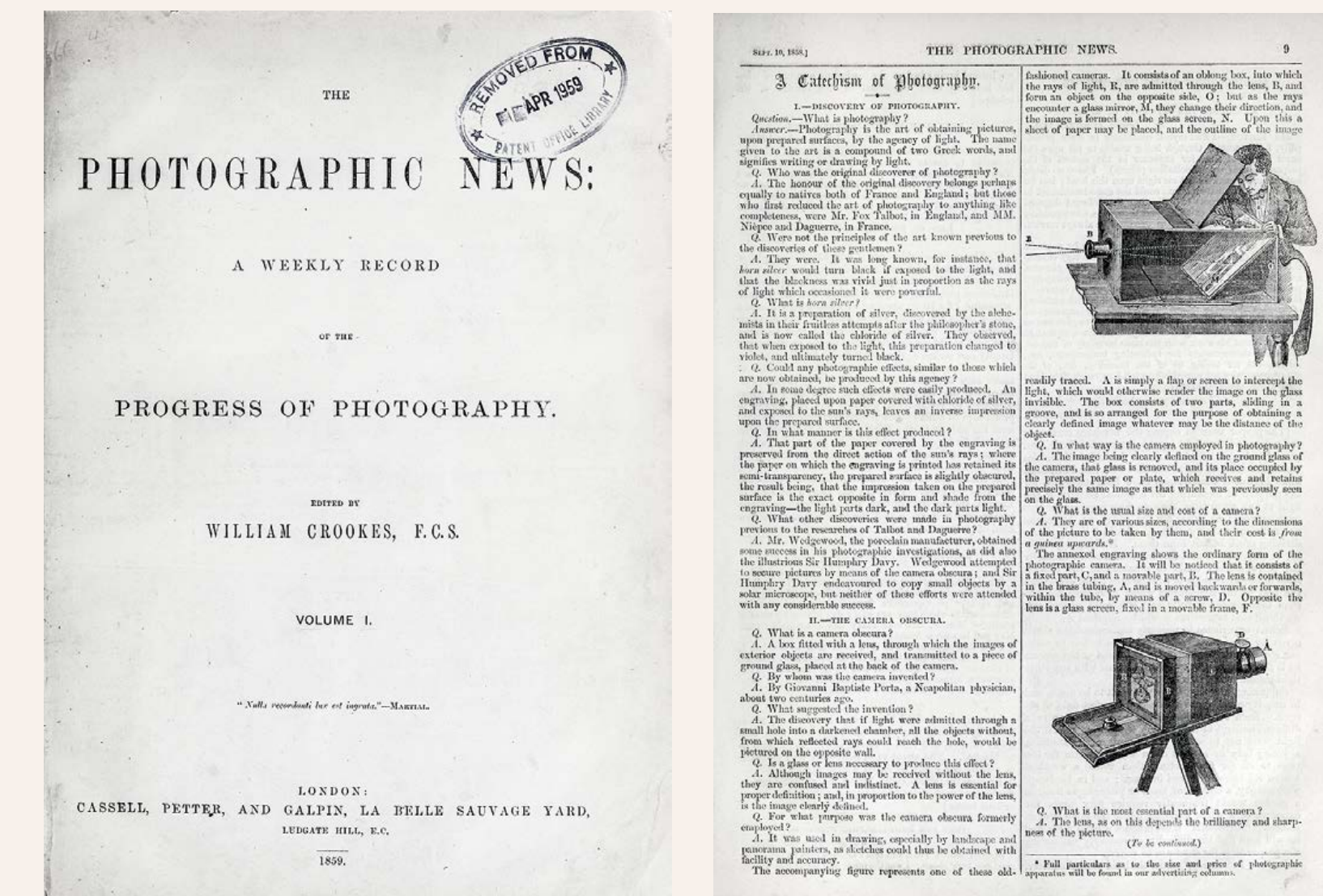

The Photographic News

o londrino, lançado em setembro de eram fragmentados em quantas edicóces subsequuesvolume agregando todas as ediçoes do períiodo. At cutidos, atualizados ou contestados à medida am que abreviados por questão de esppaço
2013

3 de maio de 2013

Estive investindo meu tempo em pesquisar mais
uma técnica fotografíca. Quero fazer placa úmida de colódio, esquecida por essas terras mas, que
nhando popularidade pelo mundo Como o ingrediente principal, o colódio puro
não è mais produzido no Brasil (ou eu não o achei) ele tem que ser importado. Isso o deixou mais caro
que minhas possibilidades financeiras atuais. Mas encarei o desafio de preparar o o colrósdio do deroro.
problema e e produzir o algodão solúvel que é depois issolvido em éter e álcoôn Depois de varias semanas tentando diversas recerdo século 19 , creio que cheguei num bom resultado algodáo soluvel foi entáo dissolvido em etere e alcocom sais de brometo de cádmio e iodeto de potássio emais éter e élcool para virar o colódio fotográfico. do". Ou seja, segurar a ansiedade esperar at's semant

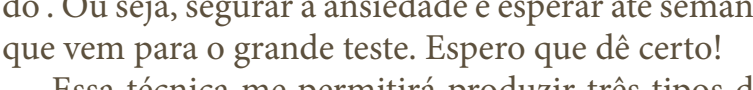
Essa técnica me permitirá produzir três tipos de
saídas fotográficas: negativos de vidro, ambrótipos
e ferrótpos.
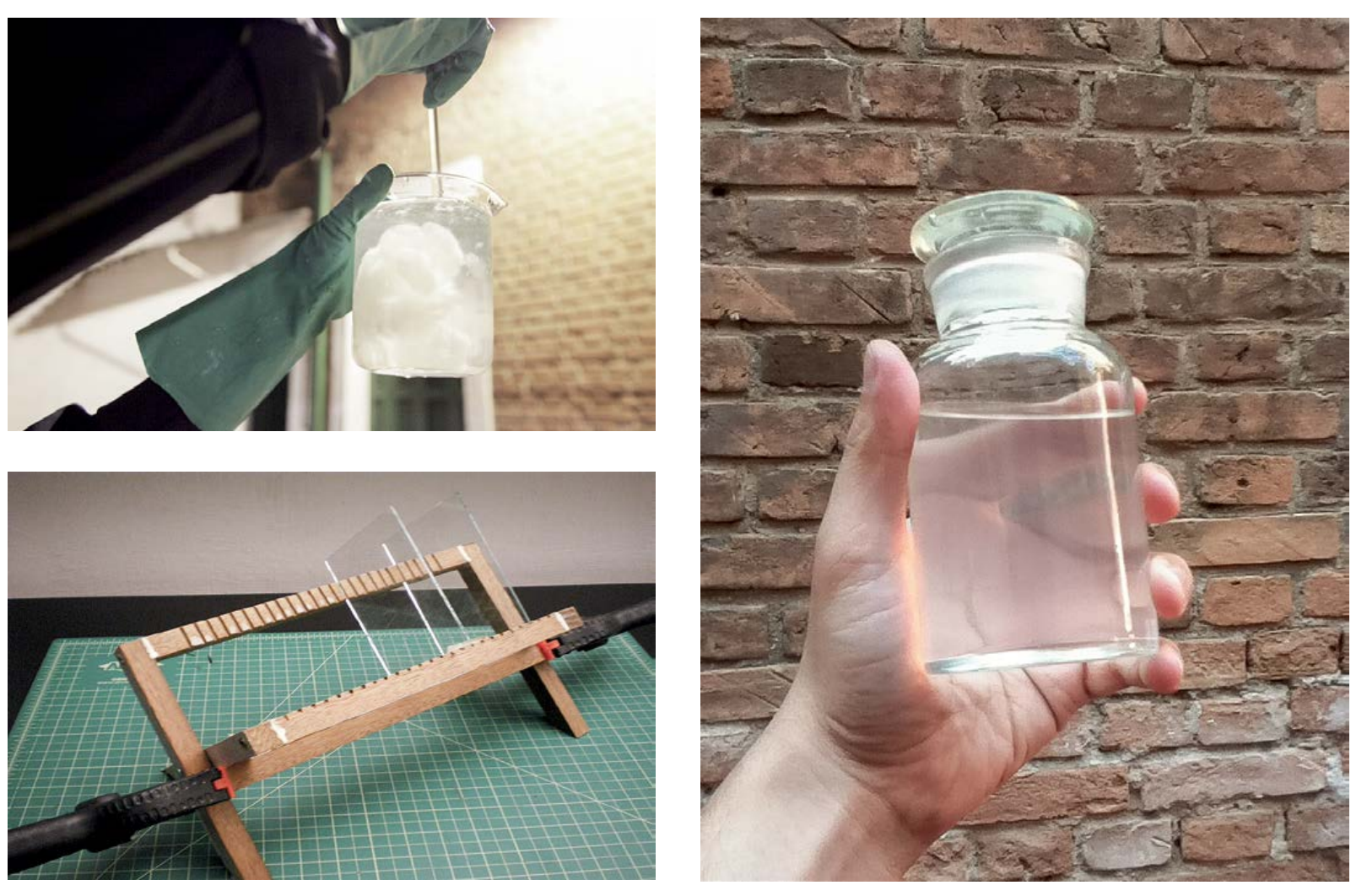

esse motivo, os artigos devem sempre ser lidos consideEu incluo alguns trechos a seguir para ter um pamente anterior àuuele em que eilitäo produz sua sé ine de fotografias de 1862 . Alguns trechos mantêm a
diagramaça original $e$ outros foram reformatados ou litio, dependendo da receita.

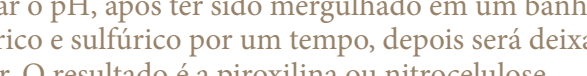

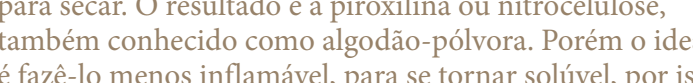

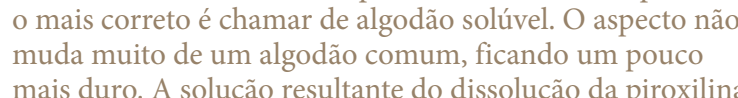

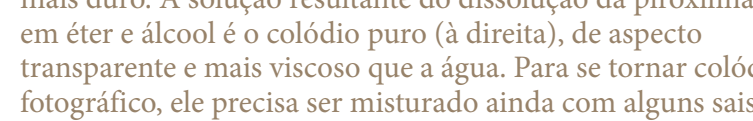

Para forogratar en placa aimida tamberm tive que aprennder

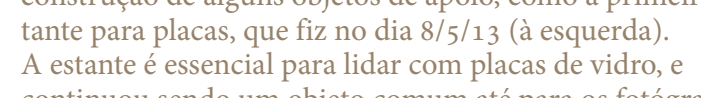

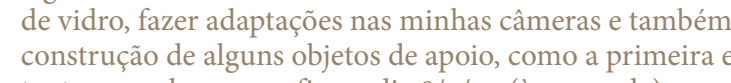

S. Paulo, 8 de novembro de 1883.
Sr. J. Gonchalves Pinheiro \& Cia.

empo uma dos Estados Unidos, outra da mannsa tendo por consequênncia grande material, posso llice
fazer - nisto ocasionar grande diferença em preço tra 25:000. Litro de verniz féto por mim 12:000
frances $8: 00$, colódio 500 de colodio $7: 000$, gros comprou do verniz francés e se gosta dele. O coll
dio e feito

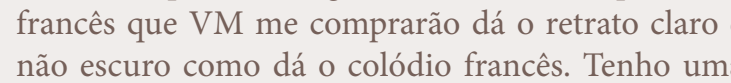
grande quantidade de tiras de chapas de 36 cxio que
dá sobrando bastante parat rís duviaias de bijou e que The posso vender a duzentos rés a tira. Lembrei-mos â pela fos Se char que se pode fazer algu nào passa de um lembrança e [?] nâo nos arranjar me estou certo que lá năa irei pois nâo vou sozinho
Por isso pode ficar descansado que nào teráa minhà concorrencia -

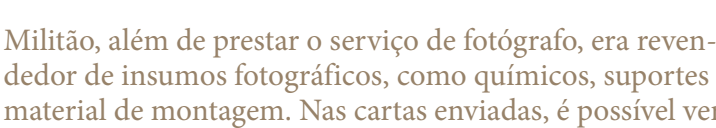
material de montagem. Nas cartas enviviads, ép possivel ver Nestac arta ficacaclaro que ele vendiao o coĺdioio que ele

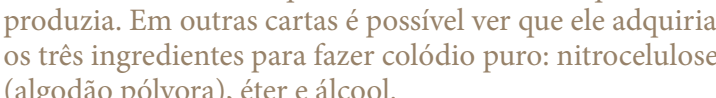

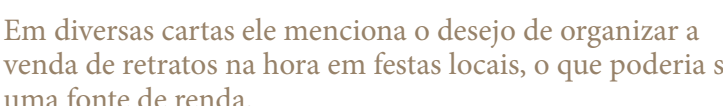



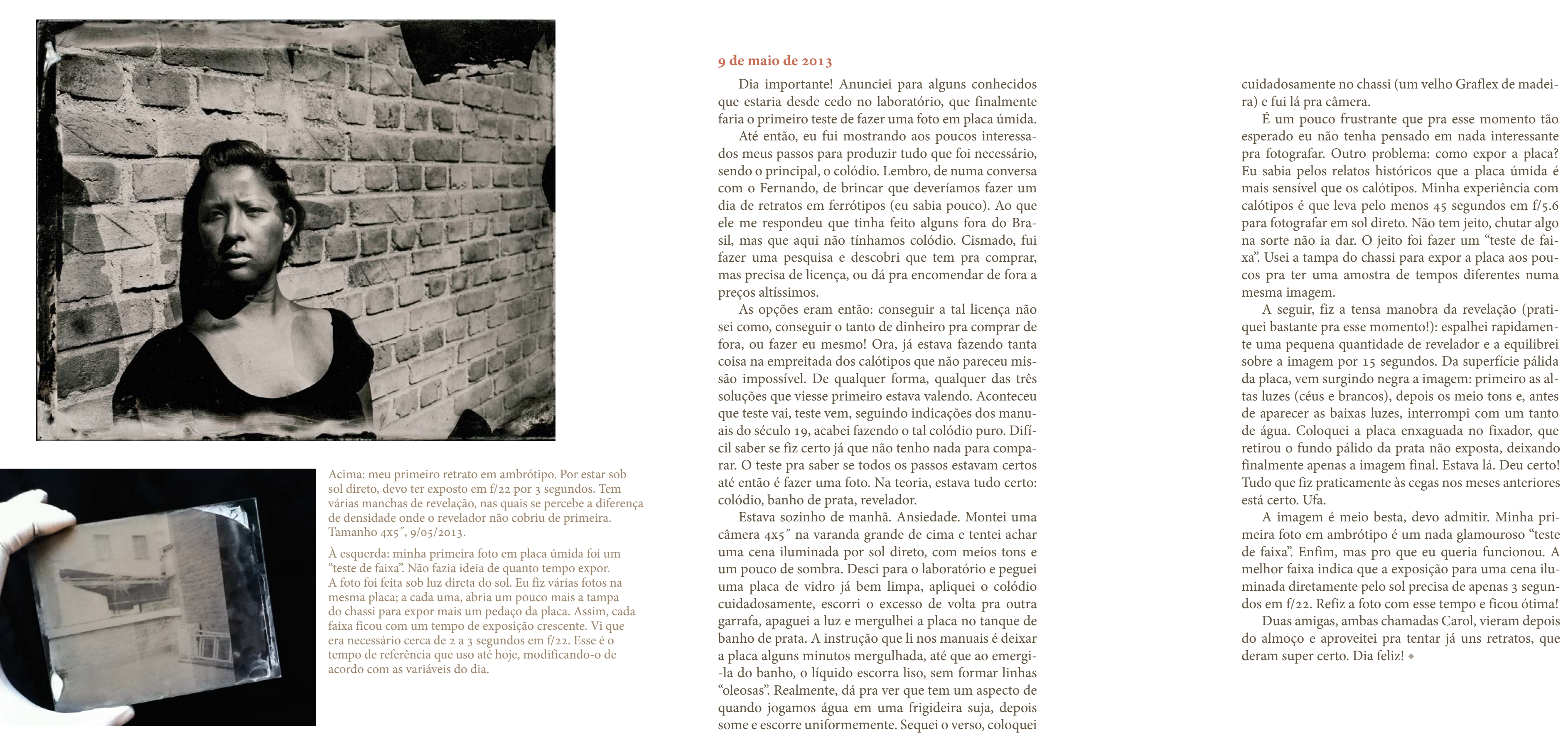

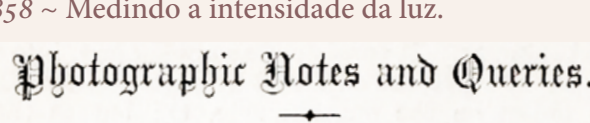

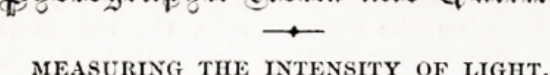

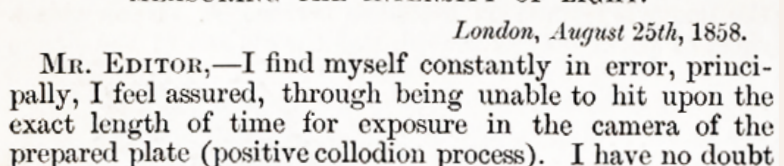

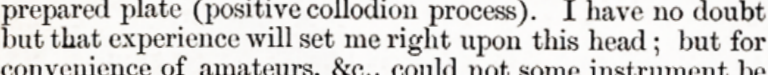

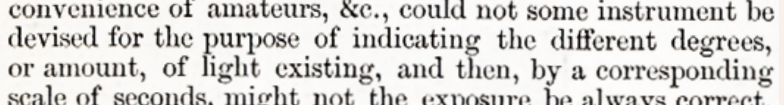

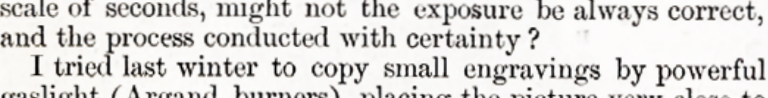

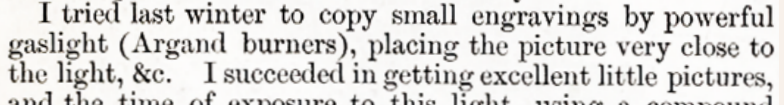

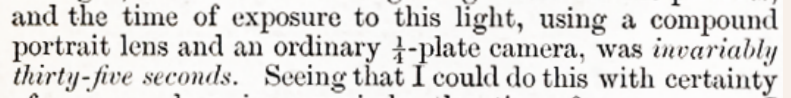

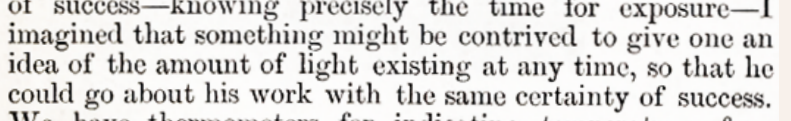

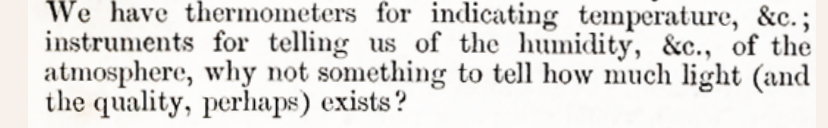

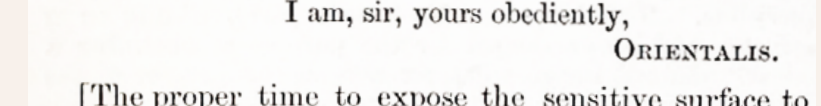

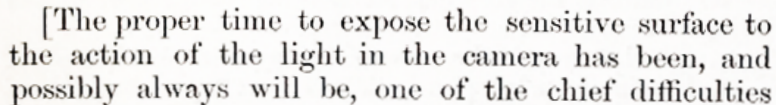

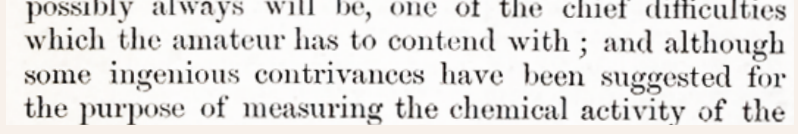

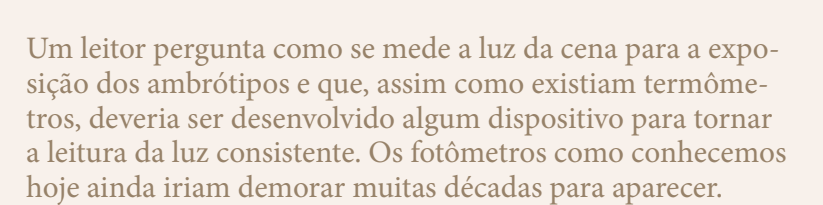

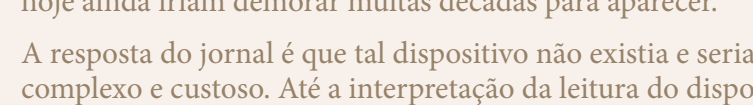

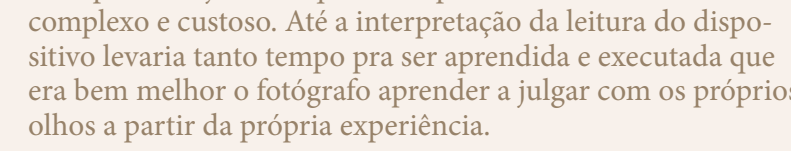

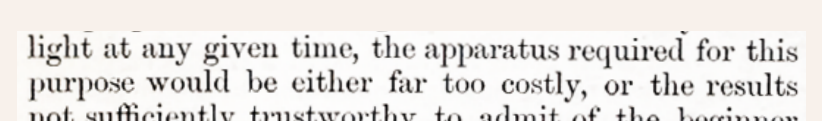

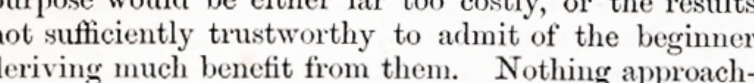

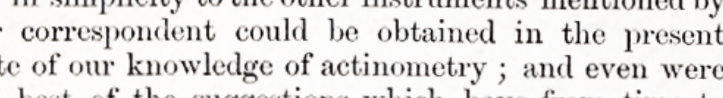

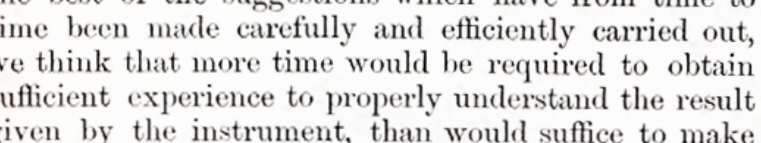

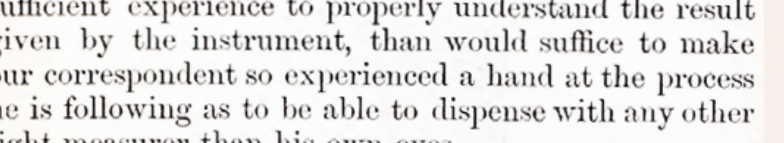

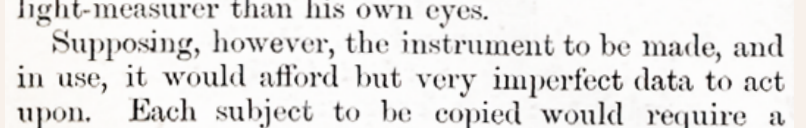

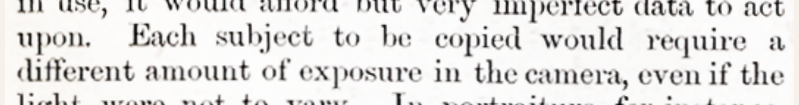

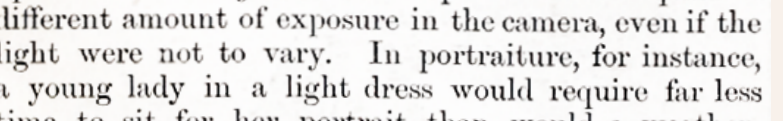

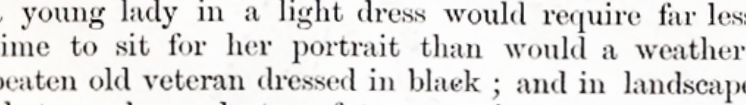
eaten old veteran dressed in black ; and in landscal

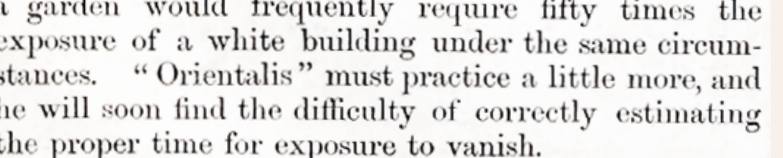

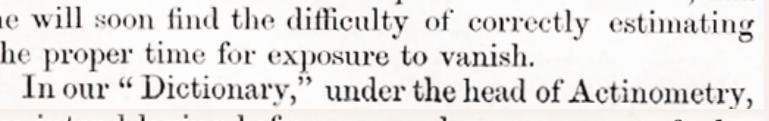

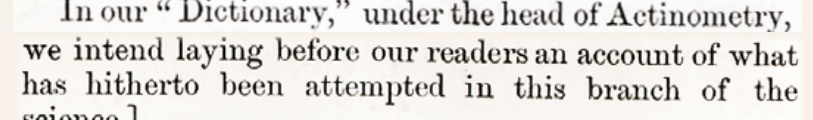

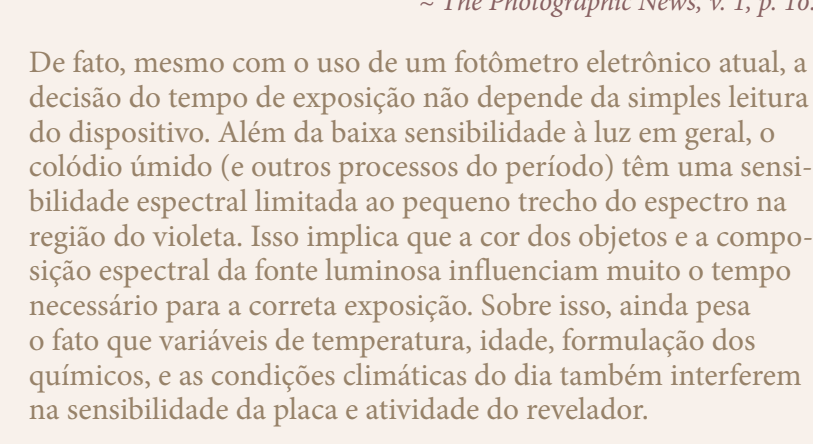




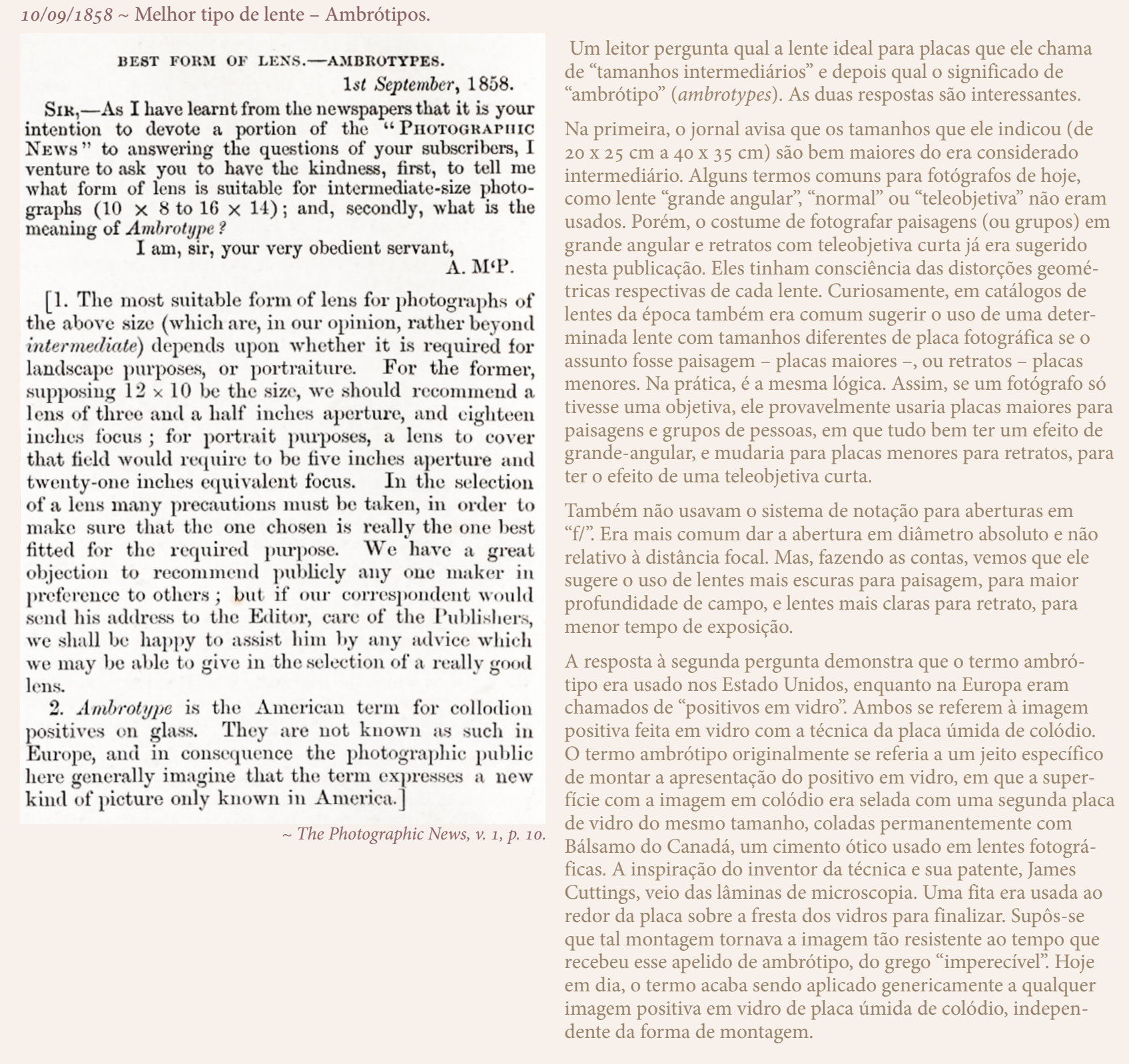

zer o verniz histórico para pro

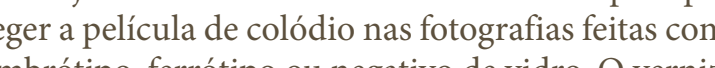

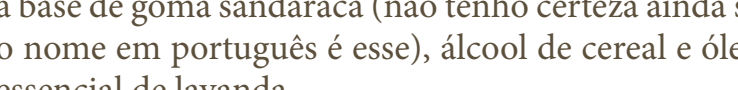
A receita leva al

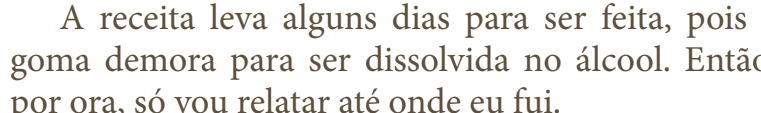
A receita que escollhi é ass

Verniz de goma sandáraca e lavanda

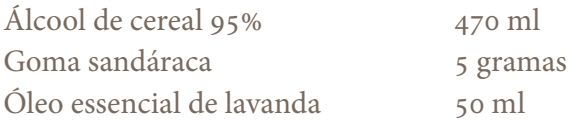
A goma foi colocada no frasco e os $470 \mathrm{ml}$ de ál-
cool de cereal forma adicionados. Pensando agora álcool no frasco e adicionado a goma aos poucos para não empelotar tudo no fundo.
Depois de agitada, a goma ainda não dissolve toDepois de aghtada, a goma ainda nao dissolve to que muita sujeira iria aparecer no líquido. São pedacos da própria planta de onde a goma foi extraída
Super natural! Agora é esperar ela dissolver no álcool dando umas agitadas sempre que possivel.
Se tudo correr bem, depois irei filtrar a soluçãa
para tirar toda a sujeira. rocedimento, "visitei" minha sporadicamente ao longo dos dias e pude observar dissolucão lenta mas contínua da goma. Ao final do
segundo dia já estava praticamente tudo dissolvido muita sujeira estava no fundo da garrafa. Como tivemos cursos no laboratótrio nesse meio
tempo, só hoje consegui filtrar a mistura e continuar A filtragem é extremamente necessária para reti-
rar a sueira da soluçăo. Eu li que a filtrageme pode ser

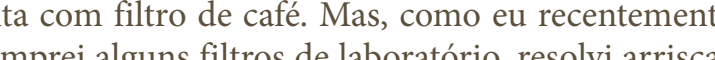
a uśálos e ter uma filtragem mais fina. O medo era filtro entupiri ea goma comecar a secar.
Un lembrete: pode acontecer uma certa sujeira principalmente se derrubar um tanto da solucáo na
pial $\mathrm{O}$ verniz endurece em contato coma a gua como pial $\mathrm{O}$ verniz endurece em contato com a agua co
eu vim a aprender), entáo é bom ter certeza de todos os frascos e ebjettos estejamm bem secos.
A solução passou sem muitos problemas pelo A soluçăo passou sem muitos problemas pelo fil-
tro; porém, tive que trocá-lo duas vezes para passar tros porém, tive que troca-lo duas vezes para passar
tudo sem demorar muito. Os filtros ficaram bem su-
jost A solucion filtrada ficou bem limpida e amarelajos! A soluçāo filtrada ficou bem límpida e amarela-
da. Adicionio o ollo de lavanda. Depois de toda essa filtragem e troca de frascos
diat ficou tudo com uma camada meio esbran quicada de
verniz seco nas coisas. Não adianta lavar com sabão

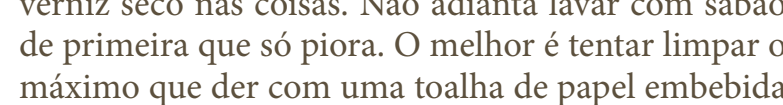
de élcool de cereal. Depois que tiver tirado o máximo E, zá que eu acabei tudo, por procedimento de envernitar una laca é muite

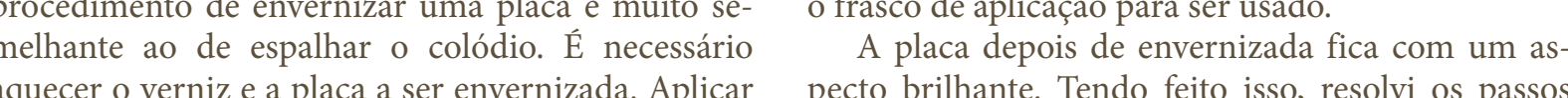

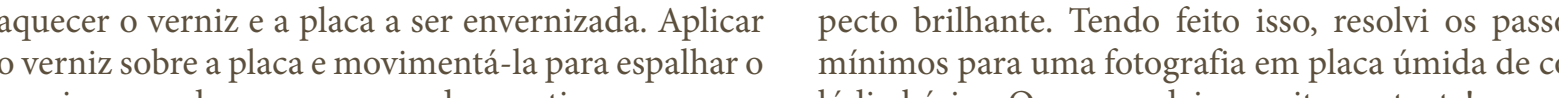

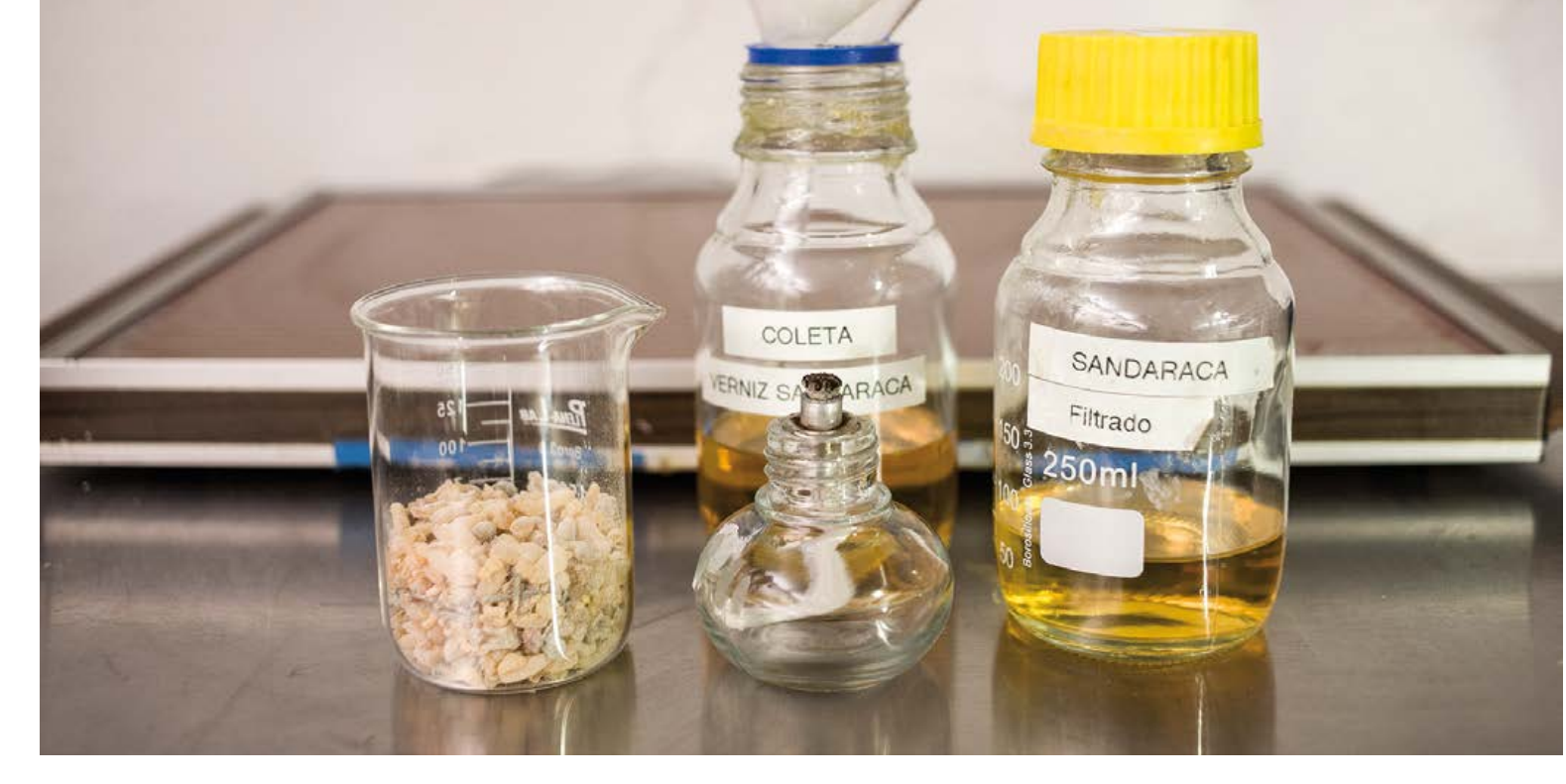

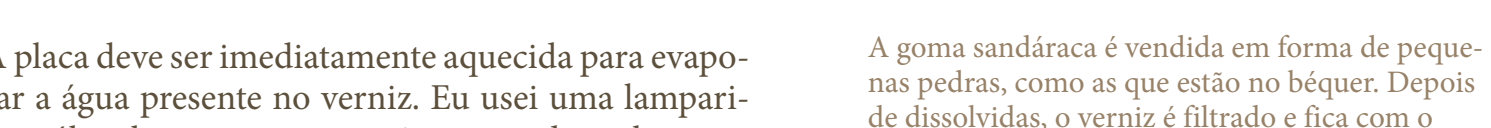

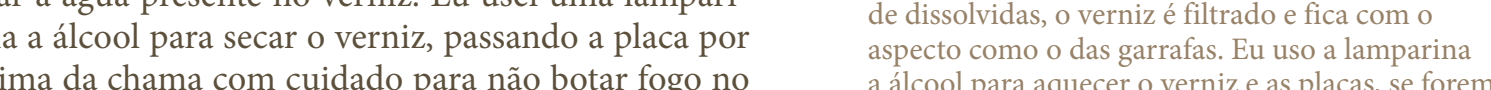

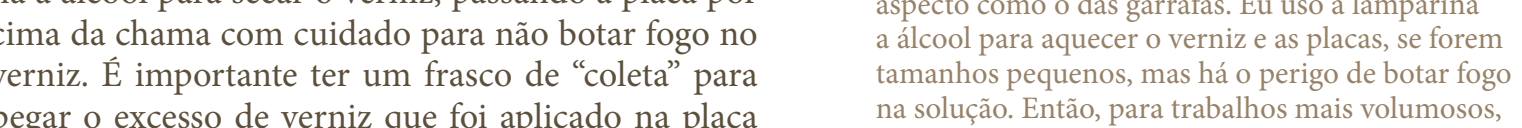

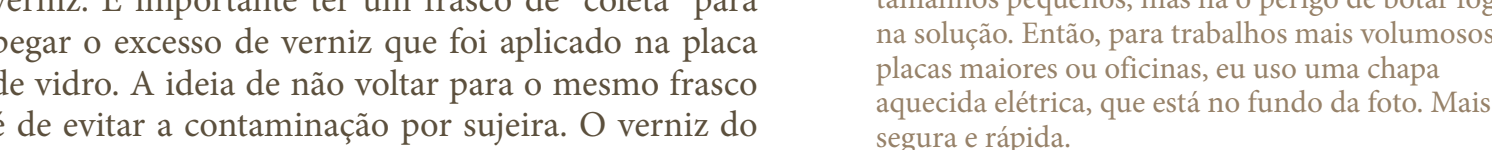


É impossivel não cogitar a ideia de fazer ambróti-

pos "por al, longe do laboratorio. Hoje resolvi fazer

processar as placas. Junto com o Fernando, arran-

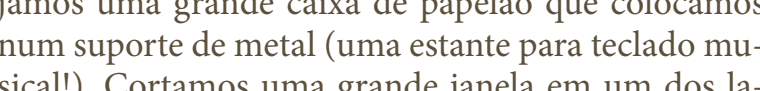

dos e prendemos uma lona opaca ao redor do buraco

Para decidirmos o que é necessário levar em uma

saída, pensamos na seguinte estratégiai: montar a cai-
xa do lado de fora do laboratório e tentar procesar

uma foto dentro dela. Tudo o que precisarmos bus-
car dentro do lab para fazer isso, deve ficar do lado

de fora. Assim, ao final tínhamos separado as diver-

sas coisas.
Fizemos très fotos com sucesso e agora cogitamos

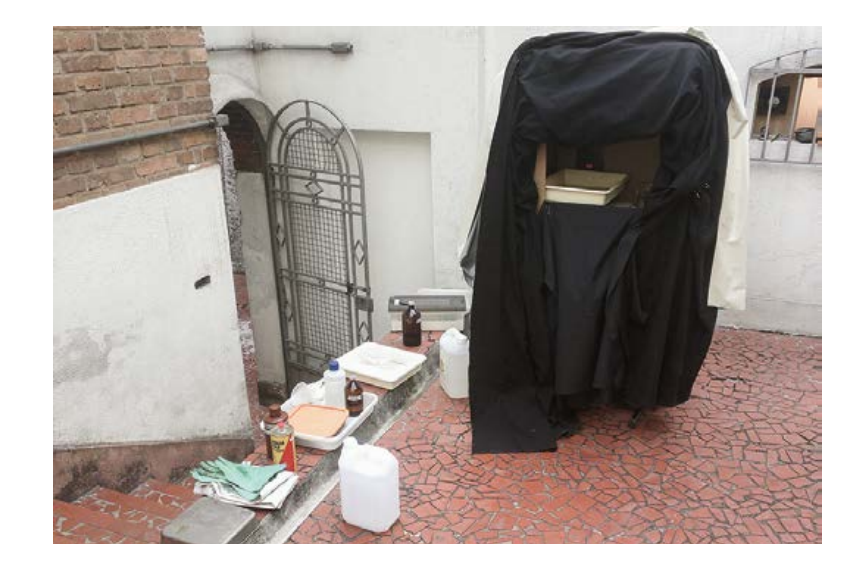

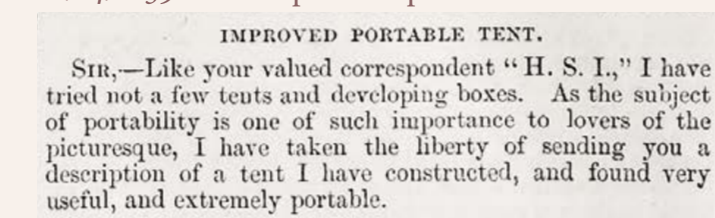

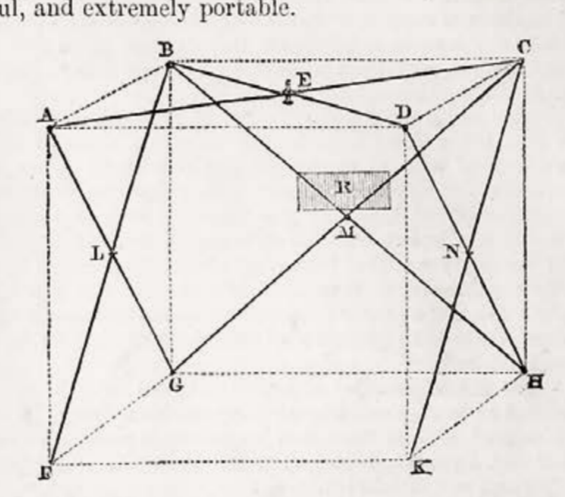

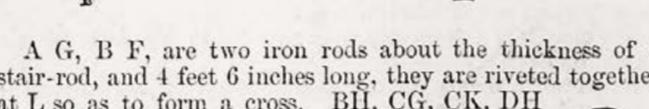

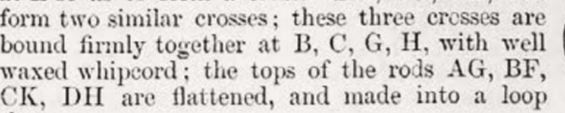

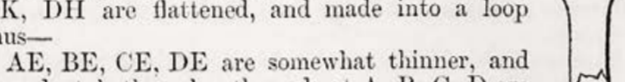

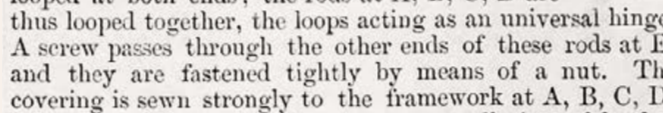

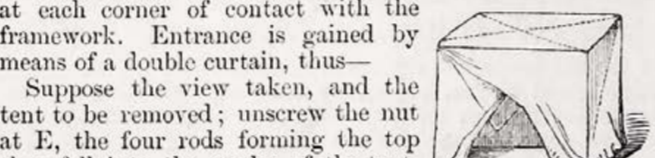

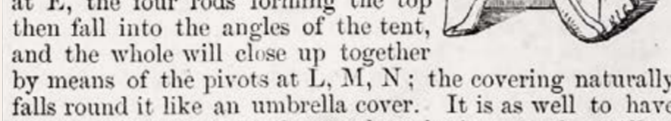

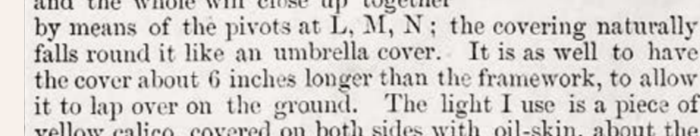

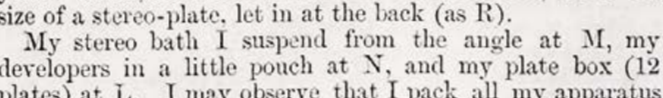

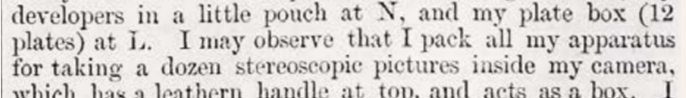

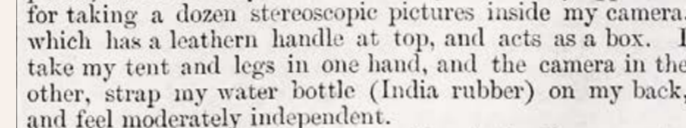

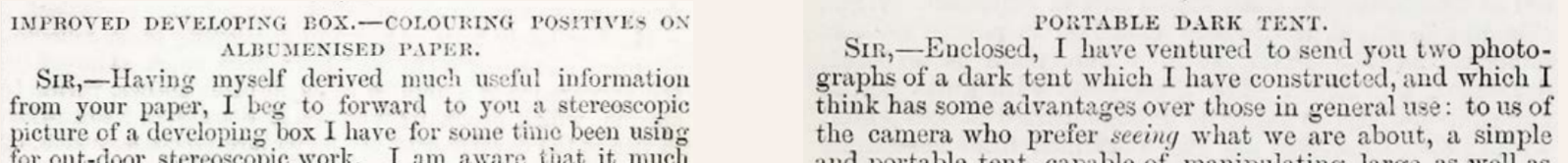

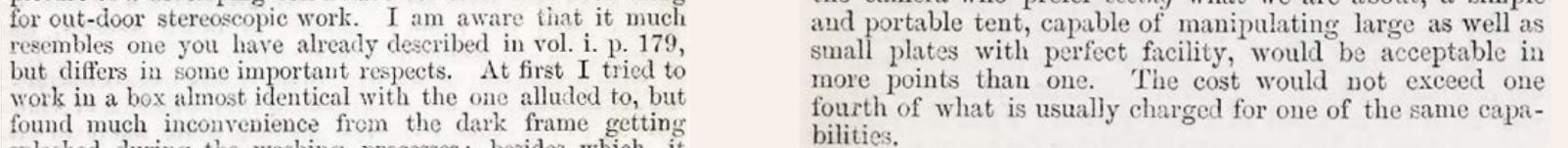

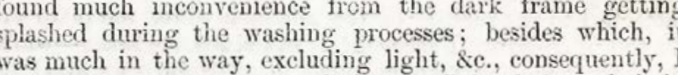

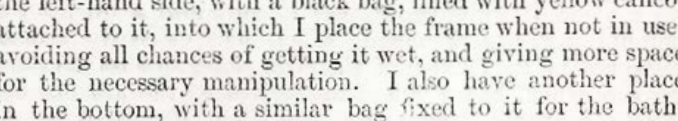

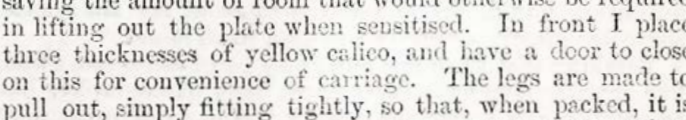

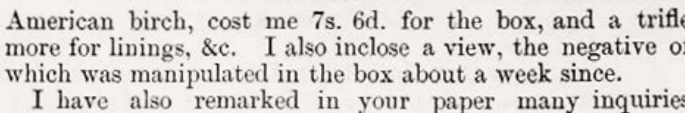

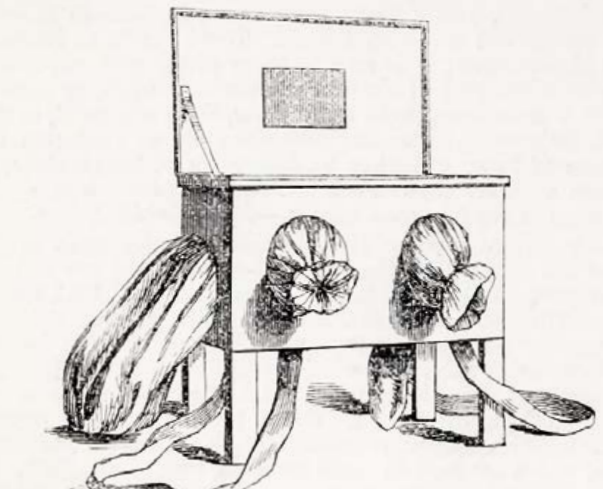

vifficulty of making the vatere-colours allhere. The plan I

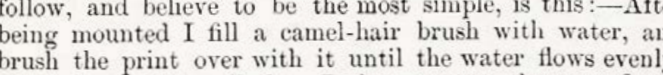

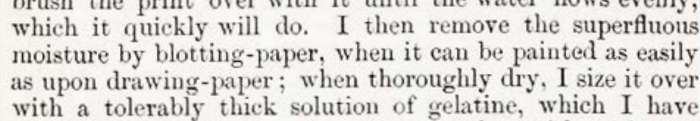

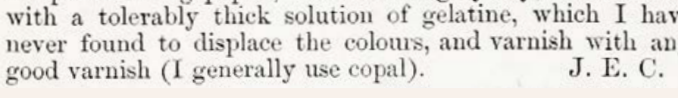

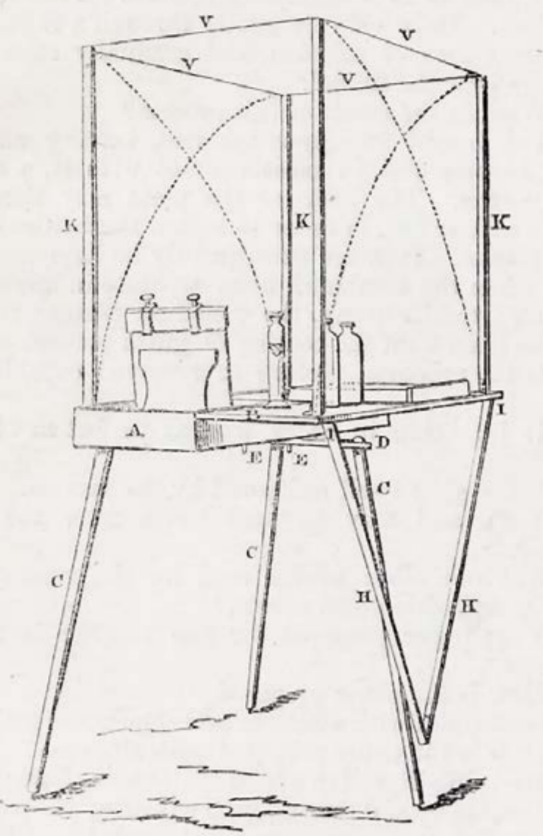

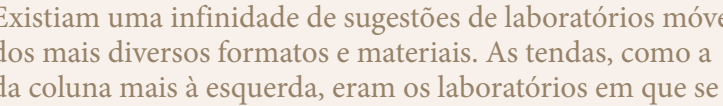

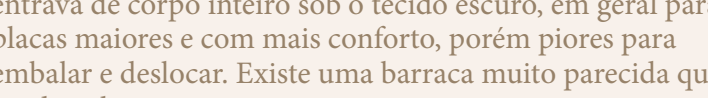

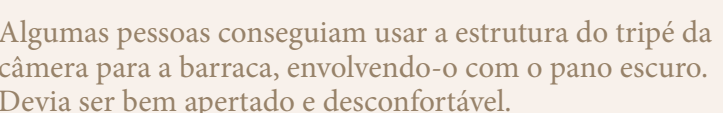

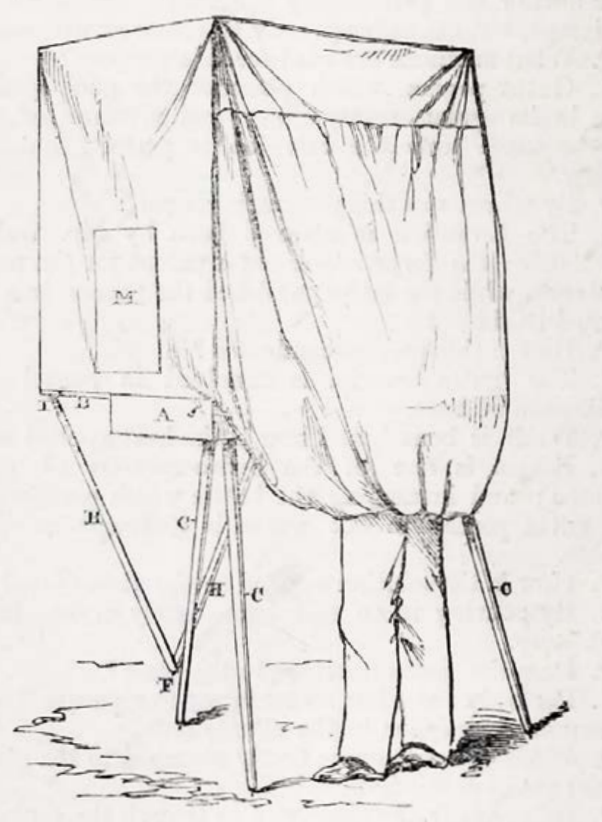

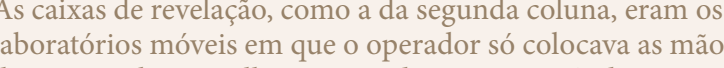

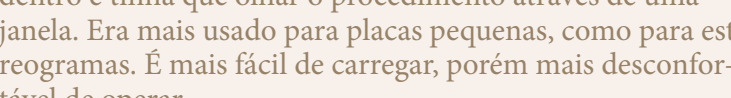

Unm meio-termo entre as tendas completase eas caixas de

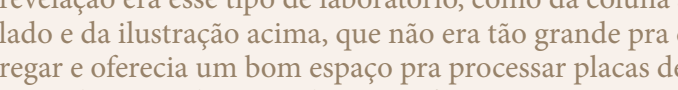




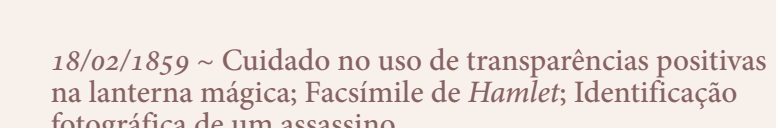

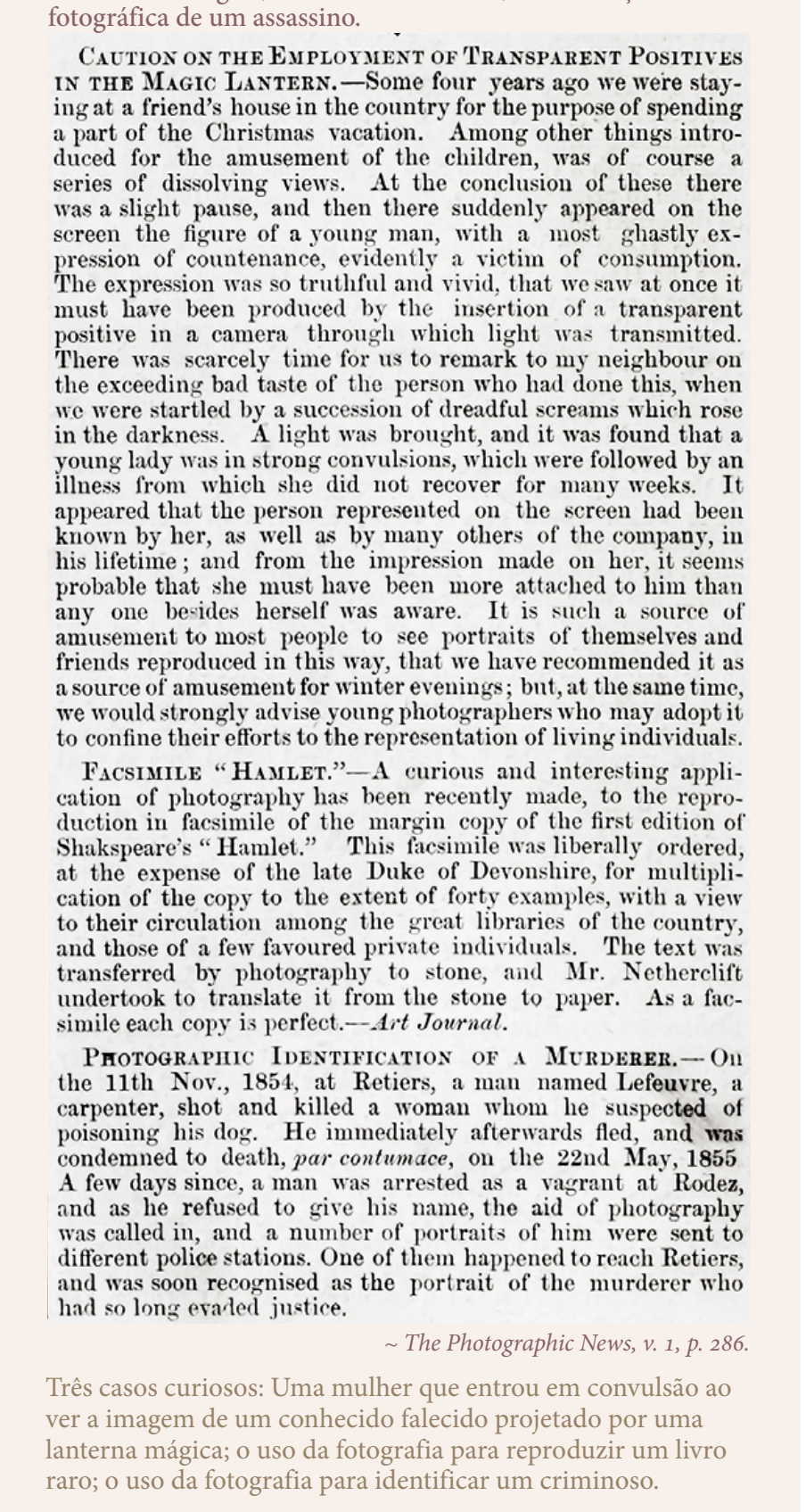

de setembro de 201

H. um rápido ensaio no quintal do laboratório, resolve mos arriscar mais e viajar para Nazaré Paulista a 70
$\mathrm{~km}$ da capital. Longe assim, não tinha como dar un Preparando as coisas para a viagem, ainda no $c$ enforto de ter dois porta-malas inteiros à disposiça-
deu pra ter uma leve ideia do esforco que era um viagem fotográfica no século 19. Ah, meu xará Roger
Fenton sofreu! Nossa estrutura de equipamentos era

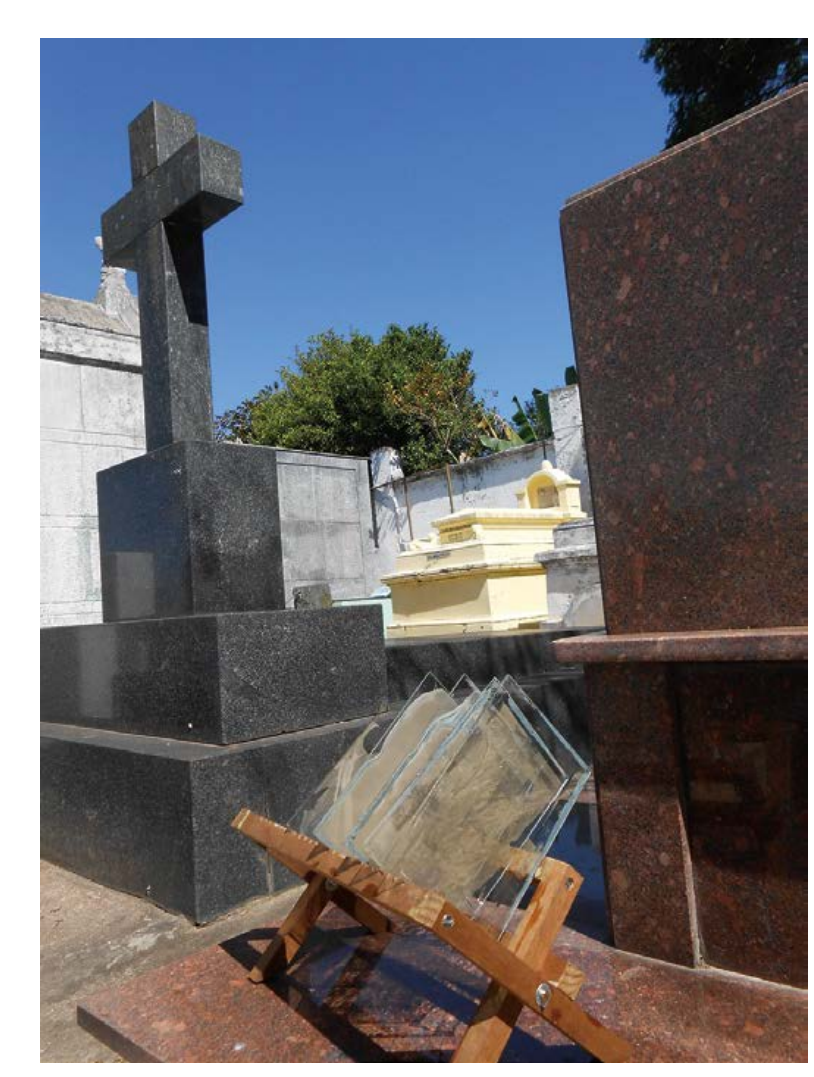

caixa de papelăo, estante de teclado, pano preto
nossso laboratorio móvel.

andeias diversas

tuas caixas de vidros limpos (para fazer

10 litros de água deionizada (mas não usamos nem metade)
-5 litros de água limp galāo vazio para a colete de água usada - variedade de pequenos instrumentos e vidrarias - uma câmera
dois tripess

Nosso time "expedicionário" foi um bom grupo
amigos amantes de fotografia dispostos a passat nológico das missōes. Ė taa estranhho explicara o que

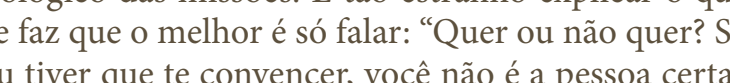
Oimportante tambémé limpar a a agenda do dia, nada de horário para voltar. Sim, demora.
Nâo sei se diz algo da nossa personalidade, mas ao chegara à cidade, fomos direto ao cemitérid o fazer no no bs tomavam sol no pátio, devidamente enterrado the chamada de Lab Móvel ma supeláo, dora-

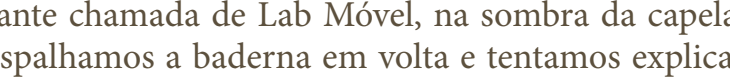

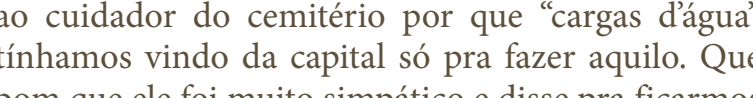
bom que ele for munto sim so

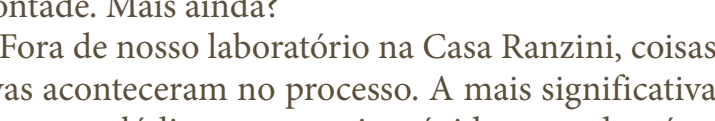

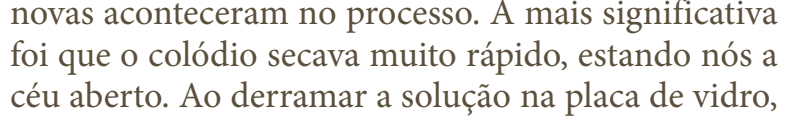

o lado que recebia o colódio primeiro já secava antes
de acabar de cobrii o resto da placa, causando manchas na sensibilizacăa. A soluçăa foi adicionar mais
álcool para retardar a secagem, o que ajudou mas nào resolveu.
Outro problema foi a lavagem final das placas Sem agua contente fica dificil. Danificiamos algum placas em uma soluçăo de glicerina e égua (1:1) que
manteria o colódio umidodo até a volta ao laboratorii para serem devidamente lavadas. Mas pensamos mal
o acondicionamento enã deu muito certo Na verllacas, percebemos que nào tinhamos pensado num
jeto bom de leval-as de volta! Voltaram equilibradas

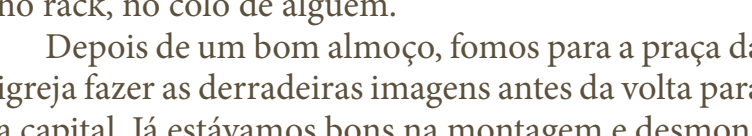

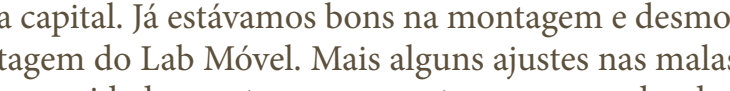

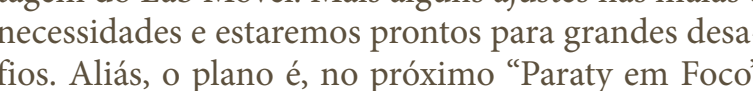

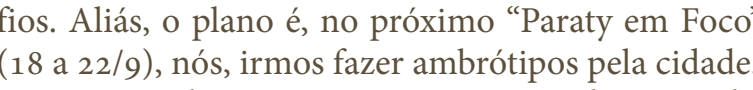
Acompanharam-me nessa empretitada:
Waldiri, Luiv, Fernando, suranan e Paulo.

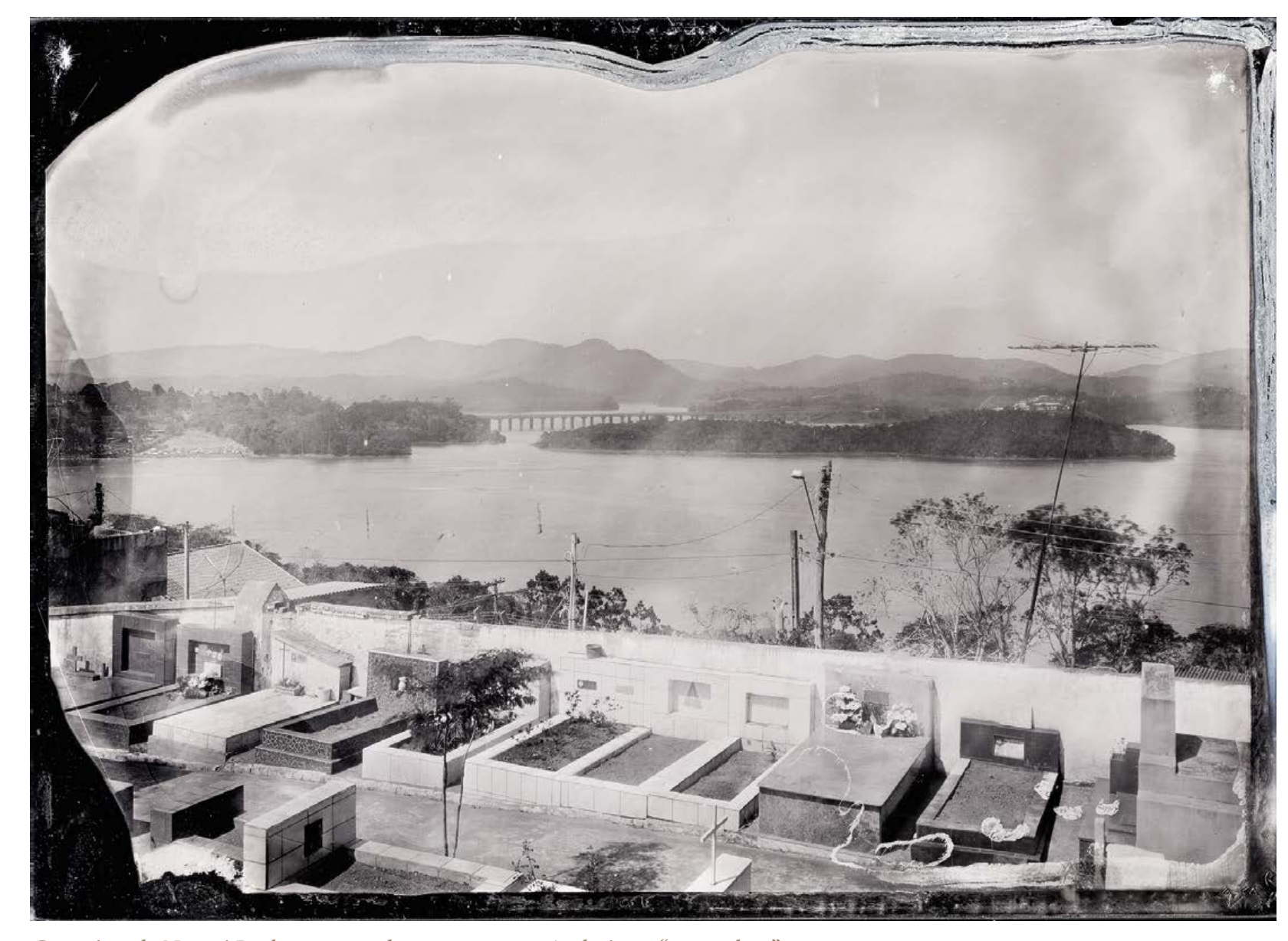

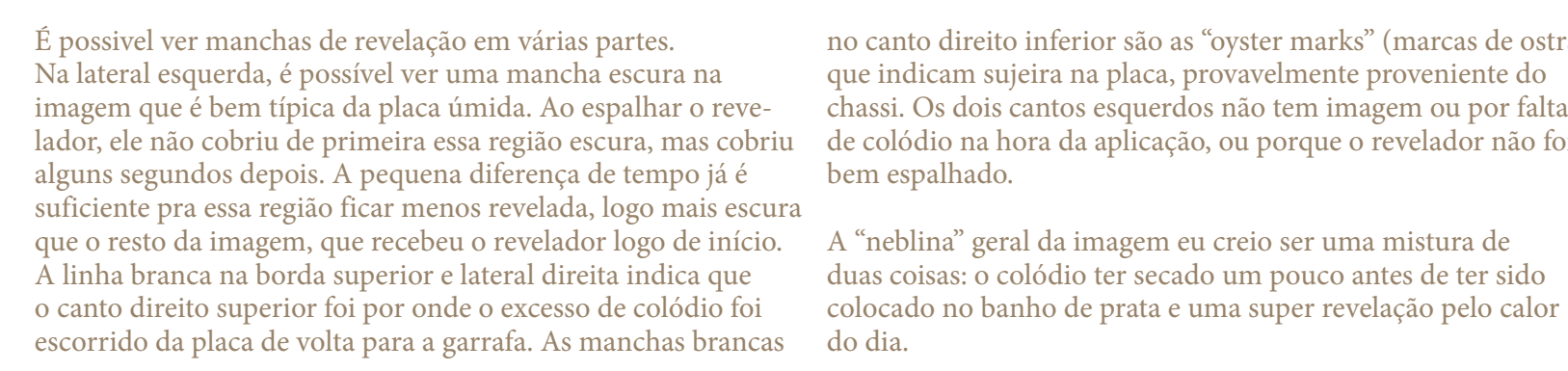




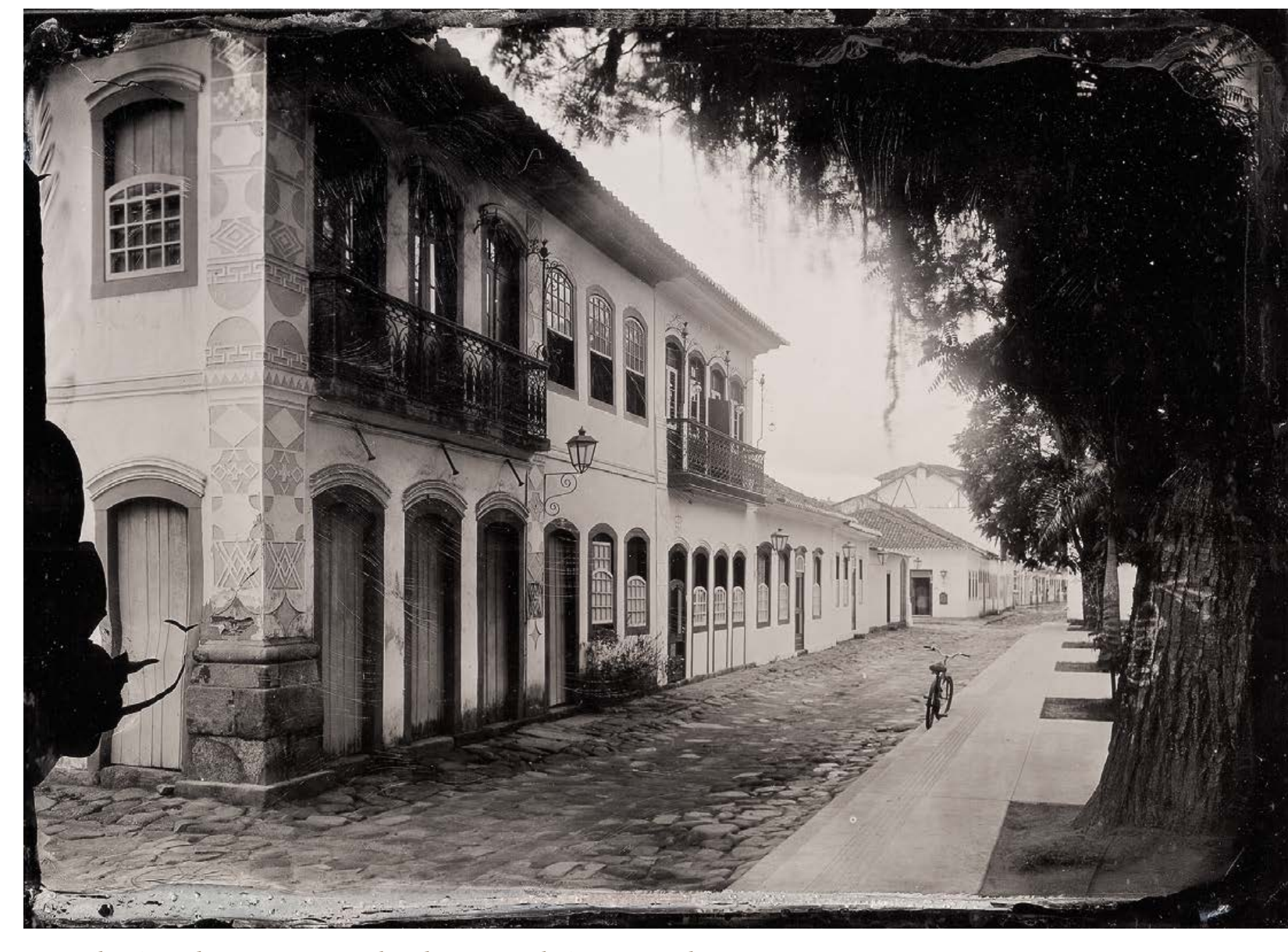

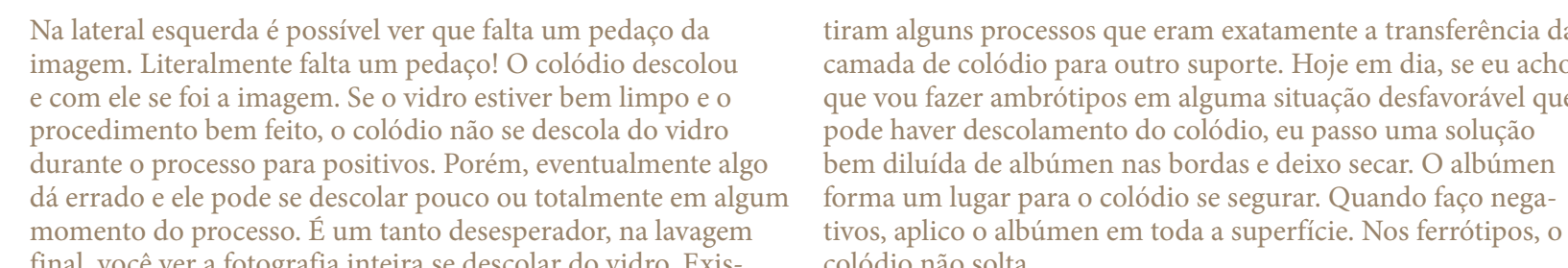

22 de setembro
(Paraty, RJ)

(Paraty, RJ)
Num ato de loucura e empolgacāo, viemos eu,
Fernando e sua esposa Suzana para Paraty (RI) para

azer nosss ativividade "off broadway" durante o fes

tival de totografiai na cidade. Náa tazemos parte
programaçao oficial, ficaremos pelas ruas fazendo

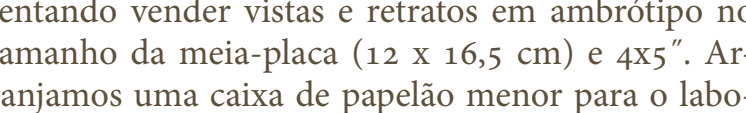

ranjamos uma caixa de papeláa menor para labo-
ratório móvel para facilitar o transporte pelas ruas da
cidade O quarto de hotel (próximo ao centro histori-

nizar os ambrótipos, bem como fazer as mananutençẽes

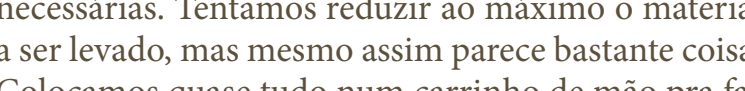

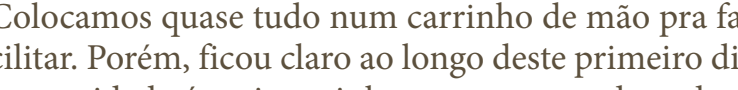

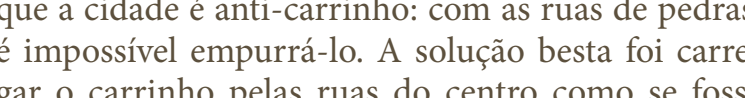

uma macal
Neste primeriro dia conseguimos sitimas vistas das

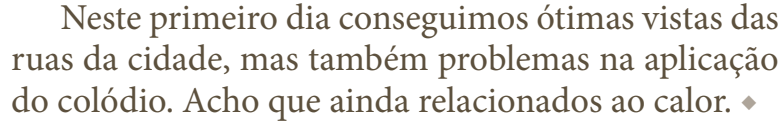

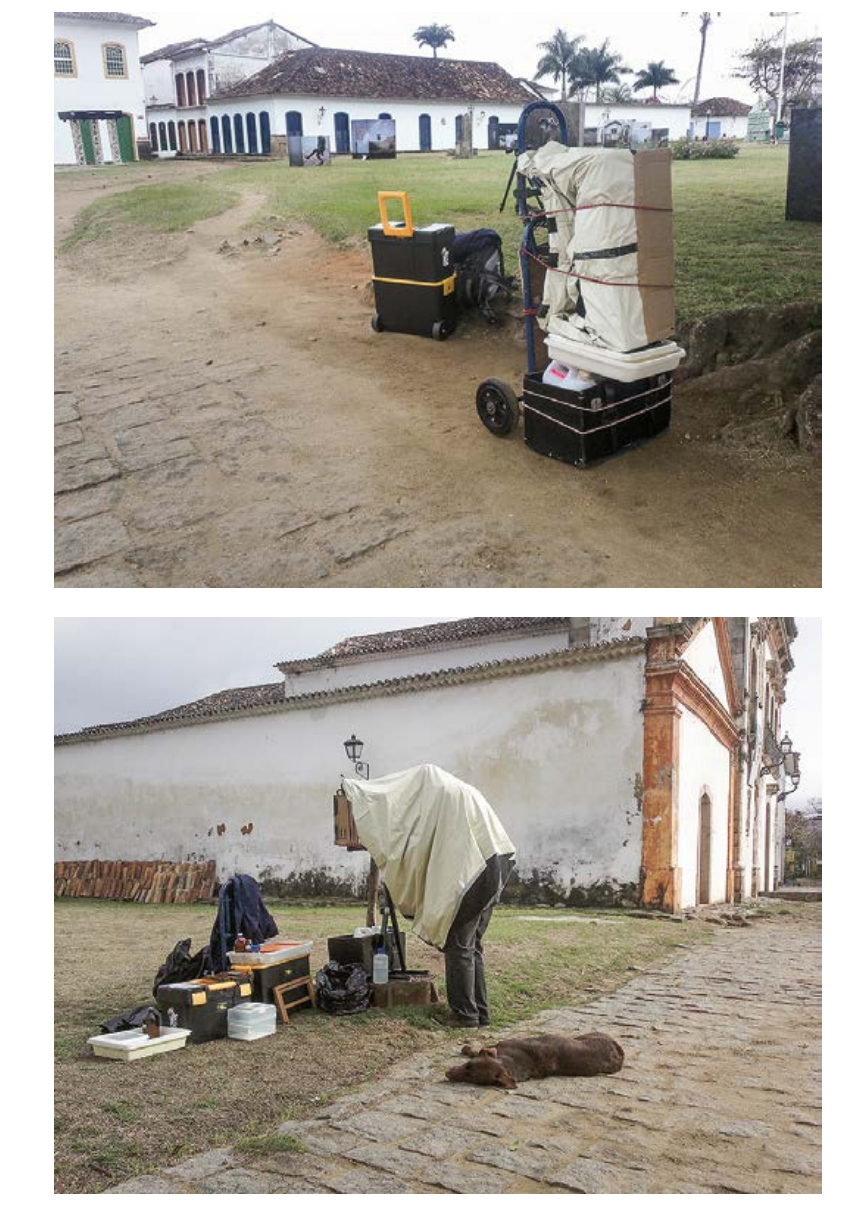
huitas coisas pequenase e soltas que 4 tis transportar. Aliás, fiquei observando os carrinhos de
doces locais. Eles temm grandes rodas de bicicleta que ajudam a transitar nas 1 .
que o carrinho de mâo. esburacadas. Bem melhor
Tamanhos de placas fotográficas

ei diversos tamanhos de também é ímportante notar que, pela natureza desse de placa em uma messma cámera, como o uso de redu maior tamanho de placa possiverl, mas permite tamaA primeira câmera que Daguerre comercializo utilzava um
como Placa Inteira. A partir dela, tamanhos meno 1/4,1/8 eassim por diante. Mesmo assim as medides tinham suas variaçoes, como a meia-placa que um inglesa?. A tabela abaixo tem os formatos que usei
Eventualmente, uso um dos termos de cada tamanho

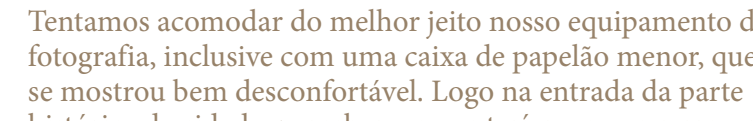

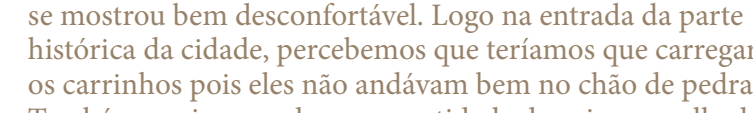

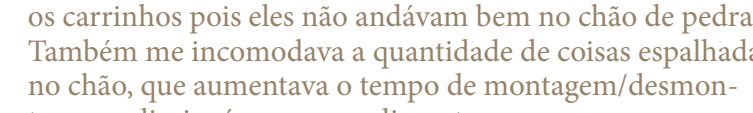



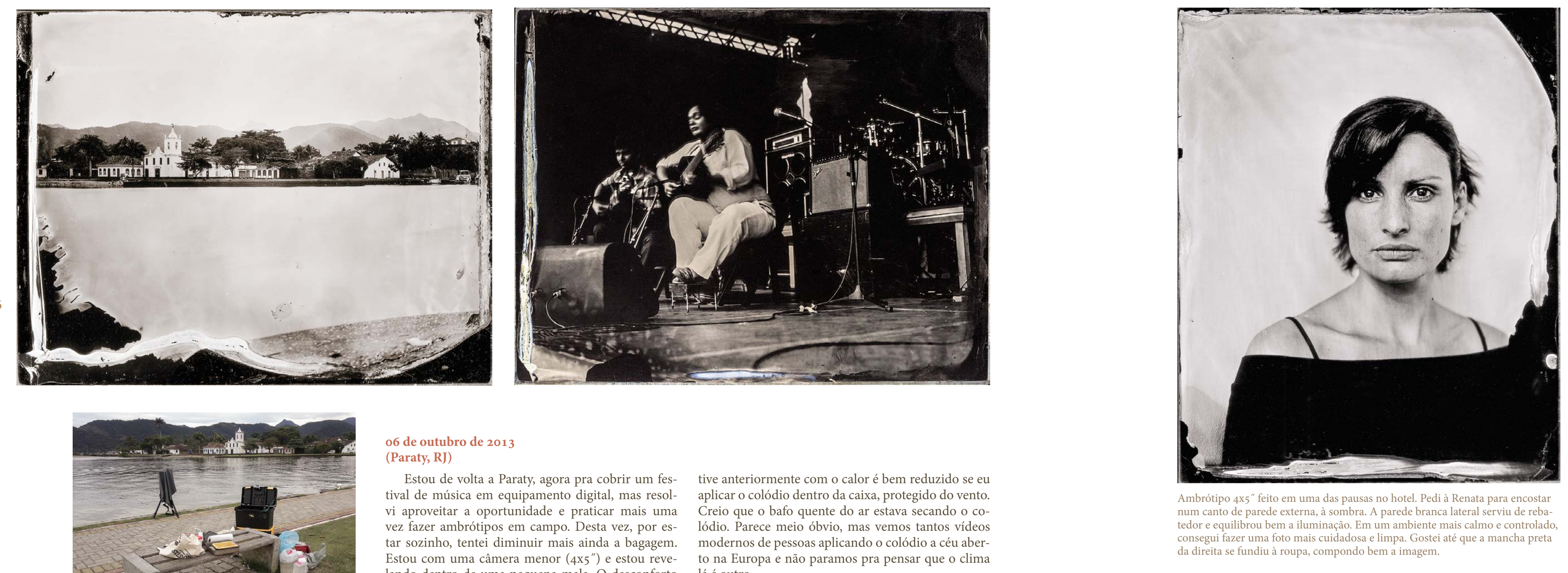

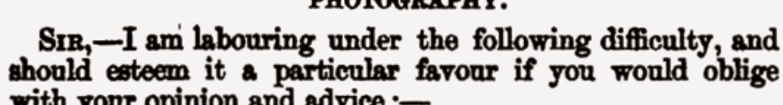

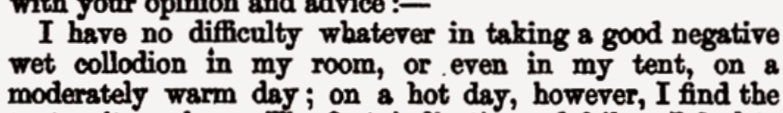

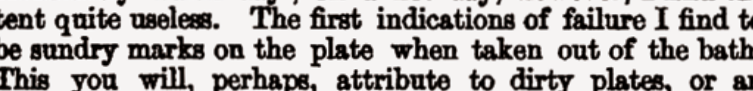

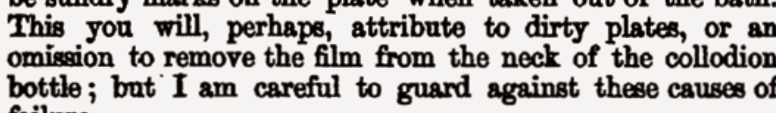

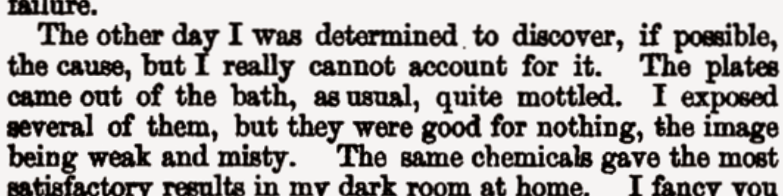

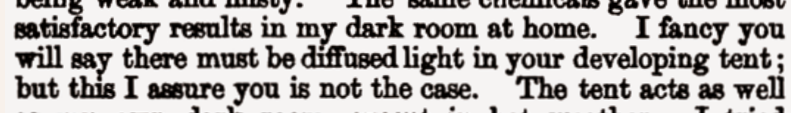

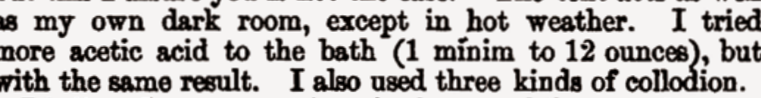

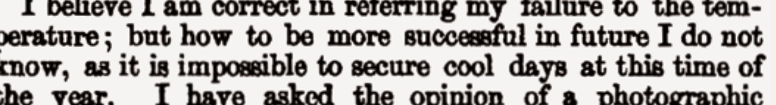

(a)

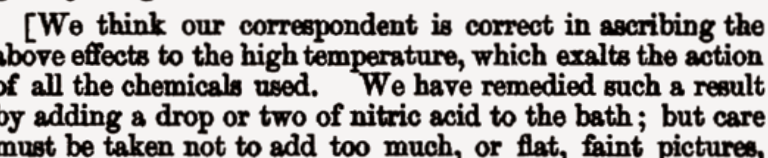

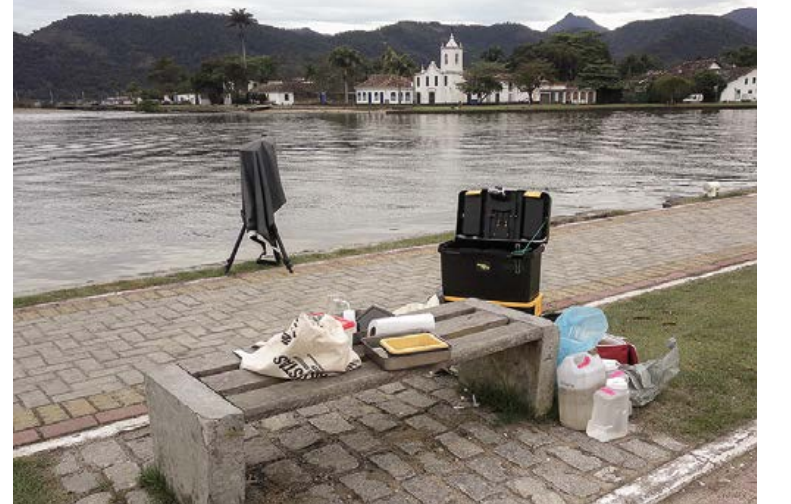

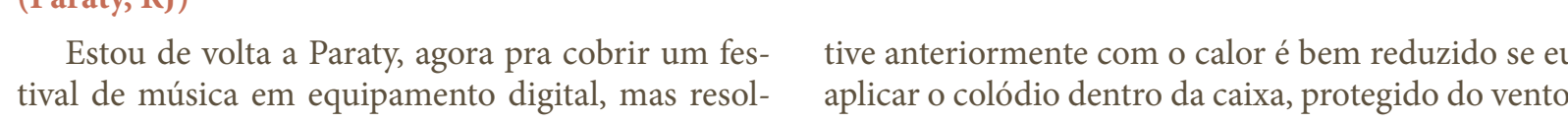

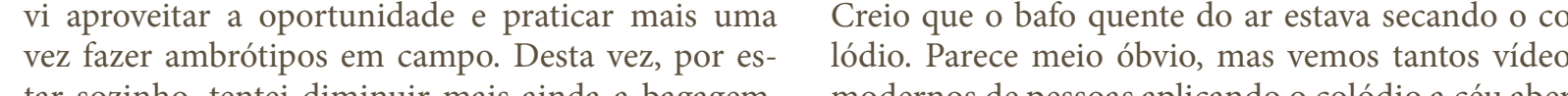

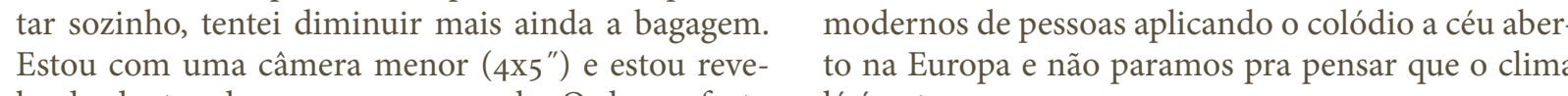

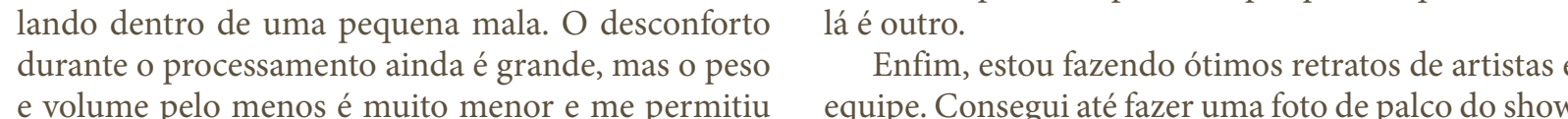

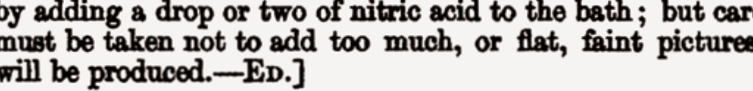



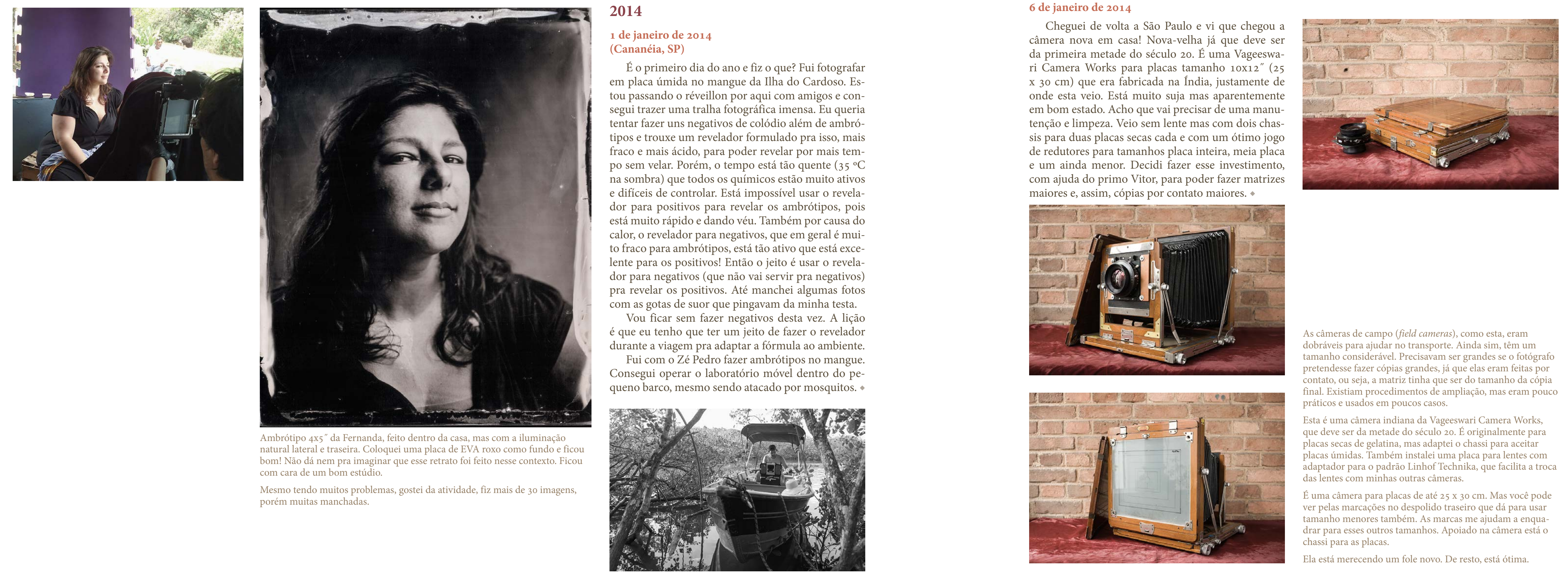

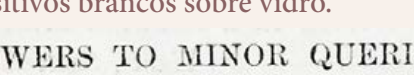

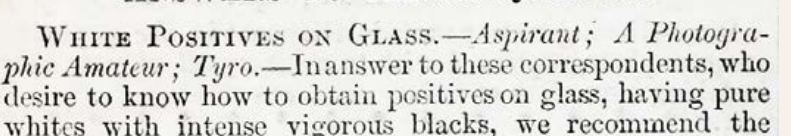

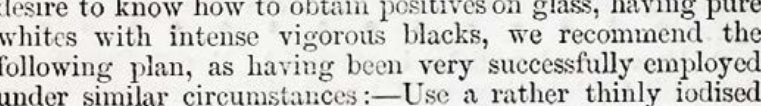

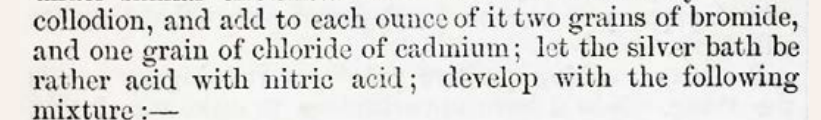

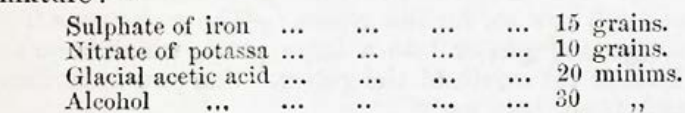

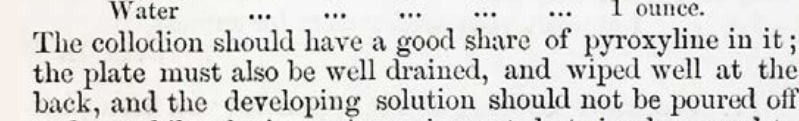

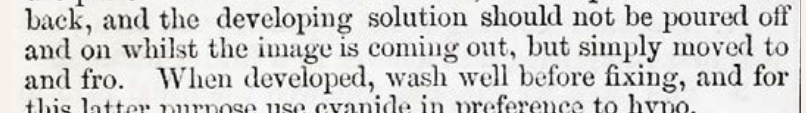

The Photogyaphic News v. ., ,

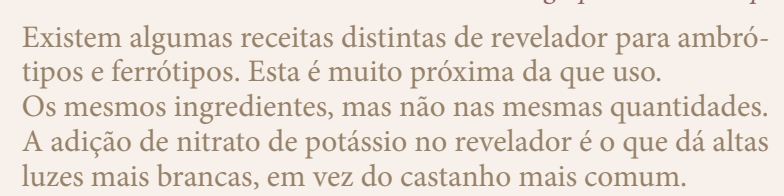

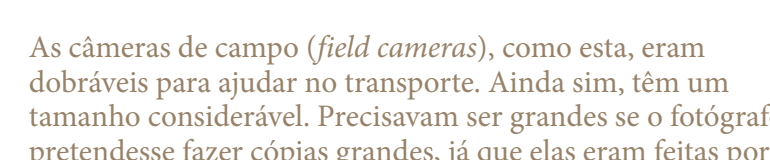

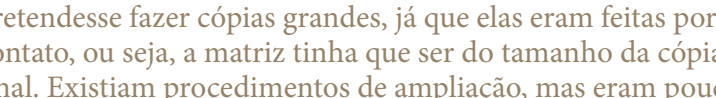

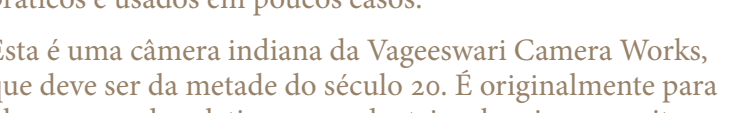

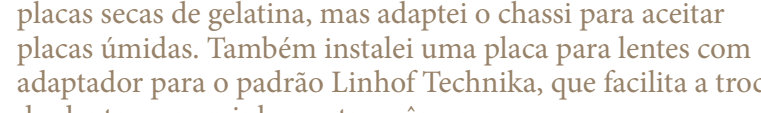

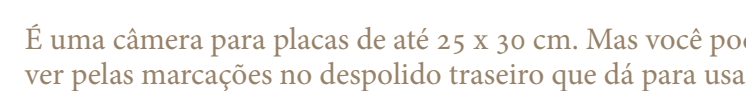

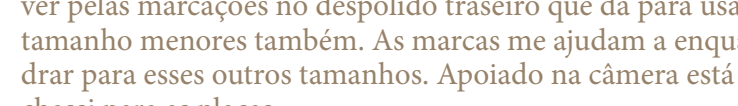

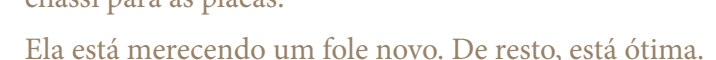



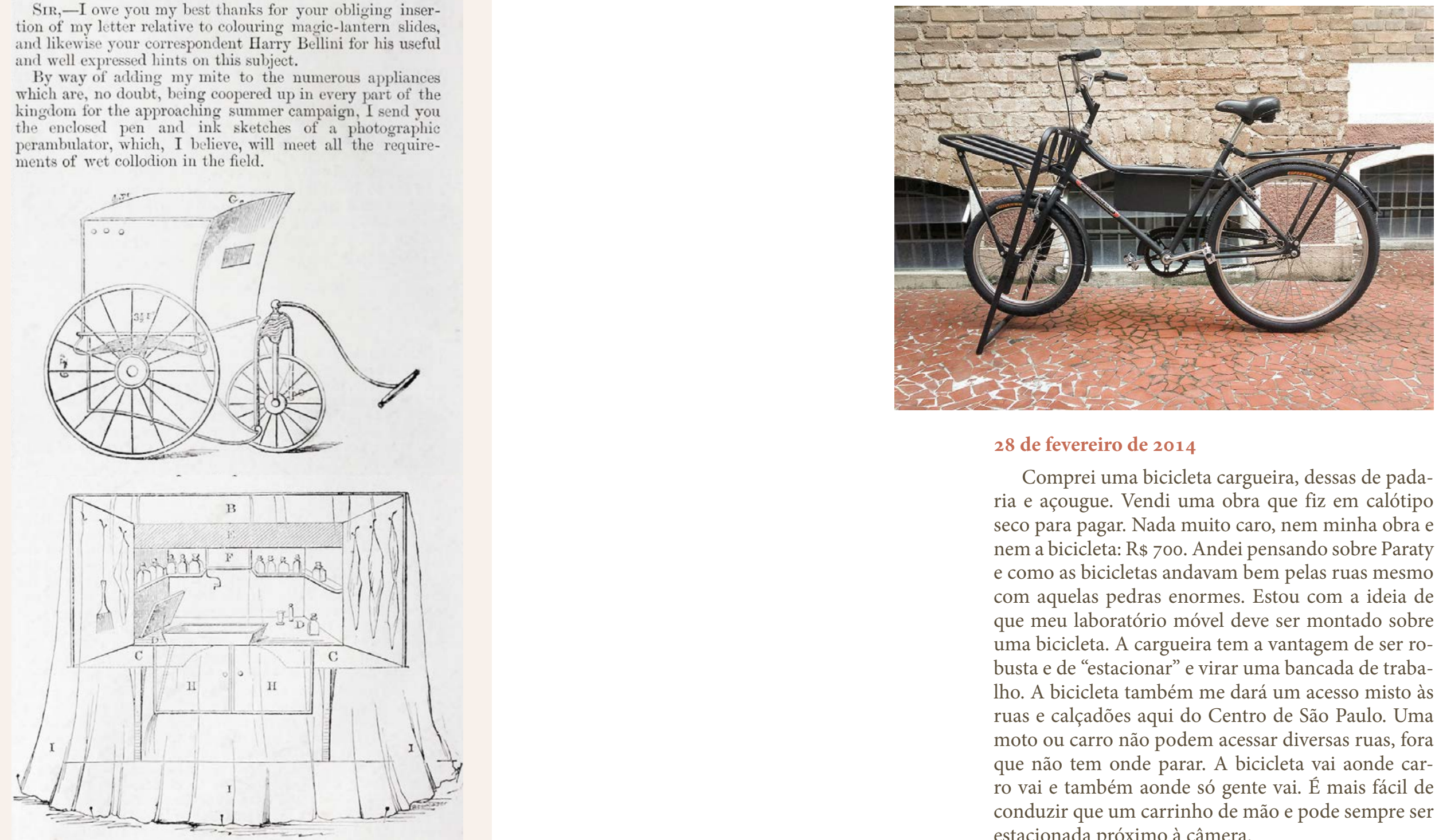

28 de fevereiro de 2014

Comprei uma bicicleta cargueira, dessas de pada-

seco para pagar. Nada muito caro, nem minha obra $e$

e como as bicicletas andavam bemm pelas ruas mesmo

que meu laboratório móvel

busta e de "sestacionar" e virar uma bancada de trab-

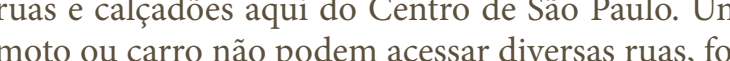

que não tem onde parar. A bicicleta vai aonde car

estacionada próximo à câmera.

Desenhel uns esbocosos de como pode ser o labo-
ratório, mas só com a bicicletá é que dá pra decid

melhor. Nos próximos dias vou comprar os materiais

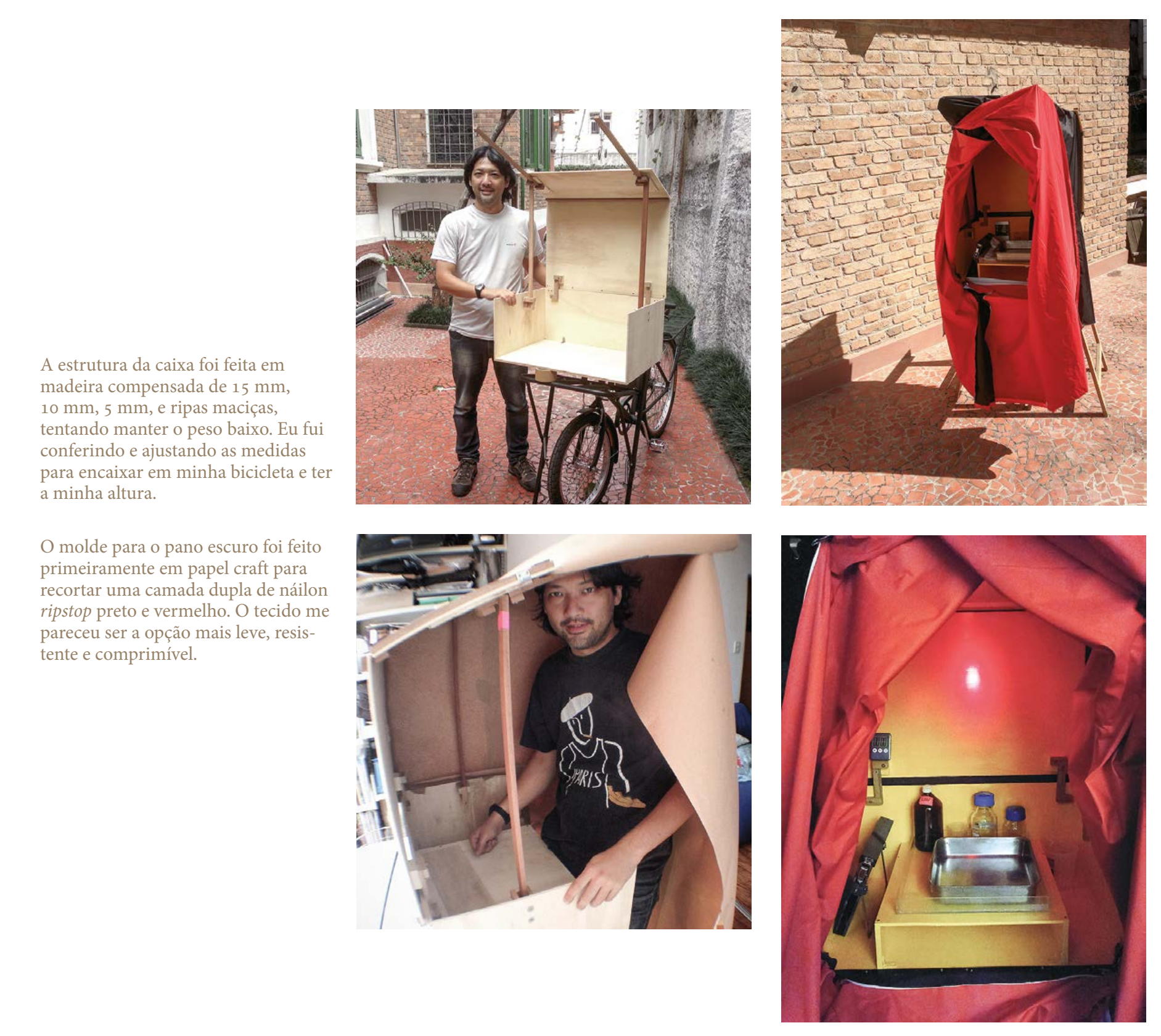

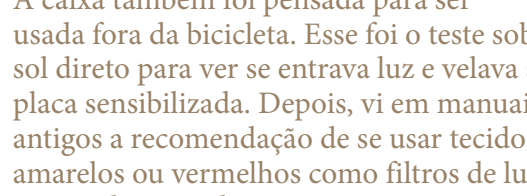
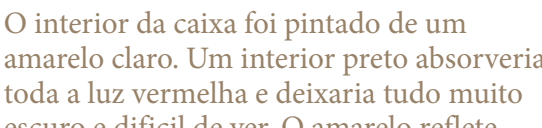

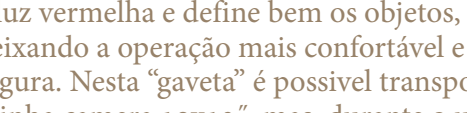

ve para guardar as bandeias se limparto

esquerdo, esta meu tanque de bant
para placas atet $13 \times 18$ com.

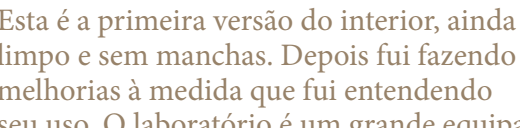




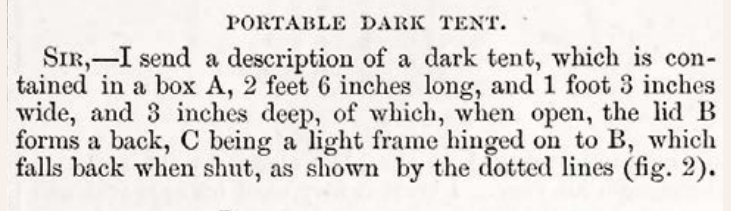
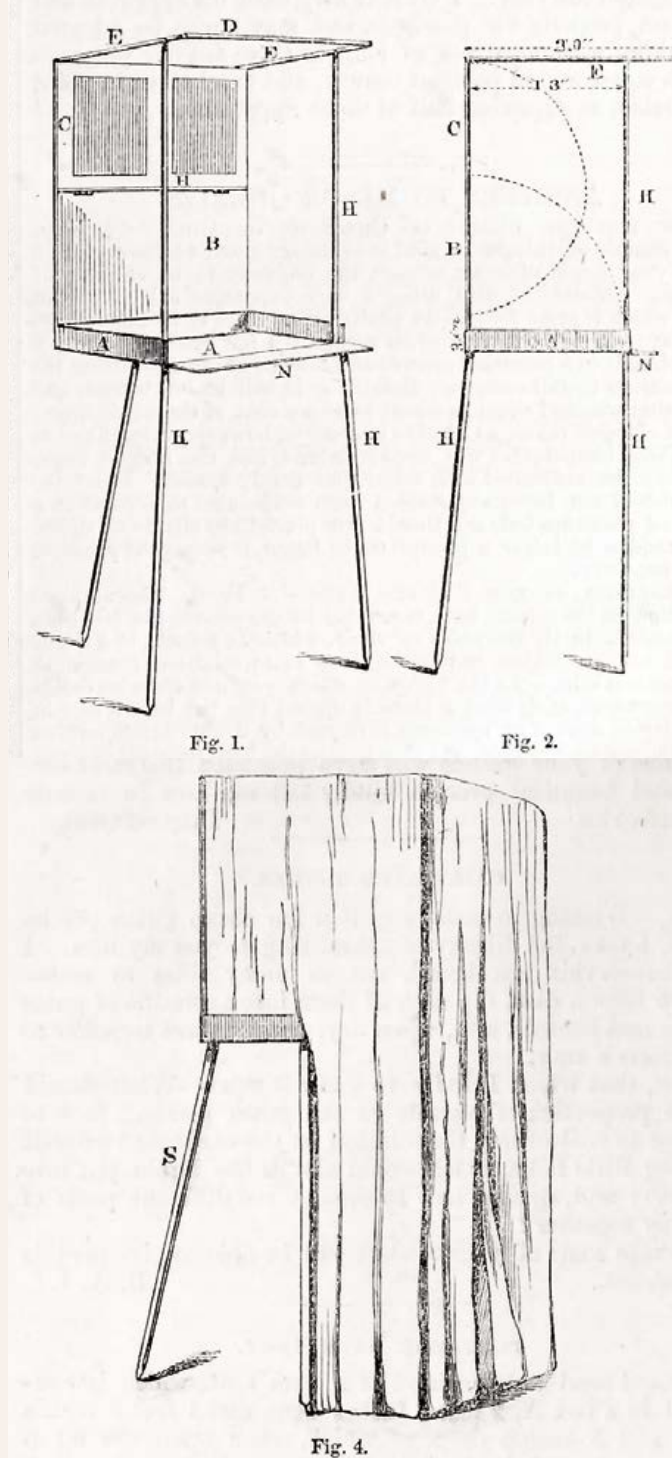

13 de abril de 2014 Simone. Fiz um ambrótipo meia placa do prédio floblema inesperado foi ter que chamara o o socorro da ci-
clovia poiso pneu murchoue enáo tenhou A parte principal da colódio-bike éa caixa e sua revelação. Até onde sei, o modelo que const

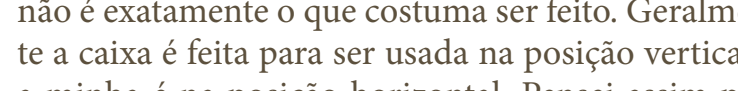
da de abrir e montar. Sua dimensáo foi pensada pars ser compatível com placas de até $25 \times 30 \mathrm{~cm}$, apesar
de ainda náa ter usado esse tamanho nela. Aaltur
total quando abertae colocada em cima da bicicles nada por uma luz que não vela a placa. Tive a ajuda No bagageiro traseiro eu quero fazer uma outra mentos de forma a que eu possa usar tudo sem coloNao o ideal mas por enquanto é que tenho-
O legal é que a caixa escura pode ser usada tamenbaixo do sol mas vale muito a pena. E Enuto bo poder sair do laboratório e fotografar pela cidade. Pe total, quando abertae colocadd A caixa foi construida inteira em madeira conclara. Isso permite que o interior fique bem mais minoso, o que facilita para achar as coisas. Minh possivel de ver frascos e tais. Aumentava bastante chance de derrubar algo por esbarrão. A iluminaçà parte superior. Por sinal, a mesma luz que uso
bicicletp

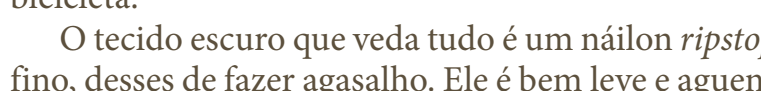
ta bem a água. Usei duas camadas, uma preta e um

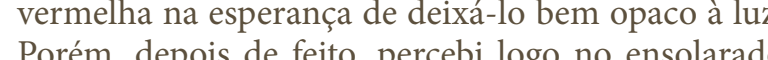
dia seguinte que a luz passa por ambas as camadas Resolvi ir em frente e fazer toste de estreiaia da caixa
aind no atelêe, e constatei que a luz que passa pelo

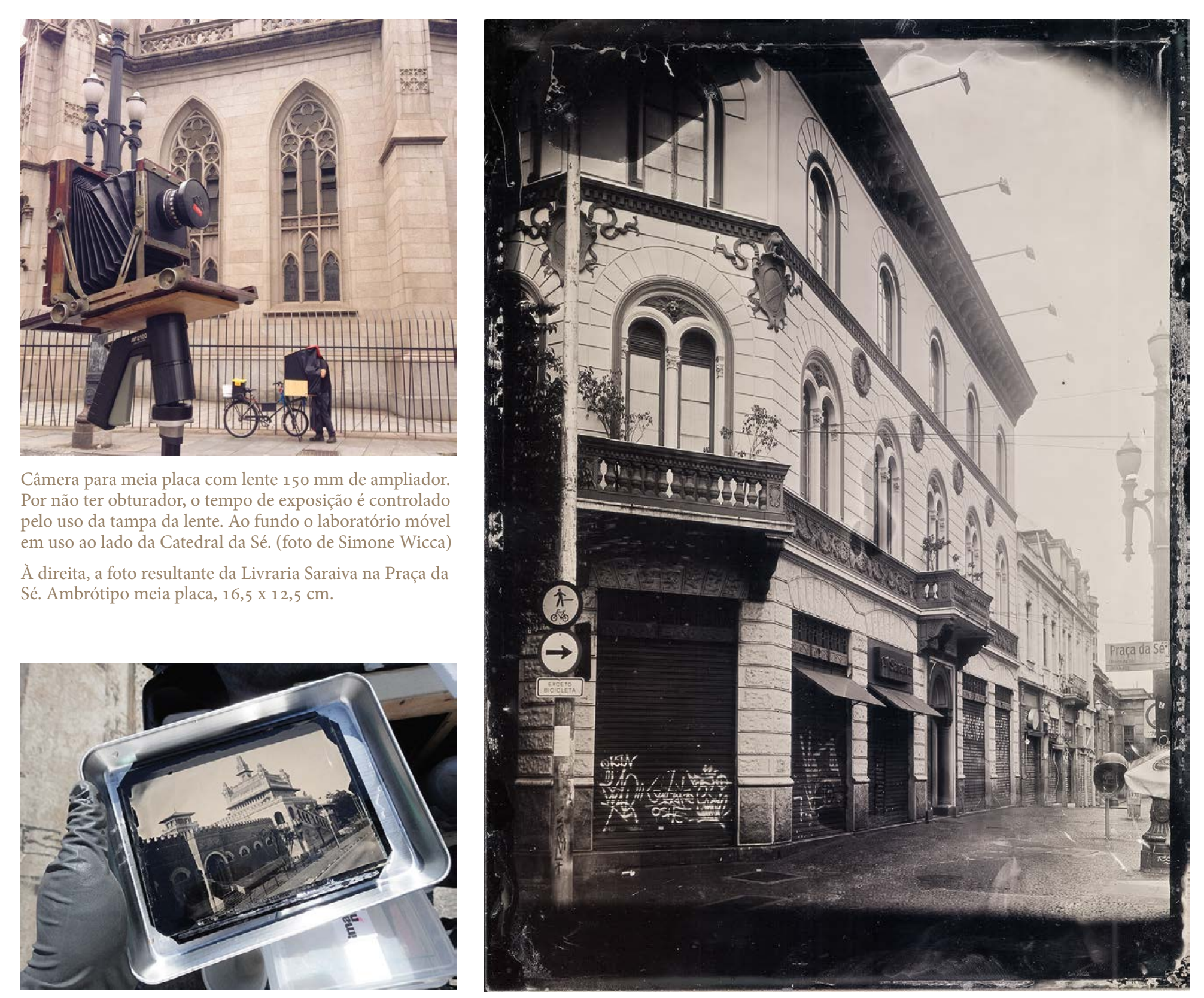



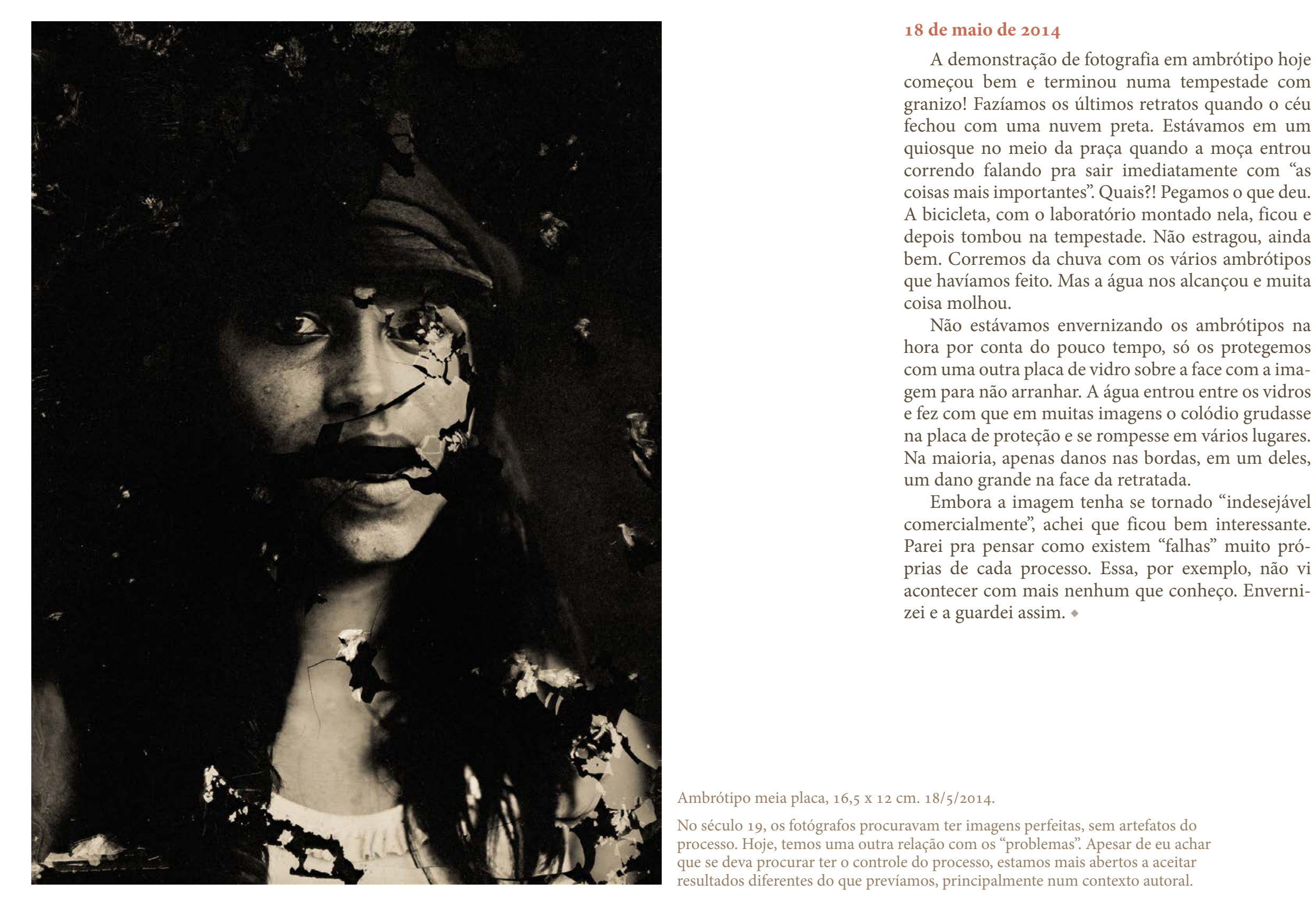

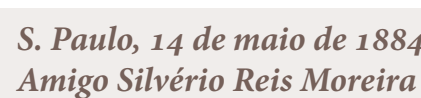

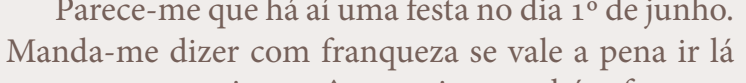

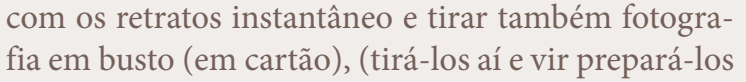

Meus respeitis a tua famlia e dispon

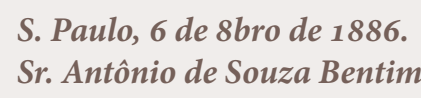

que deixava a maquina por 150 :00 0 amigo engal

que $e \hat{a}$ mesma que a mim ainda enganasese Nada

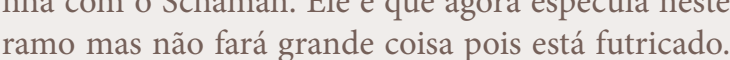

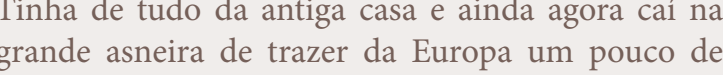

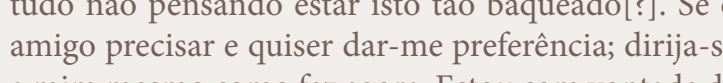

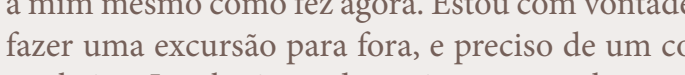
lugareses, por issose se quisere achar que se pode facec

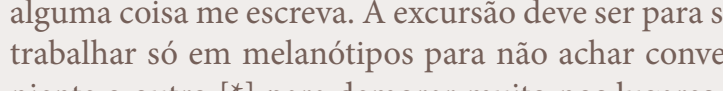

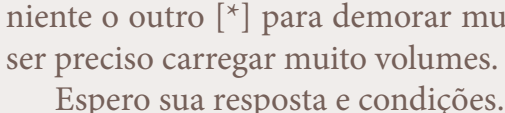

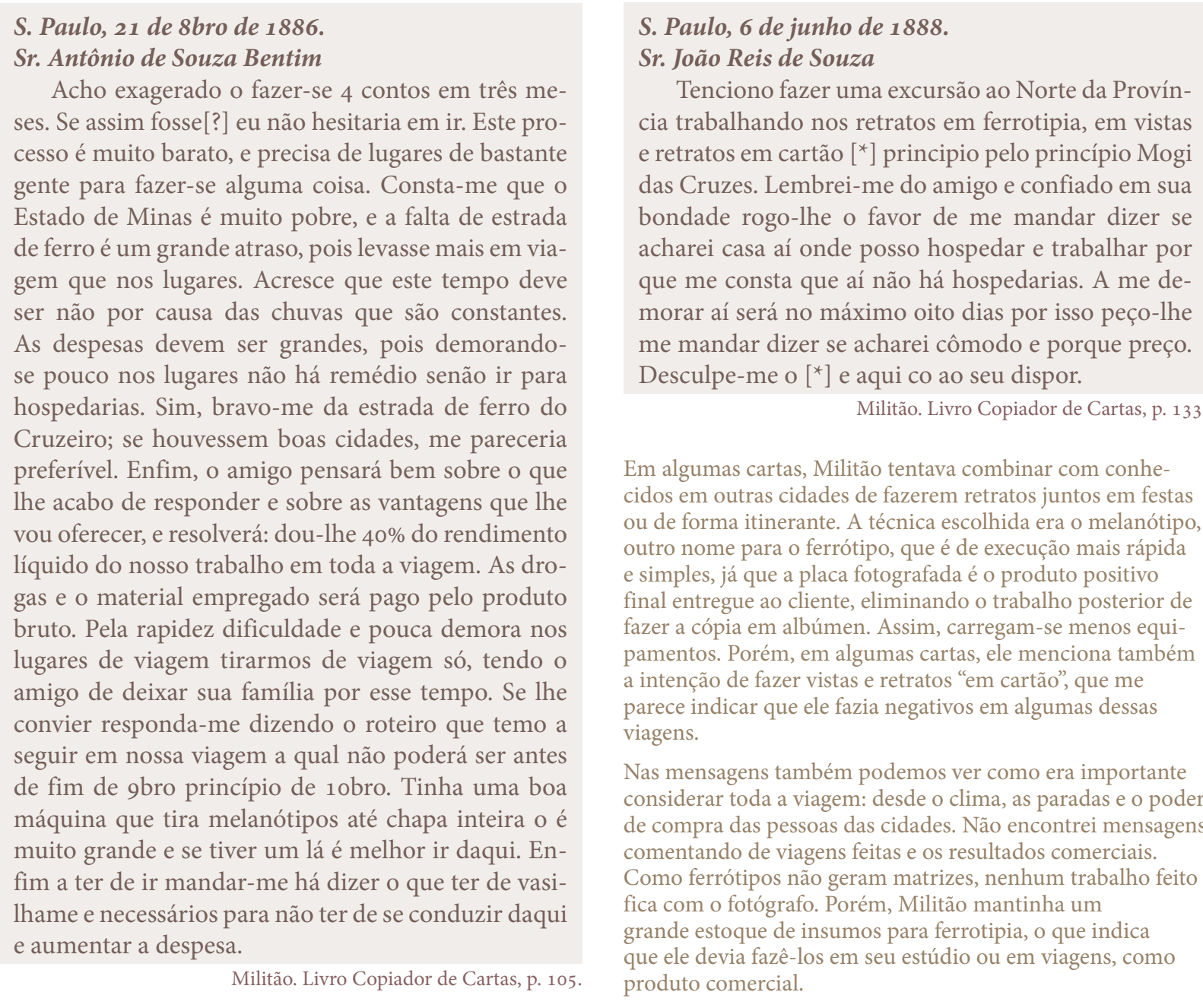




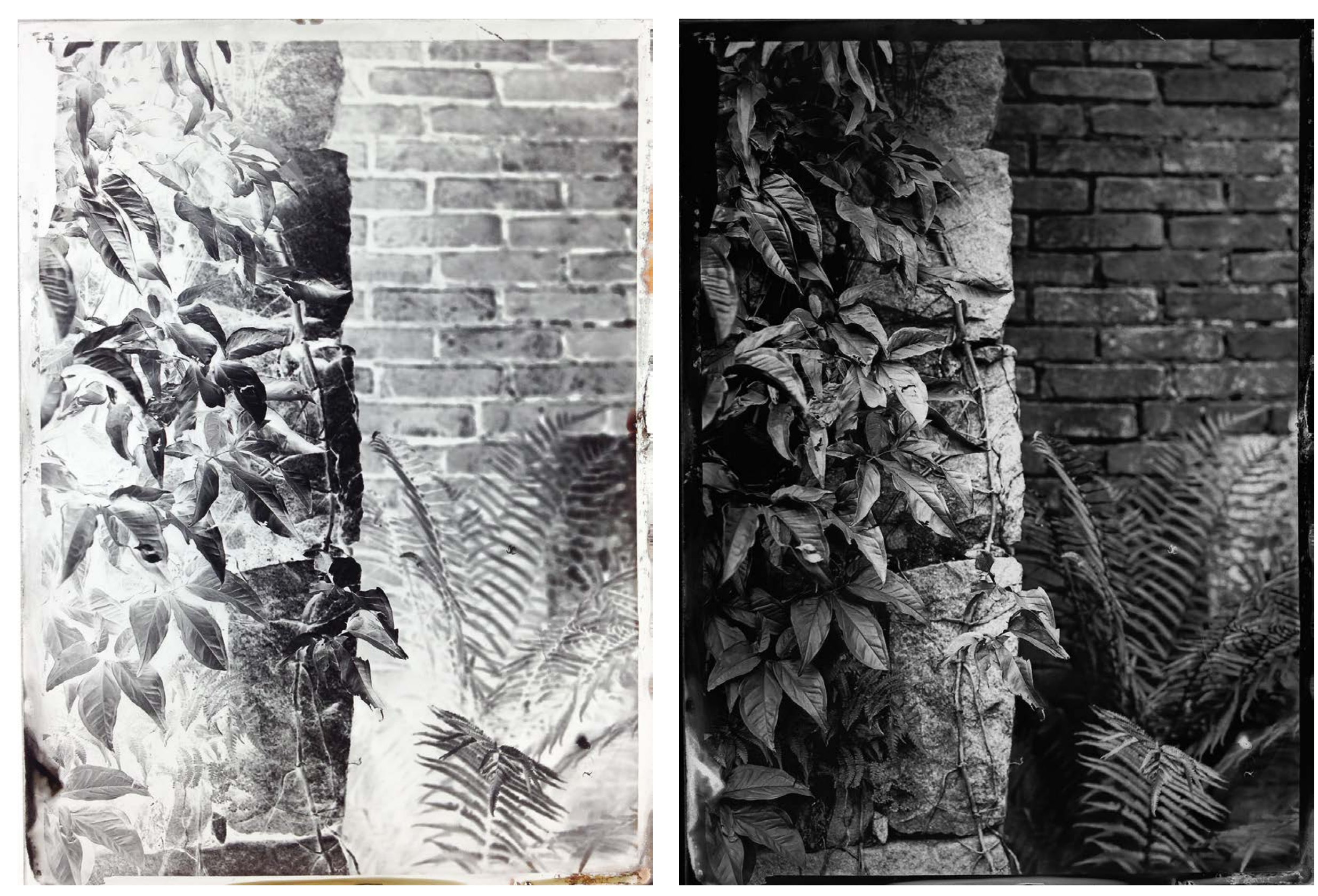

2015
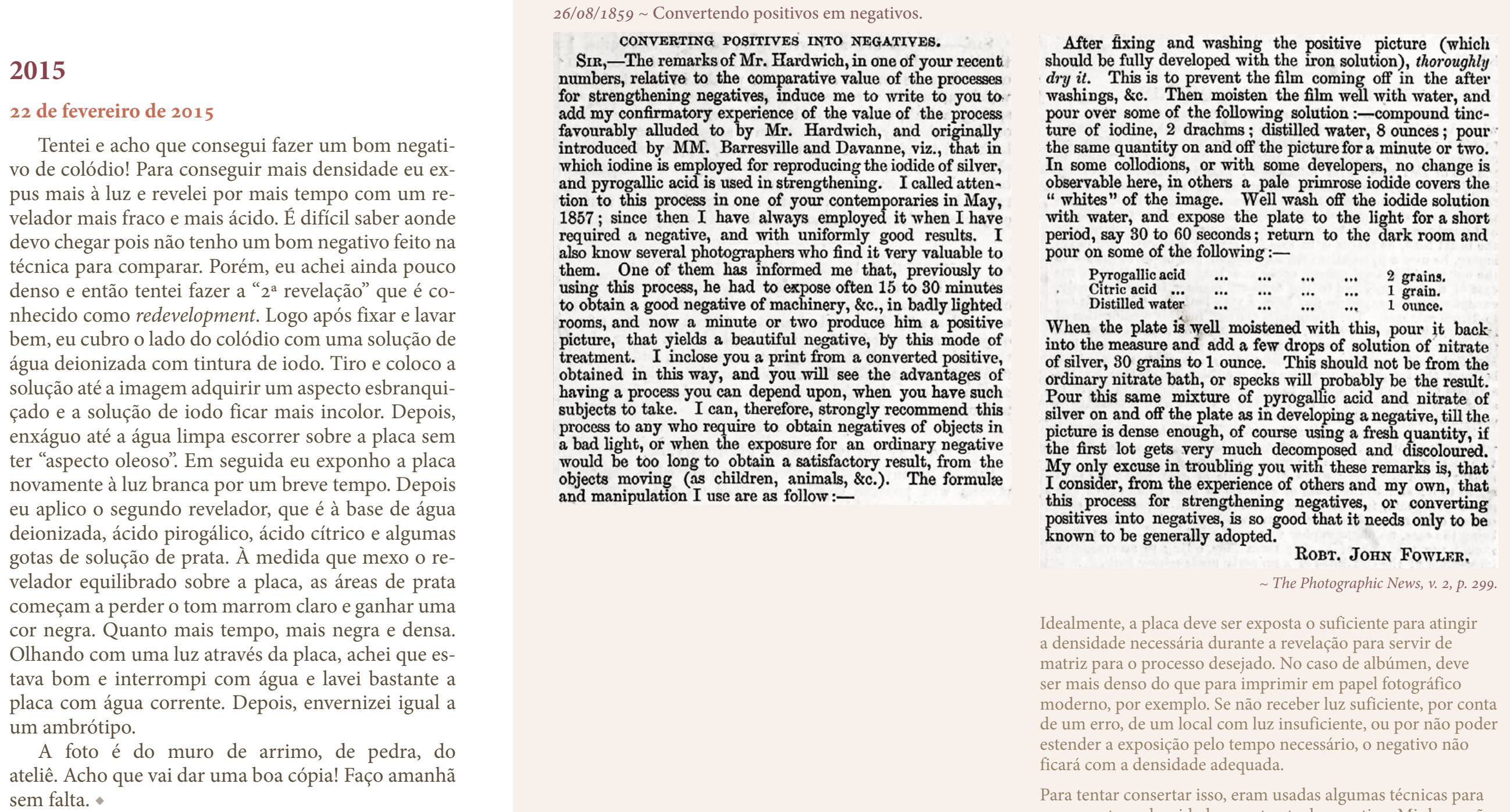

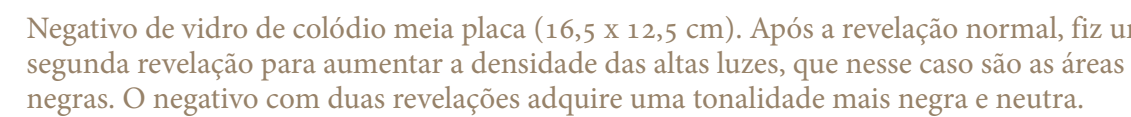



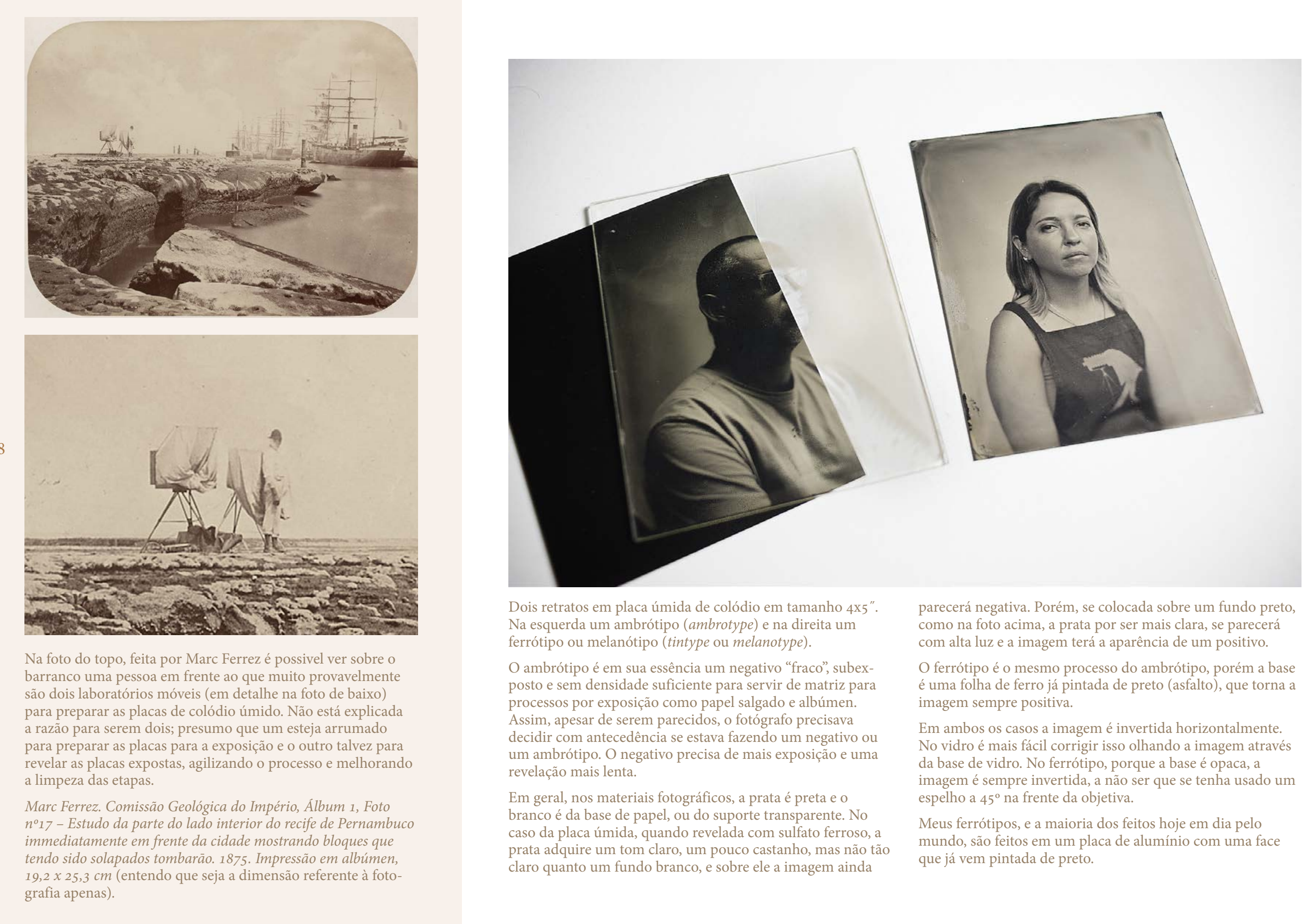

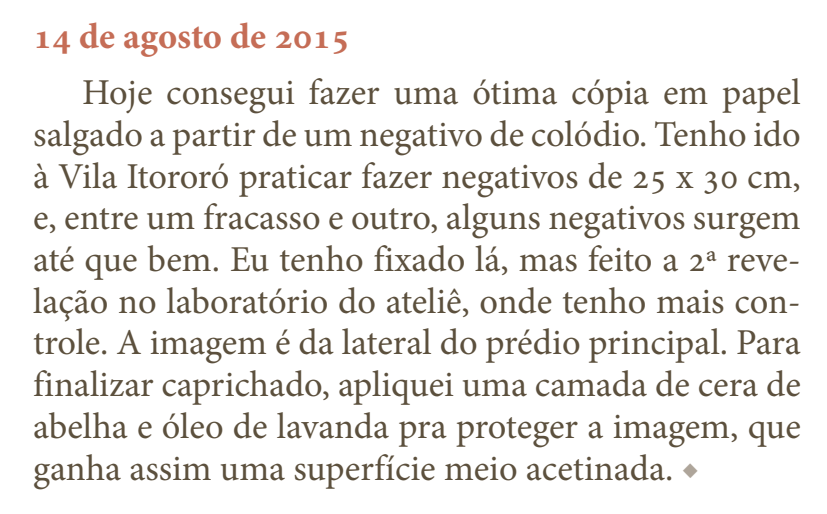

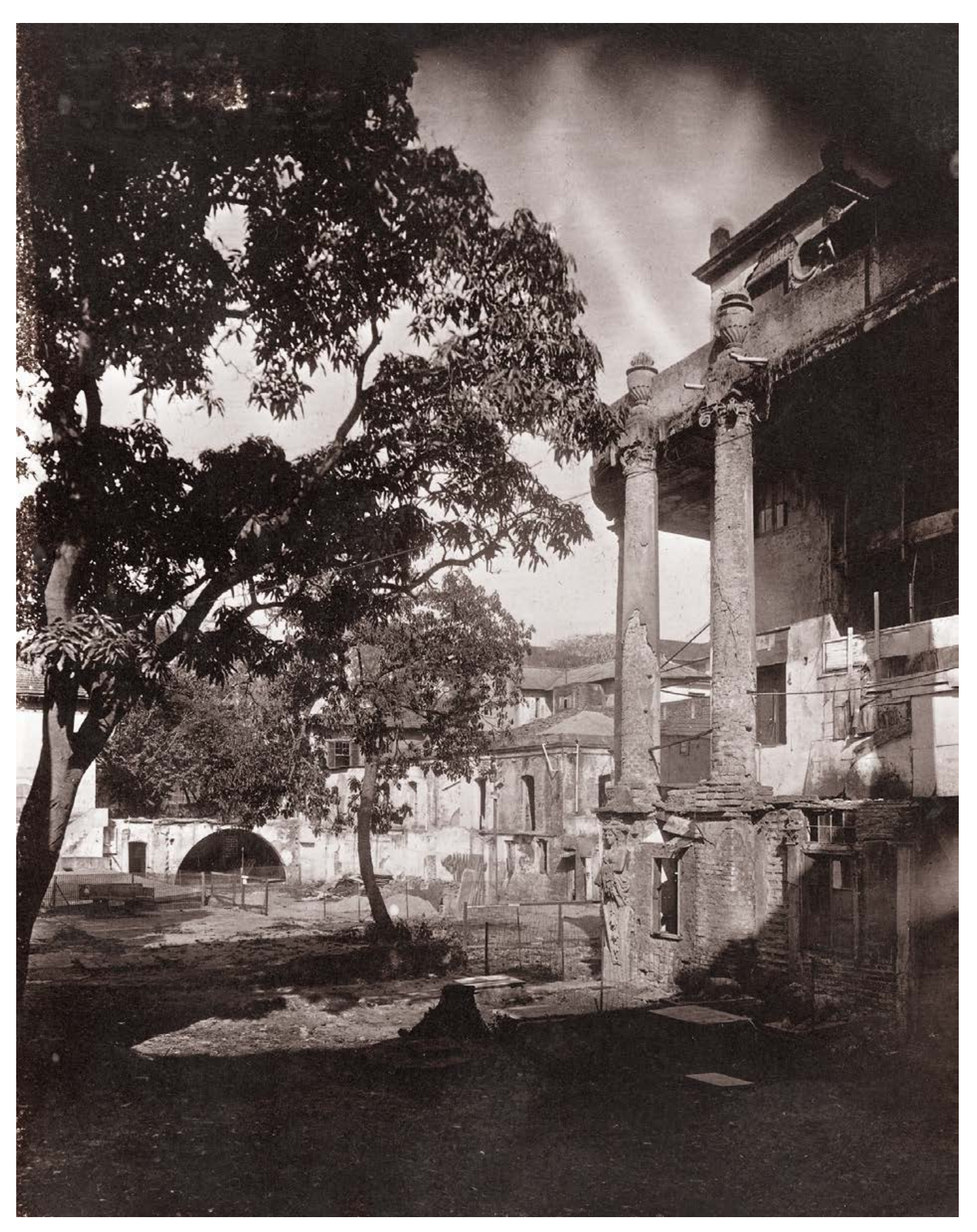




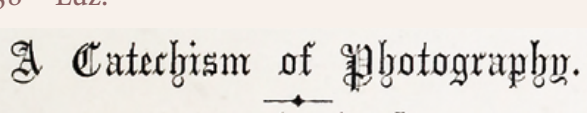

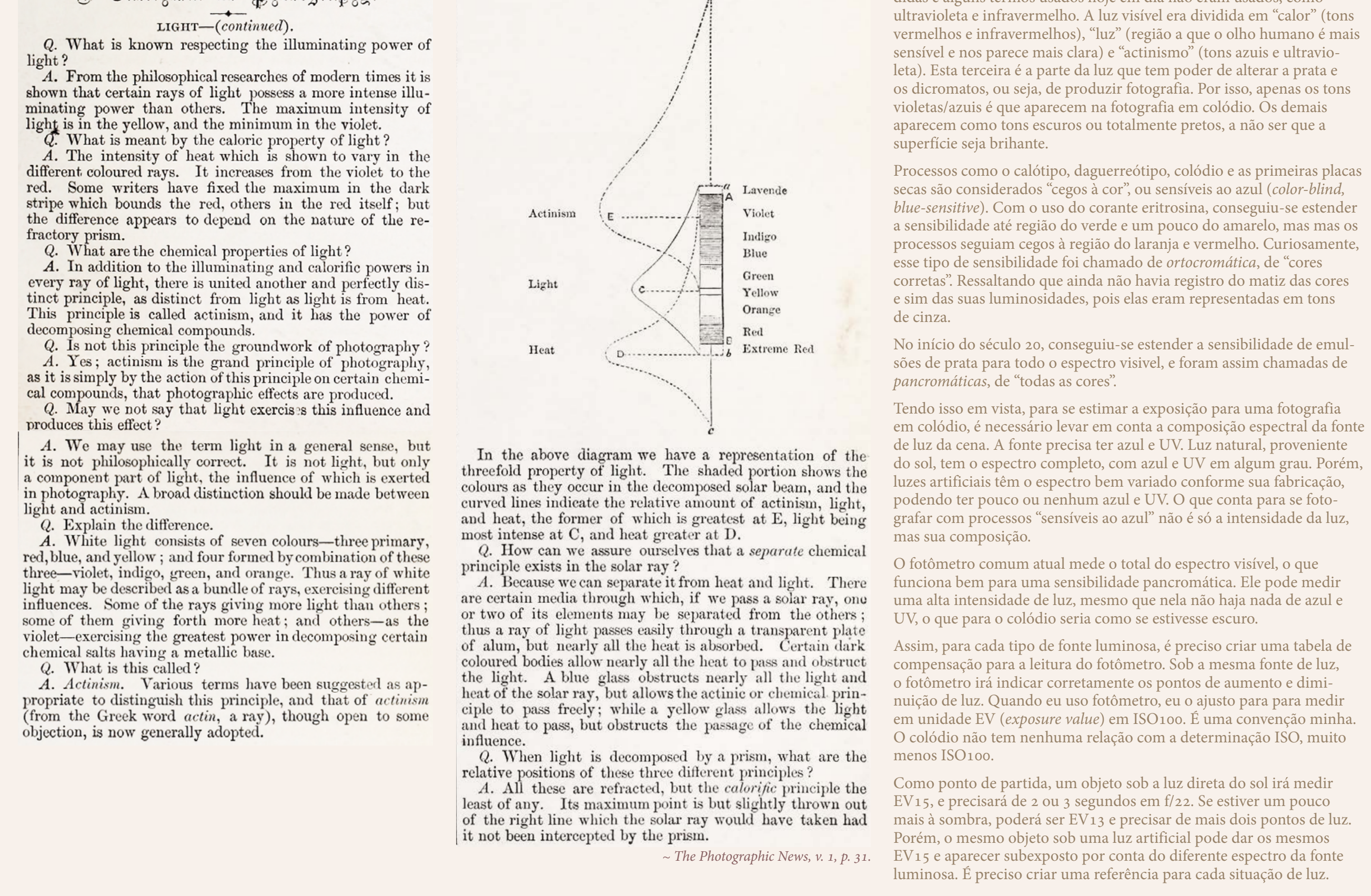

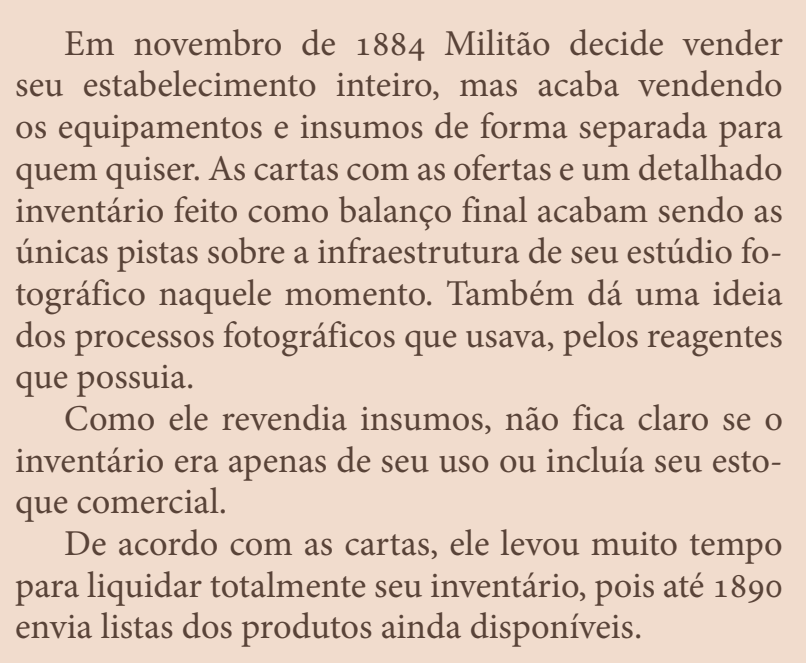

para liquidar totalmente seu inventário, pois até 1890

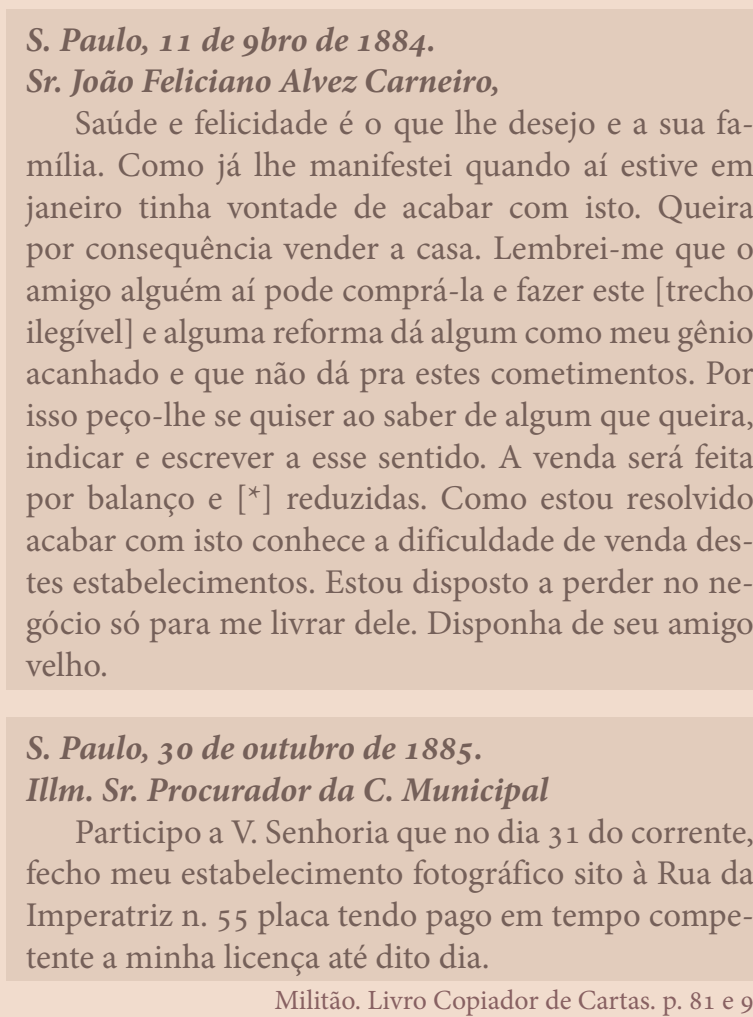

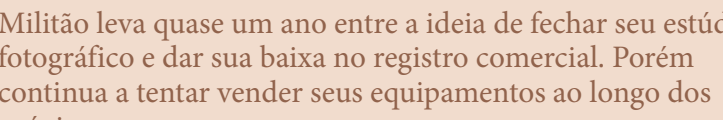

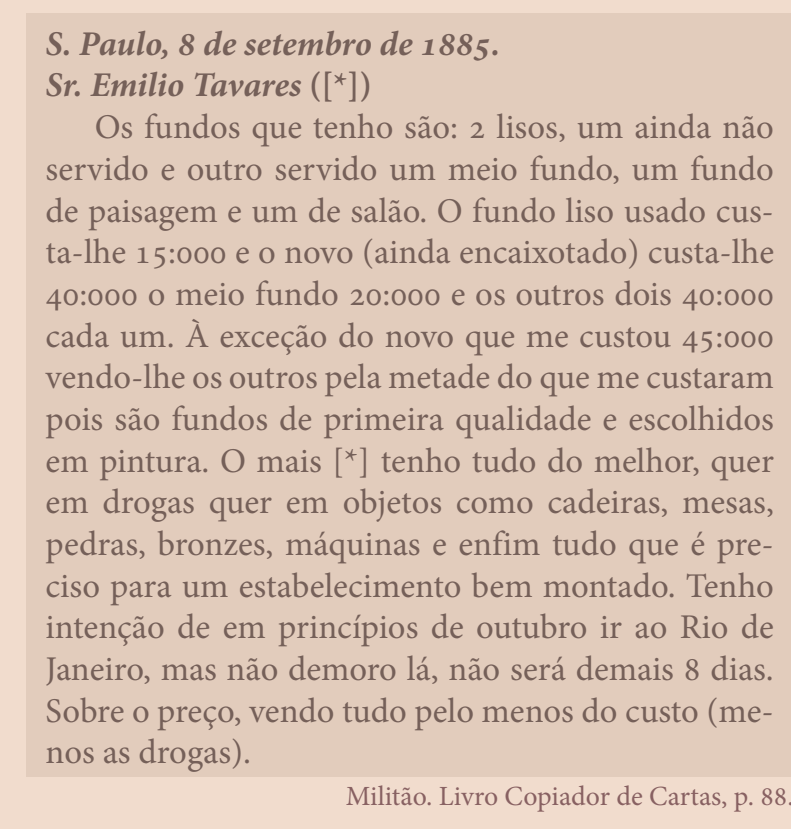

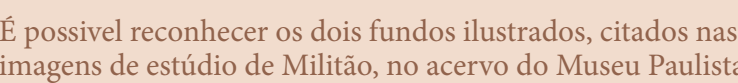

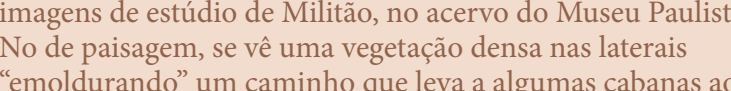

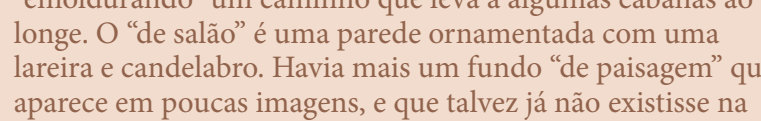



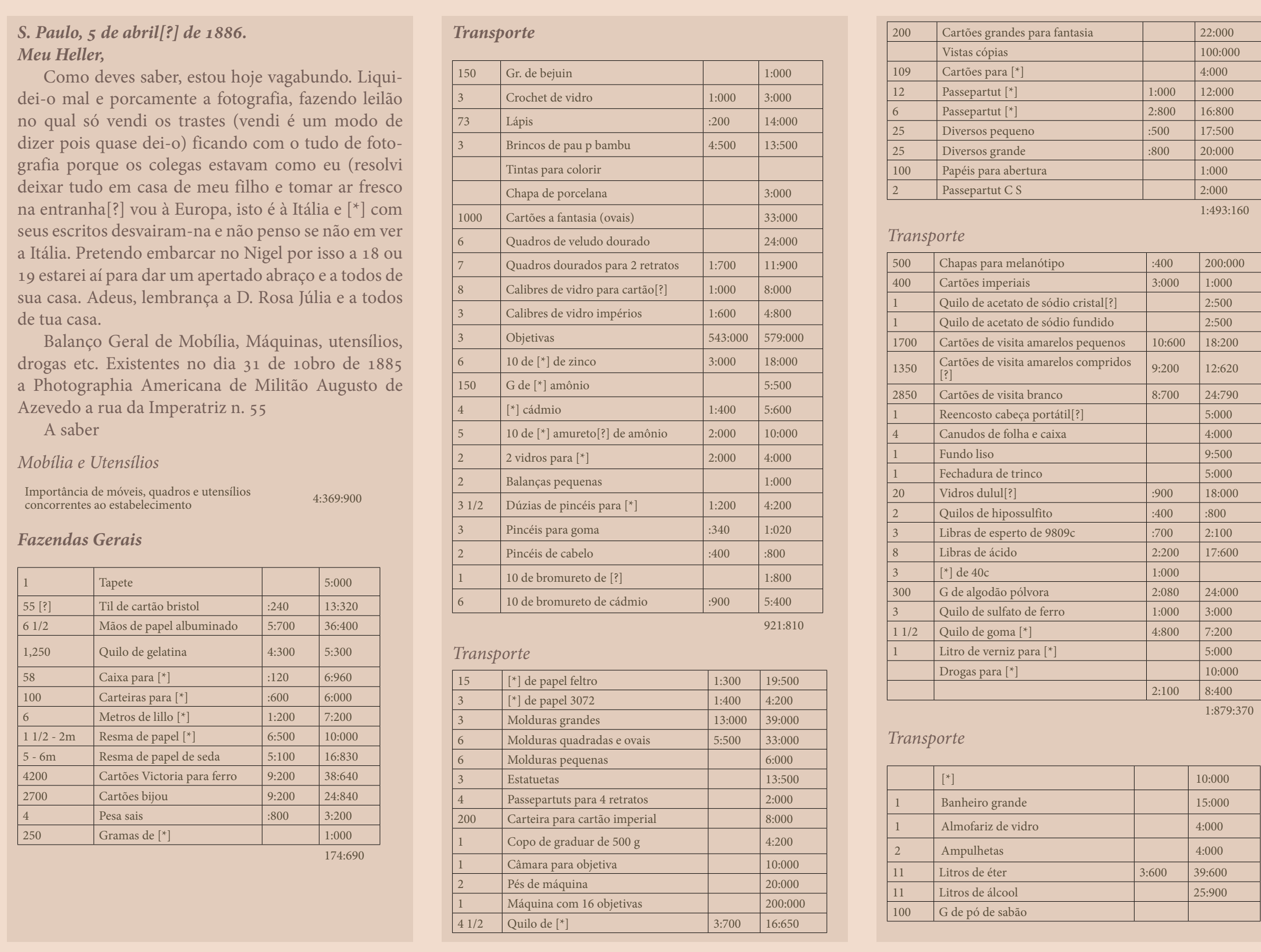

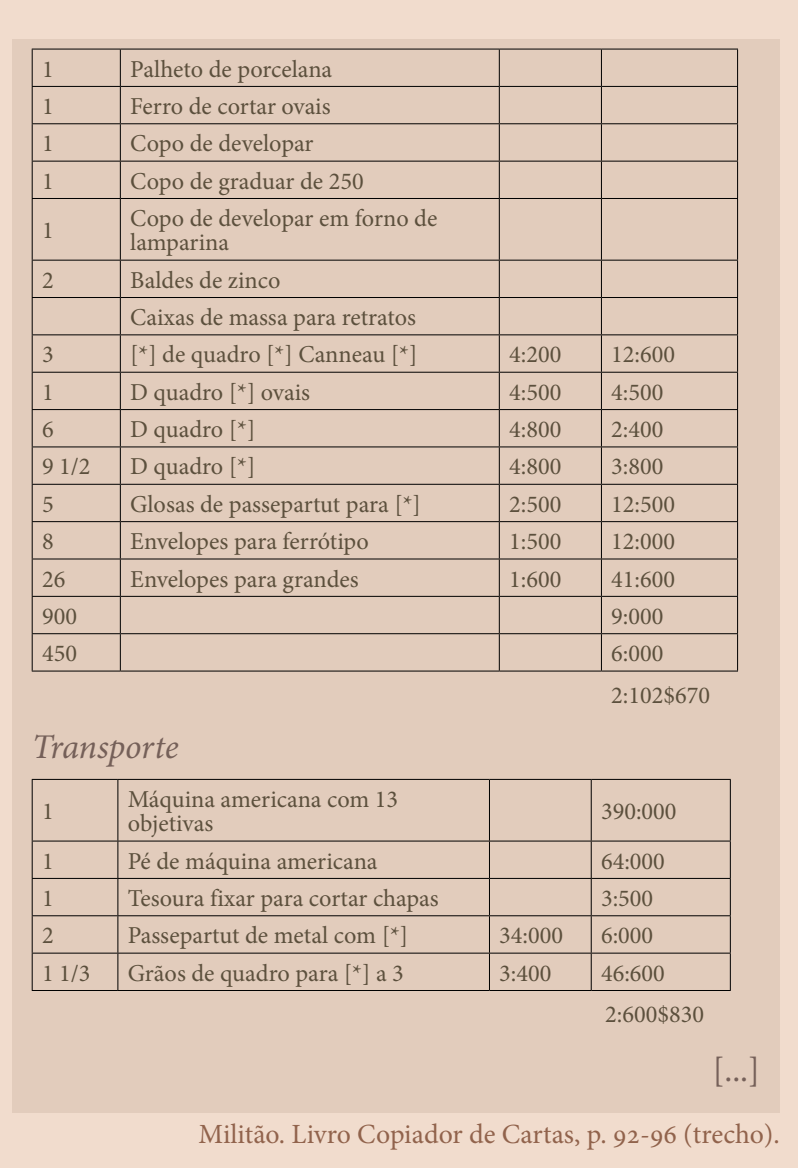

Pelas cartas, não é possivel saber qual era o mo-
led das cammeras que ele possuia. Uma pena, pois

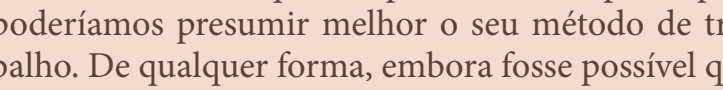

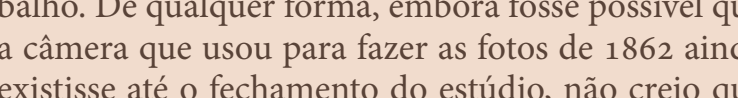

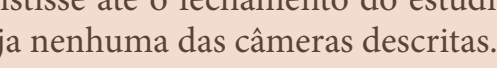

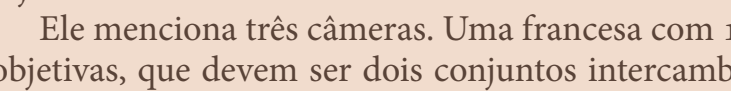

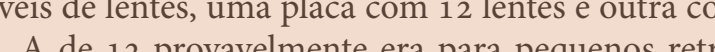
tos talvez no formato gem, e a de 4 lentes para fingur cartede ve visite. Uma traseira desizizante possibilitiva

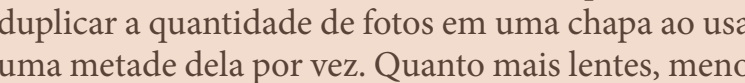
Dtamanho das imagens.
Outra camera e uma "americana, grande" que

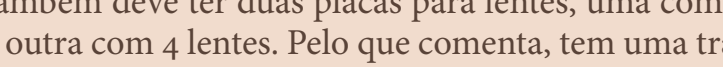

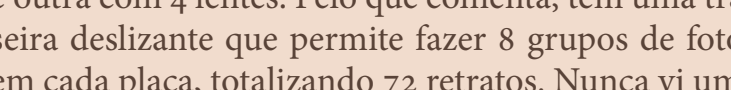
camera dessa
Estas cameras podem ter sido usadas para faze

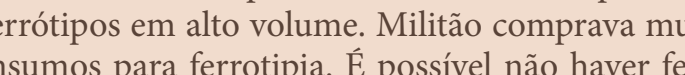

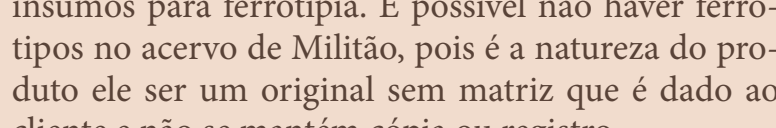

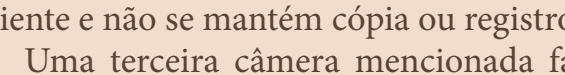

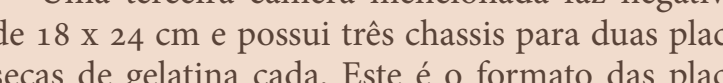
secas que Militiāo encomenda para, provavelmentest.

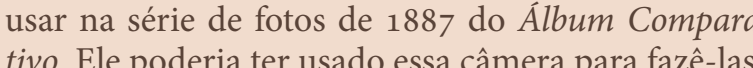
Em todas as cammeras, seria possivel fazer 0 regativos duplos que conhecemos de seu estidid Grem, ele náo mencench que terceira tenha

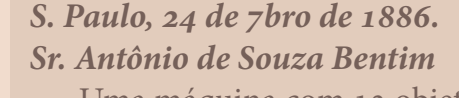

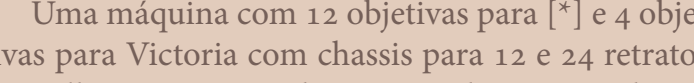

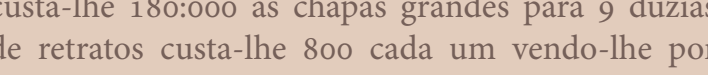

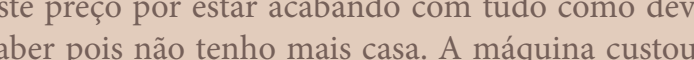
200:000. Quanto ao mais yue tenha de tudo en

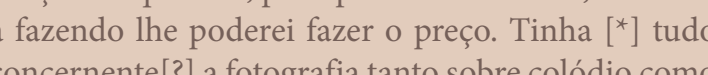

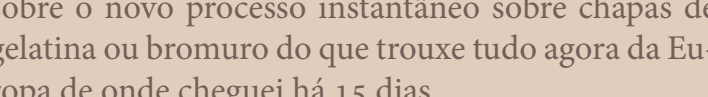

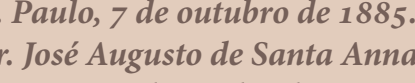

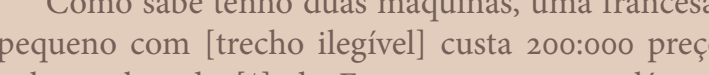

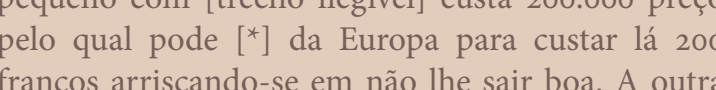
Americana, grande, servindo para todo o trabalho ags

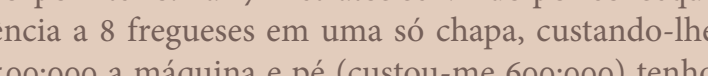
500:000 a maquina e pe (custou-me 600:000) tenh

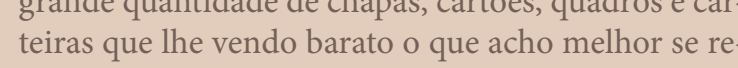
civervir ser para comprat

S. Paulo, 3 sejunho de 1890 .

W. tha do autror G. Andauim para chapas $18 \times 24$ com 3

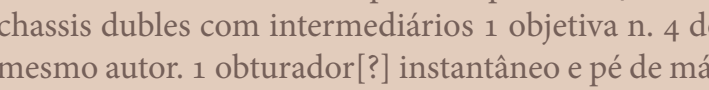
quina para companhia. 
政

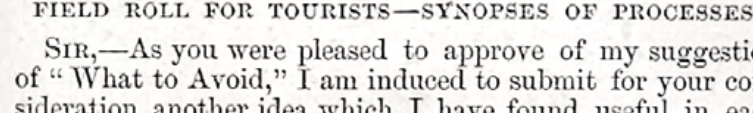

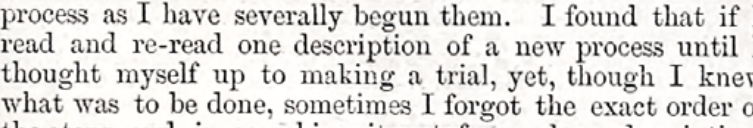

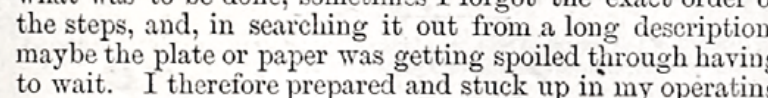

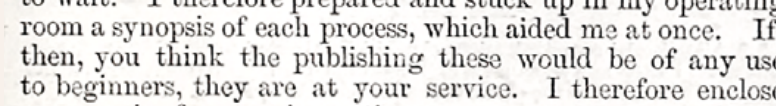

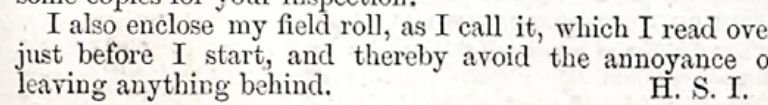

Eu logo percebia necessidade de ter uma lista de itens, para

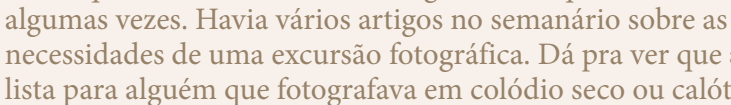

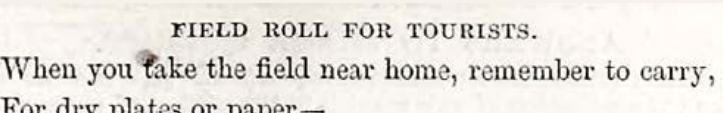

Camerat less, onder stops.
Stand and screve.
Sop.

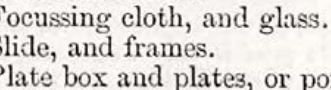

For wet collodion in addition-

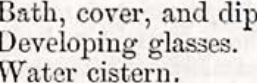

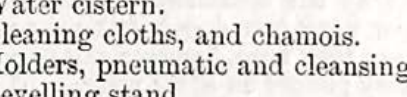

Level.
Wrase dish.
Solutions,-bath, cleansing, collodion, dereloping, and

Tent or other contrivances, and its accompaniments.
H. S. I

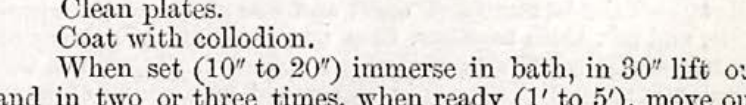

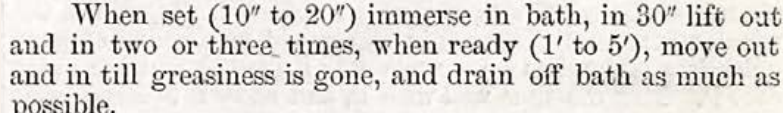

Place in dark slid

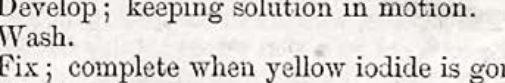

Wash w
Dry.

Varnish.
Plate claning solution, vide "Protograpritc NErss,"
vol. i. . . 156.

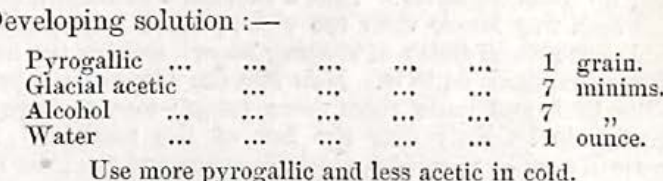

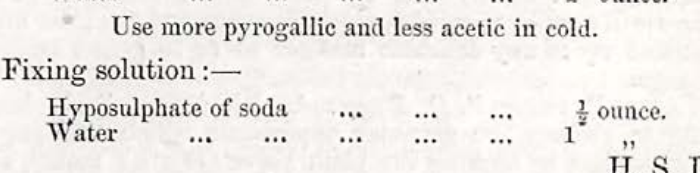

2016

29 de janeiro de 2016

Estou pensando agora no que levar para testar

- frasco $50 \mathrm{ml}$ com éter $75 \%$
- caixa com vidros (até p placas) $18 \times 24 \mathrm{~cm}$ ou

máximo o peso do equipamento, ja que vai tudo en

pamento pra uma " "ista espartana". É o minimo que
preciso levar para fazer as apaturas. Nâo vou fixar em

campo. Vou apenas enxaguar o revelador e manter
colódio úmido aplicando uma camada de glicerina

Depois de deixar o excesso de glicerina e secorrer, pos-

so guardara a placa exposta na mesm
limpos para transportá-las de volta

Lista de Itens para Lab Móvel na bicicleta
(para atés 5 placas $18 \times 24 \mathrm{~cm}$ on bax $25 \mathrm{~cm}$ )

pincel de limpeza e bomba de ar
pisseta 100 ml com álcool de cereal

pisseta $250 \mathrm{ml}$ com água deionizada

papel toalha ( $2 \mathrm{r}$

2 frascos $250 \mathrm{ml}$ com colódio: 1 de aplicacão

tanque de banho de prata
bandeja de revelação $(+$ grade

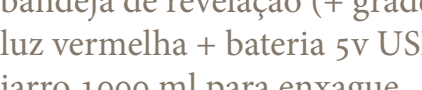

Jarro $1000 \mathrm{ml}$ para enxague
frasco $500 \mathrm{ml}$ com revelado

béquer $50 \mathrm{ml}$ para revela
galăo 5 de água limpa

gala dade de agua levada.

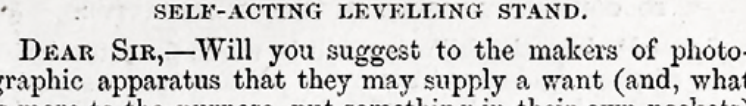

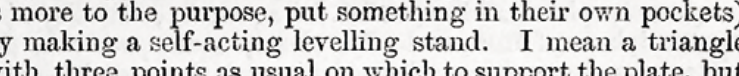

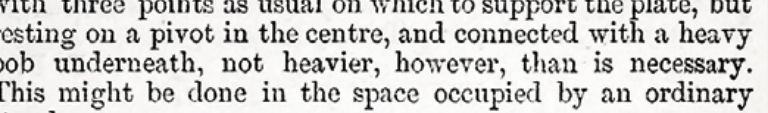

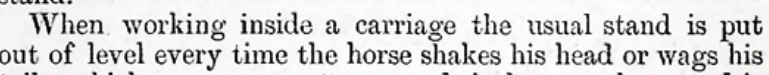

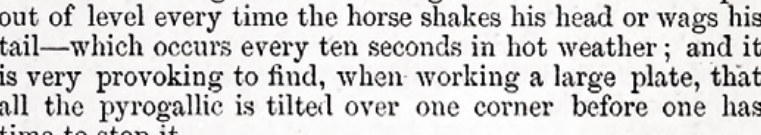

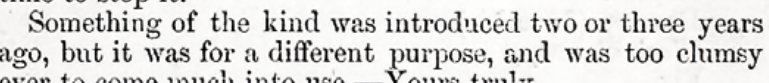

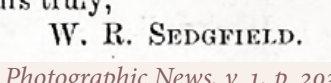

Esta é a lista "enxuta" para uma sáida fotográfica
com autonomia de até 5 placas. O limitante éa quan-

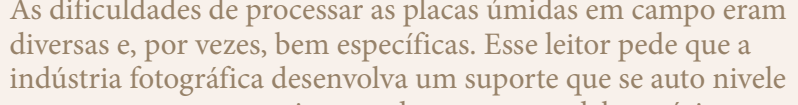

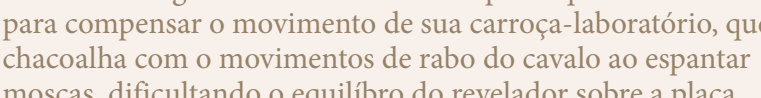

-109/1858 Um acidente fotográfico

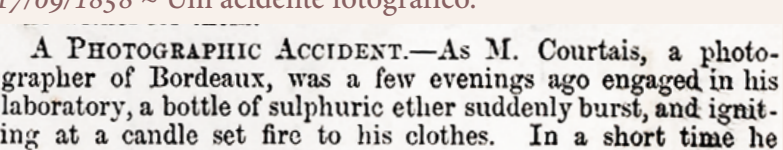

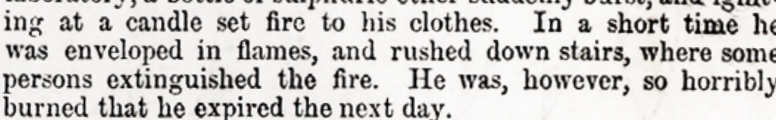

The Photographic News traz diversas informaçées sobre

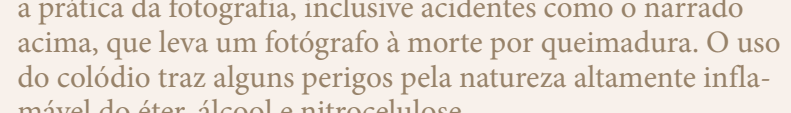


S. Paulo, 14 de 10
Sr. Paulo Wilkens
Remetollhe

Remeto-lhe uma colecão de vistas ultimamente
tiradas. Mando-lhe uma de cada uma porque não sei se tera venda ai. Estou tirando mais de outros pon-
tos e edifícios. Se tiverem vendas as que lhe mando

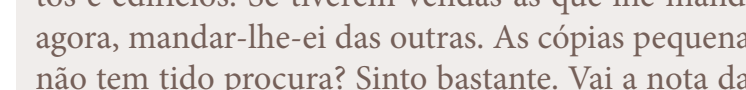
vistas que vendeu a mil e quinhentos cada uma. $\hat{E}$
bom tomar nota do número para poder pedir caso se venda.

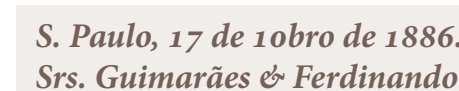
Ao nosso bom amigo o sr. Azevedo abria o espe-
cial obséquio de ser o portador do pacote contendo

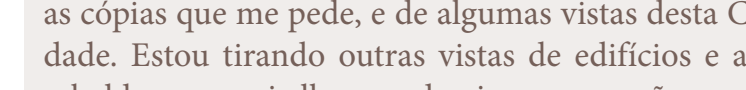
tiverem saida, escrevendo-me V[^] que as vendas[?] Recomendo-hes tomarem nota do n. da chapa que Vào dois passepartuts para retratos findosos as gumes aqui tem alguma venda

Milităo começa f fazer novas vistas dia
levarăo a ter a a ideia de fazer o allbum. fotógrafo, já no século 20 . Minha pesquisa deve pre-
sumir o tamanho físico das placas originais e fazer a

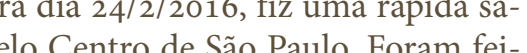
政 leia de projeto fotograficico. He ainda nào tem nome pareciam em sua materialidade. crriar algumas das vistas feitas por Militão Augusto da rua Roberto Simonsen no Centro de SP. E um

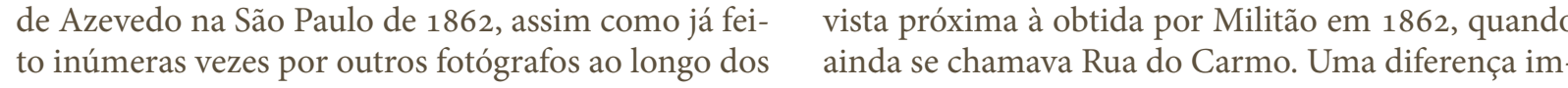

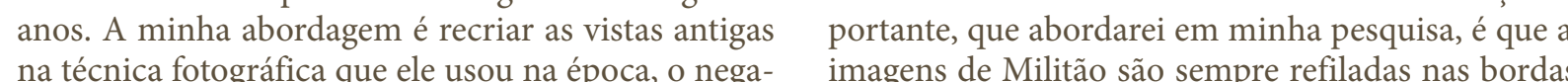

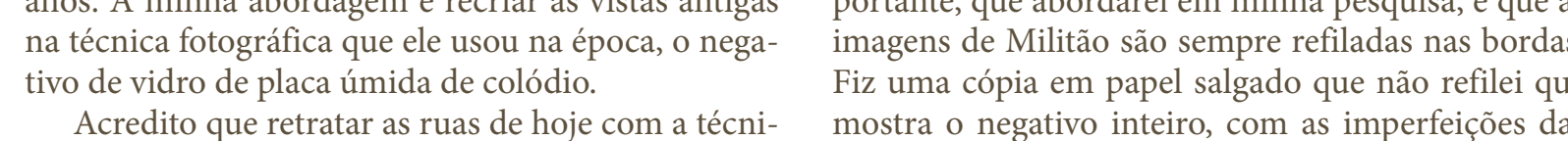

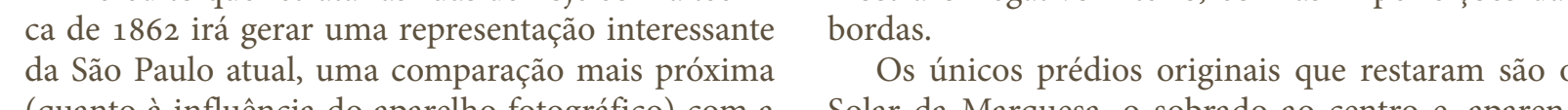

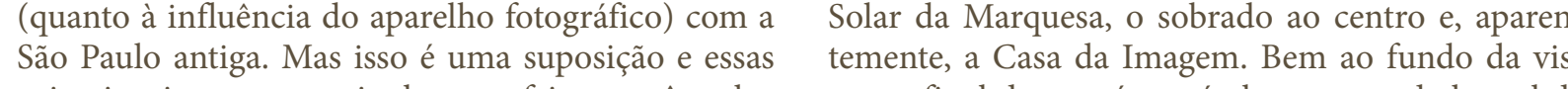
primeiras imagense mais algumas, feitas nos ângulos ta, no final da rua, é possivel ver a parede lateral é sempre bom relembrar que a i igreia atual não é Ademais, senaa pelo valor artistico, espero que o original; foi demolida e reconstruida. Na foto atu grafia brasileira. No pouco que pesquisei sobre Mili- em como resolve-lo. Eu poderia mover a camera um tao, observei uma carência e certa imprecisāo nas ex- pouco para a direita e liberar a vista. Fico pensando

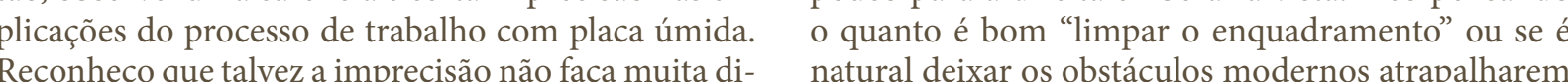
ferença aos discursos que geralmente são mais antro- a vista, que é o que eles fazem mesmo. Também, mais
pologicicos do que fotografícos. Porém, também não à̀ diretata eu ficaria na rua e, numa quarta-feria, ela

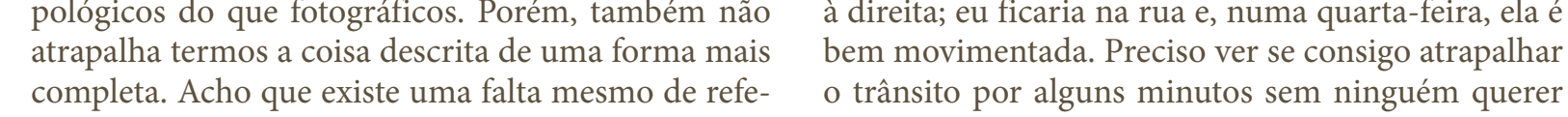

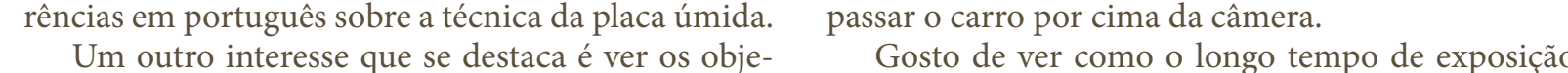

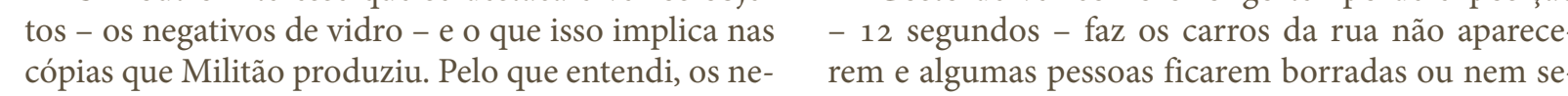

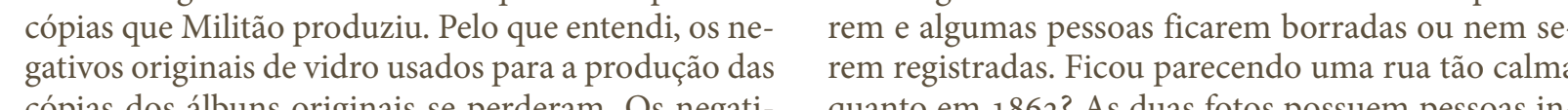

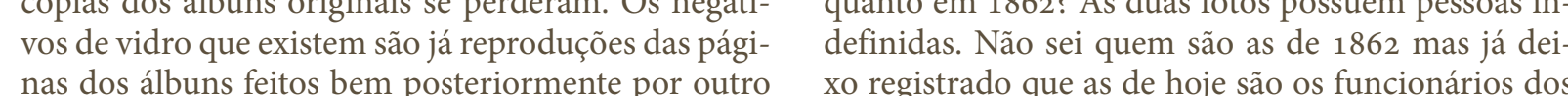

estacionamentos, agitando os braços pra chamar os
carros pra dentro. Tem também os carros estacionados em vez da carroça ao fundo em 1862 .
Fiz tamberm, nessa mesma saidalu uma vista da da
descida da Rua General Carneiro. O negativo não fiCou muito bom.
vusos ver onde o projeto anda e quais dis-
cussoes interessantes podem surgir com o seu andar. cussoes interessantes podem surgir com o seu andar
Estou tentando aprovieitar as manhaś de sol para fo-
tografar mase um processo lento de criacâo. Tentarei toga saida por semana, pelo menos nesses proximos
meseses O Mauricio me aujou na assistencia nessa
saida fotográfica e fez algumas imagens de registro.
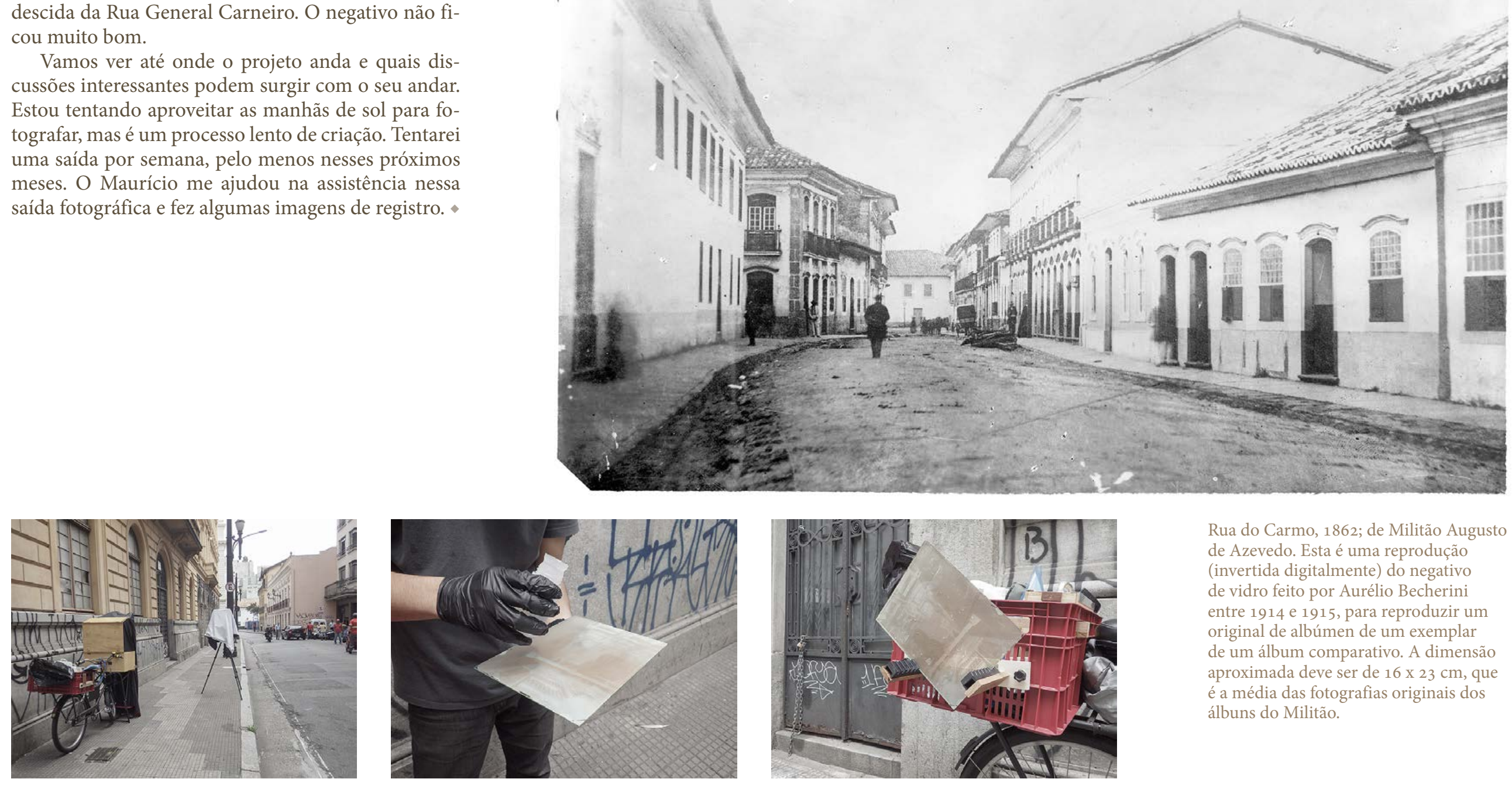

Rua do Carmo, 1862; de Militá Augus
de Azevero. Esta e uma reproduçąo (Invertida digitalm ente) do negeativ
ev vidro feito por Aurelio Becherin

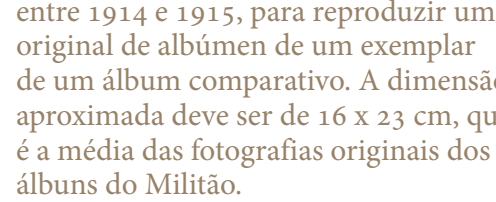




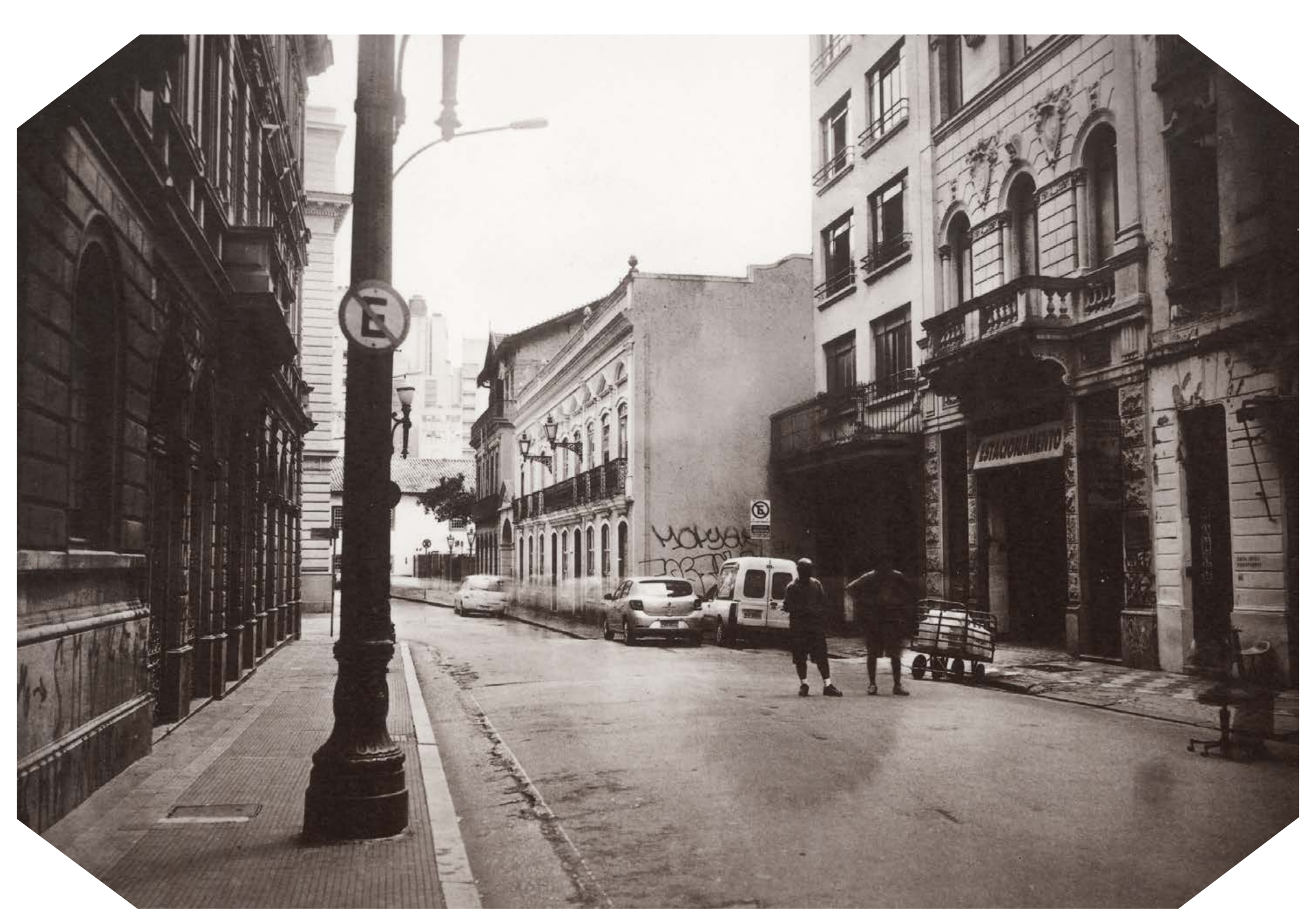




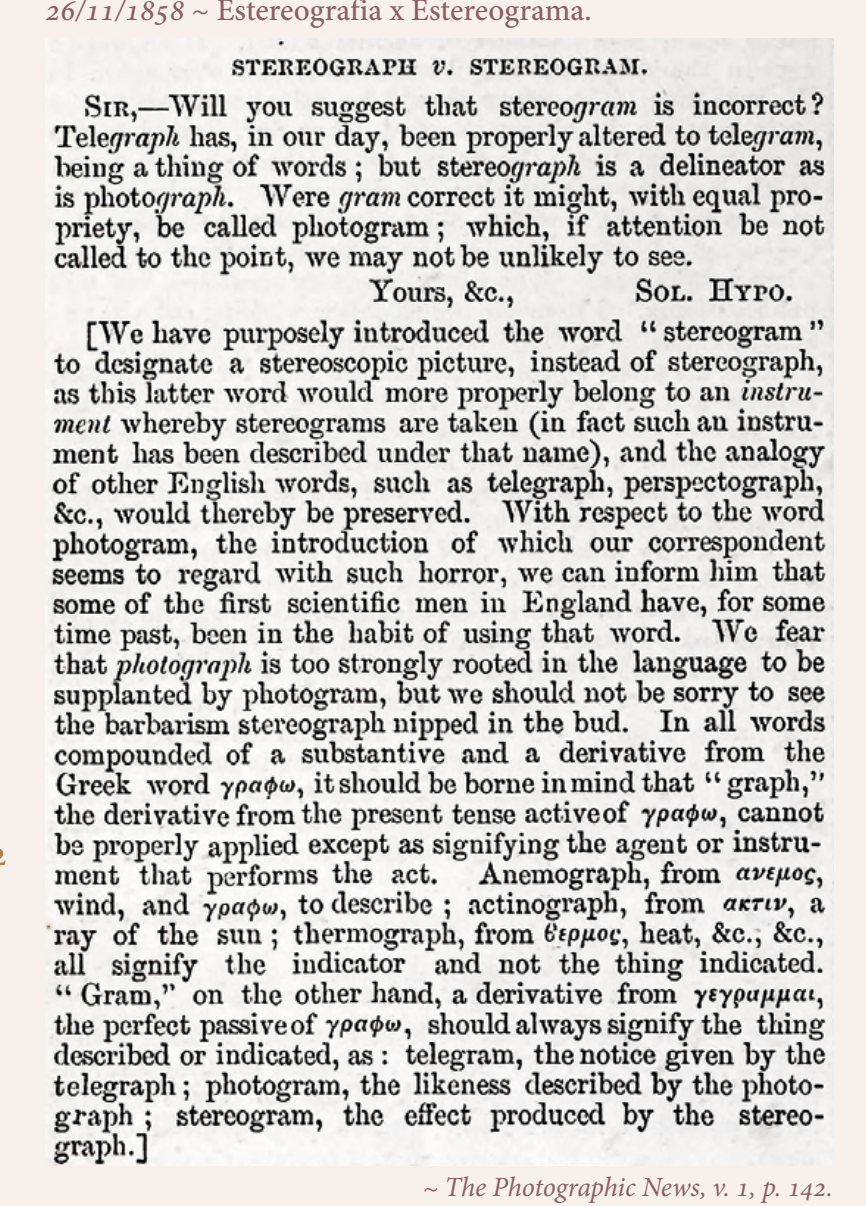

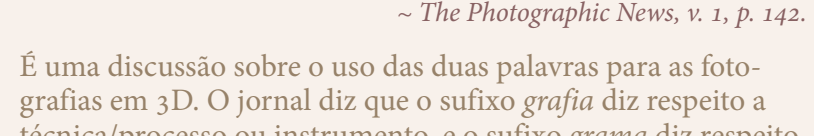
tecnicia/processo ou instrumento, é suinog grama aliz respeito
a um resultado

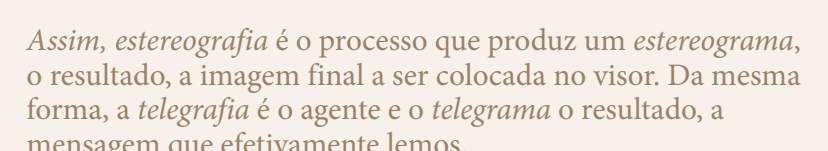

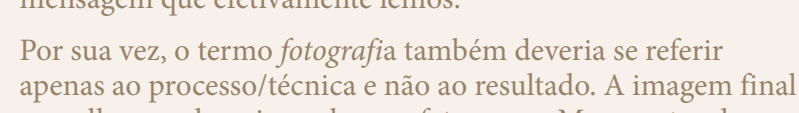

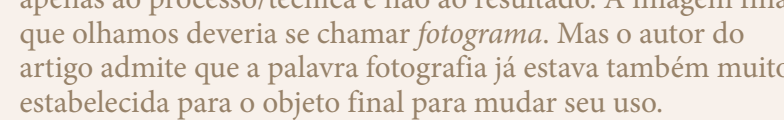

2017

19 de abril de 2017

Mais de um ano depois da primeira foto feita para pouco mais as áreas de sombra. O tempo de exposi-

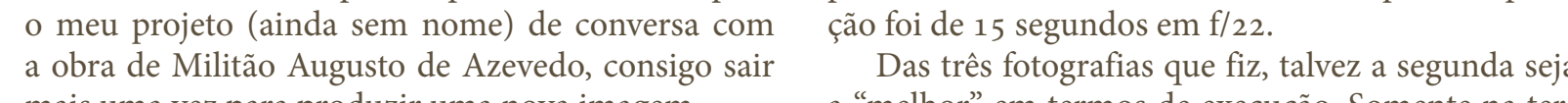
mais una vez para produzir uma nova imagem. $\begin{array}{ll}\text { Ainda sinto que estou apenas ensaiando os pro- ceira captura, lembrei de fazer a captura simultànes } \\ \text { cedimentos e metodologia. Nesse longo hiato, acabei } & \text { em video. Mas a foto saiu com uma mancha que so }\end{array}$ ficando ocupado com "todas as outras coisas da vida", percebi na volta a a laboratabrioiot Eu fiz uma segunda

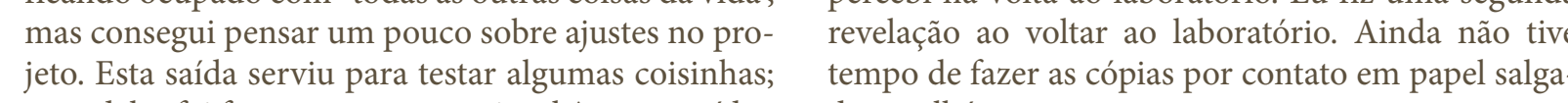

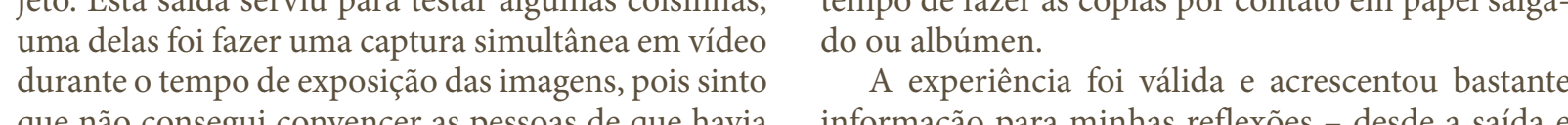
que nào consegui convencer as pessoas de que havi
muito movimento na rua no momento em que fiz foto da Rua Roberto Simonsen. $\quad$ do lugar, angulo, vendo se a luz deixa ou náo eu ter a

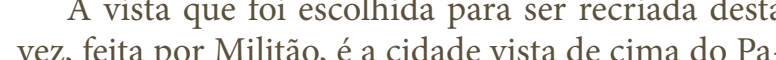
redão do Piques, hoje Rua Xavier de Toledo, em dia ção a Largo São Francisco. Na imagem dele,é é pos-
sivel ver o obelisco do Largo da Memória a a descid um ano antes na Rua Roberto ji quen, na foto que fiz para a Ponte do Lorena, que hoje é um acesso para
Terminal Bandeira. O Obelisco do Piques ainda esta

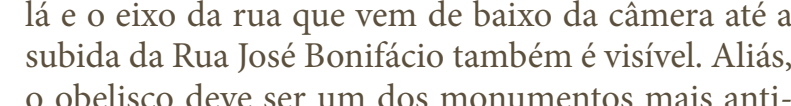
o bobelisco deve ser unit
gos da cidade, de 1814

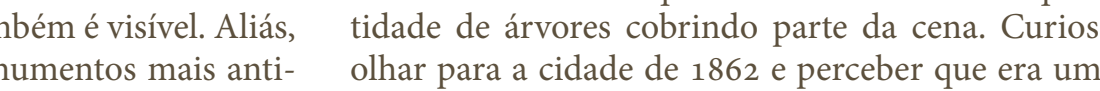

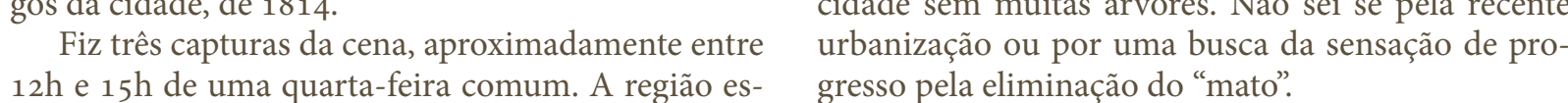

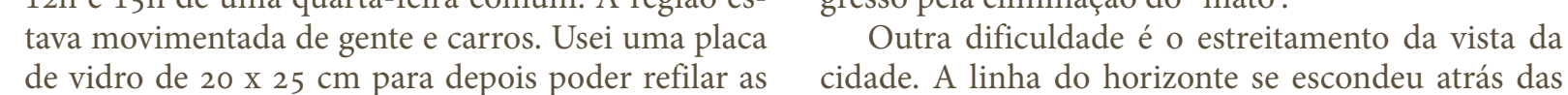

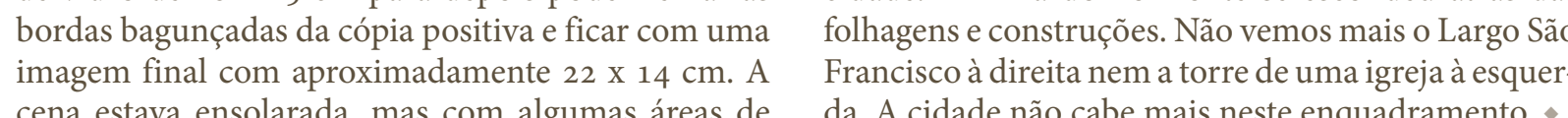
cena estava ensolarada, mas com algumas àreas
sombra. Eu calculei uma exposiçón com dois po sombra. Eu calculei uma exposiçá com dois pontos
a mais de lut do que eu usaria para um ambrotípo
e ainda aumentei um pouco para fazer aparecer um

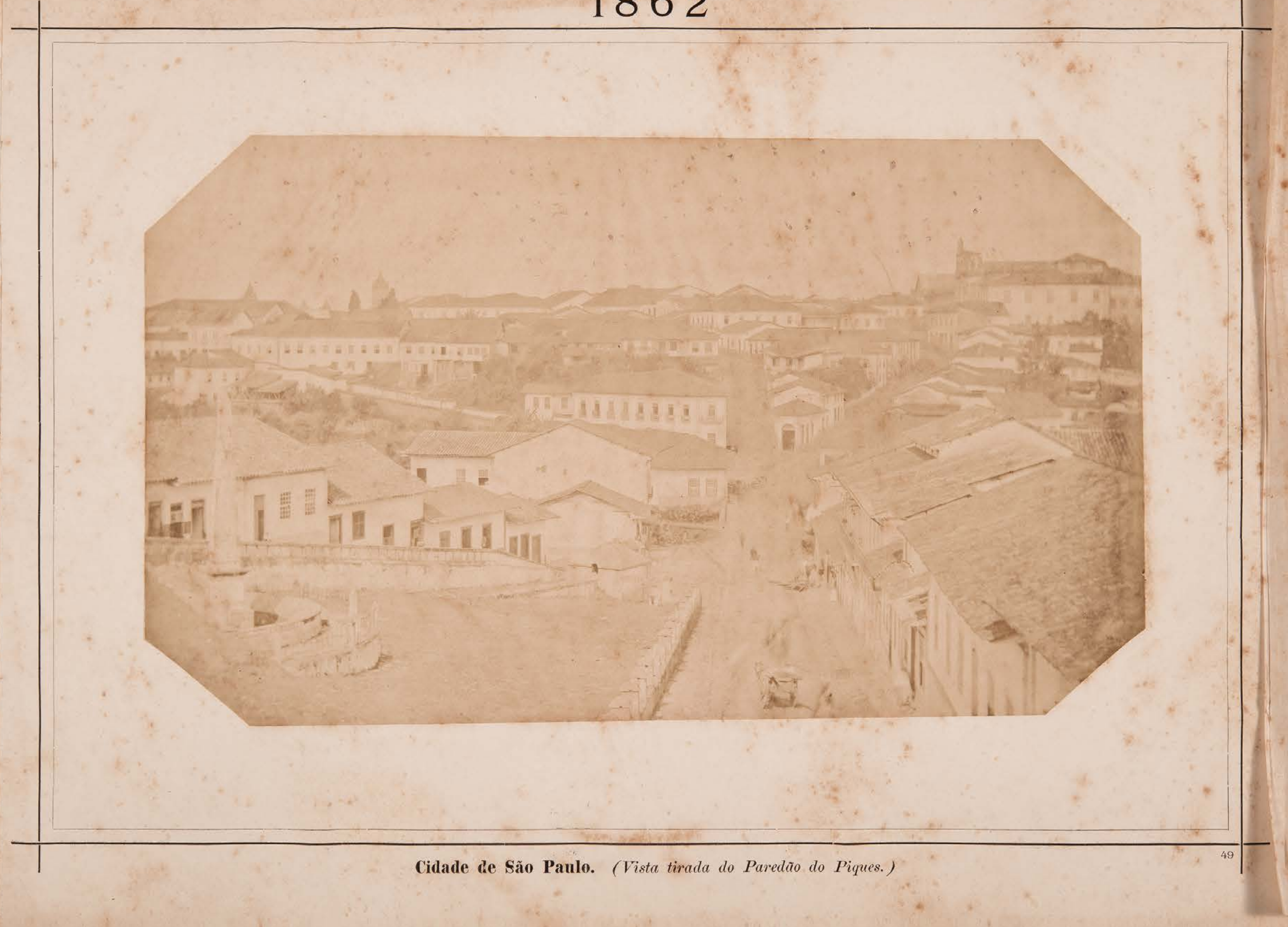




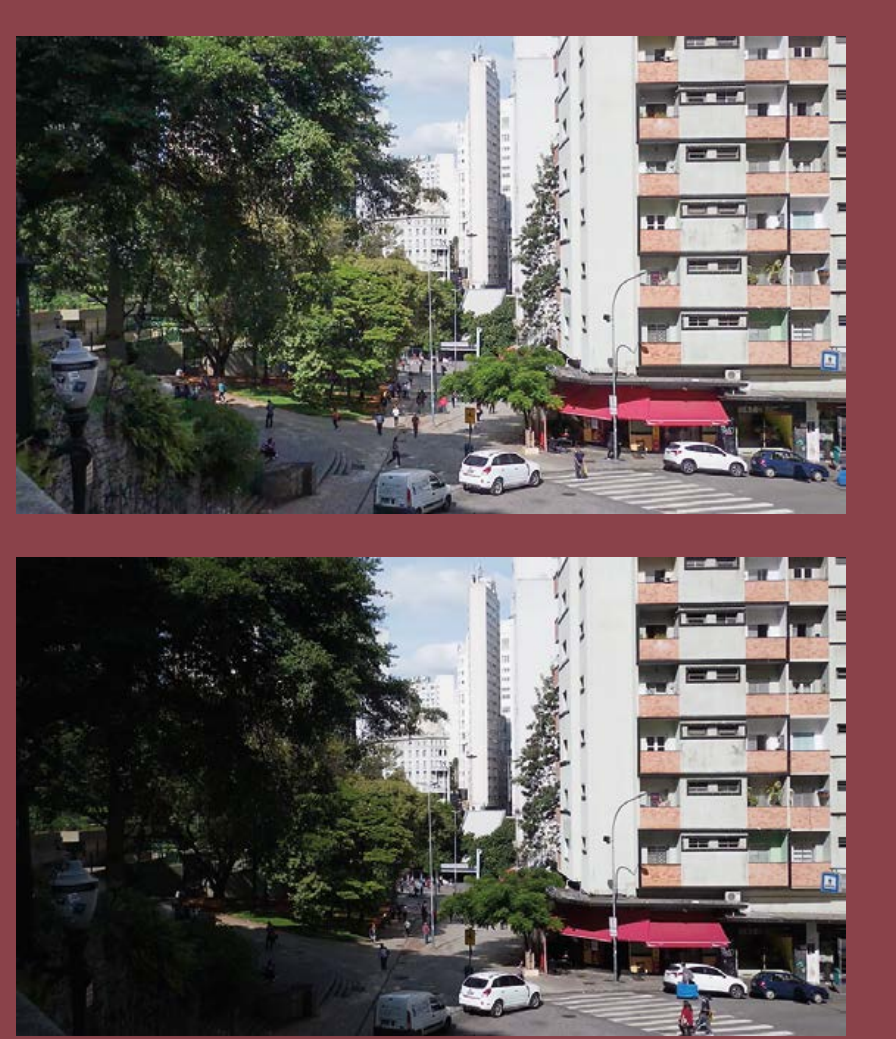




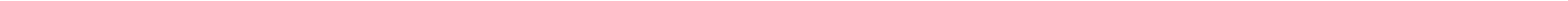




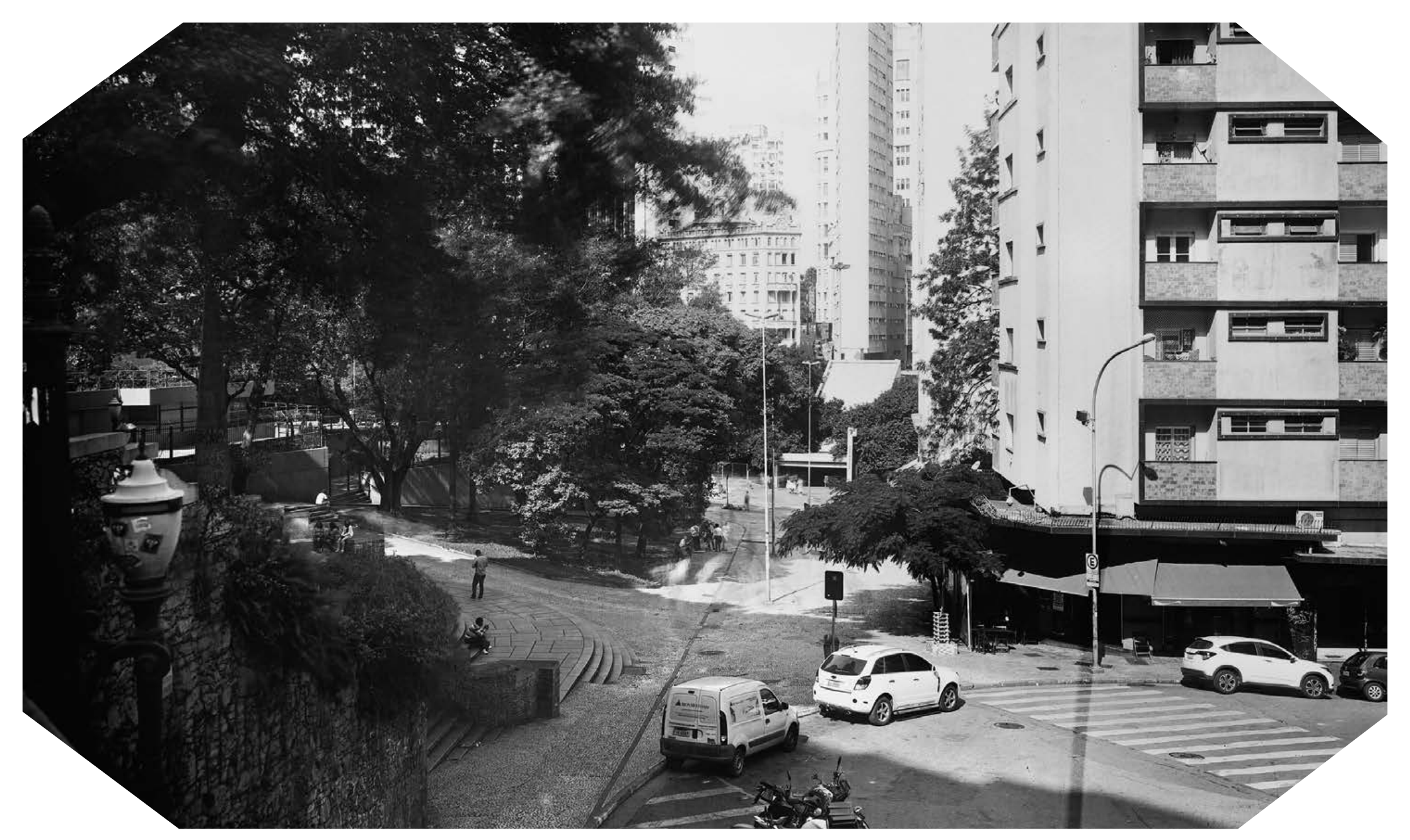




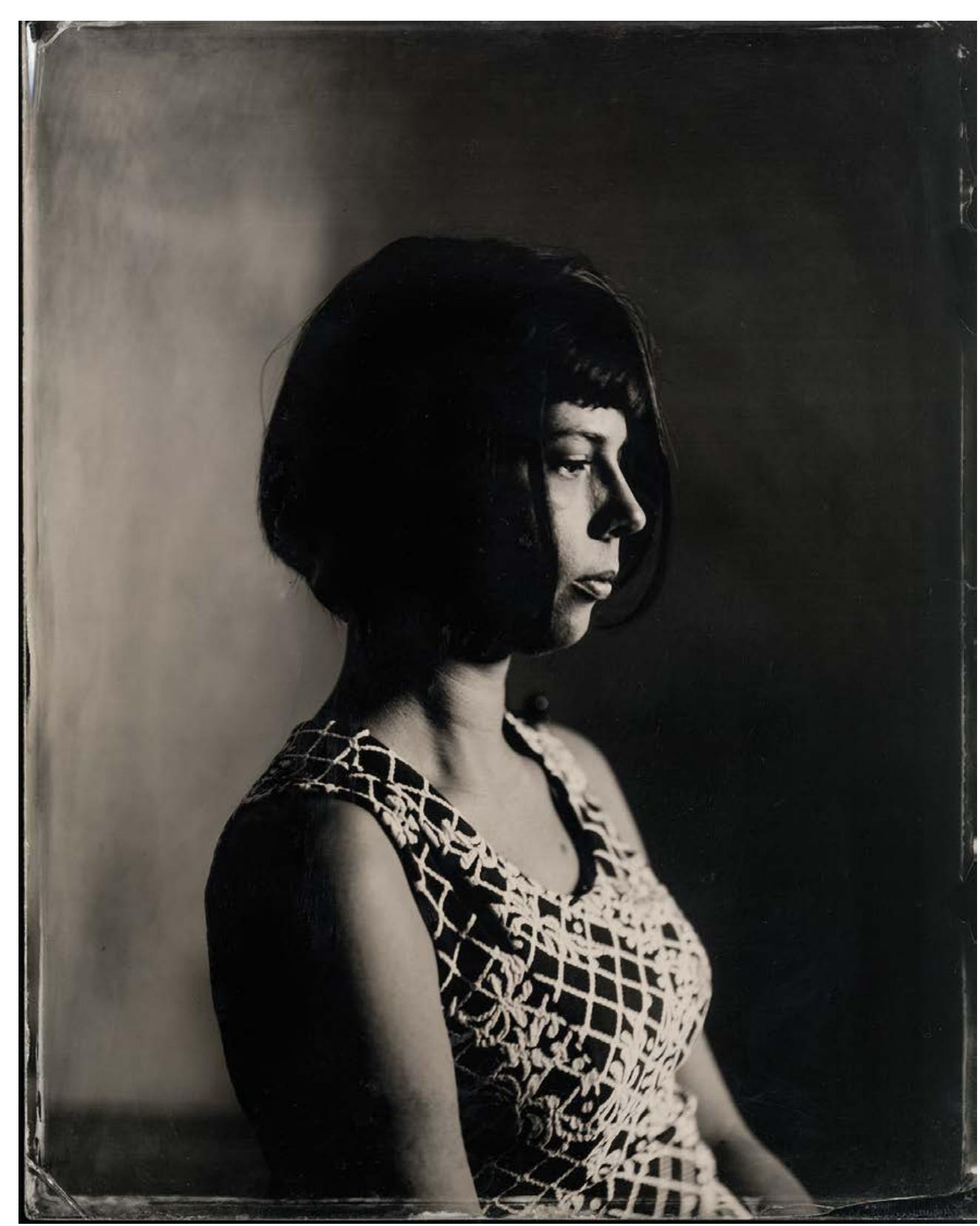

Fiz hoje uma sessão de retratos com a Simonne.

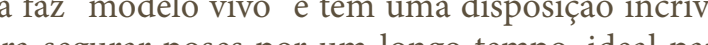
Gizer placa úmida. Fiz as fotos para a minha obra des exposicáo Sorte Revelada, do meu grupo de estuda do ambrótipo de ser transparente e negativo sob fundo

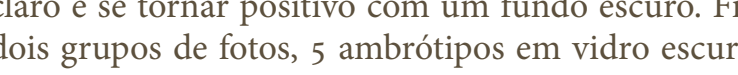
compondo o corpo inteiro dela e 5 em fundo transpa-
rente fechado em detalhes do corpo, fotografados un a um. Foi um vaivém intenso ao laboratorion. Quer
montar as imagens como um móbile para elas ficaem se recompondo com o movimento e as imagen
em vidro transparente se tornarem positivas toda ve Aproveitando a presença dela, fiz também un ontrastada. A ultima foto da sessio de corpo inteiro. Deste eu fiz mais uma revelaçäa, pia em papel salgado. Sinto que, mesmo a técnica remetendo a uma fo-
tografia antiga, perceptivel que a composição e ilu-
minaçăo são de alguém "de hojè".

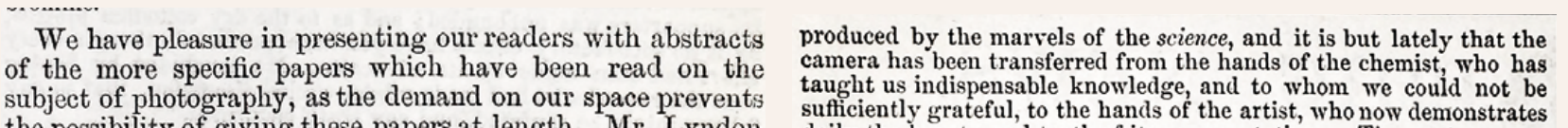

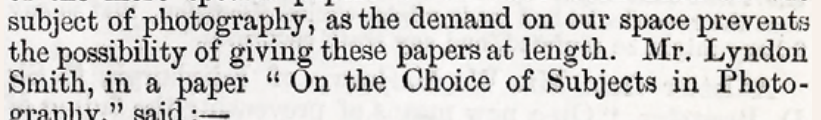

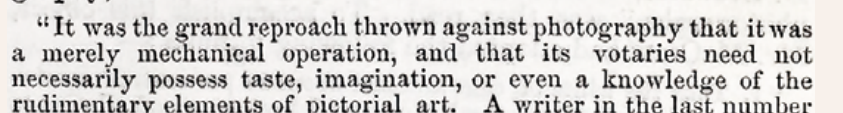

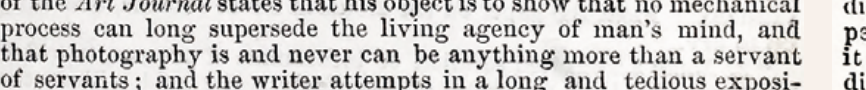

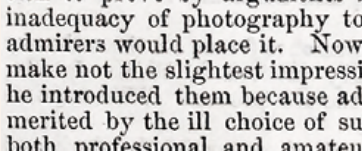

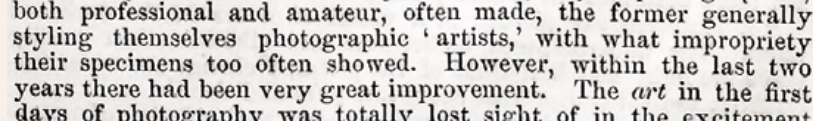

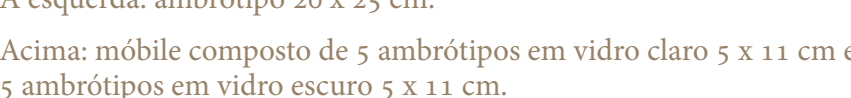
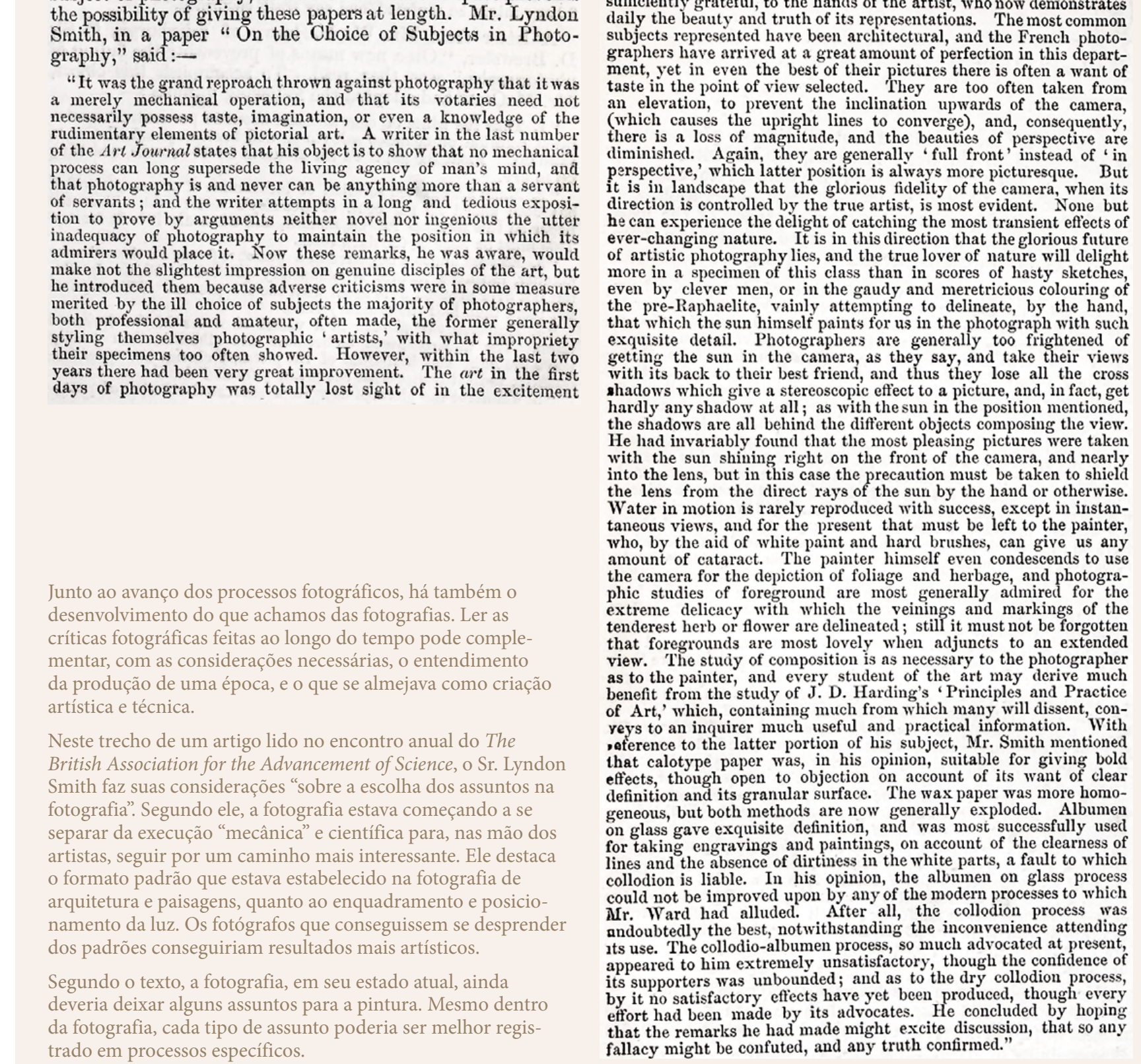
cam questōes básicas de fotometria. A frase seguinte
interessante, em que ele diz que leva o mesmo tempo

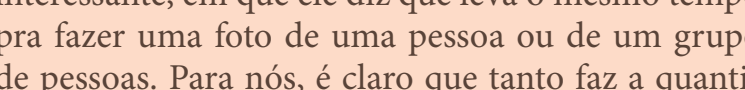
dade de gente na foto, mas, para pintura, cada pes-
soa a mais é mais tempo de trabalho. Talbot refor que para aquele momento, rea preciso posar cuida-
dosamente as pessoas implicando cue ainda naio

$\begin{array}{ll}\text { Em } 1844, \text { o ingles Henry Fox Talbot jả havia aper- } & \text { possivel fototo casuais de grupos. Seria necessário que } \\ \text { feiçoado seu sistema de negativo de papel - o calotitipo } & \text { o processo exigisse menos tempo de exposiço para }\end{array}$

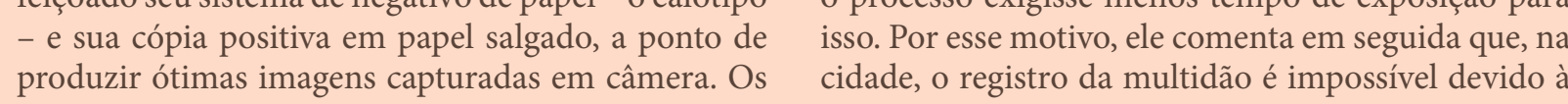

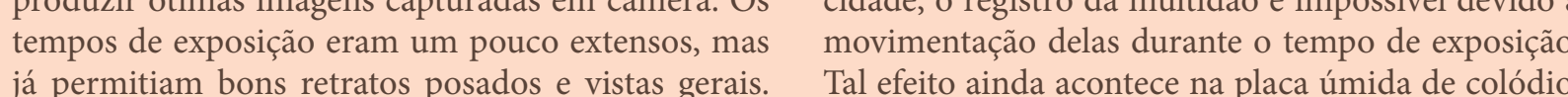
já permitiam bons retratos posados e vistas gerais. Tal feito aind acontesen
Naquele ano, ele publica o primeiro fascículo de seu The Pencil of Nature ("O lápis da Natureza"), com guir registrar com clareza as pessoas em movimento $\begin{array}{ll}\text { seis fotografias capturadas em calótipo, impressas } & \text { no quadro. Sobre isso, William Crawford comenta n } \\ \text { em papel salgadodo, e textos (com trechos que traduzo } & \text { seu livro The Keepers of Light que para se registrar }\end{array}$ livremente aqui). A publicação é considerada o pri- pessoas na cicade com placa úmida costumava-se alsom câmera.
sesera Nessee nos fascículos seguintes, Talbot explora as
possibilidades de uso prático de sua invençăo e suas vantagens sobre outros métodos de registrovisual em
diversos contextos. A cada par de paginas opostas ele incluiu uma imagem fotográfica em papel salgado
com o titulo de Plate ("Placa"), com um nummero sequencial e um texto explicando as vantagens do uso
de seu método fotografico para a respectiva imagen.

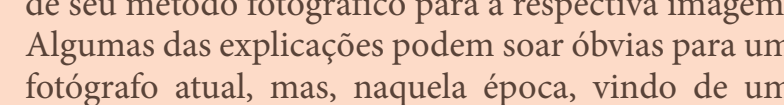
conhecimento da pintura e desenho, o aparelho fo
tografico era ainda desconhecido e nem um pouco

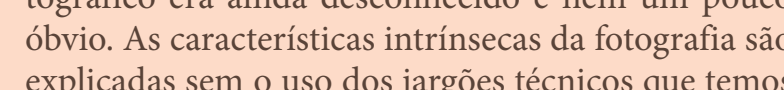
explicadas sem o uso dos jargōes técnicos que temos
hoje, mas podem ser reconheceidas no texto de Talbot. veem três pessoas posadas em uma cena com uma es
cada. No segundo paraggrafo, as primeiras frasese expli-
No texto da Placa VIII - Uma Cena em uma Bi-
blioteca - Talbot levanta a possibilidade de, devido ao calótipo ser sensível ao raios invisíveis do ultra-
violeta, no futuro ele poderia fotografar uma sala es. ente eanda assim registrar seu interior se ele fosse a nao imita a visão humana, e sim vê outra coisa. Con-
clui que "para usar uma metáfora que já empregamos

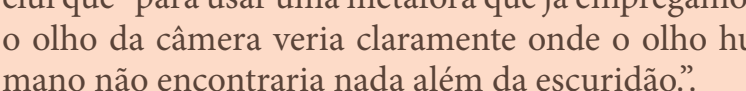
Talvez a característica principa demonstract ta reprodutibililidade da matriz em varias cópias idênticas, por isso a apresentacáa como uma
publicacáa em livo, suporte mque oleitor da época não esperaria ver ilustraçōes que não fossem gravu- $\begin{array}{cl}\text { as placas desta obra foram obtidas pela mera } & \text { duas publicaçōes de grande porte; o Sun Pictures in } \\ \text { ccáo da Luz sobre papel sensivel. Elas foram forma- Scotland (1845), em menor nummero e feito de forma }\end{array}$

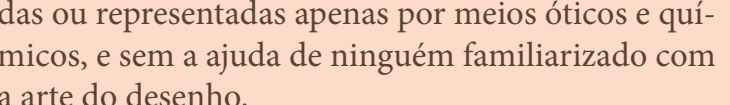
ando Talbot decide distribuir uma salgado em cada um dos 6.000 exemplares do jornal

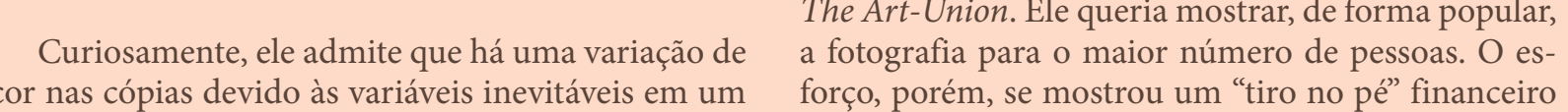

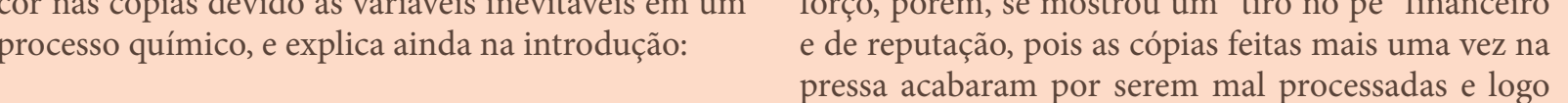
Essas tonalidades, no entanto, poderiam sem
dúvida ser trazidas mais perto da uniformidade, se qualquer grande vantagem parecesse provível de
sultar: mas, várias pessoas de gosto tendo sido sultadas sobre o ponto - ou seja, qual tonalidade en
seral merecia preferenncia - verificou-se que sus geral merecia preferência -, verificou-se que suas
opininoes nano ofereciam nanda que se aproximasse da unanimidade, e portanto, como o processo nos naeceram, dando uma má fama ao processo.
No álbum do Militâo, não hà registros claros

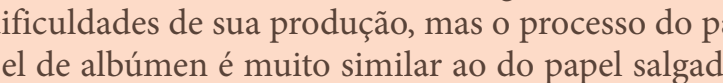
Com cerca de 60 imagens por ấlbum, é de se im claro quantos exemplares foram produzidos. Os allbúnens dos 4 exemplares do álbum que consultei estits or julgou-se melhor admitit o que parecia agrados esmaecidos em maior ou menor grau. É po páginase eadesivo onde os albúmens sáa fixados, mas
também de se imaginar algum descuido de poque as cópias não estão esmaecidas de forma igual A intencão inicial de Talbot era que O Lápis d
Natureza tivesse 10 a 12 fasciculos com 5 imagens cada. Porem, as vendas não foram como esperadas de 24 fotos. Mesmo assim, a empreitada foi homérica,
Existe o registro que foram vendidos 463 exemplaExiste o registro que foram vendidos 463 exempla-
res dos dois primeiros fasciculos, em que haviam 6 e 7 fotos, respectivamente. Ou seja, só isso dá 6.01
cópias feitas uma a uma por exposição ao sol, sen copias feitas uma a uma por exposicáo ao sol, sen
contar as muitas cópias que deram errado. Säo 23
cópias boas de cada negativo, feitas por milhares de coppias boas de
passos distintos passos distintos.
Essa operacāo pode ter forcado o "Reading Esta-
blishment" local que produriz as cópias de apressar o procecssamento, e mutita das cópias aca-
baram esmaecendo prematuramente. Talbot fez mais

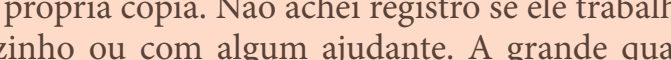
a

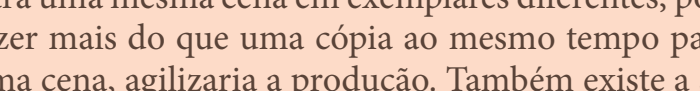
Maçá inversa. Hà ao menos uma imagen do dastem outro com um canto superior total mente negi
dicando que em algum momento o negativo brou e ele teve que continuar inp
por falta de uma cena equivalente.
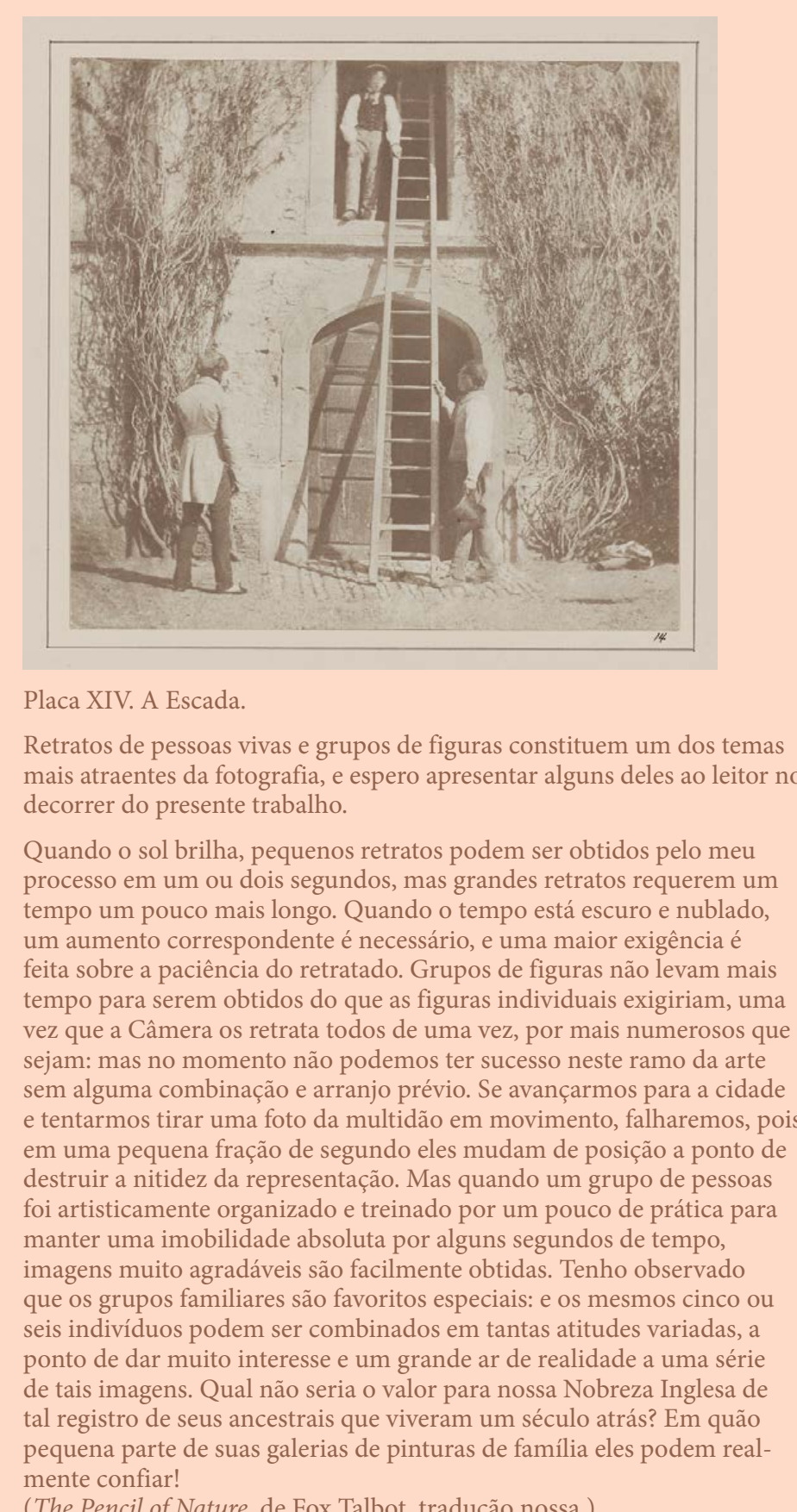
The Pencil of Nature, de Fox Talbot, traducáa noss 


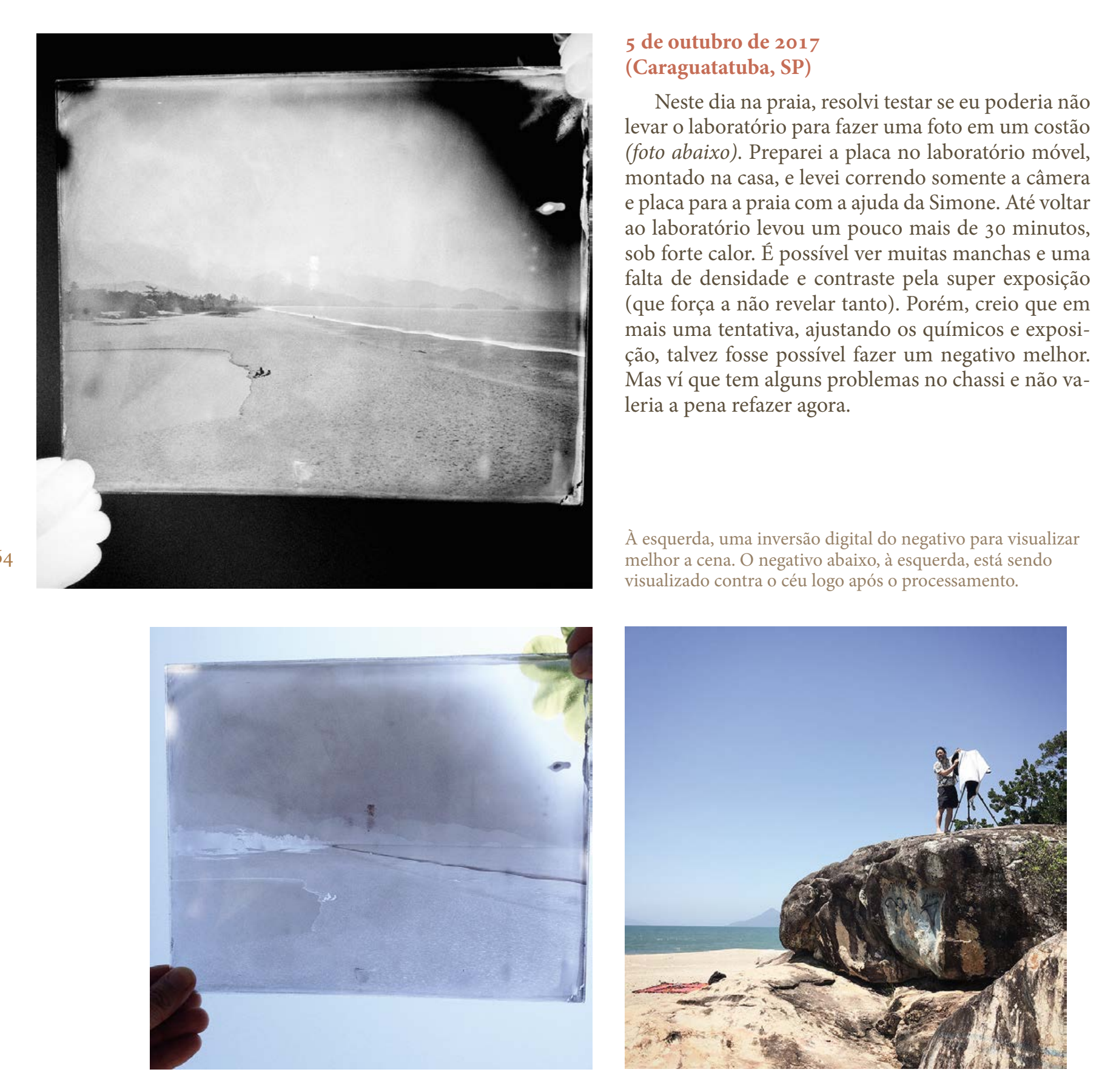

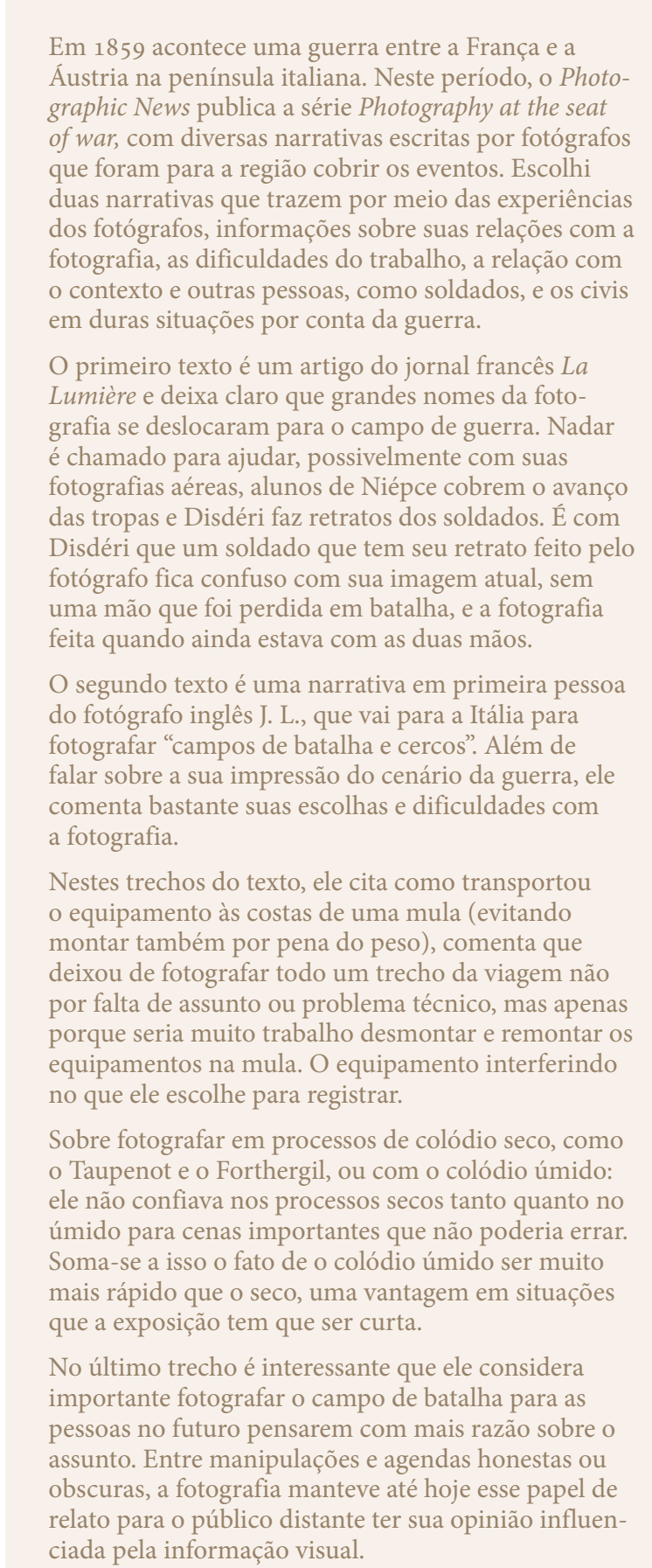

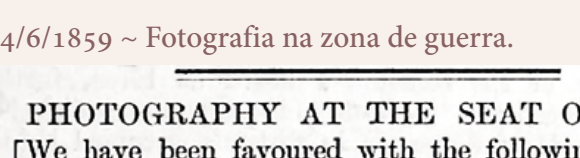

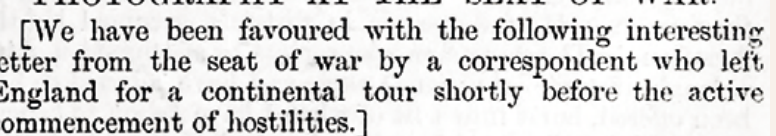

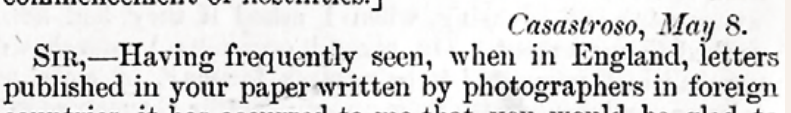

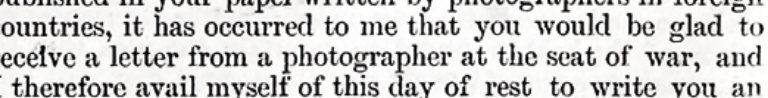

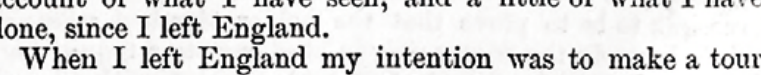

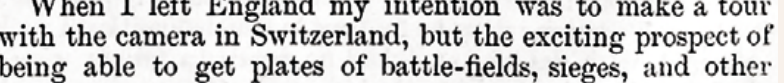

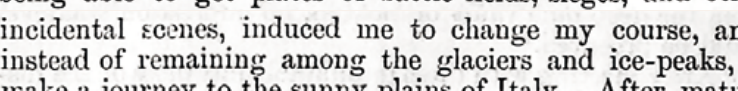

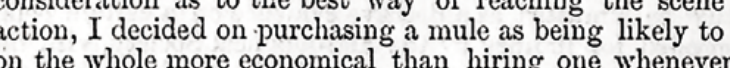

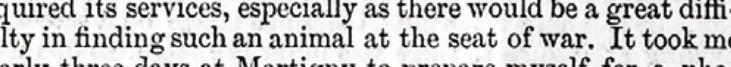

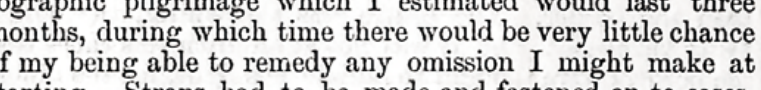

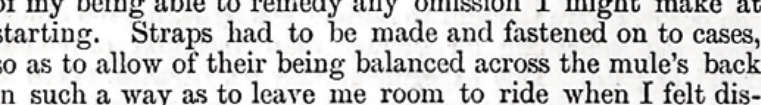

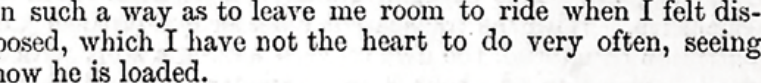

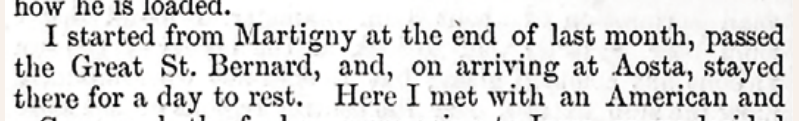

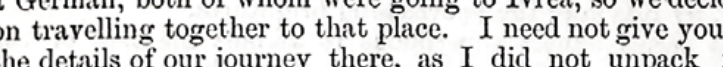

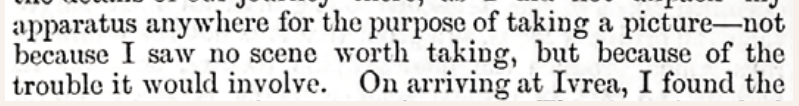

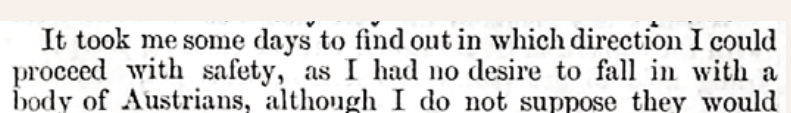

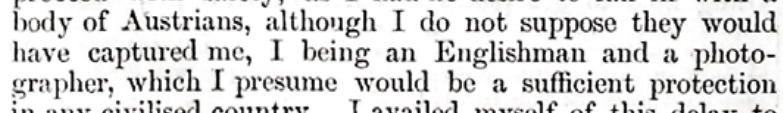

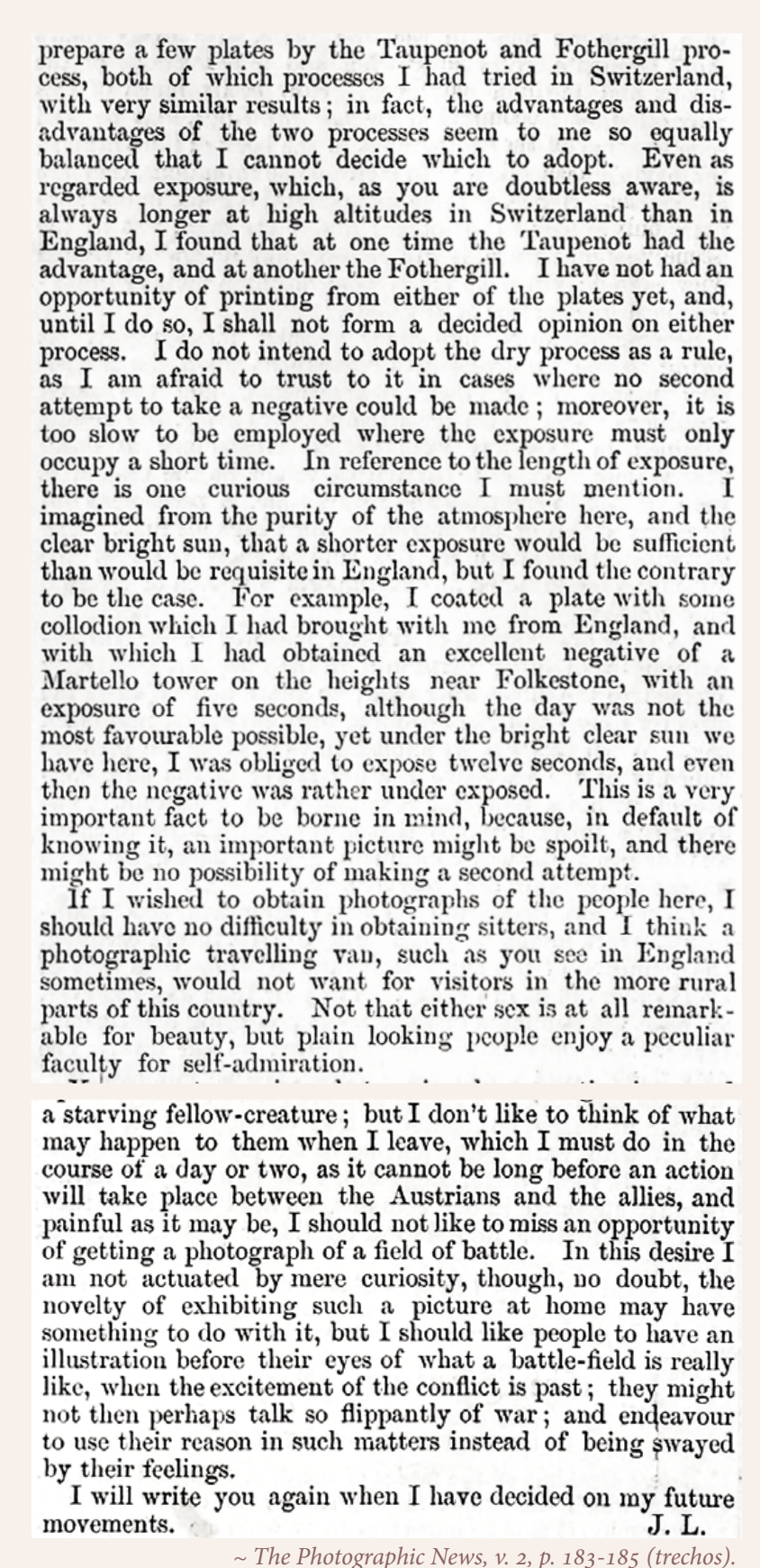



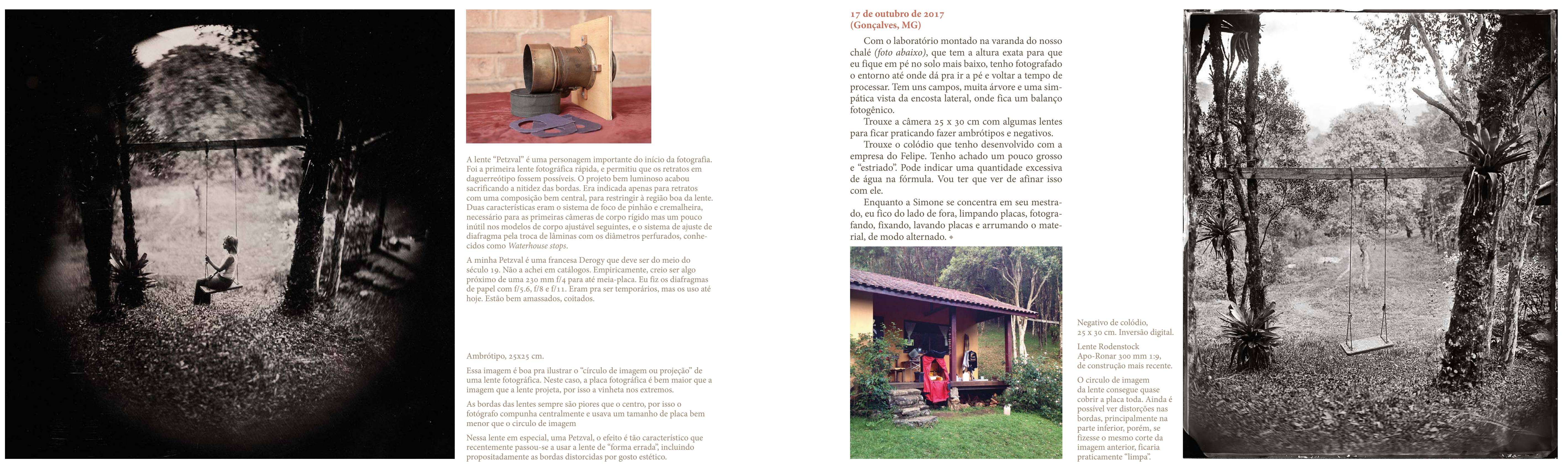

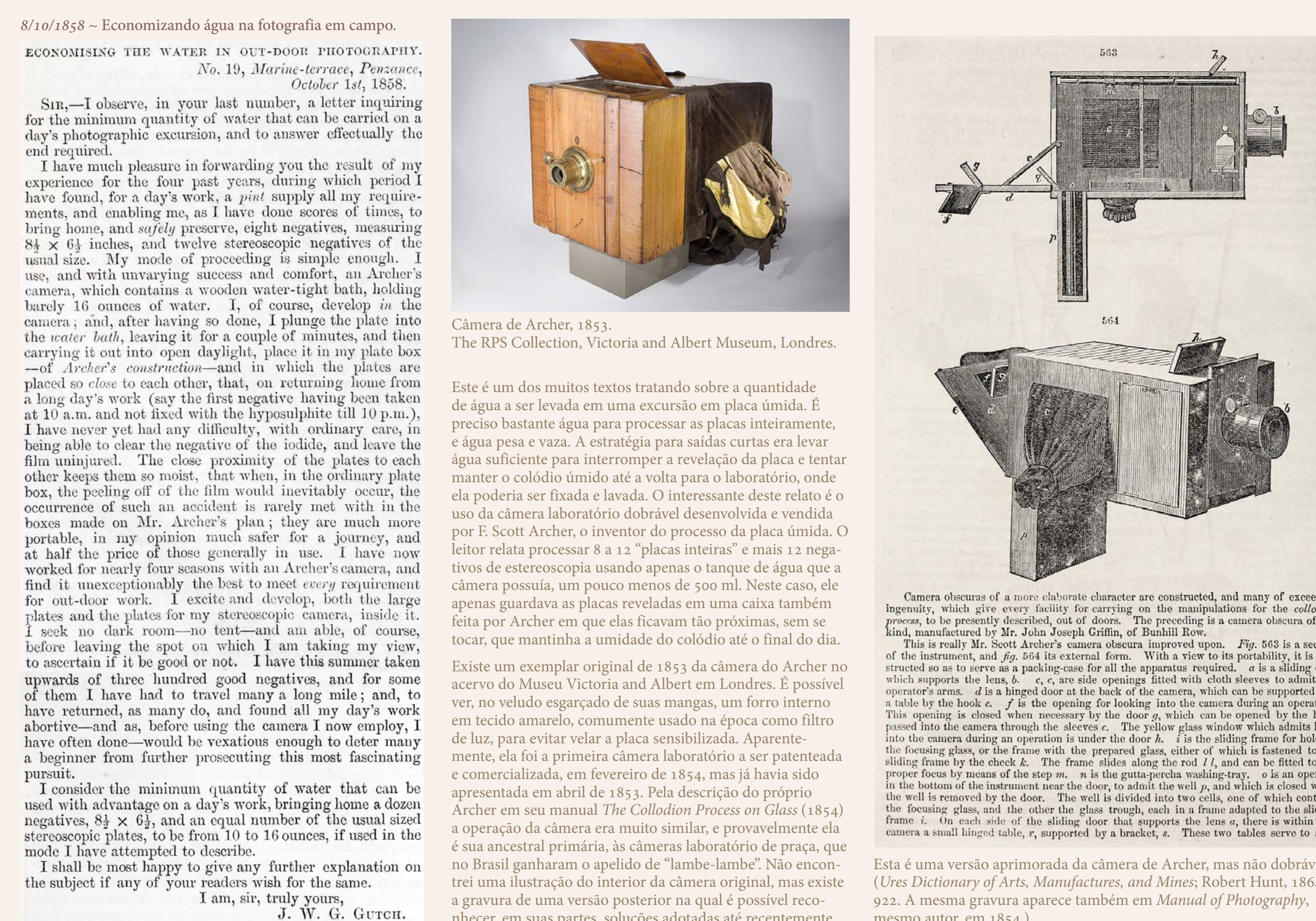

Camera de Archer 1853:
The RPS Collection, Victoria and Albert Museum, Londres.

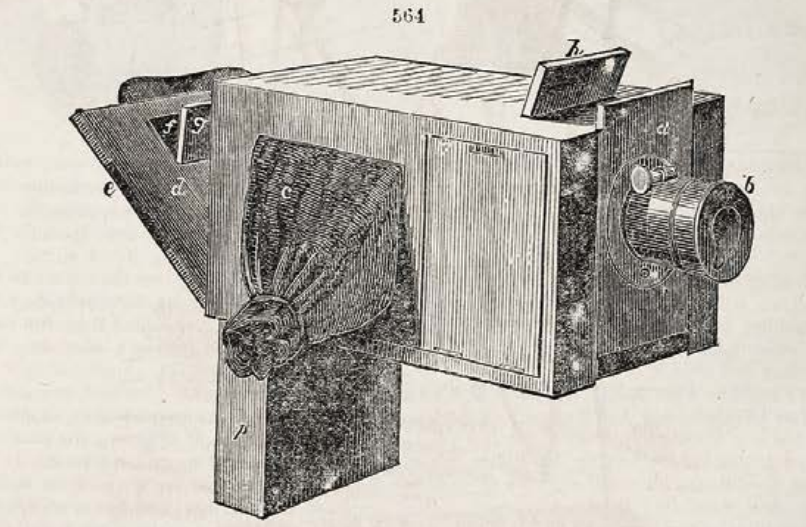

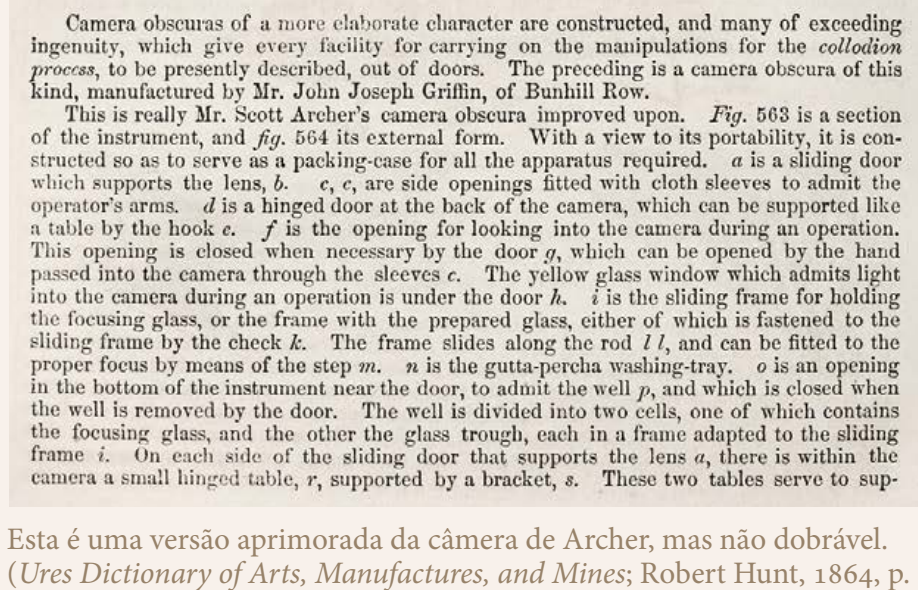

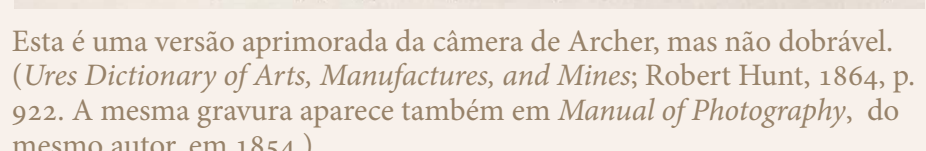

Esteé und dos muitos textos tratando sobre a quantidade
de aguaa a ser levada em uma excursaio em placa iumida.

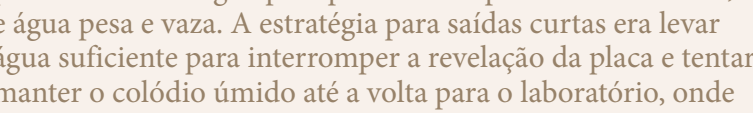

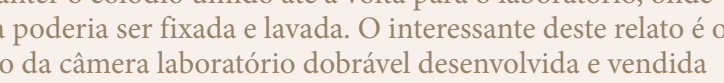

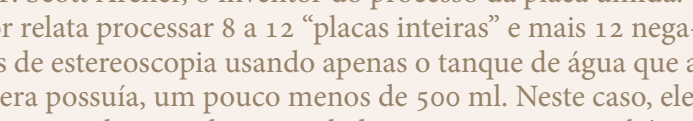

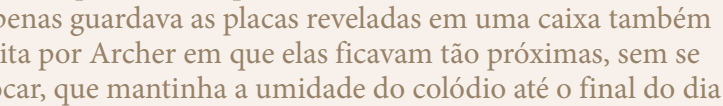

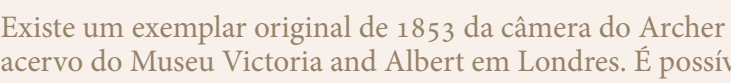

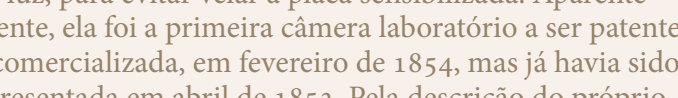

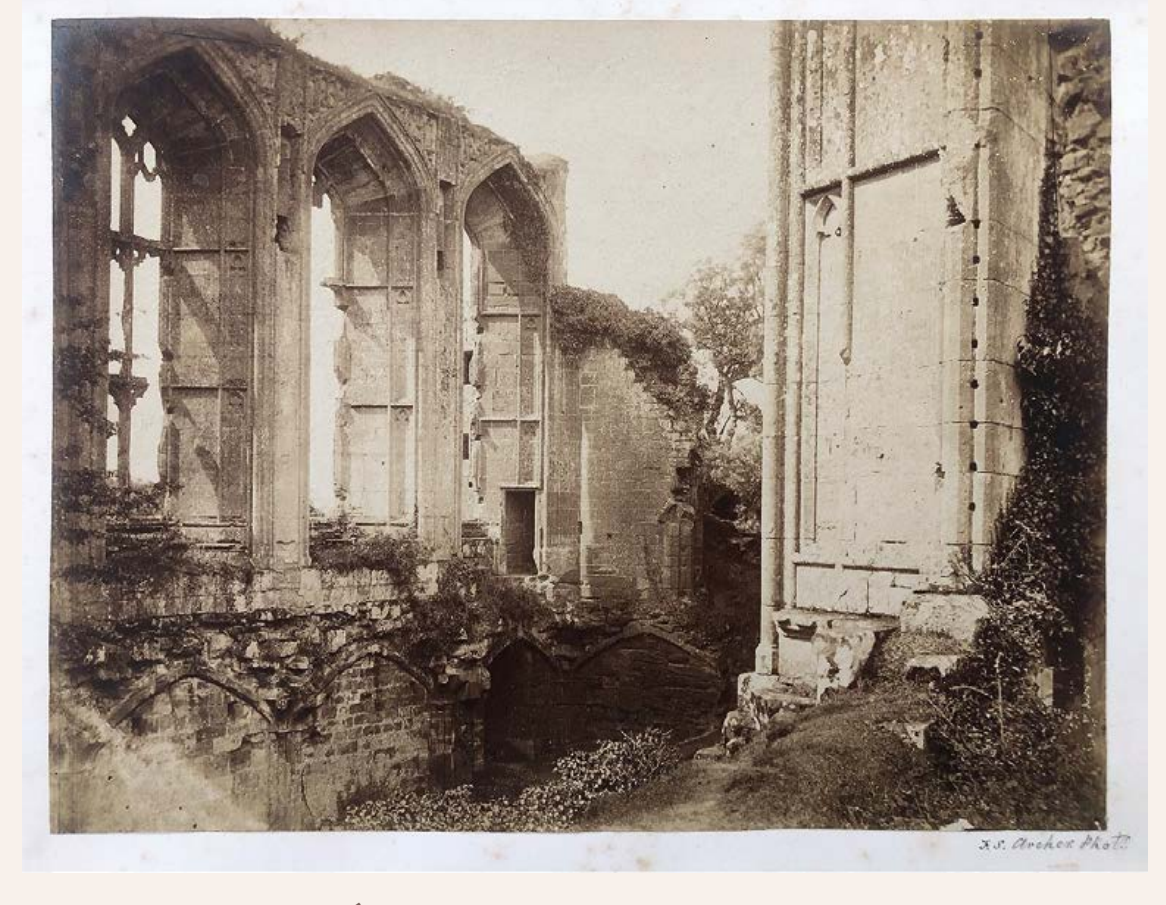

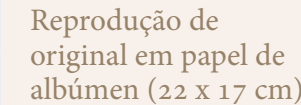

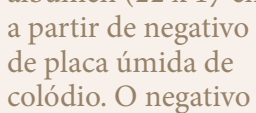

r do Colódio Úmido

Bloun ne edrederick Scott Archer (1813-1857) puseu artigo On the use of collodion on Photography, en ainda ámido para prender os sais de prata na super-
and and sem a textura de papel intrínseca aos calátítips. Ar cher naa patentela seu processo e ele fica disponive
para ouso livre de qual quer um. Com seu custo baixo e maior sensibilidadde (que o c calótitipo), o processo rapidamente adotado por praticamente todos os pro-
fissionais e amadores, e se torna o principal processo Artcher falaceun praticamente falido, deixando es-
posa e trés filhas. A comunidade logo se organizou posa e três filhas. A comunidade logo se organizou
para montar um fundo e oferecer uma pensão para a familiaia Um dos pedidos de "passar o chapéu" é a

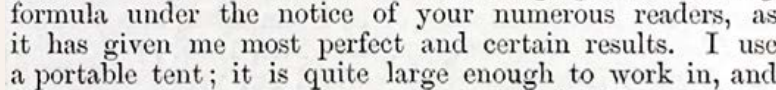

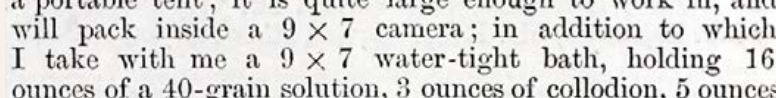

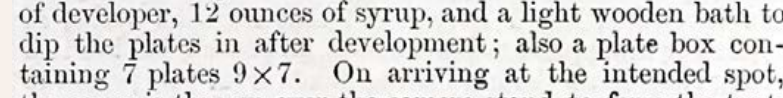

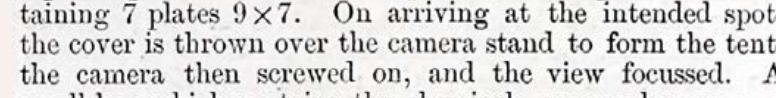

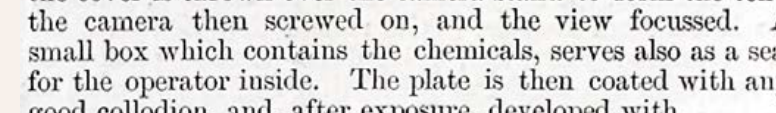

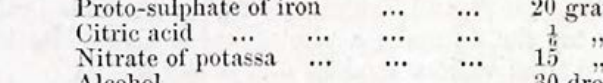

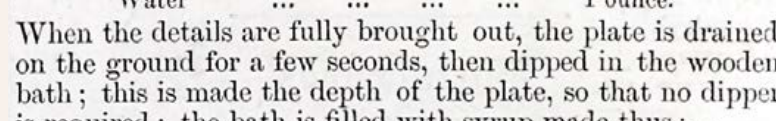

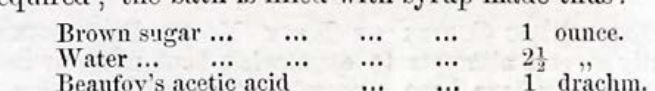

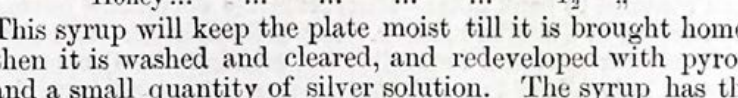

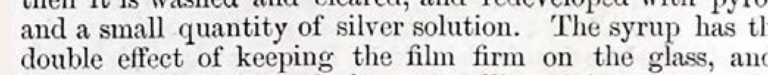

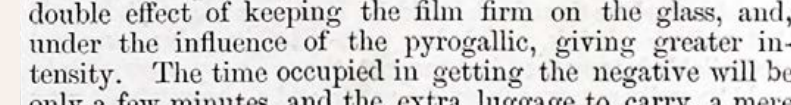

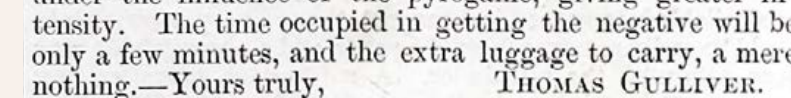

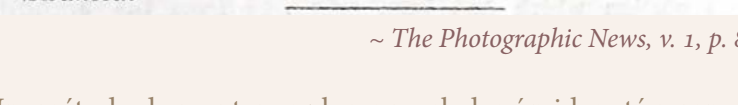

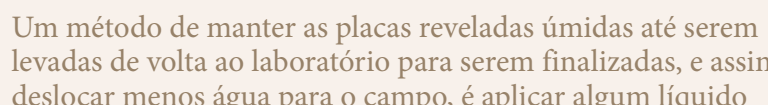

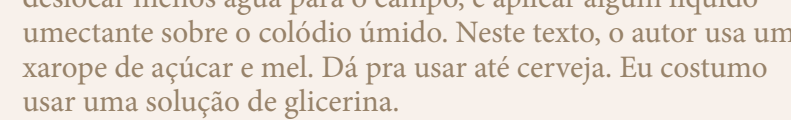

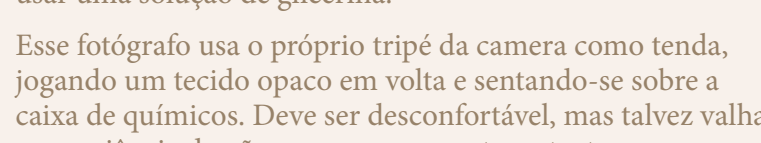




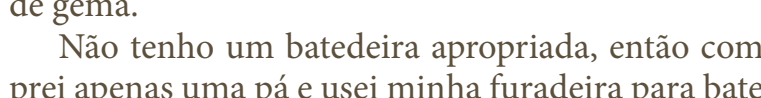

as claras em neve. Năo sei se é apropriada e se bire

clara em neve descansar durante a noite, para ela
cluefazer. Hoie filtrei o liquido e guardei em um

co de vidro. Oliquido é olbumen para cobrir follha

rar" por uns dias, pois ele fica mais líquido, logo mais
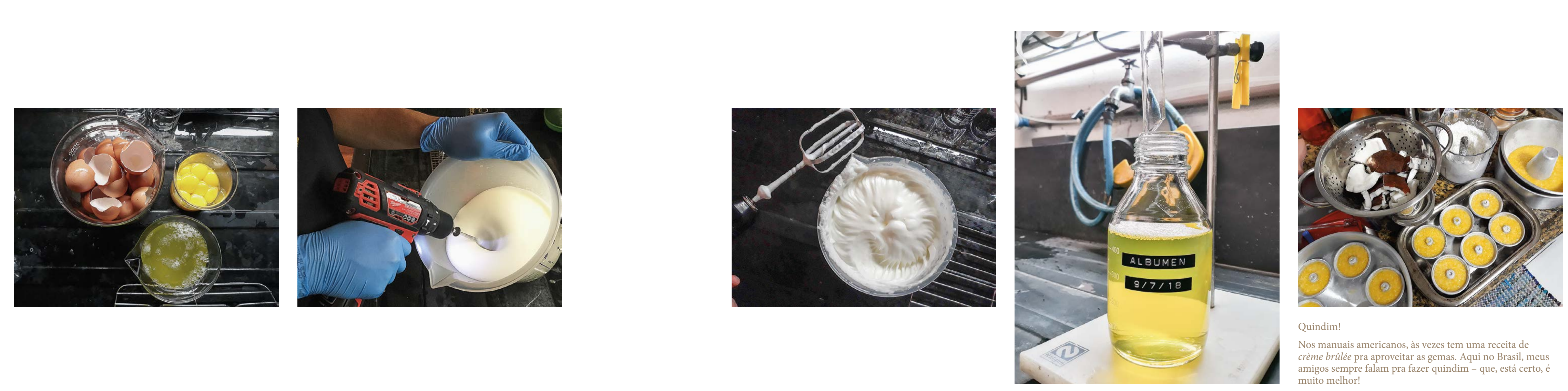

Receita feita de albúmen

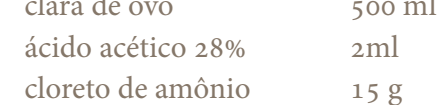


S. Paulo, 21 de janeiro de 1887
Sr. A. L. Garraux (Paris)

Rogo-lhe o obsequio de me remeter o mais de-
pressa possivel a encomenda constando de nota junta. Estou fazendo um trabalho que julgog ser muito
umportante mas talvez pouco rendoso. Ë um allbum

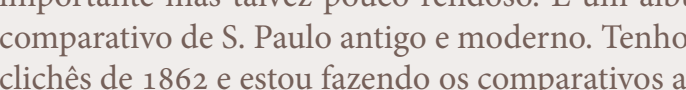
ais. Este trabalho e tiragem podem levar dois meses
por isso espero em sua atividade que a encomend. esteja aquio mais breve possivel. Não Ihe mandare
fazer a impressáo e os allums ai porque depende

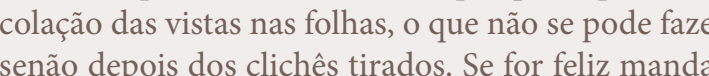
rei fazer a segunda ediçăo ai. Os âlbuns devem ter de

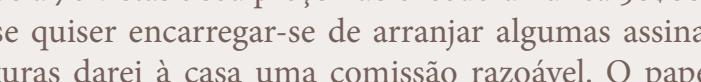

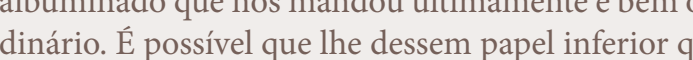
ordinariamente custa 60 a a resma. Se esse fabricante
(Schaeffner) não lhe insirar confiance Vs comprat papel ter o deféito na grossura que é fino demais o K. Os vidros brancos de Ruinett?] por experiènciai pessa na altura enão comprimento, isto que ser assin $\square$, e não assim $\square$. Se funis cificutam a embalagem ou tornar $m$ NOTA

$60 \mathrm{~kg}$ de hipossulfito de sódio (em barn $1 \mathrm{~kg}$ de nitrato fundido para impressão[?]

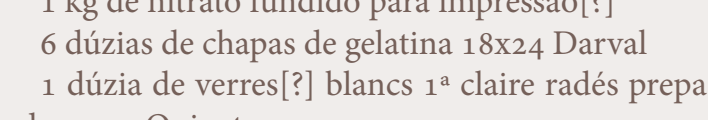
12 idem de verres[?] dancis

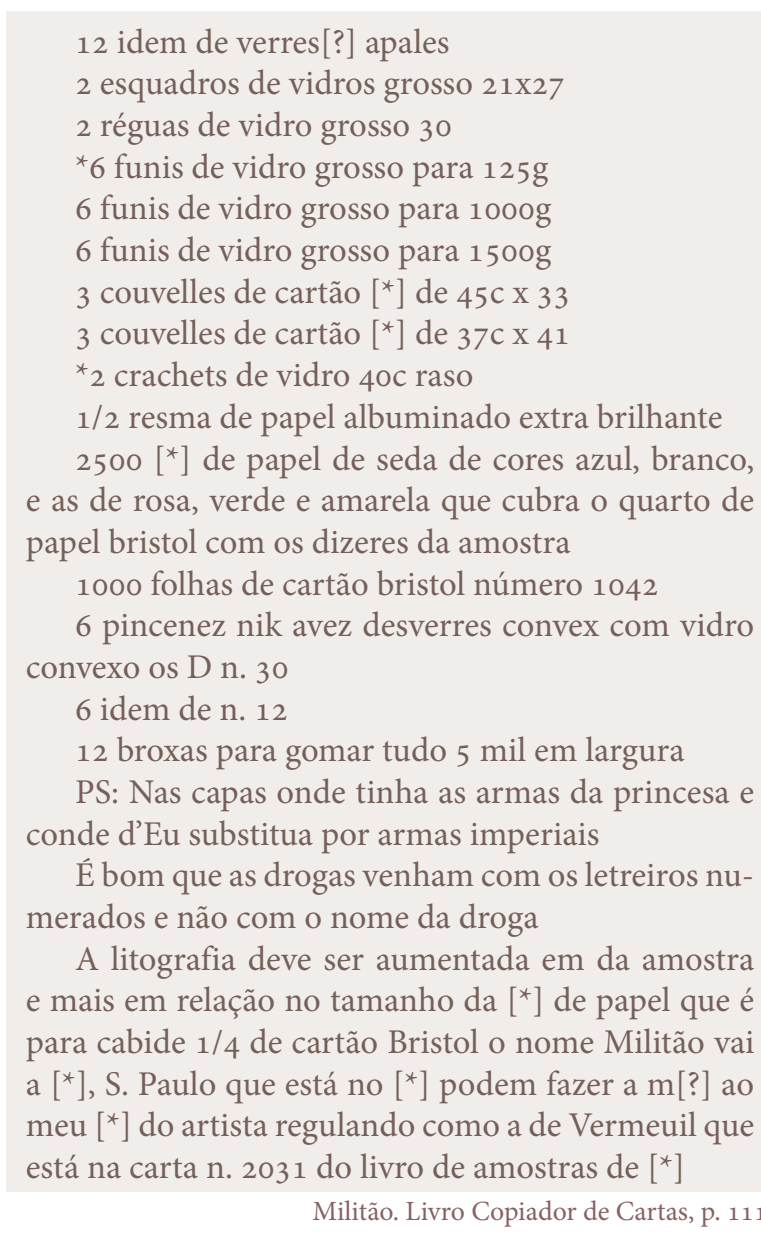
Visitei o acervo de iconografia do Museu Paulista
hoje pela primeira vezz Pedi para ver o ábum do Mi-
litâo e descobri que há dois deles no acervo, um deles de capa vermelha. Eu achei que eram todos iguais.
O anterior que vi no acervo da Biblioteca Mario de Andrade esta em piores condiçêes. Estes estão ben
testaurados, mas também sofrem com o esmaecimento e emarelamento das fotos em albúmen $e \mathrm{da}$
degradacão das páginas em oue as fotos estão das. Ambos perderam quase todas as follhas de seda glgumas imagens, pois as páainas foram retiriadas Eu passei rapidamente pelos dois álbuns pegando
and ggumas medidas das fotos. Năo consegui fazer um
ompraracáa cuidadosa das imagens em cada um por falta de tempo. Precisio voltac com mais tempo! Pena

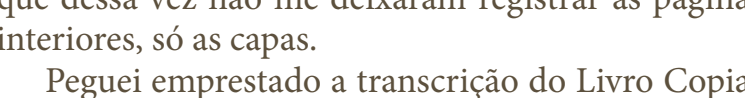
Pegueie emprestado a transcriçăo do Livro Copia-
dor de Cartas para estudá-lo. Esqueci de pedir pra ver

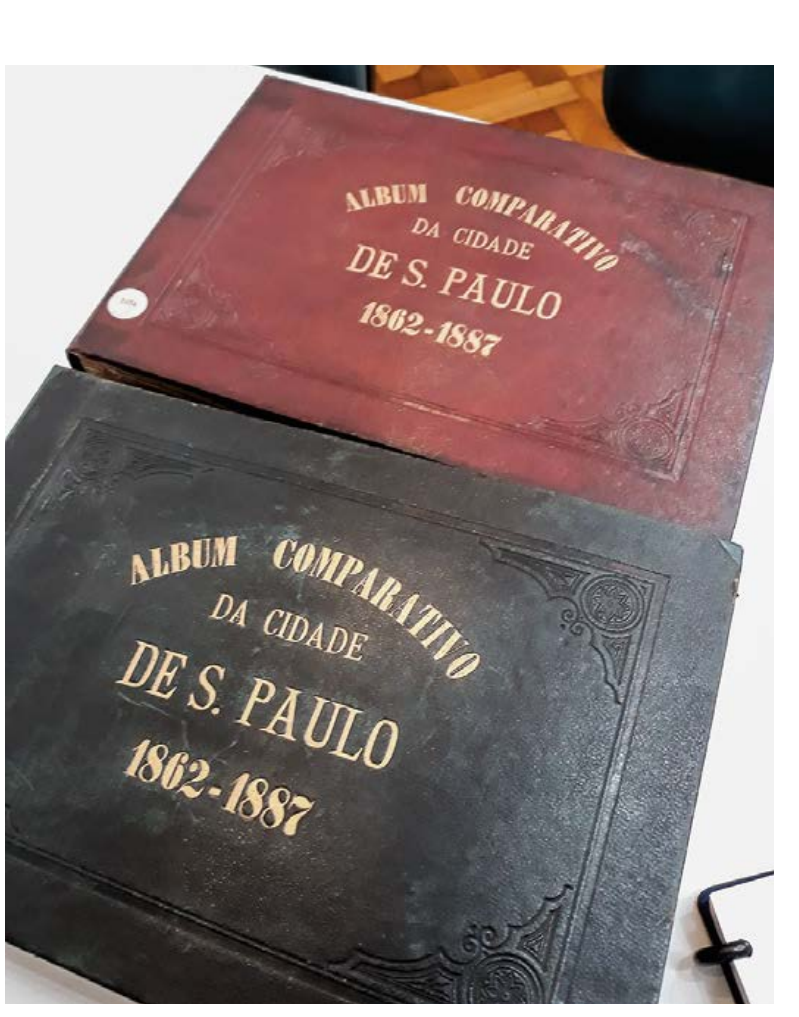

Hito, de maio de 1887

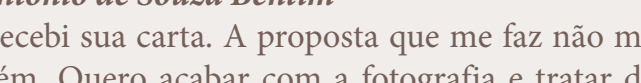
outra vida; precisando por consequênciai produziri vistas daqui (do que estor
devo concluir em junh thar mais em fotografaia. Ao menose e essa a intençáa ria pode Ter o material e máquina fazer 8005 5000 pois anguerem the podera vender pelos meus precos, pois Boa Vista n. 15.

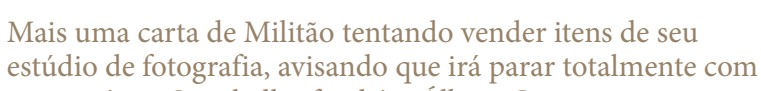

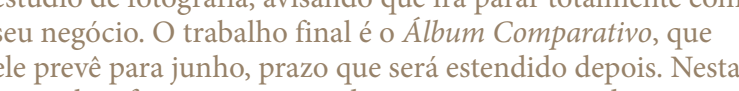

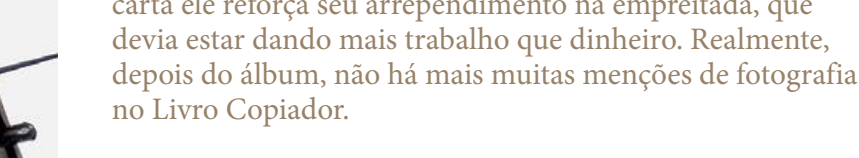




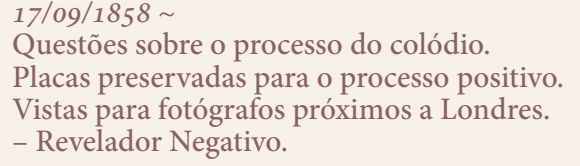

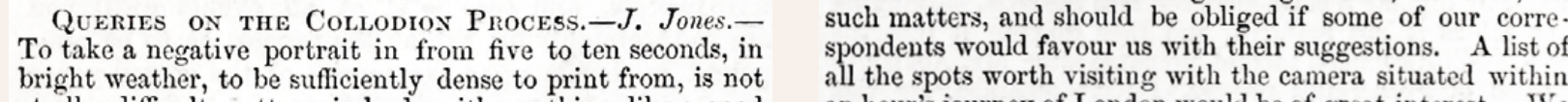

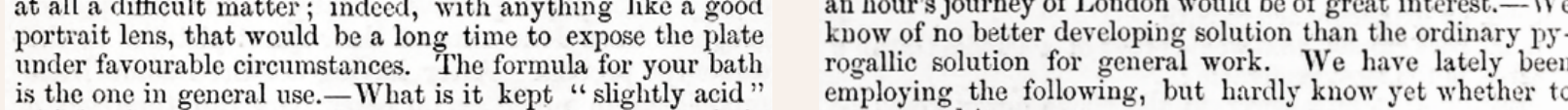

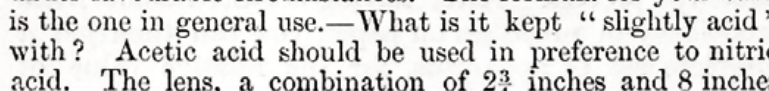

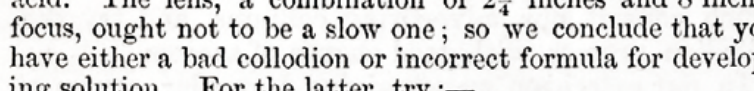

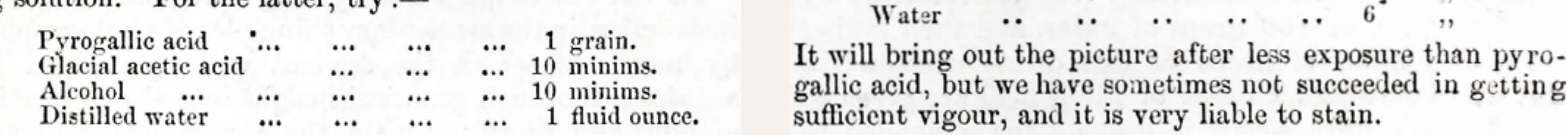

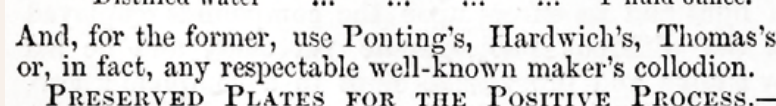

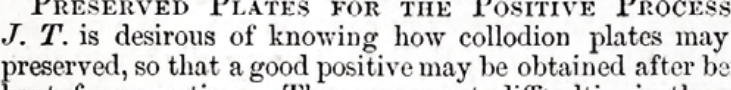

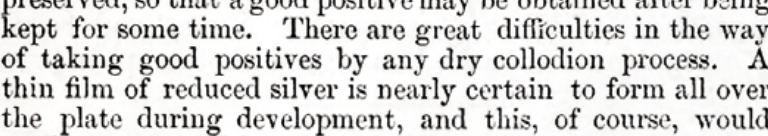

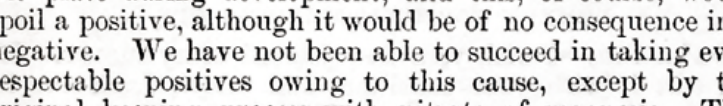

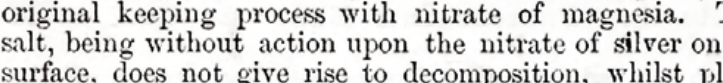

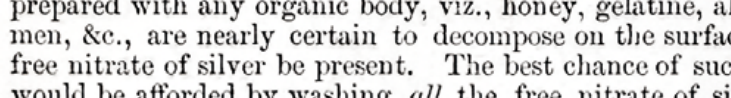

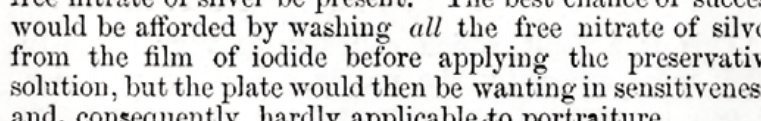

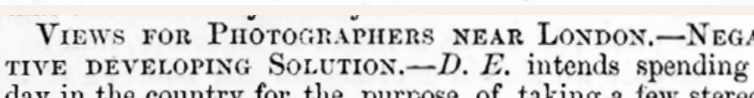

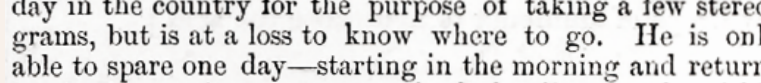
ing in the evening -consequently the locality must be with

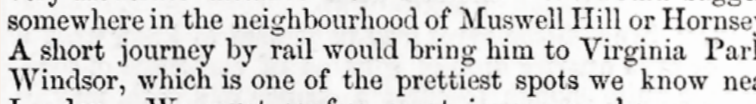

a d

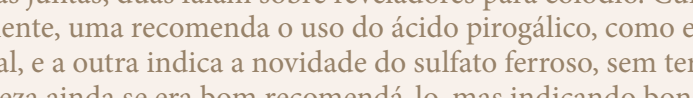

Hlacas.

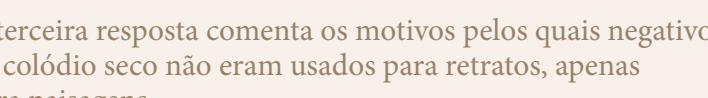

23 de agosto de 2018 Embora eu tenha feito negativos com duas revelacões com sucesso, tenho tentado fazer um bom nega certa já de primeira. Os manuais do século 19 dizer que o melhor negativo tem a exposição certa e um a melhor escala tonal. Se por questáa de má iluminacão ou alguma imperícia o negativo não tiver a densi-

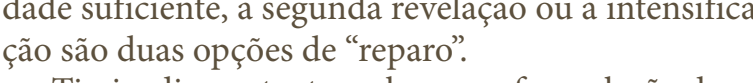
Tirei o dia pra tentar achar uma formulacăo de re.
velador que me permita aumentar a densidade do ne velador que me permitit aumentar a densidade do ne
gativo sem velar as baixas luzes. Eu diminuí bastante a quantididade de sulufato ferrososo eummentei i aunanti-
dade de acido acético eadicionei aḉcar branco par dade de ácido acćtico e adicionei açícar branco para
evitar a revelaçă de prata não exposta, o véu.

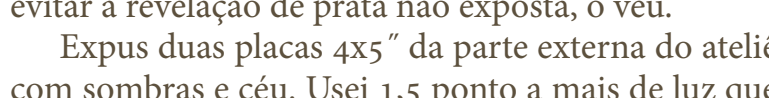
com sombras e céu. Usei 1,5 ponto a mais de luz que cäo: adicionei 3 gotas de prata 8\% a cerca de 15 ml revelador (+açucar). A primeirar revelei por 1 minuto de. mas tem uma neutralizaça da prata Parece quanto mais longa a revelação mais neutro o tom prata. Wels e há mais superficie para absorver mais do espectro
da luz. Talvez seja melhor manter o tom marrom de 1 minuto para ter mais densidade espectral. Aind

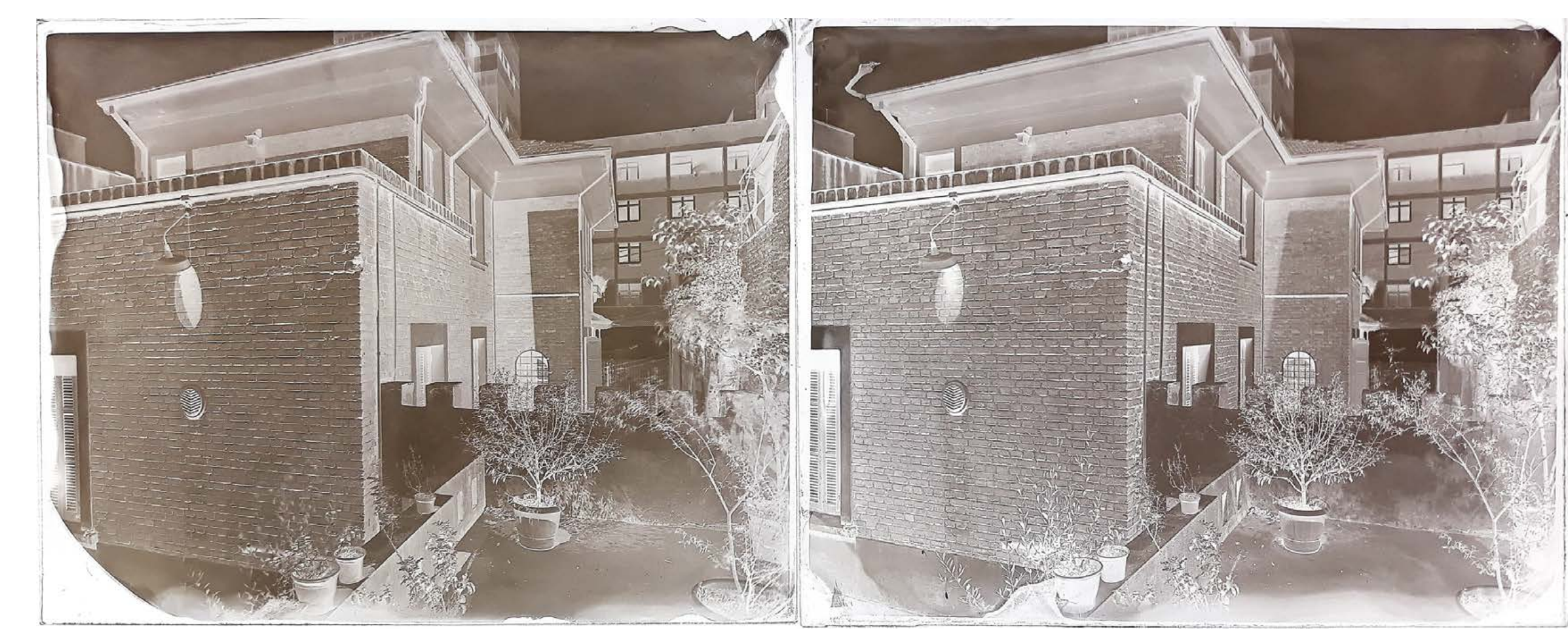




\section{A

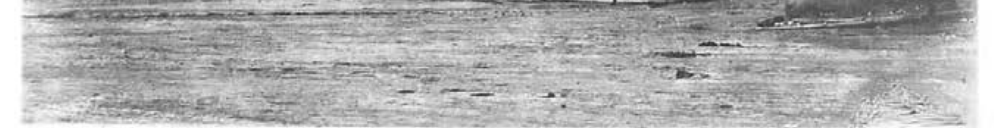

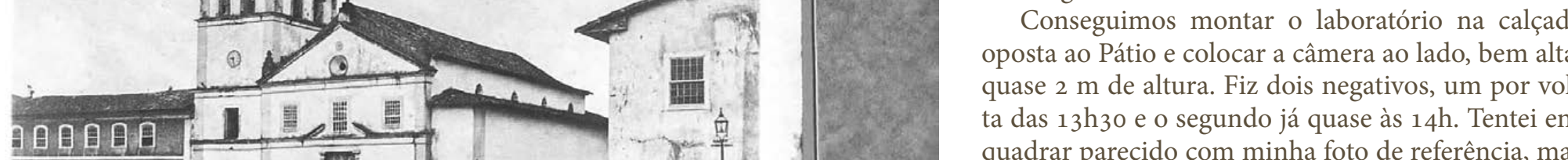

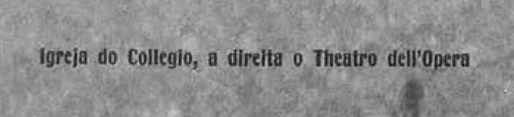

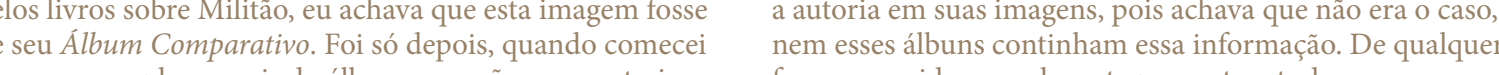

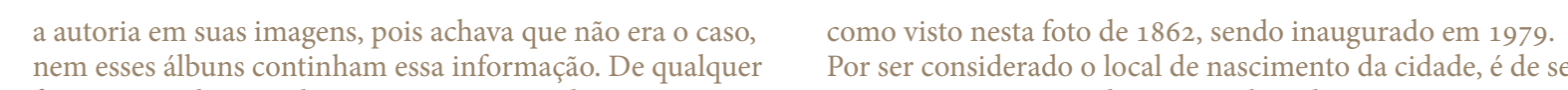

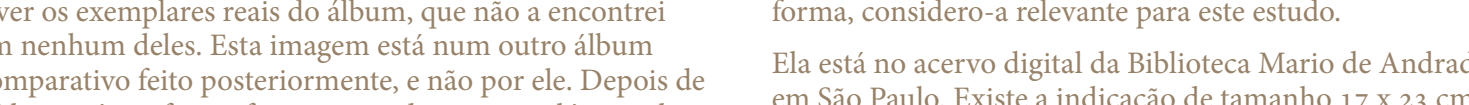

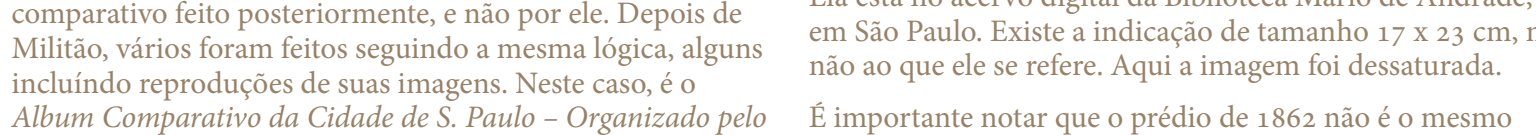

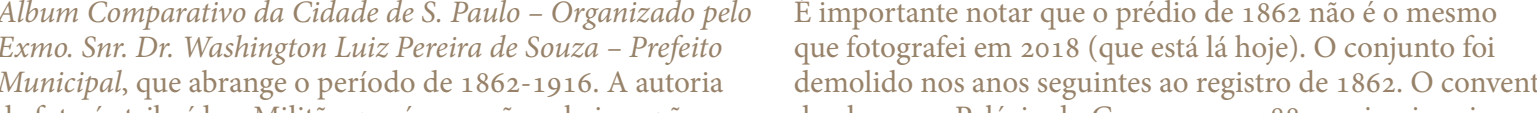

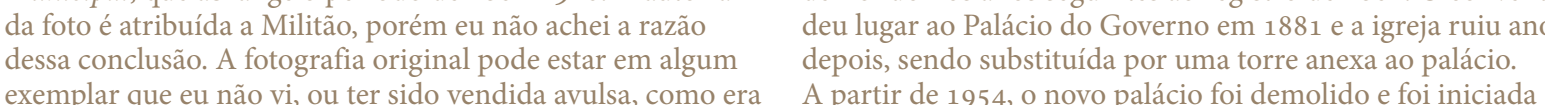

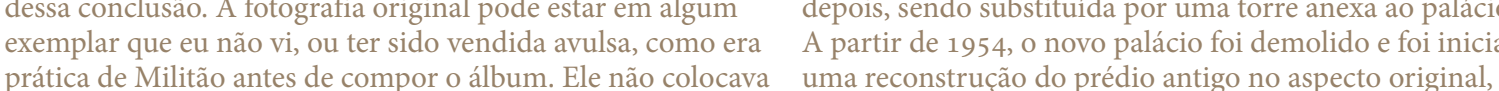

da Austrália ontem e meu cunhado Matt quis, mesmo
depois de mutas horas de vôo e poucas de descanso supor que o conjunto do Pátio tenhat tido outros aspectos

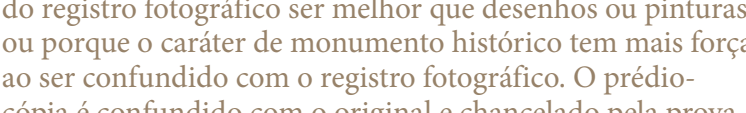

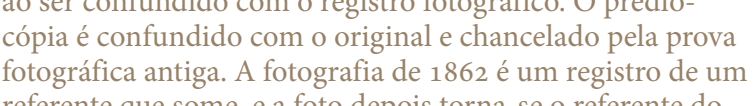

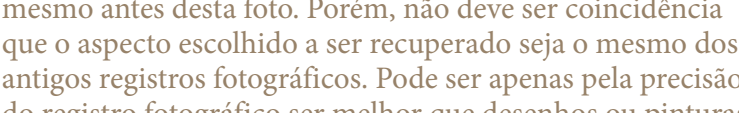

A captura foi feita em 12 segundos, com $\mathrm{f} / 11$ para
uma luz $\mathrm{E} 12$ 12. O dia estava um pouco nublado, e ao

Acho que é minha terceira tentativa de fotografar
igreja do Pátio do Colégio. Desta vez fiz placas

$\times 24 \mathrm{~cm}$ com a objetiva de $240 \mathrm{~mm}$. A Diane cheggo

muito por fotografia e estava curioso com esse jeilo

quadrar parecido com minha foto de referenncia, ma

"novo" prédio da direita. Tambem, sei que a igrejaj $j$ ia

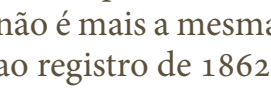
à Escola de Comércio. Nas fotos de Militía ó possi-
Francisco para eu registrar o prédio da Faculdade de vel ver que o prédio em 1862 tinha outra fachada.
prédio e o o mesmo hoje, porém sucessivas reformas deixaram irreconhecivel. Fiquei pensando em como
enquadra-lo, pois ele esta muito mais alto. Nos pares comparativos do Militáo, ele reen quadra suas cenas
recentes para ina ou 3 andares que surgiram. Deviam ser motivo de orEu não podia ii mais pra trás por conta da esco-
la, também năo levei uma lente "mais aberta". Resolv tentar manter o enquadramento de 1862 e deixar crescimento da cidade "empurra" o fotógrafo pra trás e e estimula a reenquadrá-la. Hoje, pra conseguit

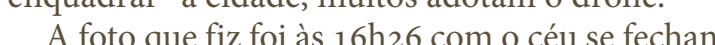
A luz mais amena exigiu mais tempo: 24 segundo ver um dia de sol direto, pelo ospecto das sombrivs Ele poderia ter exposto por uns 3 segundos. Infelizmente o negativo ficou com uma leve man-
cha no centro, pois o colódio encoston a tom cha no centro, pois o colódio encostou na tampa do
chassi. Vou trocar meu redutor para um material mais resistente, pois ele esta cedendo pela forca da comecou una chuva a juntamosos tudo correndeo o vol-
tamos para o laboratorio o mais rápido possivel.
S. Paulo, 2 de gero de 1886.
Strs. Guimaräes $\diamond$ ' Ferdinando

Rua do Ouvidor $n .35$, Rio de Janeiro)
Devido a obsequiosidade do meu an

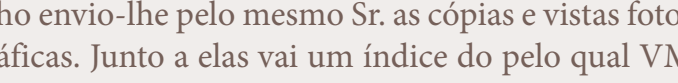
etrás das cópias estão escritos o preço o o número

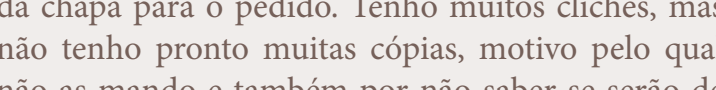
aio as ma Pela nota junto serăo V. M. que vão à comissão. $20 \%$ da comissão Se voce tiver alguma gravura ou fotografia de confiar para tirar cópia que lucraremos todos. Espero Nessas duas cartas de Militäo,é, possivel ver como funciocontinuou até depois de fechar seu estúdio de retratos.
Algumas vistas da serrad de Santos a que ele se refere fazem

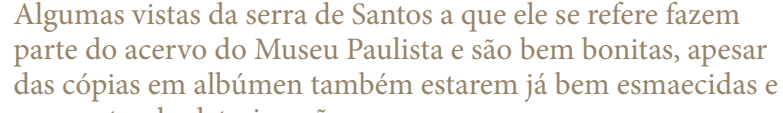

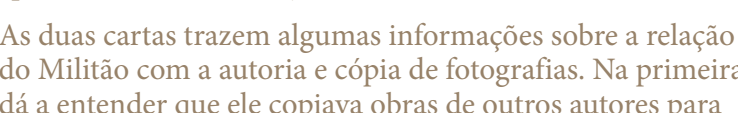

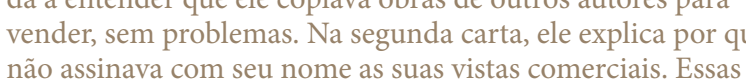

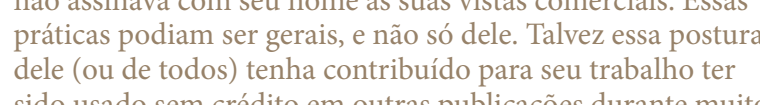

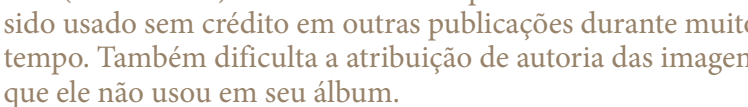

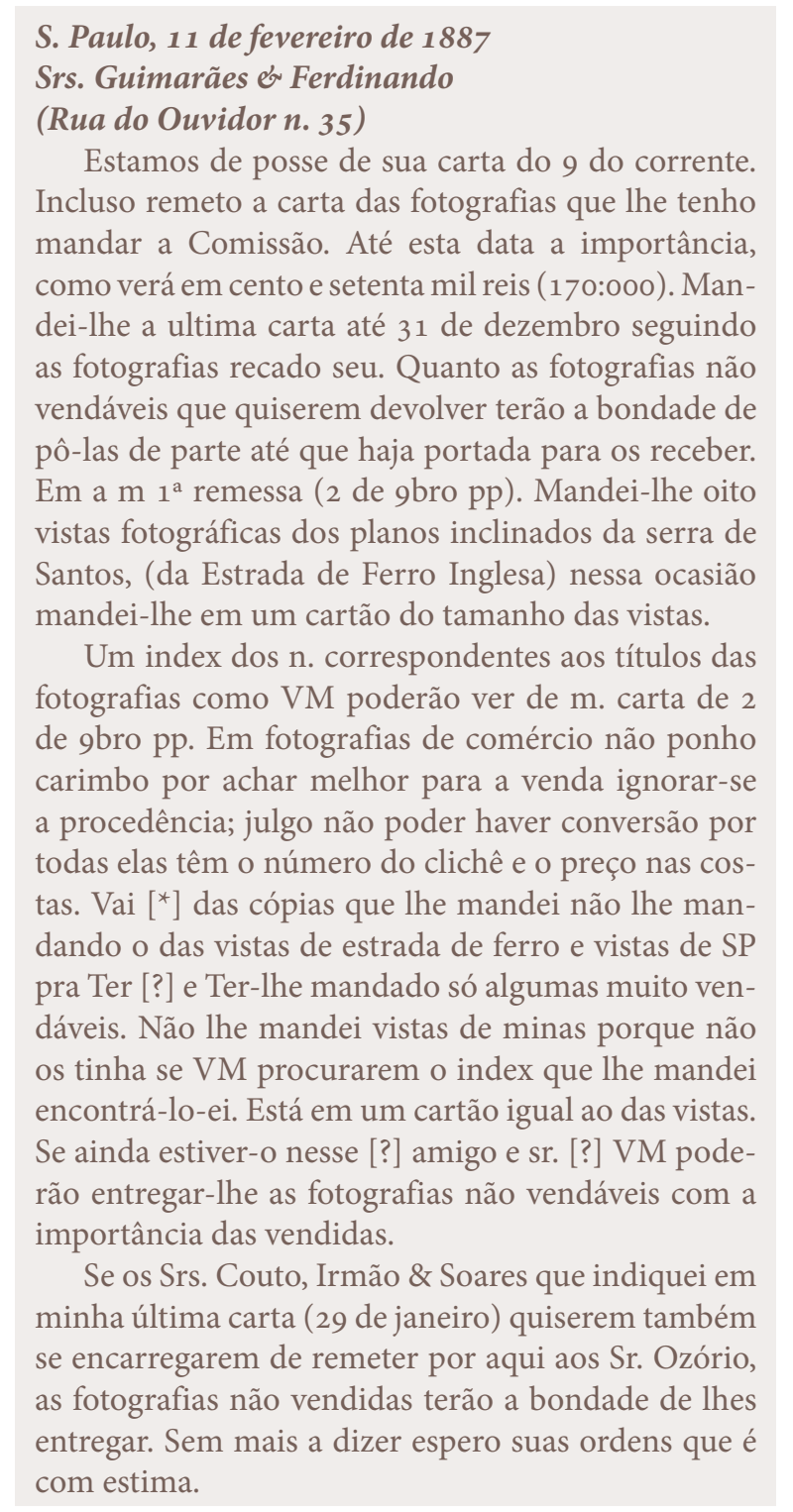



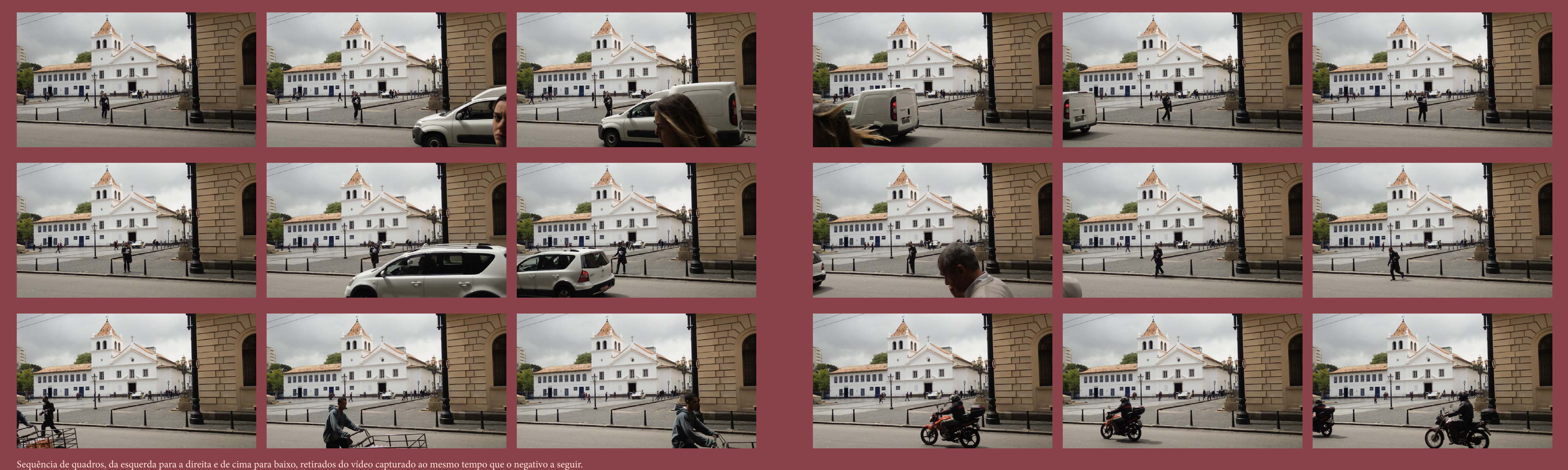

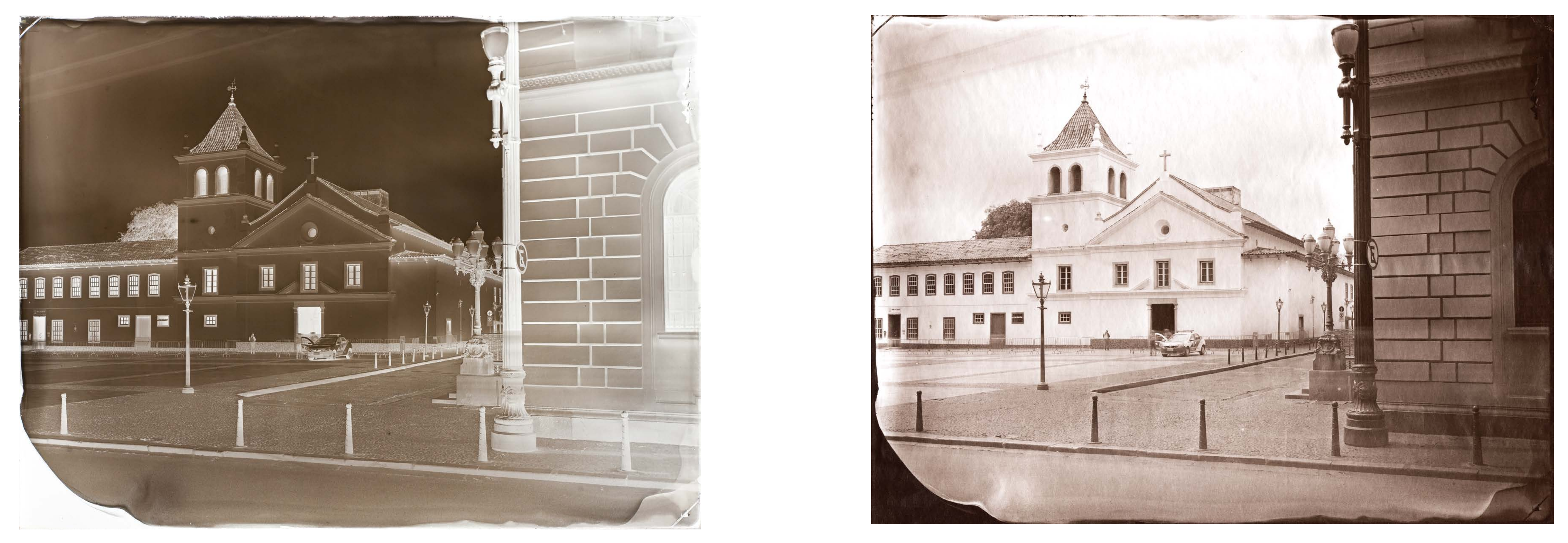


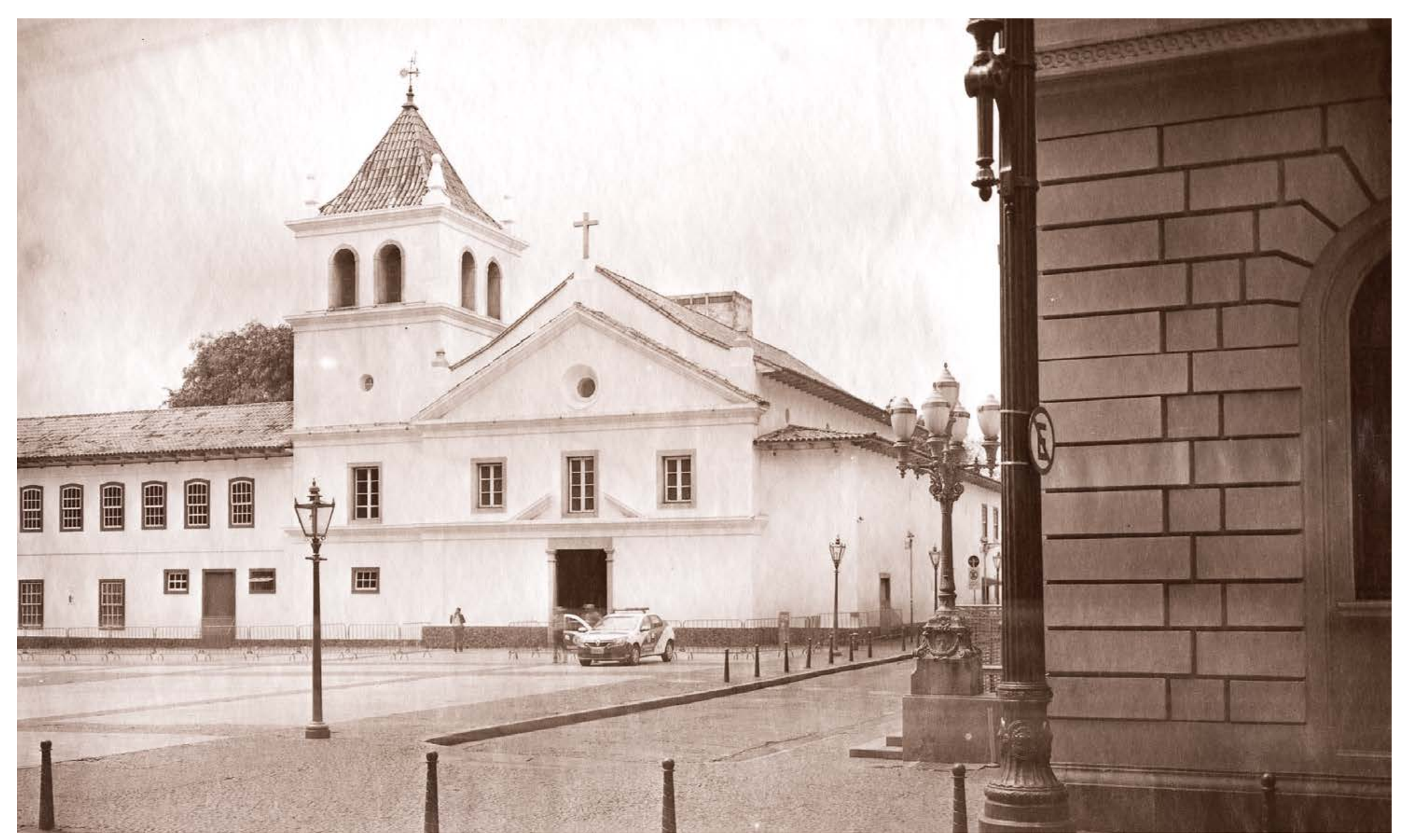



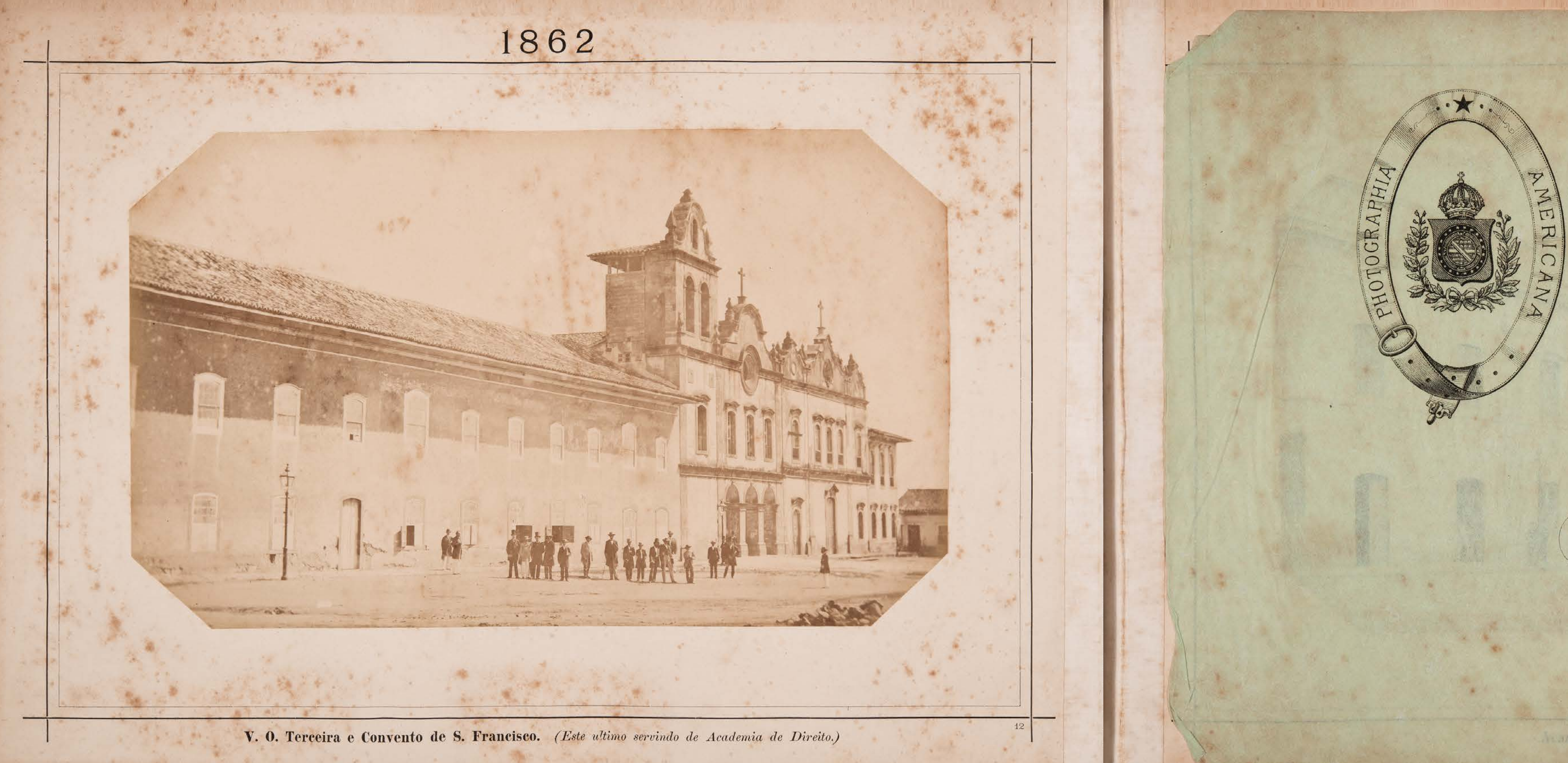

Militio 

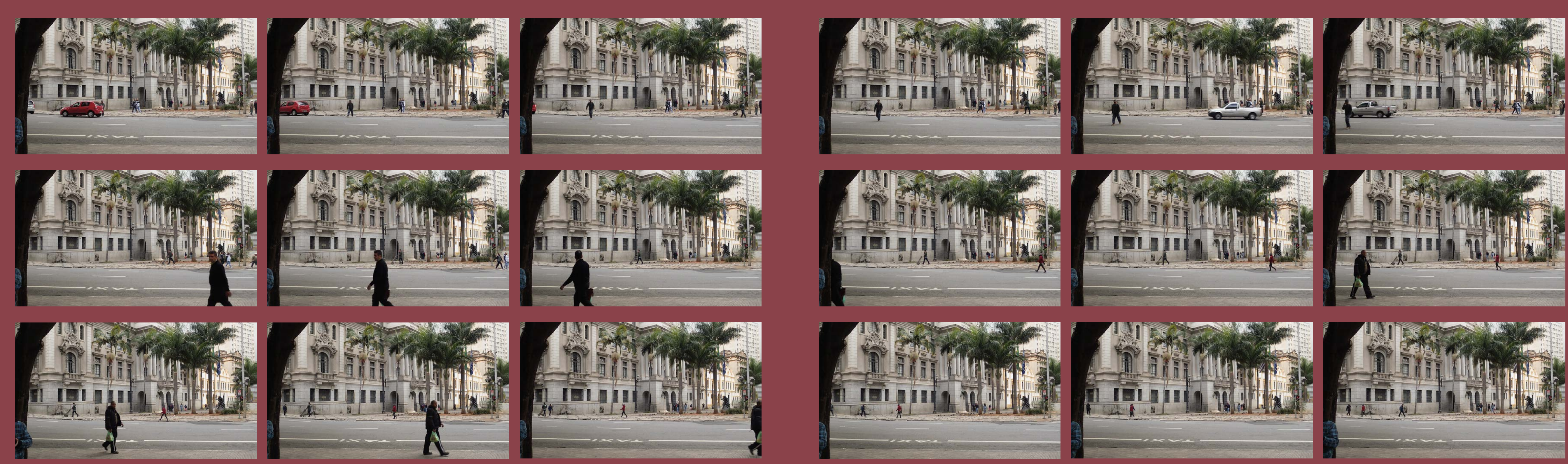

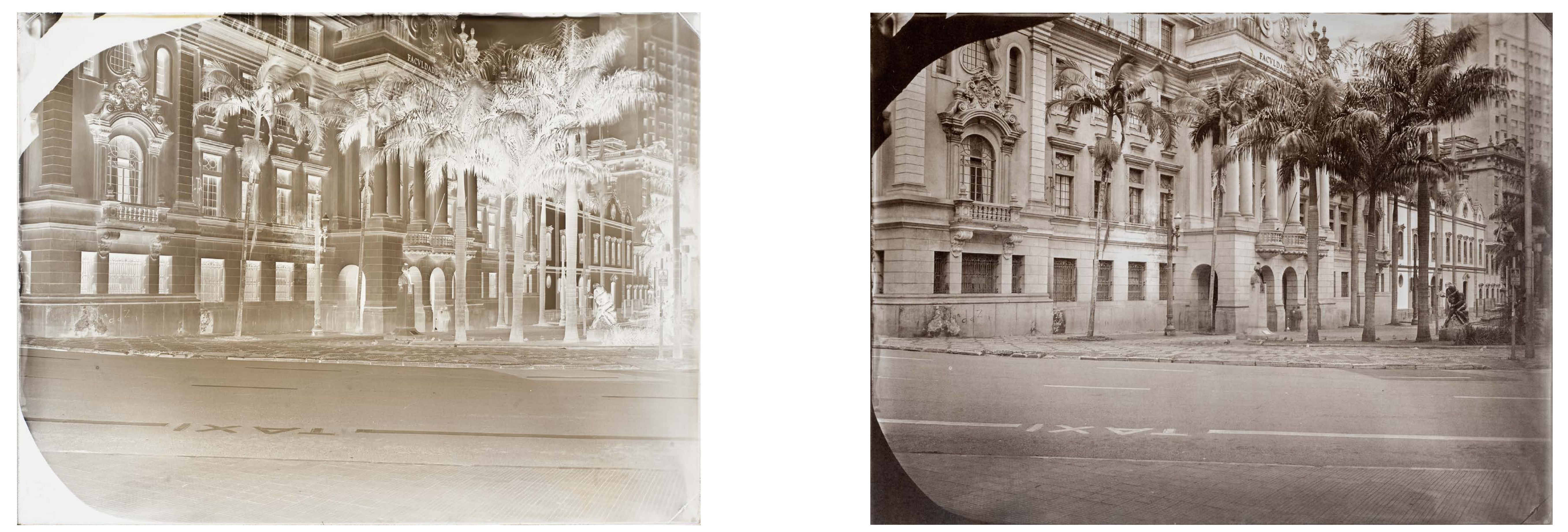


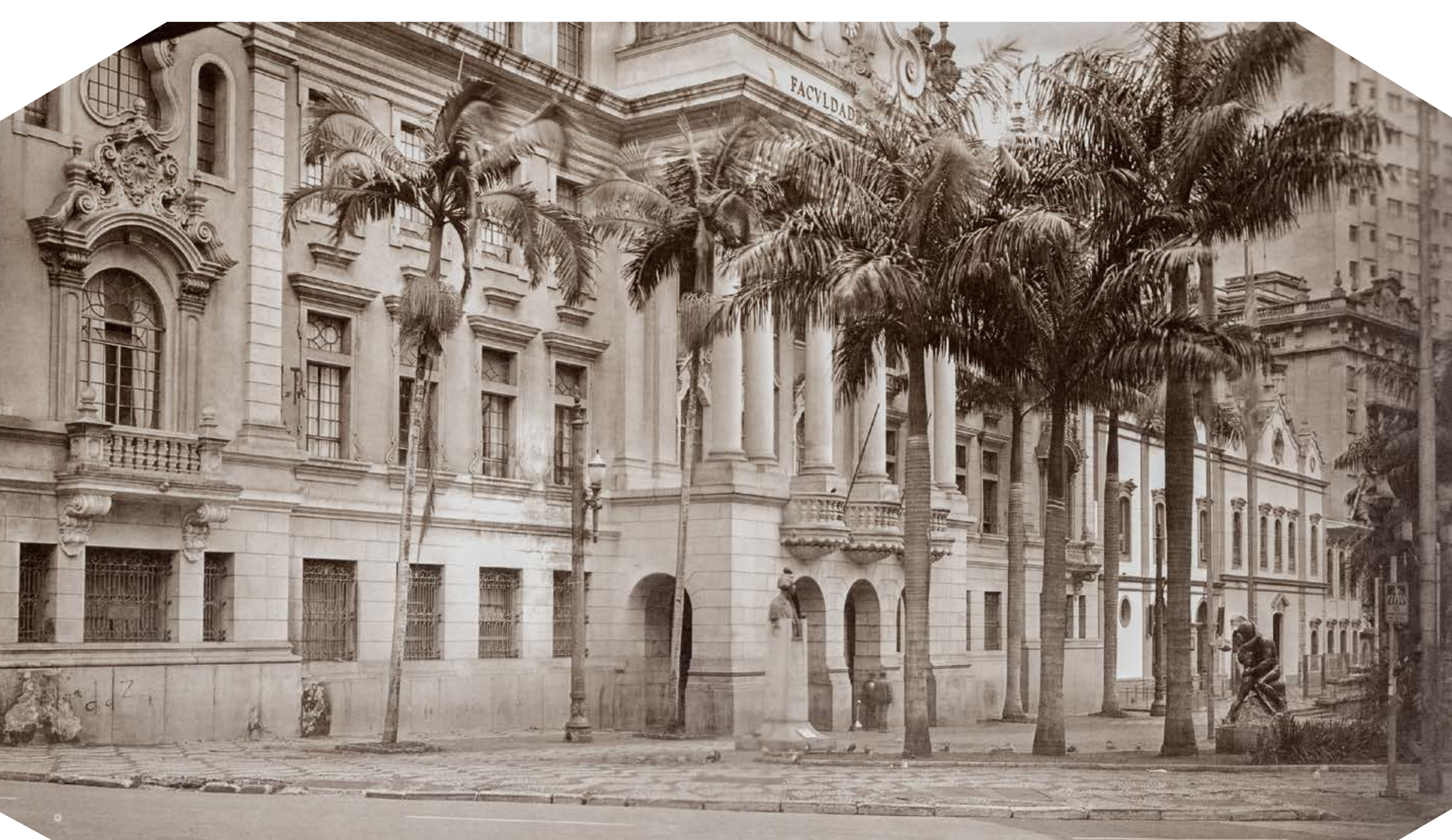


Em Campo com a Placa Úmida

Texto retirado de Photography in Print, de Vicki Goldberg.
Trecho traduzido por Raquel Dommarco Pedrão.

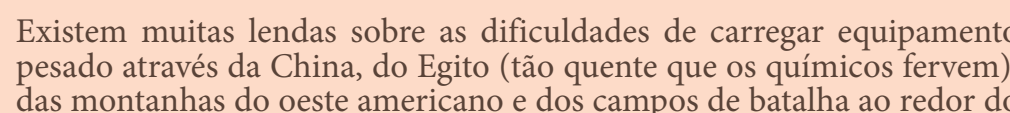

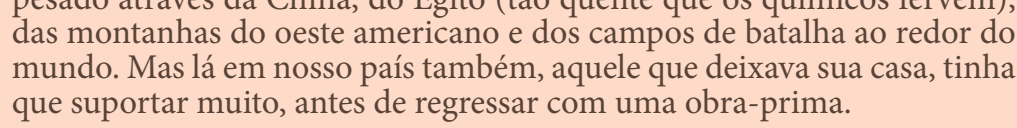

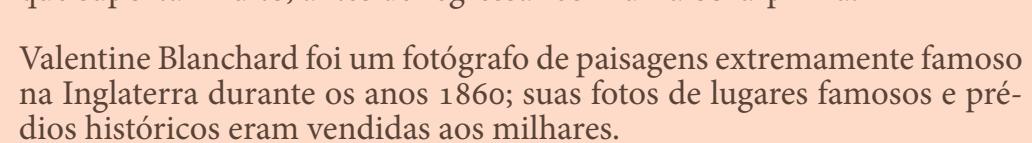

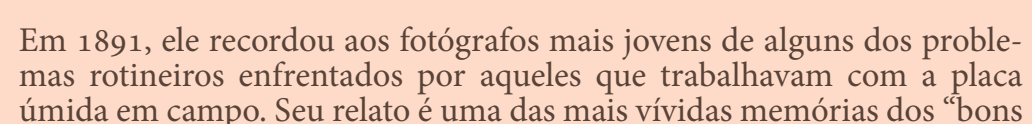

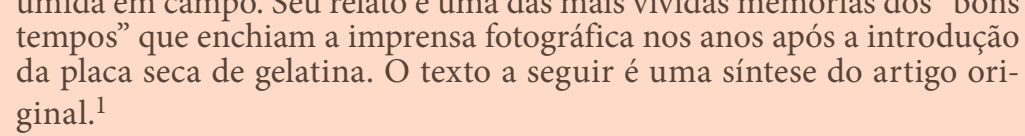

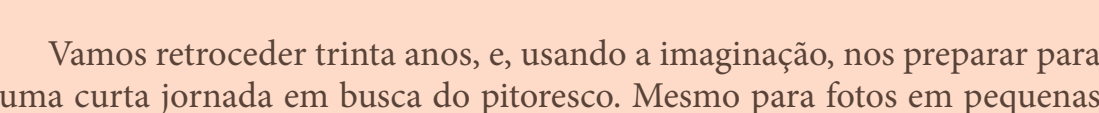
dimensöess, os apetrechos assumiam dimensóes quase sufficientes para en

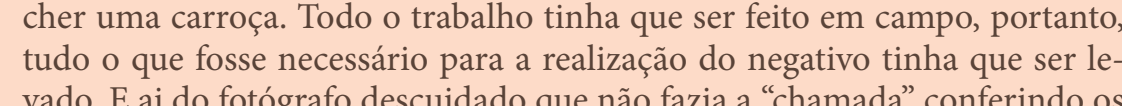
vado. Eai do fototogratas descruidado que nåo fazia a "chamada" conferindo os

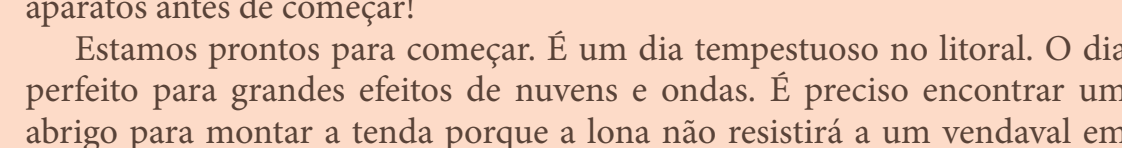

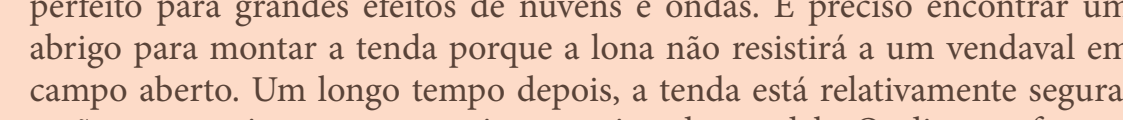

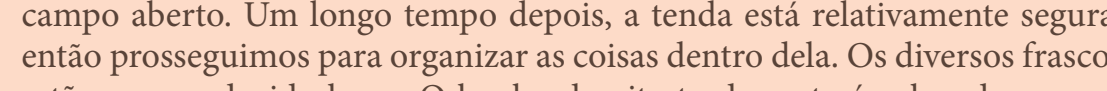

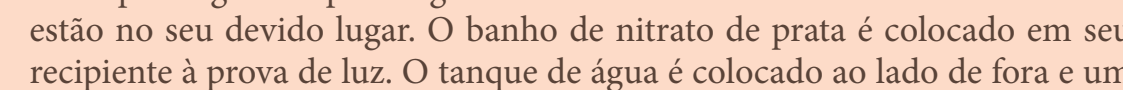

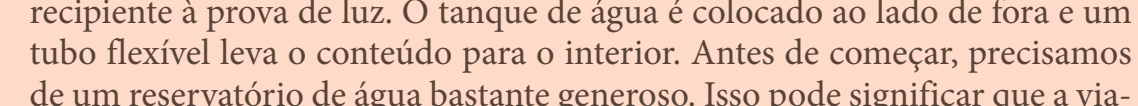
gem de un quilometro pro mar nào dará certo. Lutanos con

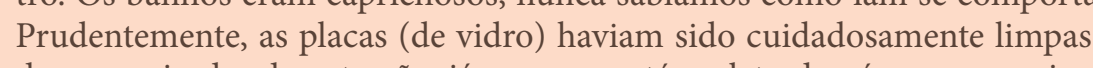

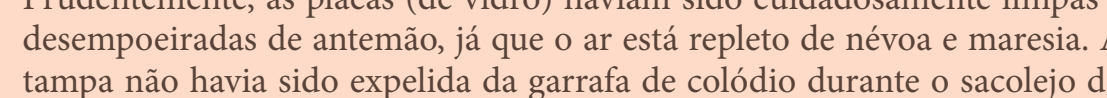

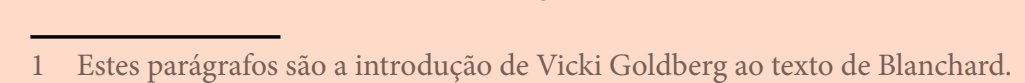

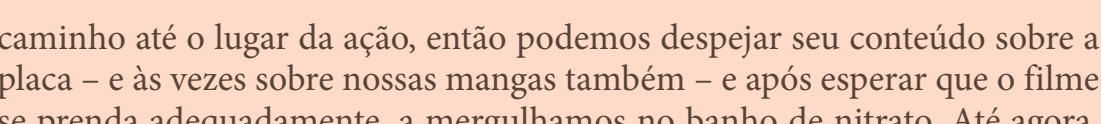
deu prenda adequadamente, certo. A placae e escorrida com cuidadado e inserida no chassie e e gimos guase sufocados do nosso buraco escuro. A cammera está no seu trip
e estamos prontos. Nosa jornada á provavelmente descendo um penhasce e estamos prontos. Nossa jornada á provovelmente descendo um penhascea
porque tivemos que buscar abrigo para a tenda um pouco olonge da praia

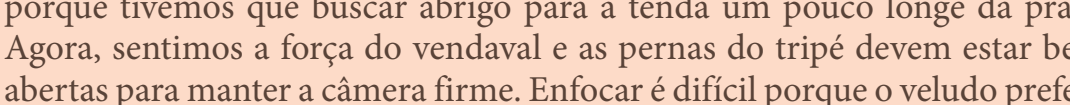
cobrir a lente em vez da nossa cabeca, mas escolhemos a exposiçāo. Uma dura subida no penhasco nos leva de volta a tenda, ond
novamente abrigados, prosseguimos para a revelaçáo e, quem sabe, serem 0 S

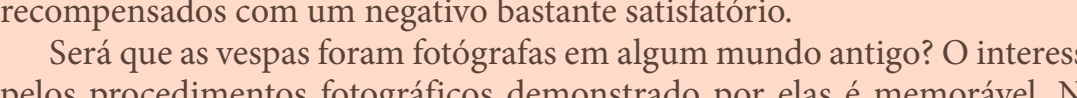
pelos procedimentos fotográfícos demonstrado por elas é memoróvel. No
momento em que a anela amarela da tenda é aberta apenas uma polegada para deixar entrar um sopro de ar fresco ao ofegante trabalhador lá dentron sem dúvida uma dessas espalhafatososas damas pretass-e-amarelas entrará par

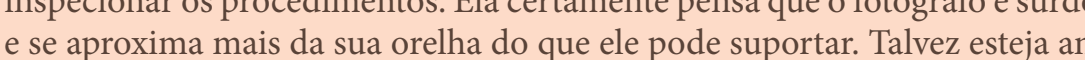
siosa para dar alguma dica. Sua lingua e incomodad e incompreensivel, entáa após algum tempo, ela voa para longe irritada, mas logo dá lugar a outra de

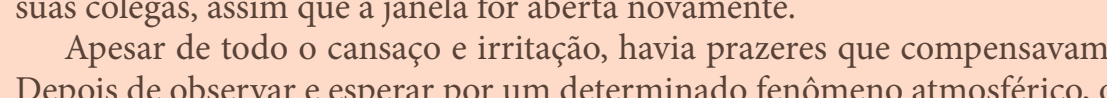

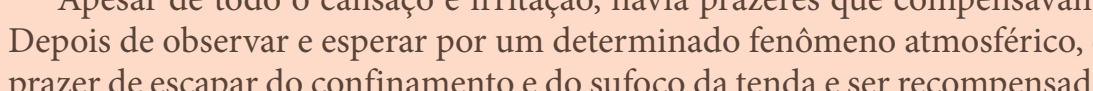

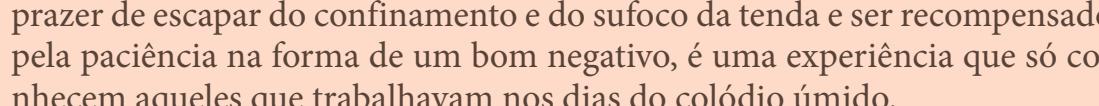

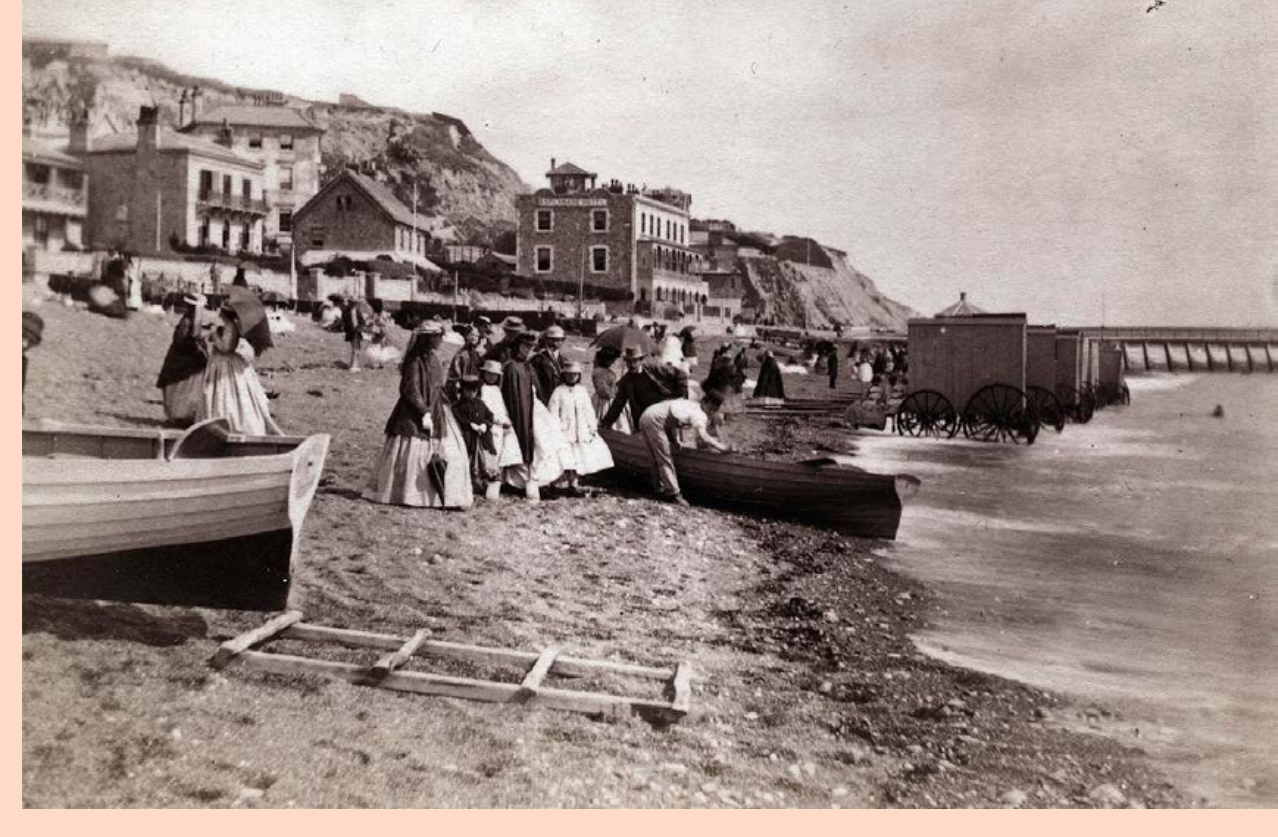

Valentine Banchard - Ventnor, Illa de Wight, ca 1865 Imprecsīo em albúmen 10 x 57 . 


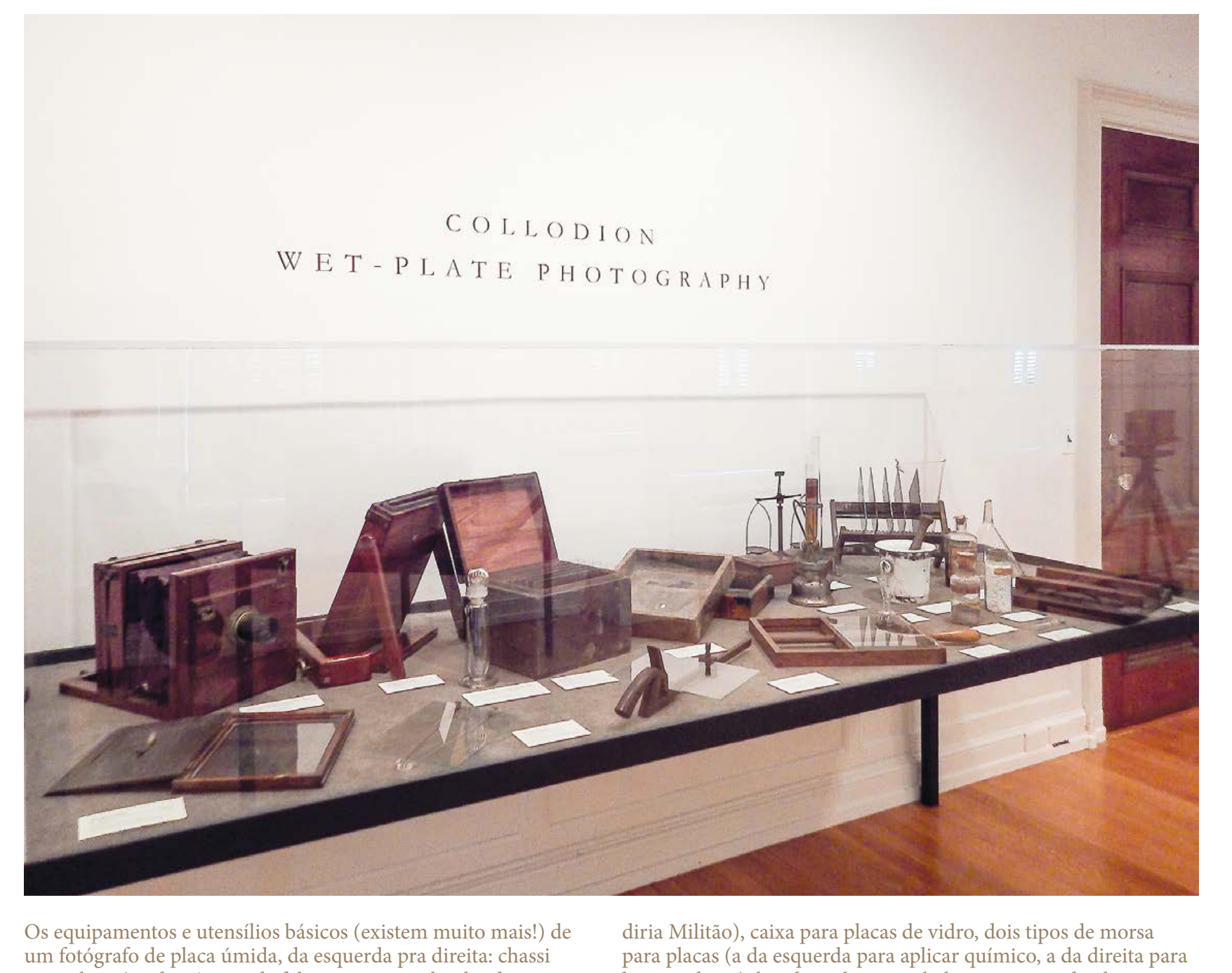

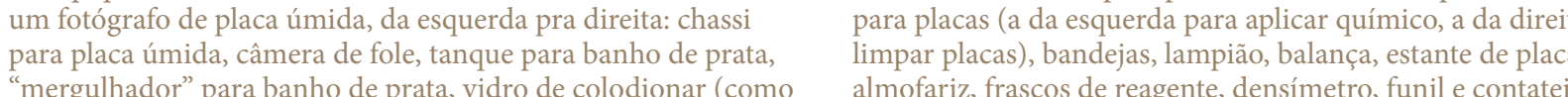

11 de novembro de 20

Numa pausa das oficinas que viemos fazer, Simo-

ate George eastman, of fundador da Kodak viveu ate seu que leva seu nome. Aliás, interessante a históri my friends why wait?

(Aos meus am

Em uma das muitas salas havia alguns conjuntos nes. Havia uma de equipamentos para daguerrétít seca de gelatina. Foi a primeirira vez que vi um conunto completo, original da época, dos equipamentos

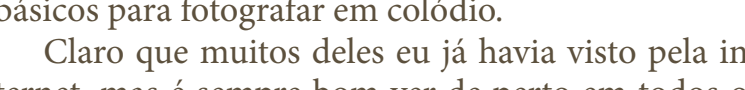

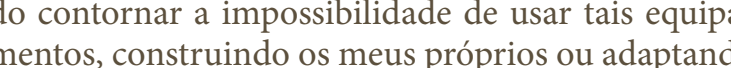
equipamentos de outras épocas. Fiz unas fotos para registros. pena que a cúpula $d$

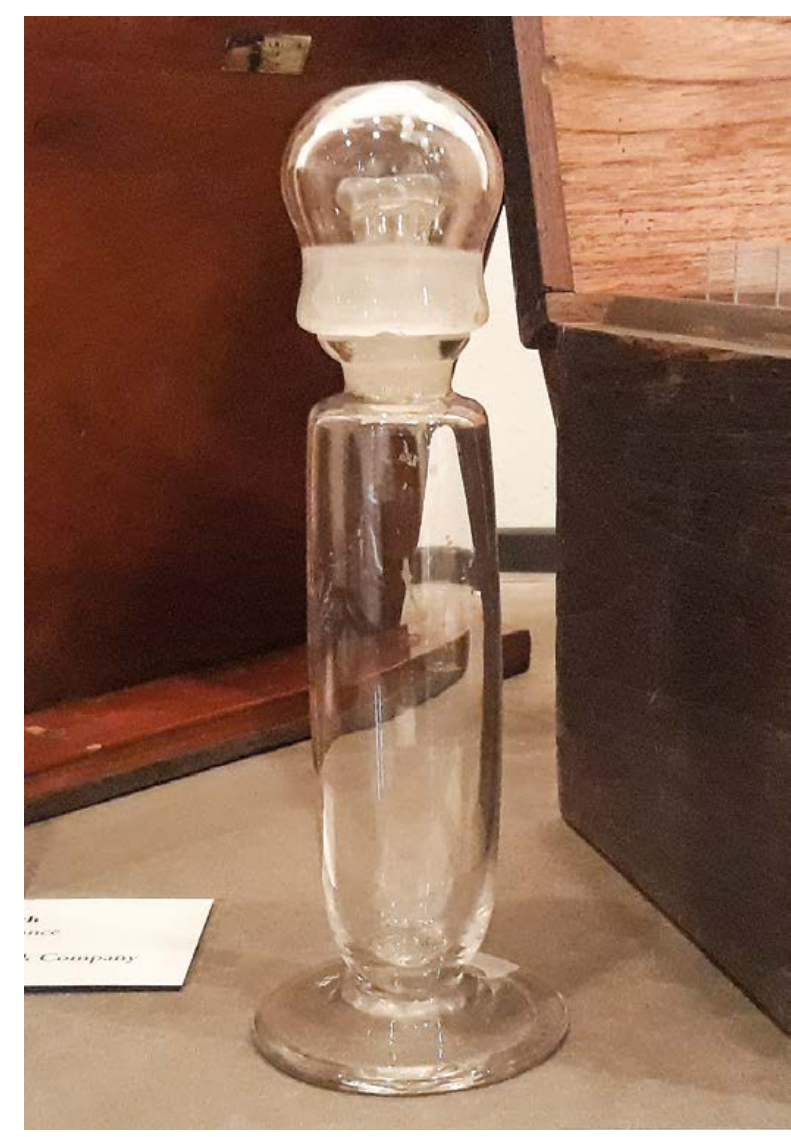

Acima, uma antiga garrafá de vidro de aplicar colódio,
vidro de colodionar' como a chamou Militia em suas

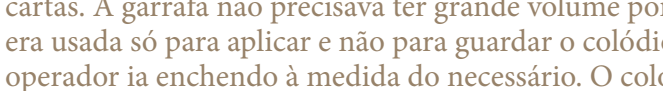

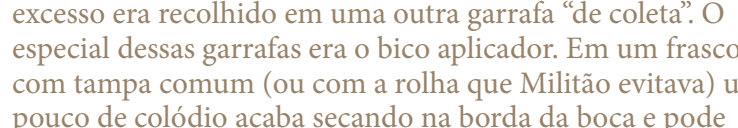

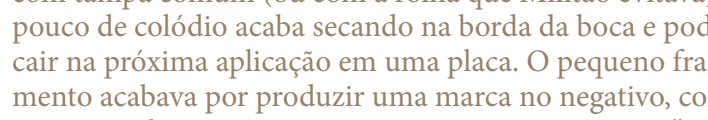

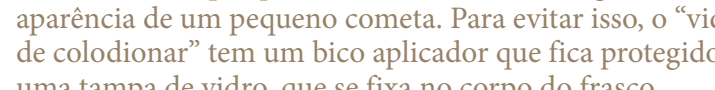

$\underset{1}{=}$

(B) Dorenty

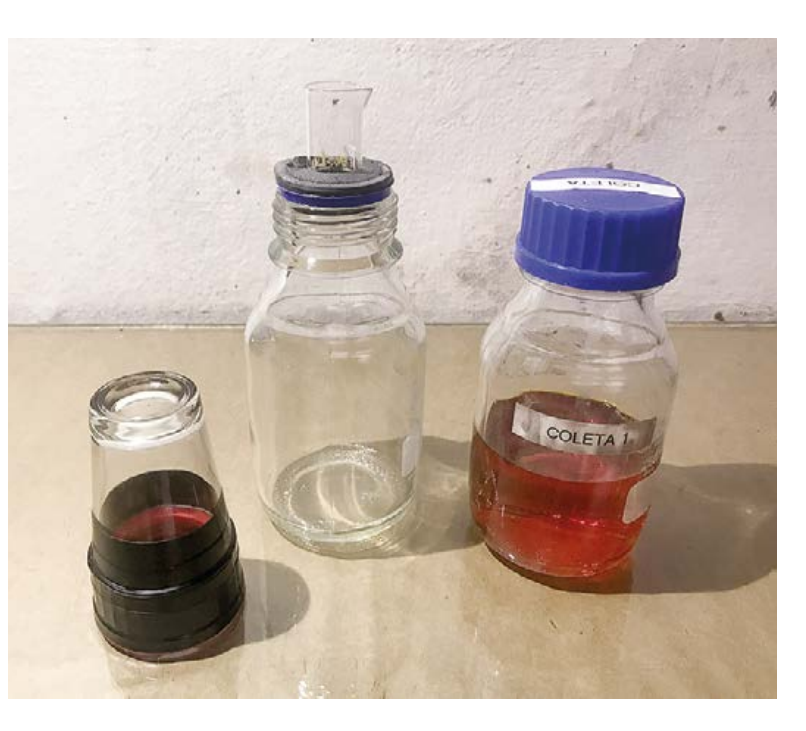

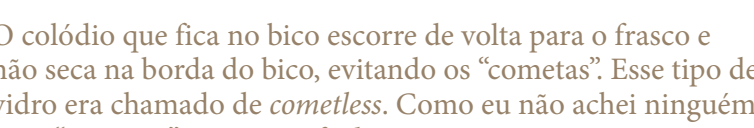

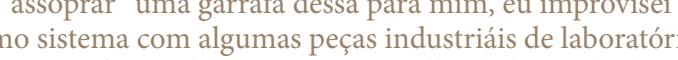

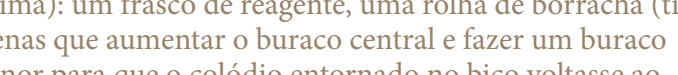

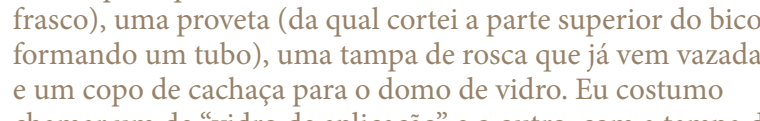

S. Paull, 5 de jullho de 1883 .
Sr. A.L Garraux (Paris),

Se ainda for tempo rogo mandar-me 4 vidros para

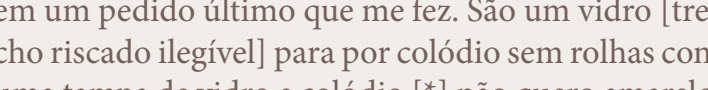
pra cá há muito.

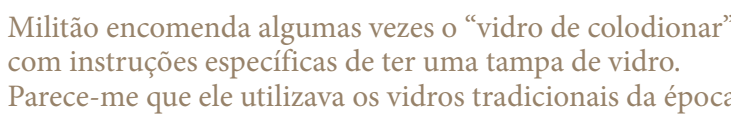


Clye Anratenr

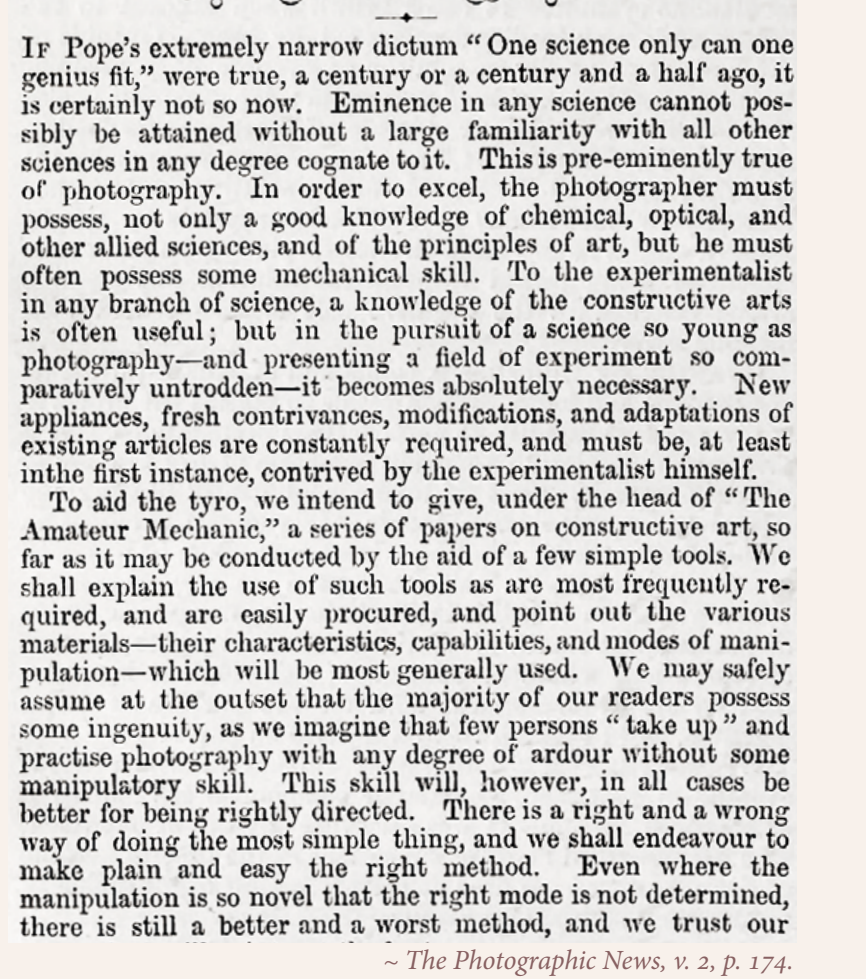

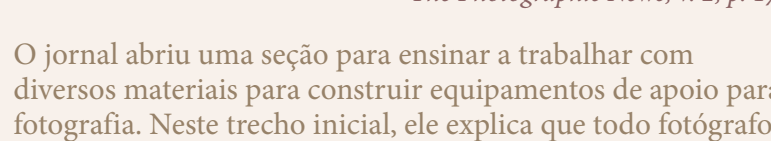

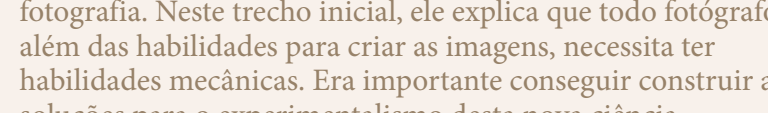

Eu nà tenho acesso aos equipamentos do século 19, tirando
algumas lentes. Meu experimentallismo e para o passado, que

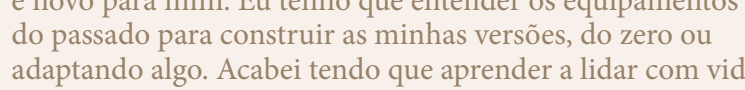

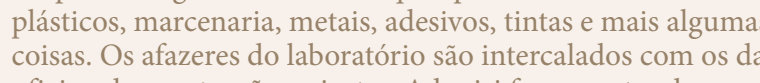
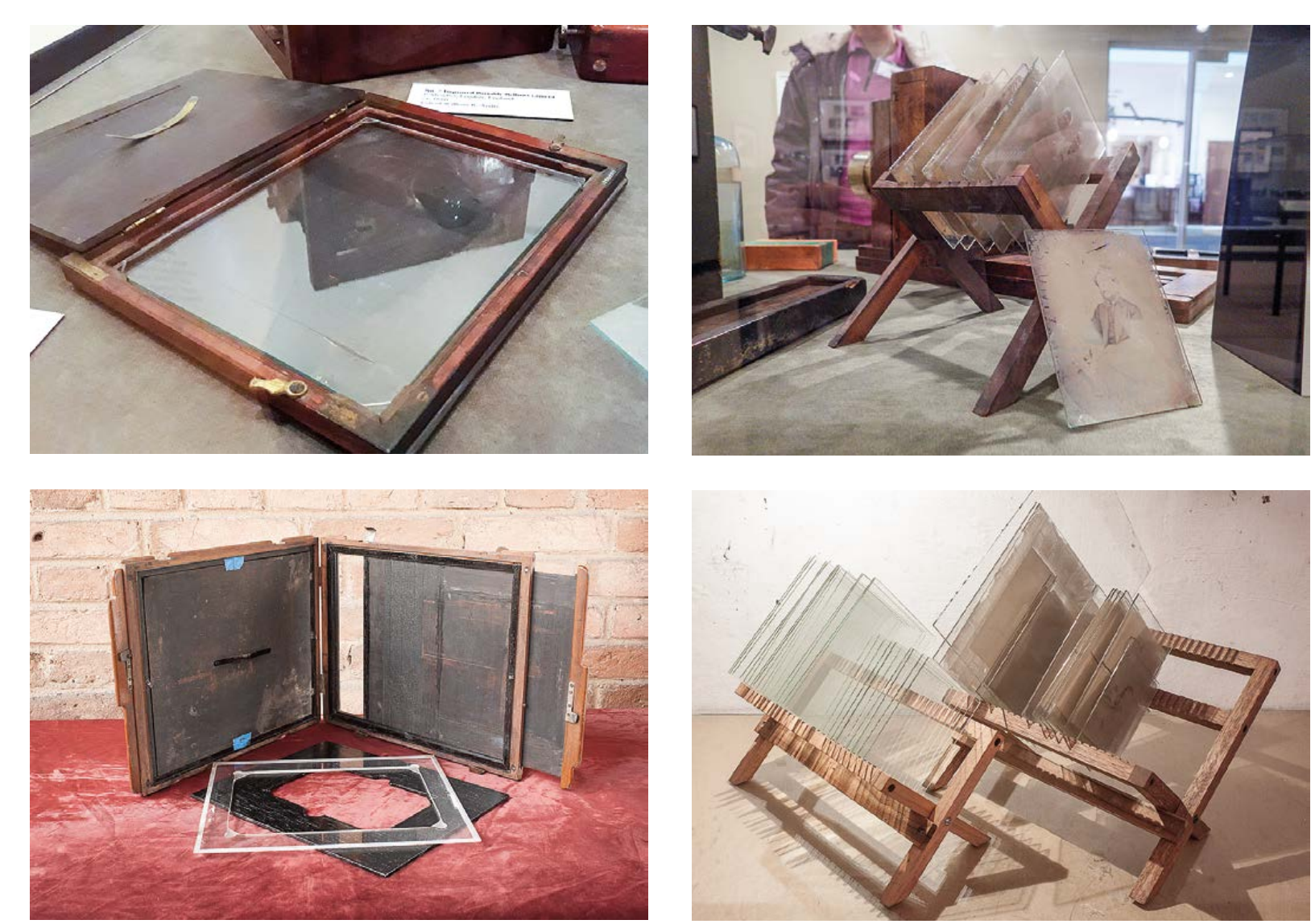

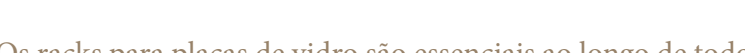

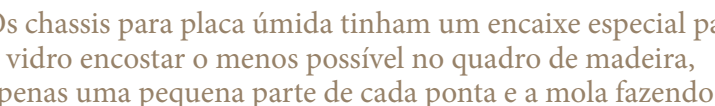

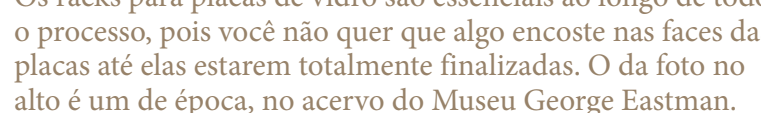

Eu constrú alguns como os da foto de baixo, a o longo dos
anos, por conta da quantidade de a lunos nas aulas que dei.

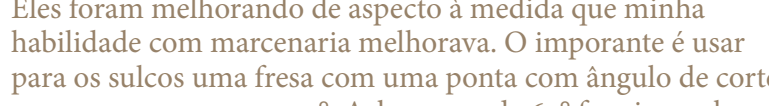

O meu chassi, na foto de baixo, ériginalmente para placa
seca de gelatana. Nele, ela ficica apoiada, em contato com todo

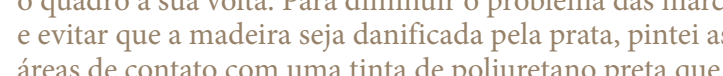

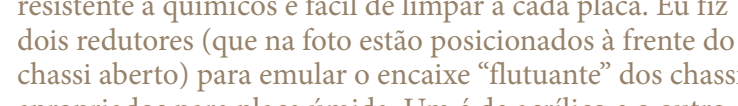

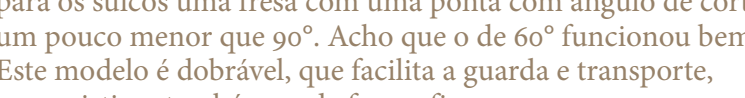
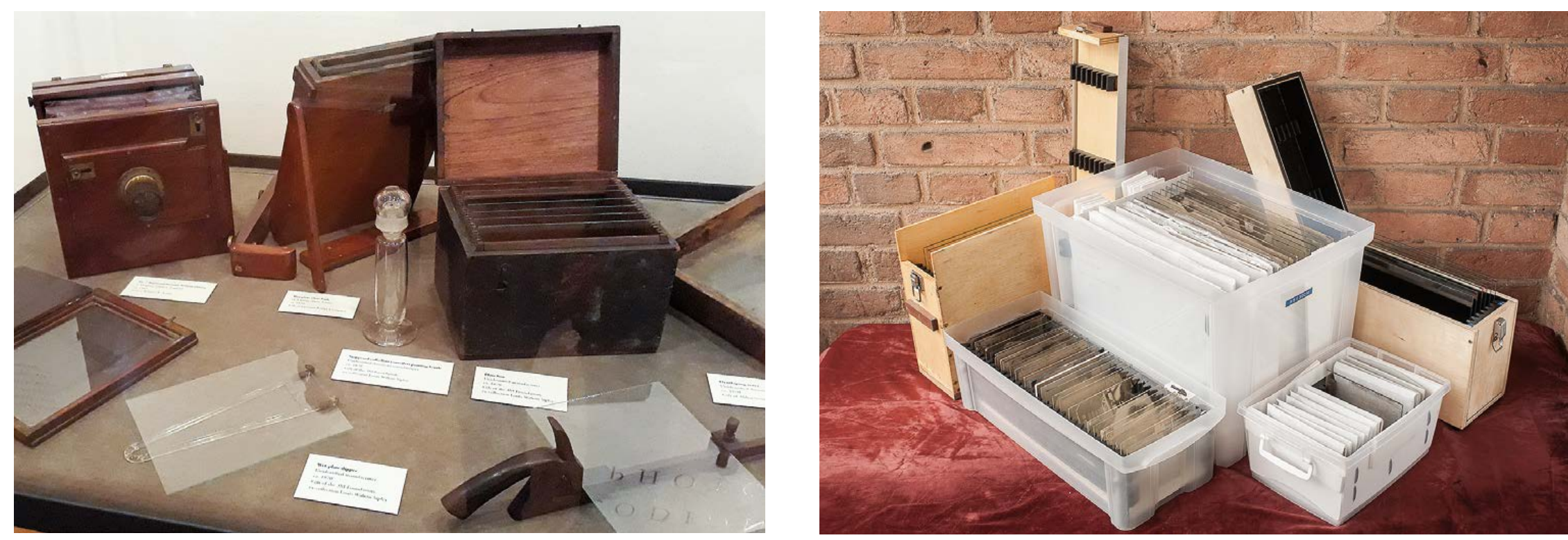

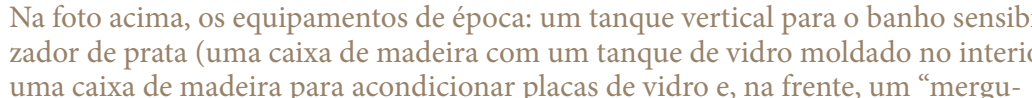

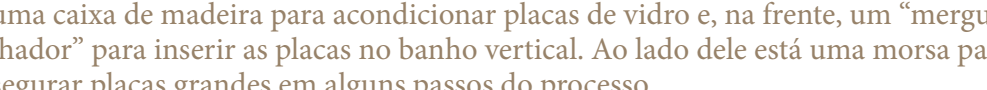

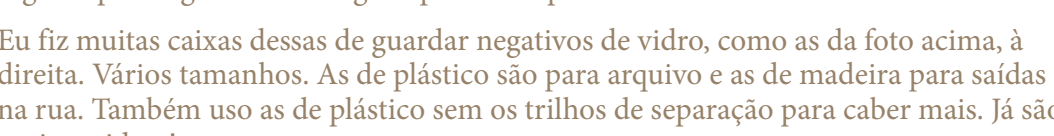

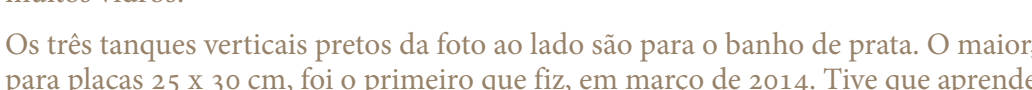

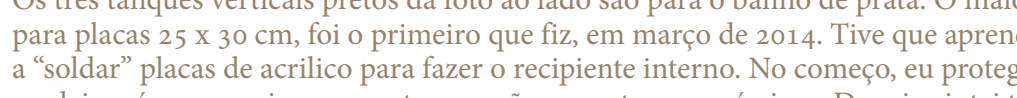

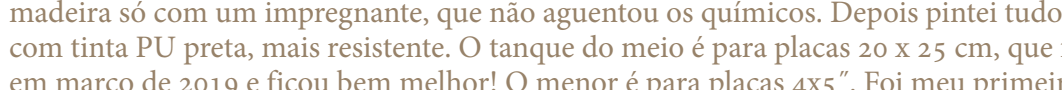

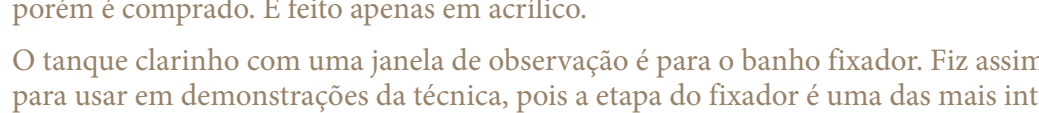

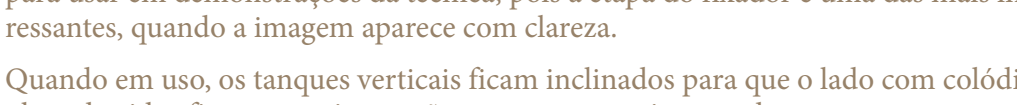

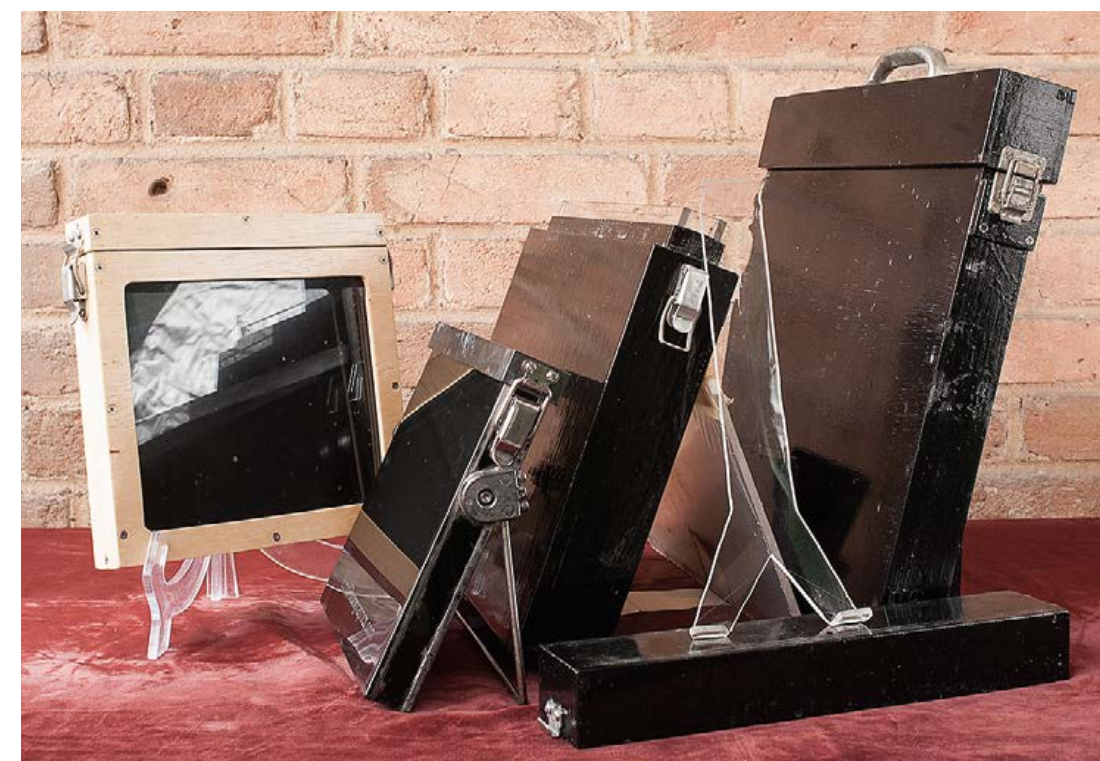




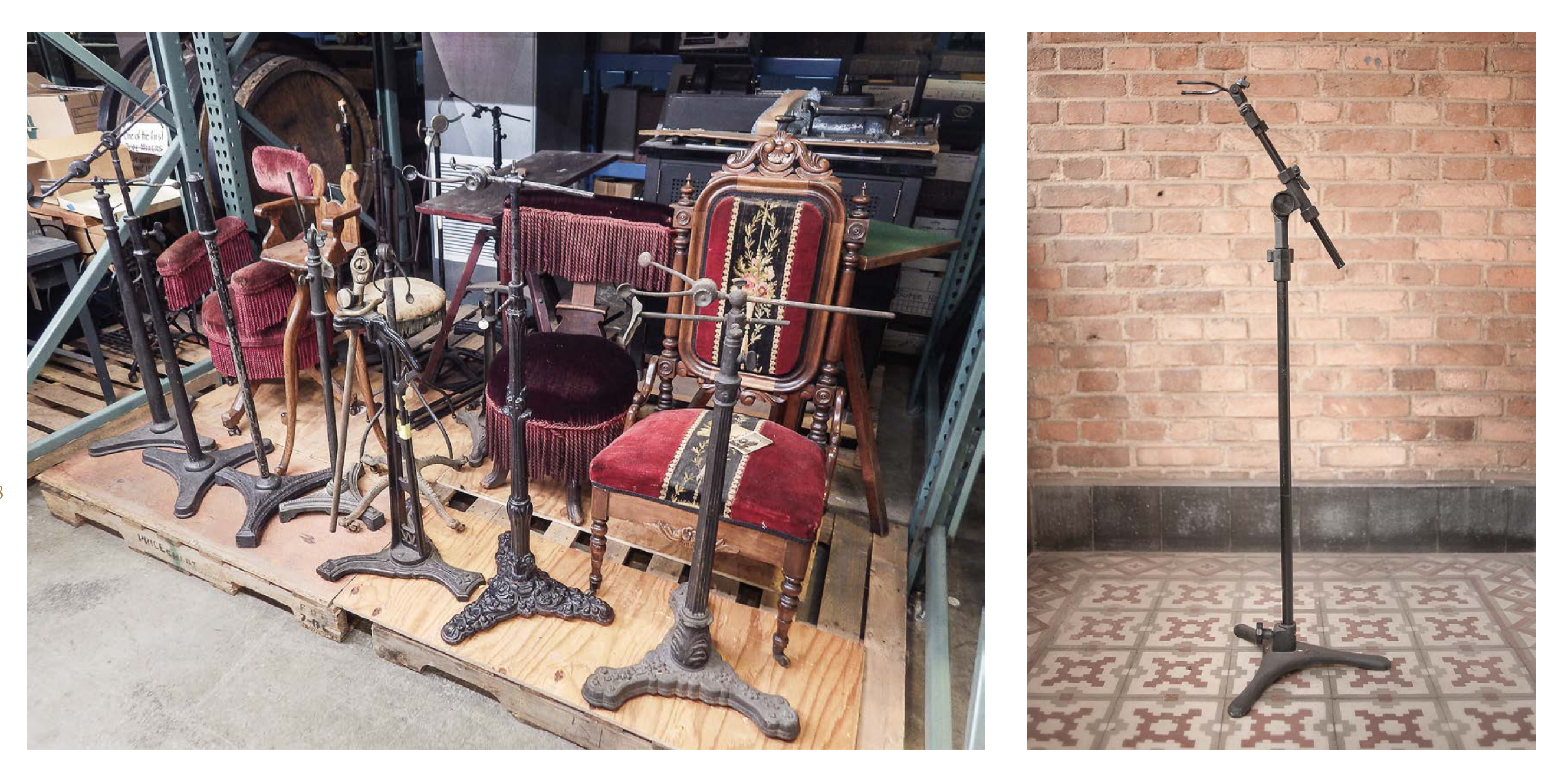

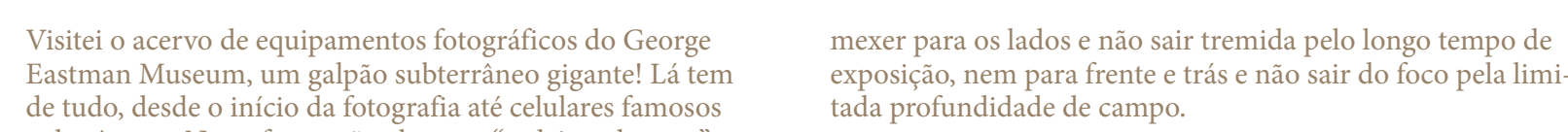

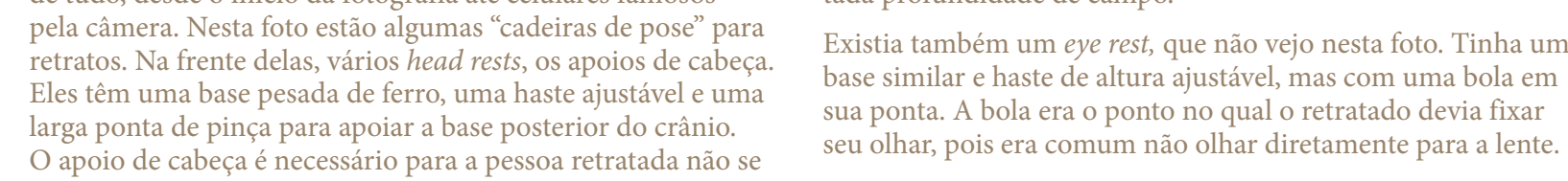

12 de novembro
(Rochester, NY)

Fomos convidados para jantar na residência de
France Scully Osterman e Mark Sosterman Ambos sao pesquisadores de processos fotográícicos e tam-
bém têm traballhos autorais muito bons. A casa fice perto do museu, um sobrado cheio de objetos foto-
gráficos bem escolhidos decorando asla e mais um tanto de outras tecnologias antigas, como um tocado
de cilindros fonográficos de cera. Um porào enorm abriga o laboratório principial. Lá en contrei na parede
um desenho de Mark explicando a "re-revelaçăo" que Porém, é no sotão que está o lugar mágico: um estudio de luz natural norte, al luz oposta ao Sol, mais
suave e uniforme Luz de cés ocklight. No Brasil seria a luz vinda do sul. Fles montaram com muito

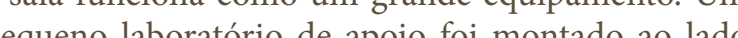
de uma janela coberta de vidro vermelho. Uma cortina delimitava o espaç, fazendo parecer um grande
trocador de roupa. Assim, eles conseguem preparar processar rapidamente as placas úmidas, sem ter

fotografia que lhe foram úteis em seu inicio, sua impressao original de uma foto em albúmen feita por tocou um pouco para nós).
inda havia luz, nos mostrou quena garagem, onde está reformando um Ford numa próxima viagem a Rochester, ter alguma aula na casa deles e nao no museu.
Ah, a comida estava ótima e muito caprichada
feita pela France. Ficamos felizes ao ouviri a máquina de moer cate na cozinha ao final. Foi tambem o me-

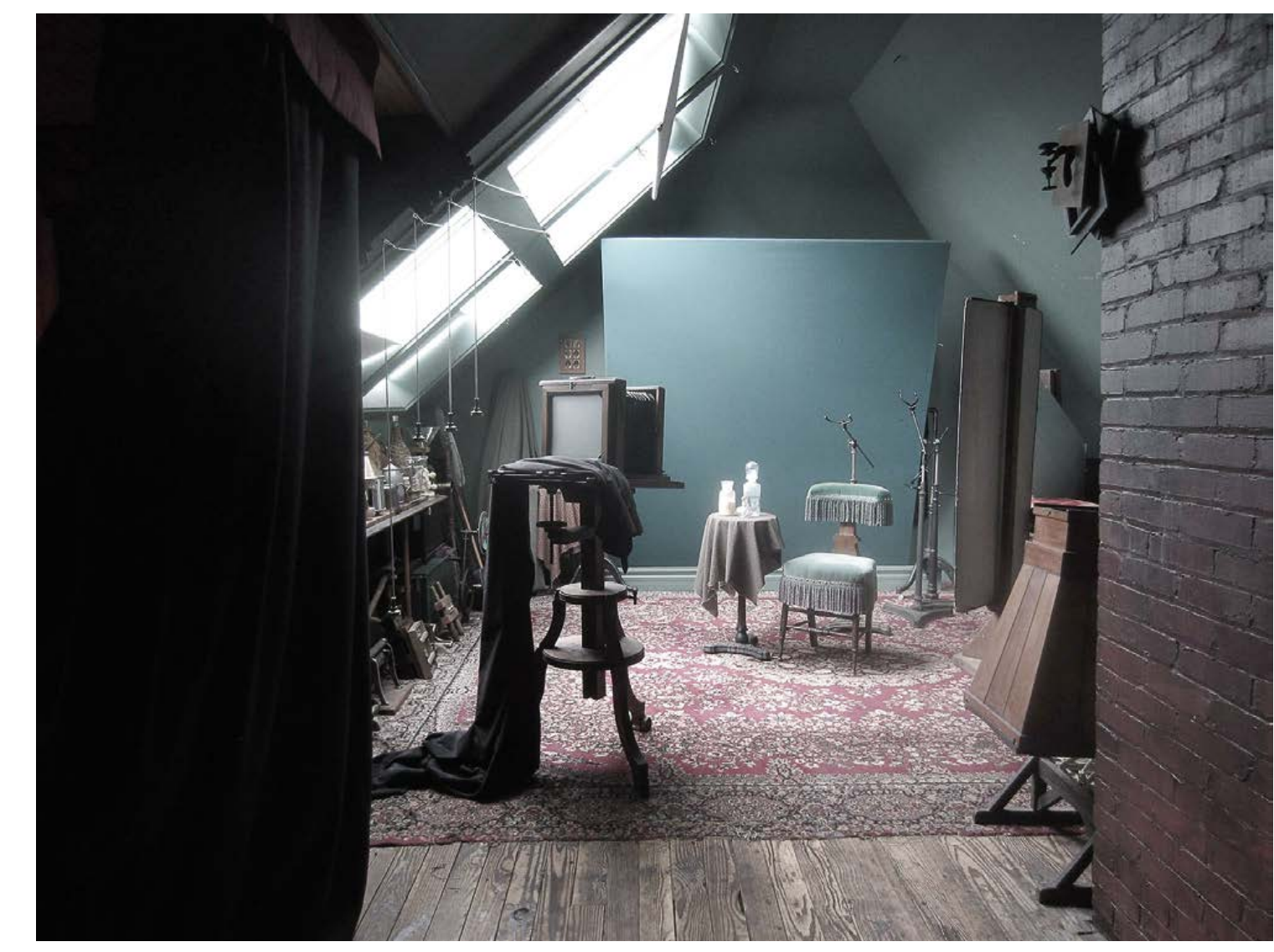

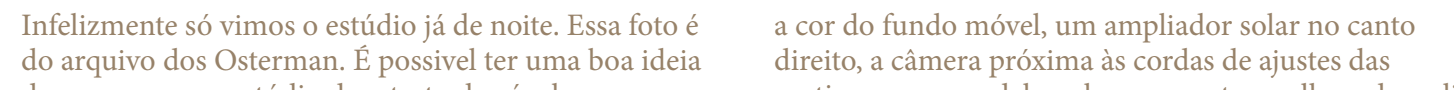

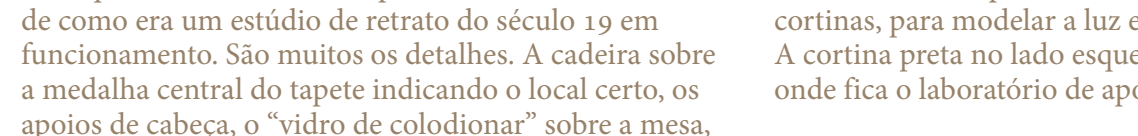


S. Paulo, 7 de maio de 1887 .
Sr. A. L. Garraux (Paris)

Em 21 de janeiro do corrente ano fiz-lhes uma
encomenda. mu uma carta dessa data que copiava encomenda disse-the precisar a dita encomenda con
pressa porque parte dos objettos eram para um trabs

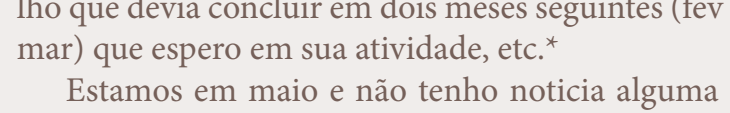
tal respeito:
Mandei-Ihe $2^{2}$ vez a 3 de fevereriro aumentand o pedido caso ainda näe estivesse $01^{\circ}$ pronto $\mathrm{p} ㇒$
poderia ficar para mais tarde $2^{\circ}$ pedido.

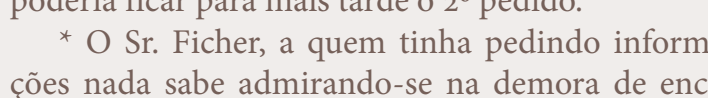
menda ainda mais da ausenncia de cartas a respe mento de minhas cartas, o que não é possivel. Per

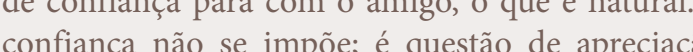

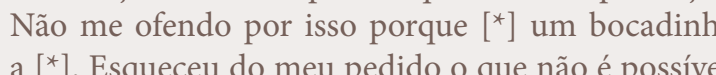

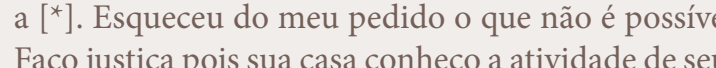
empregados. A diferencáe [trecho ilegivell que esta
falta me tem causado VS táo bem como em deve re Por último tenho a dizer para seu governo que esperareie ianda até 15 do corrente mês, não aceitanta pois de tantos anos de nossas relaçés comerciais não

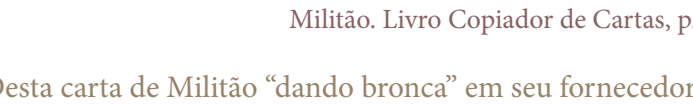

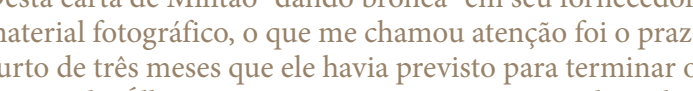

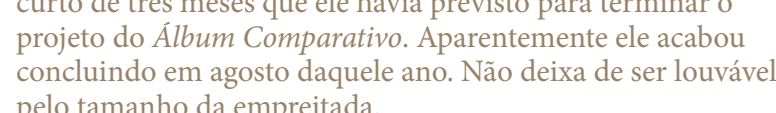

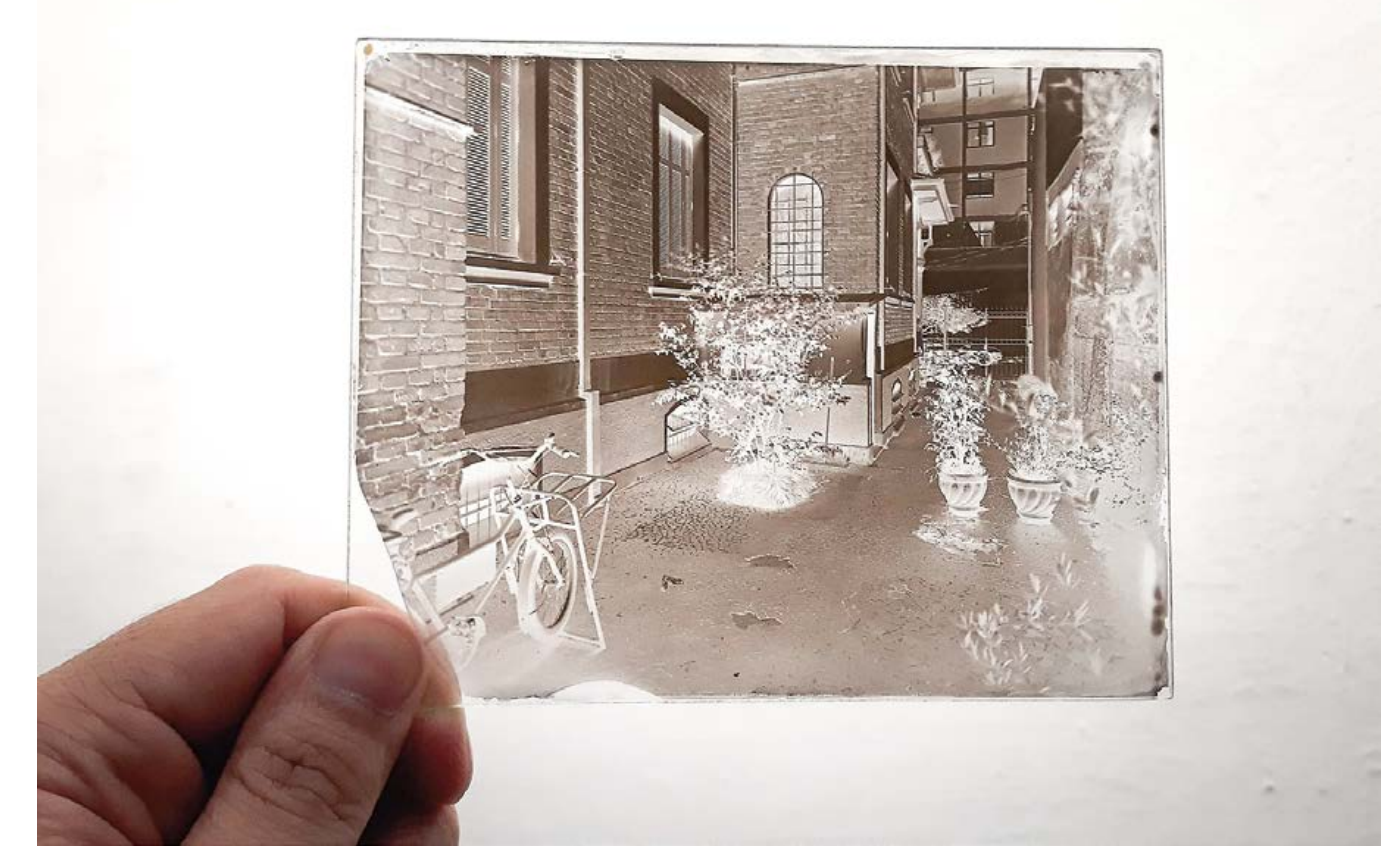

4 de novembro de 2018

Consegui um bom negativo no teste de hoje. Um boa densidade nas altas luzes uma boa cor castanha
que dáa a densidade espectral. As baixas luzes tambén estãa limpas e "vazias" de informaçāo, que é o ideal
para o albümen ou papel salgado.
13 de fevereiro de 2019

de Militão no Museu Paulista. Porém, são de retratos feritos em esstudio, nada das ma-

Só tem negativos de retratos. Alguns são únicos

poses) em vidro de aproximadamente $11,5 \mathrm{x}$

São negativos de colódio com tradicionais mar

Tons marrons, indicando uma revelação con

Envernizados, porém com a camada bem fin
fosca, talvez por desgaste por abrasaso.

- Alguns vidros grossos, cortados com alicate
Nos retratos duplos, ovidro não ficava alinhar

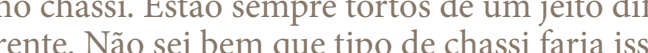

Segurava o negativo como polegar no canto es
querdo onferior e escorria o excesso pelo canto

Deixava os cantos sem colódio ou verniz,
chava o sufficiente garantir a parte central d

placa. Talvez seja uma das razōos para seus

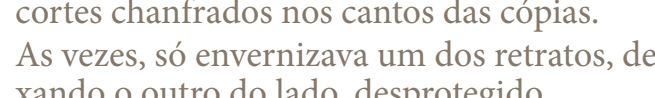

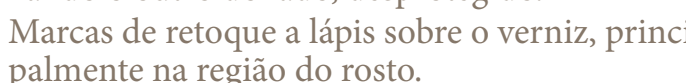

Retoque com tinta vermelha sobre o lado do
vidro. A mancha vermelha clareava reigioss da
imgaem por funcionar como barreira espectrat imagem.
Anotava numeros de refereneciala riscando comm
uma ponta seca o lado do colódio próximo às

Eu estava em dúvida se ele usava uma ou duas claçoes, mas, pela cor da imagem, ao menos dentro velador "de ferro".
Achei interessantes os negativos de dois retratos em que ele só envernizou o lado que iria usar. Teve
tanta certeza que a outra foto naq prestava ye nem valia o esforço de cobrir com o verniz (não seria pelo que a relač̃o com o negativo era bem póticsa 0 de gativo era o meio do processo e não o objetivo final. Só importando a regiaio que iria gerar a cópia, não se
importava com as bordas our foto ao addo
Rio, 17 dejulho de 1895.

Recebi tua carta de 6 com o retrata o o retrato
Luizinha. Parece incrivivel que $o$ Rauvelaul[?] nâo

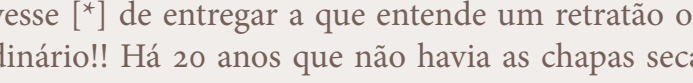

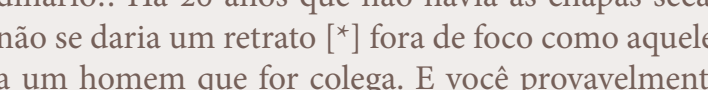
hâo lhe disse nada.
Estou muito aborrecido com a morte do velh migo Ferreira Nobre. Era uma camaradagem de 30
nos. Um bom coracão, inteligente, mas sua cabee não se governou. O ano passado perdi dois amige
velhos. Este ano um e com outro bem mal. E E ess

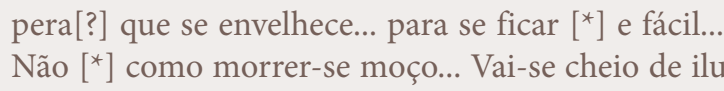
óes e - acreditando em giz. Eu nãa compro jorna que os leio. Quando encontro alguma coisa bem es crita verdadeira ou falsa; e poder mandar-te, irá o te
bom senso (que todos nós acreditamos tê-lo) separar
otrigo do joio. . ... Veste trech a

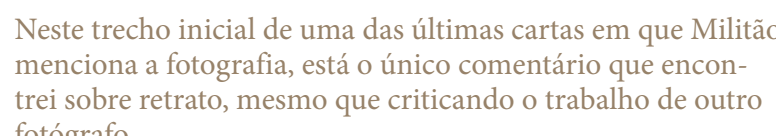


Negativos Feitos POR Militão No iníio do uso do colódio úmido, aplicava-se
o colódio oobre alacas agurando-a como uma ban-
deja, sobre os cinco dedos bem abertos. Logo perce-
beu-se que os pontos de contato dos dedos esquenbeu-se que os pontos de contato dos dedos esquen-
tavam o vidro e poderia deixar marcas no negativo drãa foi a segurara p placa por um dos cantos, fazendo
uma pinça com o polegar por cima do vidro e um pequeno papel cartáo entre os outros dedos e olád
de baixo da placa. O fotógrafo, aa aplicar o colód phla tazer com que o liquido chegue o mais pert brir, logo, sem imagem. Se tocar no dedo, este canto

Os cantos e bordas de uma placa de colódio são
bem característicos do processo. Tem o canto onde se segura, como dito, e tem o canto por onde se es-
corre o excesso de colódio, que com certeza é todo

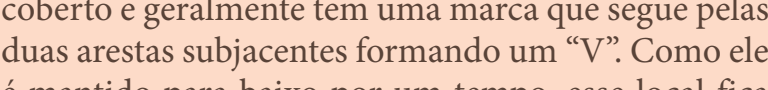
mais grosso e pode gerar uma mancha mais dens Como a camada de colódio é mais grossa nessa áre
o fixador tem mais dificuldade de "limpar" os sas de prata (que são esbranquicadoss) e pode acabar so
brando uma borda clara. Os outros dois cantos po
dem ou não estar cobertos de colódio, por preferến $\mathrm{O}$ verniz é aplicado de forma similar ao colódio (mas pode ser segurado como bandeja) e deixa
também marcas similares. É possivel ver o canto por onde se escorre e excesso de verniz pois ele costum
deixar uma marca mais grossa em "V". Não necess

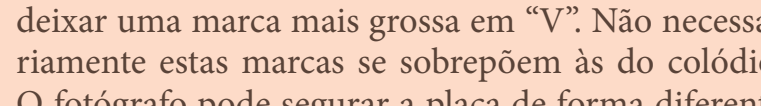
para aplicar overniz:
As bordas tambén "chassi" da cammera - o estojo opaco onde a placa
sensibilizada é colocada parmitia que se fotografasse em metade da placa
suada na cammera.
e depois na outra metade. Assim se faziam dois retra-

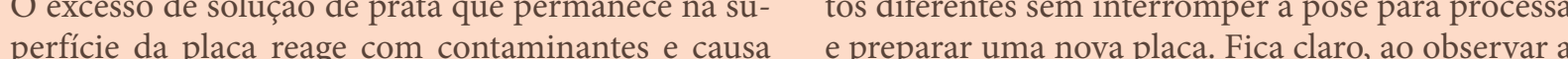
manchas na superficie da imagem. Para evitar isso, copias positivas que existem no Museu Paulista, que

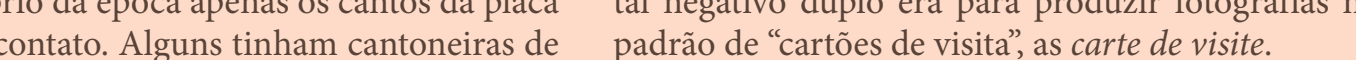

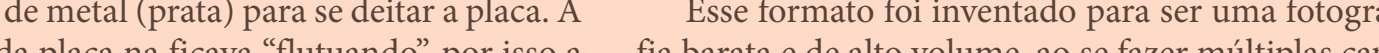
$\begin{array}{ll}\text { maior parte da placa na ficava "flutuando", por isso a fia barata e de alto volume, ao se fazer múltiplas cap } \\ \text { imagem vai até sua borda e seus cantos em geral têm } & \text { turas pequenas em uma mesma placa. Ela era entä }\end{array}$ alguma marca do tipo de apoio usado.
As manchas e marcas na regiáo próxima às bordas da placa eram inevitáveis para os fotógrafáos da ápoca, ras tinham 4 ou mais lentes que podiam ser abertas final. Sentiam-se livres para reenquadrar o assunto iguais ou poses distintas. Junto com uma traseira

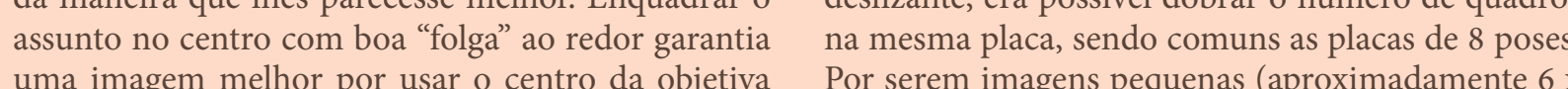

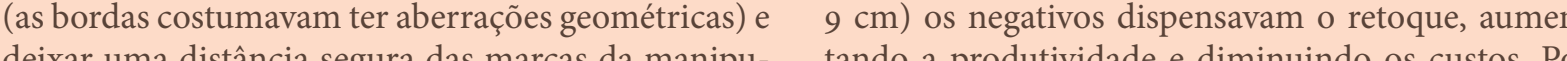
laçä. Por conta do enquadramento folgadoé comum eseas caracteribles ver na periferia das imagens nos negativos, ou escon- negativos duplos, em geral escolher apenas um dos
didos sob o passe-partout das coppias, parte do estu-
lados para copiar e ainda se dispor a fazer cuidado

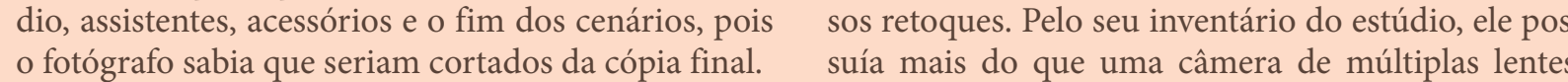
Os negativos do acervo do Militäo de Azevedo Seu aparente metodo de trabahlo pode indicar un

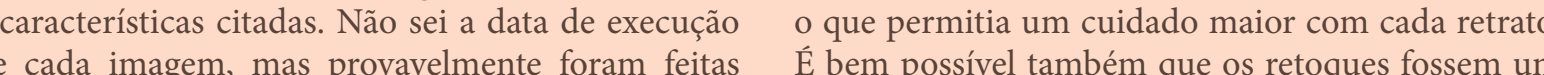

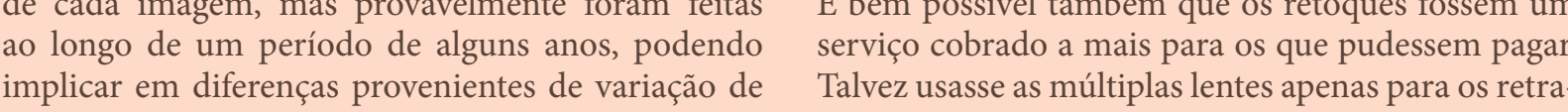
materiais, equipamentos e procedimentos utilizad que ele usava o revelador de sulfato ferroso e nà de ácido pirogalico, provavelmente fazendo apens Muitos dos negativos são de dois retratos distintos
mesma placa. Ele deve ter usado na câmera una tos em ferrótito.
Comento a seguir algumas marcas que identifiComento a seguir algumas marcas que identifi-
quei no material, provenientes da execuçáo enão da
degradaçáo do supporte. Quero esclarecer que, quando digo "feitos por Militäa", me refiro às imagenens produCarneiro \& Gaspar, que podem ter sido feitas por ou

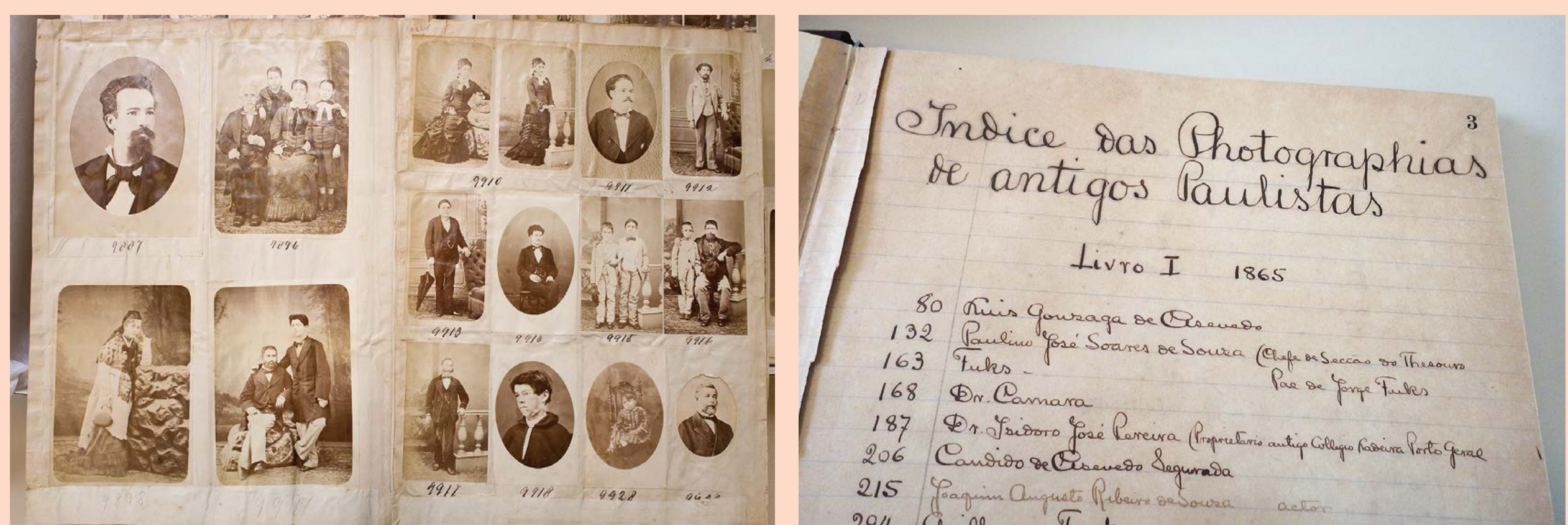

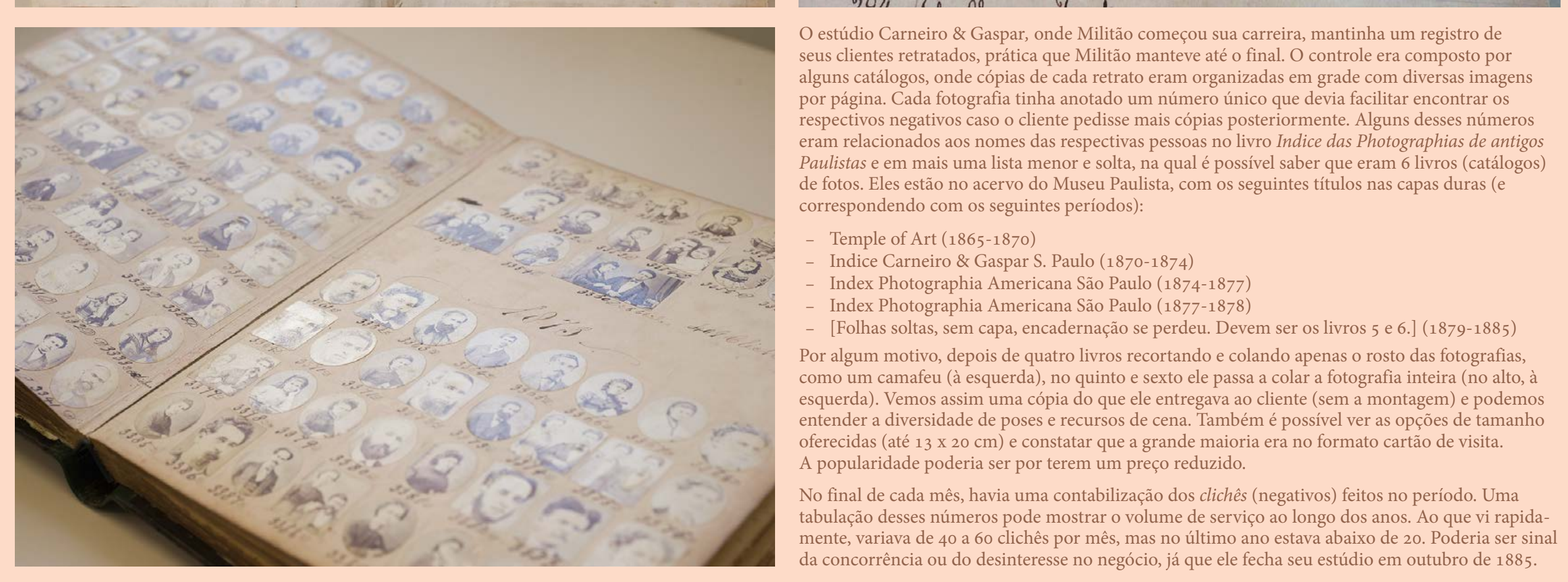




$$
\text { iLA has }
$$




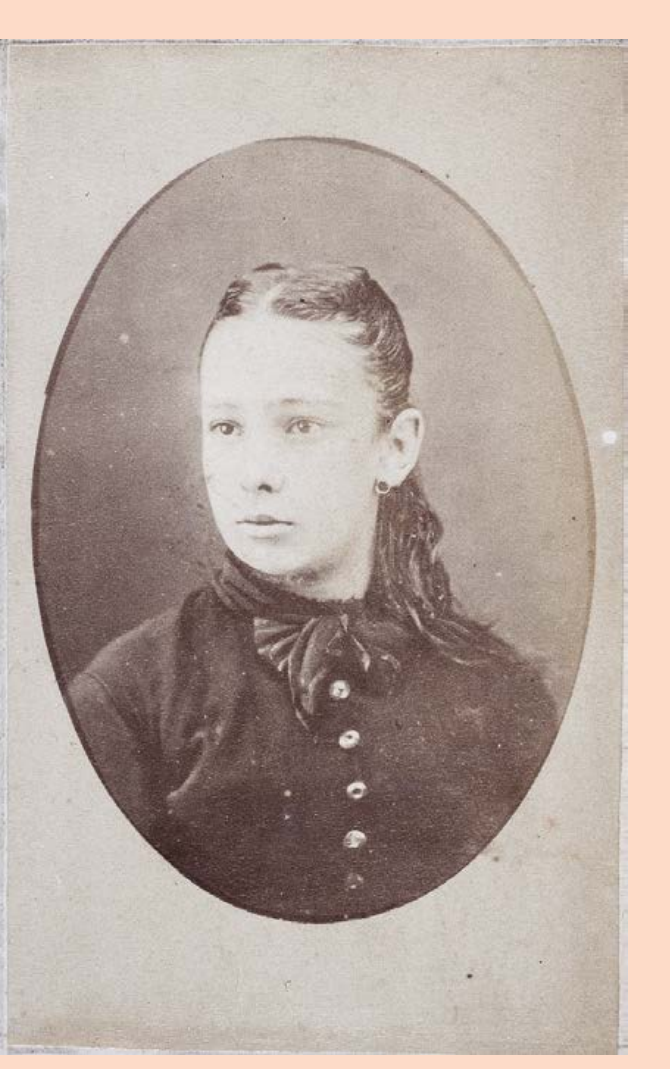

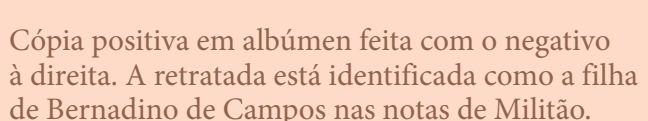

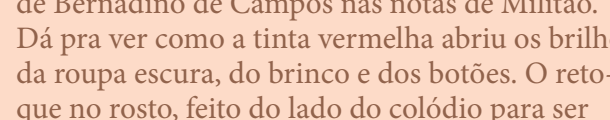

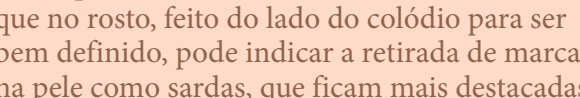

$$
\text { c }
$$$$
\text { o }
$$

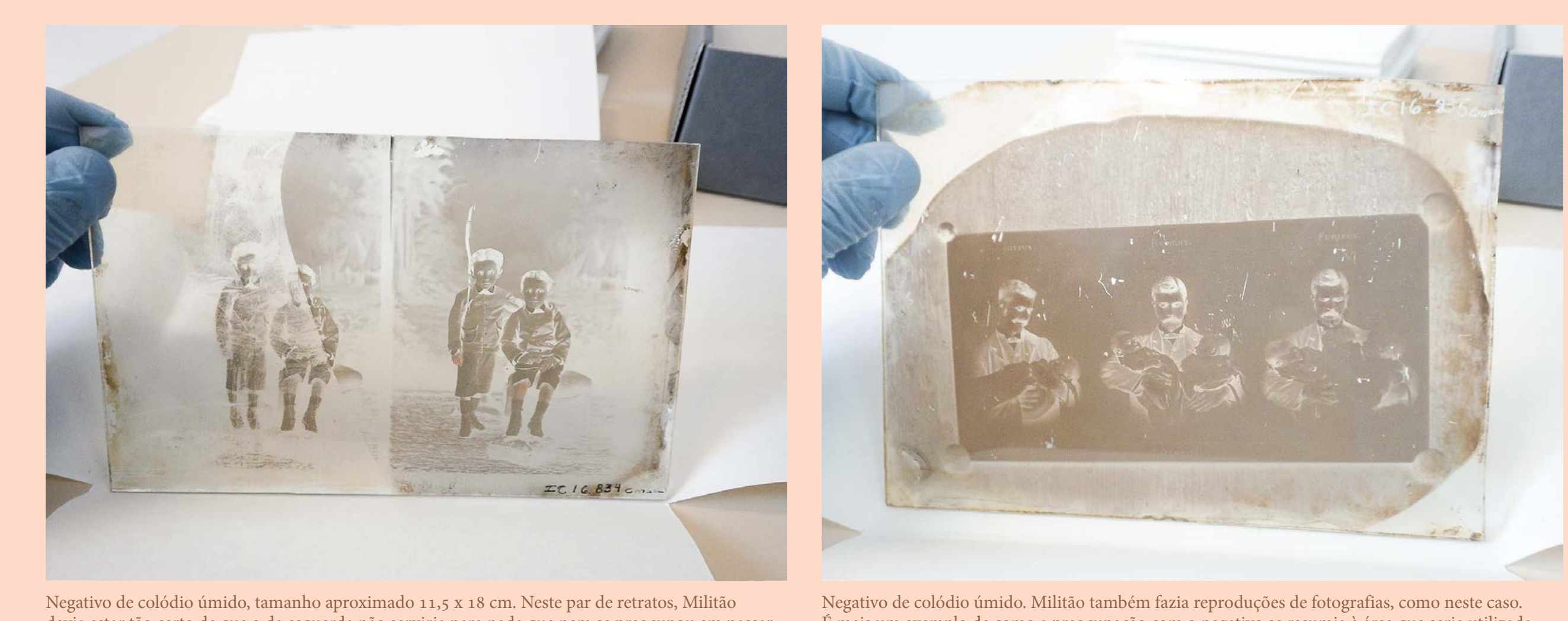

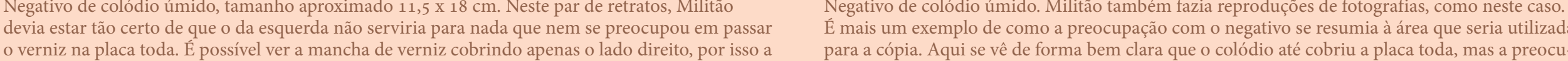

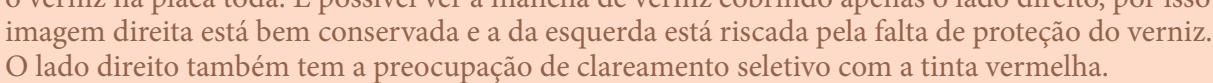

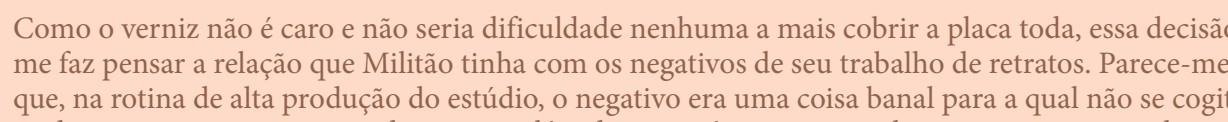

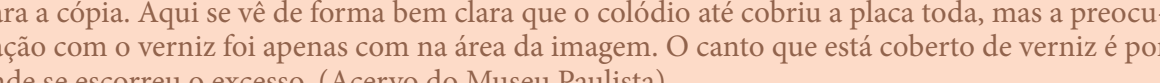

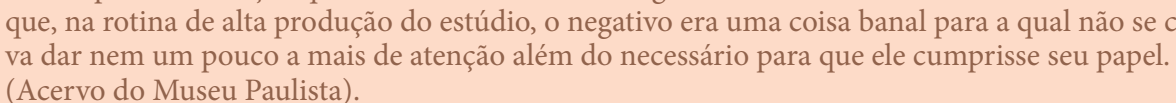




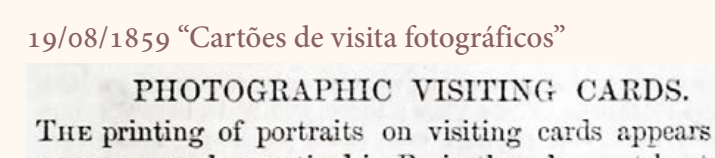

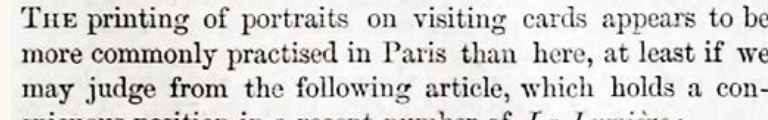

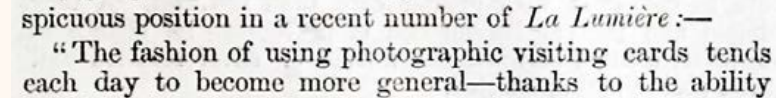

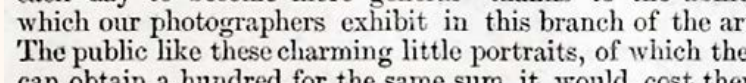

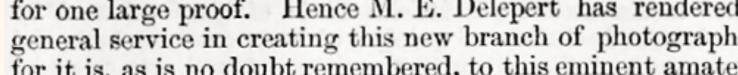

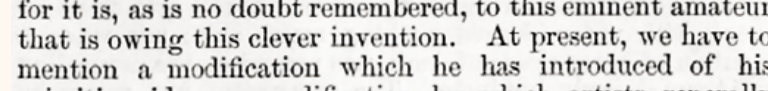

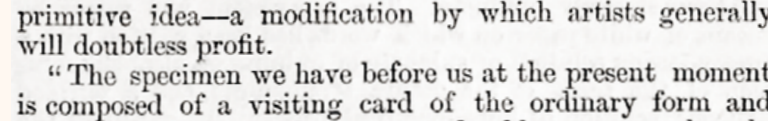

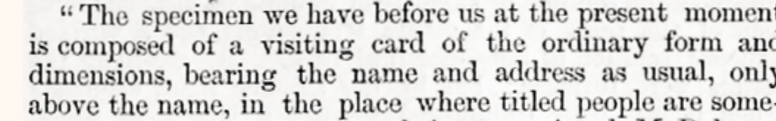

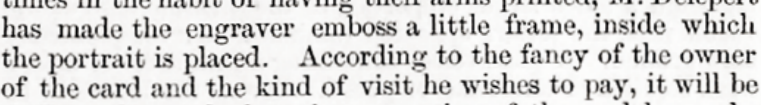

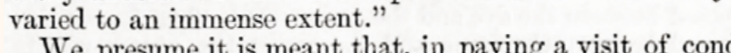

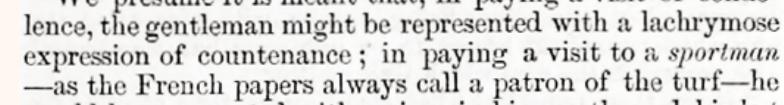

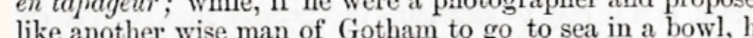
to those whio have seen the pictorial illlustratitions of the

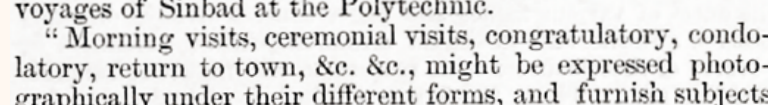

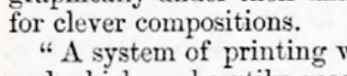

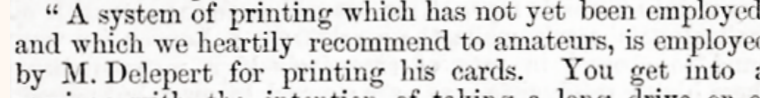
looking after your business. You drive yousustr

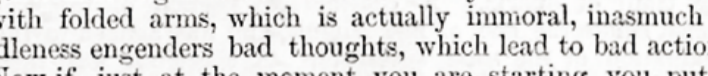

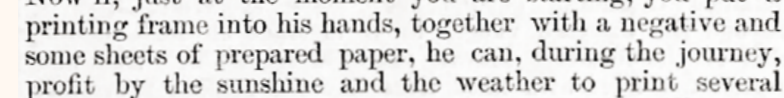

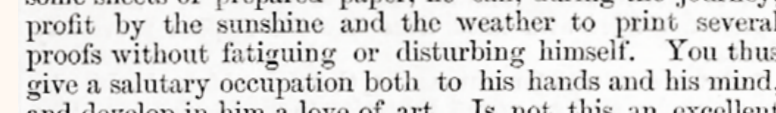

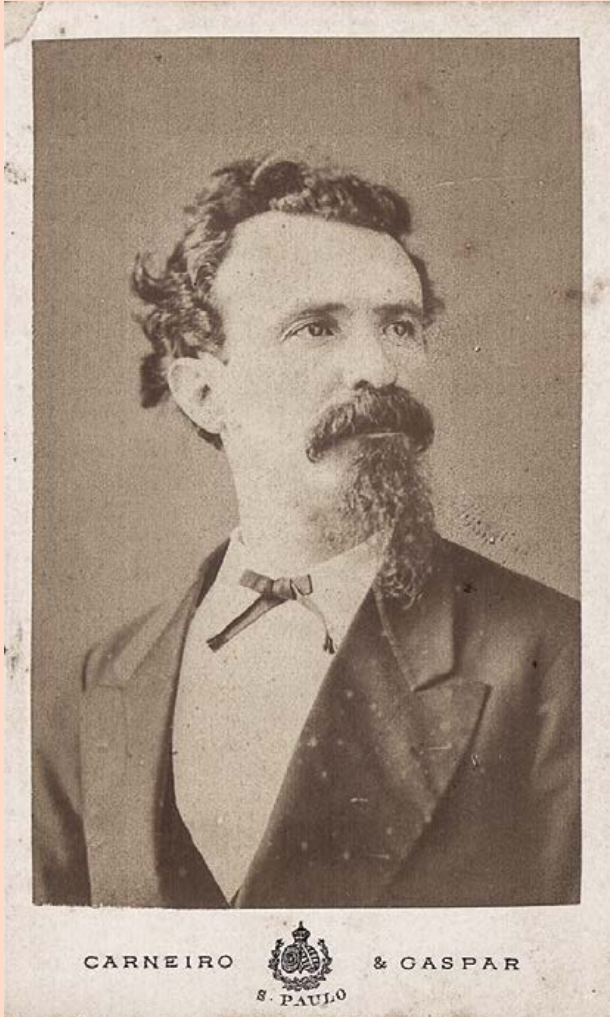

Nester retrato, oproprio
Milition. Eि possivel ver

para fazer os albuimens

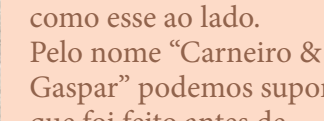

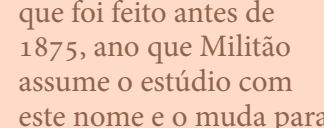

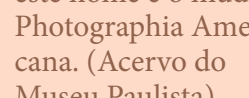

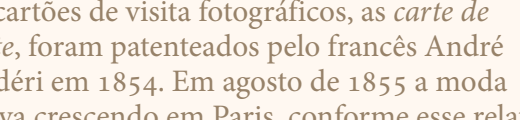

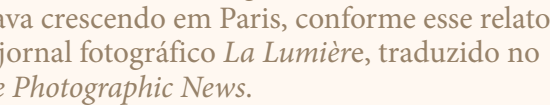

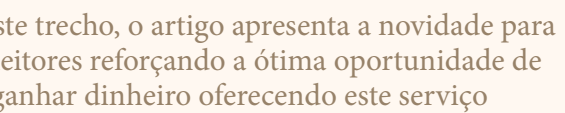

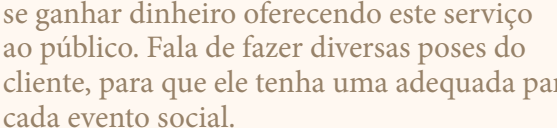

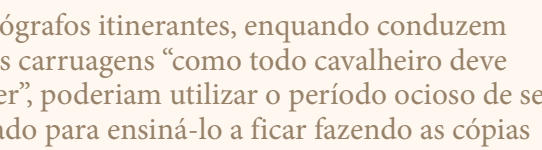

glês comenta que a moda ainda

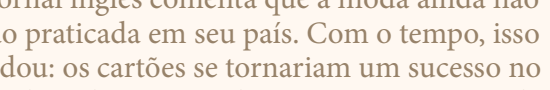

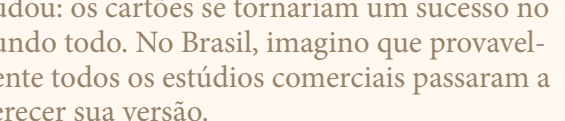
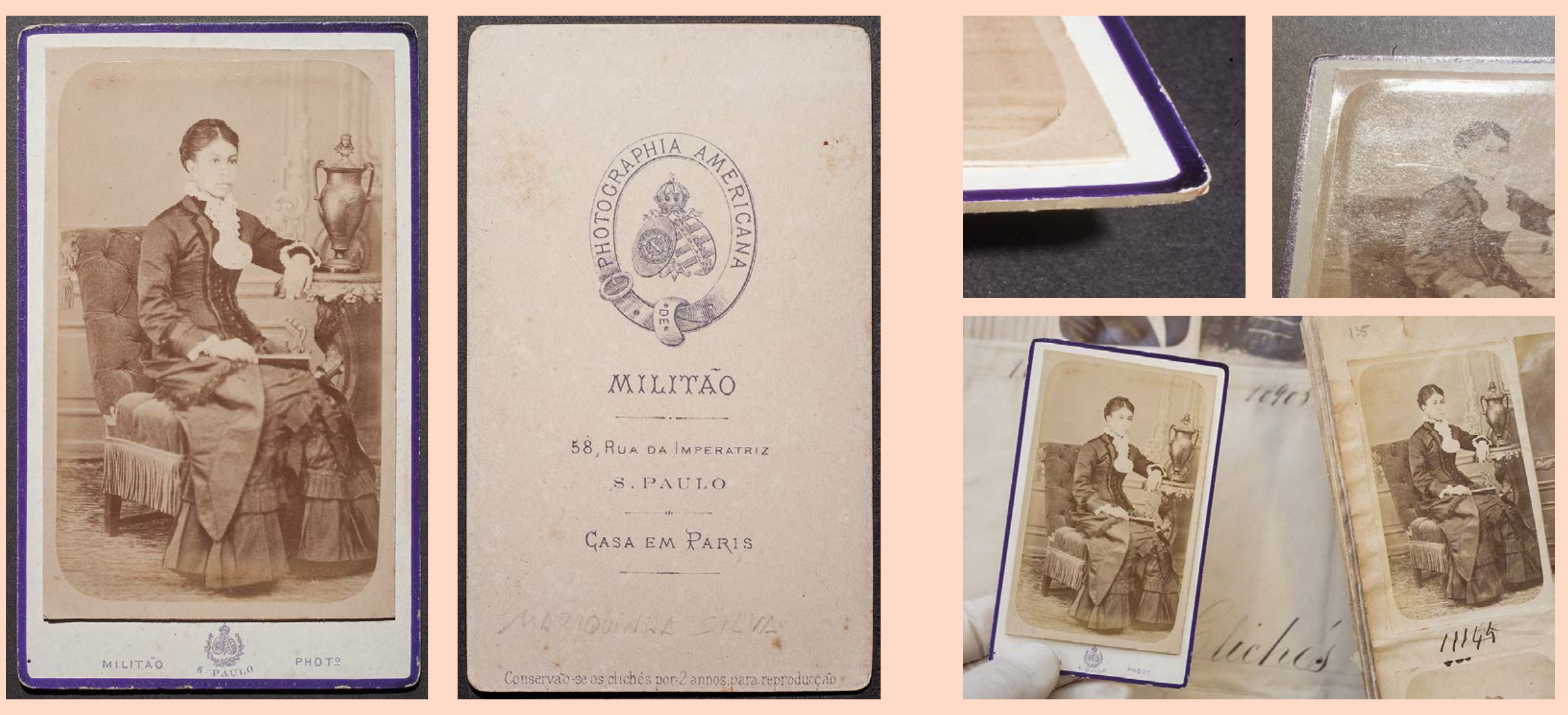

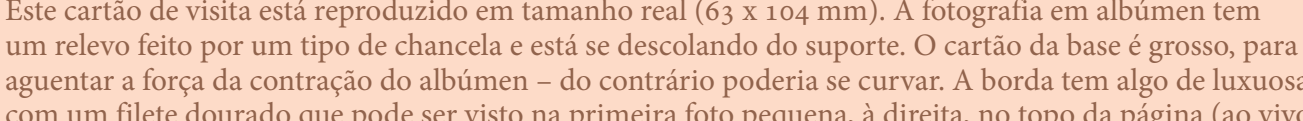

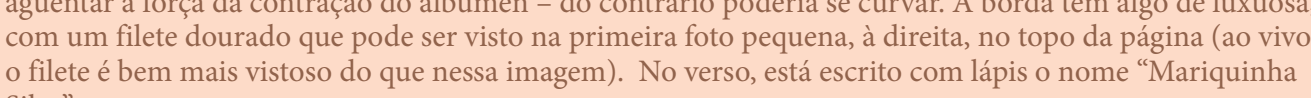

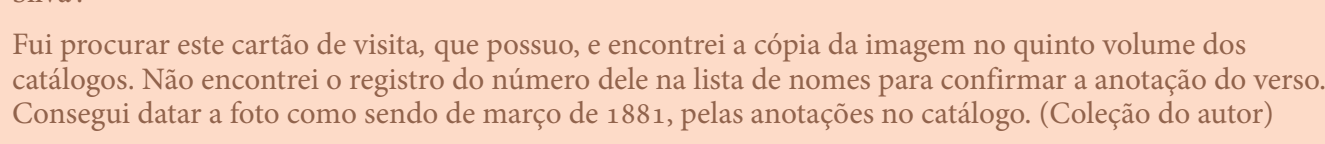


N DRY COLLODION

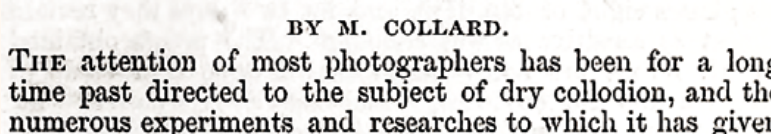

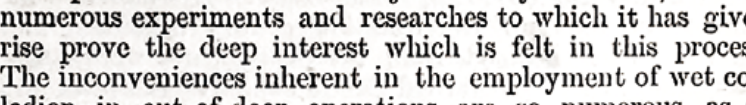

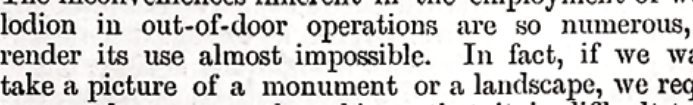

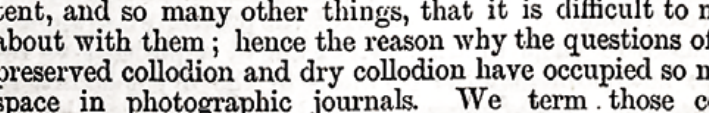

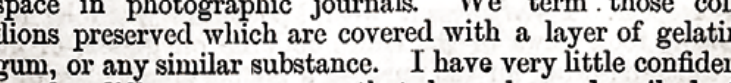

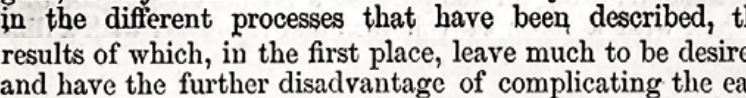

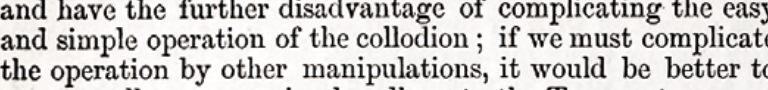

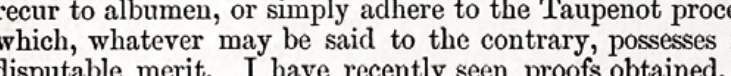

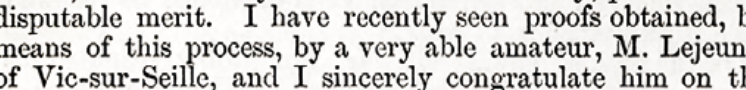

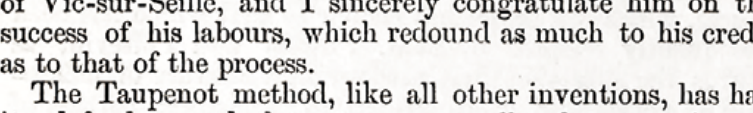

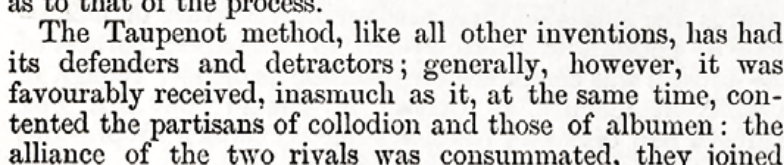

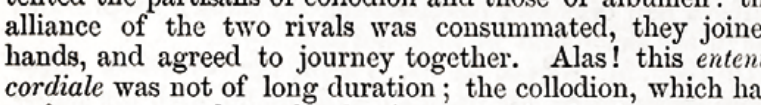

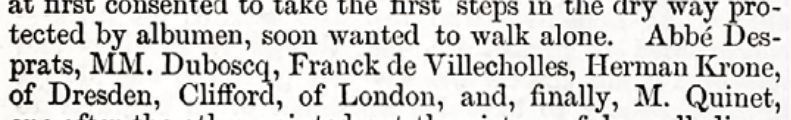

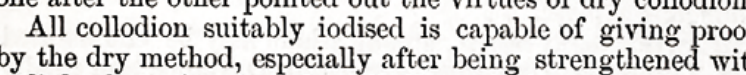

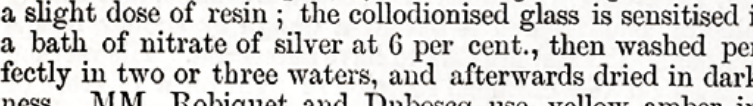

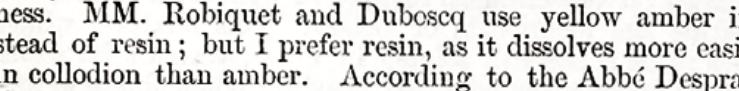

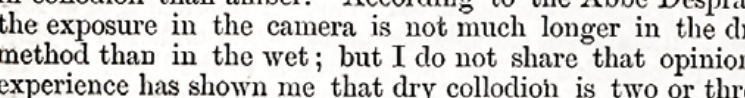

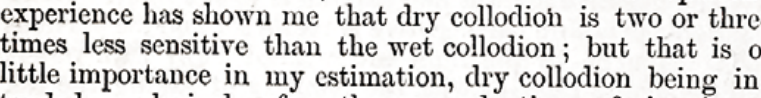
$\underset{\substack{\text { cended ed exclusively for } \\ \text { objects. }}}{\text {. }}$
TOTAL ECLIPSE OF THE SUN, SEPT. 7, 1858.

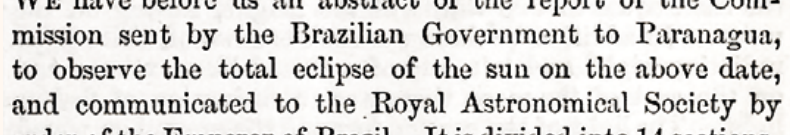
4.-In this section several currous facts are recorded. In
the early stage of the echipse both M. de Mello and MI. Liais

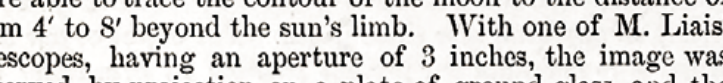

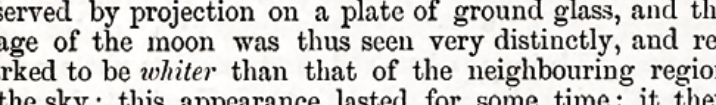

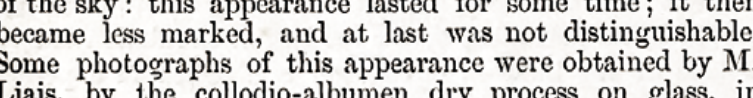

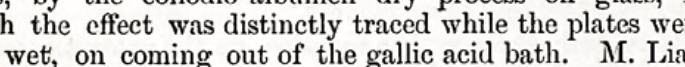

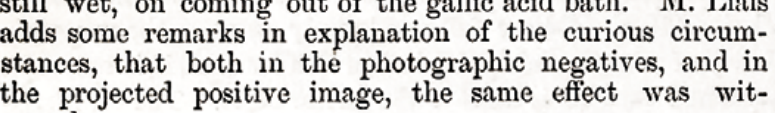
- The Photographic N News

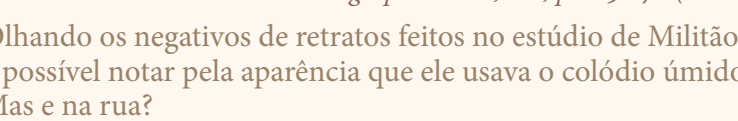

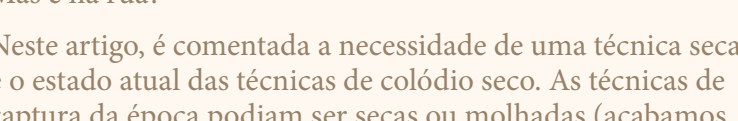

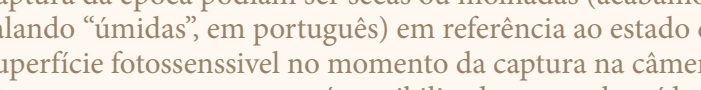

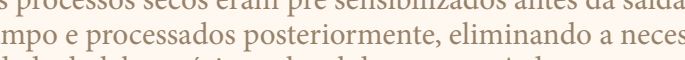

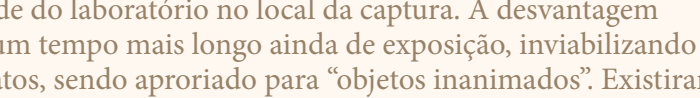

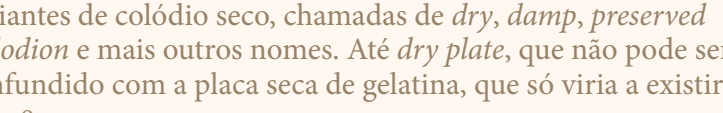

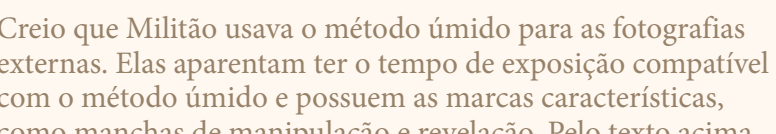

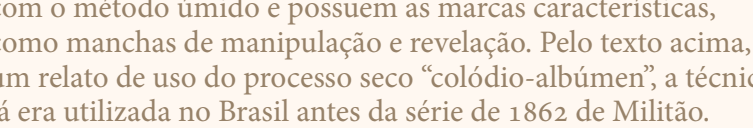

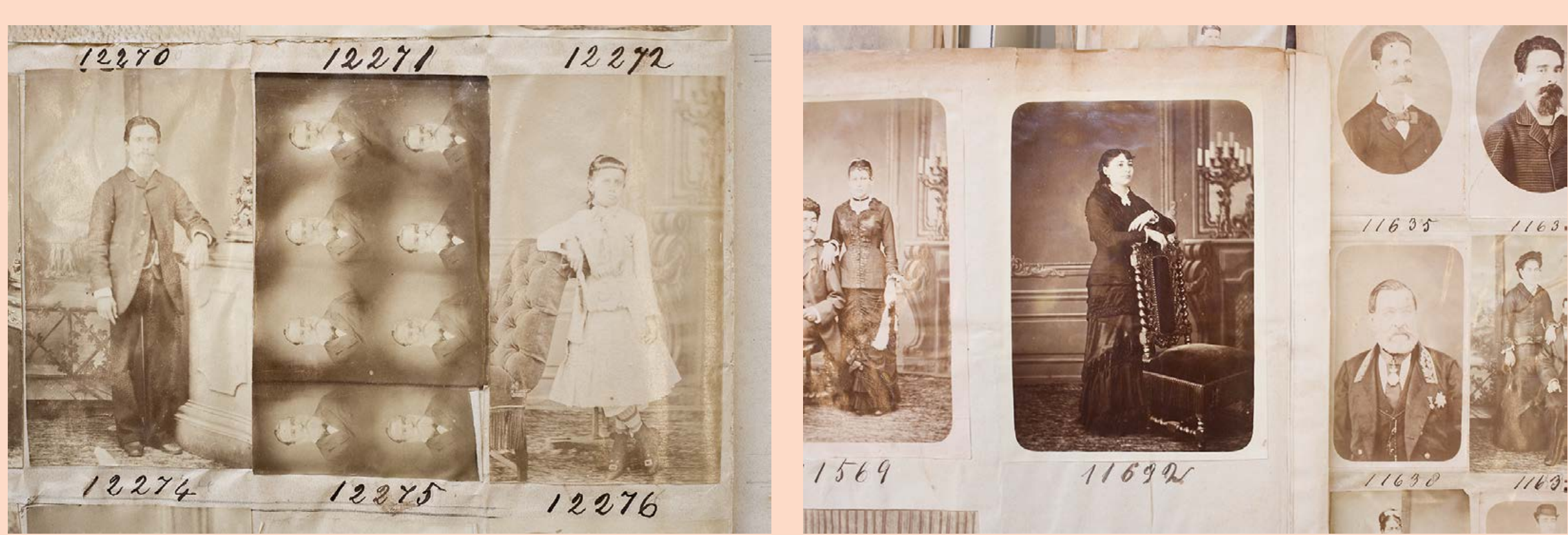

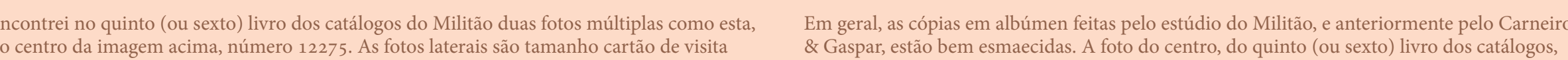

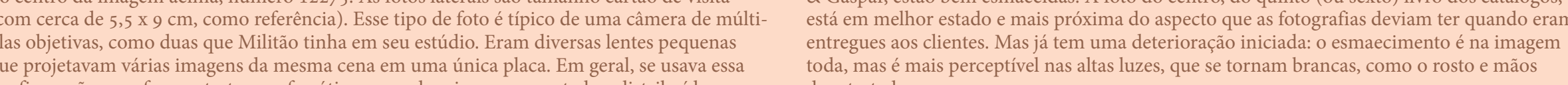

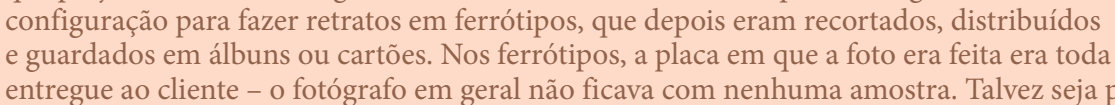

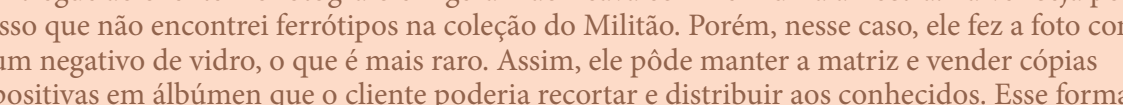


$25317589 \sim$ Dedos Man

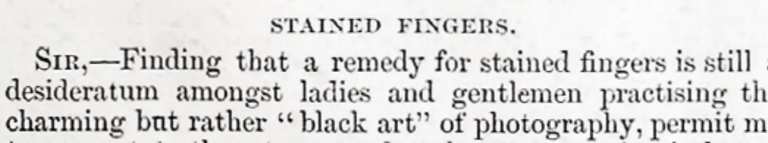

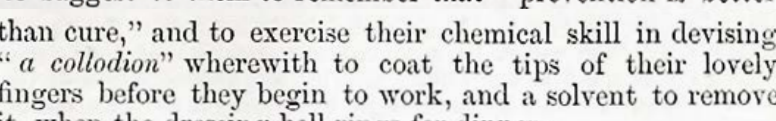

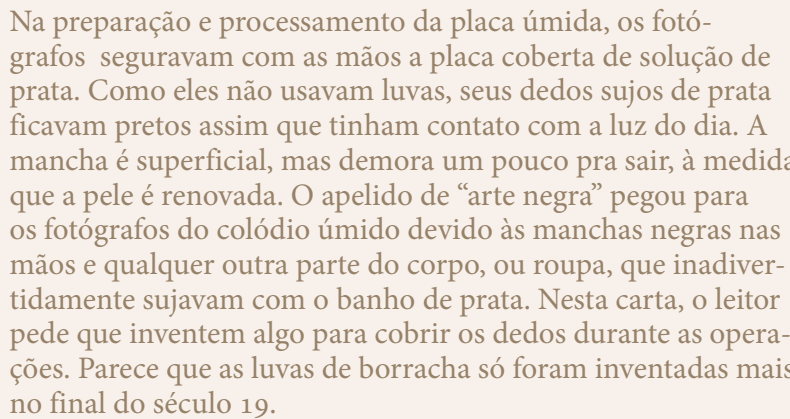

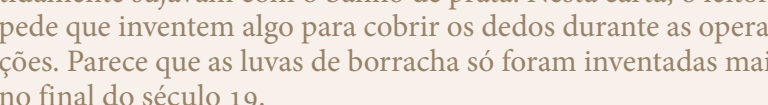

ta grande para $25 \times 30 \mathrm{~cm}$ de ans suficiente pra desconfiar. Foi o primetrot

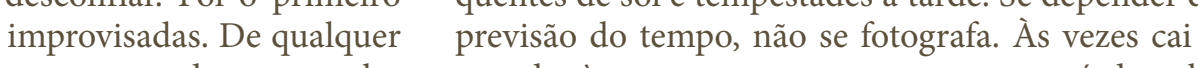

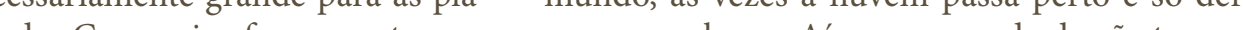
enor, para placas de até $20 \times 25 \mathrm{~cm}$; será mais fá- parado para sair. Hoje amanheceu nublado com a ta

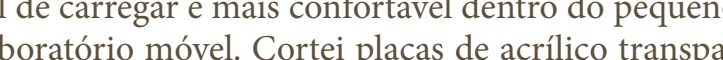
ente grosso, de $5 \mathrm{~mm}$, e colei as partes com metac-
to de metila, que é mais uma solda resistente. Desta molde em madeira consegui fazer uma boa com Vai ficar secando grampeado por uns dias

ro de 20

à frente, apesar de be

tigo algo como: em dias de sol, se fotografa, em diais
nublados se fazem as cópias e em dias churvosos

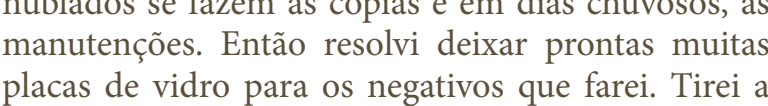
manhă arara cortar 12 placas de $18 \times 24 \mathrm{~cm}$ de vid Creio que esse tamanho nãó é tâo grande para con-
plicar minhas saídas fotográficas e ainda dá uma bou

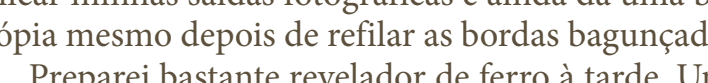
forte soluçáa de estoque baseada no manual de $\mathrm{M}$ ção variando sua diluiçāo. Fiz assim: água destilada morna 235 - acúcar branco 45

açucar branco $45 \mathrm{~g}$
- ácido acético glacial $20 \mathrm{ml}$.
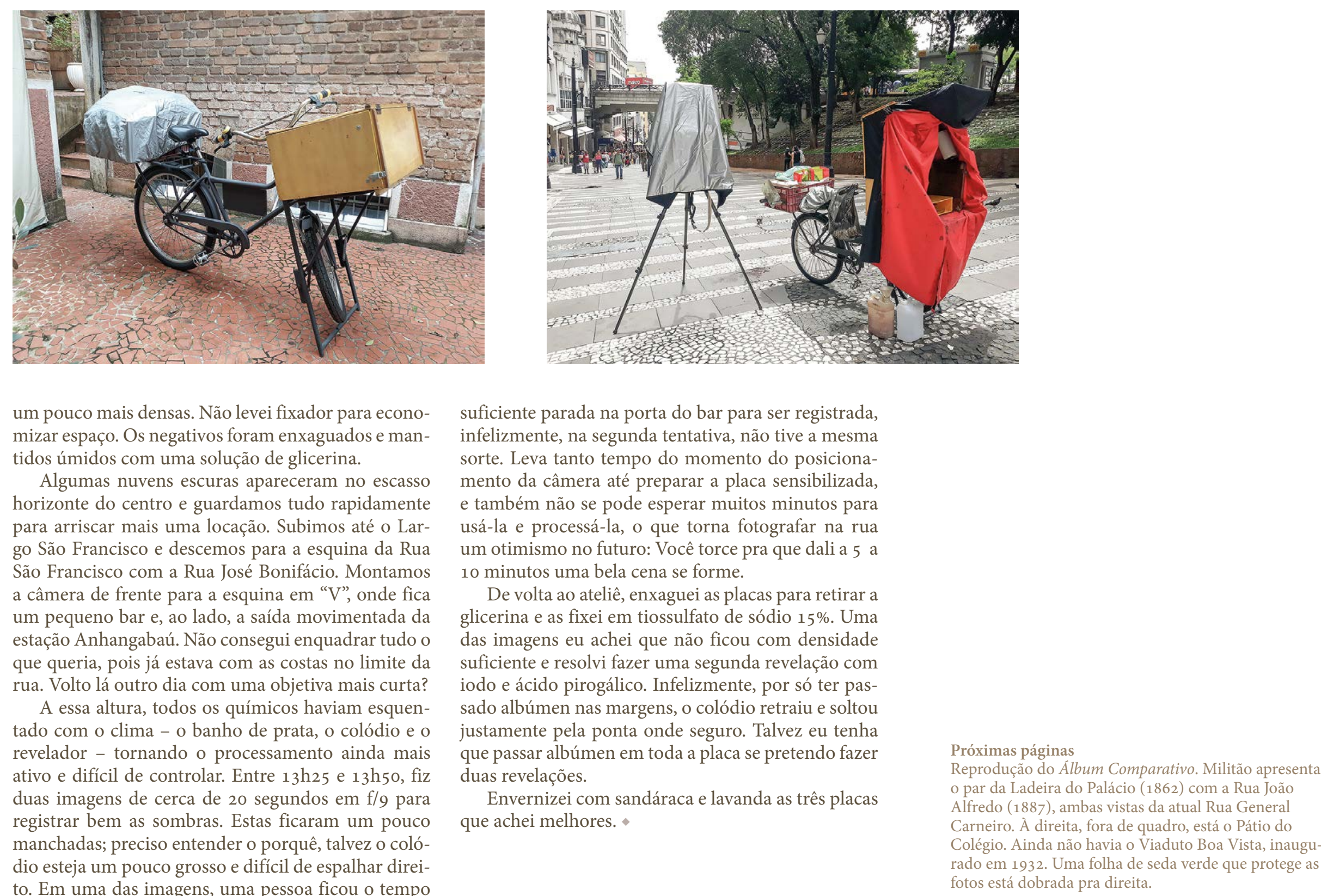


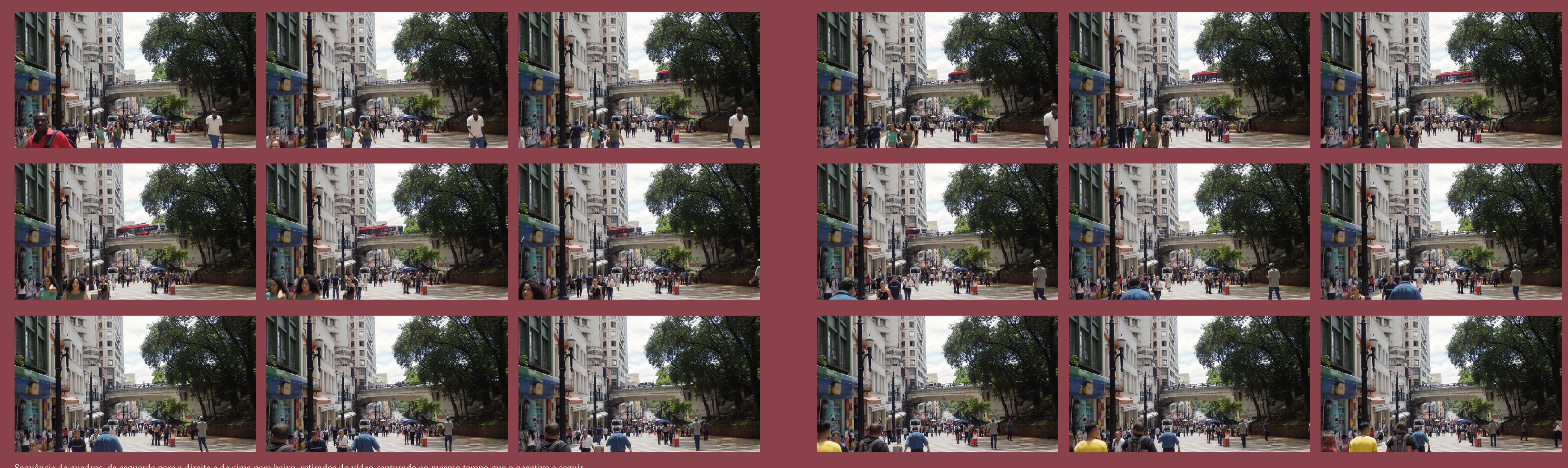

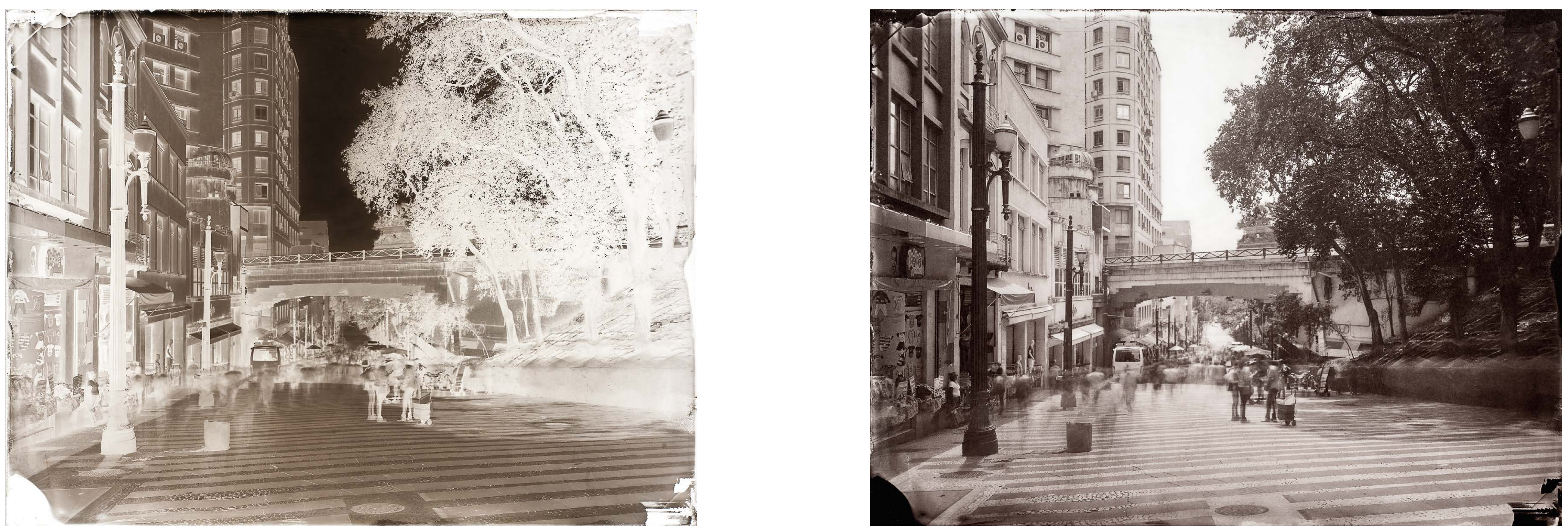


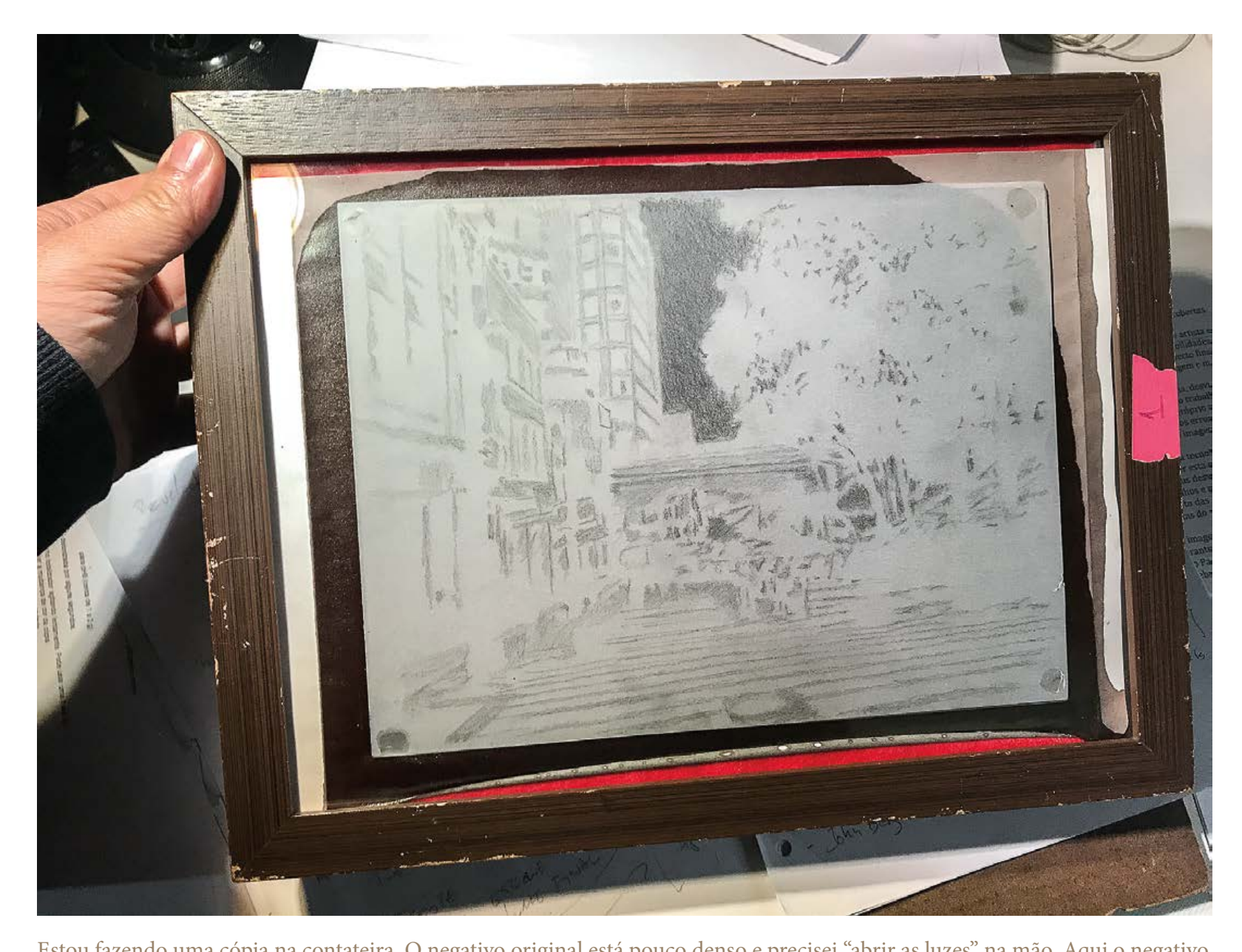

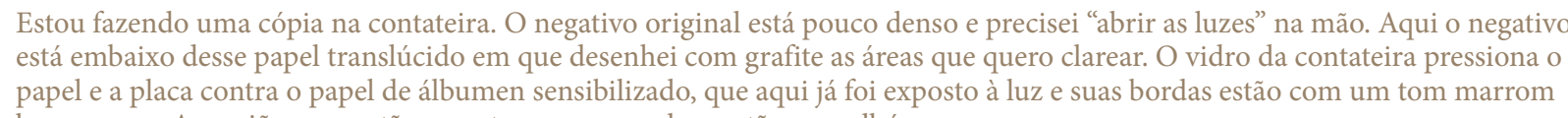

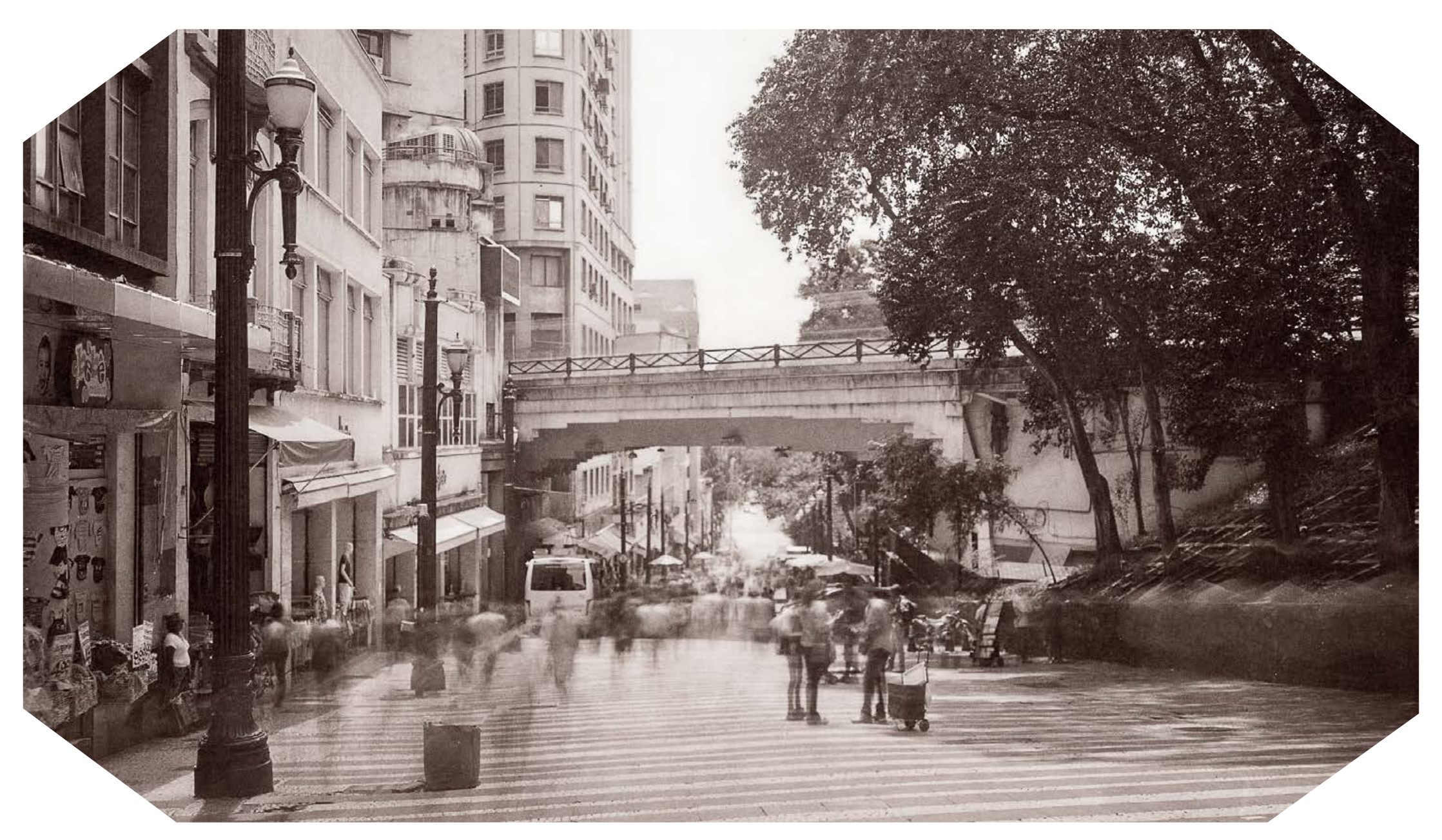




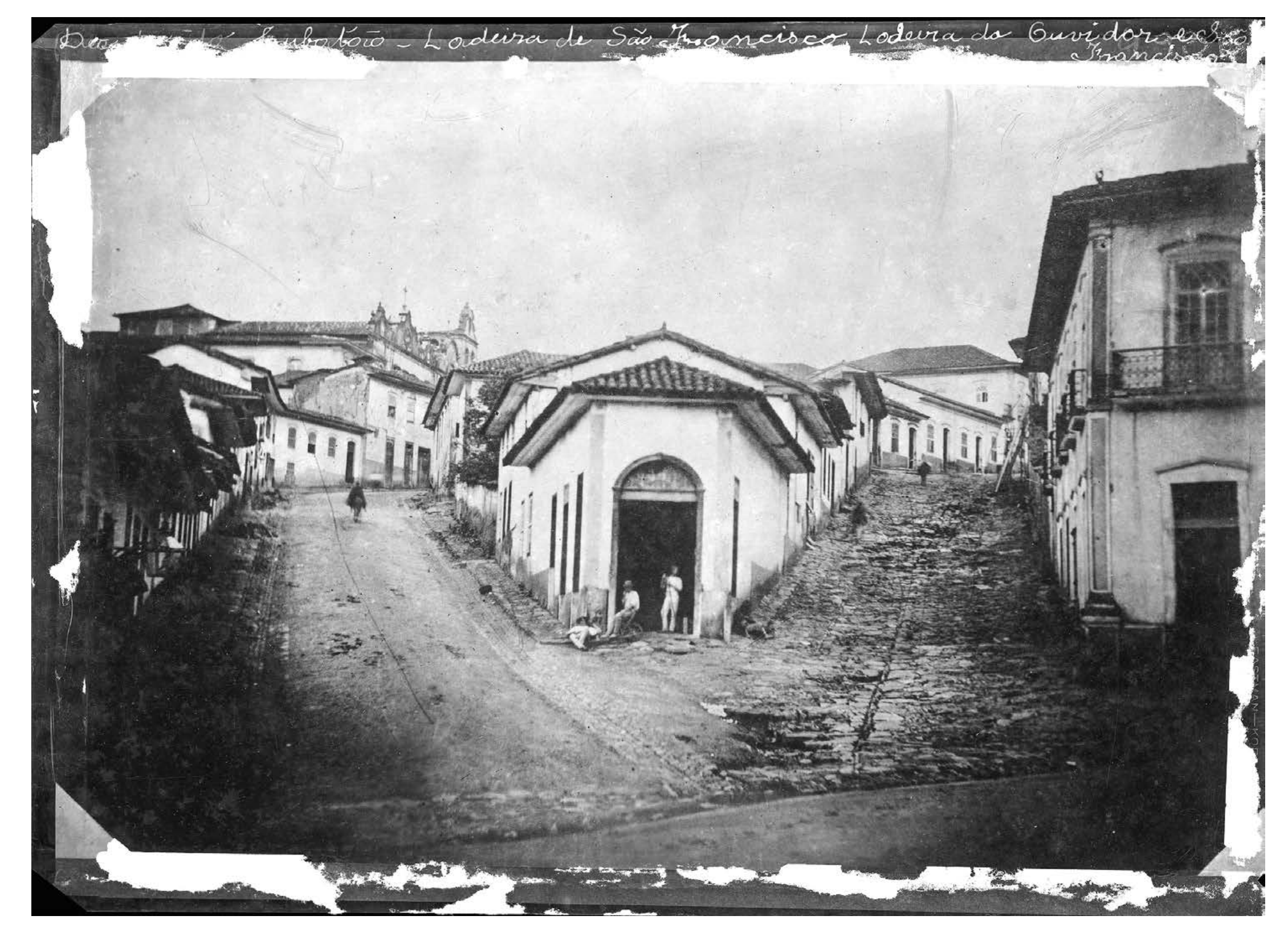




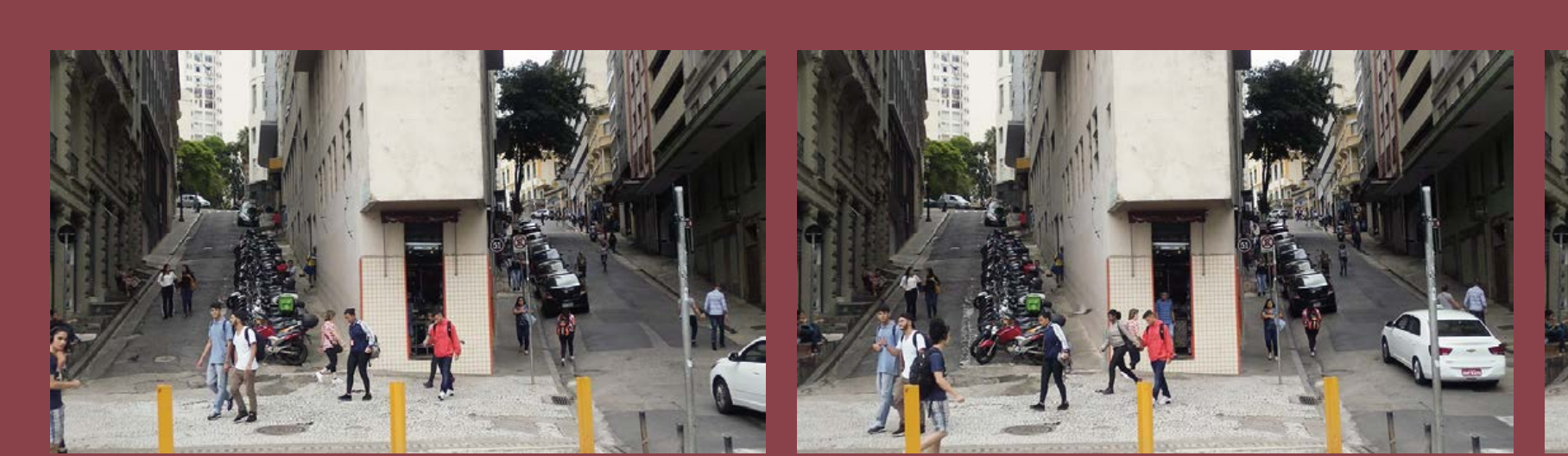

BNA

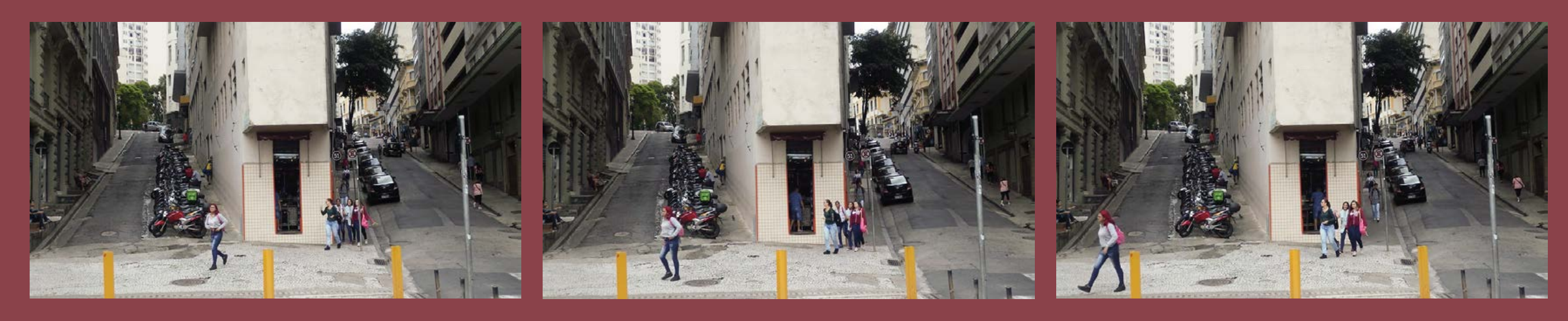

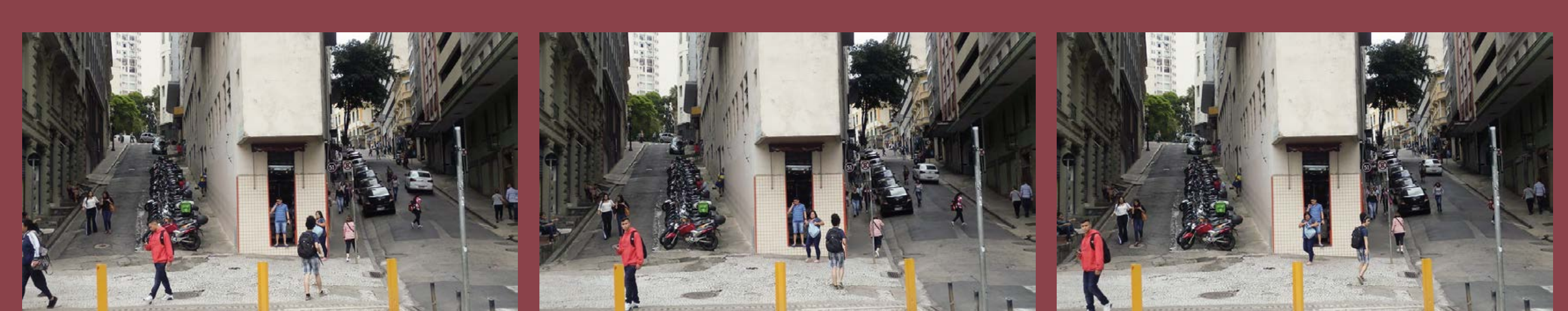

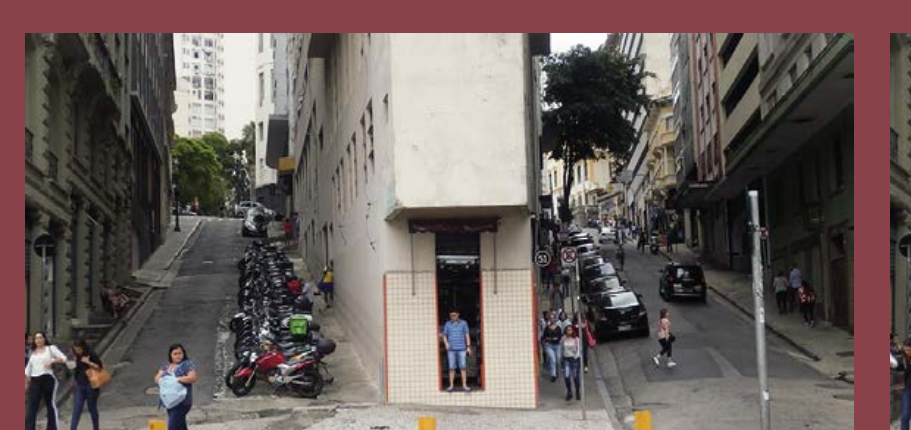

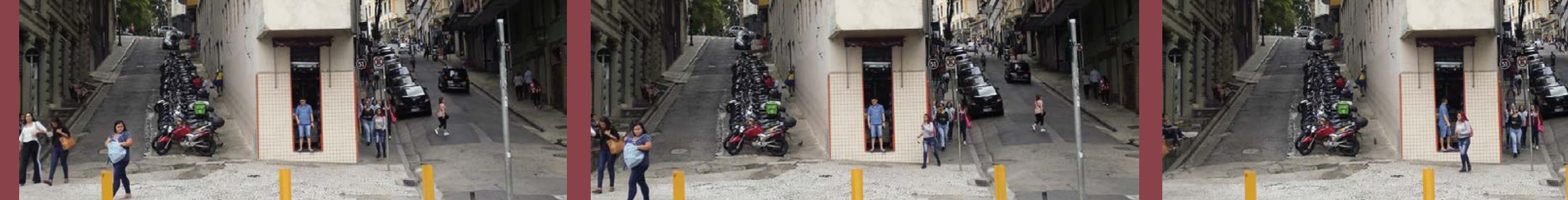

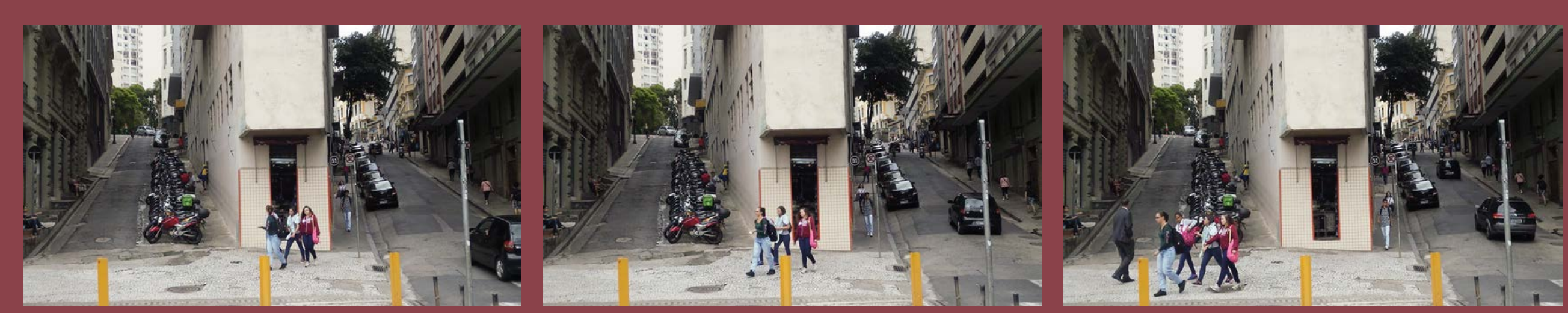



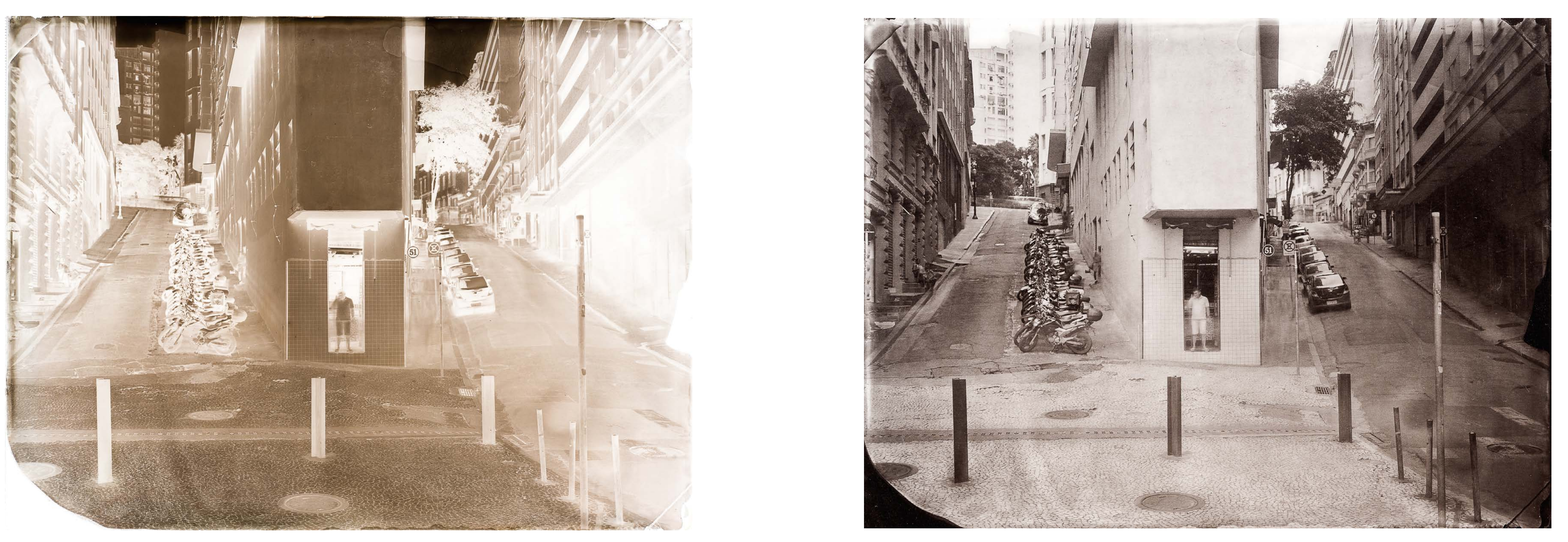

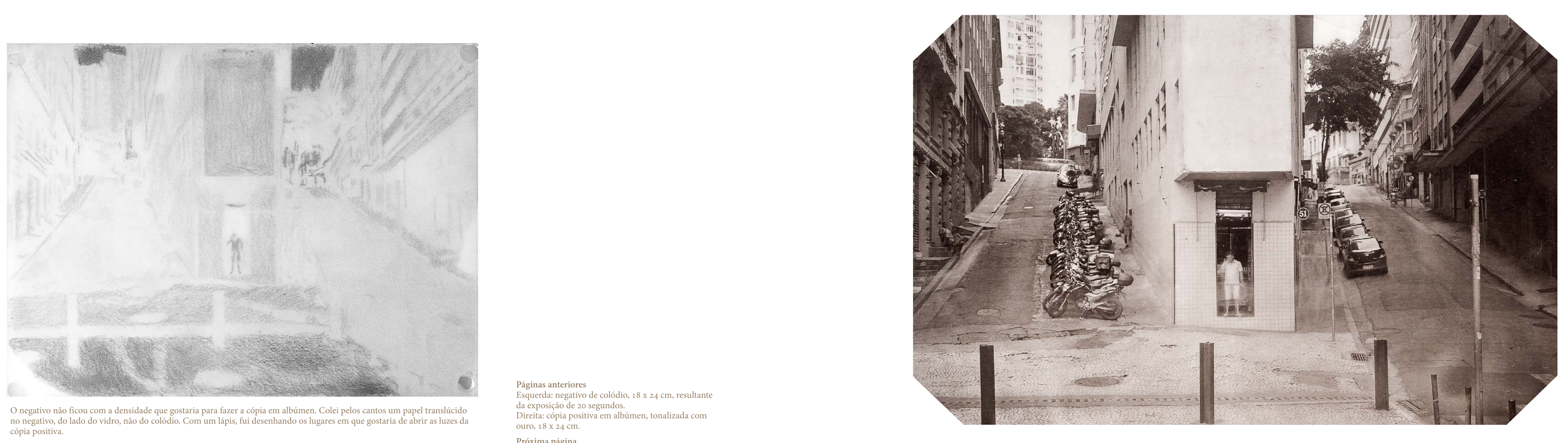


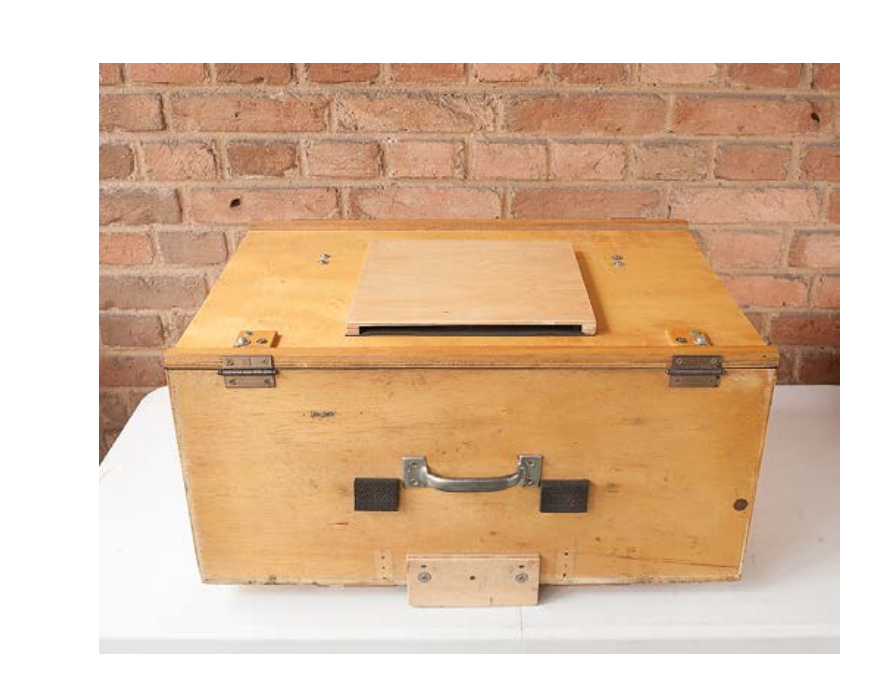

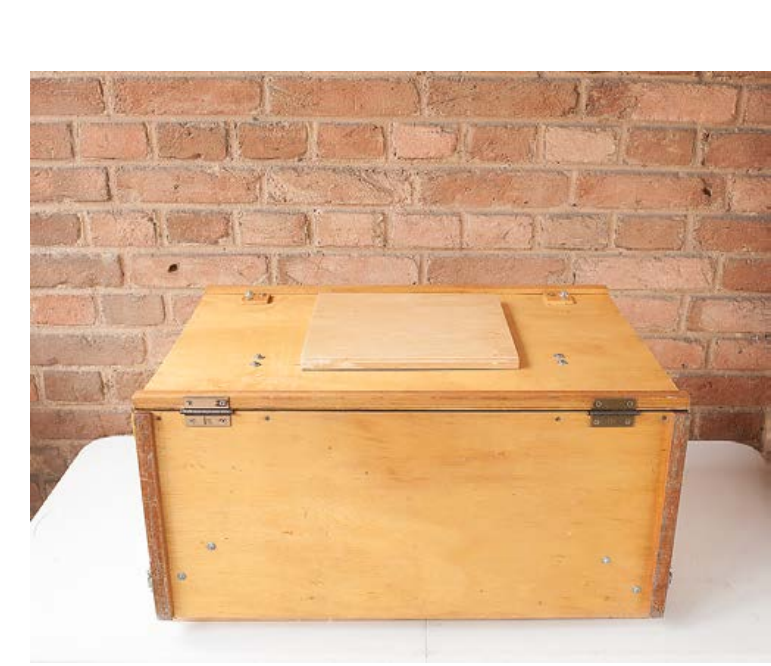

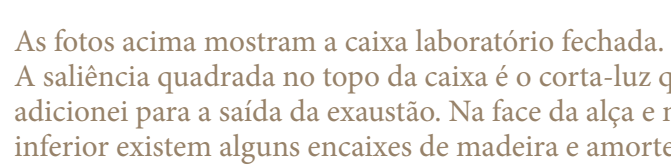

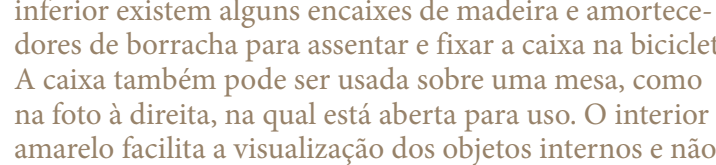

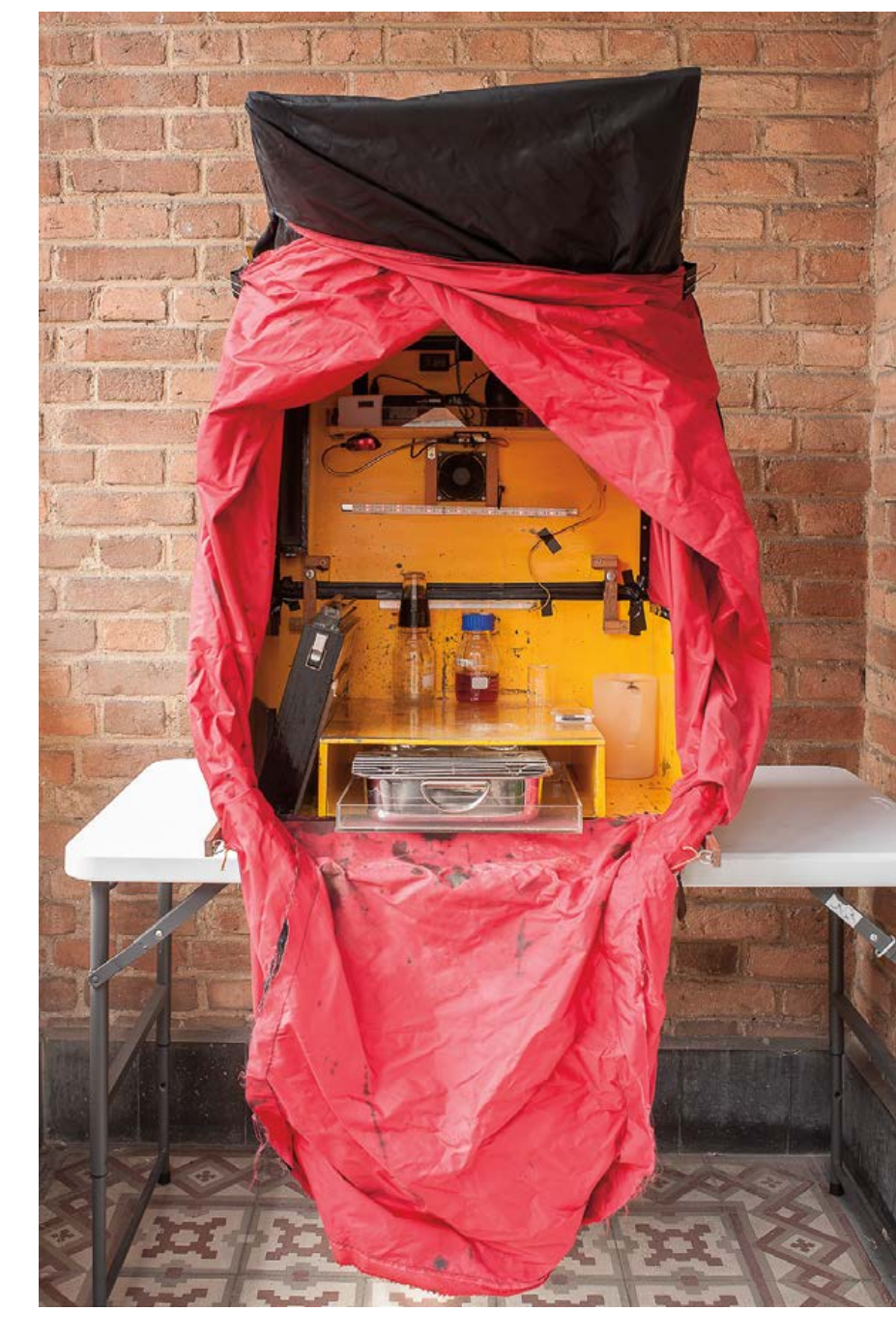

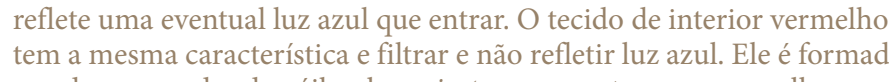

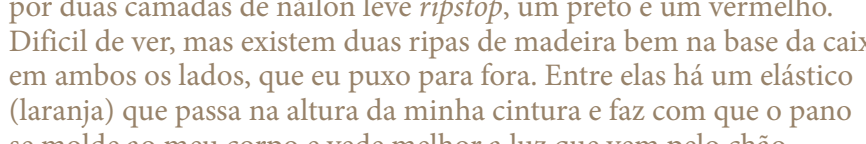
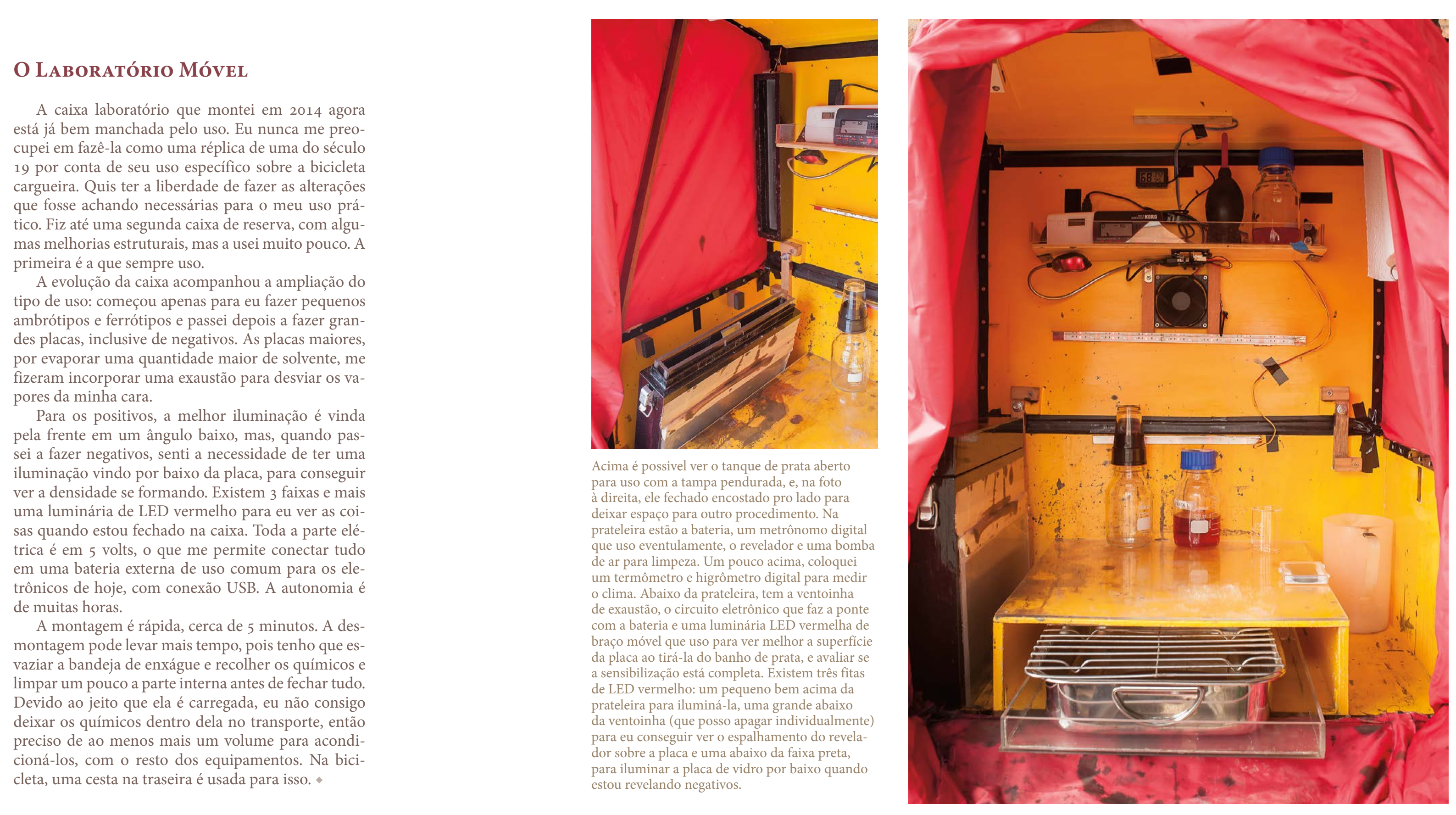


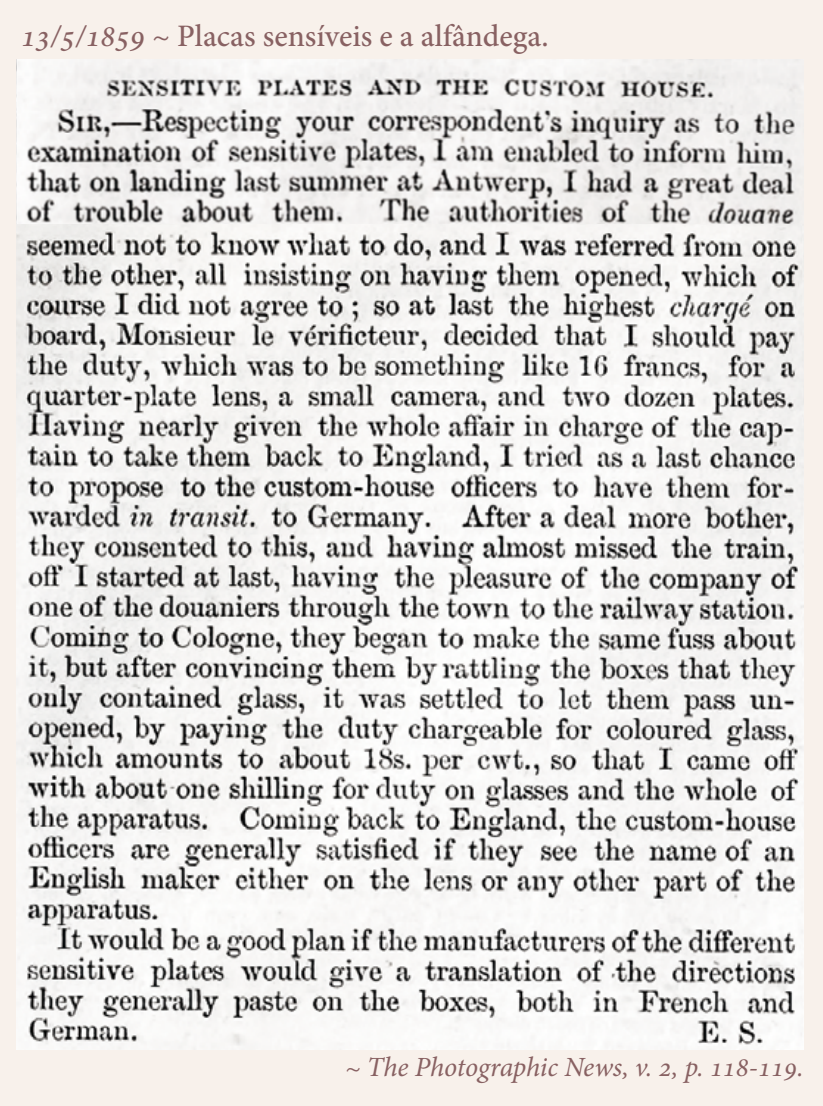

Paulo, 25 de froro de 1886.

Incluso remetot fatura e pertence de uma caixa em-
barcado no Haver[?] a bordo do vapor "Villa de San-

Rogo-lhe o obséquio de mandar despachar as
mercadorias contidas no dito caixoo, pedindo-lhe

de gelatina ou bromuro não podem apanhar luz por
isso VM recomendará ao despachante para não abrir os embrulhoso o que é permitido na Alfándega a vista deles ficarem inutilizados com qualquer raio de lluz.
Despachado que seja o volume VS me remeterá com Despachado que seja o volume VS me remetera con
cargo pela estrada de ferro. Mandando-me a competente nota para ser satisfeita de sua importância.
Militán. Livroc Copiadorde Cartas p.

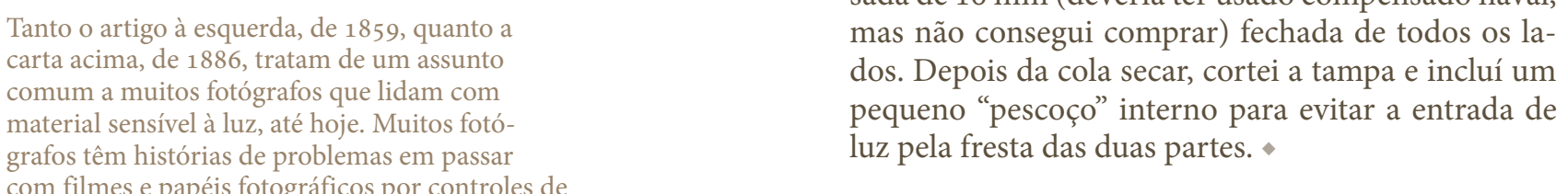

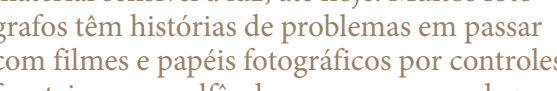

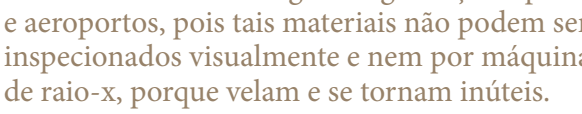

A fotografia digital năa sofre do mesmo
problema, efor um alvioi para mutos profissio.

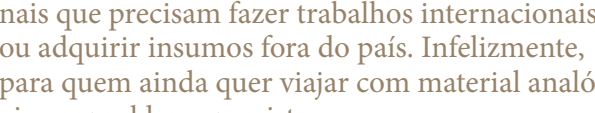

para quem ainda quer vite
gico, oproblema persiste odas as placas que, áa áso muitas. O mais seguro se 列

3 de marco de 2019

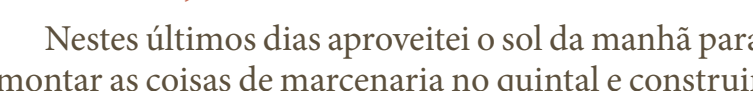
dias $\mathrm{e}$ parece não estar vazando, ou nâo o sufficieint pra eu desconfiar. Fiz a caixa com madeira compen-
sada de $10 \mathrm{~mm}$ (deveria ter usado compensado naval

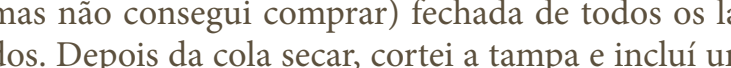
pequeno "pescoco"s" interno $\mathrm{P}$,
luz pela fresta das duas partes,

5 de março de 2019 Fiz as cópias positivas das imagens da última sai-
da. O papel de albuimen que fiz ainda tem algumas fa-
lhas de aplicacão sobre a follha. Mas a receita de $1.5 \%$ de cloreto de amônio e $15 \%$ de prata parece que de

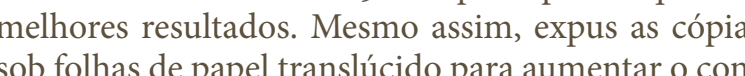
sob follhas de papel translucidido para aumentar o con-
traste, ja que os negativos não ficaram super densos Tonalizei as cópias com ouro-bicarbonato somente mais chocolate. Após a lavasem final deixei escorre o excesso de água e depois passei as cópias para sect ria fazê-los com algum papel grosso, porém preferei
usar uma papel translúcido (Canson Croquis) uma caixa de madeira para protegero o tanque do ba
nho de prata que fiz. Deixei o tanque com égua de março de 2019

f̧o de 2019

xa para o tanque para prata. Pintecom duas demàos de tinta PU preta resistente e colo-
quei fechos e vedaçoes para poder transportar cheii de liquido nas saídas. Por último fiz un "mergulhador", para poder colocar e tirar as placas de dentro
do tanque. Esqueci de comprar, mas preciso colocar do tanque. Esqueci de comprara mas preciso colocar
uma alca na tampa. Mas já sta pronta para a proxima 9 de marco de 2019

Coisas que
saída fotográfic Minha caixa de vidros limpos caiu, junto com a
bicicleta toda, no meio da calçada do Centro de São Paulo. O tanque de prata que acabei de fazer resistiu e não vazoul Nada quebrou do laboratório e frascos "apenas" todas as placas
que? Voltar pro estúdio. de se viajar para fotografara no períiodo dos negativos

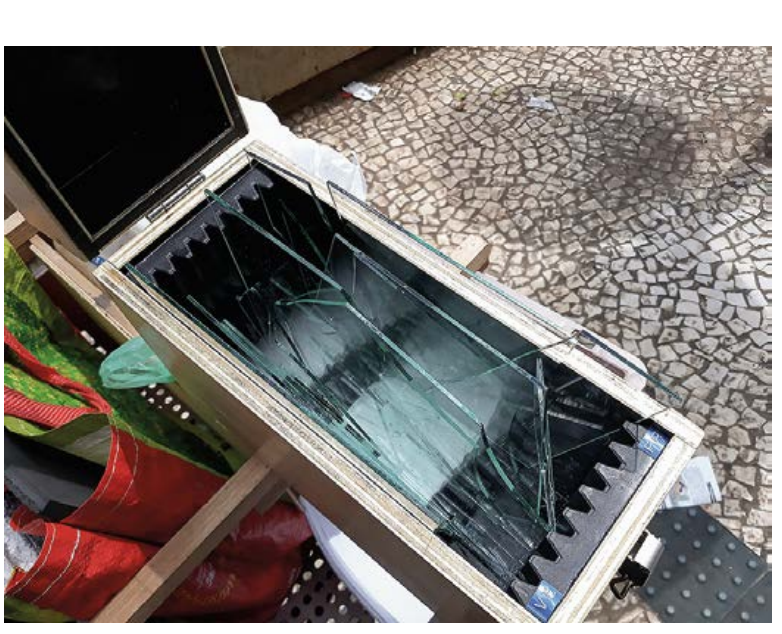

mas o pior do verão parece Media a temperatura dentro do labotorio: entre $14 \mathrm{~h}$ e 15 hro e estava uns $30^{\circ} \mathrm{C}$ e $60^{\circ}$ Fiz duas fotos do Teatro Municipal visto da esqui-
a da Rua Xavier de Toledo, em frente ao Shopping A segunda exposição foi 16 segundos em f/16 Talvez tenham ficado um pouco superexpostas Depois fomos à Rua 15 de Novembro, próximo
una do Comércio, fazer uma vista voltada para $a$

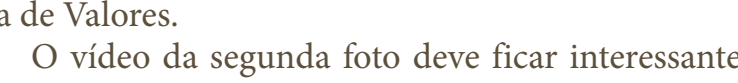
O video da segunda foto deve ficar interessante,
pois mostra um furgão amarelo que surge no meio
da exposiçăo mas nano ficou registradado no negativo A segunda exposição foi de 60 segundos em
$8 / 2$ para EVV11,5.
No processamento das placas, de volta ao ateliê, No processamento das placas, de volta ao ateliế,
vi que apareceram alguns pontinhos pretes ao final. Estou achando que pode ser do uso de fixador velho.
Emelhor mesmo fazer una leva nova de fixador para

A esguerda, caixa coms vidros swebrados depois ones

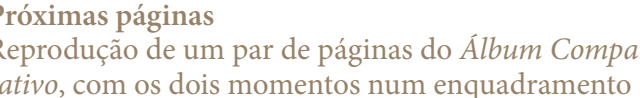

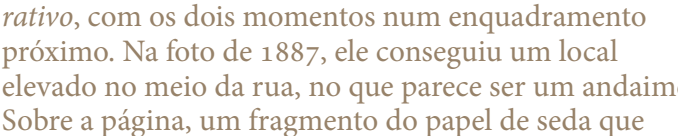

NOTES FOR ALPINE PHOTOGRAPHER

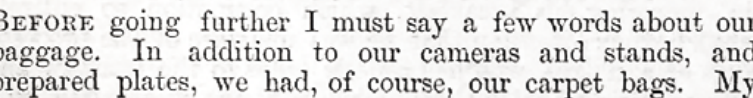

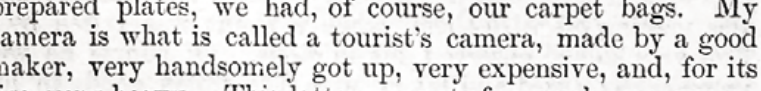

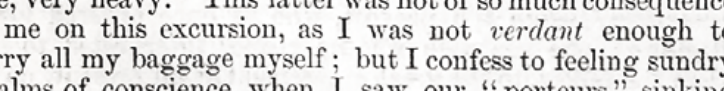

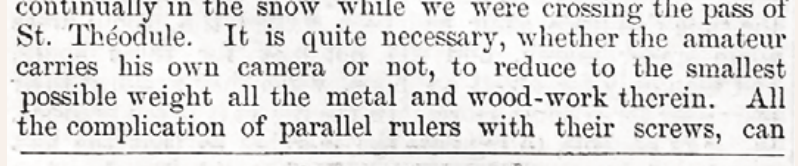

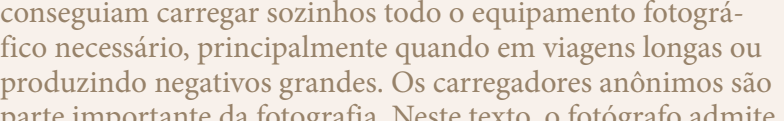

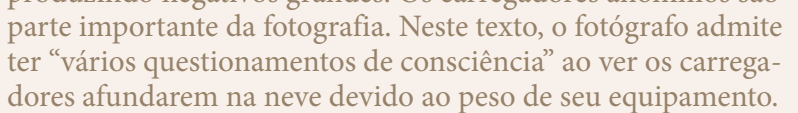

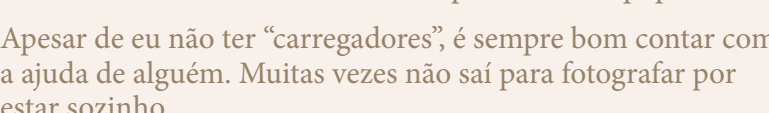$$
\text { - }
$$ 


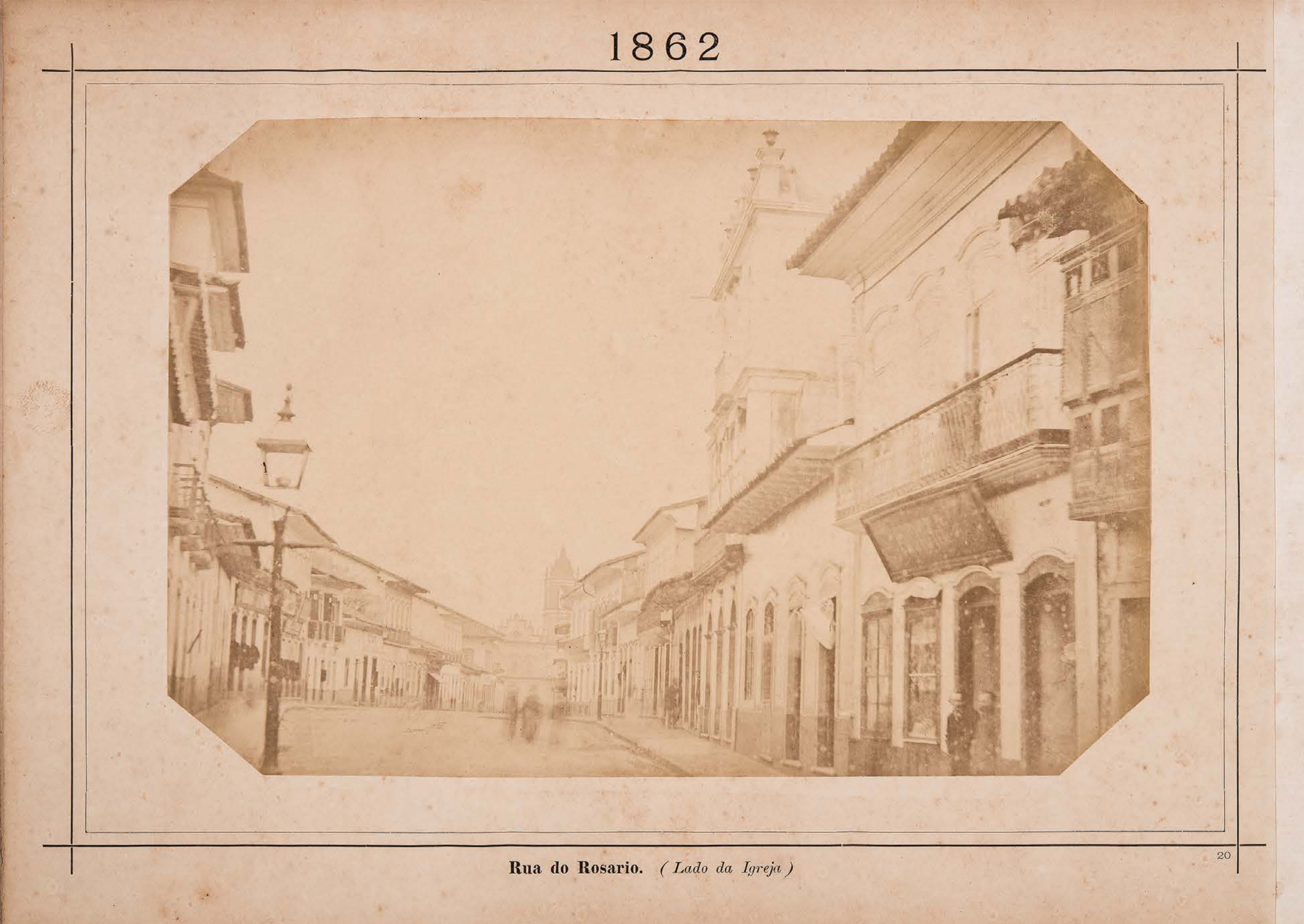



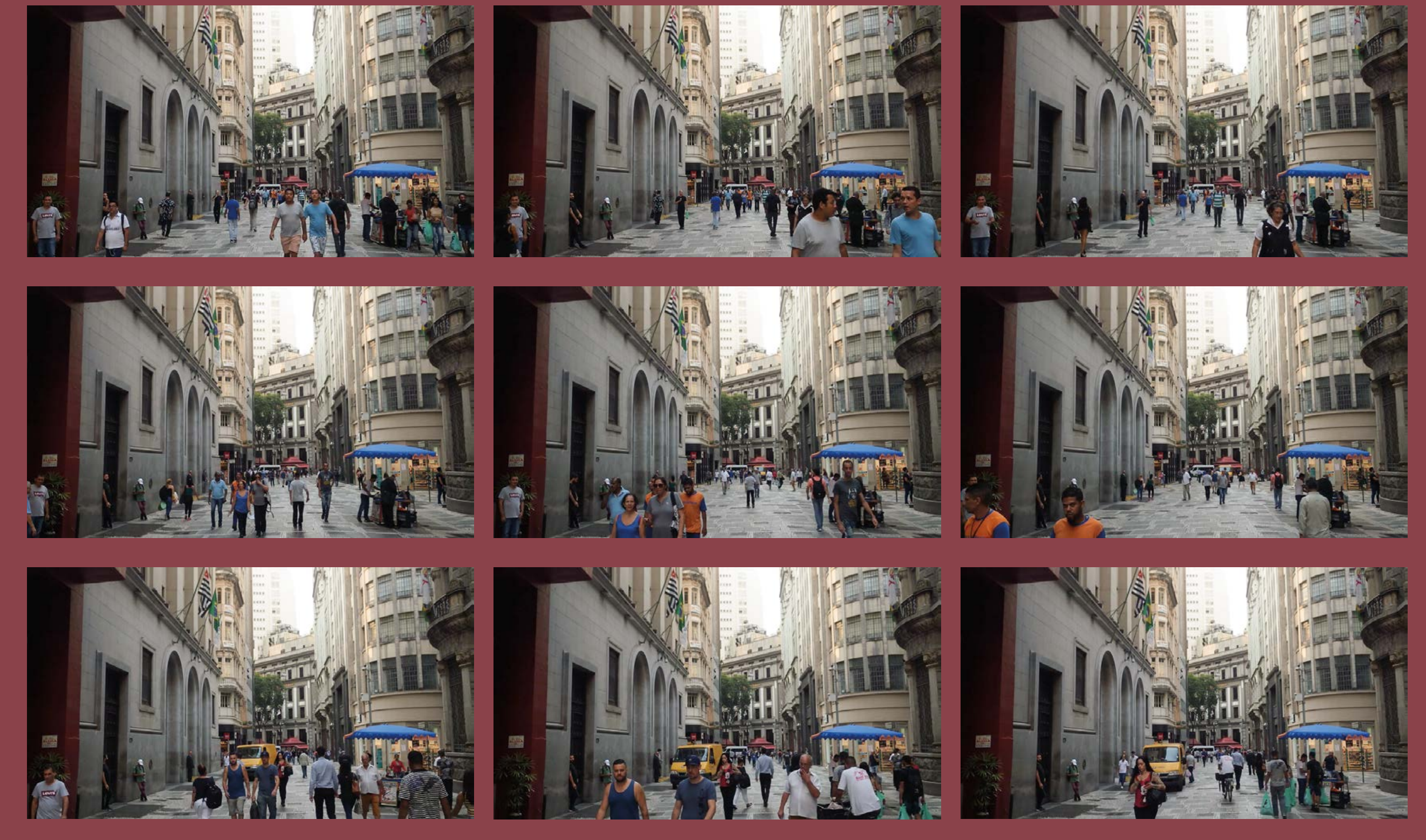
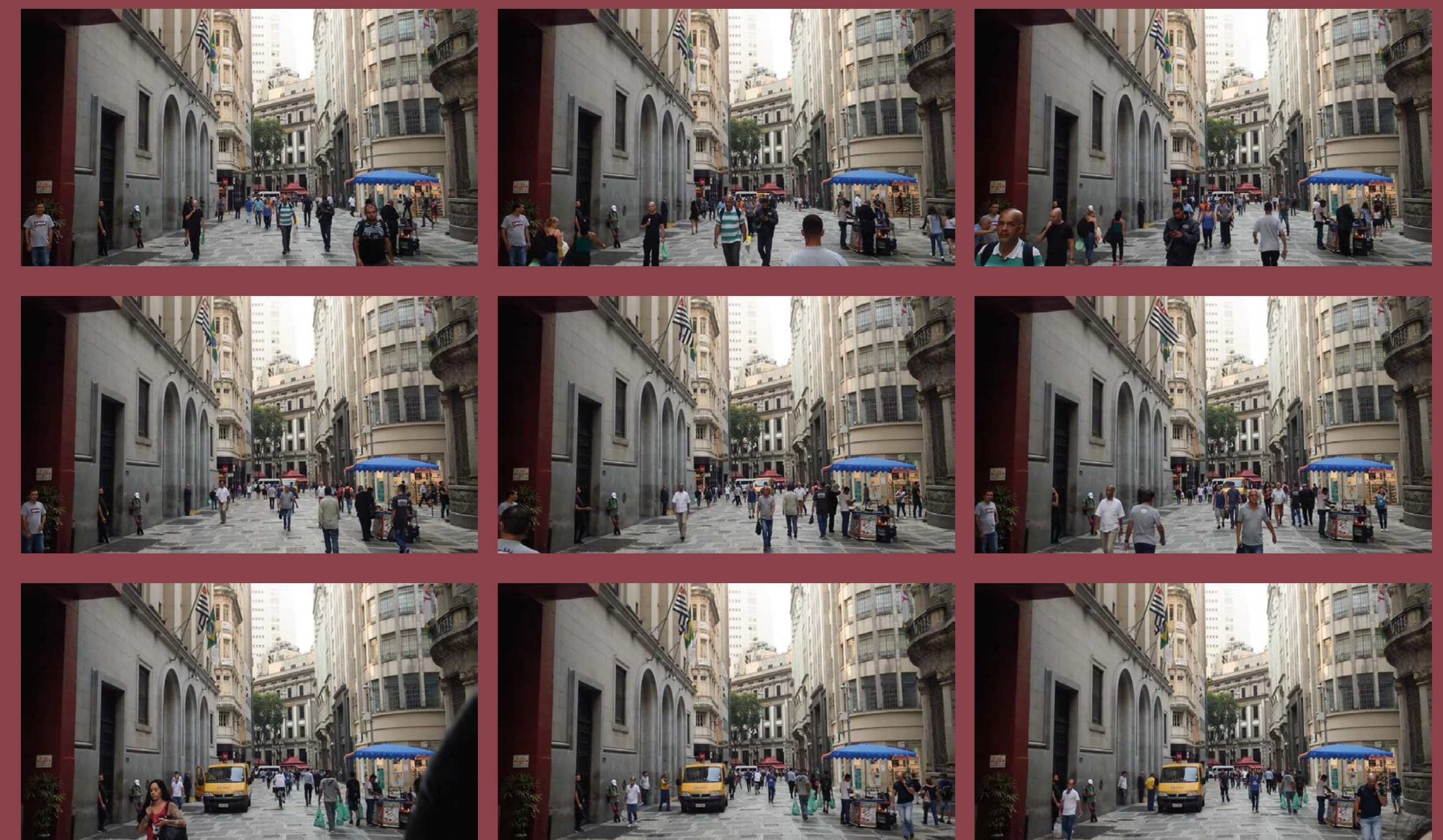

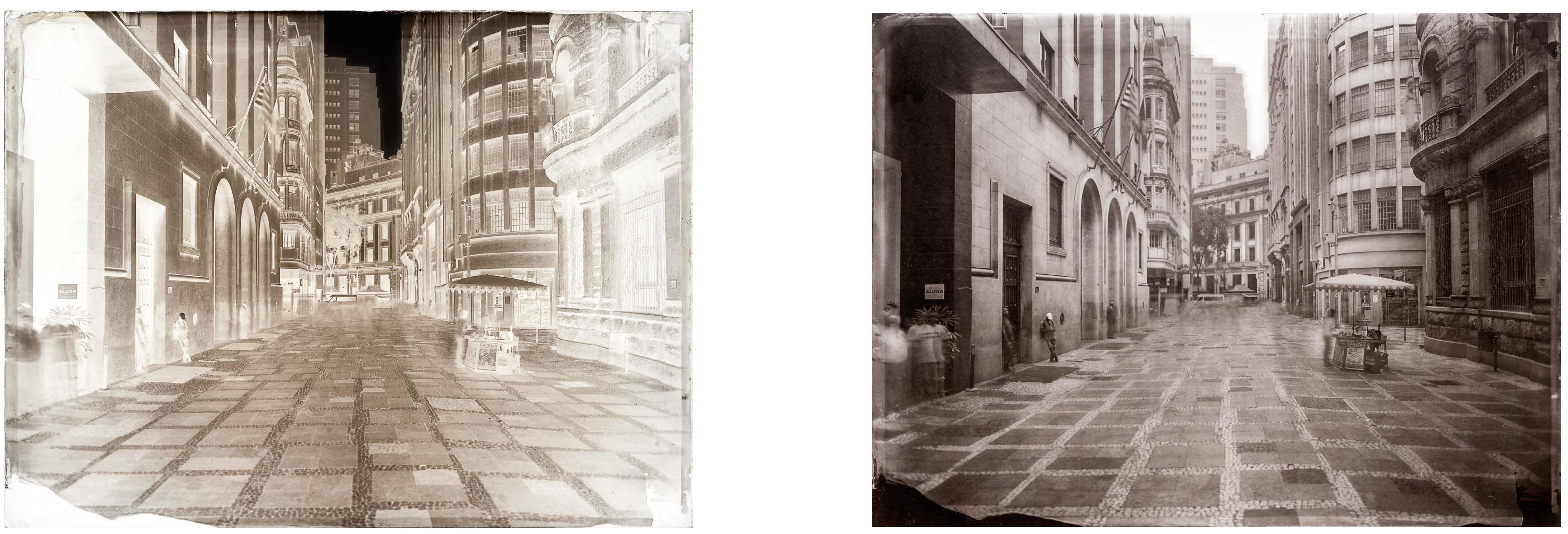


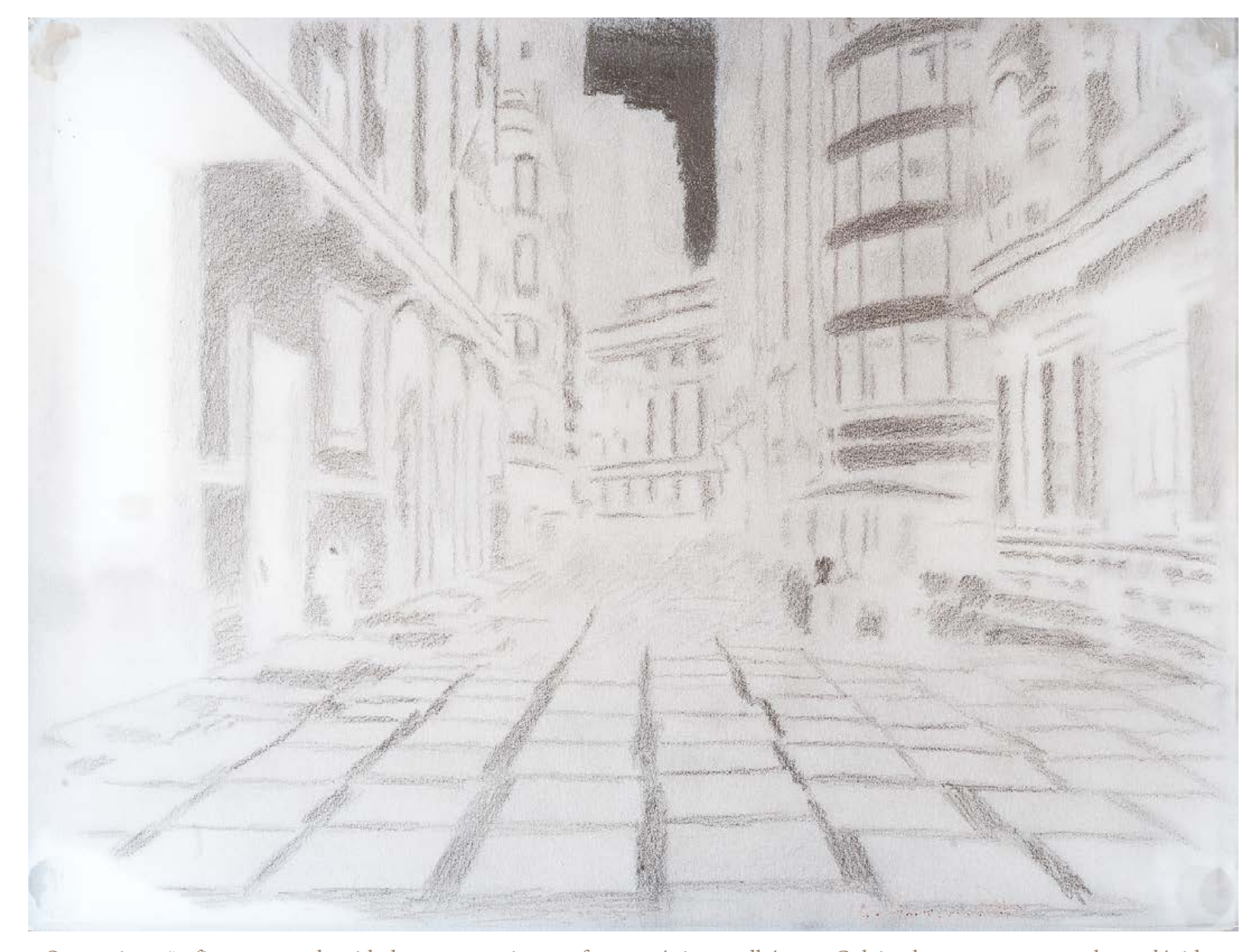

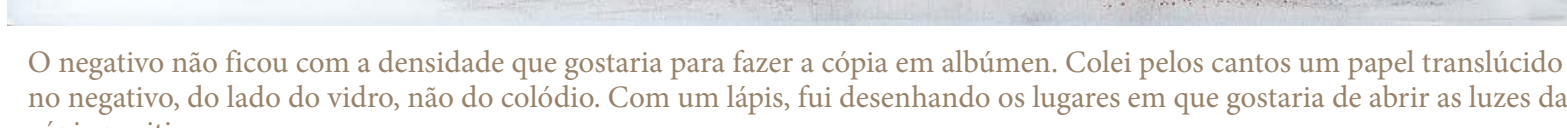

Páginas anteriores
Esquerda: negativo de colódio, $18 \times 24 \mathrm{~cm}$, resultante da

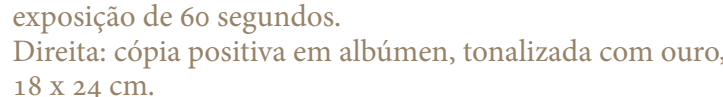

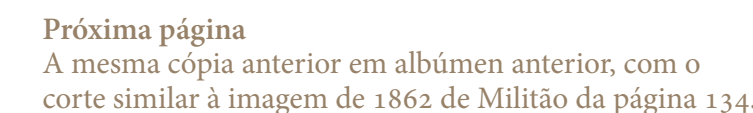

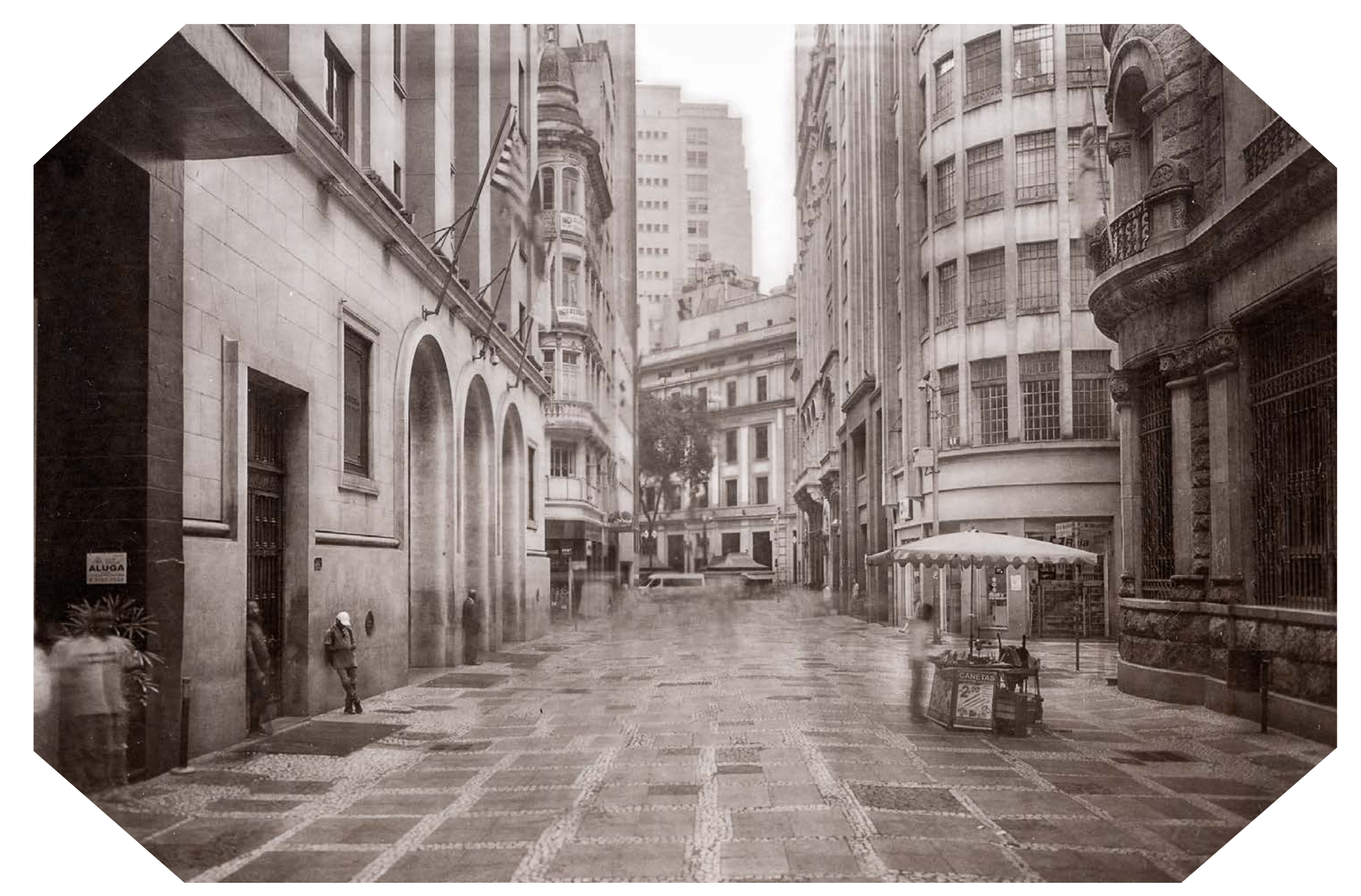


equtrotograybir \$orietics.

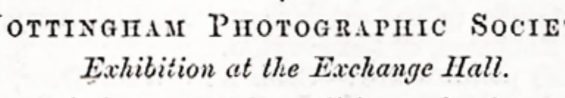

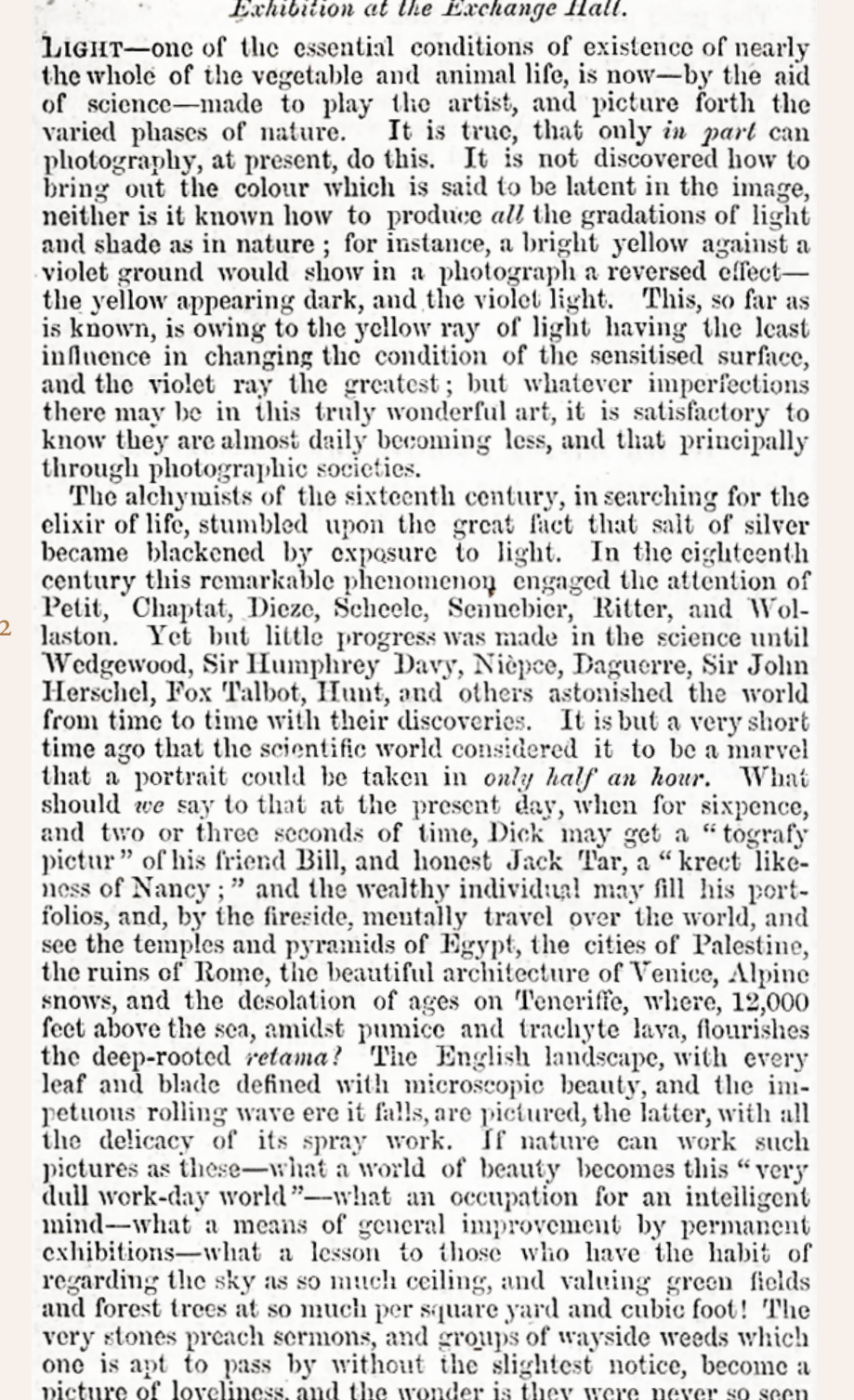

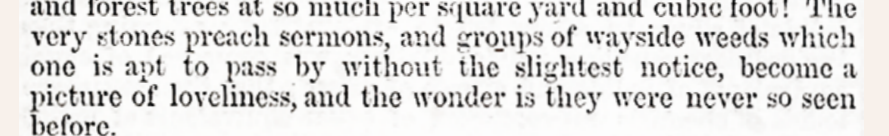

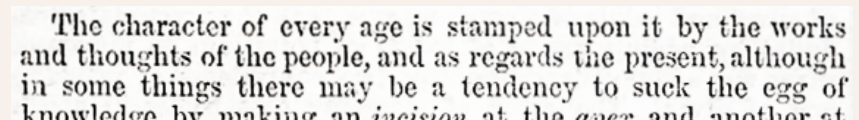

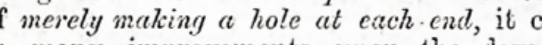

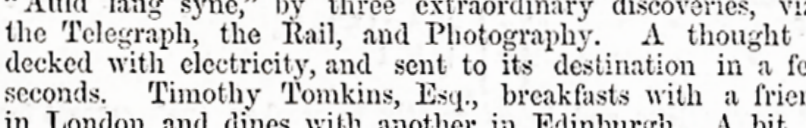

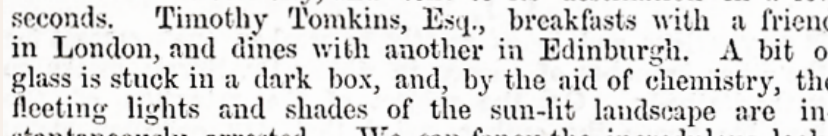

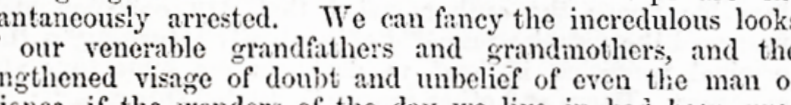

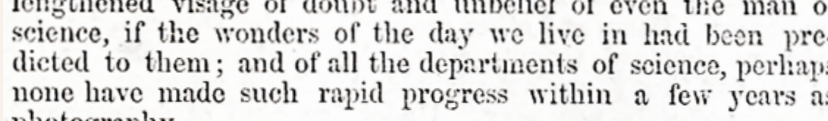

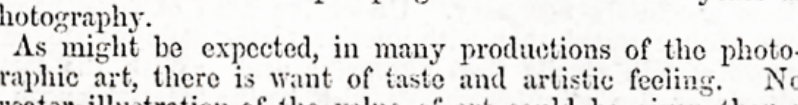

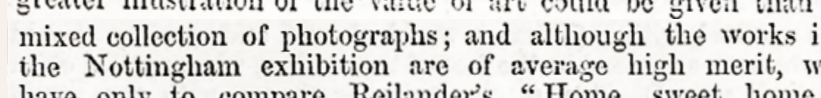

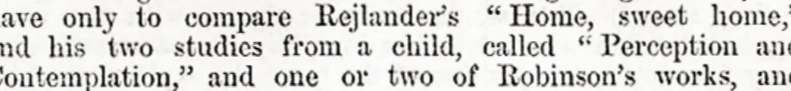

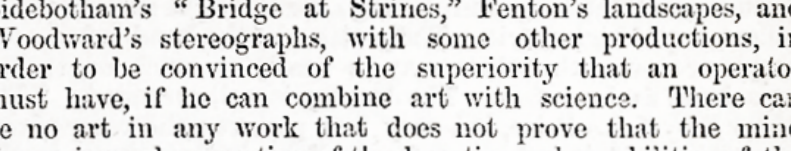

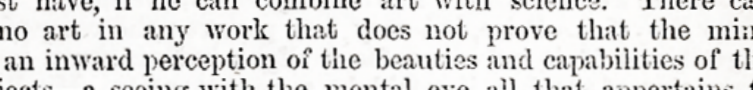

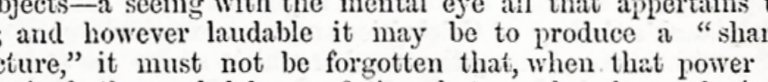

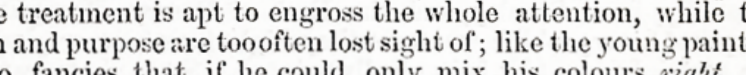

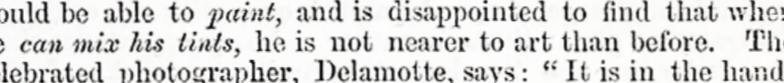

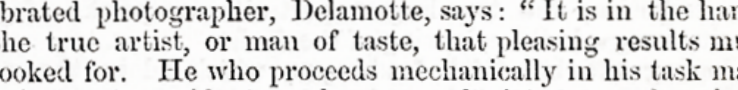

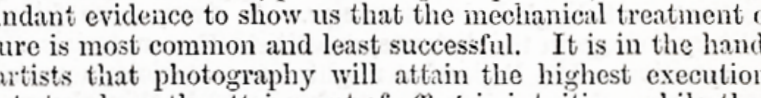

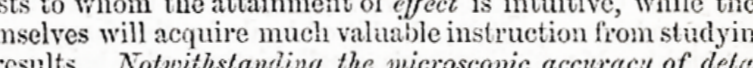

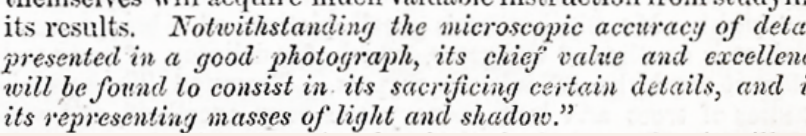

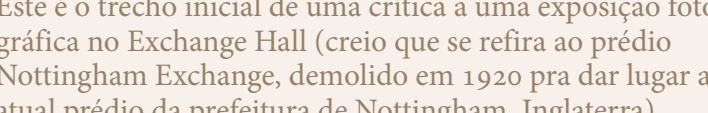

Quis insistiri

fcaria muito manchada de sol e sombra. Resolvi esa foto sob a sua sombra pra ter uma luz mais suave. São Paulo, mas desta ver Medimos meio da exposiç̧a, o sol abriu sobre a lateral da A foto final ficou interessante, uma mistura da Nubladoi a melhor hora para essa foto. O dia o sol es thva atrás do teatro, deixando sua fachadad na som uma escolha estranha para um padrãa "cartão postal".
Mas, como o circo estava montado, resolvi seguir en frente. Comecei com um enquadramento bem cen-
tralizado no eixo do Viaduto do Chá, mas a cada foto 政 a época do colódio, interromper uma exposição
ampando a lente se houvesse uma lufada de vento age agtasse a copa das arvores, evolyse a abri a fui enquadrando mais pro lado. A última foto foi jă poderia tambem interromper minha exposição ao

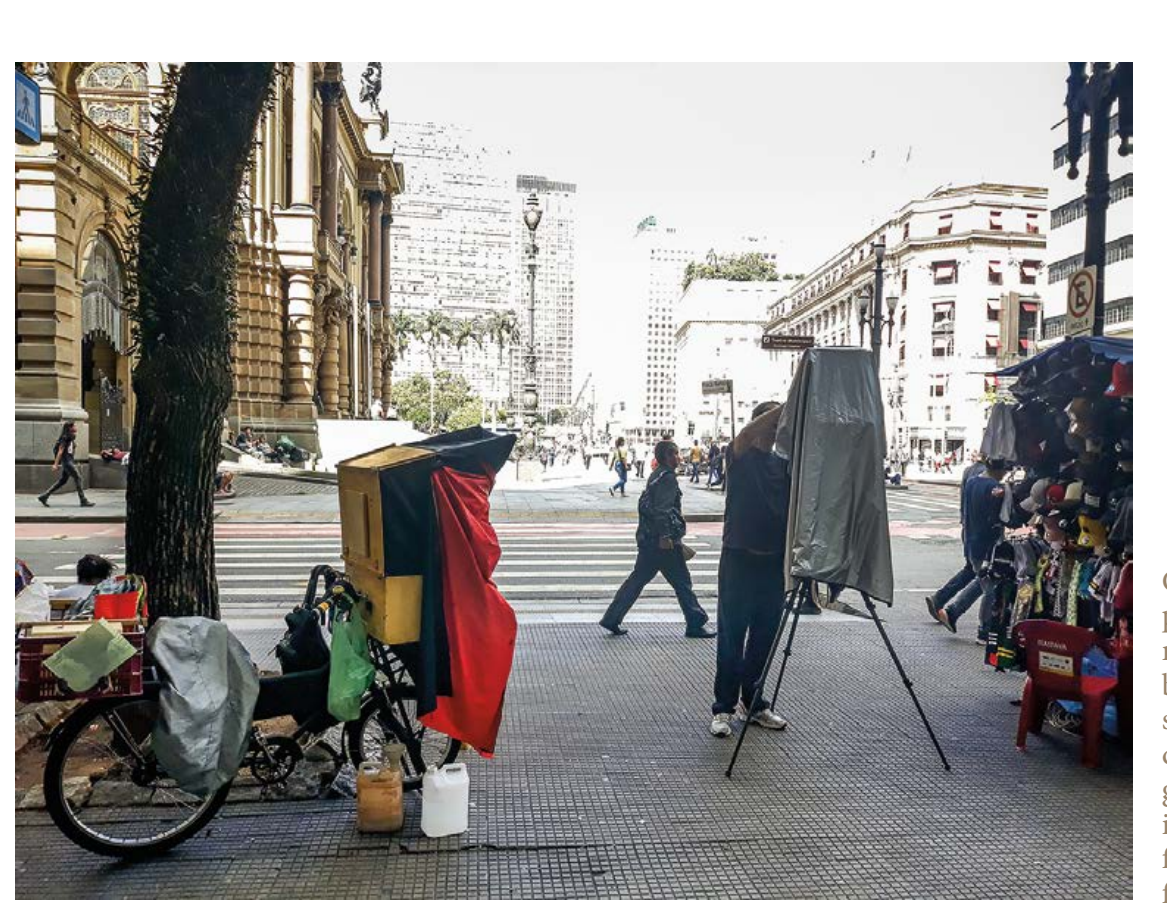

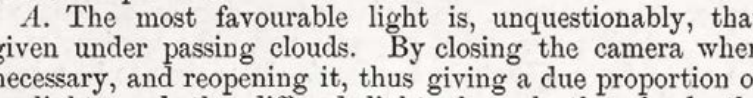

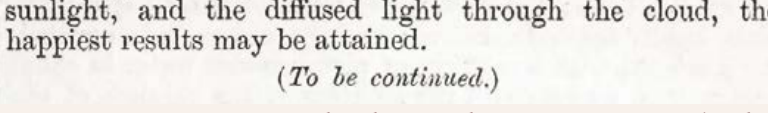

guvenal responde que a melhor luz para uma boa foto é sob

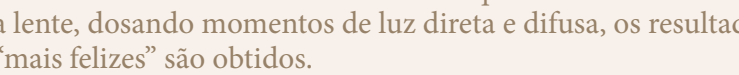

Assim, muitas fotografias aue vemos do passado podem nä
ser apenas um recorte continuo do tempas sim a soma de
multiplos recortes intermitentes do tempo.

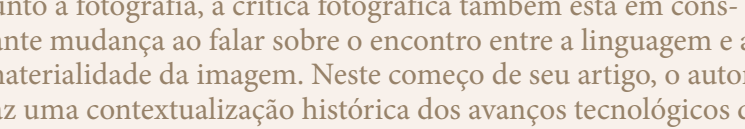

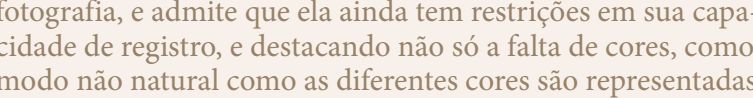

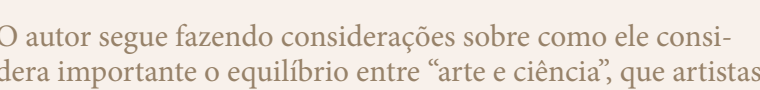

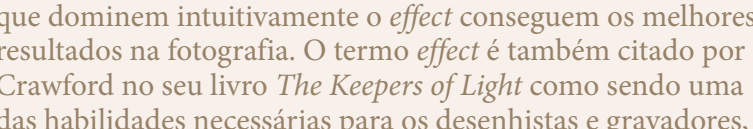

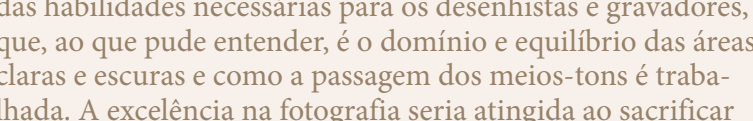

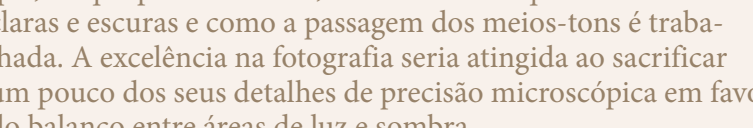

25/103/1859 A Sociedade Fotografíica Francesa.

9lootographic Socrietics.

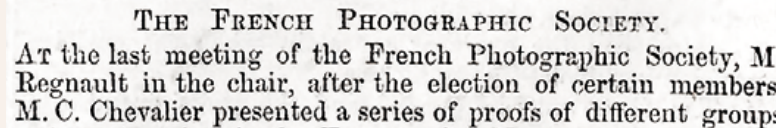

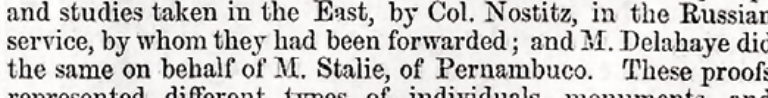

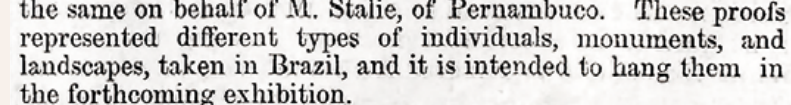

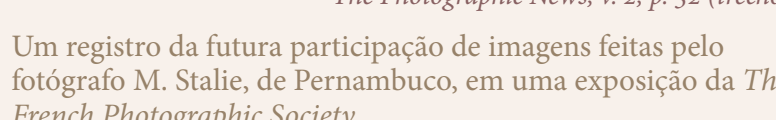



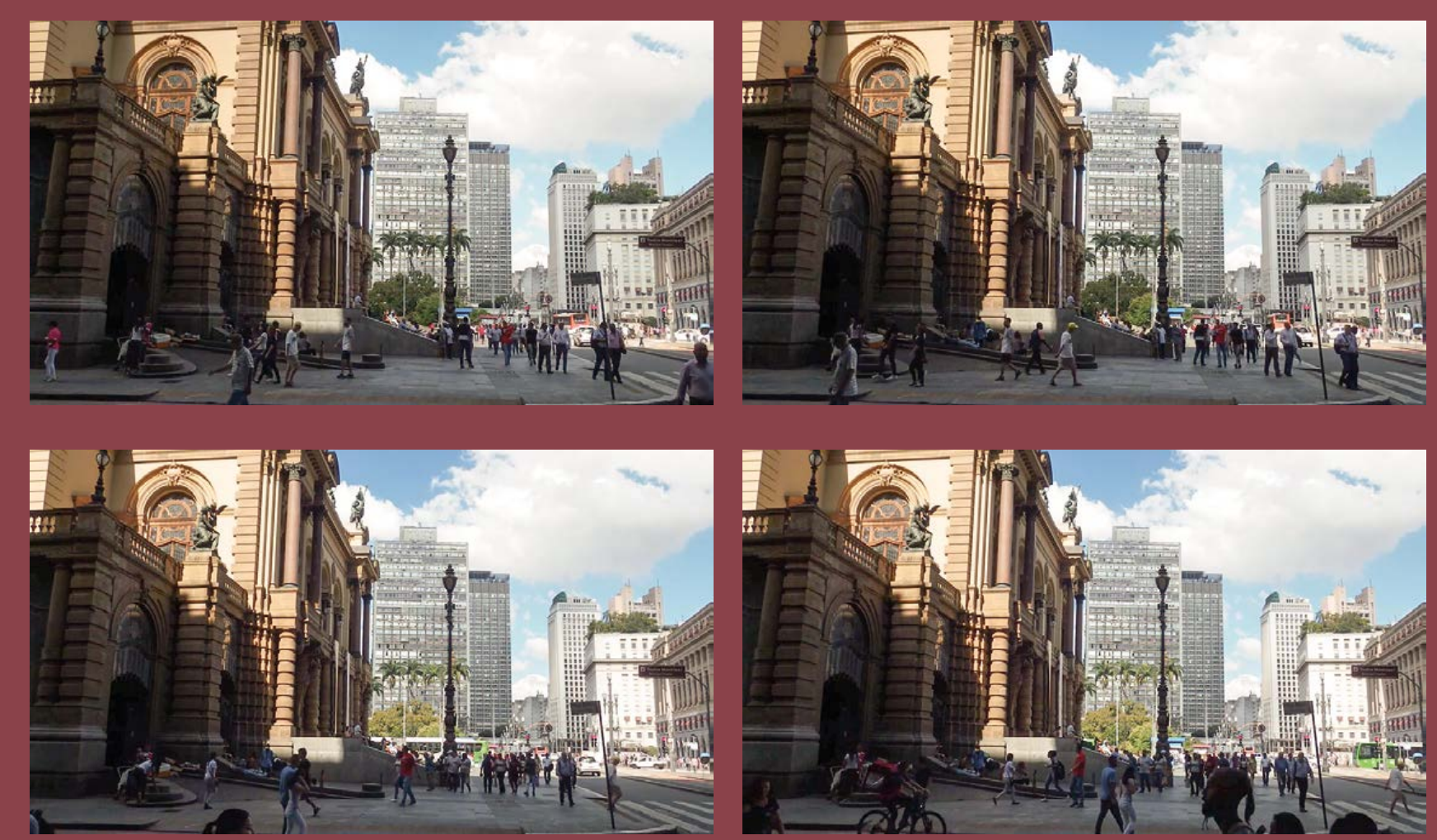

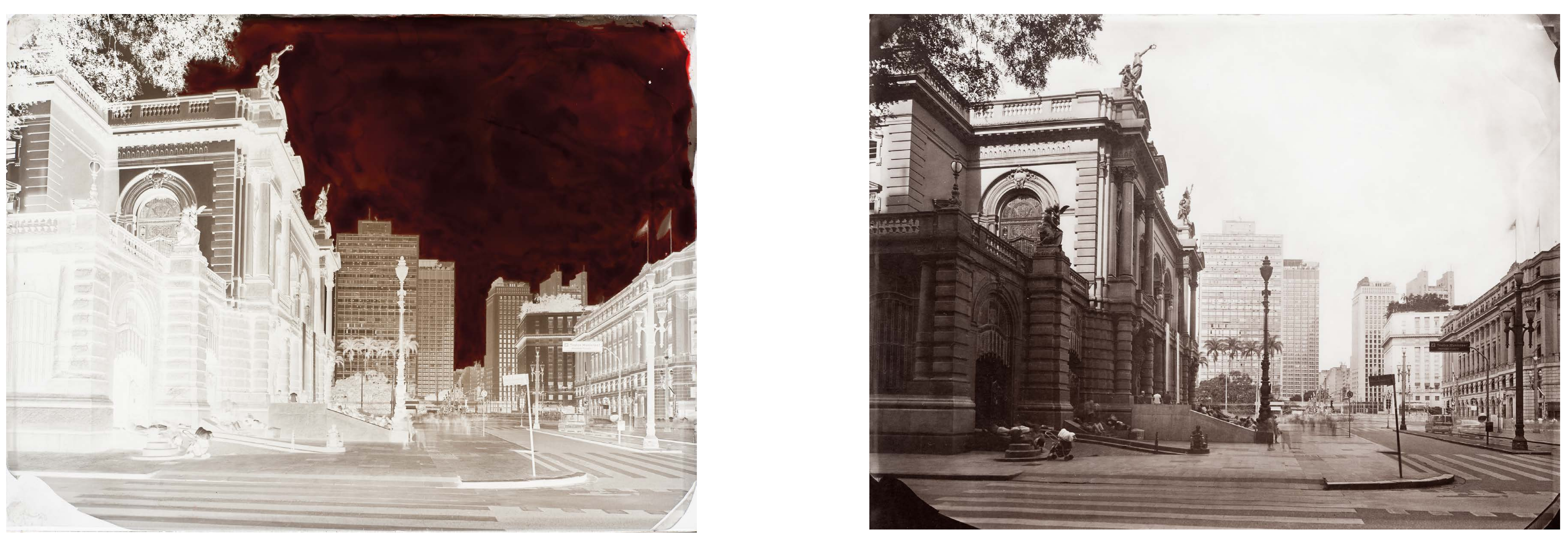


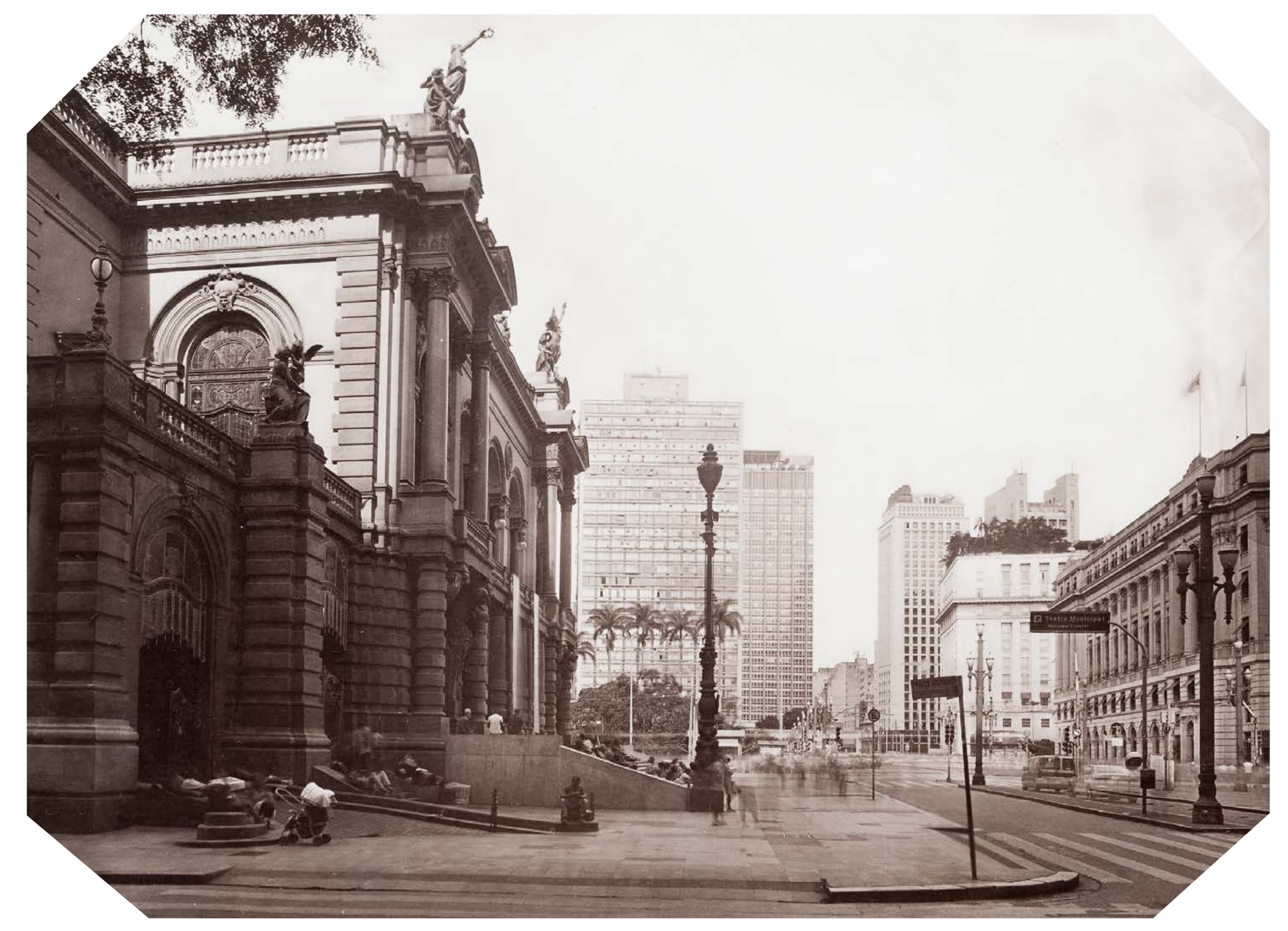


To MINOR QUERIES.

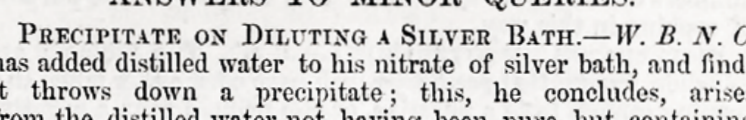

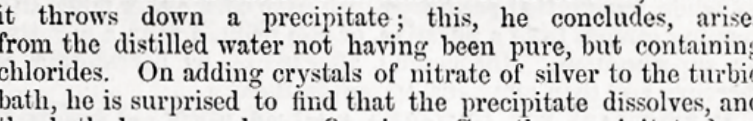

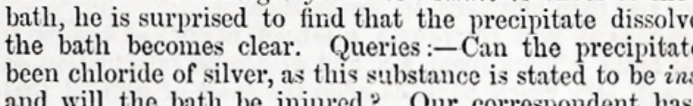

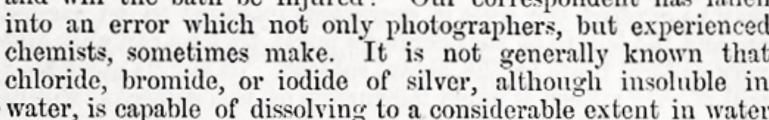
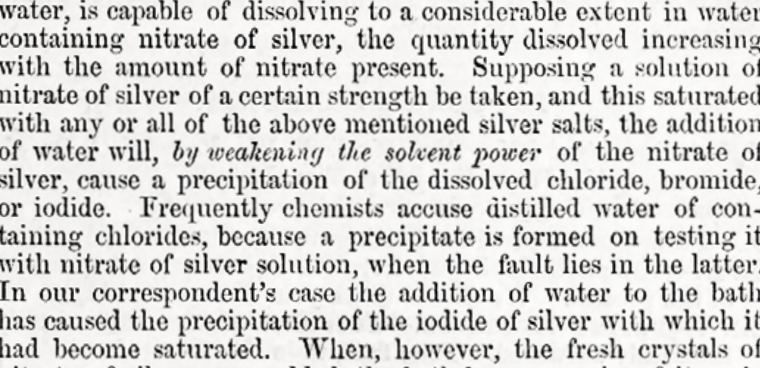

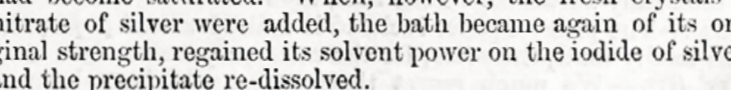

O"banho de prata" em que se sensibiliziza a placa de colódio

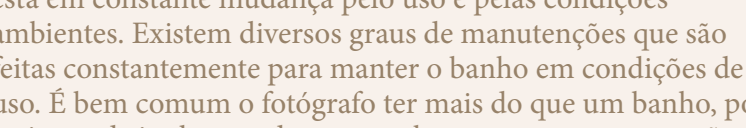

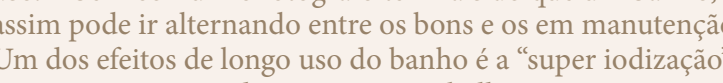

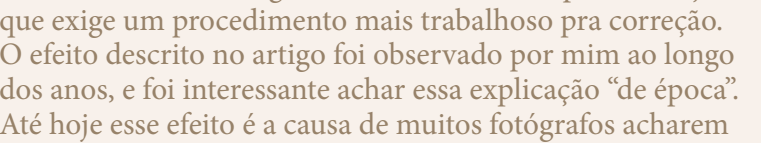

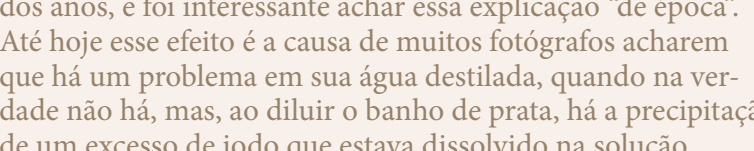

9 de abril de 2019

maio de 2019

iodizado", pois ao repor o volume do banho co azendo a manutençăo dos banhos de forma errad água turvar, mostrando que a prata estava preci Sanho para evaporar eo volume voltar à quantida nấ for metalizada (exposta à luz), volta a dissolver na solução à medida que o volume é redurido ea sua onizada ou deslada até ficar com $50 \%$ a mais que o volume ori
d. Se o banho turvar (precipitado branco), deip

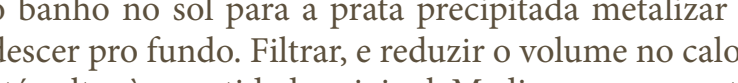
tté voltara à quantidade original. Medir e repor a prat Se não der pra colocar no sol, funciona també adicionar uma quantidade de caulim, agitar, deix
decantar e filtrar.

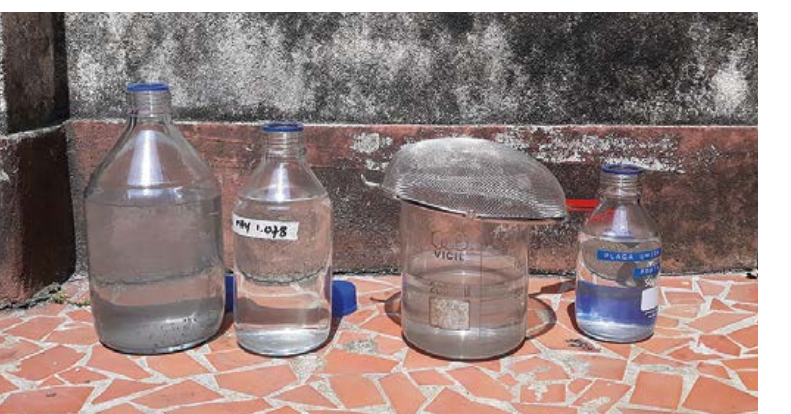

政 Processamento mais agressivo dos negativos. Porém estou achando que será mais garantido fazer na placa mesmo com algum arranhâo na i magem ainda úmicolódio nẫo vai descolar. aliquei o albúmen

Solução para subbing

1:40 com água destilada/deionizad Usar imediatamente.

O melhor é filtrar a solução de clara com algodão nntes de aplicar, passara a face da placa em vapor Para aplicar, uso a "Xicara de doente" para derr mar a solucáa sobre a placa, como se estivesse appli-
cando colódio, e deixo escorrer num outro recipiente para descarte.
Deixo secar num rack coberto com papel toalha. Descobri que subbing vem de substratum ou subs

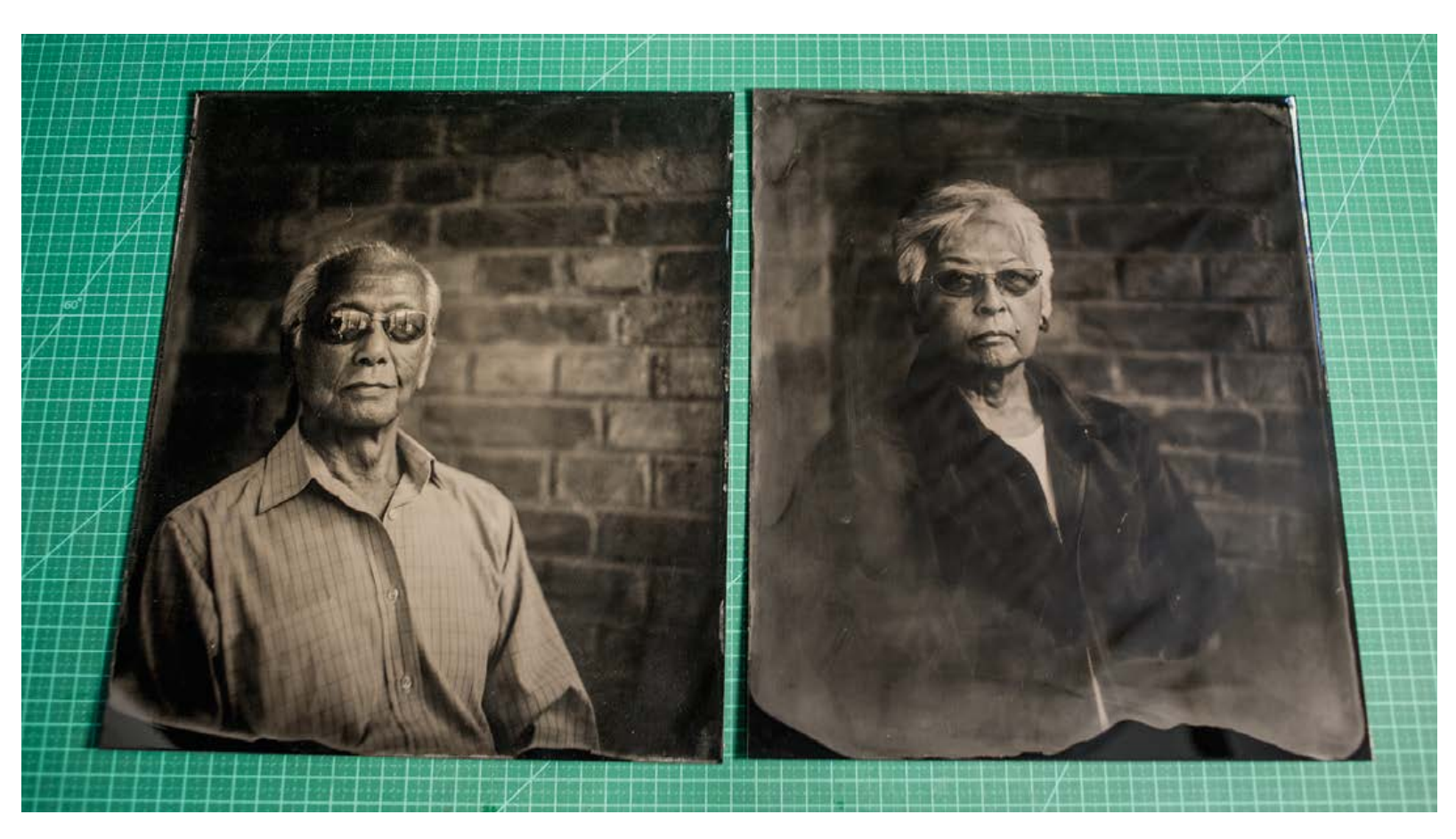

mera SLR Ricotoh 35 mmm.

nãe (que feu zo po anos ontem), de tarde.

Aproveitei pra fazer retratos de cada um em fer
rótipo $25 \times 30 \mathrm{~cm}$ com a cammera indiana. Usei a lente

$360 \mathrm{~mm}$ 5.5 Tele-Xenar que cobriu a placa toda!
O colódio estava bem lento, não sei se pela idade

ou por algo na lente, ou os dois. Vou ficar observand
essa lente, pois devo uśa-la bastante para retratos.

essal lente, pois devo usá-l a bastante para retratos.
Problema: invasaso de luz no chassi. Provavelmen-

te por una fenda do dedrrkslide. Causou um véu,
parte inferior do retrato. Lembrar de arrumar! nontada por Daguerre para cobrir jinelase, recente-

Ao bloquear o espectro não usado pelo colódio, a intensidade da forte luz fica mais confortável para os

13 de setembro de 2019

Usei uma folha de filtro plástico para luz de pal-
co da LEE, no 161 "slate blue". Apesar de o fotômetro

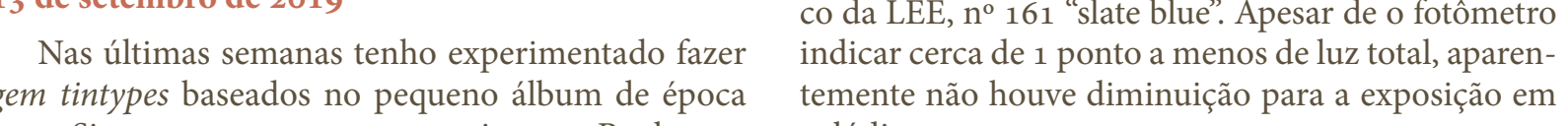

que a Simone comprou em nossa viagem a Rochester

Quis fazer versōes de 1 ou 2 imagens em uma pas
do tamanho de um cartão de visitata
(1).28

(2) (อ)

axi 1 Ra

Os ferrotitipos foram muito populares no secullo 19 pele baix

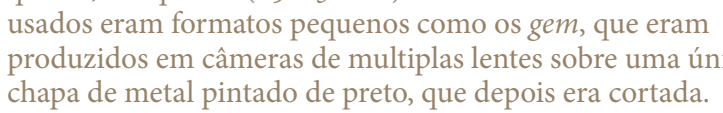

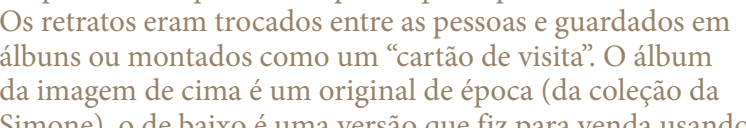

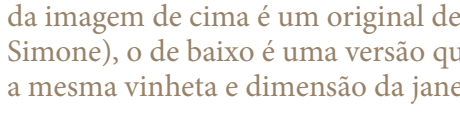




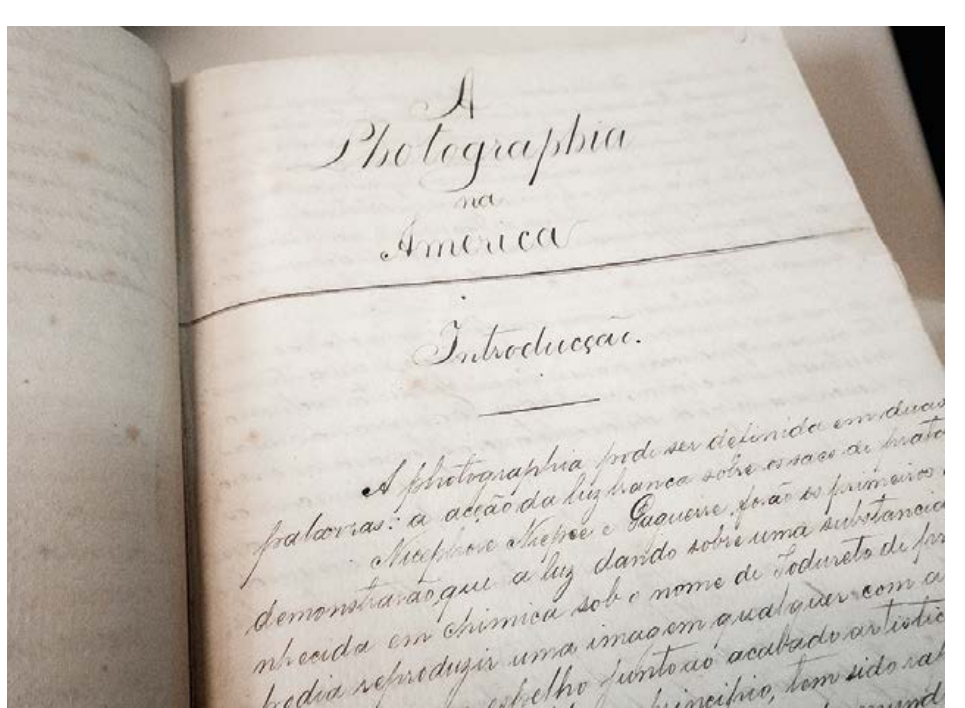

S. Paulo, 3 de maio de 1888

Sábado passado teve um sujeito em minha casa
tendo-se fotógrafo e querendo comprar drogas e

zendo-se fotografo e querendo comprar drogas e objetos
de fotografia. Nâo tendo o que queria [* ${ }^{*}$ de tudo um

Ao sair (4h da tarde) pediu-me para levar em confianç um tratado de fotografiá- fotografiaia na América par
Liebert. Pensando tratar com um homem sério confie
o liviro pedindo-no ele nessa ocasiáa um pedaco de lápis de retoque com que tomou nota o que lhe dei. Ao sair tudo. Na $2^{\circ}$ feira nào me apareceu. Na $3^{\circ}$ feira proci Indagando cheguei a o conheciciento que esse
en sua empregada motivo pelo uual hhe escrevi em sua empregada, motivo pelo qual he e escrevi ped
que VS Sf faca com que esse tal... Manfredo Laberg de so agora hhe sei o nome me mande imediatamente o d
tratadado ou a sua importanncia que é quinze mil rés para evitar a a alguma cena desagradável em sua casa para
o que estou disposto.

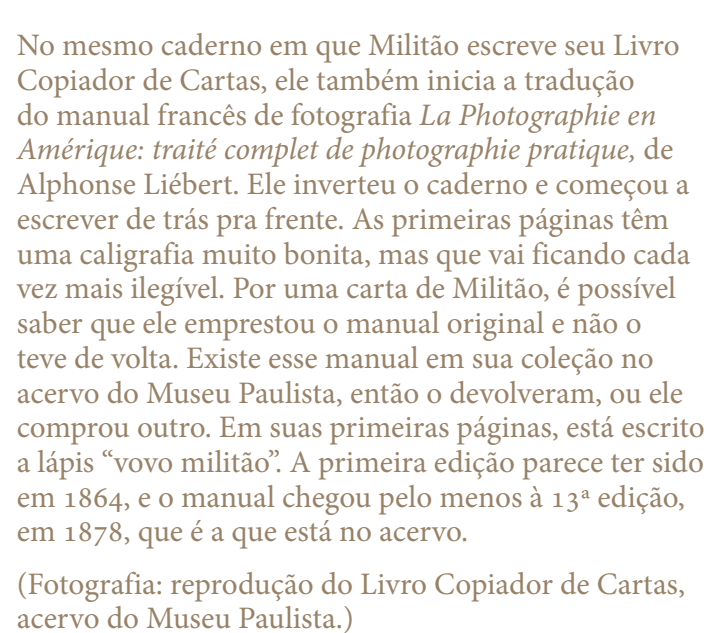

nbro de 2019

de papel de albumen

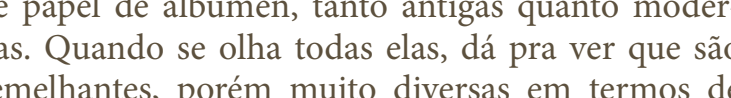

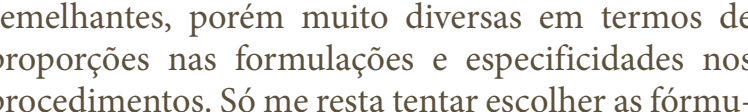
las que me parecem fazer mais sentido e partir para experimentacăâ. Tenho tirado algumas duvidas con me ensinar o passo a passo. O ideal seria ir até lá em
Rochester para ter uma oficina a esse respeito. Infe-

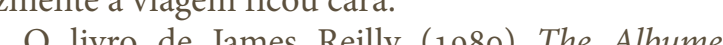
O livro de James Reilly (1980) The Albumen
as Salted Paper Book tem informaçés bem interes-s
santes sobre o processo. Peguei dele algumas idéias santes sobre op
para testar.

26 de setembro de 2019

Aprovertei que vou fazer um banho novo de prata

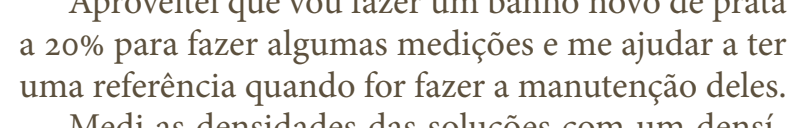
Medi as densidades das soluçōes com um dens-

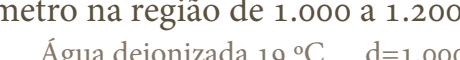

Soluçáo de prata $20 \%$ d=1.1.162
Assim, cada $1 \%$ de prata adiciona aproximadamente $\mathrm{d}=0$. Para estimar a densidade resultante de uma por-
centagem de prata, multiplicar a porcentagem por 8,1.

Ex claro, uma referênciaia aproximada, pois o banho
em geral pode estar contaminado con em geral pode estar contaminado com outras coisa
que interferem na mediçấ.

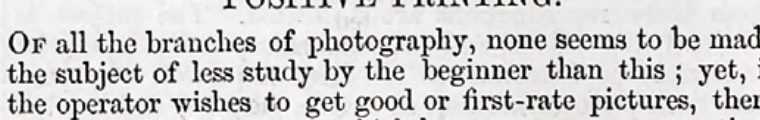

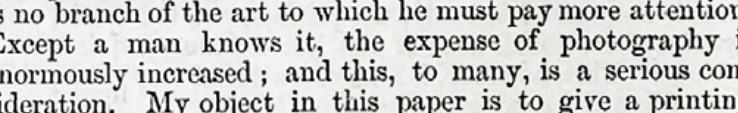

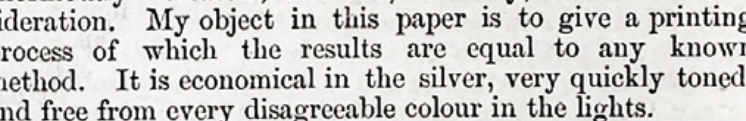

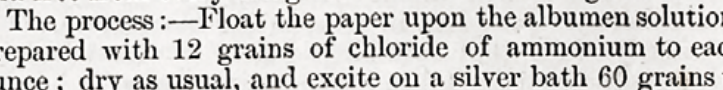

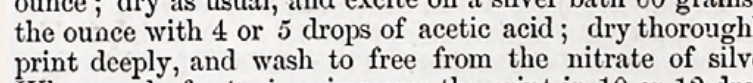

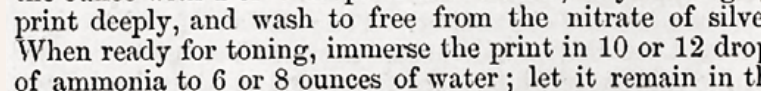

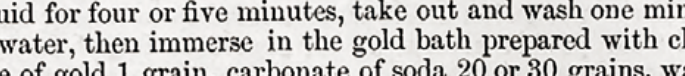

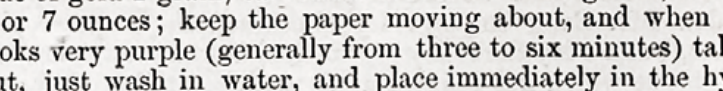

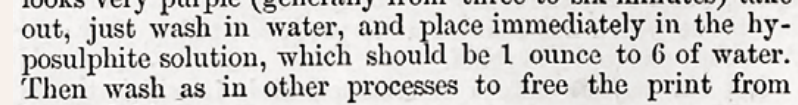

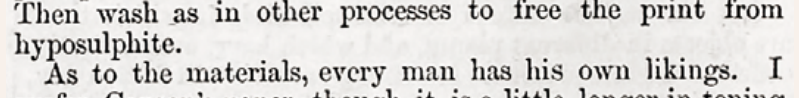

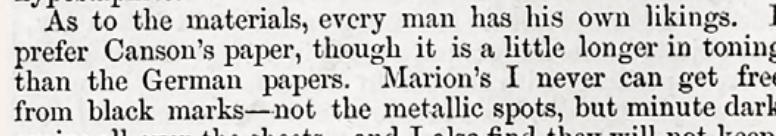

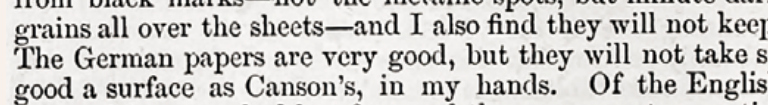

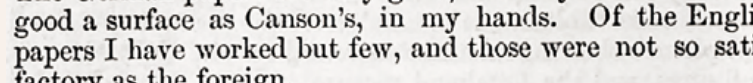

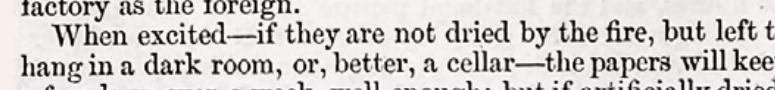

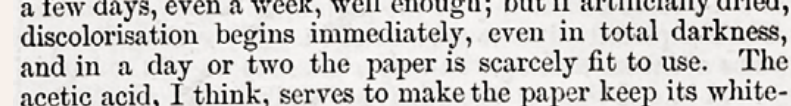

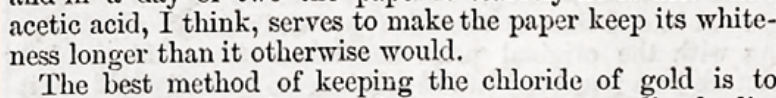

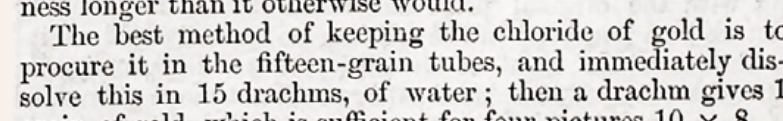

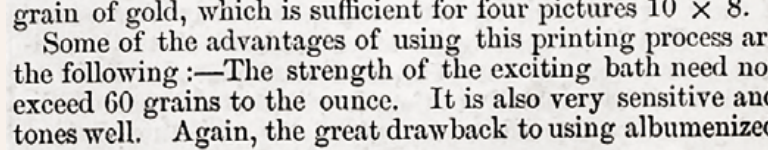

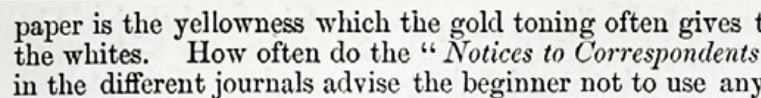

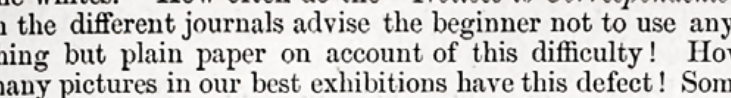

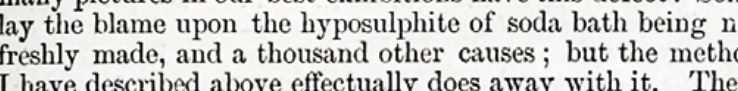

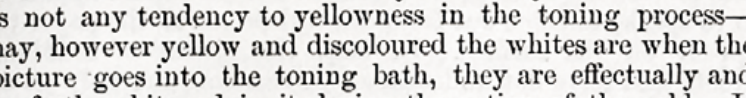

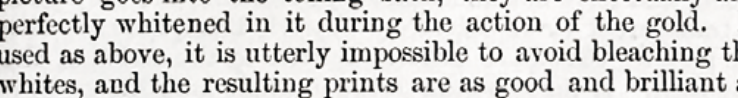

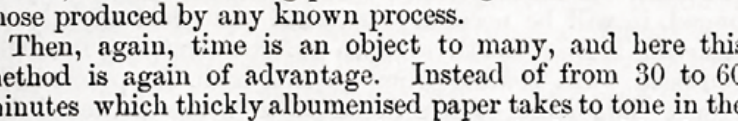

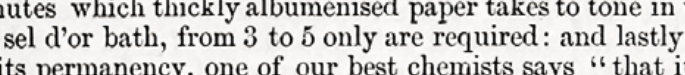

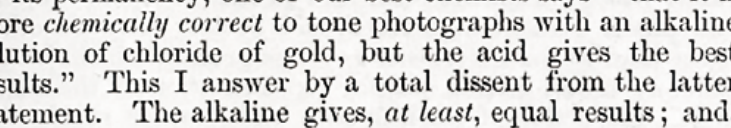

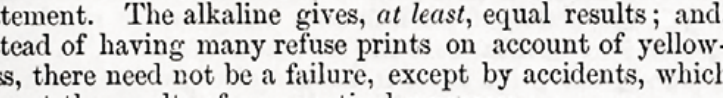

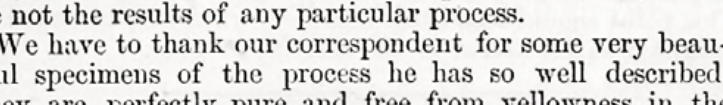

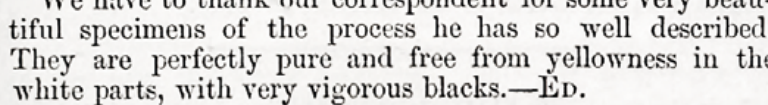


para subbing, mesmo com ovo fresco. Parece não ele sugeriu diluir mais. ollbumene e adidicinara ácido
erico a banho de prata. Diz que ové acontece banhos de prata mais velhos. Vou experimentar.

para negativos é uma mistura de óxido ferrico vern

17 de outubro de 2019

Testei as sugestöes de Mark $O$ ab́n jé

Albúmen para subbiing
Clara de ovon nuvo
Agua deionizada $5 \mathrm{ml}$
$1000 \mathrm{ml}$

Obanho de prata estava em $\mathrm{pH} 4$ e adicionei íc-
do nitrico para chegar em $\mathrm{pH}$ (poucas gotas).
um teste sem camera e funcionou bem. Sem véu

um teste sem
albúmen.
Exposicão

albumen.
Exposição
Minha base

A referenncia visual é expor o máximo que der
mas mantendo os pretos vazios, sem informação,

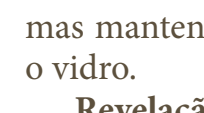

Ajustara a proporção dos químicos de modo que

Consiga estender a reverlacáa por 90 segundos
sem véu de base nos pretos

Com temperatura em

bem em 25-10-100.
Hoje usei os papéis de 1,5\% da ultima leva. Porém

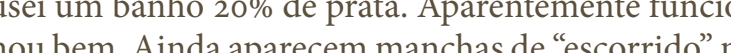
folha de albümen. Principalmente apos tonalizar, que a diferença de espessura dos escorridos dificul exposição ainda é cruciale e tenho dificuldade de julCreio que devo observar

- Baixa luz em Dmax. "Bronzing". Denso mas ainda com contraste.

Interessante: Uma cópia que eu havia exposto
lavado hà mais de uma semana, guarddada no esculavado há mais de uma semana, guardada no escu-
ro, ainda estava boa. Totalizei e fixei sem problema (como dito pelo Crookes).
6 de novembro de 2019

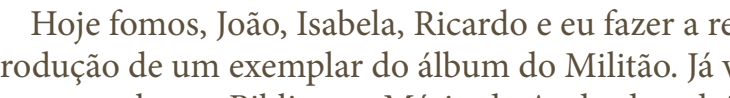

o Museu Paulista. Porém o que achei melhor para

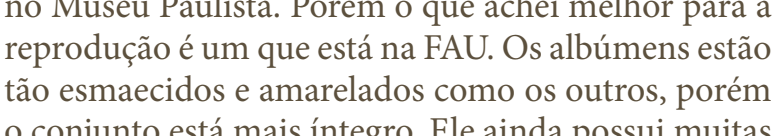

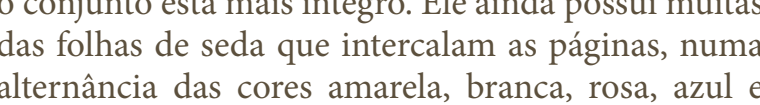

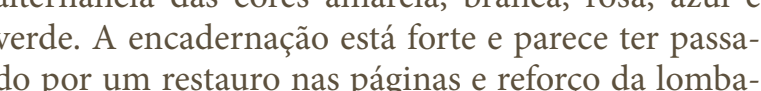
do por um restauro nas páginas e reforcóo da lomba nagens, se são todas iguais ou se há alguma variàcao. Tudo bem, fica pro futuro.
Fizemos as reproduçōes em captura digital con Fizemos as reproducōes em captura digital com
uma boa câmera e ente, com iluminacăa cruzzada e
polarizada Registramos também duas refererencias de polarizada. Registramos também duas referênccias
cor colorchecker para ajudar no pós processamento

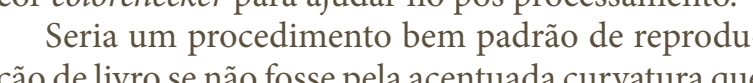
çăo de livro se não fosse pela acentuada curvatura que
as páginas adquiririam com o tempo. Melhor seria, se com mais tempo e estrutura, pudéssemos ter usado
um vidro pesado sobre as páginas para deixa-las planas na hora de fotografar. Deixamos um diafragma has curvaturas. Usamos alguns suportes para balancear a lombada à medida que passavamomos as paginas
Capturamos todas as 68 páginas, incluindo as sem
imagem as capas ealguns detalhes da estrutura.

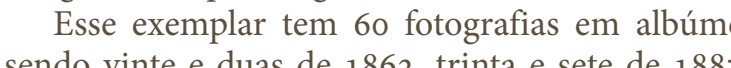
uma de 1868. Das fotografias de 1862 dezoito s. ppresentadas com o par compantwo de 18887. As fotografias sào refladas mantalmente sem tam
padräo, adequando o corte a contendo. tre 20 e $223 \mathrm{~cm}$ na horizontal 111 e $16 \mathrm{~cm}$ na ver
tical. Todas elas têm os quatro cantos chanfrados

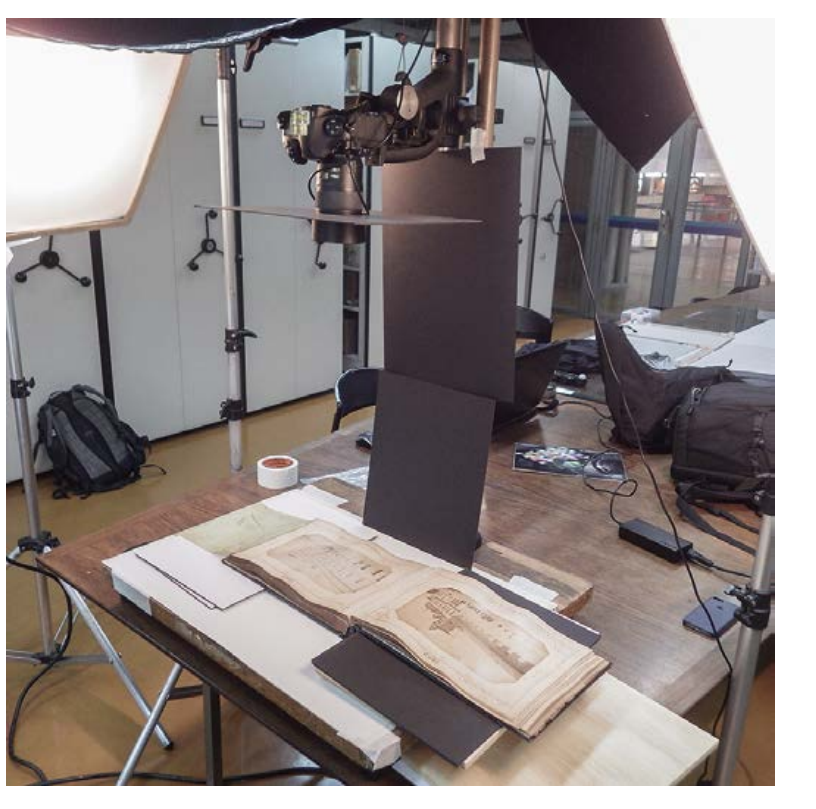

Wremente. Ja vi outras fotografias daquela eppoc
mo o mesmo corte, entáo devia ser uma escolha es

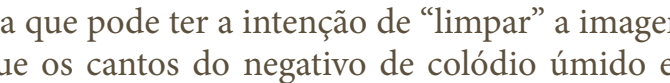
Os albúmens foram. dos das páginas, feitas de um tipo de cartão bristol, a
balbumen e eacabaram ficando contorcidas. vinheta decorativa, a legenda da imagem e o qquência de lugares, mesmo que com imagenens even nalmente diferentes do mesmo local.
Além das legends os os capa e o nome de Militấo estampado em cada foll
Meu Portilho,

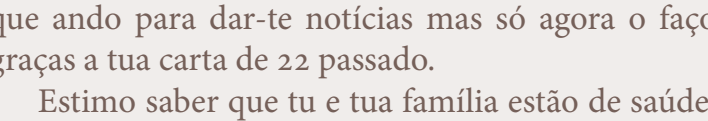
tar tăo longe e eatrapalhado com um servico que te podido fazer. Mas sei por seu mano que ela estát boa. Como Verdi despedindo-se da música escreveu seu e 1878 [sic]. Parece-me um trabalho útil e talvez guém qués tido a pachorra de guardar clichés de 2
gat Stista, e gratidàa ao lugar em que estou a 25 anos
Nada te direi disto port frormaçess por antas cyornais. Sempre a mesma

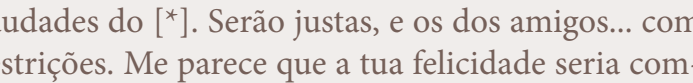
peta se tivesses a a tuddo a tua familila. Entấo as saudda

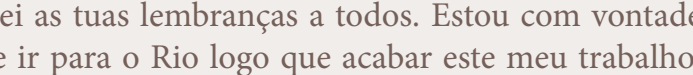
lá car se puder. Isto nunca será antes de meados rando na Rua da Boa Vista 15. arta.p. .12 


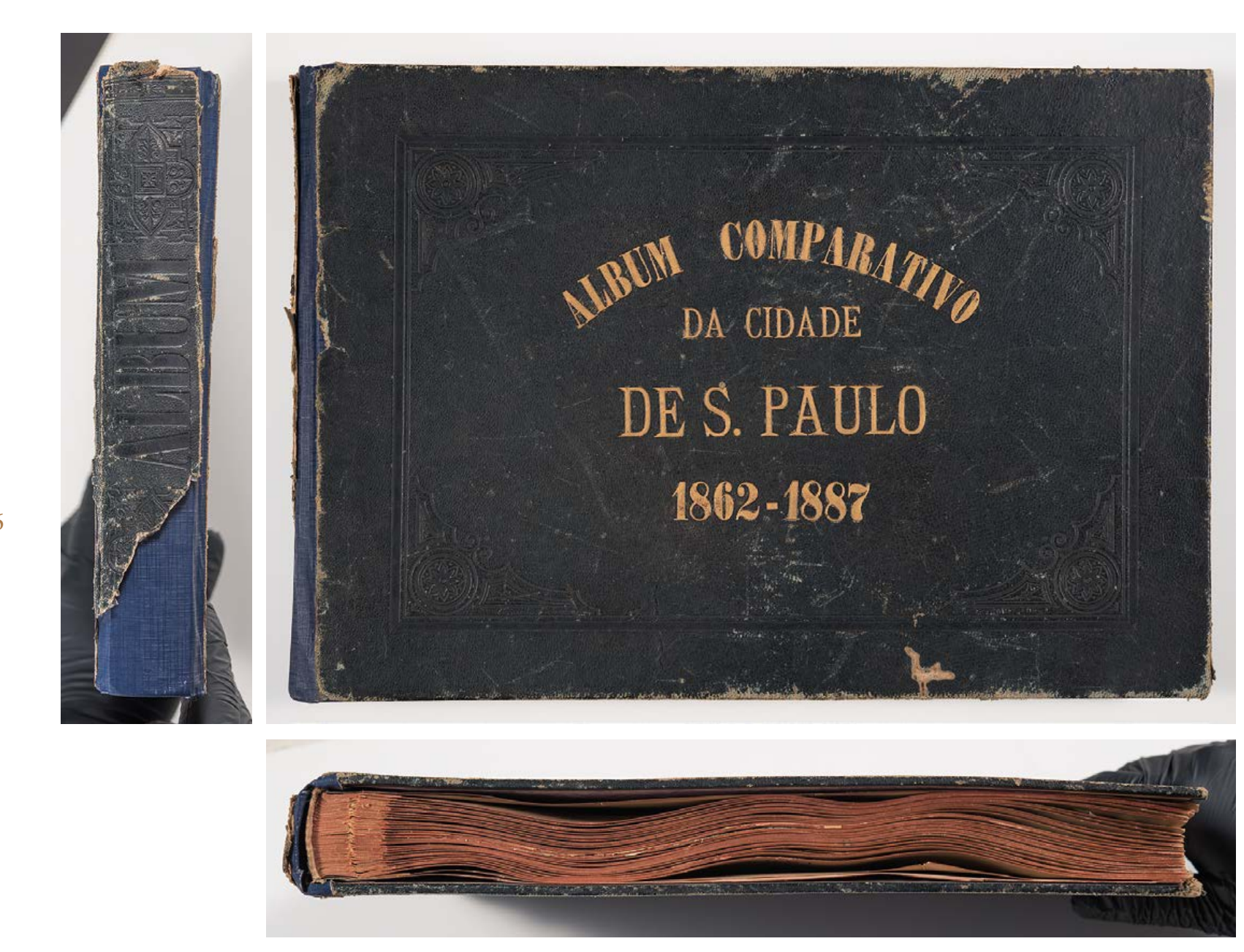

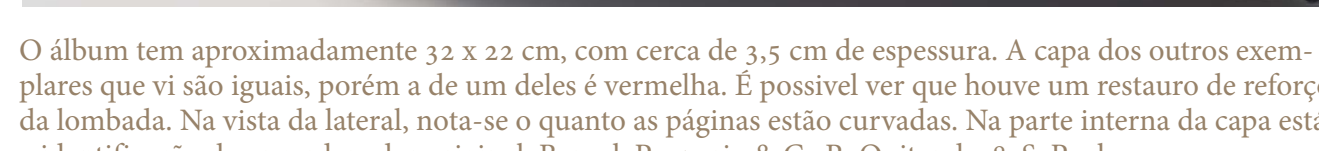

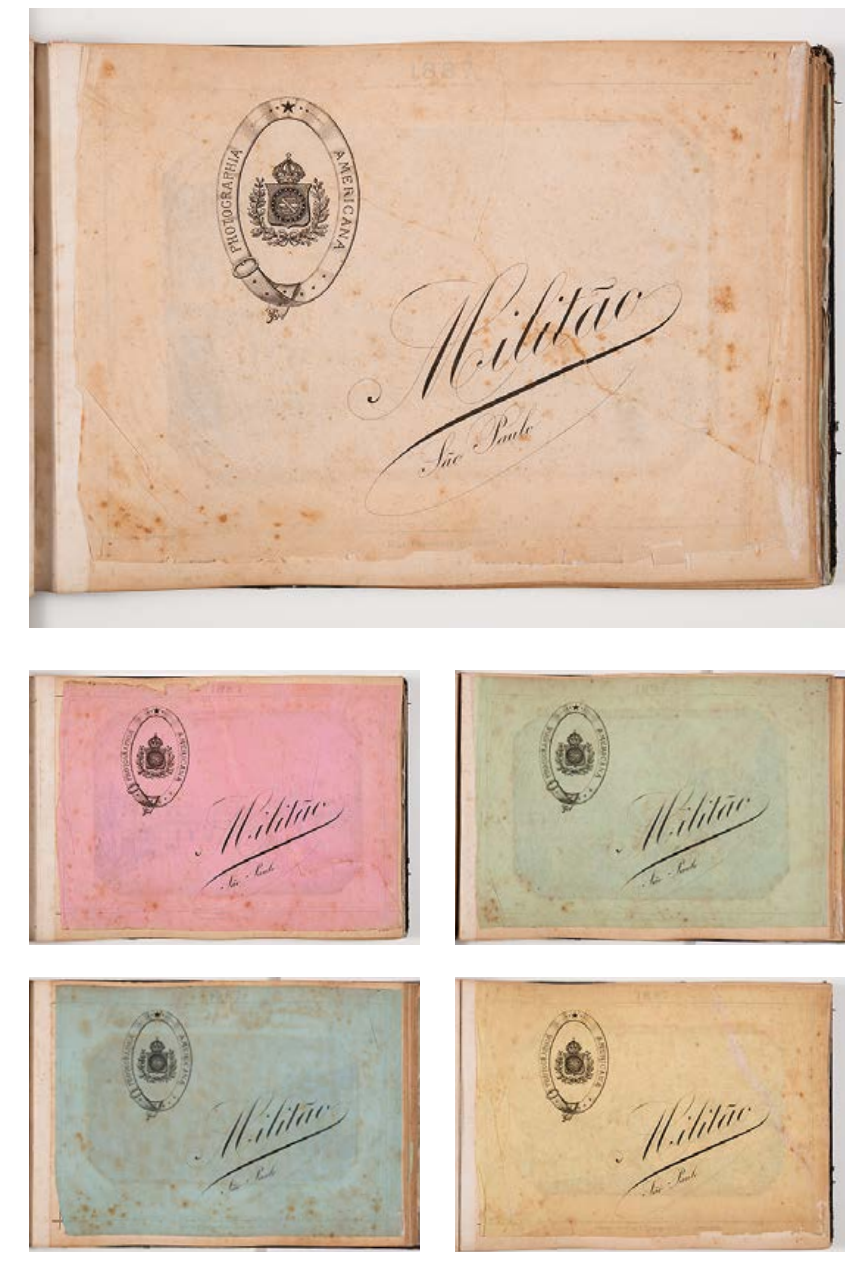

As folhas de sestata que intercalam cada página, com cores sortide
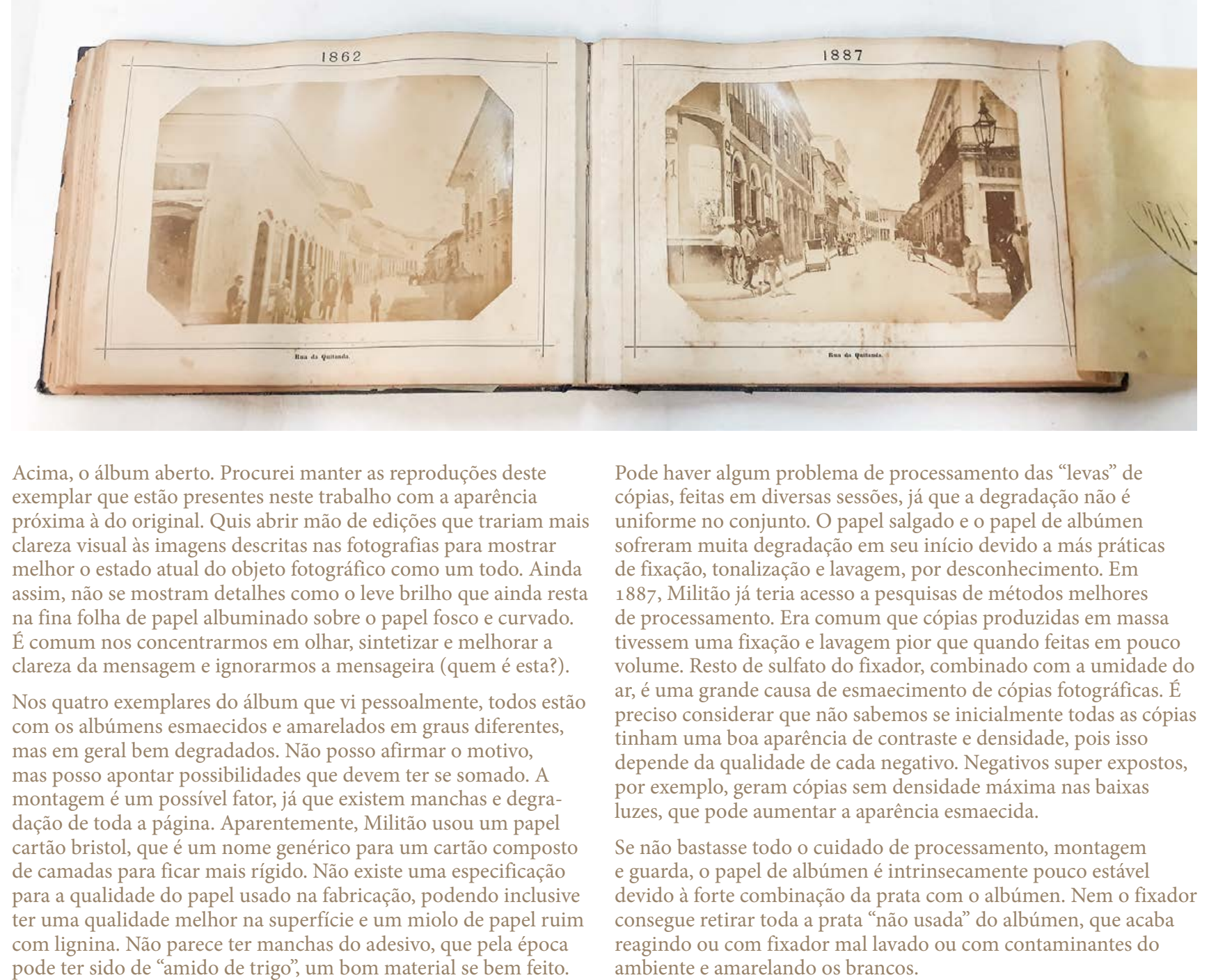

Paulo, 17 de julho de 1887

Náo tenho organo[?] papel. Estarei comprando

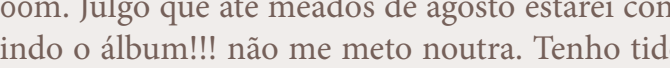
ss tuas por tua familia Depois de acabado o alavisarei para te dizer adeus na ne andina SPaulo, 4 de agosto de 1887. Paulo de 1862 e 1887 cuijas assinaturas findaram o para anunciar o seu estabelecimento para rece. berem assinaturas. Se quiserem fazer-me o favor $e$ e or-lhe uma lista. É possivel que ai nào tenha assina tura mase é desencargog de consciência. Não precisa de
uda2 Sem mais com estima. S. Paulo, 25 de agosto de 1887.
S. Joauuim Floriano Wander Não tendo por quem mandar-lhe o álbum que $V$ S

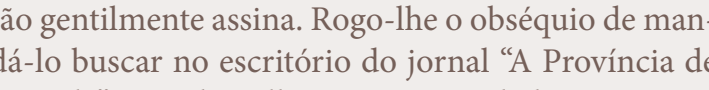

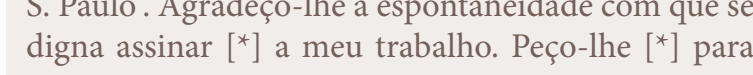
assinar-me. 
$\overline{\text { INSTANTANEOUS PHOTOGRAPHY }}$
BY C. A. BRELERY, ESQ.

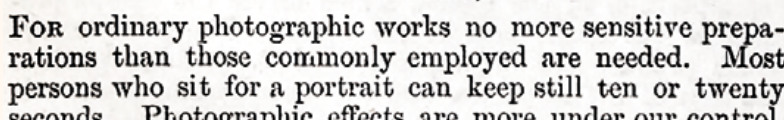

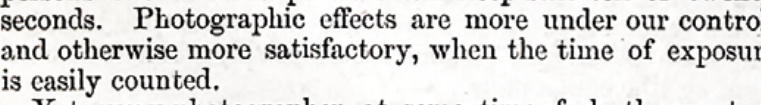

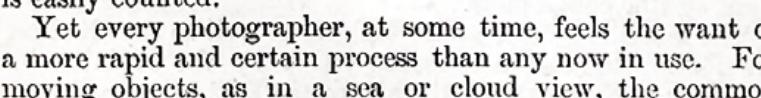

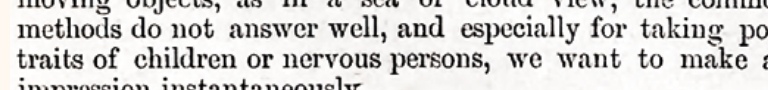

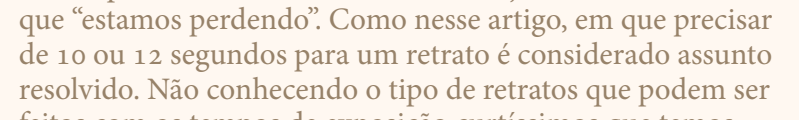

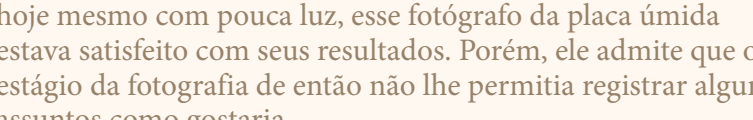

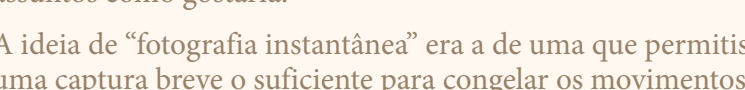

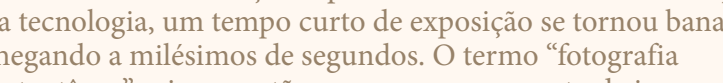

umat fote que sere revelasse instantaneamente num objetof fina
visualizavel como

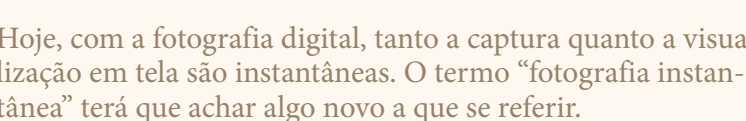

bro de 2019

Finalmente fixer a placa negativa que fiz do for

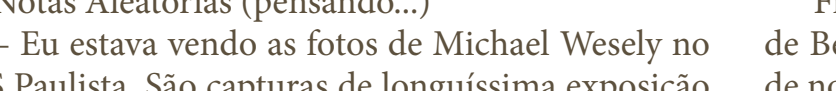
da construçáa do predio do musel- Me confirmo $\begin{array}{ll}\text { que: quanto mais curta a exposicāa, mais tudo que é } & \text { isso, teria ficado muito boa. Acho que a placa estava } \\ \text { animado se torna táo sólido quanto um prédio. Mas } & \text { sujad de algo (carbonato ou poira) na hora que apli- }\end{array}$ os predios se movem. Instantâneo? Longa exposiçấ? - Algumas realidades são conhecidas por inte-

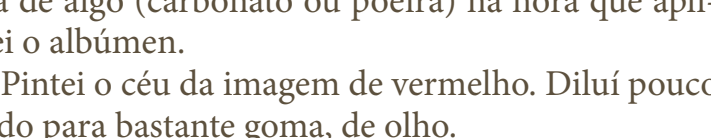
E bom deixar descansar um pouco, pois um $\mathrm{p} \not$
E bis escuro mais grosso decanta. Também adicionei uno
pouco de álcool para eliminar a espuma da agitacá.

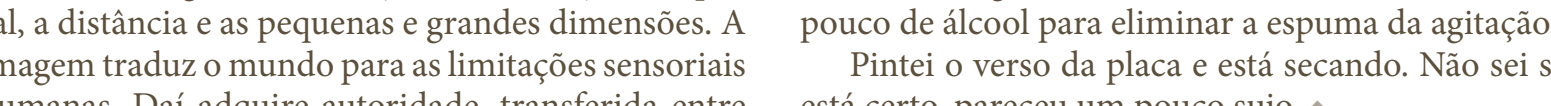
humanas. Daí adquire autoridade, transferida entre está certo, pareceu um pouco sujo.

- Fotografia digital: sem textura intrínseca. Q textura ou materialidade é estabelecida na captura? - Fotografia da a possibilidade de reobservar a - O Acaso Inesperado e o Acaso Esperado. Pod 作 comecar como uma surpresa, un acaso da fotot. resperado. Se aprovado, comeca ser procurado até so ornar uma tecnica em si, um acaso esperado. Messmo há de recusarar imagens que foram "longe demais". busca están nesse equilibrio.
Hoje fit una copia em albúmen para ver o efeito bra e coberta com 4 follans de papal vegetal por da máscara vermelha ranco, é preciso deixar a camada densa e uniforme. medecido para retiriar a máscaran. A a guna amolece a Observaçōes de procedimento:
astante oxido para facilitar bloquear o ceu. o pigmento em suspensão.
- Filtrar com algodào: talvez o óxido que com- Filtrar com algodão: talvez o óxido que com-
prei seja meio sujo. Filtrar a soluçáo em um funil prei sela meio sujo. Hiltrar a soluçá em
com algodâno deu uma tinta mais homogênea e sem Acho que não estou fazendo certo. Preciso estu30 de dezembro de 2019

-iz uma copia em albumen do negativo dos cahoós de - A camada grossa de tinta pode craquelar. Adi-Acerd A cópia ficou até boa. Penso em om fazer o mesmo com alguns negativos do projeto do Militáa. apenas ao redor dos prédios $\mathrm{e}$ a arvoreres pelo lado do colódio e colavam papel preto, amarelo ou laranja no
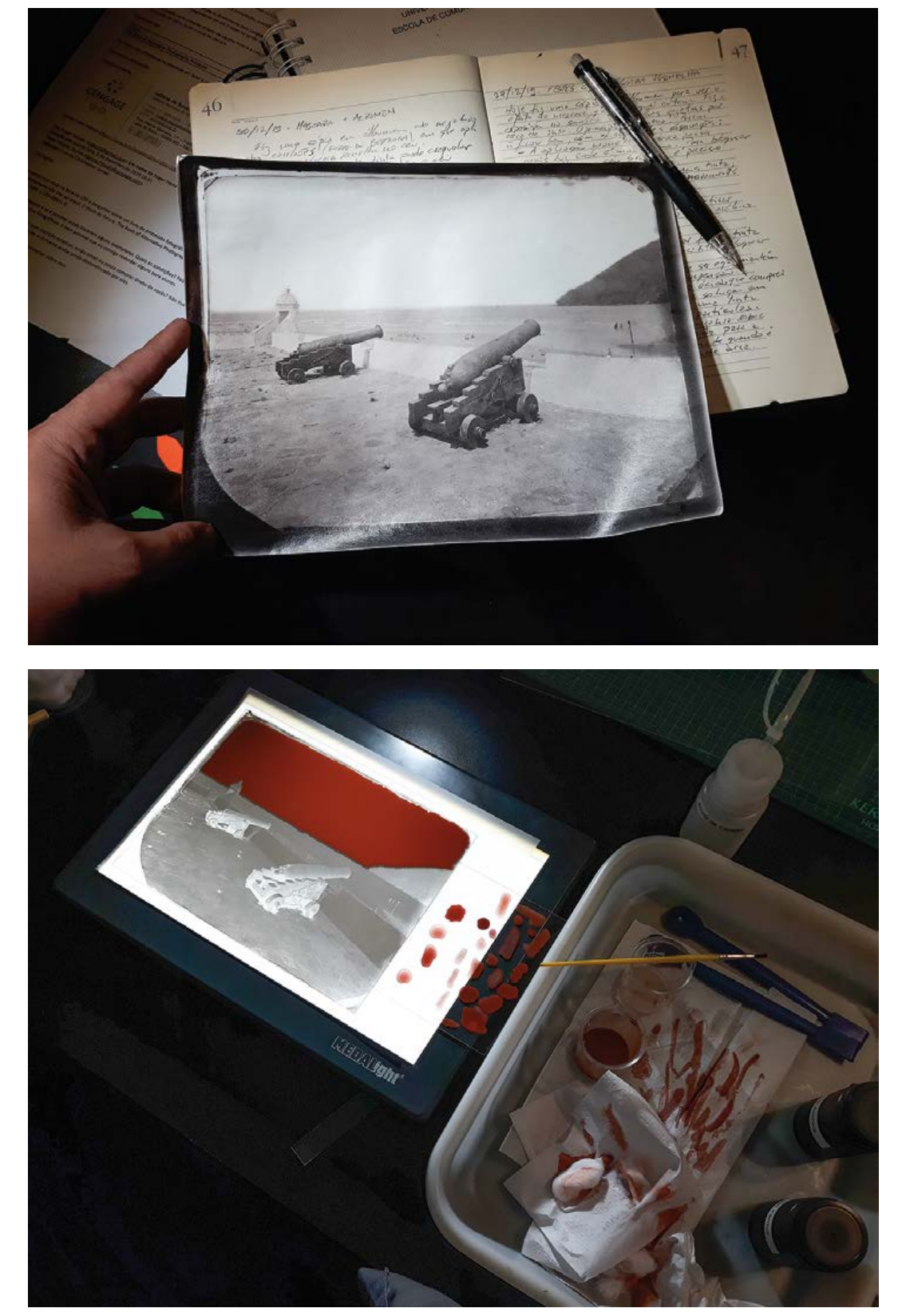


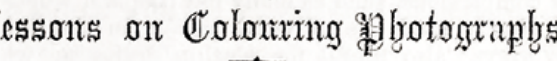

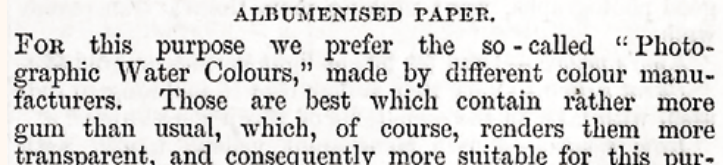

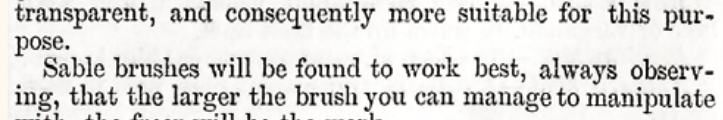

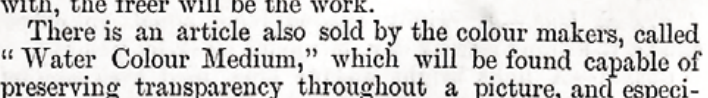

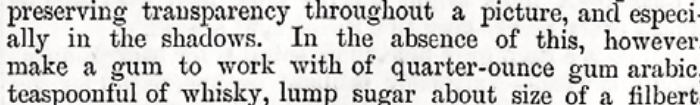

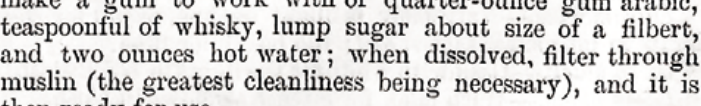

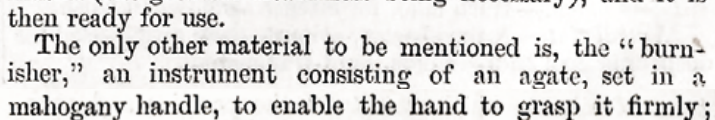

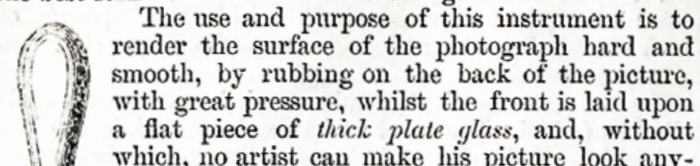

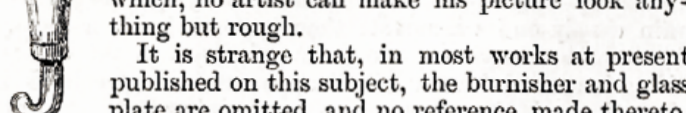

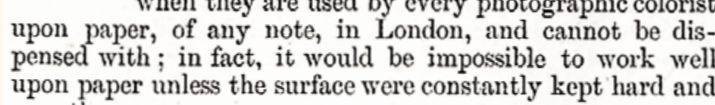
$A$ photograph, in printing and toning, may be male of

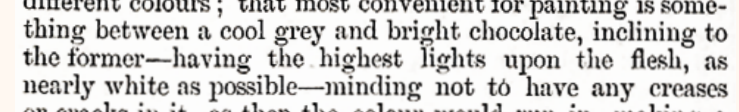

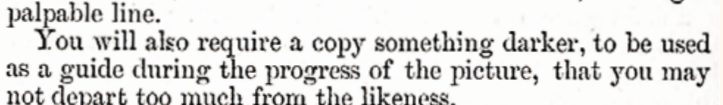

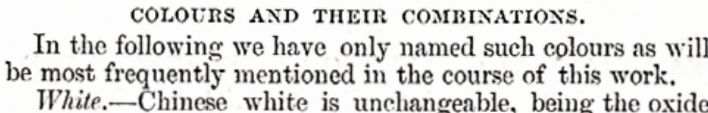

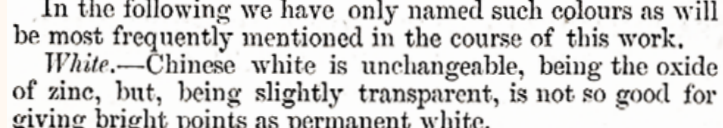

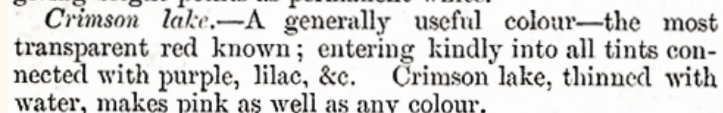
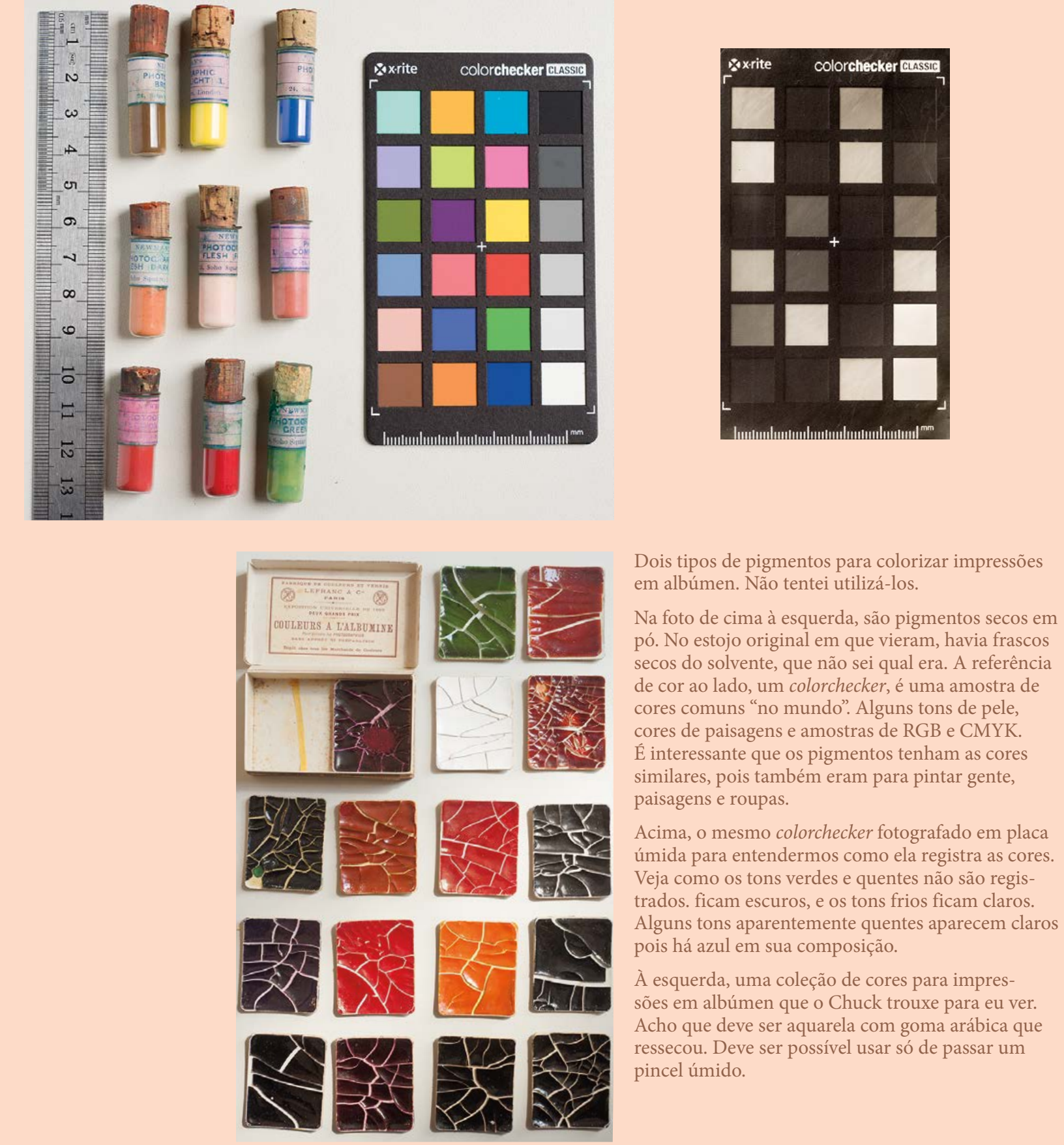

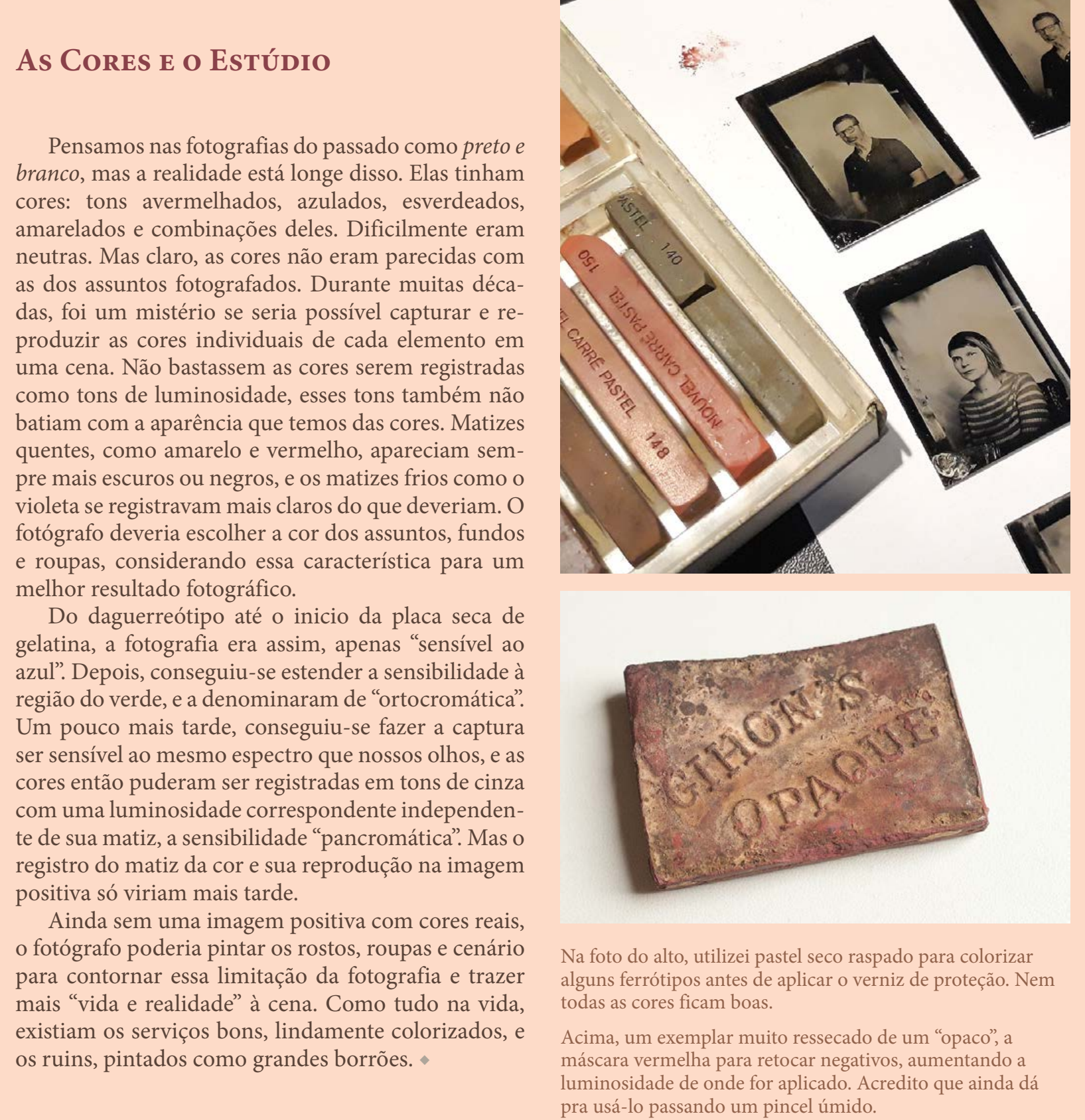

Traduzi este trecho da introdução do guia da Ko
lk sobre fotografia forens deraçês sobre a informaçăo fotográfica em seu uso

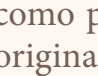

$\mathrm{O}$ que fotografias mostram?

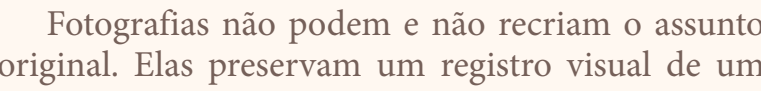
Ino perfecicioi por uma testemunha occular Descricis

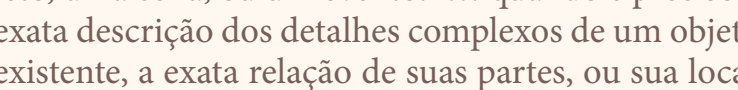
Tecnicas toografificas podem ser usadas simple. inder a višào e compreensiao. Qual ca ou meio fotografifco, poremm, a fotogratafia so

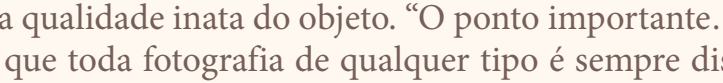

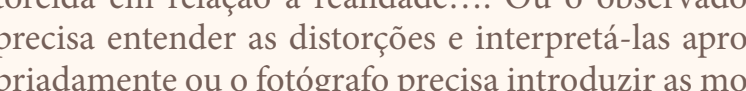

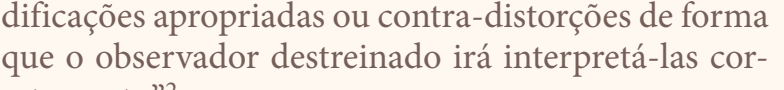

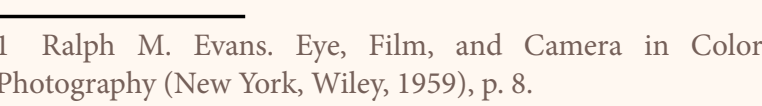



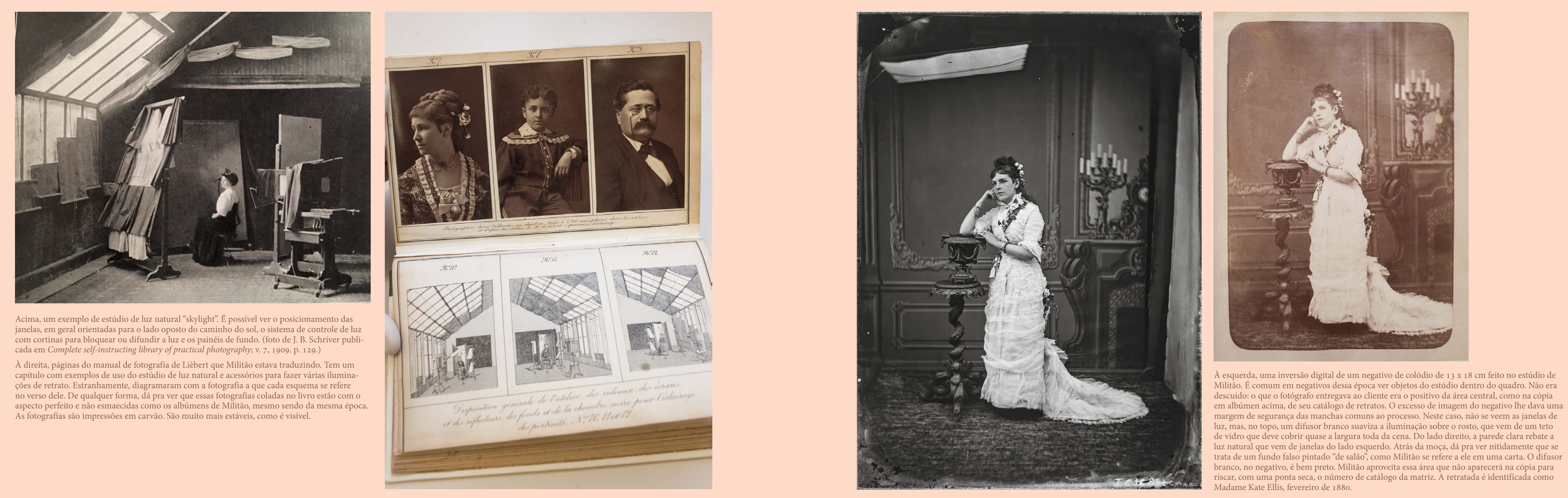

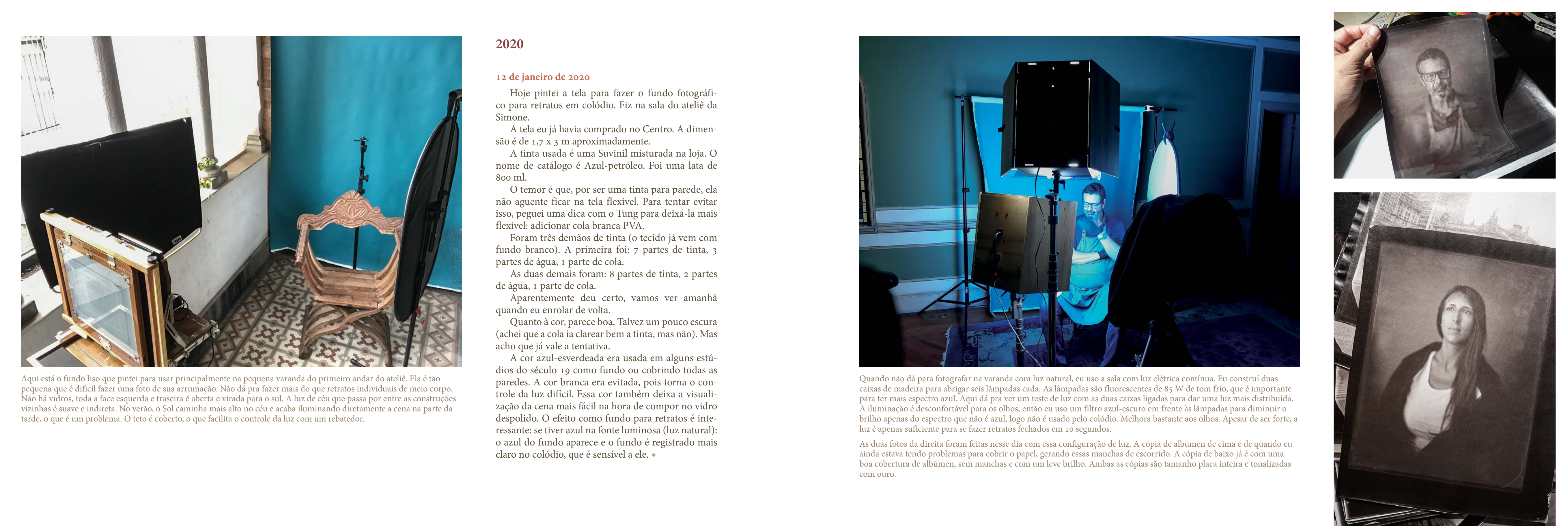


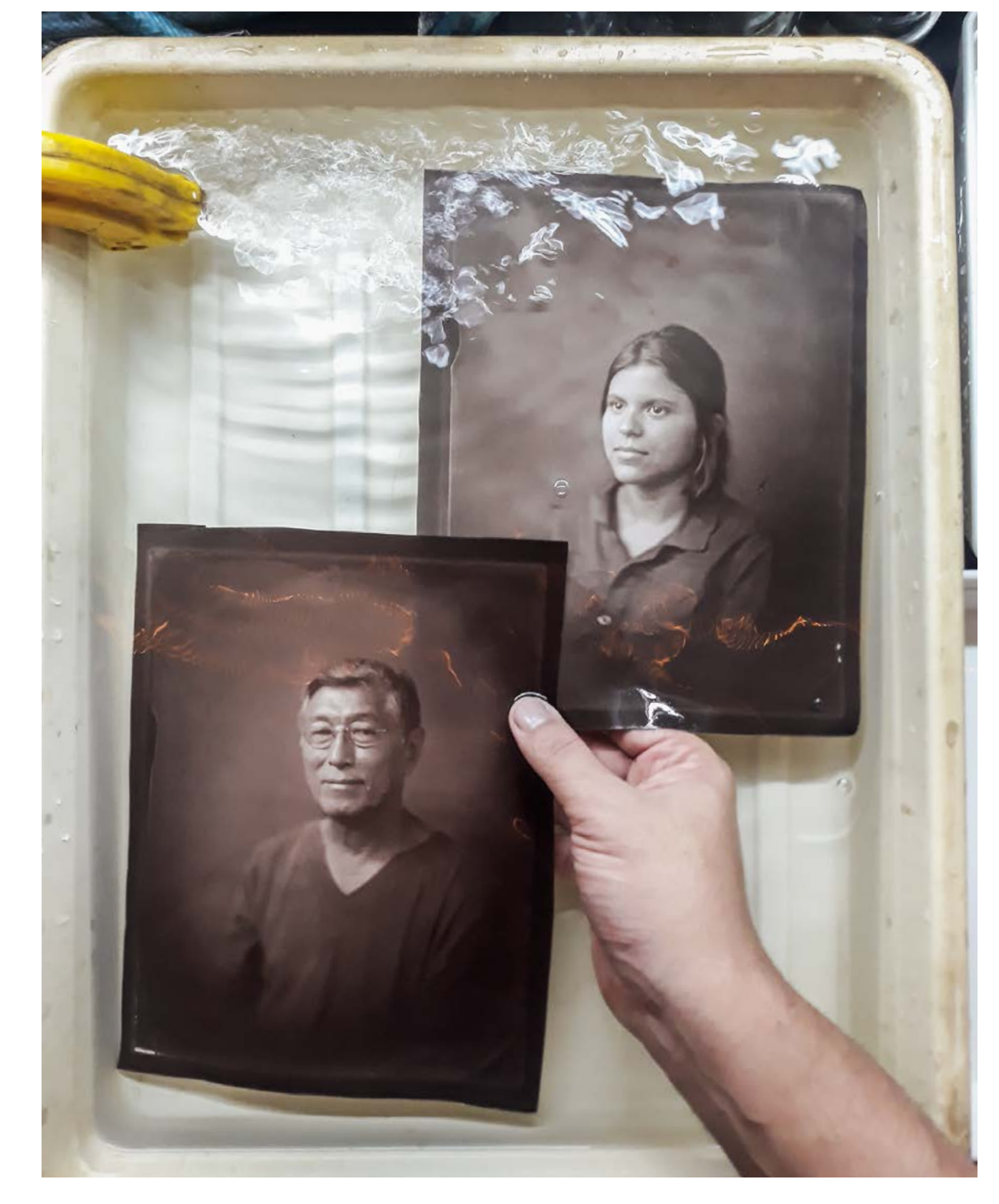

21 de fevereiro de 2020

Hoje o Chikaoka veio visitar o ateliê com a NathaGiver um retrato de cada Fiz negativos em place in eirae ficaram um pouco fracos. Fiz uma segunda re velacão para aumentar um pouco a densidade. Fico
no limite para fazer os albúmens.

28 de fevereiro de 2020

Mais uma leva de albúmen para papel. Desta vez,
vou tentar com outra batedeira. Eu estava fazend Apesar de interessante acho que não estábatatendo tỗ bem as claras. Se bem que hà de se imaginar con de casa, estava lá encostada sem fazer bolos há ano Infelizmente. Os ovos são bem novos, com 4 dias amônio. Bati por 15 minutos em velocidade máxima Ficou uma clara em neve bem rígida. Deixei descansando para liquetazer.

9 de fevereiro de 2020

A clara em neve liquefez quase toda, ficando ape
nas uma crosta grossa no topo. Acho que ficou benas una crosta grossa no topo. Acho que ficou bem
liquida, pois passou sem muita dificuldade por um
filt

J́́ tentei cobrir algumas folhas para testar
parece bem melhor, mais fluida. Não está ficand com marcas de escorrimento como tem acontecid

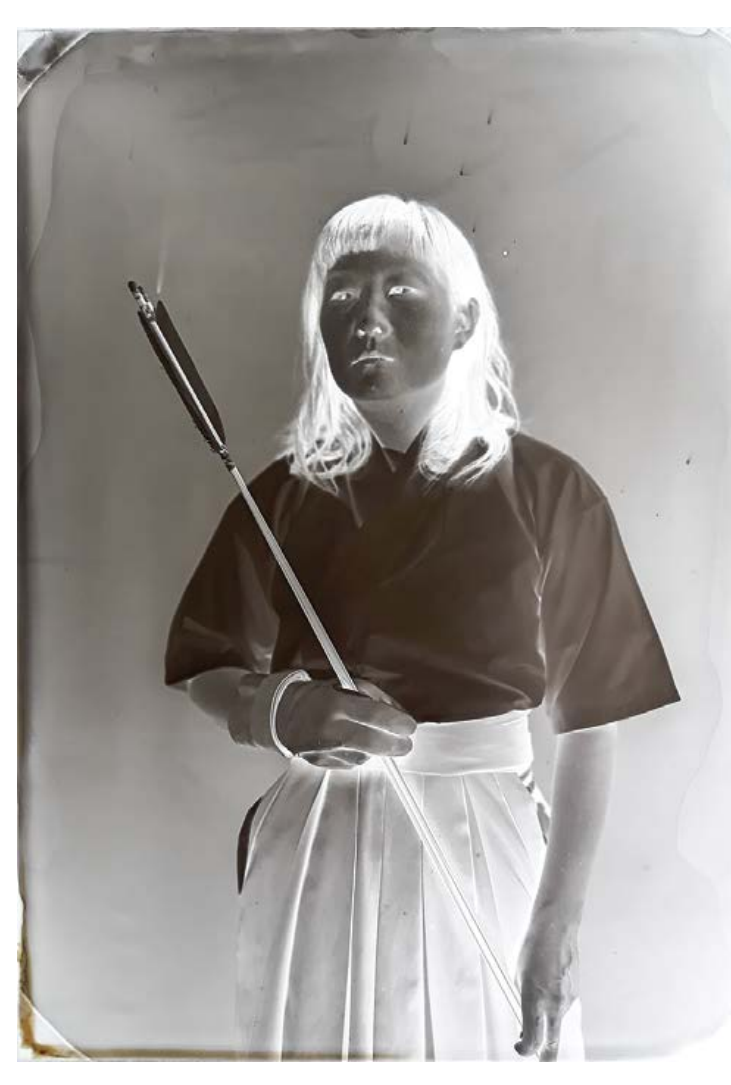

2 de março de 2020

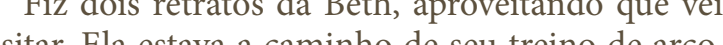
Retrato 1 (fechado), EV 10,$5 ; 24 \mathrm{sem} \mathrm{f/5,6.}$ Retrato (aberto), $\mathrm{EV} 11,2,20 \mathrm{em} \mathrm{f} / \mathrm{s}, \mathrm{s}$
Revelados por cerca de um minuto.

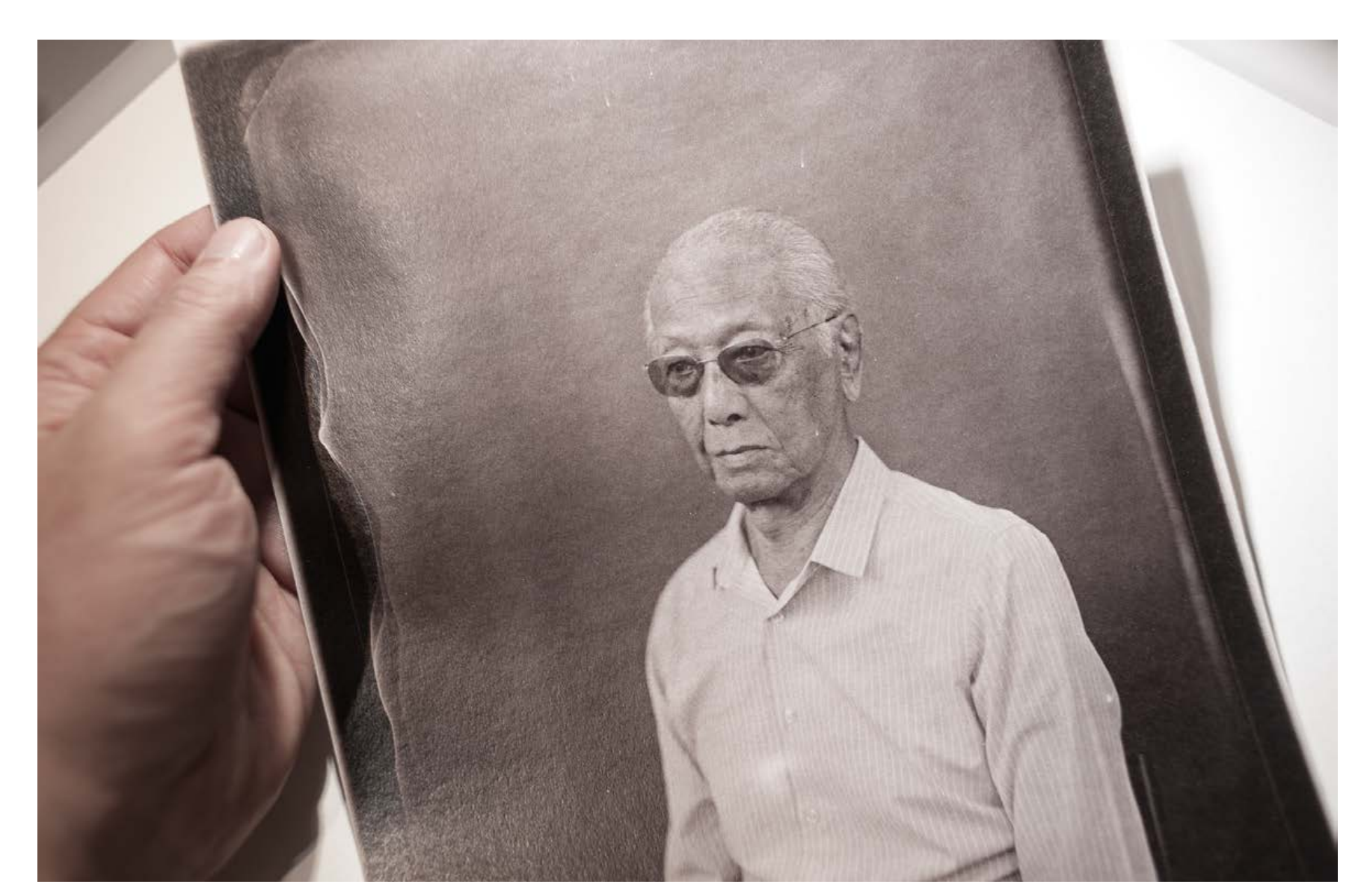

de março de 2020

Meu par visitou o ateliê e aproveitei que o fund 8 de março de 202

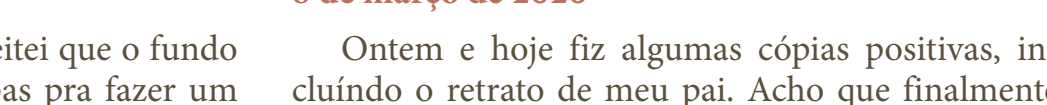
retrato dele em placa $18 \times 24 \mathrm{~cm}$. O terceiro retrato consegui resolver uma boa receita de albúmen. Ele

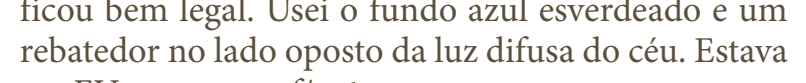
$\mathrm{m} \mathrm{EV} 10 ; 20 \mathrm{sem} \mathrm{f} / 5.6 \mathrm{com}$ a $240 \mathrm{~mm}$.

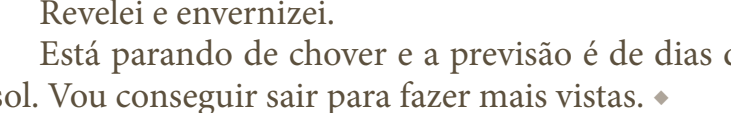


anais da Minha Casa de Vidro por Fulia Margaret Cameron
(Manuscrito de $\left.1874^{1}\right)$

É estranho que a Sra. Cameron tenha cometido dessizes em relacăa às
datas do próprio trabalho, mas Anais da Minha Casa de Vidroe épenas um

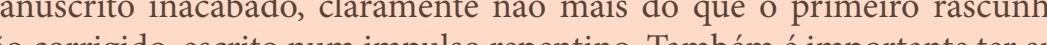

mente o fato de que esse manuscrito foi escrito dez anos apos ela comecar a fotografar. Minha explicacãa está indicada nas notas de rodapé.
A fotografafi da Sra. Cameron, agora com dez anos de idade, ja passou da

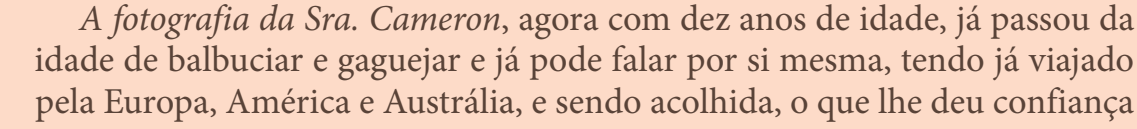
Portanto, penso que Anais da Minha Casa de Vidro será bem recebido
pelo publico, e, empenhandiso-me em revestir minha prequena história de luz,
de indumentaria, estou confiante de que o relato fidedigno de um trabalho de indumentária, estou confiante de que o relato fidedigno de um trabalho
incansável, com a história do interesse humano ligada a esse trabalho, em alguma medida, agregaŕa valor a ele.

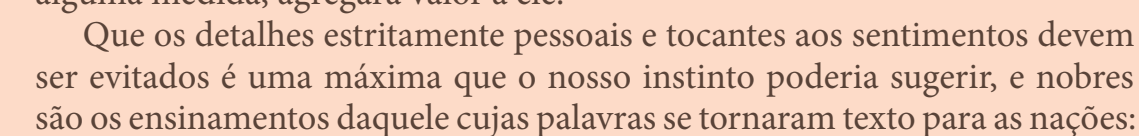
Be wises not easily forgiven
Aret these, hhosesting wide the doors that bar
The secret bridal chamber of the heart Are those, who
The secret bridd
Let in the day ${ }^{2}$

Portanto, é com esforço que contenho o transbordamento do meu cora-
çào e digo, simplesmente, que minha primeira cammera e lente me foi dada por minha querida e falecida filha e seu marido, com as palurves "Expermentar a fotografatia pode entretê-la, mãe, em sua solidão em Freshwater".

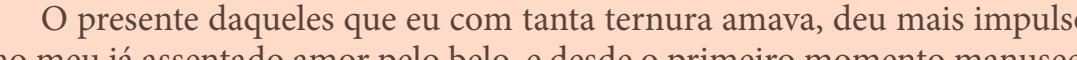
ao meu ja assentado amor
minhal lente com um ardor terno, e para mim se tornou um ser vivo, com voz e memória e vigor criativo. Durante muitas e muitas sens
trabalhei infrutufiferamente, porém não sem esperanças

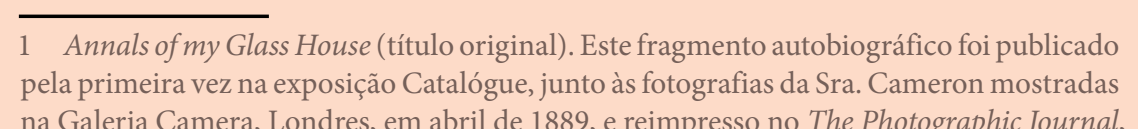

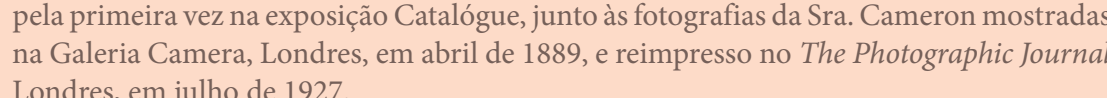

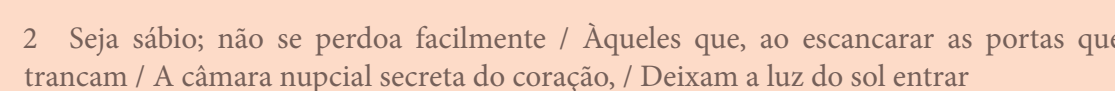

A crowd of hopes
That sought to sow themselves like winged lies

Born out of everything I heard and saw

Ansiava por capturar toda a beleza que veio antes de mim e, por fim, essa
ânsia foi sasitsfeita. As dificulddades so aumentaram o valor da busca. Comecei sem conhecimento dessa arte. Não sabia onde colocar a caixa escura como focar meu modelo, e minha primeira foto, para minha consternacão,
apaguei esfregando a măo sobre o lado coberto do vidro. Era um retrato de

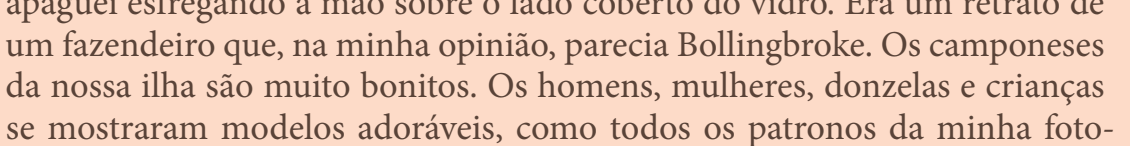
se mostraram modelos adoráveis, como todos os patronos da minha foto-
grafia ja sabem. Paguei a este fazendeiro dois xelins por hora e, após muitos xelins e horas
dedicadas a experimentos, fiz minha primeira foto, e foi essa que apaguei ao egurá-la triunfante para secar.
Transformei meu deposito de carvão numa sala escura e um galinheiro envidracado que havia dado aos meus fillos se tornou minha casa de vidro

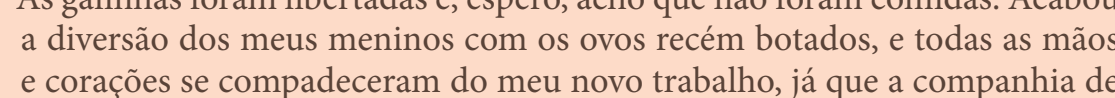

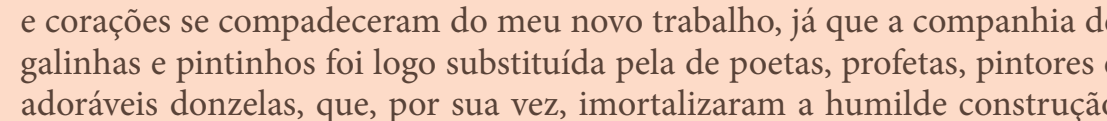
da fazend.

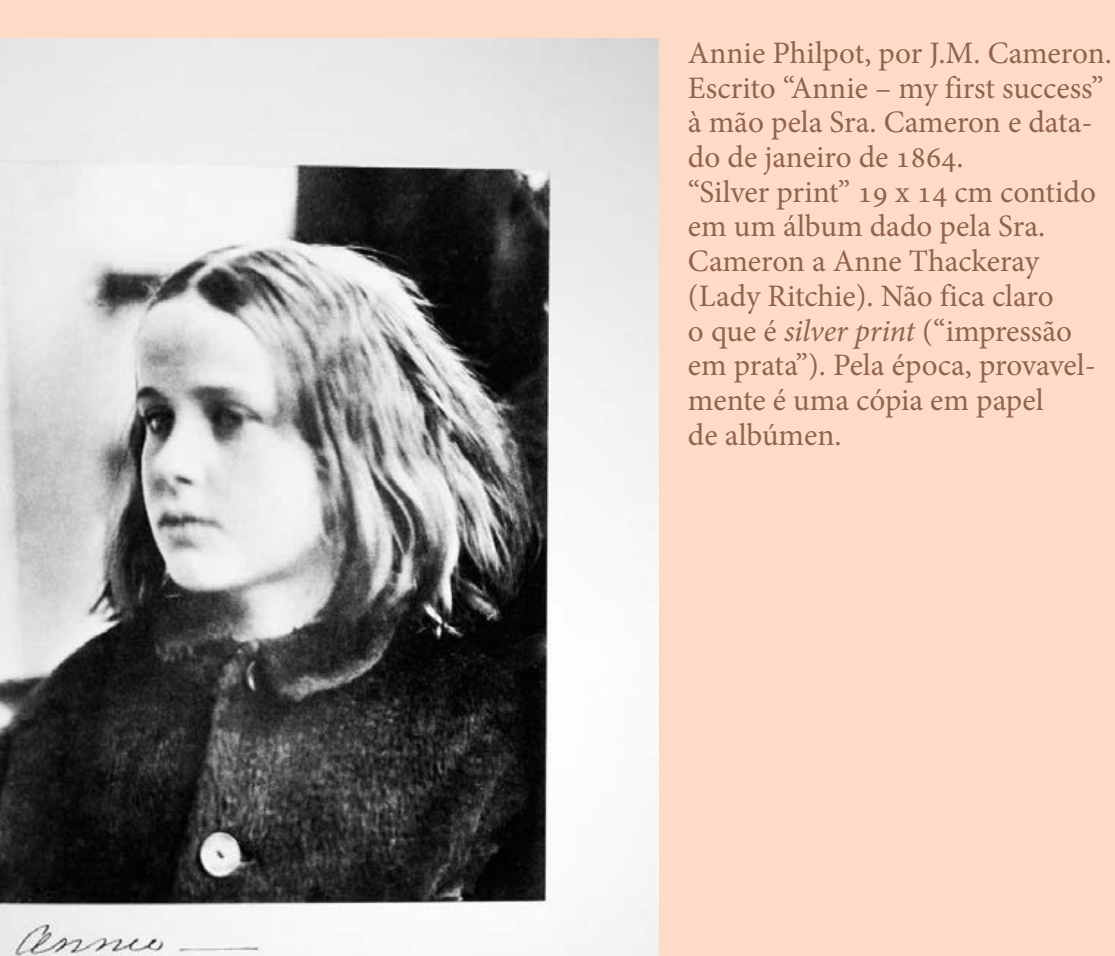

Após o sucesso com o fazendeiro, eu, em seguida, tentei com duas cria ficuldade em enfocar. Eu estava na metade de um lindo retrato guando our

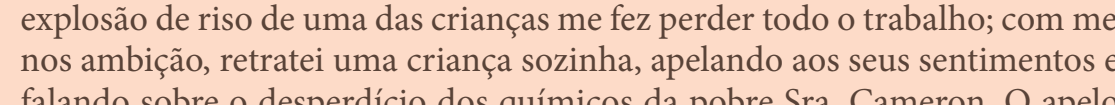
urtiu efeito, e resultou num retrato que chamei de "Meu Primeiro Sucesso"s para a crianca. Senti como se ela houvesse feito a foto sozinha. Copiei, ton-
lizei, fixei e emoldurei o retrato naquele mesmo dia e apresentei-o ao pai liziei fixei e emoldurei i retrato naquele
crianca - tamanho 11 por polegadas.

3 Uma multidâo de esperancas / Buscam semear-se como aladas
tuddo o que vi e ouvi / Revoando sobre mens sentidos e minhha alma

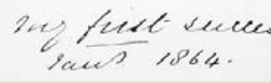

A pequena, doce Annie, com cabelos da cor do sol! Nenhum prêmio pos-
terior póde apas a Annie já tem 18 anos, como eu gostaria de encontráala e e testar meu toque Tendo, desta forma, começado, nano irei deter meus leitores com outros
detalhes de pequeno interesse; apenas tive que trabalhar e colher uma farta Creio que aquilo que disse meu fillho mais novo, Henry Herschel, hoje
um fotografafo muito notavel, é verdade - que meus primeiros triunfos em
minhas fotos for de foco formu uma caso Isto é, quando focalizava e chegava a algo que, aos meus olhos, era muito belo, eu parava ali em vez de ficar
girando a lente, uuscando um foco mais definido, algo em que os outros
fotografatos insistem. minhas fotos fora de foco foram um acasoo. Isto é, quando focalizava e che-
gava a algo que aos meus olhos, era muito belo, eu parava ali em vez de ficar 


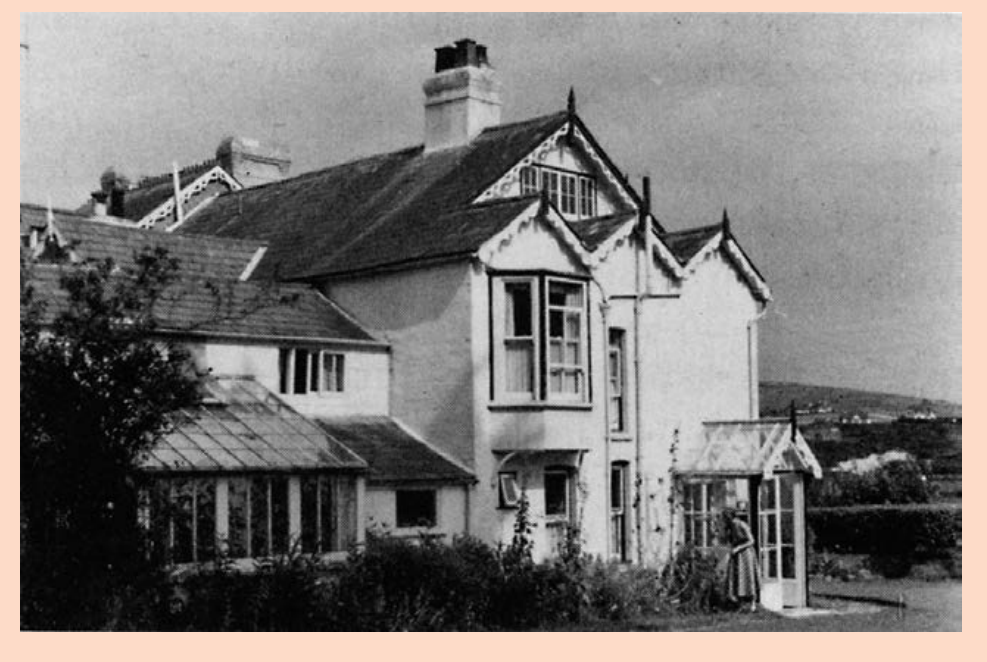

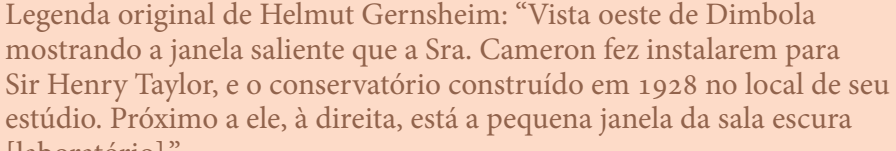

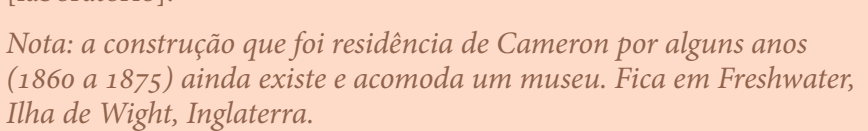

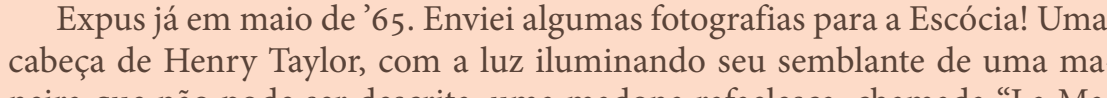

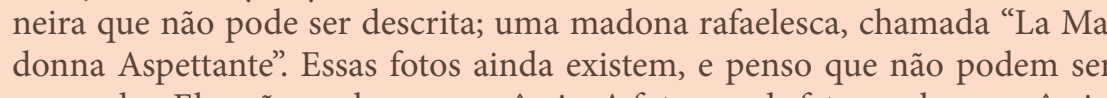

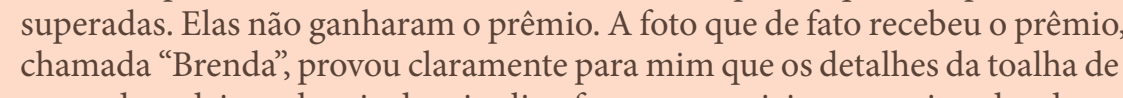

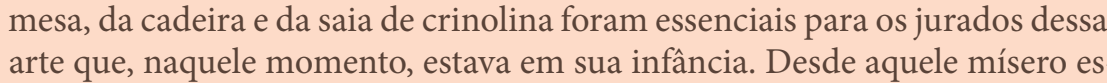

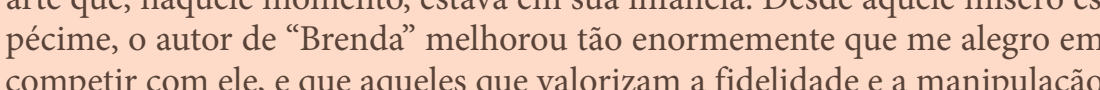

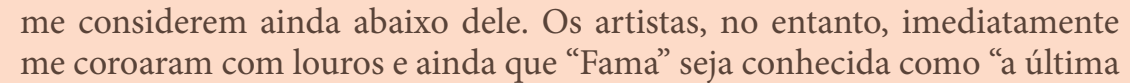

enfermidade das mentes nobres", devo confessar que quando aqueles, cujo
julgamento eu reverenciava e valorizava elogiaram os meus trabalhos "meu

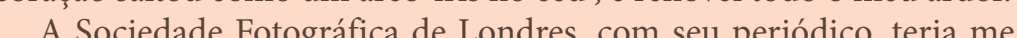
nimado muito, se eu não tivesse dado àquela criticca o peso que ela merec Foi cruel e manifiestamentite injustoto, para mim, comparecere à premiação. des, o que parecia convidara à ironia eà bile dos jornais impressos Enviei minhas fotografias para a Alemanha. Berlim, o lar da arte foto
gráficis, me concedeu, no primeiro, ano uma medalha de bronzer; no ano seguinte uma medalha de ouroe e uma in lon, me premiou com uma medalha de prata, com o interesse, espero, pelo A compaixão pescoal me ajudou muito Meu maride em tod hos os mo entos, admirou cada foto com prazer,

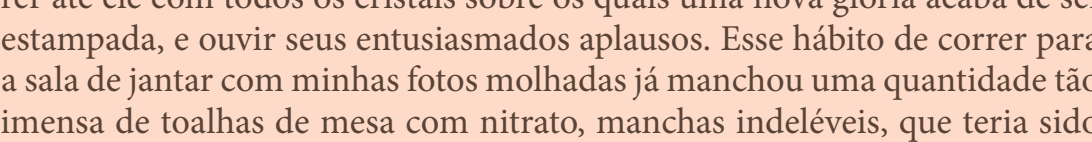
mensa de toalhas de mesa com $\mathrm{n}$

Nosso principal amigo, Sir Henry Taylor, emprestou-se muito às minhas primeiras tentativas. Apesar do receio de que, possivelmente, sentando-se ez, com a grandeza próoria do afeto altruisto se compromotenu a ser Fre Laurence com Julieta, Prospspero com Miranda, Assuero com a Rainha Ester,

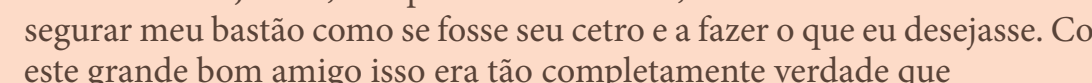

The chord of self with trembling
Passed like music out of sight. 4

áo só minhas fotos foram tiradas, mas inteiramente por causa do retrato de de e o bem-estar de um verdadeiro rei Cophetua que, em sua Miranda vil

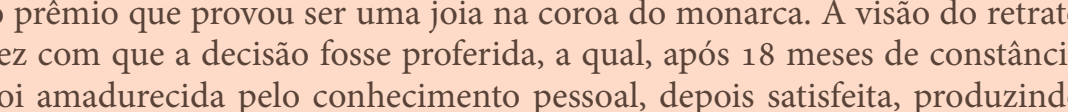

4 O acorde do ego, vibrando / Se passou por música, longe dos ollos. um dos mais bonitos idilios da vida real que pode ser concebido e, o que
de muito mais importancia, um casamento de bem-aventurança com criancas dignas de serem fotografadas, como sua måe fora, por sua belezá, m-
também deve ser observado que o pai era eminentemente bonito, com un cabeca grega de tez corada saxônica.
Desde o começo de sua infância, outra pequena empregada min

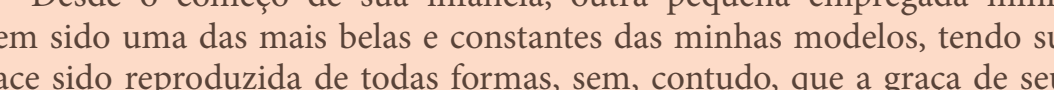
contornos tenha perecido. No outono passado, seu rosto ilustrando a prino
rosa There has fallen a splendid tear
From the passion flower at the gates

era tăo puro e perféto em seus contornos quanto foram meus estudos de
Madonna dez anos antes, com dez vezes mais emocão na expressāo. Os atra Madonna dez anos antes, com dez vezes mais emoçà na expressão. Os butos bastante incomunn de seu carater ea complexidade de sua mente,
assim posso chamà-lo, merecem a devida mençao, e sâa o fascínio daqueles cuja vida se mistura com a da famililia como amigoso intimos da casa.
Fui aclamada por algumas correspondencias muito bonitas sobre minha

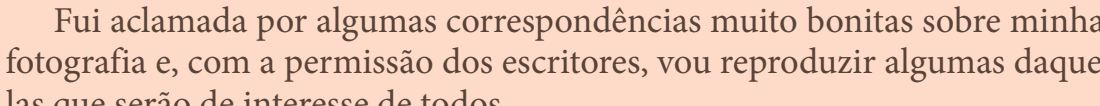
las que serão de interesse de todos.
Um homem extremamente gentil de Berlim demonstrou grande entoUm homem extremamente gentil de Berlim demonstrou grande entu-
siasmo, pelo qual me sinto mutto grata a ele. Escrevendo em uma lingua
estrangeira ele evidentemente consultou o dicionario, que oferece dois estrangeira, ele evidentemente consultou o dicionário, que oferece dois ou
trés significados para cada palavra, e ao escolher entre esses dois ou trés,o

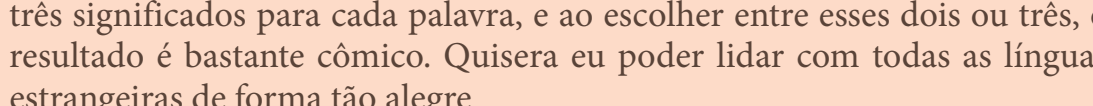

O Sr. anuncia à Sra. Cameron que ele recebeu no primeiro semestre
uma Nota de Libra, etirou as fotos como a sra. Cameron deseja. Ele vai OSr - eo Comitie se arreendem muito*t que agora seja imposivive
levaro

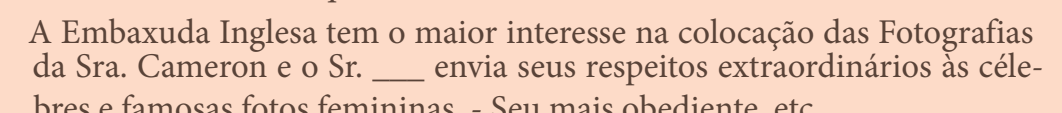

5 Cailu uma esplềndida lágrima / Do pé de maracuuia no portäo.
A gentileza e delicadeza desta carta são evidentes e os erros são facil"Cuidado - que era a palavra necessáría - é expressado por "Sorgen", bem
como "Sorrow" (sofrimento). Invertemos a sentença e lemos - Para ter as

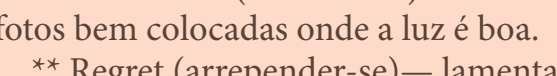

$* * *$ Winkle (buzina)- - significa canto de sala em alemão.
$*$ * um alemåo a uma senhora artista e, em todos os casos, a Alemanha sempre minhas felizes associaçóes com aquele país, tendo o privilégio de fotografar
o principe e a princesa herdeiros da Alemanha e da Prusssia. Essa carta alemã tinha um refinamento que permite sorrir com o escritor,
não do osscritor. Menos simpático, no entanto é o riso provocado por alguis cartas inglesas, dentre as quais dou um exemploc

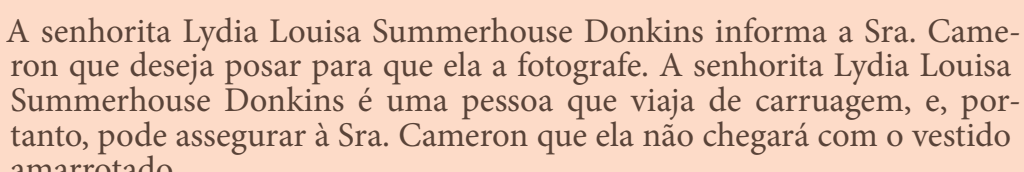

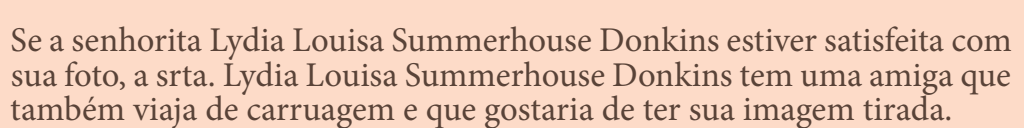

Respondi à senhorita Iydia Louisa Summerhouse Donkins que a Sra. Ca-

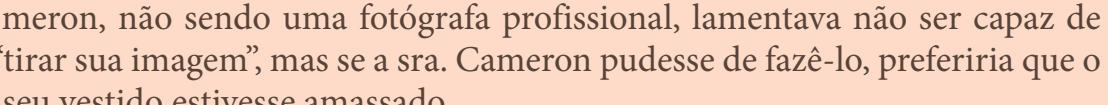
seu vestido estivesse amassado.
Pareceu que ensinar um pouco de arte seria uma gentileza, porém mais
de uma vez me arrependid de não ter conseguido realizar una foto dessa pessoa, com sua carta afixada Quando tive tais homens diante da minha càmera, toda a minha alma se
esforcou para cumprir o seu dever perante eles, registrando fielmente sua esforcou para cumprir o seu dever perante eles, registrando fielmente sua
grandeza do interior bem como os atributos externos A fotografiala quando tirada dessa forma, é quase e materializacāo de uma
oraçâ. O maior sentimento de devoçấ que presenciei foi ao fotografar meu 


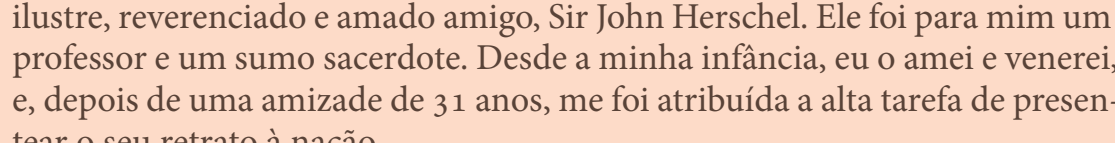
tear o seu retrato à naçio
Ele se correspondia
a

do Talbótipo e do untotipé, as descobertas cientificas enviadas àquela terra inculta eram água para o
labsesecados efamintos, isso sem falar da bencâo de uma amizade oue demonstrava ser tá leat

grafar o nobre rosto do meu grande Mestre, mas durante trés anos tive que Enquanto isso, fotografei outro rosto imortal, o de Alfred Tennyson, e
es Sujo". Parecece uma representaçąa de Isaias ou de Jeremias, e Henry Taylo Fisse que a imagem era taa boa quanto o melhor poema de Alfred Tennyson.

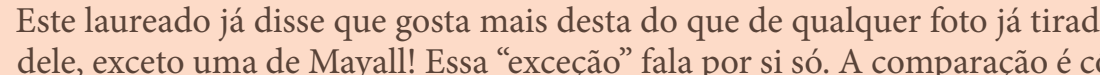
mica demais. É mais ou menos como comparar uma das estátuas de cera de padrinho do meu fillho mais novo. Num dia memorável, os trés padrinhos do meu filho vieram pessoalmente eficaram diante da pia batismal, não por
obrigacăo, mas movidos pela verdaderira afeição a mim e ao meu marido. E certamente, Poesia, Filosofia e Beleza nunca foram tão bem representadas Virgínia Somers, cercaram a pequena fonte da Igreja Mortlabce.

Quando comecei a fotografara, enviei meus primeiros triunfos a esse ado-
rado amigo, e deixo aqui sua aclamaçáo pelo meu sucesso. A data é 25 de

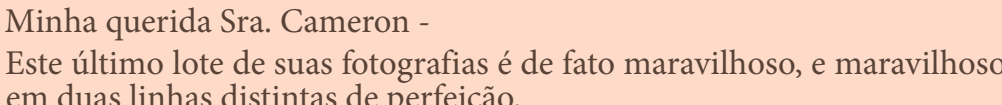

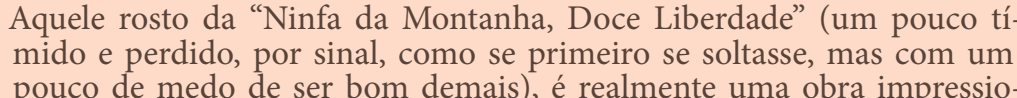

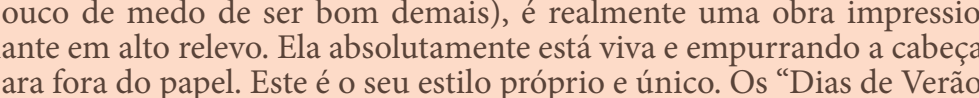

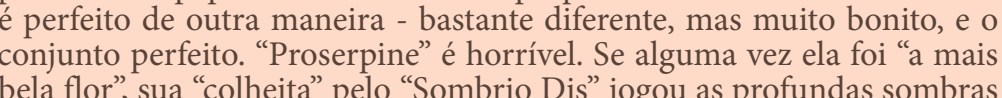
bela flor", sua "colheita" pelo "Sombrio Dis" "ogou as protundas sombras
do thades nao apenas na cor, mas em todoo contorno expressao de suas

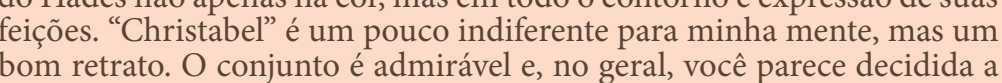

Isso foi encoraj
10 de março de 2020

Cobri mais 30 folhas de Canson Crobarrt com albúmen $2 \%$ para comecar a fazer as cópias positivas fi-
nais dos negativos já feitos. Também já pensando no proximos negativos que quero ainda fazer de alg
vista. Assim que passar a intensa dor nas costas

15 de março de 2020

Coronavirus!
Se não bastasse a dor nas costas que está me atra-
hando a movimentacâa, a a pandemia de Covid- -19 palthando a movimentacăa, a pandemia de Covid-19
está no Brasil. Na última semana a cidade começou parar para uma quarentena. No dia 130 Luis avisoo
pano viria ao atelie pois está com os sintomas do virus vai aguardar o resultado do exame.
Estou com falta de trabalho e o tempo parece
que vai piorar. Ou seja, nada de saídas fotográficas
por ora. que var $\mathrm{p}$.

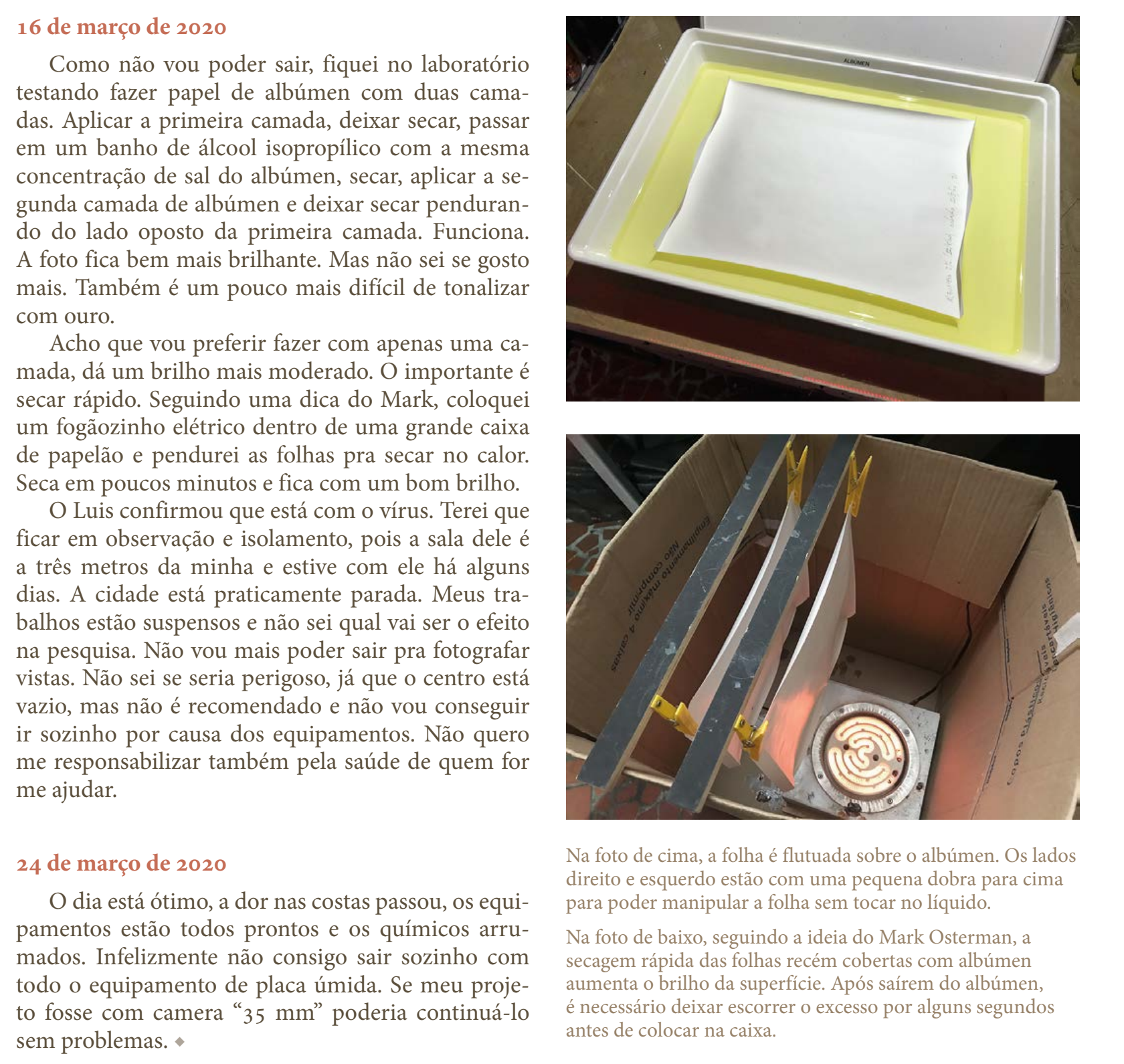




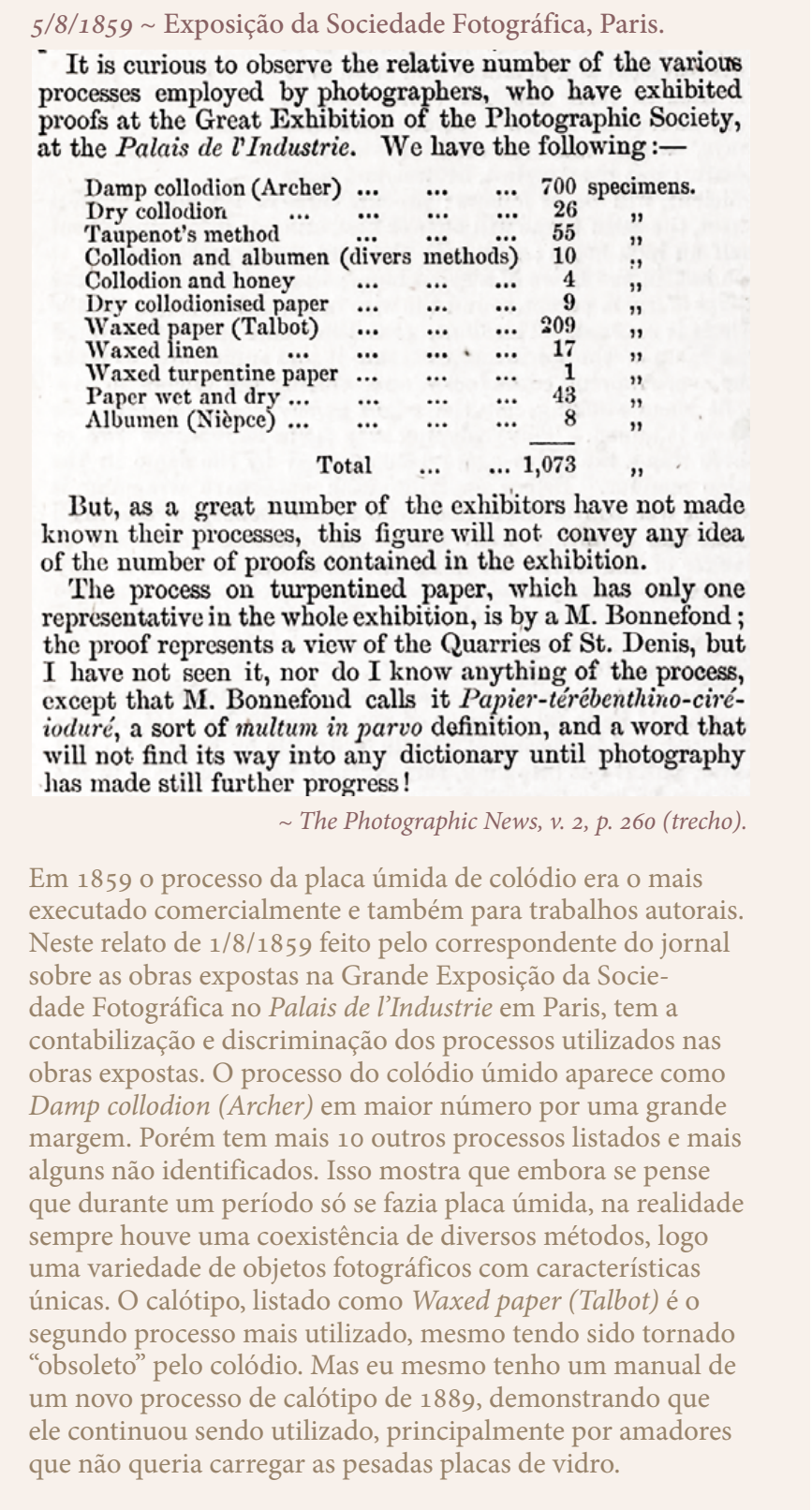

2 de maio de 2020
Tenho ido pouco ao laboratório por conta da pan-
demia. Comon ninguém pode se encontrar presencial-

Está muito claro que a situação da cidade não val ma retratas remotos!! Já que videoconferênncia é o que çoes. A saida será fazer um livro. Pensei no mesmo temos por ora, por que não tentar juntar com uma formato do album do Militão. Quem sabe encartar o
tecnologia do seculo 19 . Pelo menos me distraio des- albúmense se possivel se clima esquisito. Decidi fazer retratos em formato gem, pois posso
usar uma lente rapidida de $\mathrm{f} / 1.4$ para fotografara a telh

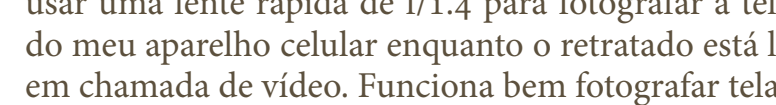
Fiquei pensando nos negativos duplos do Militão
Gions se posivel. quero investigar um pouco mais isso para fechar
pieto. Eu tenho uma ideia de como as traseiras des

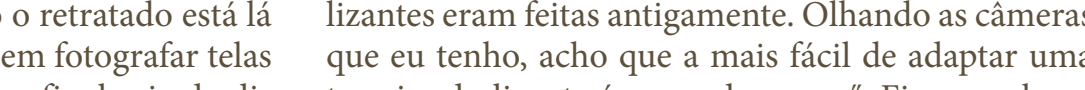
mensão menor $\quad$ de projeto das peças em madeira, mas alguns deta A experiênciaé diferente de um retrato presencial,
mas tem alguma semelhancas. O retratado ainda ter que posar parado por alguns segundose o ohar para
câmera de seu celular. Eu vou dando comandos para
ele se posicionar melhor e tento escolher com ele ele se posicionar melhor e tente escolher com ele
local com a melhor luz onde ele esta. Eu anunciei para hoje um "Dia do Retratto" e tive
5 clientes! Considero um sucesso da experiência ev
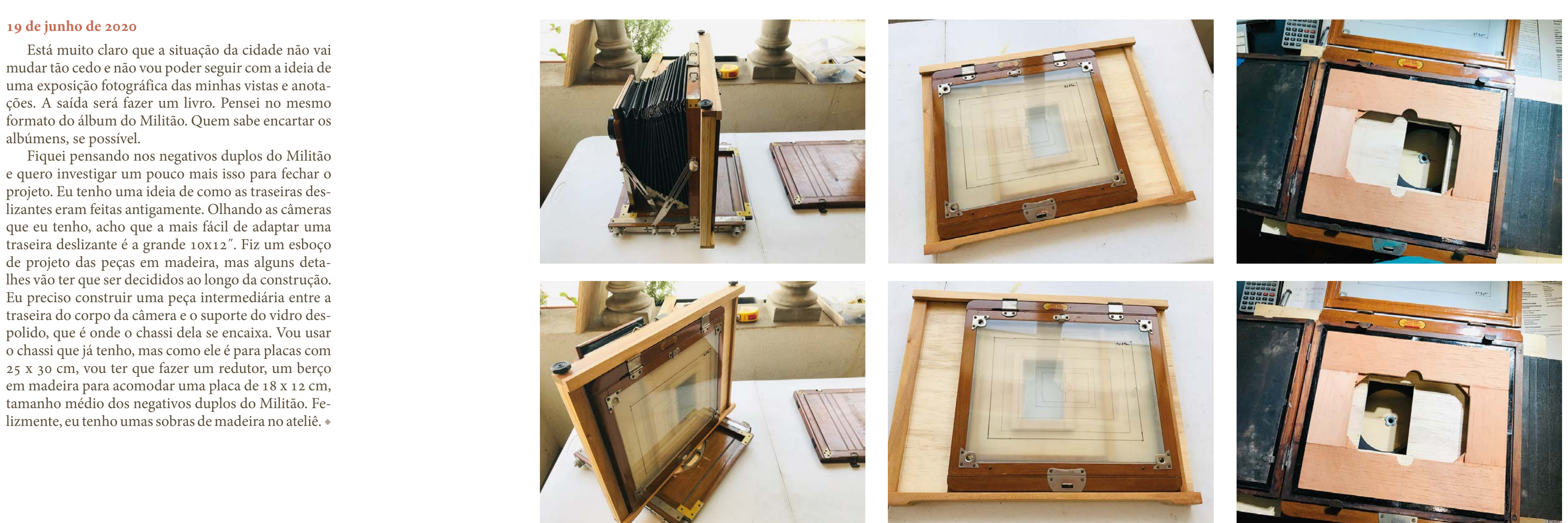

Nas fotos desta pagina é possivel ver o adaptador que fiz par

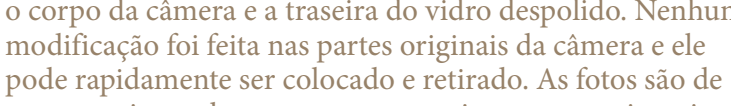

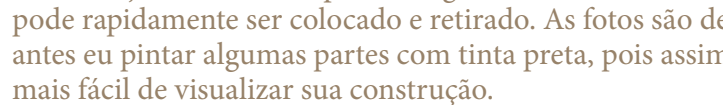
Na coluna acima, dá pra ver como a peç, de madeira mais
clara, se encaixa no meio da construçáio original.
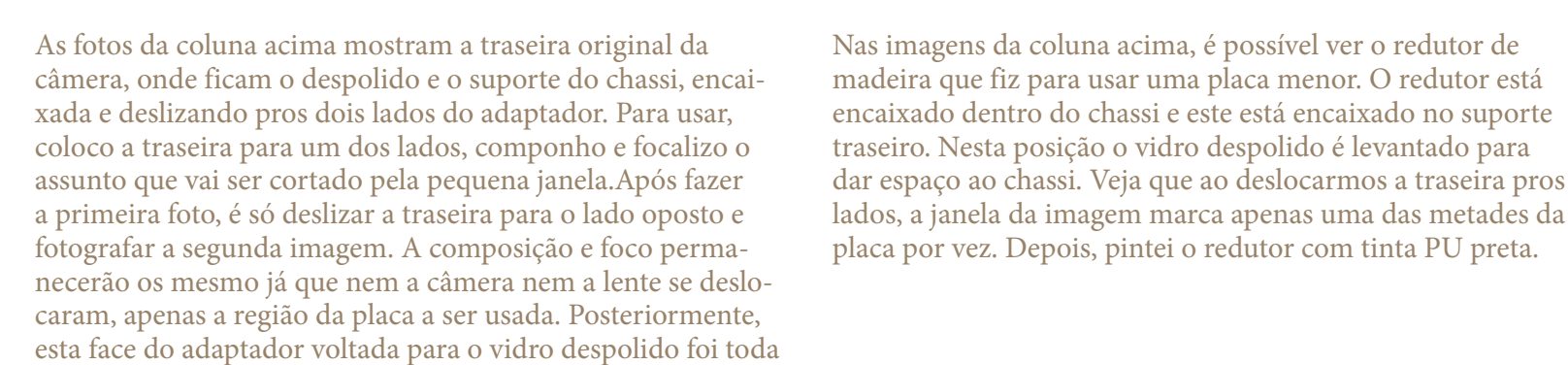

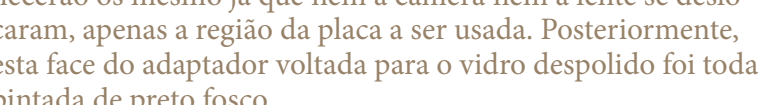




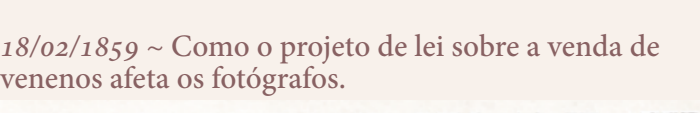
FHE SALE OF POISONS BLLL AS IT AFFECTS

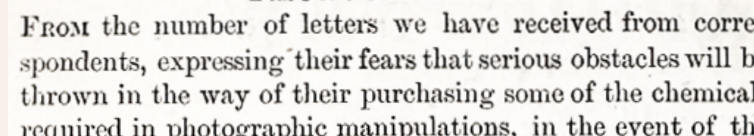

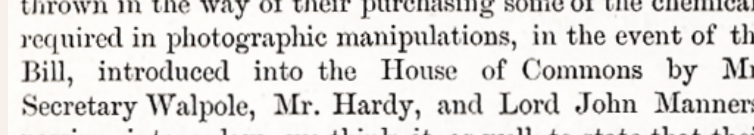

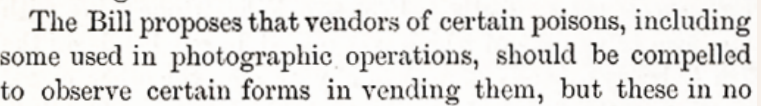

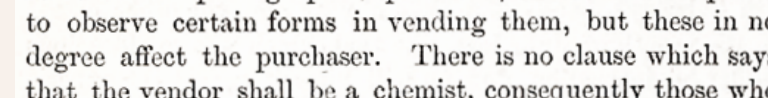

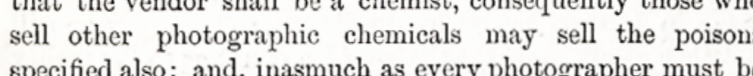

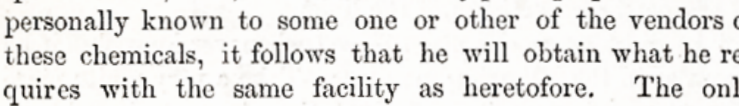

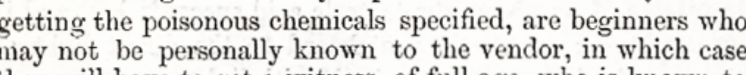

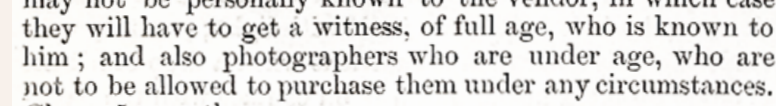

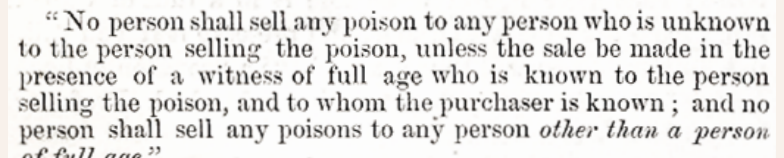

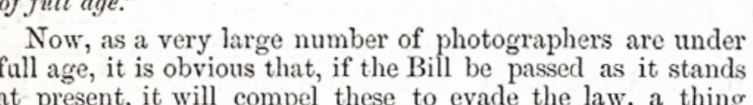

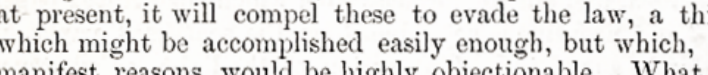

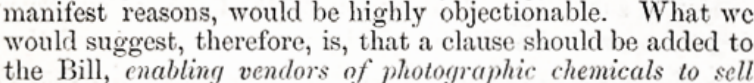

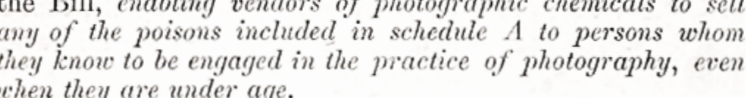

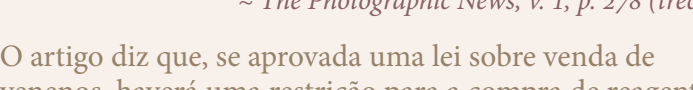

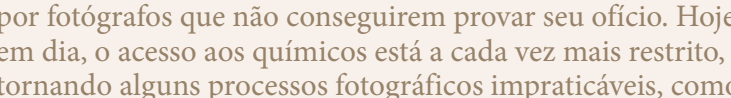
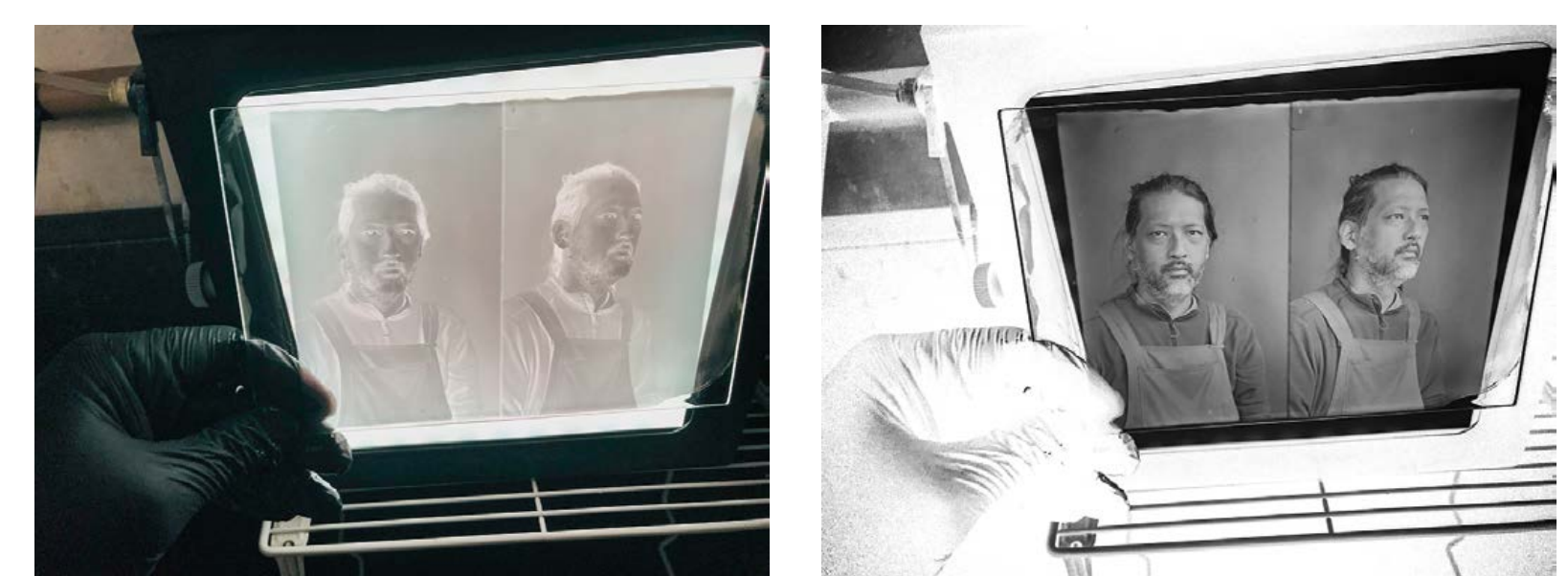

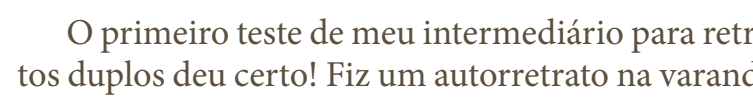

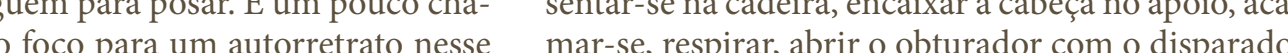

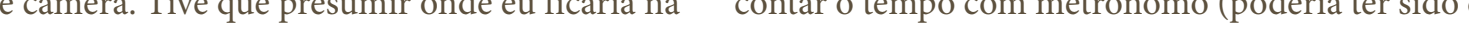

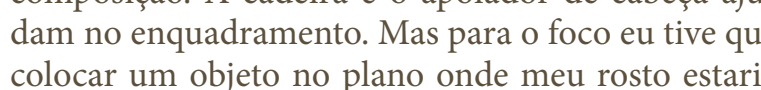

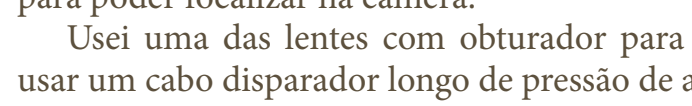

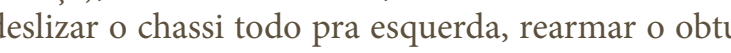

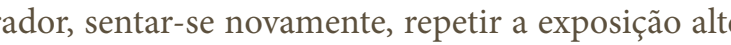
randoou nas

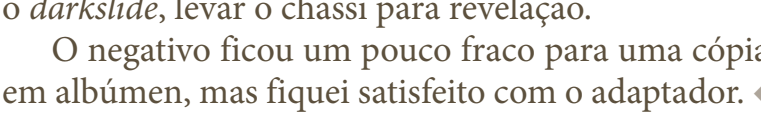
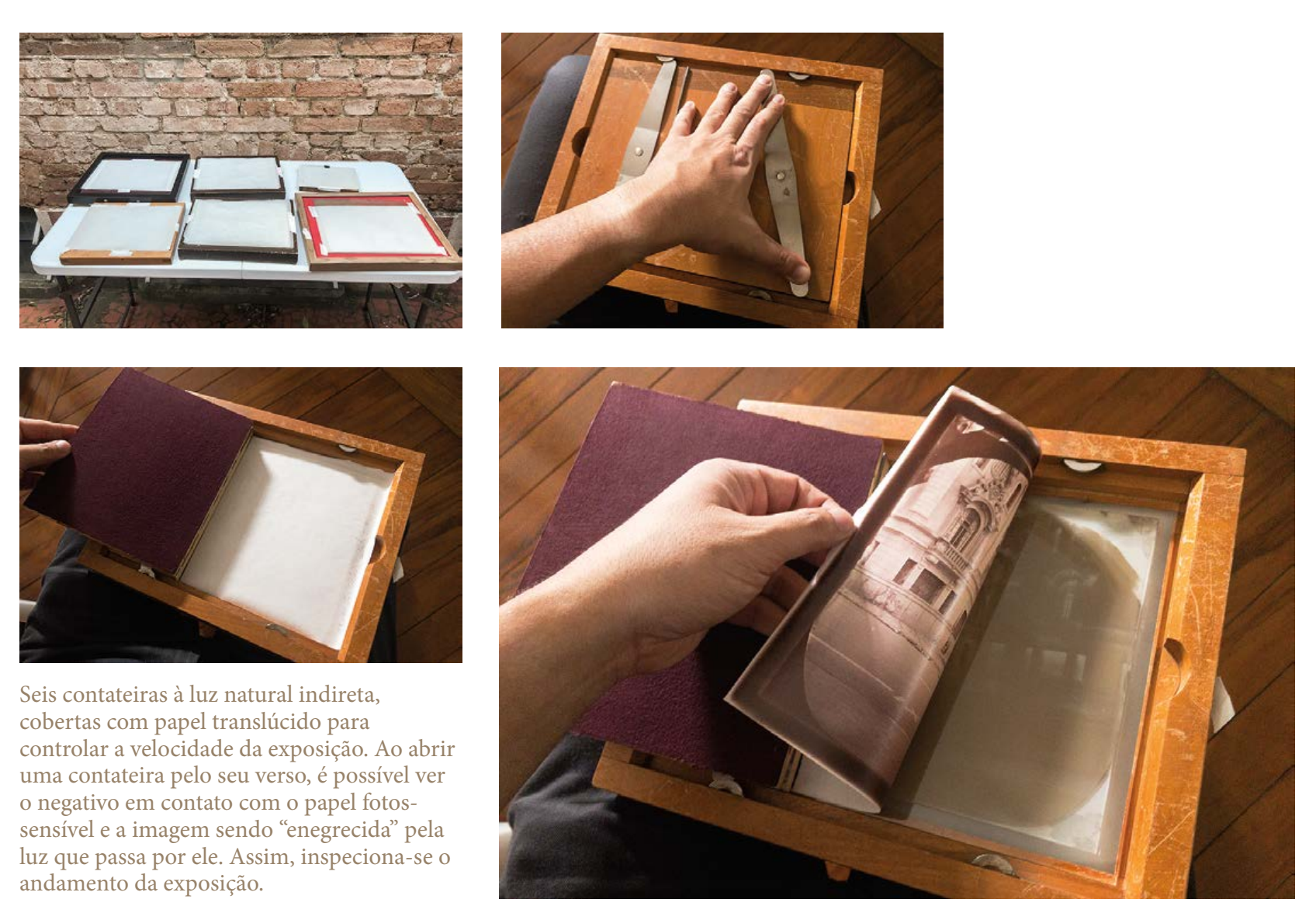
a por consequênncia necessidadede de recorrer à cobrann Jc que é 58:240. Conto ser servido. Dessde áa ll

S. Paulo, 29 de 8 bro de 188 .
Sr. Francisco Pinto de $S$ S R. de S. Leopoldo n.29(Santos) (a) tos no sábado remetendo-os na $5^{a}$ feira futura. Peço

Vio era són na captura que a fotografaia necesithva de tem

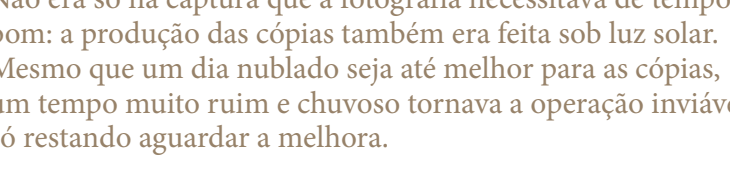

Estou imprimindo muitas cópias de albúmen dos
meus negativos das vistas da cidade para fáa preparee a várias follhas de albúmen e tenho
tentado fazer assim: segunda passo o dia preparando no escuro ainda, sem fixar. À medida que
vão secando, eu as guardo numa caixa opaca. Assim

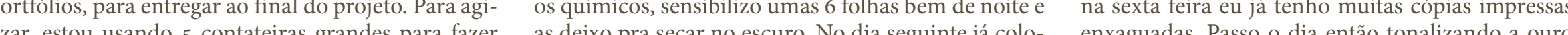

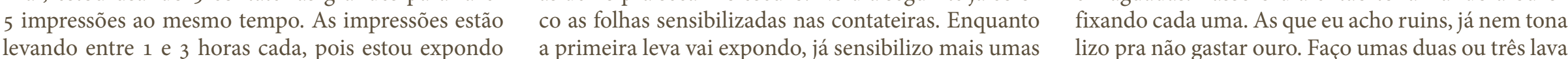

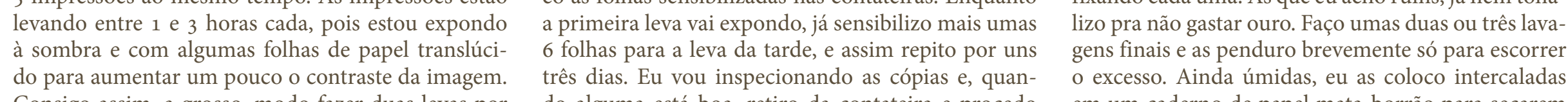

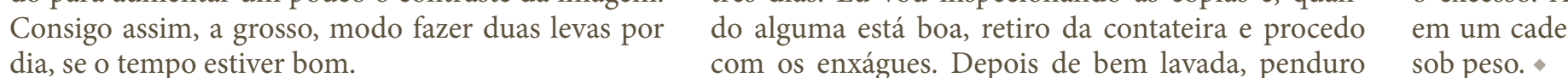




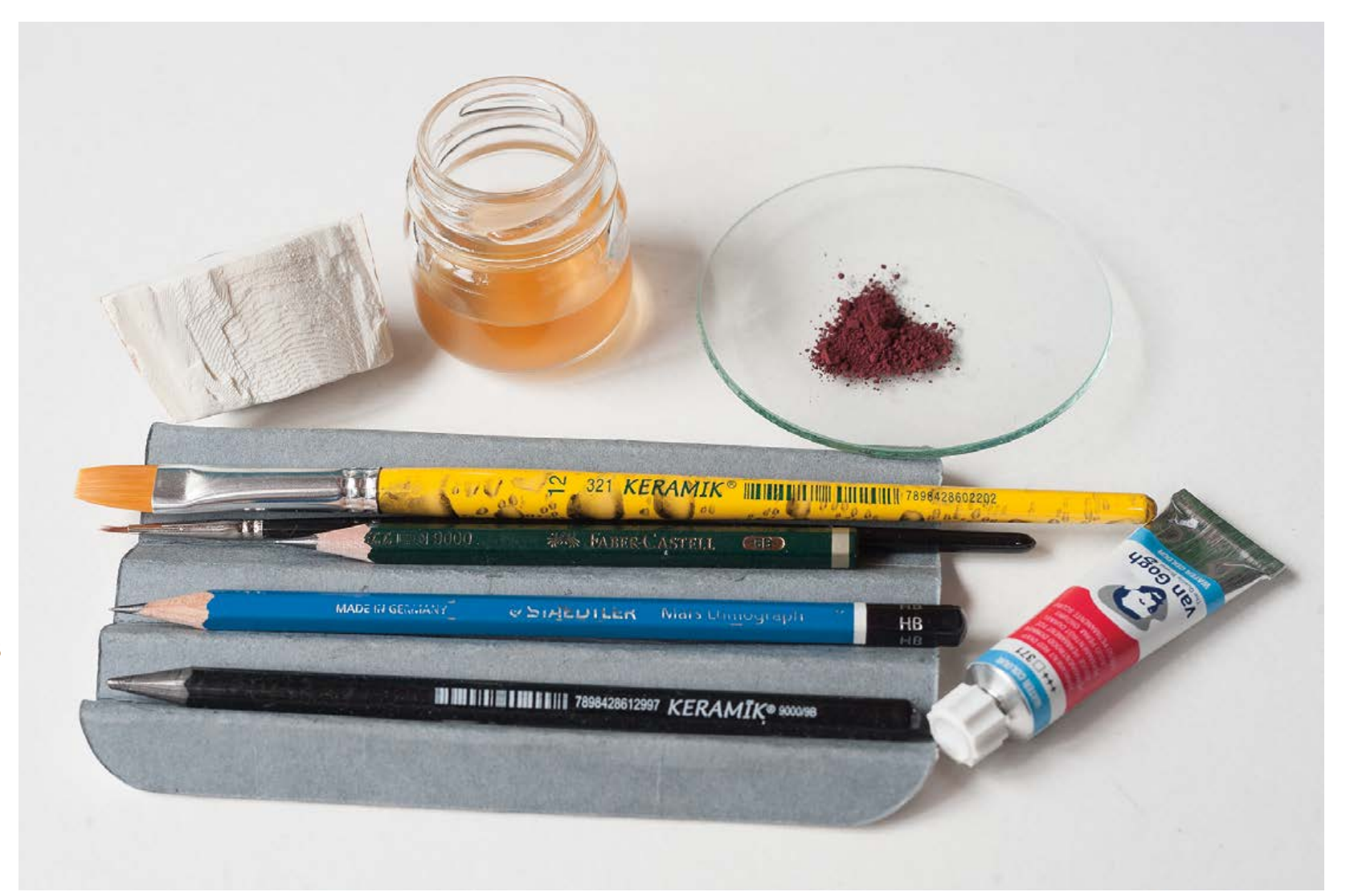

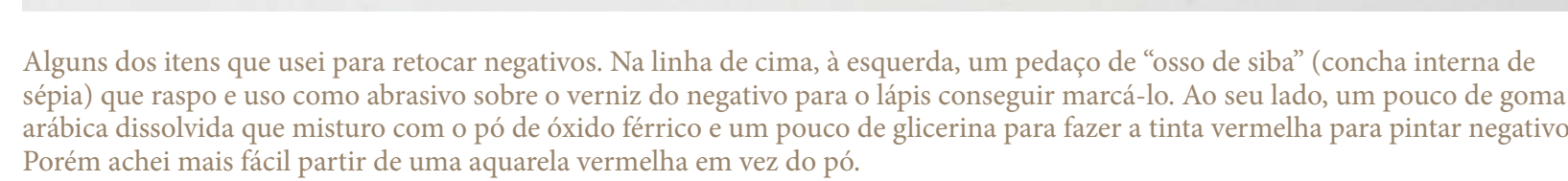

Experimentei um pouco o retoque com lápis no lado do colódio, para ter traços mais finos e precisoo
Como o colódio é coberto pelo verniz, o lapis nă consegue marcálolo. E preciso desgastar um pouc
a superficie "polidad." Em ingless, me passaram que cobri queé um molusco que aqui no Brasilé conhecdo pelos nomes choco, sépia ou siba. Achei pra com-
prar em loja de produtos para pássaros, pois ele ficam Eu raspo um pouco, fazendo um pó bem fino,
esfrego levemente sobre o verniz na aarea que pretendo retocar com lápis. Eu posso daí riscar, ou melhor, pontilhar, com a
ponta do grafite o que eu quiser que fique mais claro na cópia, em geral mora Comprei uma bisnaga de aquarela vermelha par fazer a mascara vermelha. Ê mais fácil de usar que
partir do oxido ferrico. Mas posso tentar usar rouge

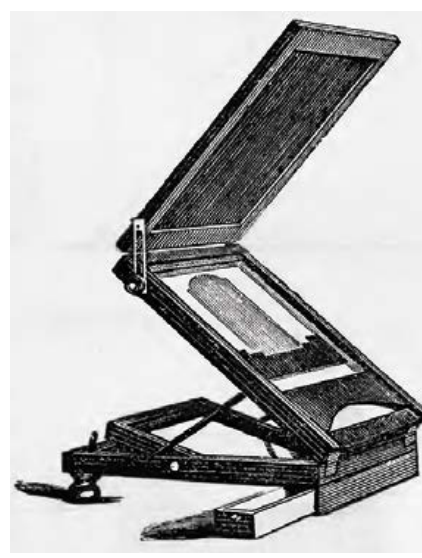

15 de setembro de 2020

Finalizei boa parte das cópias em albúmen que e um registro dos materiais consumidos, só tenho um

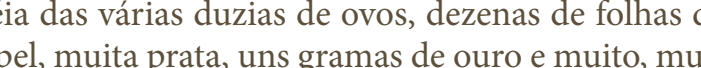

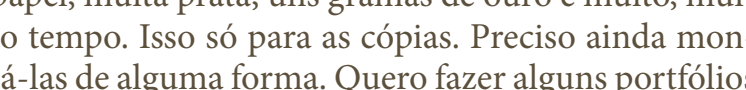
Eu nem vou conseguir completar o projeto no amanho que planejei inicialmente, com a quant
ade de copias que pensei em fazer. Tenho umas cópias boas, fora as muitas que ficaram ruins. Nào
nem a quantidade de cópias de um unico exemplar do álbum do Milităo! Nâo sei quantos exemplares ele
acabou fazendo, mas se forem só dez, já são 600 cópias em albúmen, feitas una a uma. Só me faz mais Impressionado como o trabalho que ele teve para fazer
seus ábuns, e entender porque ele exclamava "nâa

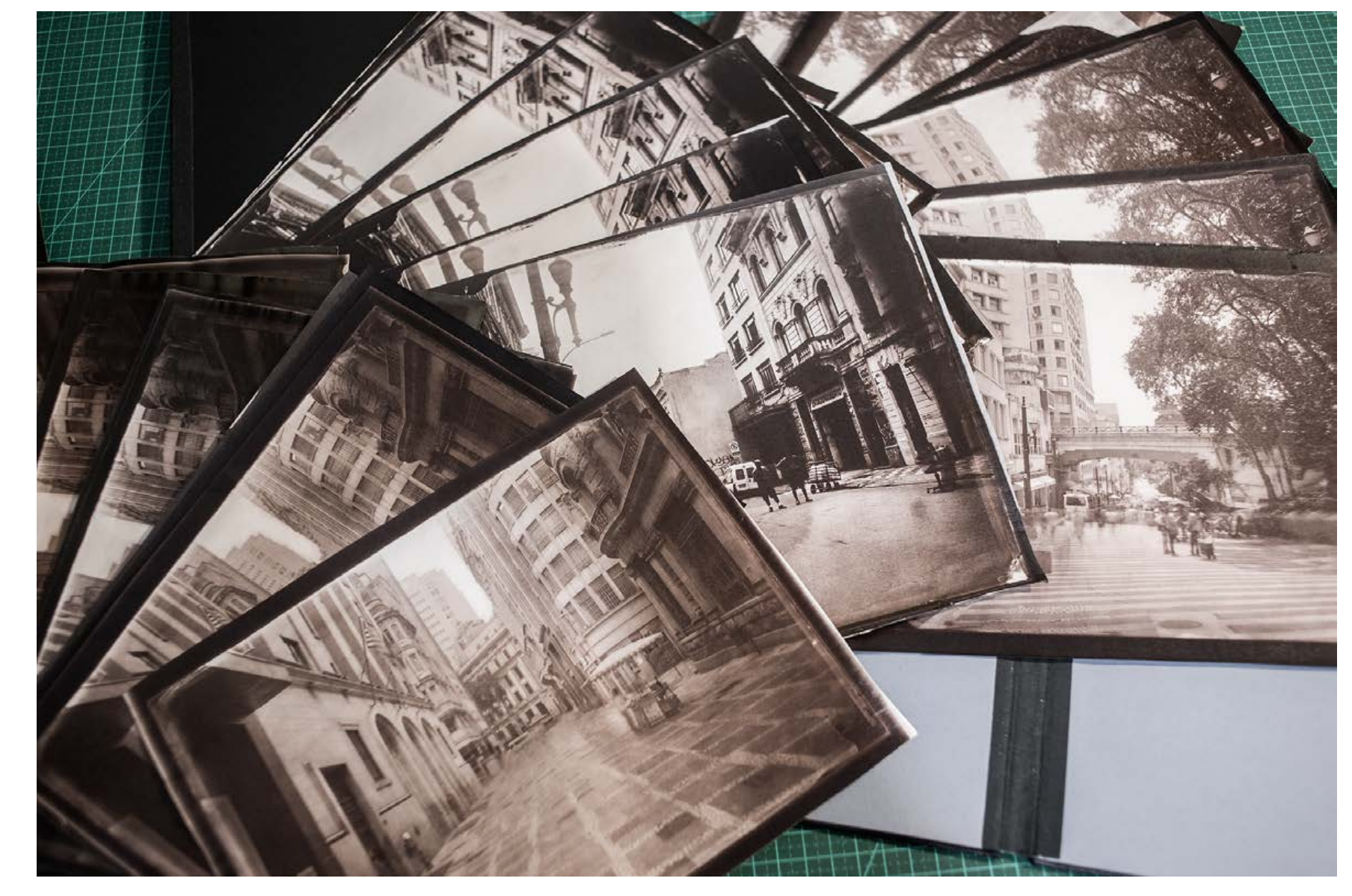


GIPHANTIE
Tiphaigne de La Roche, 1760

Capitulo XVII. A Tempestade.

A alguns passos do ruidosos globob, havia um buraco no chão e se viam
quarenta ou cisquenta degraus cobertos de relva, ao pé dos quais havia uma trilha batida, subterrânea. Entramos. Meu guia, após me conduzir por diver -

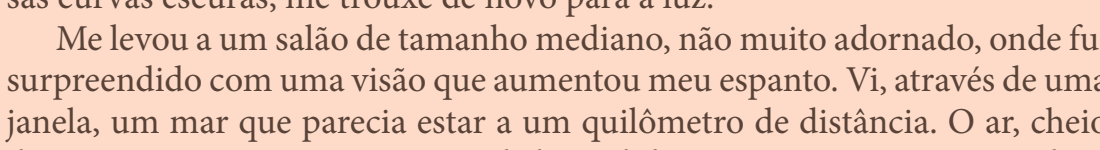

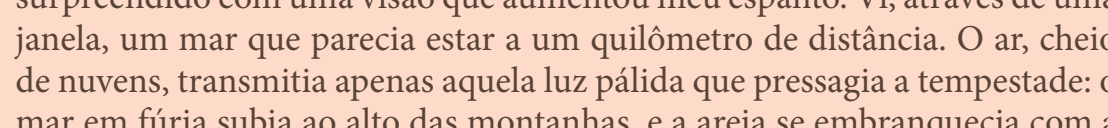
mar em furia subia a a alto das montanhas, $\mathrm{e}$ areia se embrannuecia com espuma das ondas que quebravam na praial
Por qual milagre, exclamei, o ar até há pouco sereno de forma tầ repentina se obscureceu?? Através de qual maravilha estou vendo o oceano no
Centro da Africa? Após dizer estas palavras, me precipititi adiante para con 作 pancada, e ainda mais por tantas coisas incompreensiviveis, dei cinco ou sels

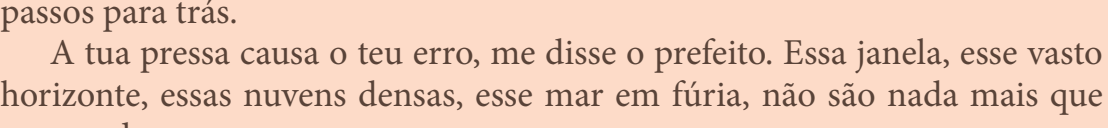
um quadro.
De um espanto, passei a outro. Rapidamente me reaproximei; meus olhos
ainda estavam incrédulos, e minhas mâos mal podiam convencer-me de que uu quadro poderia criar tamanha ilusão.

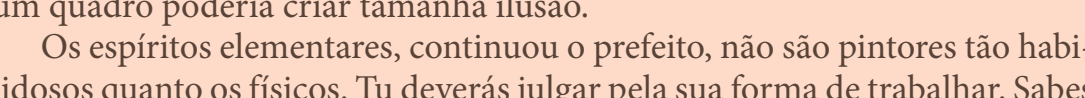
que os raios de luz, refletididos nos diferentes corpos, criam imagens e pintam
estes corpos sobre as superficies polidas, na retina do ollho, por exemplo, na água, no vidro. Os espíititos elementares estudam como fixar essas imagens
efémeras; eles compuseram uma matéria extremamente sutil, muito viccosa

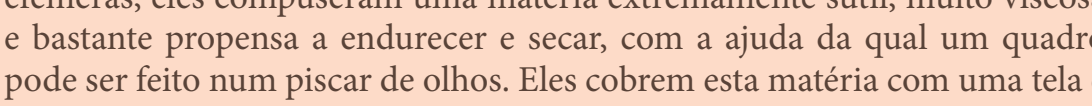

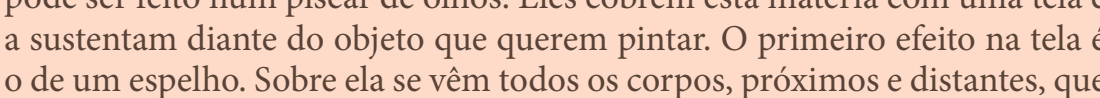

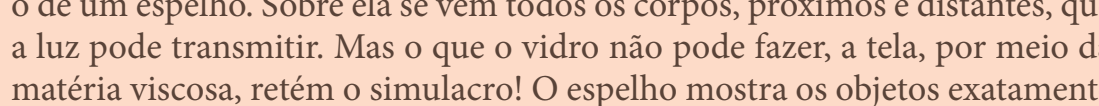
como são, mas não retém nenhum. Nossas telas os mostram com a mesm
exatidào, e retêm a todos. Esta impressao das imagens é feita no primeiro Instante em que são recebidas na tela, que imediatamente é levada para
lugar escuro. Uma hora depois, a sutil matéria secce e obtém-se um anu lugar escuro. Uma hora depois, a sutil matéria seca e obtém-se un muadro
de grande valor, já que nâo pode ser imitado pela arte, nem danificado pelo

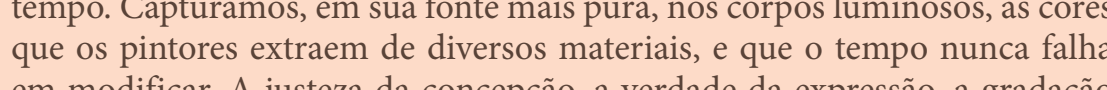
em modificar. A justeza da concepcāo, a verdade da expressão, a gradacăa
das tonalidades as pinceladas mais fortes ou fracas, as regras da perspection

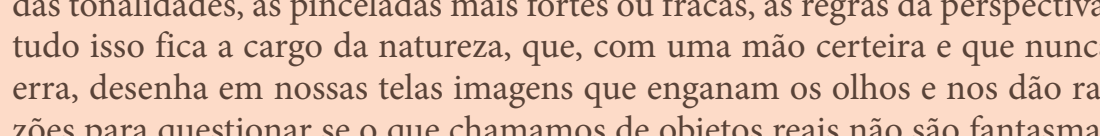

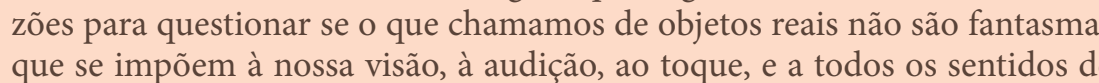

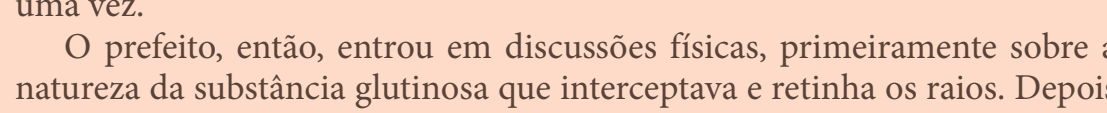
natureza da substância glutinosa que interceptavae retinha os raios. Depót
sobre as dificuldades de preparáala e utiliza-la. E, por fim, sobre o conflitio sobre as dificuldades de prepara-la e utiliza-la. E, por fim, sobre o conflit
entre os raios de lue a a substancia seca. Trés problemas que proponho aos
fisicos do nosso tempo, edeixo à sua sagagacidade.
Enquanto isso, eu não conseguia tirar os ol olos do quadro. Um espectador sensível
que da praia contempla um mar tempestuoso, não poderia ter impressoes mais vividas: tais imagens são equivalentes às próprias coisas.
O prefeito interrompeu meu exxtase; estou prendendo-te, disse ele, muito tempo 政 goricamente o preocupante estado deste mundo, e a tempestuosa passagem do homen
por ele. Vira os teus ollhos e contempla aquilo que saciars tua curiosidade e aumentart ou a Fortuna da Raça Humana.

Mal o prefeito disse essas palavras, e uma porta dupla se abriu à nossa direita, le.
vando-nos a uma enorme galeria, onde minha surpresas se transformou em deslumbra-

mento.
Acima, dos dois lados, duzentas janelas deixavam a luz entrar com tal intensidade que os olhos mal podiam tolerar seue esplendor. O espaço entre elas estava pintado com

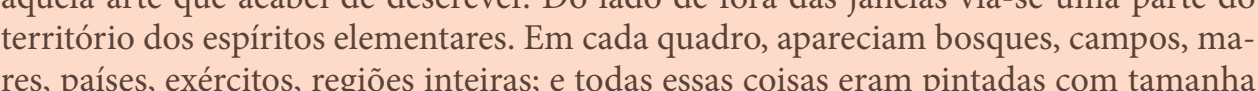
vendo através da janela não era pintura, ou se o que estava vendo no quadro não era Investigue com os olhos, disse o prefeito, investigue os mais memoríveis aconteresta dessese enormes avanncos, dessas grandes facanhas? Ses Seus vestigios mais reais saio os 
É curioso que o conto Giphantie, altamente fo-
tografico, tenha sido escrito quase 80 anos antes do anúncio público do daguerreótipo, em 1839 , tid
como o iníio da fotografia prática. A descricáo
processso dos espiritos elementares tem uma simila ridade nos passos que é impressionante, apesar de
imagens não serem capturadas por câmeras, mas retamente sobre elelas semelhantes a espellos. Vale
lorçar que o daguerreótipo é uma imagem sobre

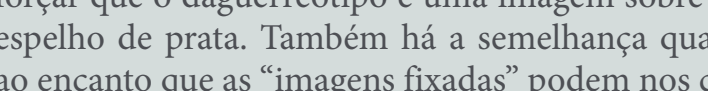
sar. Nós certamente nåo batemos nossac cara nas for
grafias como o personagem o faz ao pensar que grafias como o personagem o faz ao pensar que
colocar sua cabeça por uma janela. Mas talvez, se b têssemos, a pancada poderia quebrar o encanto e no
fazer dar alguns passos pra trás e repensar o que ela Alaro, ao ver fotografies devemos nos har the ser levados pelo seu encanto e mesmo tentar enfiar
cabeça nela como se fosse uma janela - às vezes sentimos que dá certo. Talvez o segundo momento sén
o de dar uns passos para trás e ver do que se trata esse "unadro". O que propus aqui foi olhar com
nos pressa as fotografias do passado distante, mas os mesmos questionamentos valem para as fotografias
recentes. Busquei no trabalho do Militäo um refe recentes. Busquei no trabalho do Militão um res
rencial para este exerćcio de pensar se a fotografia sua materialidade e suas condiçóes de criaçäo. Tent chos de meu próprio caminho, como quando cien-
listas tentam rearanos tistas tentam recuperar o DNA incompleto de um
animal extinto usando trechos do DNA de um anié ivual ao que eraa assim como o que resulta deste
traballo sao apenas dideas do que pode ter sido.
Interessante que passo este trabalhe todo defen- dendo que a fotografia é influenciada pelo contex
em que é criada, e também que é importante conside

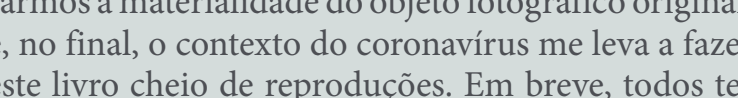

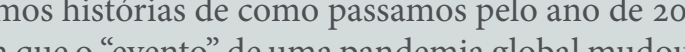
planos de todos. Logo vi que para mim seria imprast avel continuar a fotografarar em placa úmida nas r r lao incompativel com meu contexto e decisivo pa-
s fotos que pude e não pude fazer. Minha intenģ

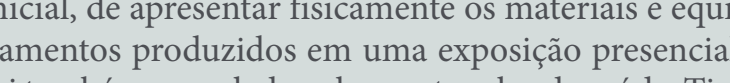
cancelada pelos protocolos de saude. Tive forma de livro. Um desafio para mim.

Reproduçoes sao um problema, pois a fotogra-
acaba sendo impostora dela mesma. Se o ditad onto", no caso das geraçōes de reproducōes fotogntsriamente em qualidade, mas em informaçồs

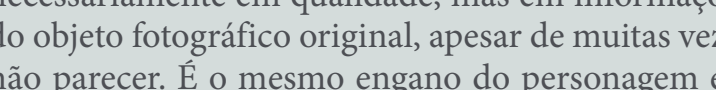

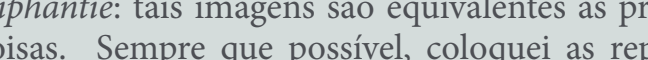
coes em tamanho original, descrevendo seus mate
cis, e também fazendo fotos em diversos ang para mostrar melhor o objetoe e não sóa a imagem

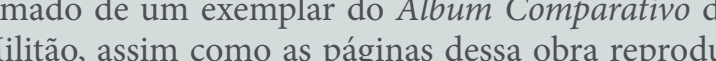
las aqui, para dar ao leitor um pouco da impression manipular o origin

Incentivo os gue se interessam por fotografia
Entar ver pessoalmente exemplares de objetos

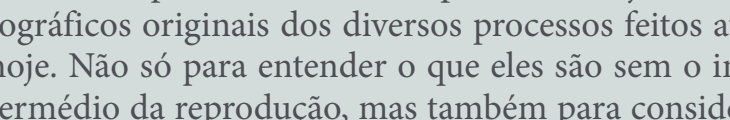

rar o uso de algum desses processos como elemento
de criação autoral. Pode ser chocante perceber que

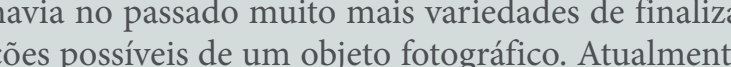
a maior parte das imagens feitas nunca deixa o limb
das telas digitais e, quando são materializadas

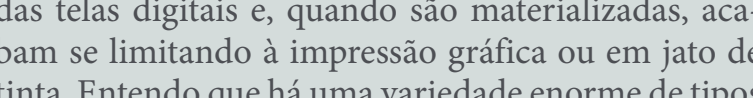
de impressora jato de tinta que imprimem numa va-
riedade enorme de tipos de pappés, mas são, em sua essência, todoso o mesmo processso de impressasoo en de valor $a$ a riorit só un alerta de que há um enorme
nenu de possibilidades já desenvolvidas que estão disponiveis à consideracăá.
$\mathrm{O}$ aspecto um tanto caótico das várias fontes $\mathrm{d}$ nfformacão que incluí é minha tentativa de transmi-
ir o que foi para mim estudar, praticar e fotografar m placa úmida. A dificuldadad náo é só descrevere Lembro de ere lidido uma palestrá do fisicico Niels Bohr sobre seu princípio da complementariedade, e del algo de uma forma geral para qualquer contexto, use
mais formas, até antagónicas; cerque, defina o algo pela complementaçäo de descriçōes limitadas. É um primeira vez seu princííi em uma convençáo en 1833, que Fox Talloo faz suas primeirias anotaçóses sootográficic negativo-positivo. Duas pessoas tentand plementariedade.
Relata o próprio Talbot, que à beira do lago de
Como local procurado por sua beleza, ele tentava
fazer um registro da paisagem, provavelmente para azer um registro da paisagem, provavelmente par
levar de volta como souvenir à sua casa na Inglaterrr Sendo antes da fotografiai, o que se podia fazer para
lso era um desenho ou pintura à mào Para aux-

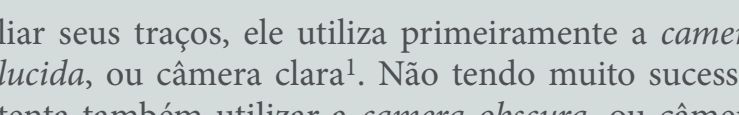

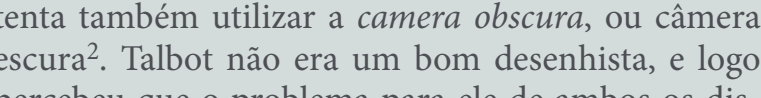

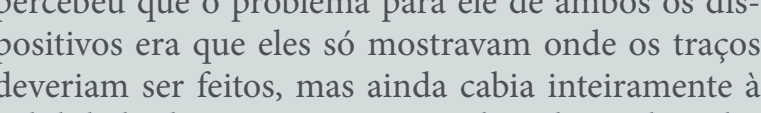

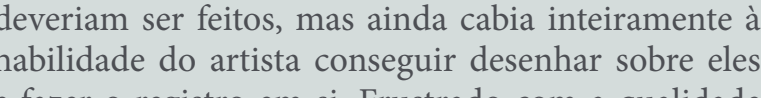

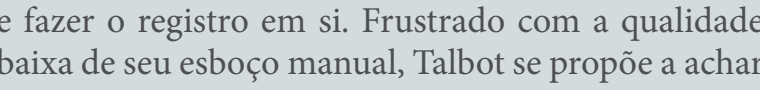
uma forma de fazer com que a imagem formada pela
camera escura fosse diretamente registrada sobre o

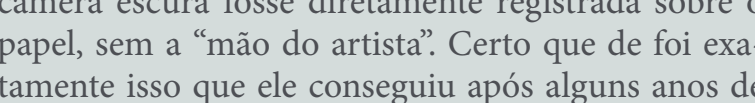
pesquisa, ele incluiu as seguinte nota aos exemplares
de $O$ Lapis d d Natureza:

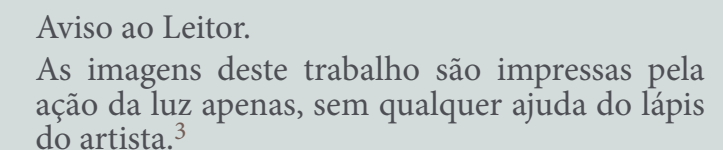

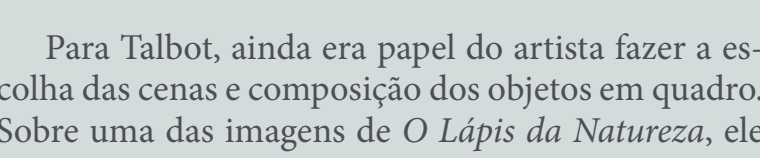

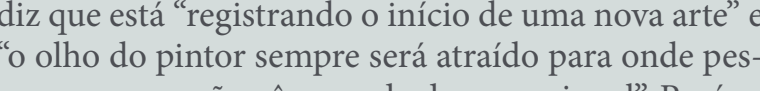
soas comunns nan veem nada de excepecional." Porém,
o registro final sobre o papel seria obra da natureza.

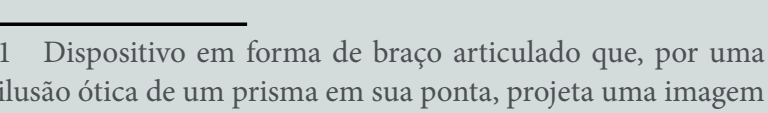

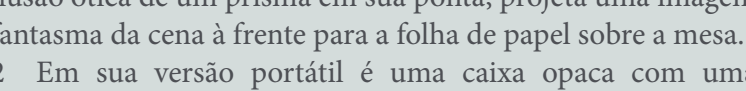

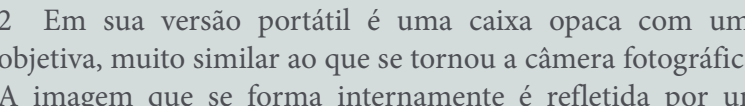

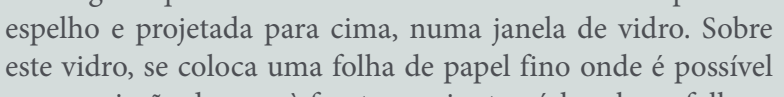

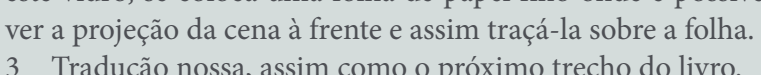

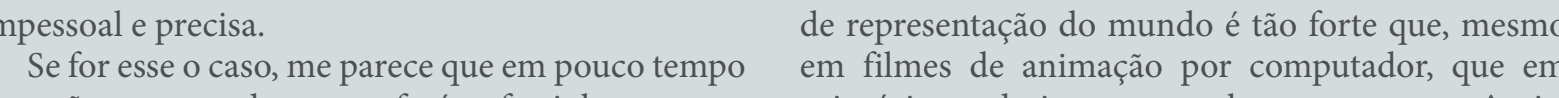

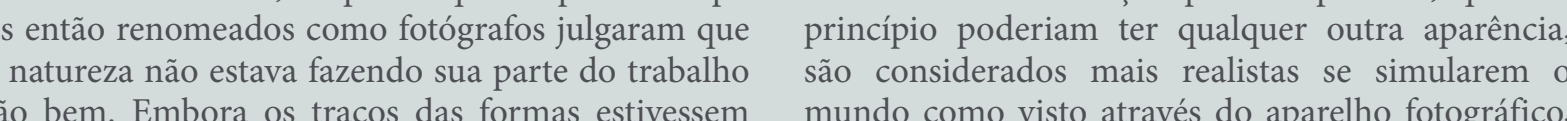

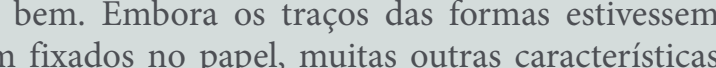

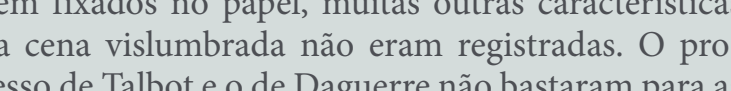

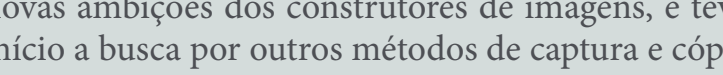

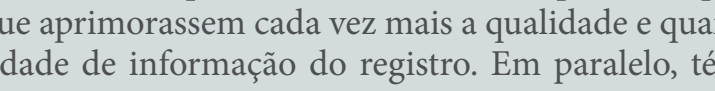

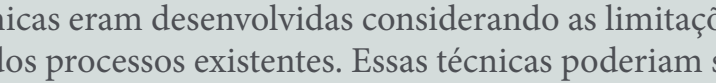

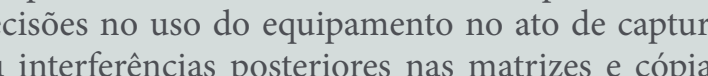

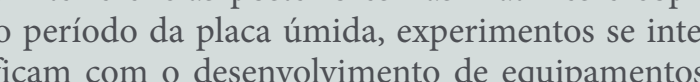

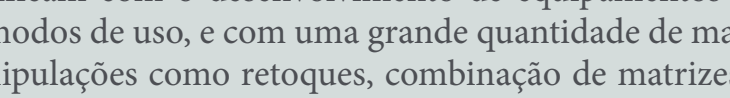
colorizacesese mudancas de suporte.

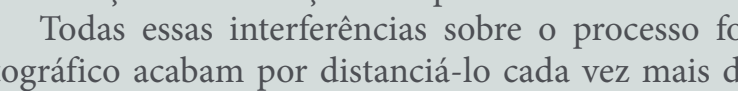

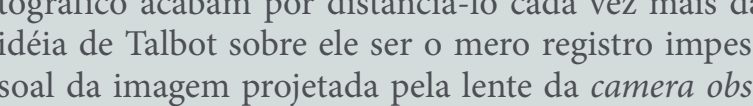

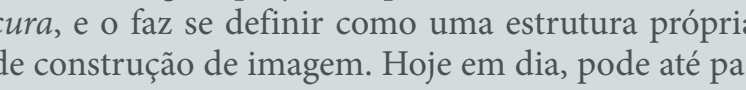

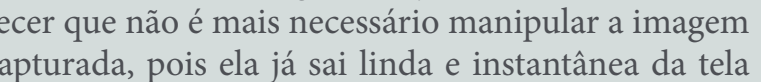

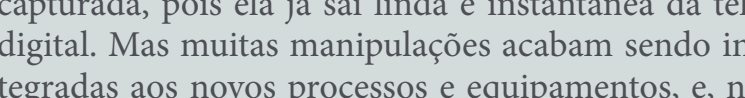

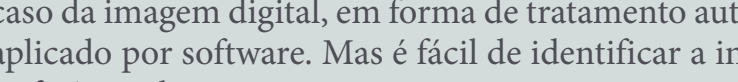

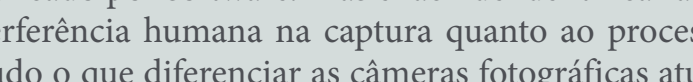

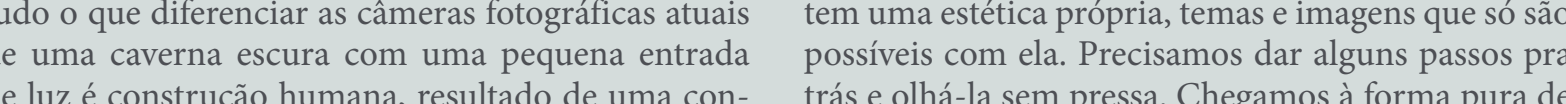

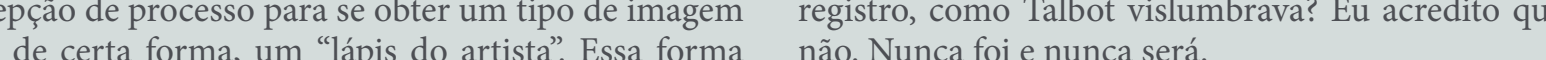
a câmera escura. Se o desenvolvimento da técnica fotográfica ten
sido uma busca por um maior realismo do regis tro, para mim fica a impressão de que os envolvido
nunca chegaram a um acordo sobre o que é a realidadee como ela deve ser registrada, fazendo com que
a fotografia tenha se expandido em direçoes muito diversas e interessantes, expondo também a falta
unanimidade sobre a intenção em seu uso. Mesmo aqueles que não fotografam procurando registrar
um mundo realista" encontram na vocaçao cientifica da fotografaia um grande trunfo artístico, esta
dubiedade com o real. De forma que não sei dizer se acabamos ajudando a natureza com um novo lápis bs, em sua tarefa de desenhar-se a si própria, con Embora neste resgate eu tenha me surpreendido nem coloquei tudo aqui, sei que não cheguei perto

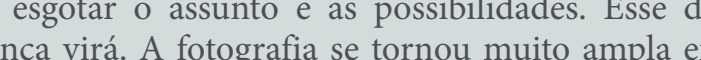
mos de usos, intençōes, motivos, procedmentios

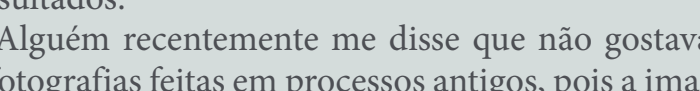

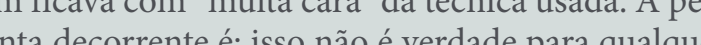



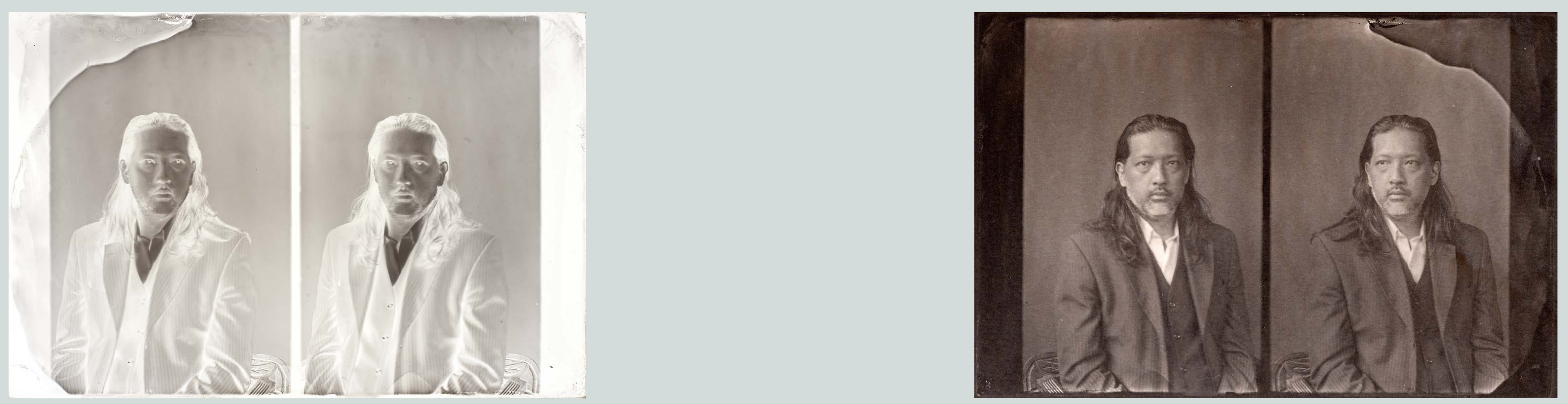
$\begin{array}{ll}\text { Pelas anotacāo do Livro Copiador de Militiāo, ele } & \text { se o tempo for frio ou fresco. Pode ser guardado por } \\ \text { mais tempo na geladerira, mas deve ser tirado com an- }\end{array}$ servaçōes sobre as differentes qualidades dos encon- tecedência para voltar à temperatura ambiente antes especificas sobre o papel, além de ser extra-brilho

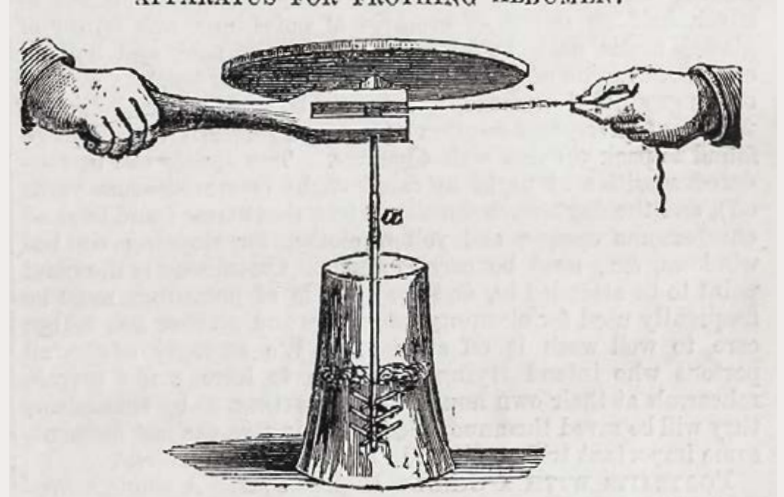

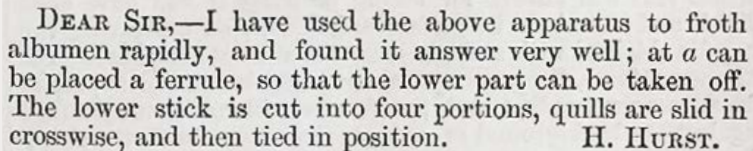

Felizmente eu posso ter o luxo de usar uma batededira orbital
eletrica. Quanto mais bemb batido allumen, mais rapidio ele O meu procedime do projeto, pois fui pela estrada autodidata, tirando dúvidas em conversas com colegas. As in truçōes a seguir são apenas um resumo do métod
resultante para se ter ideia geral do processo. Acho passos ainda me geram dúvidas. Se alguém for segur duir seus próprios testes e também con

Aplicacăo
Deixar a albúmen em temperatura ambiente

Se houver sólidos, filtrar em filtro de café.
Colocar o alburmen cuidadosamente em travessa

um pouco mais larga que a folha de papel.
Retirar bolhas e sujeiras da superficie com a aju-

Você terá que testar papéis adequados para o
processo. Em geral, são finos, pouco texturizados

e aguentam os banhos de água. Eu usei o Canson

Preparação do papel

Albúmen $2 \%$
Clara de ovo (albúmen)
Cloreto de amónio

Usar vors novos, com atét dias, de refereñencia casca, gema ou calaza (filamento branco).

Bater em batedeira até se formar uma clara
heve rigida
Deixar descansar coberto por um pano para Deixar descansar coberto por um pano para
guefazer por algumas horas (deixar de um dia para Ditro) em uma sala fresca.
Drenar cuidadosamente somente o liquido, seg ando o restante da crosta de
Filtrar em filtro de café. Guardar em um frasco fechado por alguns dias fa-

Dobrar 1cm ao longo de cada lado menor da follh

Curvar a folha com o meio para baixo e deití-la
Conte suave e continuamente sobre o albúmen até ela ficar
plana flutuando sobre o liguido.

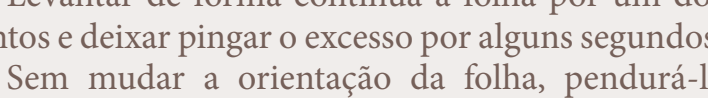
para secagem.
O ideal é sećlas com calor para aumentar o bri-
lho. Nảo usar secador de cabelo. Guarde as follhas secho. Não usar secador de

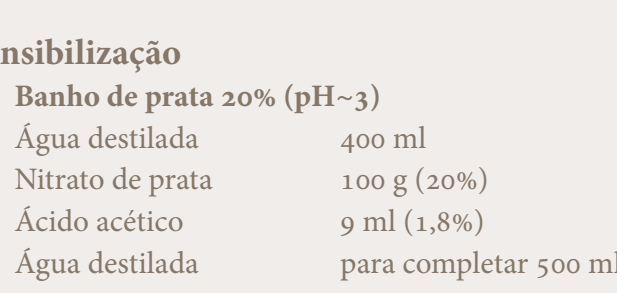

da de uma tira de papel. Arraste-a pela superficieie $d$
Colocar o banho de prata em uma bandeja um

Após a exposiçăo, recortar o excesso de margen

de uma tira de papel.
Segurarar a folha allbuminada pelas dobrase curvà-

-la da mesma forma que no procedimento anterior.
Deitar a folha sobre o banho de prata: ao invés do centro pra bordas, fazer de um lado para outro Deixar flutuar por 3 minutos antove deixar pingar o e excesso por allumus um dos Sem mudar a orientaçáo da folha, pendurar-la ho Flutuar por cerca de go segundos.
Levantar de forma continua a folha por um dos Com a folha sensibilizada seca, é necessário usar
uma contateira nå muito maior que o negativo $e$ e
que tenha a madeira de pressão bipartidida para vocé que tenha a madeira de pressaio bipartida para você
poder inspecionar a cópia. poder inspecionar a copia.
O tempo de exposicáa à lux depende de alguns
fatoress: o principal é a densidade e contraste do neerer ão de apenas alguns minutos. Negativos mais suaves devem ser expostos virados para o céu oposto ao So a contateira com algumas follhas de papel vegetal. A
exposicãof fica mais longa, podendo levar até algumas horas.
E necessário expor até a imagem ficar um tanto mais escura que o desejado, pois ela clareia durante deve ter um aspecton levementente metalizado, pois indi-
ca que estána densidade máxima

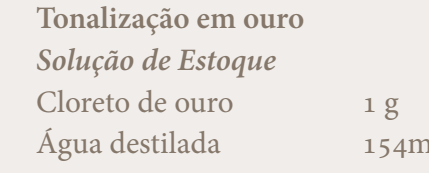
Tonalizador de ouro-bicarbonato
Soluciá de trabalho $\begin{array}{ll}\text { Solluçáa de e estoque de ouro } & \begin{array}{l}20 \mathrm{ml} \\ \text { Agua destilada }\end{array} \\ 700 \mathrm{~m}\end{array}$

Pode-se adicionar mais água ou ouro para contro-
lar a velocidade da tonalizaçao. Uma velocidade entre 5 e 10 minutos é
cópias $20 \times 25 \mathrm{~cm}$.
Cada $10 \mathrm{ml}$ de solução de estoque irá conter

Antes de colocar no tonalizador, deixar por un
minuto em um pré banho com o mesmo pH.

$\begin{array}{ll}\text { Água deionizada } & 500 \mathrm{ml} \\ \text { Bicarbonato de sódio } & \text { para } \mathrm{pH} \text { ( cerce de } 122\end{array}$ Colocar a cópia no banho totalizador agitand
lentamente. É possivel usar uma fraca luz incandes cente para avaliar a mudança de cor da cópia.
Deixar até adquirir uma coloraçáo neutra-azu lada. Enxaguar em água por alguns minutos. Troce pelo menos uma vez de àgu

Fixação

Fixar em dois banhos de 5 minutos cada em soluFixador de tiossulfato de sódio $(15 \%)$

$\begin{array}{ll}\text { Agua deionizada } & 700 \mathrm{ml} \\ \text { Tiossulfato de sódio (penta) } & \\ 235 \mathrm{~g} & \text { (150 g se anidro }\end{array}$

Lavar por 5 minutos em água corrente.
Banhar as cópias em um auxiliar de lavagem $2 \%$ de sulfito de sódio em água por Lavagem em água corrente por 30 minutos.
Enxiague final em água deionizada.

Secage

Pendurar para pingar o excesso de água.
Secar entre folhas de matataborazas ofo pos

Opcionalmente, secar fixando a cópia sobre uma
placa de vidro maior, colando ao redor dos lados com 
A secăo A Catechism of Photography (Um Ca-
tecismo de Fotografia) do The Photographic News

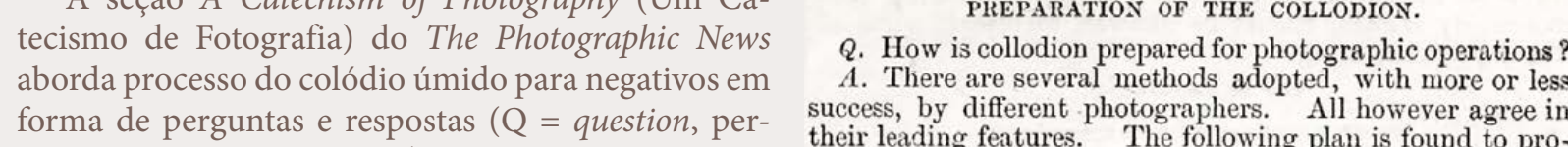
gunta; $A=$ answer, resposta).
Creio mulas e procedimentos possam ser parecidos con Rectified sulphuric ether

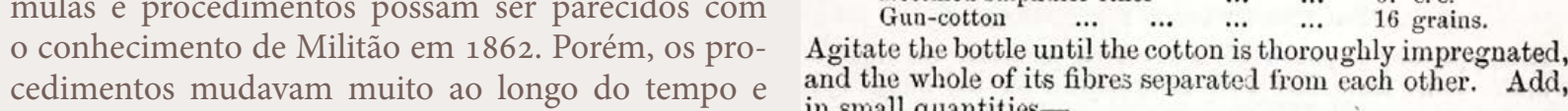
por gosto pessoal. Particularmente, não são as

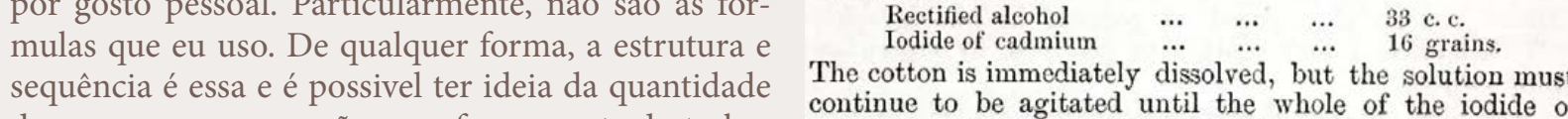

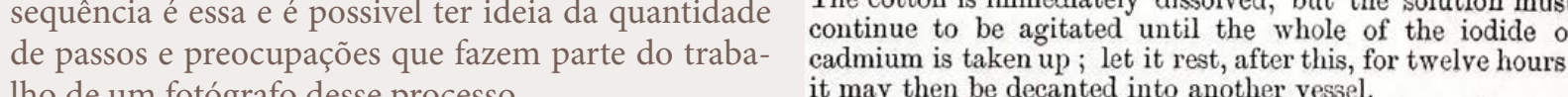

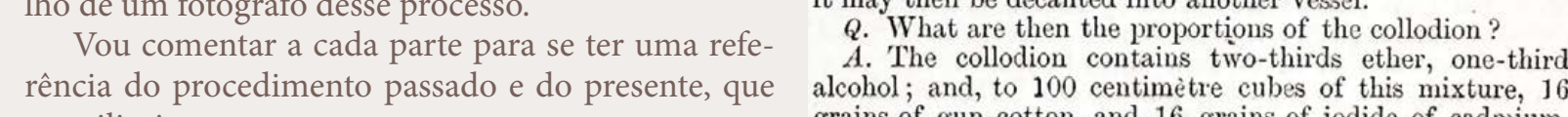

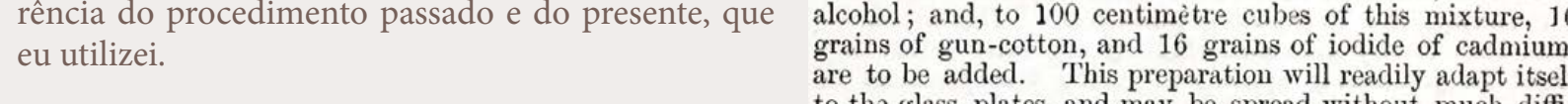

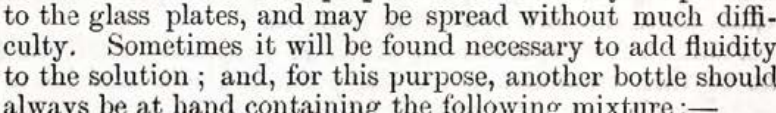

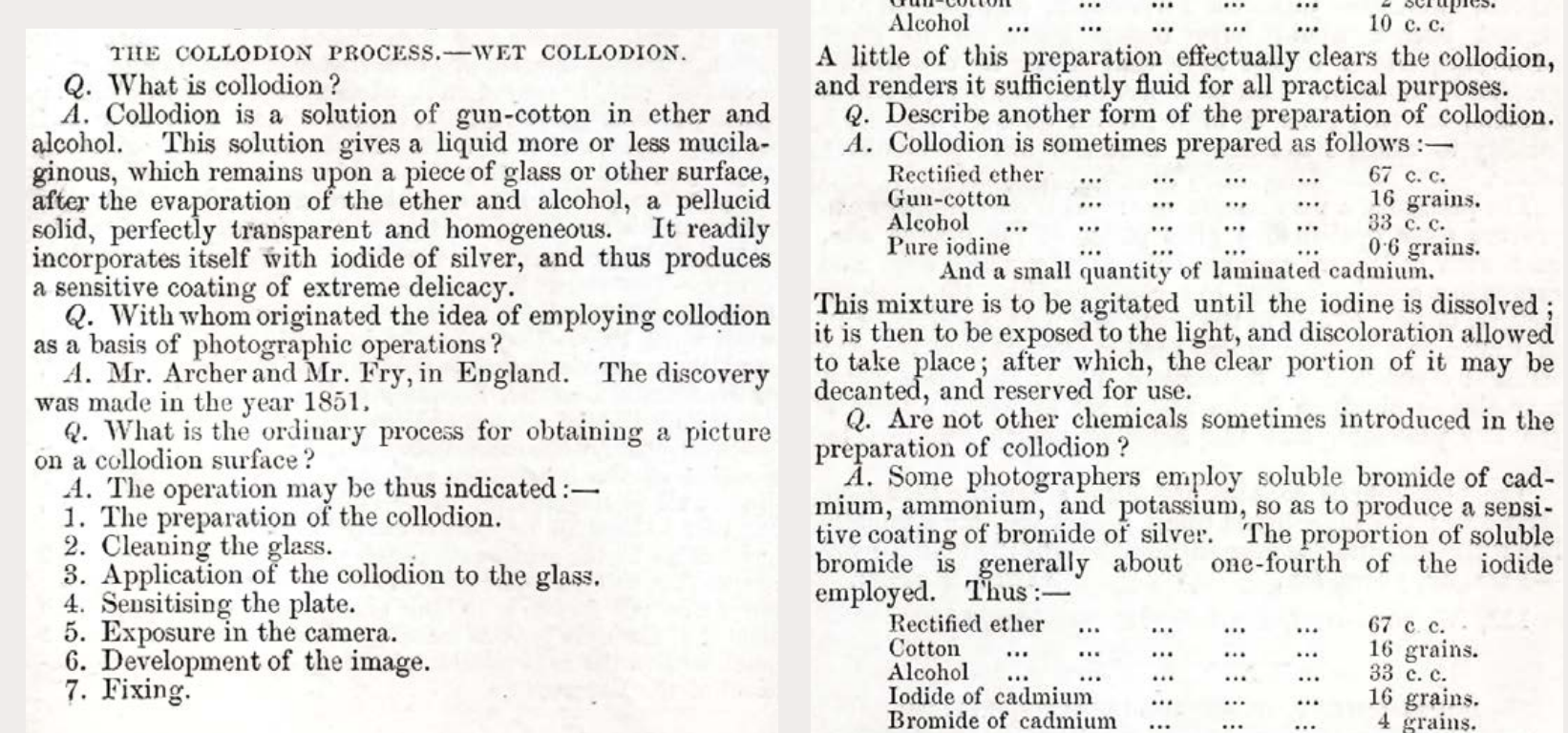

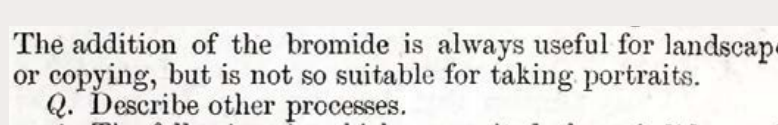

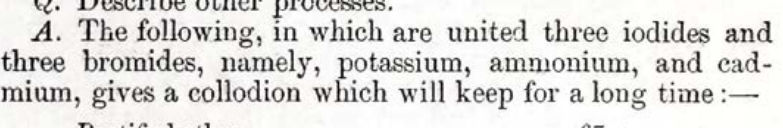

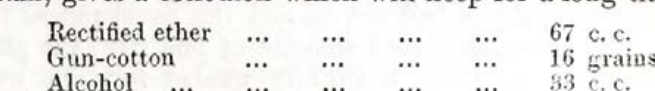

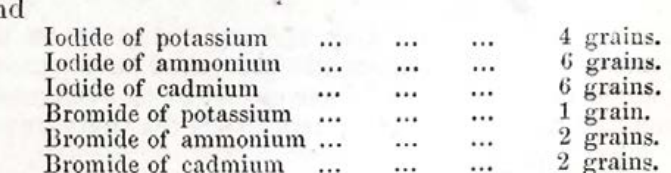

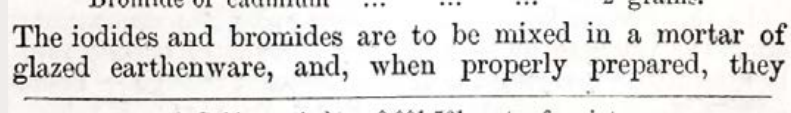

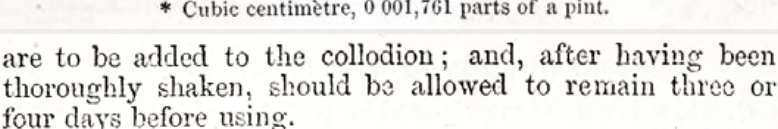

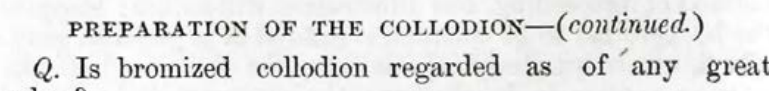

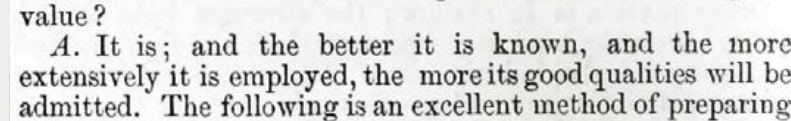

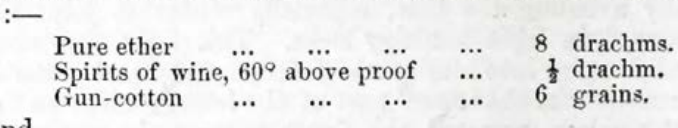

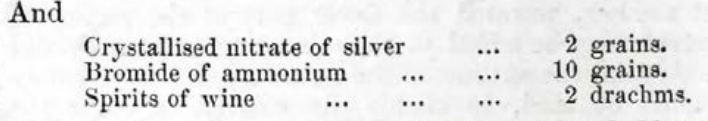

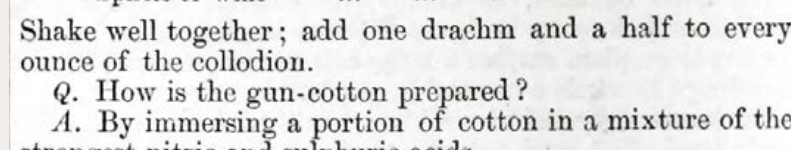
ald

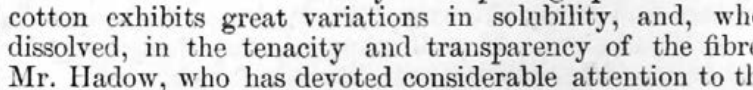

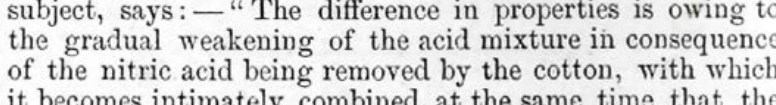

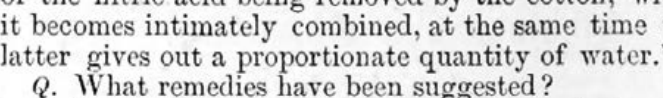

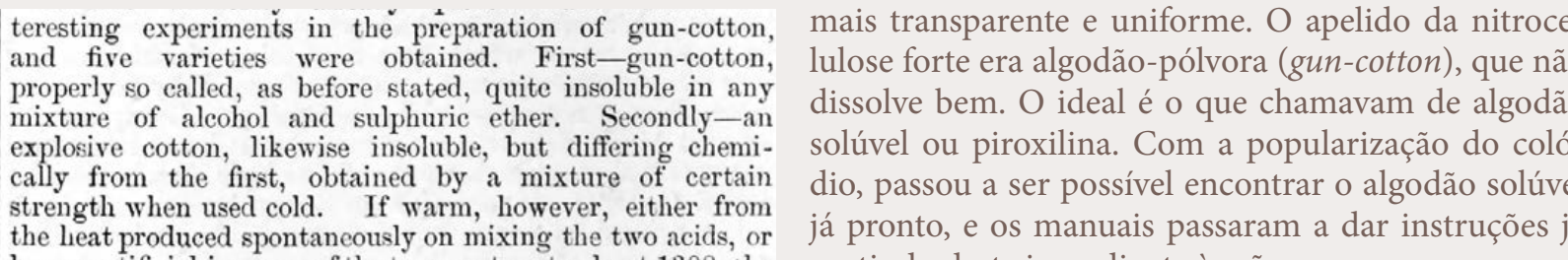
, the partindo deste ingredieftes

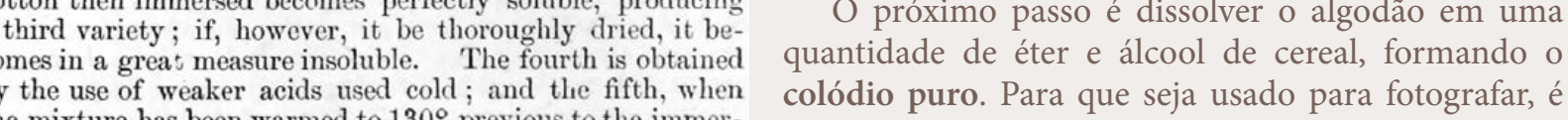

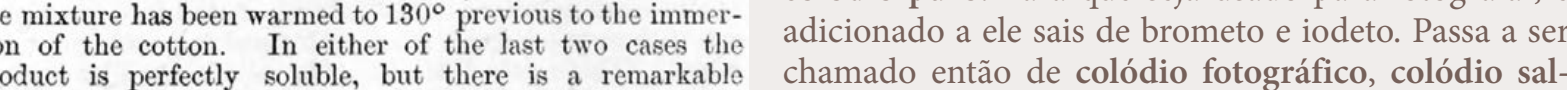

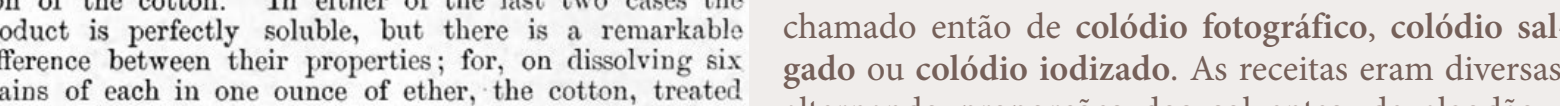

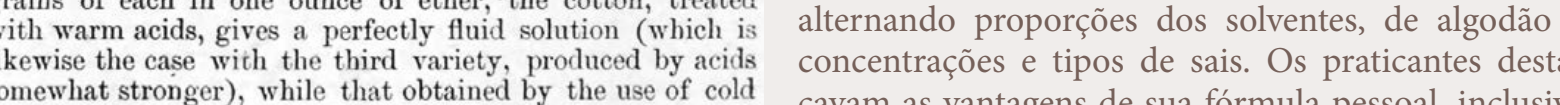

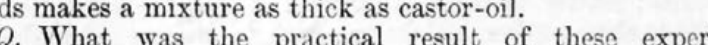
cavam as vantagens de sua fórmula pessoal, inclusie
com variantes para épocas do ano eassuntos. Uma in

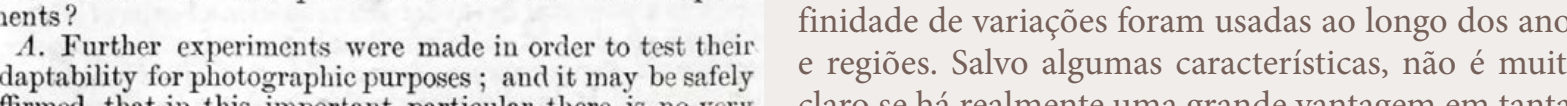
claro se ha realmente uma grande vantagemem em tantas
variaces. Eua acabie por usar a mesma receita ent toda
minha pesquisa. Ela é formulada por Mark Osterman, Colódio fotográfico $500 \mathrm{n}$

Os manuais mais antigos continham instruçôes

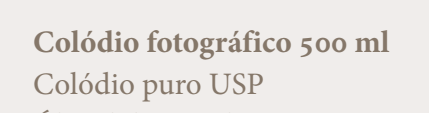

Utrico e ácido sulfún ande de ácidos e uma fumaça sufocante que não deve ser inalada. Apesar de eu ter feito o procedimento
nos primeiros anos de minha pesquisa, desaconselho
qualquer um sem conhecimento em quimica a tentar Brometo de cádmi
Iodeto de potássio
Água destilada $220 \mathrm{ml}$
$140 \mathrm{ml}$
$140 \mathrm{ml}$
$3 \mathrm{gl}$
$4 \mathrm{~g}$
$4 \mathrm{ml}$ 
How ro croose Grass.
ac. What sort of glass should be selected for the collodion
proceess?

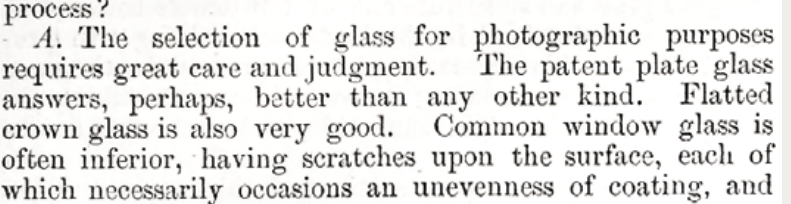

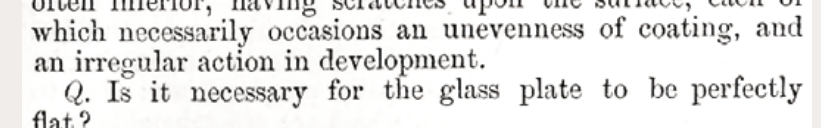

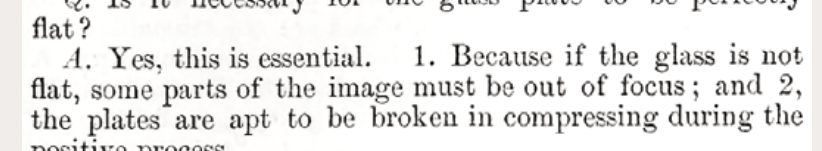

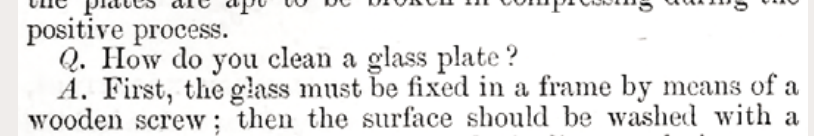

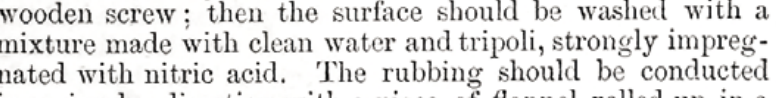

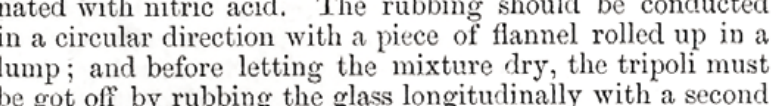

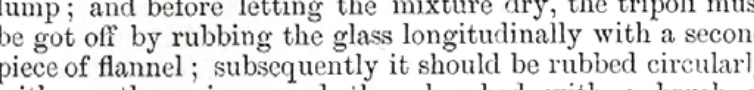

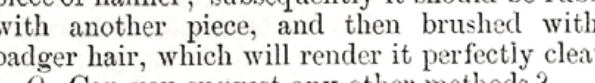

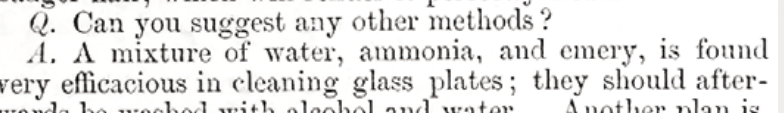

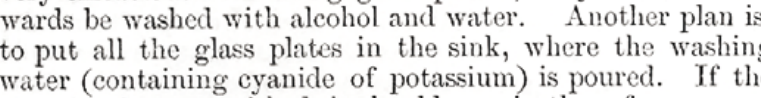

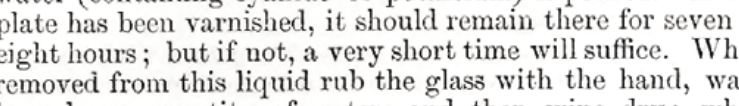

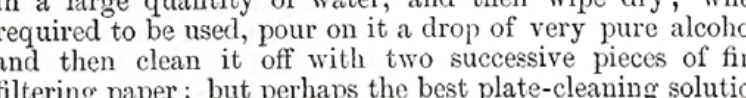

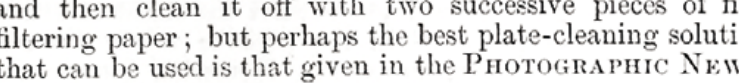

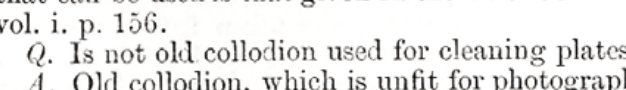

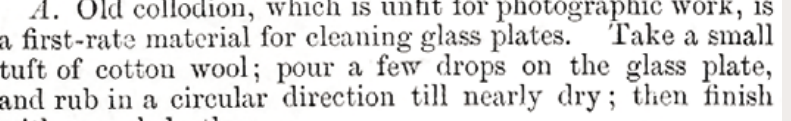

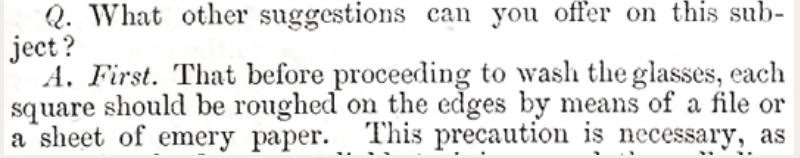

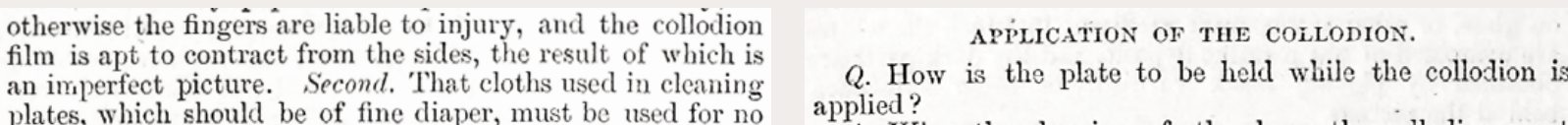

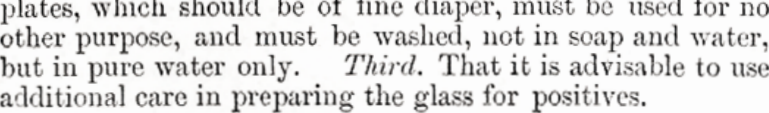
Como escolher vidro

Achar uma placa de vidro totalmente plana, essen-
cial para usar como negativo, era mais difícil cial para usar como negativo, era mais difíili antigig-
mente do que nos dias de hoje. Atualmente, umb bo
Gabricante de vidros comuns pode fornecer um vithe de 2 mm satisfatoriamente plano para esse uso co
cousto baivo Eu aprendi a cortar as placas nos vários tamanhos
que uso com um riscador moderno, diferente do que era usado. As arestas afiadas devem ser desbastadas
como o lado "fino" de uma pedra de amolar. A place

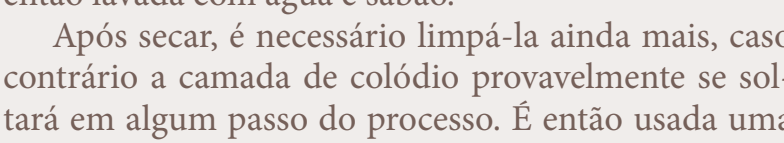
solucão de limpeza feita com trés partes iguais (p
volume) de água deionizada, carbonato de cálcio e A. When the glass is perfectly clean, the collodion muss

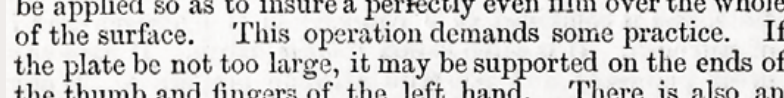

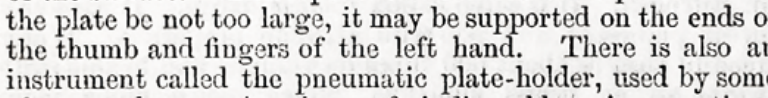

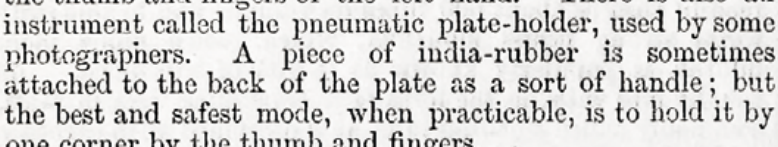

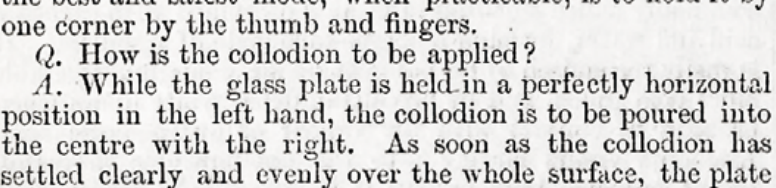

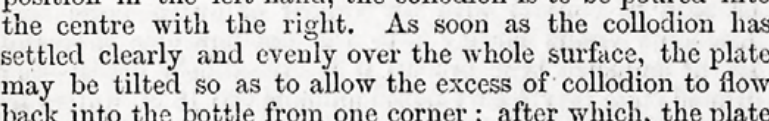

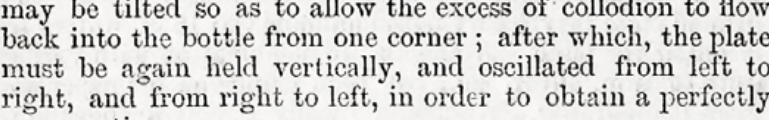

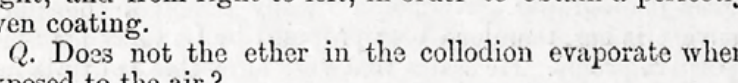

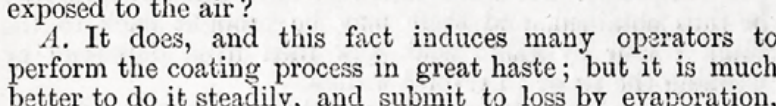

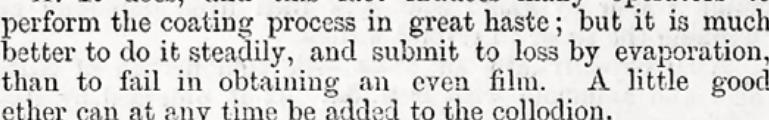

Aplicą̧ão do colódio

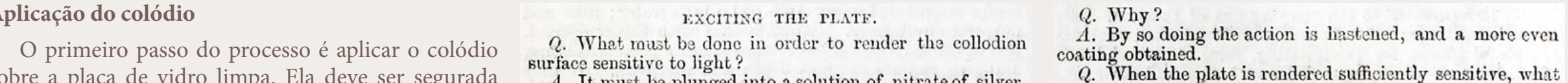

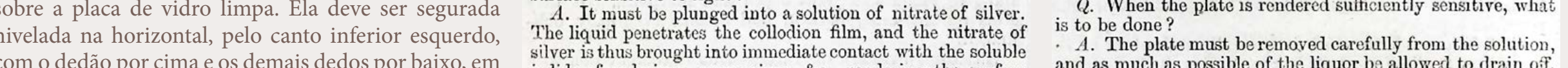

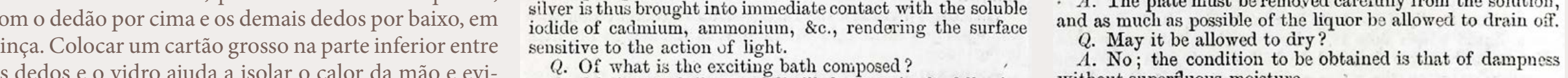

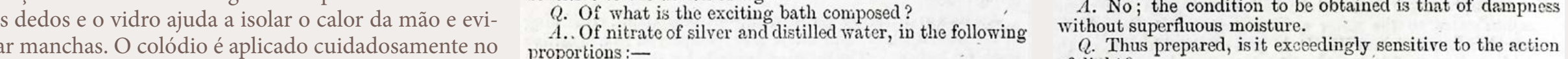

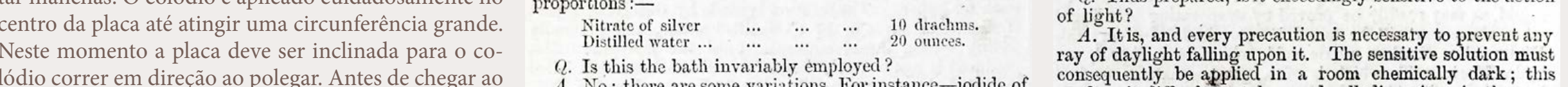

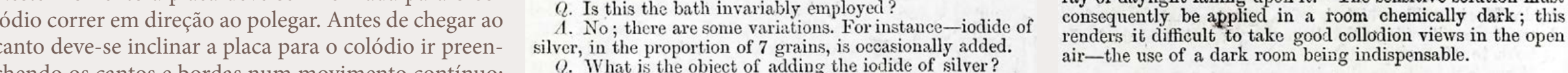

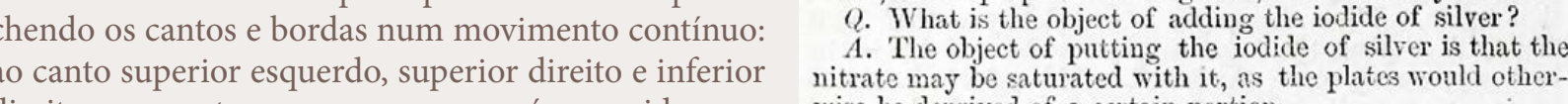
direito, momento em que o excesso é escorrido par
orecipiente de coleta. A placa é lentamente levantad para a vertical enquando se oscila para ambos os lados

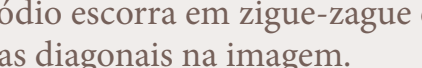

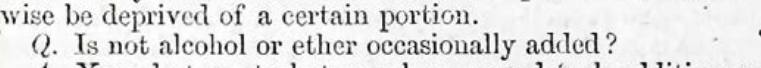

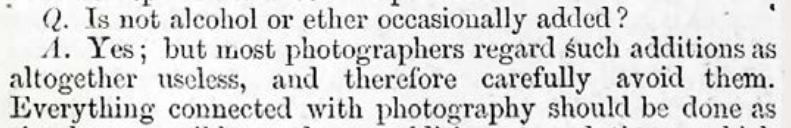

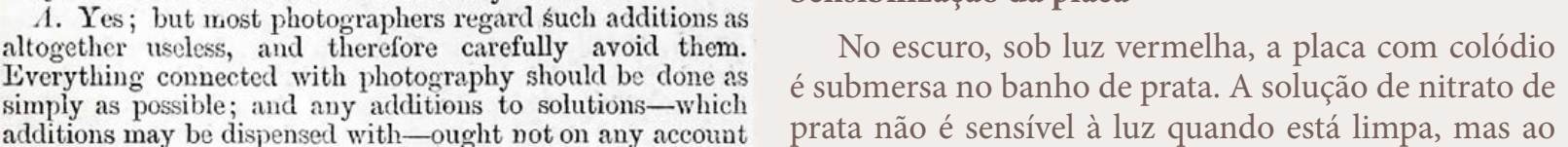
prita

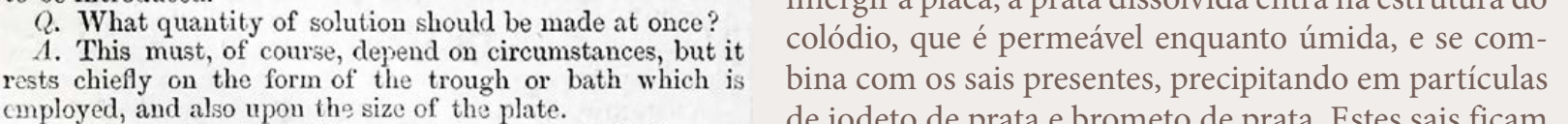

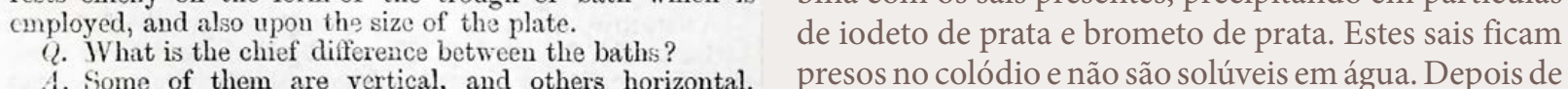

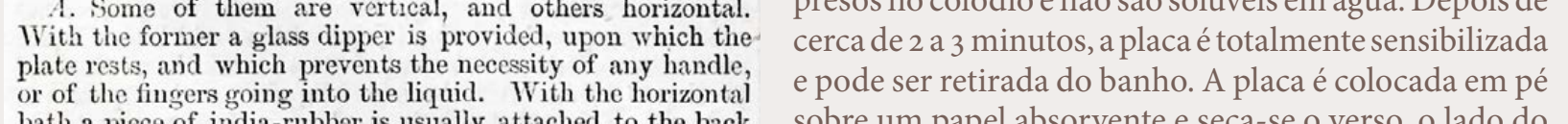

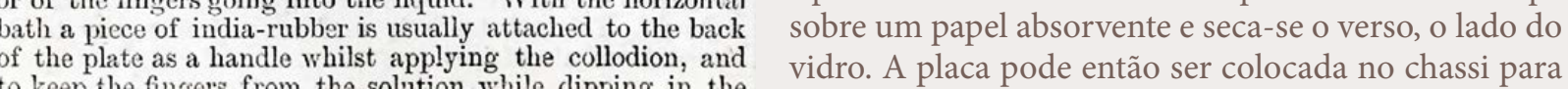

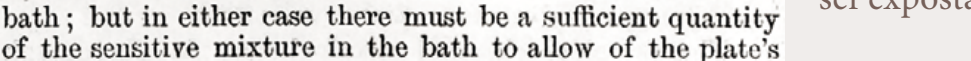

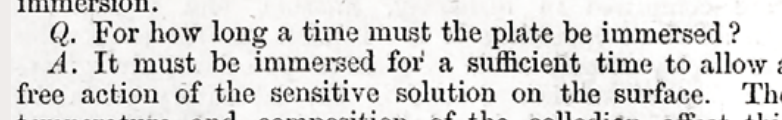

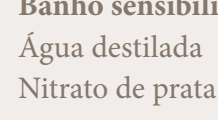

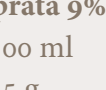

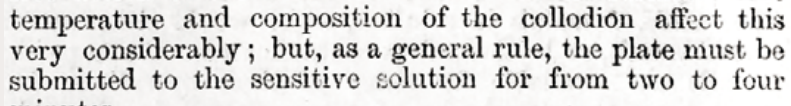
É comum o fotógrafo ter mais de um banho de

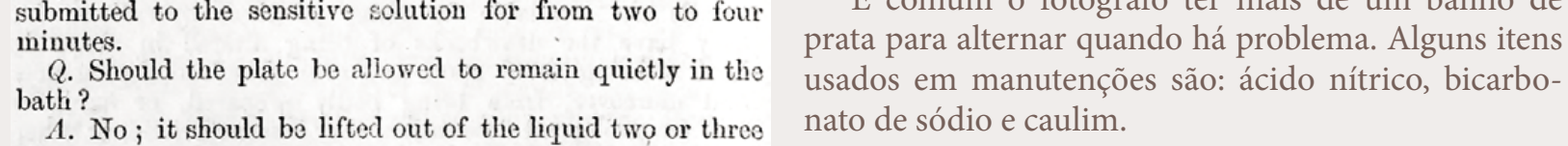




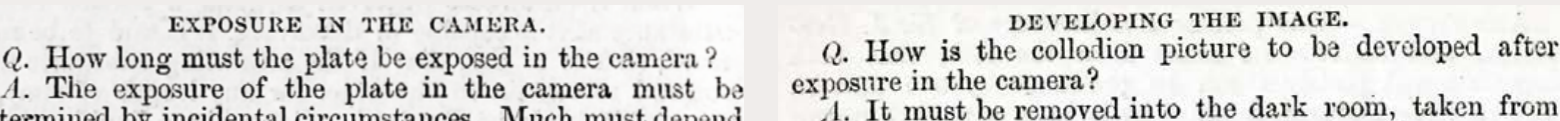

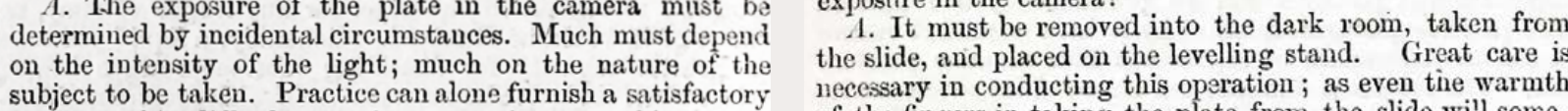

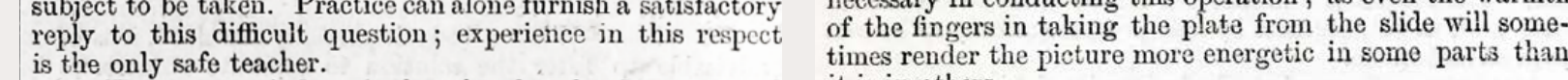

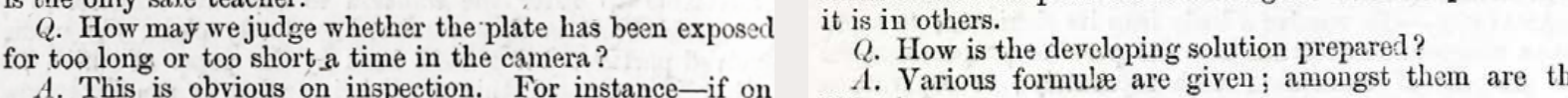

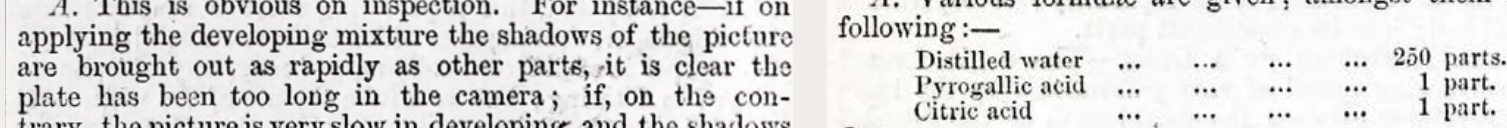

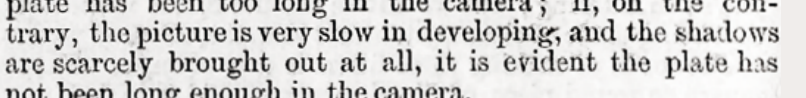

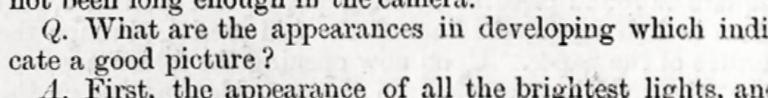

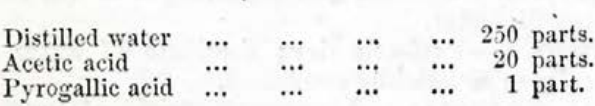

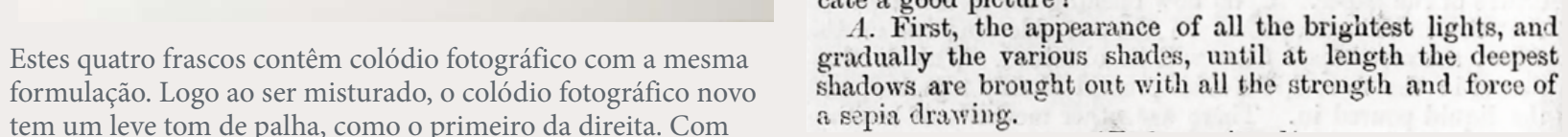

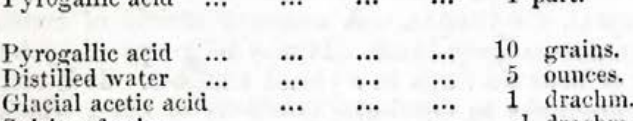

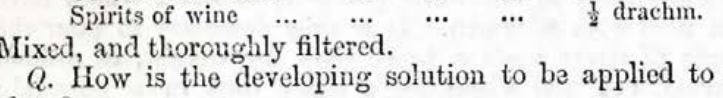

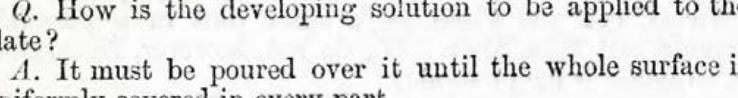

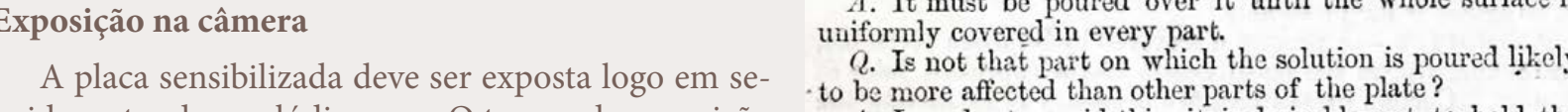

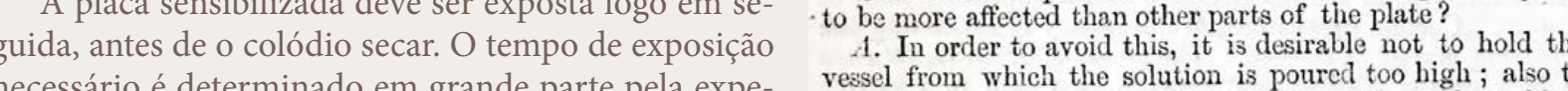

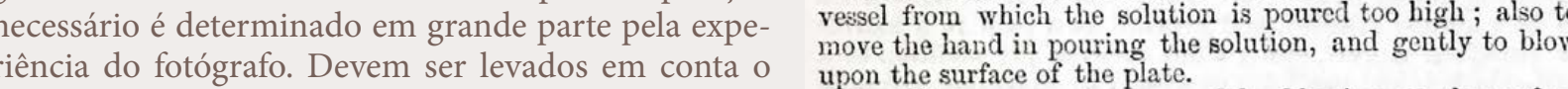

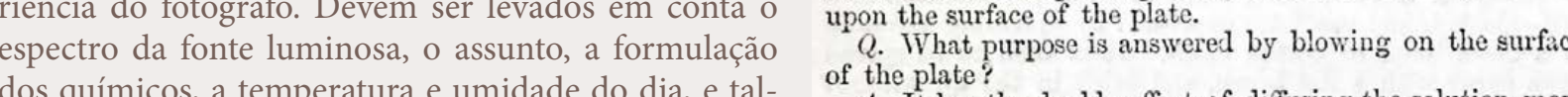

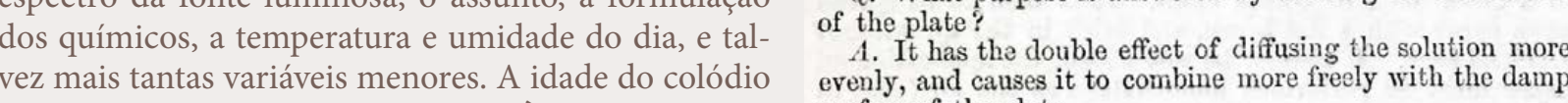

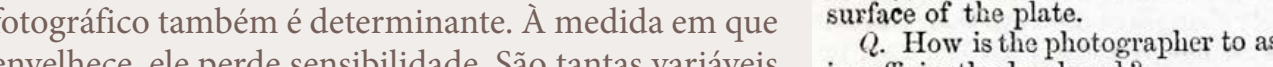

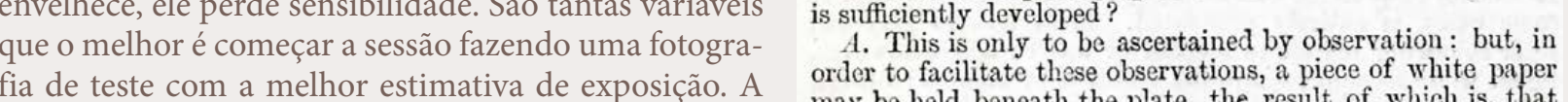
partiti dela, fazer os os justseses necessararos.

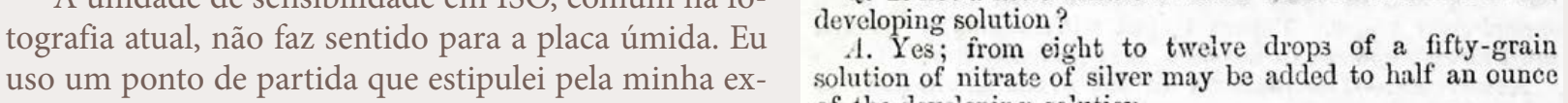

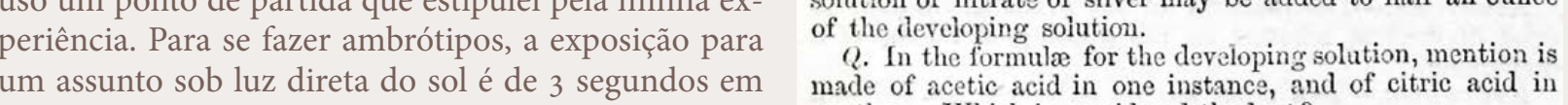

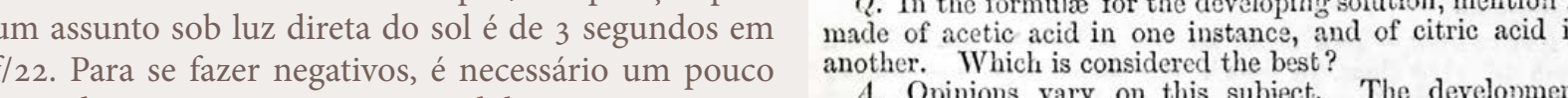

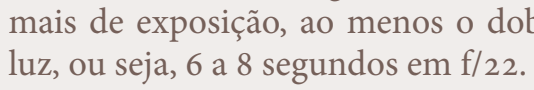

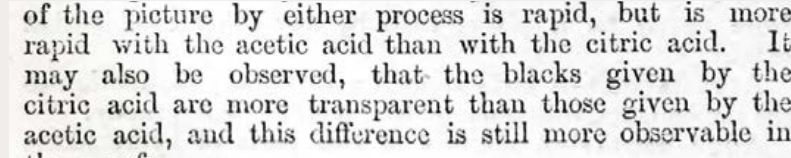

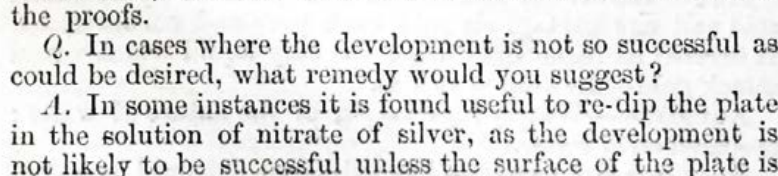

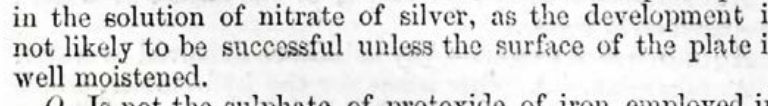

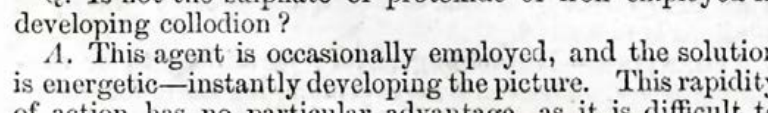

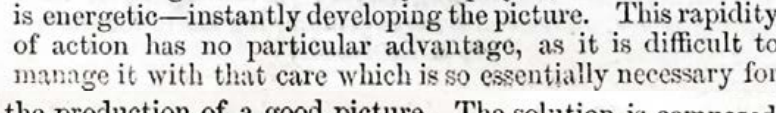

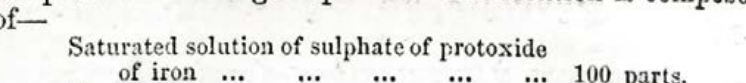

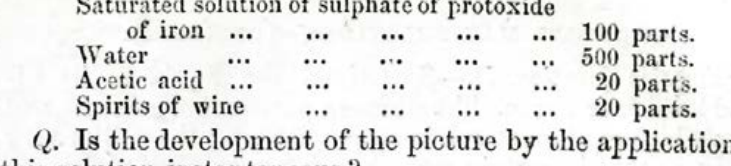

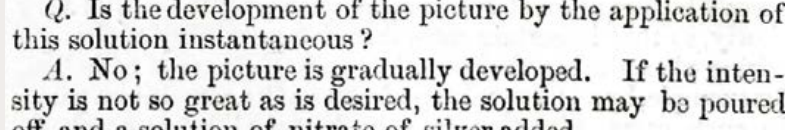

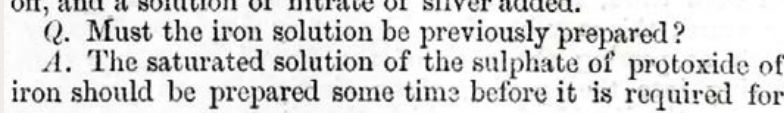

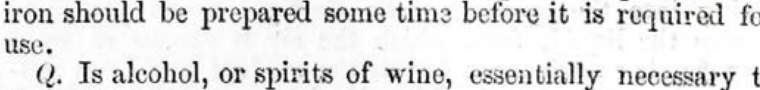

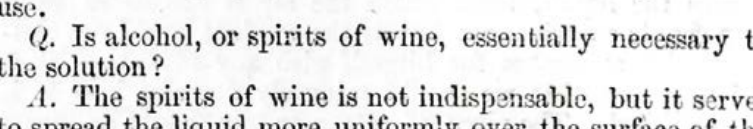
av When may the picture bo considered sulficiently
leveloped?

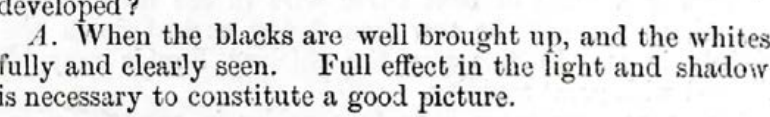

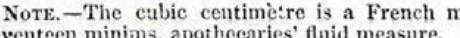

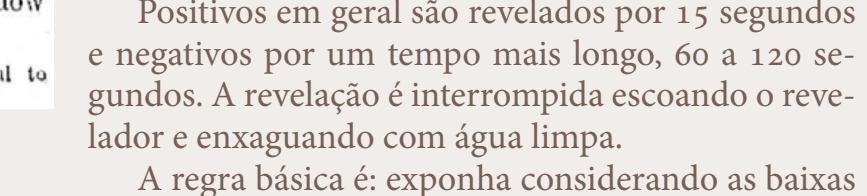

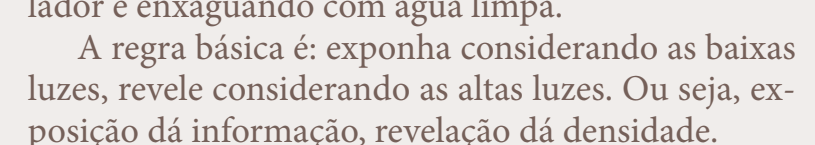

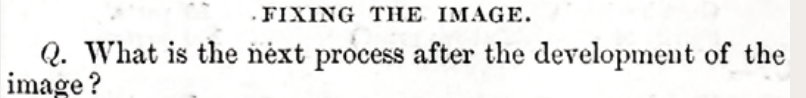

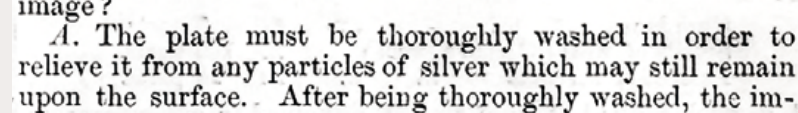

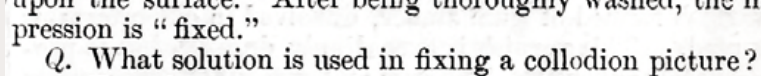

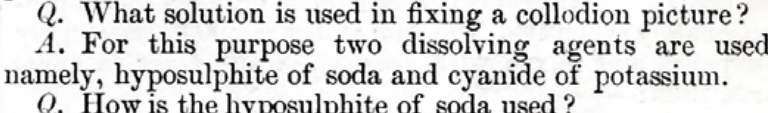

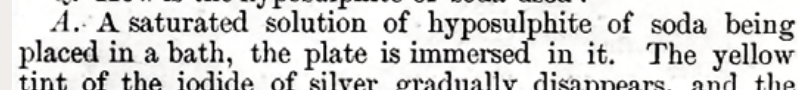

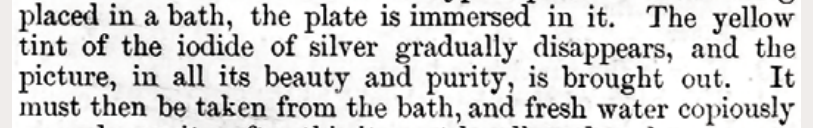

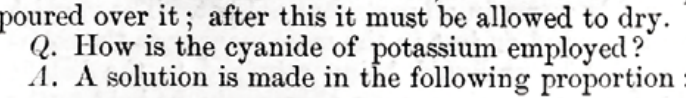

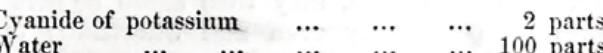

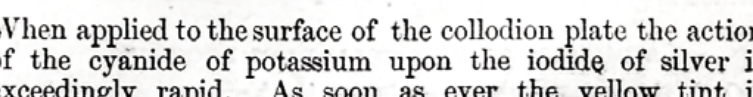

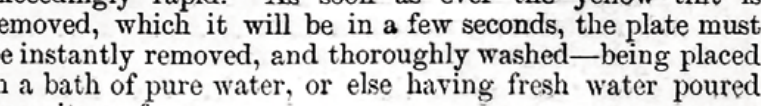

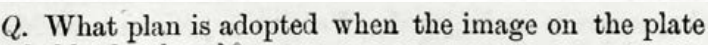

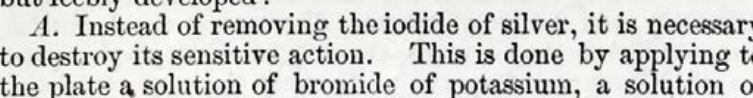

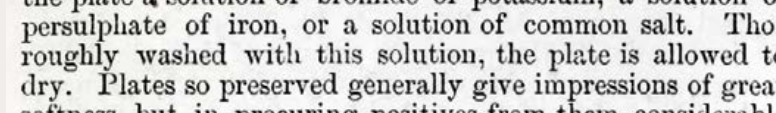

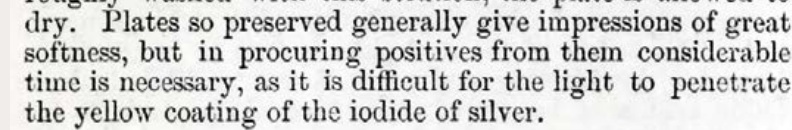


Fixando a imagem

Apos revelada enxaguada, a placa tem que ser gem e ainda é sensivivel à luz. prata que não virou ima-

de colódio bution dor se deixado pra agir por mais tempo. Assim, pod se corrigir super exposiçōes ou revelaçäes, reduzin
um pouco a densidade geral. O fixador de cianeto razōes anteriores. O perigo é que é um químico tóx epotencialmente perigoso se misturado com ácidos
Eu untilizei o fixador de tiossulfato seguninte para Fixador de tiossulfato de sódio " hypo" (15\%) $\begin{array}{ll}\text { Agua deionizada } & 1000 \mathrm{ml} \\ \text { Tiossulfato de sódio (penta) } & 235 \mathrm{~g}(150 \mathrm{~g} s \\ \text { Sulfifo de sódio } & 30 \mathrm{~g}\end{array}$ $0 \mathrm{~g}$
para 1 litro

Para positivos, eu prefiro usar o fixador rápido comercial da Ilfford de tiossulfato de amonnio. minutos para se livrar de qualquer resto de fixador, $q$ ent

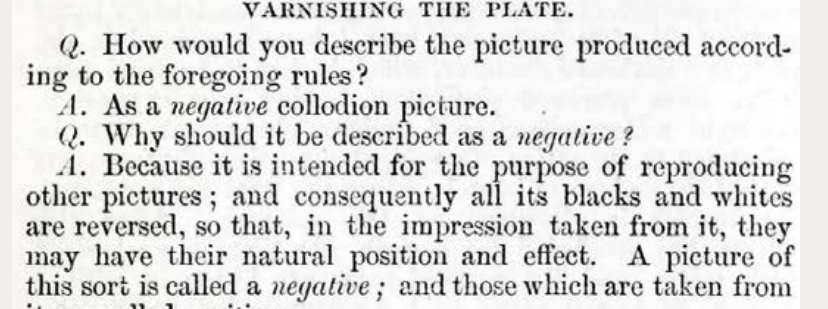

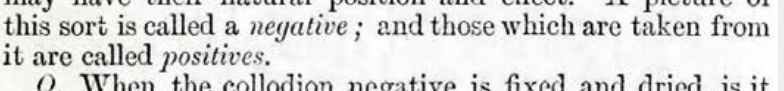
liabie to change?
A. The oolodion film is verr liable to injury, and it is

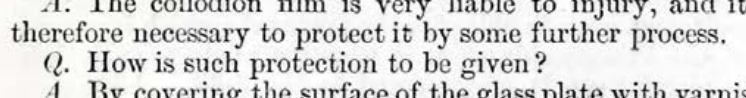

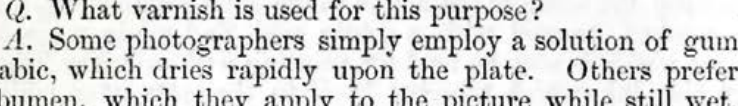

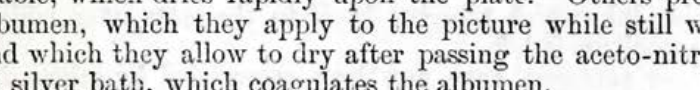

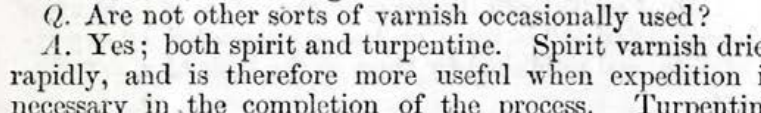

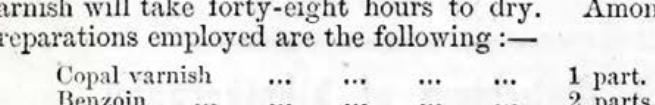

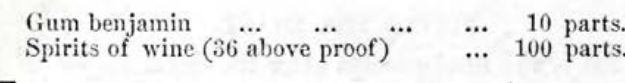

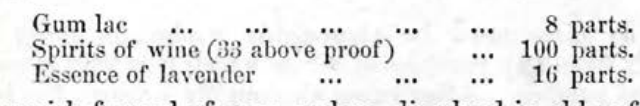

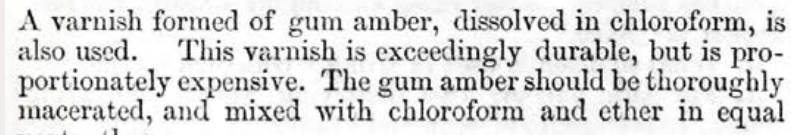

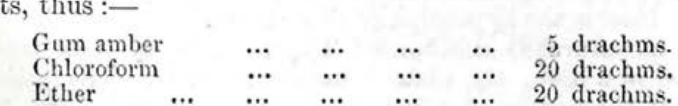

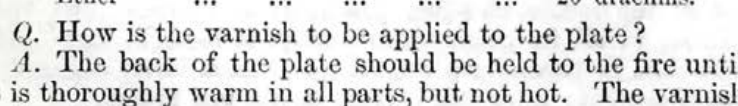

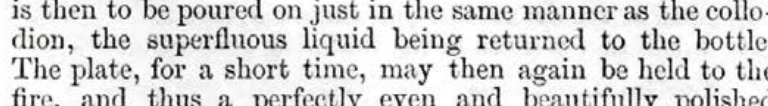

O colódio é uma superficie frígili à abrasão. A prata fenctara resultante da revelação do ambrótipo nagem com uma camada que utilizo éa seguinte:

Verniz sandáraca
Alcool de cereal $95 \%$

Goma sandaraca

A solucáa devidamente filtrada deve ser aplicacad elhante à da aplicaçăo do colódio. Após a retirada do d excesso, o verniz tem que ser secado colocando-se
placasobrou uma fonte de calor em geral uma pequena
lamparina, tomando o cuidado de não botar fogo no alcool presente no verniz. Após ele estar seco e curado 
Este trabalho registra uma pesquisa de alguns
projeto, a Camila Mangueira, Celina Yamauchi, Clíu-
nos que, apesar de contar com muitas horas soli-
dio Mubarac, Solange Ferraz de Lima e Wladimir tárias em leituras e procedimentos, é resultado do $\begin{array}{ll}\text { e appoidores. Sem eles, teria sido um caminho mais } & \text { Ao Boris Kossoy, Mark Osterman e Ricardo Men- } \\ \text { des, por dividiri comigo, e com todos, os resultados de }\end{array}$ longo, ardcuo, demorado e nao tao enriquecedor. Al- seus caminhos já percorridos. guns deles sao citados ao longo de meu diário, mas
estendo meus profundos agradecimentos a todos que tem me ajudado nesta jornad

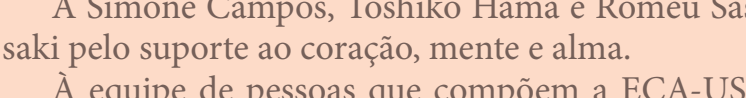
À equipe de pessoas que compõem a ECA-US Reforce os seguintes agradecimentos:
Ao professor loâo Luiz Musa por abrigar o

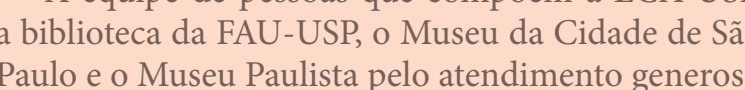
de forma entusiasmada, com conversas agregadoror investigacáo. Em especial, por incentivar a a descornA Casa Ranzini pelo. apoio e suporte de infraes-
A tura, ao Felipe Silva pela generosidade de desenvolver em parceria alguns insumos químicos para o Aos professores que contribuíram com seu tempo
e conhecimento para apontar as potencialidades do

A Laura Del Rey, Letícia Lampert e Fábio Peixoto
por contribuir com a forma final do trabalho.

Ficha TécNica

\section{Texto e pesquisa: Roger H. Sassaki}

Orientaçä: Joäo Luiz Musa

Projeto graficico: Laura Del Rey e Leticia Lampert

Diagramaçäo: Roger H. Sassaki e Laura Del Rey

Tratamento de imagens: Roger H. Sassaki
Encadernacāo e acabamentos artesanais: Rosana Chat
Autorizo a reprodução e divulgação total ou parcial deste trabalho, por qualquer meio convencional ou

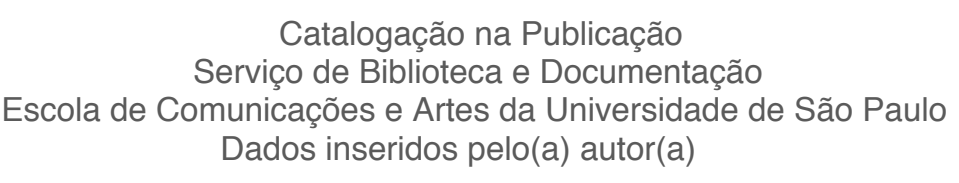

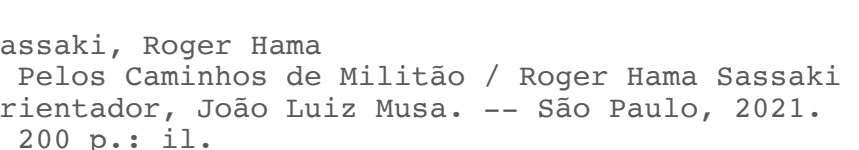

Dissertacăo (Mestrado) - Prograna de Pós-Graduaçäo em Artes
visuais - Escola de comunicaçoes e Artes / Universidade de

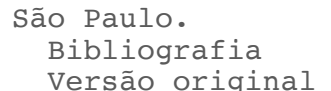

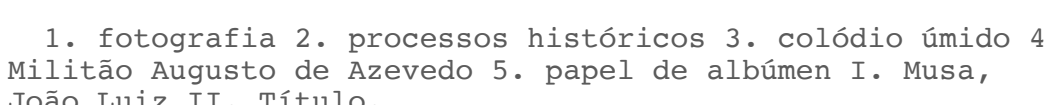

CDD 21.ed. - 770


Fonte: Minion Pro | Papel: Munken Lynx Rough $120 \mathrm{~g}$

Tiragem: 6 exemplares

Impresso pela gráfica Ipsis em março de 2021, em São Paulo. 